UNIVERSIDADE DE SÃO PAULO

FACULDADE DE FILOSOFIA, LETRAS E CIÊNCIAS HUMANAS

DEPARTAMENTO DE HISTÓRIA

PROGRAMA DE PÓS-GRADUAÇÃO EM HISTÓRIA

ECONÔMICA

ROBERTO PEREIRA SILVA

\title{
Celso Furtado, entre a história e a teoria econômica (1948-1959): uma interpretação historiográfica
}

Versão corrigida

São Paulo

2015 


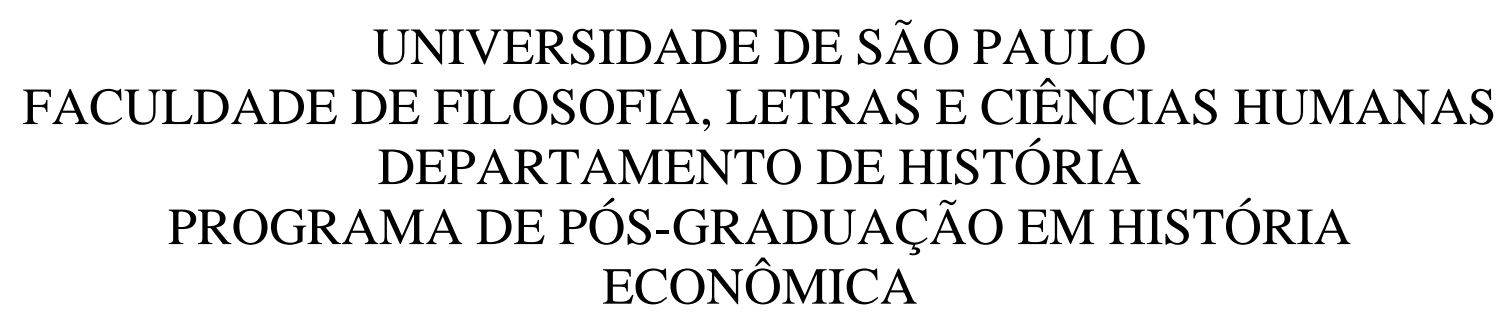

\section{Celso Furtado, entre a história e a teoria econômica (1948-1959): uma interpretação historiográfica}

Roberto Pereira Silva

Dissertação apresentada ao programa de Pós-Graduação em História Econômica da Faculdade de Filosofia, Letras e Ciências Humanas da Universidade de São Paulo, para a obtenção do título de Doutor em História.

Orientador: Prof. Dr. José Jobson de Andrade Arruda

São Paulo,

2015 


\section{Agradecimentos}

Primeiramente, agradeço ao Prof. José Jobson de Andrade Arruda, que foi muito mais que um orientador. Desde quando aceitou orientar minha dissertação de mestrado, em 2007, eu testemunhei, de longe, a redação de dois livros e, de maneira mais próxima, a redação e reescritura dos artigos recentemente reunidos no livro Historiografia: teoria e prática. Ter tido esse contato próximo, ver a rapidez com que produzia, aprofundava, ampliava os textos foi uma constante inspiração.

A professora Maria Arminda do Nascimento Arruda, para além da ajuda com o título desta tese, marcou minha formação com um curso sobre os intérpretes do Brasil.

Agradeço aos professores Renato Perim Colistete e Rosa Maria Vieira, que leram este trabalho quando ele ainda estava muito incipiente, mas conseguiram apontar caminhos a seguir. Participaram, também, da defesa da tese, onde novamente reiteraram seu compromisso de pesquisadores sérios, apontando lacunas e sugerindo leituras e discussões.

O professor Fernando Novais colocou questões difíceis e estimulantes na defesa da tese. Posso dizer que seus escritos oferecem um conjunto de proposições e reflexões que mobilizou e ainda mobiliza grande parte dos meus interesses metodológicos como historiador.

Também na defesa pude contar com os comentários do professor Maurício Chiafin Coutinho, a quem agradeço a leitura atenta e minuciosa do texto.

As conversas com Rosa Freire d'Aguiar Furtado e os recursos disponíveis no Centro Internacional Celso Furtado de Políticas para o Desenvolvimento ajudaram muito nesta pesquisa.

Em 2014 fiz parte do Grupo de Estudos Historiográficos Ibero-americano, coordenado pelo professor Jobson e pela professora Laura de Mello e Souza. Os encontros foram uma renovação para mim, pois aconteceram quando estava perdendo o fôlego de escrever este trabalho. Agradeço a todos seus membros: professoras Maria Arminda e Iris Kantor, e os colegas Alberto Luiz Schneider, Renato Adura Martins, Eduardo Holderle Peruzzo, Gabriel Aladrén, Carlos Fernando de Quadros, Leandro Vizin Villarino, Marcelo Kochenborger Scarparo. 
Aos colegas do Instituto de Ciências Sociais Aplicadas da Unifal-MG agradeço por me acolherem tão bem nestes últimos e facilitado meus primeiros passos como professor.

Com os amigos do Núcleo de Estudos em História Econômica e Economia Política (Nehep), também da Unifal-MG, discuti uma série de questões pertinentes à tese de doutorado. Além disso, o convívio constante e franco tornaram minha adaptação à cidade de Varginha muito mais fácil. Agradeço especialmente a Michel Marson, Thiago Gambi, Daniel Cosentino e Bruno Aidar.

Experiência fundamental da docência foi o contato com um grupo de estudantes muito interessados, que me ajudaram a pensar questões importantes da tese: Janaína Bathain, Francisco Monticeli, Rafael Fernandes Pereira, Josiane Brito, Elton Rosa, Gustavo Noronha, Gabriel Kato, Aline Maruyana, Barbara Elisa, Silvia Pretylla e Regiane Reis.

A tese não teria sido concluída sem o auxílio luxuoso de dois grandes amigos: Pedro Afonso Cristovão Santos e Marcos Paulo de Passos, ambos leitores argutos e atentos. A eles acrescento outros, que também contribuíram para a elaboração e discussão de aspectos e temas deste trabalho: Gabriel Rossini, Cristiano Addario, Wiliam Nozaki, Fábio Correa e Leandro Galastri.

Sem esquecer, claro, os amigos, presentes para tudo, mesmo que à distância: Sergio Leal, Eduardo Marcolan, Camilo Gomes da Silva, Adriano Guerra, Otávio Rangel, Luiz José de Souza, Erika de Souza Lopes, Gabriel Rossini, Cristiano Addario, Erick Sposito, Edson Tadeu Queiroz, Dino Grejo, Fernando Grejo, Julio Cesar Leal, Miriam Della Posta Azevedo, Alecsander de Souza, Fabio Martins.

Francine Nunes acompanhou a maior parte deste trabalho e fez de tudo para me deixar mais alegre durante o processo.

E minha família, quem mais sentiu minha falta, minhas ausências e que fez de tudo para me dar forças para concluir esta tese. Agradeço aos meus pais, Dirce Buonocore Pereira Silva e Edson Pereira Silva, e ao meu irmão, Ricardo Pereira Silva. E, sobretudo, à minha avó, Anna Polli, que não esperou para ver seu neto se tornar professor e nem viu essa tese ser concluída.

Agradeço, finalmente, o apoio financeiro que recebi do Cnpq e da Fapesp. 


\section{RESUMO}

SILVA, Roberto Pereira. Celso Furtado, entre a história e a teoria econômica (19481959): uma interpretação historiográfica. Tese (doutorado). Universidade de São Paulo, Faculdade de Filosofia, Letras e Ciências Humanas, São Paulo, 2015, 393 fls

Este trabalho analisa a obra de Celso Furtado entre 1948 e 1959. Seu objetivo é investigar como o autor trata a relação entre história e teoria econômica, enquanto um dos principais elementos de sua formulação da teoria do desenvolvimento econômico. Procura-se delinear como essa problemática foi sendo reelaborada ao longo do tempo, entendendo que estas reformulações decorrem dos problemas específicos da economia brasileira, dos diagnósticos que produz sobre esta e dos debates na história do pensamento econômico brasileiro. Metodologicamente, o trabalho está ancorado na historiografia em sua acepção crítica: compreendida como uma reflexão sobre a produção escrita, entrelaçando autor, obra e meio. Nessa perspectiva, procura-se evidenciar como os influxos do presente, a retomada do passado brasileiro e as perspectivas de futuro foram elaboradas e organizadas por Celso Furtado, num arranjo de dialógica transtemporal. Para isso nos centramos em cada conjuntura de elaboração dos escritos de Celso Furtado. Investigamos a participação de Celso Furtado na Comissão Econômica para América Latina (CEPAL), o debate sobre planejamento econômico - que envolveu, também, Raúl Prebisch, Eugenio Gudin e Octávio Gouveia de Bulhões - a publicação de A economia brasileira (1954) e a tentativa de responder tanto aos problemas conjunturais da economia brasileira quanto apresentar uma primeira tentativa de conciliar história e teoria econômica. As resenhas e comentários publicados na revista Econômica Brasileira e o livro Perspectivas da economia brasileira (1958) explicitam o posicionamento de Celso Furtado frente ao Plano de Metas e apresenta alterações importantes em seu diagnóstico da economia brasileira. Finalmente, examinamos Formação econômica do Brasil (1959) como uma nova resposta ao desafio de conciliar história e teoria econômica.

Palavras-chave: Celso Furtado; Historiografia; Economia Brasileira; Desenvolvimento Econômico; História Econômica do Brasil 


\begin{abstract}
SILVA, Roberto Pereira Celso Furtado, between history and economic theory (19481959): an historiographical interpretation. Tese (doutorado). Universidade de São Paulo, Faculdade de Filosofia, Letras e Ciências Humanas, São Paulo, 2015, 393 fls

This study analyzes the work of Celso Furtado between 1948 and 1959. Its aim is to investigate how the author deals with the relationship between history and economic theory, while one of the main elements of its formulation of the theory of economic development. Searches to outline how this problem was being reworked over time, understanding these restatements as resulting from the specific problems of the Brazilian economy, from diagnosis which produces about this and debates in the history of Brazilian economic thought. Methodologically, the work is based on historiography in its critical meaning: understood as a reflection on the written production, entwining author, work and environment. In this perspective, we try to show how the inflows of present, the resumption of the Brazilian past and future prospects were prepared and organized by Celso Furtado, in a dialogic and trans-temporal arrangement. For this we focus on each elaboration's conjuncture of the writings of Celso Furtado. We investigated the participation of Celso Furtado at the Economic Commission for Latin America (ECLA), the debate on economic planning - which also involved Raúl Prebisch, Eugenio Gudin and Octavio Gouveia de Bouillon - the publication of the $A$ economia brasileira (1954) and the attempt responding both to the economic problems of the Brazilian economy has a first attempt to reconcile history and economic theory. We investigated the participation of Celso Furtado at the Economic Commission for Latin America (ECLAC), the debate on economic planning - which also involved Raúl Prebisch, Eugenio Gudin and Octavio Gouveia de Bouillon - the publication of the Brazilian economy (1954) and the attempt to respond both to the economic problems of the Brazilian economy and present a first attempt to reconcile history and economic theory. The reviews and comments published in the Economica Brasileira journal and the book Perspectivas da economia brasileira (1958) explains the positioning of Celso Furtado on the Target Plan and presents important changes in their diagnosis of the Brazilian economy. Finally, we examine Formação econômica do Brasil (1959) as a new response to the challenge of reconciling history and economic theory.
\end{abstract}

Keywords: Celso Furtado; Historiography; Brazilian economy; Economic Development; Economic History of Brazil 


\section{Sumário}

Introdução p. 9

\section{Capítulo 1: (Re) conhecendo a economia brasileira}

As armadilhas da teoria econômica e a necessidade da história p. 21

A Cepal e as armadilhas da teoria econômica na América Latina ........................................ p. 44

As armadilhas da teoria econômica no Brasil ................................................................... p. 52

Ragnar Nurkse, Celso Furtado e o debate sobre desenvolvimento econômico......................... p. 66

Ragnar Nurkse e Problemas da formação de

capital em países subdesenvolvidos (1951)............................................................ p. 71

Celso Furtado e Formação de capital e desenvolvimento

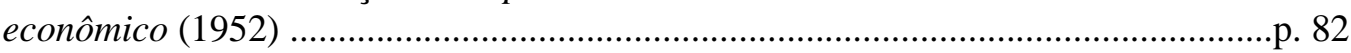

Resposta de Ragnar Nurkse à Celso Furtado.............................................................. 99

\section{Capítulo 2: A educação prática}

O planejamento econômico da Cepal no Brasil........................................................................ p. 109

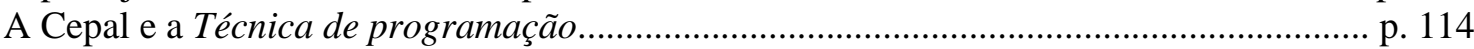

O debate sobre planejamento econômico no Brasil............................................................ p. 120

A crítica de Otávio Gouveia de Bulhões................................................................. p. 122

A resposta de Celso Furtado....................................................................................... p. 129

A réplica de Otávio Gouveia de Bulhões................................................................ p. 134

Debate entre Eugênio Gudin e Raúl Prebisch........................................................ p. 136

A lição prática: A técnica do planejamento econômico.......................................................... p. 144

\section{Capítulo 3: O desenvolvimento econômico na história e a economia brasileira}

O livro A economia brasileira (1954) e a relação entre

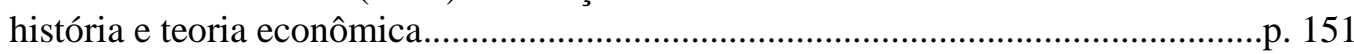

História e teoria econômica no processo de

desenvolvimento europeu

O desenvolvimento econômico na América Latina e no Brasil:

a economia colonial

Fim da economia colonial, cafeicultura e a crise do nascimento

do mercado interno

Intermezzo: de Formação de capital e desenvolvimento econômico a

Completando o aprendizado: A teoria do desenvolvimento

na ciência econômica 


\section{Capítulo 4: A maturação dos conceitos: a herança do passado e as perspectivas de futuro}

A revista Econômica Brasileira e a teoria do desenvolvimento econômico examinada sob o crivo da economia brasileira p. 248

A programação da economia brasileira: O Plano de Metas e os

desequilíbrios econômicos. p. 271

\section{Capítulo 5: Presente, passado e futuro: Formação econômica do Brasil}

O sentido de Formação econômica do Brasil

p. 296

Impulso externo em uma economia subdesenvolvida:

o Nordeste açucareiro e a pecuária. p. 315

Impulso externo em uma economia subdesenvolvida:

a economia mineira.

Uma longa decadência: final do século XVIII e meados do XIX

p. 343

A formação da economia cafeeira, a questão da mão-de-obra e a nacionalização da política econômica

Perspectiva dos próximos decênios: dez anos de diagnósticos sobre o Brasil.

Conclusão p. 380

Bibliografia. p. 385 


\section{Introdução}

Jorge Luis Borges, comentando a biografia de Samuel Johnson escrita por James Boswell, nota que, ao longo do livro, "o doutor Johnson vai perdendo sua figura, por vezes simpática, por vezes ridícula, fugindo ao propósito da escrita de uma 'biografia dramática"”, como pensara, inicialmente, Boswell. Essa percepção é remetida ao Dom Quixote, de Cervantes, "um personagem às vezes ridículo, às vezes simpático, principalmente na segunda parte, quando o autor aprendeu a conhecer o que seu personagem é e esqueceu de seu propósito inicial de ridicularizar os romances de cavalaria". ${ }^{1}$ Acredito que o estudo de Celso Furtado tem sido isso, uma tentativa de conhecê-lo melhor e, principalmente, de libertá-lo da visão que lhe impus, quando tomei contato com sua obra.

Foi durante a graduação em história que tive contato com a tese de doutorado de Celso Furtado, Economia colonial no Brasil nos séculos XVI e XVII. Sob a orientação do professor Paulo Iumatti, iniciei uma iniciação científica que me levou a recuar no tempo, para trabalhos de Celso Furtado sobre Administração publicados na Revista do Serviço Público. Ao dedicar-me a estes textos, percebi que aspectos da obra de Celso Furtado não haviam sido explorados, e, minha hipótese foi que a memória histórica sobre ele havia minimizado os textos que não estavam claramente inseridos na problemática da teoria do subdesenvolvimento.

Essa teleologia dos estudos me fez aceitar o desafio e buscar outros textos da juventude de Celso Furtado que também permaneciam no esquecimento. Isso me permitiu visualizar um Jovem Celso Furtado, cindido em interesses diversos: crítica musical, artística, história, jornalismo, cinema, administração pública, ciências sociais e economia. O objetivo de nossa dissertação de mestrado, orientada pelo professor José Jobson de Andrade Arruda, no Instituto de Economia da Unicamp, foi analisar como esses interesses foram reorganizados, selecionados e hierarquizados dentro de um projeto de vida e obra As circunstâncias específicas do país - a institucionalização do conhecimento social e econômico, a ampliação da intervenção estatal — e do mundo a Segunda Guerra Mundial, a reconstrução da Europa - enredaram-se na biografia pessoal do Jovem Celso Furtado, que de jornalista se transformou em Técnico em Administração Pública, soldado da Força Expedicionária Brasileira, até decidir-se a cursar o doutorado em ciências econômicas na França. Sua tese de doutorado recebeu

\footnotetext{
${ }^{1}$ BORGES, Jorge Luis. Curso de literatura Inglesa. (organização de Martín Arias e Martín Hadis). São Paulo: Martins Fontes, 2002, p. 149.
} 
uma análise verticalizada em nosso trabalho de mestrado, procurando deslindar a relação de Celso Furtado com o conhecimento histórico, uso de fontes, citações, e, sobretudo, os diálogos que sua obra estabeleceu com os intérpretes do Brasil: sobretudo, Caio Prado Júnior e Gilberto Freyre.

Durante a pesquisa, nossa inquietação com as possibilidades de reconstituir a formação do pensamento de Celso Furtado, no que ela tem de circunstanciada, de biográfica, de social, e, claro, de elaboração teórica, encontrou a problemática historiográfica de José Jobson de Andrade Arruda, que, à época de nosso ingresso no curso de mestrado em história econômica, estava elaborando e ampliando.

À medida que progredia o estudo de Celso Furtado, fomos clarificando que havia um problema que perpassava sua obra: a relação entre história e teoria econômica, manifestação, no plano epistemológico, da preocupação em compreender a especificidade das economias subdesenvolvidas. Essa percepção, que está oculta em $O$ Jovem Celso Furtado, nossa dissertação, nos levou a prosseguir com o trabalho sobre o autor, avançando no tempo e nas questões colocadas. Este avanço, cujo resultado é esta tese, foi iniciado com uma ideia muito clara: Celso Furtado aplica seu modelo de subdesenvolvimento ao passado brasileiro. $\mathrm{O}$ estudo das fontes utilizadas em $A$ economia colonial no Brasil nos séculos XVI e XVII nos levava a esta conclusão, pois parecia evidente que fazia um uso demasiadamente seletivo dos autores que lia. Mas, à medida que o trabalho avançava, que as hipóteses foram testadas em congressos e apresentações científicas; que as discussões e mesmo o entendimento do método historiográfico se aprofundaram, essa impressão foi se dissipando e, acredito, fui conhecendo um pouco melhor meu personagem, percebendo a conexão entre seus problemas teóricos e as soluções que propôs. Não se trata de aplicação de um modelo teórico à história, simplesmente. É uma construção, digamos, dialética, operando da teoria para a história, do presente para o passado, e, sempre, visando o futuro.

Ao final, não posso dizer que conheço muito melhor este personagem chamado Celso Furtado. Para mim, ele ainda permanece imprevisível, difícil de interpretar. E, confesso: prefiro que seja assim.

\section{$* * *$}

A principal questão que esta introdução precisa responder é: por que mais um estudo sobre Celso Furtado, investigando um período já bastante examinado? De fato, 
os trabalhos disponíveis, na forma de livros, teses e artigos, não param de crescer $^{2}$; e, ainda, o período entre 1949 e 1964, permanece sendo o mais estudado, por abarcar duas de suas principais obras, Formação econômica do Brasil (1959) e Desenvolvimento e subdesenvolvimento (1961). Essa profusão de textos, assentados em diversas perspectivas teóricas e disciplinas das Ciências Sociais e da História, escrutinaram temas, abordagens, aspectos teóricos e a ação prática de Celso Furtado. Deveríamos abordar cada um desses trabalhos separadamente? Seria possível uma avaliação de pesquisas tão diversas, sobre a política, a democracia, a formação da nação, as teorias do desenvolvimento econômico, o subdesenvolvimento, as matrizes intelectuais, influências e aspectos institucionais de sua obra? Poderíamos, por outro lado, fazer tabula rasa de tudo o que foi produzido e sugerir a apresentação de um novo Celso Furtado? Não iremos seguir nenhuma das alternativas e, por isso, cabe justificar nossa abordagem.

Comecemos, primeiramente, com o que de mais palpável atrai o interesse dos historiadores: as fontes. Nesta investigação, os textos de Celso Furtado. O Centro Internacional Celso Furtado de Políticas para o Desenvolvimento tem feito um trabalho notável de divulgação de trabalhos inéditos, cursos, relatórios técnicos, artigos dispersos em periódicos, manuscritos. ${ }^{3}$ Além disso, disponibilizou para a consulta a biblioteca particular do autor. Esse conjunto de publicações apenas começa a ser incorporado

\footnotetext{
${ }^{2}$ IGLÉSIAS, Francisco. Celso Furtado: pensamento e ação. In: Idem. História e ideologia. São Paulo: Editora Perspectiva. 1971, pp. 159-234; MALLORQUIN, Carlos. Celso Furtado: um retrato intelectual. [1993] São Paulo: Xamã; Rio de Janeiro: Contraponto, 2005; MORAES, Reginaldo. Celso Furtado. O subdesenvolvimento e as idéias da CEPAL. São Paulo, Ed Ática, 1995; CEPÊDA, Vera Alves. Raízes do pensamento político de Celso Furtado: desenvolvimento, nacionalidade e Estado democrático. (Dissertação de Mestrado, Ciências Sociais, FFLCH-USP), 1998; GUIMARÃES, M. E. Celso Furtado: A utopia da Razão. Um estudo sobre o conceito de subdesenvolvimento (1945-1964). (Tese de Doutorado. Departamento de Sociologia da FFLCH-USP), 1999; TAVARES, Maria da Conceição. (org.) Celso Furtado e o Brasil. São Paulo, Editora Fundação Perseu Abramo, 2001; BRESSER-PEREIRA, L. C. \& REGO, J. M. A grande esperança em Celso Furtado. Ensaios em homenagem aos seus 80 anos. São Paulo: Editora 34, 2001; LIMA, Marcos Costa, \& DAVID, Maurício Dias (orgs). A atualidade do Pensamento de Celso Furtado. Goiás: Verbena Editora, 2008; COELHO, Francisco Silva \& GRANZIERA, Rui Guilherme (orgs). Celso Furtado e a Formação econômica do Brasil (Edição comemorativa dos 50 anos de publicação (1959-2009). Prefácio Fernando Henrique Cardoso. São Paulo, Editora Atlas, 2009; VIEIRA, Rosa Maria. Celso Furtado: reforma, política e ideologia (1950-1964). São Paulo: Educ, 2007; SABOIA, João; CARVALHO, Fernando J. Cardim de. (orgs) Celso Furtado e o século XXI. Barueri, SP: Manole; Rio de Janeiro, IE-UFRJ, 2007; ARAÚJO, Tarcisio Patricio de; WERNECK VIANNA, Salvador Teixeira; MACAMBIRA, Júnior. (orgs) 50 anos de Formação Econômica do Brasil: ensaios sobre a obra clássica de Celso Furtado. Rio de Janeiro: Ipea, 2009; FURTADO, Celso. Formação econômica do Brasil: edição comemorativa: 50 anos. Organização de Rosa Freire d'Aguiar Furtado. São Paulo: Cia das Letras, 2009; BORJA, Bruno. A formação da teoria do subdesenvolvimento de Celso Furtado. (Tese de doutorado, Economia Política Internacional, IE-UFRJ), 2013. BIANCONI, Renata. L'oeuvre de Celso Furtado à Paris: le parcours d'un intellectuel et homme d'État. (Tese de doutorado, História Moderna e Contemporânea, Université Paris-Sorbonne), 2014.

${ }^{3}$ Veja a coleção Arquivos Celso Furtado, atualmente no sexto volume.
} 
pelos críticos, mas ainda há muito por fazer. No que se refere às fontes de informação, carecemos de um catálogo completo das publicações de Celso Furtado, sobretudo de seus artigos em jornais e revistas, bem como de indicações seguras sobre a origem dos textos que compõem os livros que publicou. Essa tarefa, condição mínima para o estudo da evolução do pensamento de qualquer autor, ainda precisa ser realizada.

Contamos com três volumes de escritos autobiográficos de Celso Furtado que têm sido uma das principais fontes de informação pessoal sobre o autor. Entretanto, ainda não existe edição de sua correspondência, o que permitiria aos pesquisadores um primeiro confronto e uma precaução quanto à "ilusão biográfica", aos problemas que a autobiografia oferece, como nos ensina Pierre Bourdieu. Contudo, essa ausência de ferramentas básicas para a pesquisa histórica, se nos intimida, não se constituiu como um fator desencorajador para muitos intérpretes de sua obra. Em que pesem as dificuldades de acesso que qualquer pesquisador brasileiro encontra em arquivos e bibliotecas nacionais, é preciso reconhecer que muitos textos impressos e já disponíveis de Celso Furtado não foram analisados, mesmo em estudos mais verticalizados de sua obra. Ainda assim, não nos parece acertado utilizar como critério de seleção e julgamento, procedimentos que não estavam no horizonte metodológico de seus intérpretes.

Com estas constrições, procuramos desenvolver este trabalho convictos de que, se alguma novidade pode haver em revisitar escritos já tão estudados de Celso Furtado, ela consiste em um método de interpretação, método alicerçado na História, ou melhor, na Historiografia.

Nossa escolha metodológica foi, por assim dizer, uma imposição do objeto, menos que uma opção pessoal. Se tomarmos as interpretações sobre Celso Furtado, identifica-se uma constatação que as perpassa, uma característica subjacente que revela talvez o cerne da atitude do autor, qual seja: seu propósito claro de intervir na realidade, a preocupação em alterá-la, construir um novo futuro, uma utopia racional pois, com os instrumentos da razão, pretende intervir no mundo para modificá-lo. Esse o ponto focal das interpretações, este o coração do projeto furtadiano, este o traço que pretendemos ressaltar.

Mas outra pergunta, inevitavelmente, aparece: se o que persiste em todas as interpretações de Celso Furtado é seu propósito de intervir na realidade, construir o futuro, qual a contribuição que este trabalho pode oferecer, ao concentrar-se no aspecto mais afirmado e repisado da obra do economista brasileiro? 
A proposta deste estudo é examinar qual relação a obra teórica estabelece com a realidade que pretende intervir. Este foi, sem dúvida alguma, um tema que preocupou Celso Furtado desde os inícios de seus escritos, e foi formulado, em diferentes momentos, com ênfases e respostas diversas, na questão mais precisa dos limites da teoria econômica para captar as especificidades da realidade em permanente mutação que pretende explicar. Em outros termos: quais as possibilidades de conciliar o esforço teórico e conceitual, abstrato por natureza, aos influxos, à pulsação da realidade em contínuo processo de transformação? Este é um dos motes da obra de Celso Furtado, que se refere, em último caso, à possibilidade de intervenção na realidade a partir de um conhecimento formalizado e teoricamente coeso. Esta preocupação desdobra-se em outra: em que medida a própria elaboração conceitual, ainda que abstrata, não é resultado da observação da realidade particular, específica, esta também compreendida a partir de um conjunto de significações e valorizações do próprio sujeito que observa e teoriza? Existiria uma epistemologia que não é, também, um engajamento na realidade, sobretudo quando se trata da ciência econômica, esta disciplina tão próxima da política, da intervenção, do Estado? ${ }^{4}$

Vejamos, portanto: o engajamento e a intervenção, horizonte implícito no exame da relação entre teoria econômica e história, apontam para os condicionamentos sociais do indivíduo na construção de sua epistemologia. ${ }^{5}$ Estabelece-se assim, um elo entre o presente e o futuro, pois a compreensão daquele é feito com vistas à sua alteração e à construção de alternativas, que se apresentam como um horizonte a ser alcançado através de instrumentos teóricos formulados no conhecimento do presente. Entretanto, compreendê-lo, na obra de Celso Furtado é, também, compreender o passado, pois a sociedade, sempre em transformação, não somente aponta para o porvir, mas o faz em conflito com a herança e as determinações do passado que, em último caso, iluminam o presente e oferecem seus principais traços delineadores.

Dessa forma, esse conjunto de questões nos colocou a problemática da compreensão da obra de Celso Furtado enquanto um projeto de futuro, alicerçado no

\footnotetext{
4 "Existe uma ligação profunda entre as questões da epistemologia e as da história política. Uma vez que algum experimento político ambicioso encalhou, as suposições realistas implícitas nessa prática estão fadadas a parecer menos convincentes". EAGLETON, Terry. As ilusões do pós-modernismo. Rio de Janeiro: Jorge Zahar Editor, 1998, p. 22.

${ }^{5}$ A preocupação em intervir na realidade, como um aspecto central do conflito entre teoria econômica e história, foi examinada, no que se refere ao Methodenstreit entre a Escola Austríaca e a Escola História Alemã em: GRIMMER-SOLEN, Erik. The rise of historical economics and social reform in Germany, 1864-1894. Oxford, Clarendon Press, 2005. Esta problemática está presente, sob o aspecto da participação social, em: RINGER, Fritz, $O$ declínio dos mandarins alemães. A comunidade acadêmica alemã: 1890-1933. São Paulo, EDUSP, 2000.
} 
conhecimento do presente mas que recupera, neste últimos, seus elementos formativos e conformadores. Nesse ponto, nos colocamos no território da História, do diálogo com a temporalidade. Nosso método, portanto, tem de estar alicerçado na temporalidade. Adotamos como eixo interpretativo o método historiográfico, em sua acepção crítica, “que pressupõe um renovado conceito de temporalidade, a ruptura da tradicional tríplice compartimentação do tempo histórico, anunciando um novo regime de temporalidade, a dialógica da transtemporalidade, em que passado e futuro se enlaçam sob a égide do tempo presente, concepção que projeta o historiador à condição de mestre do enredo, senhor do tempo". 6

A proposta metodológica de José Jobson, ao complexificar a temporalidade, capta o entrelaçamento entre presente, passado e futuro, e o transforma em chave interpretativa para as obras históricas enquanto "capazes de expressar o entorno problematizado das múltiplas temporalidades que nelas se entrecruzam, necessariamente, escandindo o tempo a partir do qual falam seus atores e agentes, bem como os universos sociais, a ambientação cultural e as motivações pessoais de seus construtores". 7

Dessa forma, ao compreender o trabalho do historiador como centrado em seu tempo presente, em sua temporalidade social, na qual não aparece como indivíduo mas como portador de um projeto, abre a perspectiva para problematizar o presente, pois este é, a um só tempo, o significante do passado, o que permite que este seja entendido não em sua positividade, não sob a insígnia "como de fato ocorreu", mas (re)significado a partir dos problemas contemporâneos e, também, nas perspectivas de futuro que se apresentam para cada sociedade. Trata-se de compreender o presente como um tempo "saturado de agoras", que é sempre uma (re)atualização do passado em vista do futuro. ${ }^{8}$

Por sua vez, a relação passado, presente e futuro não invoca uma causalidade linear entre as três temporalidades, mas sim um "enlace de sentido": inteligibilidade mútua que só pode ser captada se assumirmos que o presente não é só resultado do passado, mas o interpela e interpreta; e também o futuro pode ser mais que um horizonte utópico, pois é construído, refeito, contradito a partir dos significados sempre

\footnotetext{
${ }^{6}$ ARRUDA, José Jobson de Andrade. Historiografia: consciência crítica da produção histórica. In: idem. Historiografia. Teoria e prática. São Paulo: Alameda, 2014, p.20.

${ }^{7}$ Idem, pp. 49-50.

${ }^{8}$ Idem, p. 33.
} 
transitórios do presente. Este, portanto, aparece enquanto "cristalização do passado e do futuro", na expressão de Hannah Arendt. ${ }^{9}$

No entanto, é possível perguntar, adentrando em campo minado, se é possível considerar Celso Furtado historiador e, dessa forma, aplicar uma metodologia formulada no campo da História, onde a reflexão sobre a temporalidade é sua matériaprima. A obra de Celso Furtado tem em seu núcleo a proposta de alargar o escopo da teoria econômica, incorporando os resultados das Ciências Sociais e da História. As respostas que ofereceu estiveram enraizadas no exame da conformação histórica dos problemas do presente. Esforço intelectual que procurou averiguar na história de sociedades específicas a funcionalidade dos conceitos econômicos, e, também, elaborou suas categorias e conceitos a partir dos dilemas da experiência social, pois só eles poderiam dar inteligibilidade ao fluxo histórico. Desse procedimento duplo nasce e desenvolve-se a obra de Celso Furtado.

Imerso, portanto, na problemática do presente, é a partir deste que compreende e interpreta o passado. Mas ao mesmo tempo, é também de seu tempo vivido, social, tempo presente, que procura alterar o futuro, entrelaçar a resolução das determinações imediatas à viabilização de um projeto de futuro. Assim, o método historiográfico se coaduna com o exame da obra de Celso Furtado.

No entanto, é preciso, ainda, explicitar como iremos operacionalizá-lo em nosso trabalho. Uma vez que os circunstanciamentos econômicos, sociais e culturais de Celso Furtado são o cenário onde se move, as instituições em que trabalhou, os veículos onde divulgou seu trabalho, seus canais de circulação assumem relevância em nossa análise. Isso nos remete, também, aos diálogos que Celso Furtado estabeleceu e buscou em sua obra. Nesse ponto, procuramos captar os debates implícitos e explícitos de sua obra, e isto será uma instância importante, pois é um dos acessos para observarmos sua preocupação com o presente.

Isso se desdobra, por sua vez, na preocupação em destacarmos a conjuntura da economia brasileira que subjaz aos escritos de Celso Furtado, pois ambos (diálogos intelectuais e conjuntura econômica) são esclarecedores de sua obra.

De outra parte, evitamos, na medida do possível, hierarquizar a produção de Celso Furtado, dando ênfase para alguns artigos, resenhas, intervenções pontuais que, muitas delas ainda não trabalhadas pela bibliografia, talvez por esse caráter circunstanciado, assumirão grande relevo no trabalho, pois será onde o aspecto imediato

\footnotetext{
${ }^{9}$ Idem, p. 42.
} 
de suas preocupações está visível, não acobertada pelas discussões teóricas, embora sempre pressupondo-as e testando-as.

Será essa compreensão do presente, ou seja, como os dilemas coetâneos são introjetados na obra de Celso Furtado, que nos revelará as conexões com o passado e o futuro. Com o passado, pois seu esforço conceitual é sempre uma via de mão dupla entre compreender os problemas do presente, formulá-los conceitualmente e confrontálos, revê-los ou ampliá-los pelo exame do passado: exame este no qual a compreensão do emaranhado de fatos pretéritos é organizado sob o crivo de categorias e conceitos que, embora vazados pela história, têm sua origem nos problemas da realidade dos países subdesenvolvidos.

A abertura para o horizonte de futuro, por sua vez, é captada na medida em que os diagnósticos elaborados por Celso Furtado são, também, propostas de intervenção e modificação da realidade, possibilitada pelo seu escrutínio a partir de categorias que possibilitam seu conhecimento preciso e fornecem instrumentos para sua modificação. Dito de outra forma, nos diagnósticos sobre o presente, vazados pela experiência do passado, há sempre a proposta incisiva de alterar o futuro.

Por tudo isso, a obra de Celso Furtado força o intérprete a refletir sobre a temporalidade, razão pela qual dissemos que o método foi uma imposição do objeto.

Porém, antes de concluirmos, precisamos esclarecer o leitor sobre o que não irá encontrar neste trabalho. Não iremos nos deter nas "influências intelectuais" de Celso Furtado por dois motivos. Primeiramente, já existem muitos estudos sobre o tema, investigando a influência da Cepal, das teorias do desenvolvimento econômico, dos historiadores econômicos brasileiros, dos intérpretes do Brasil, de Keynes, de Mannheim, do pensamento político autoritário. Dessa forma, nos limitaremos, quando necessário, a nos referir a estes trabalhos. Mas, por outro lado, há um outro motivo pelo qual a própria noção de influência pode conduzir a vias pouco seguras. O estudo da obra de Celso Furtado me parece ser um exemplo conspícuo de independência intelectual que, de certa forma, minimiza ou transforma qualquer sistema de pensamento a uma condição utilitária aos propósitos de formulação de uma teoria que procure explicar a realidade dos países subdesenvolvidos. É possível falar de Celso Furtado, o que Lucien Febvre disse a respeito de Lutero: "un homme du tempérament de Luther, s'il ouvre un livre: il n'y lit qu'une pensée, la sienne". ${ }^{10}$

\footnotetext{
${ }^{10}$ FEBVRE, Lucien. Martin Luther: un destin [1928]. Paris: Presses Universitaires de France: 2009, p. 25.
} 
Não iremos, igualmente, buscar a coesão da obra de Celso Furtado: interessanos, muito mais, as alterações, as hesitações, os problemas formulados e reformulados à medida que a atuação prática e epistemologia teórica se movimentaram.

Finalmente, não tivemos fôlego para realizar um estudo sobre "Celso Furtado e seu tempo", no qual fosse possível reconstituir cada passo de sua vida pública, a elaboração de seu pensamento e os diversos acontecimentos sociais, econômicos, culturais dos anos de 1950. Mesmo o estabelecimento seguro dos diálogos que Celso Furtado estabeleceu com o pensamento econômico brasileiro foi dificultado pela ausência de trabalhos monográficos sobre a corrente do pensamento liberal. ${ }^{11}$ Nesse sentido, a obra de Ricardo Bielschowsky continua sendo uma fonte inestimável de informação e interpretação, razão pela qual nos valemos dela em todo esse trabalho. ${ }^{12}$ Sua erudição e acerto metodológico, ao não apenas examinar as principais correntes de pensamento econômico no Brasil, mas confrontá-las com as transformações da economia brasileira, foi a principal referência para situar Celso Furtado no conjunto de diálogos com outros economistas.

Uma última palavra dever ser dita, ainda, sobre o recorte cronológico. Optamos por balizar este estudo em dois momentos que, embora não possam deixar de ser relacionados com a conjuntura histórica brasileira e com a biografia, situam-se na publicação de escritos de Celso Furtado. Iniciamos em 1948, pois é nesse momento que aparece o primeiro texto abordando um aspecto da teoria econômica e, ao mesmo tempo, criticando-a por não considerar a experiência histórica concreta. É o momento do nascimento da abordagem da relação entre história e teoria econômica, não mais considerada com ênfase na perspectiva histórica, como aconteceu em Economia colonial no Brasil nos séculos XVI e XVII, mas, agora, num esforço que se renovará em outros escritos, de questionar a teoria a partir da realidade dos países atrasados, subdesenvolvidos. Este é um dos motes unificadores da obra de Celso Furtado e que este trabalho procura assinalar.

Essa preocupação não tem um desfecho, sendo reiterada, reinterpretada, reinventada durante toda a obra do economista brasileiro. Contudo, colocamos como

\footnotetext{
11 Ainda que haja trabalhos de grande valor nessa vertente, ainda faltam muitas informações para conseguirmos estabelecer a datação dos principais textos de autores como Eugênio Gudin, Roberto Campos e Octávio Gouveia de Bulhões, já que muitas das reedições e coletâneas de seus trabalhos não trazem a data e o local de publicação. Isso dificultou enormemente o trabalho de confronto entre os textos dos autores.

12 BIELSCHOWISKY, Ricardo. Pensamento econômico brasileiro. O ciclo ideológico do desenvolvimentismo, 1930-1964. Rio de Janeiro: Contraponto Editora, 2000. .
} 
limite cronológico justamente a publicação de Formação Econômica do Brasil, em 1959 que, nos parece, sintetiza os esforços dos últimos dez anos de embate para a formulação de uma teoria do subdesenvolvimento que conseguisse captar as especificidades da economia brasileira. Também do ponto de vista biográfico, este livro marca a consolidação de uma fase, pois é escrito depois de seu desligamento da Cepal e antes de dedicar-se com afinco aos problemas do Nordeste, que, no entanto, já recebem um tratamento significativo nesta obra. Marca, também, os estertores da vontade política de desenvolvimento econômico, pois é neste ano que o Plano de Metas começa mostrar sua face "perversa", com aumento da inflação, deterioração das contas públicas e aumento das tensões sociais que irão mergulhar o Brasil, alguns anos mais tarde, em um período de ditadura militar.

Do ponto de vista da obra de Celso Furtado, a opção poderia ser pelo término da análise em Desenvolvimento e subdesenvolvimento (1961). Entretanto, como iremos salientar ao longo deste trabalho, os principais passos teórico-metodológicos para este livro foram dados nos anos que examinamos, além de que este volume reaproveita um conjunto de escritos publicados durante a década de 1950.

Ademais, o exame de Formação econômica do Brasil nos pareceu um bom ponto de chegada pois, como iremos argumentar, ele marca uma conjuntura específica: de arrefecimento da corrente liberal e de consolidação do desenvolvimentismo. Dessa forma, o livro nos colocou uma questão a mais, em se tratando de nosso método historiográfico: em que medida a escritura desse livro revela essa supremacia do desenvolvimentismo. Dito de outra forma, qual a consequência, para uma obra escrita sempre em combate e com uma ênfase propositiva de política econômica, surgir em um momento de arrefecimento do debate, de diminuição da artilharia de Celso Furtado. Essa conjuntura teria aberto uma possiblidade para um maior refino teóricometodológico?

A tese está dividida em cinco partes. De início, examinamos as primeiras propostas de conciliação entre teoria econômica e história, tanto sob a perspectiva teórica, quanto no exame da conjuntura da economia brasileira, em princípios dos anos de 1950. Iremos, também, indicar brevemente a importância da Cepal nesse período inicial de Celso Furtado como um economista.

A segunda examina as possibilidades de operacionalização da política econômica cepalina, através do planejamento econômico. Neste momento trava-se um diálogo denso entre Celso Furtado e Raúl Prebisch, de um lado e Otávio Bulhões e 
Eugênio Gudin, de outro. O embate travado sobre a questão da planificação terá consequências marcantes na obra de Celso Furtado.

Em seguida, nos detemos na análise do livro A economia brasileira, precursor de Formação econômica do Brasil, no que se refere, sobretudo, à análise da economia cafeeira e sua crise, e a primeira síntese dos problemas com os quais Celso Furtado se defrontou até 1954: a questão da teoria do desenvolvimento econômico e seu relação com a história; a elaboração de diagnósticos sobre a conjuntura econômica brasileira; a busca de uma fundamentação epistemológica para as duas questões anteriores, expressa na revisão da história do pensamento econômico.

A quarta parte trata da maturação do pensamento de Celso Furtado, agora consolidado ao ponto de tornar-se a referência crítica para o exame de obras sobre teoria econômica, conjuntura brasileira e planejamento econômico.

Finalmente, examinaremos Formação econômica do Brasil, buscando captar sua relação com a maturação do pensamento de Celso Furtado. Para além disso, tentaremos recuperar em que medida esta obra organiza as temporalidades, o presente, o passado e o futuro na construção de uma visão integrada da formação da economia brasileira que é, também, a consolidação epistemológica de uma teoria econômica vazada pela história e pelos conceitos das ciências sociais. 
Capítulo 1: (Re)conhecendo a economia brasileira 


\section{As armadilhas da teoria econômica e a necessidade da história}

Captar os momentos mais imediatos da vida de Celso Furtado significa, para o historiador, deixar de procurar o economista, o formulador da teoria do subdesenvolvimento, o técnico que participou de diversas missões internacionais e que esteve à frente da política econômica de três presidentes do Brasil. Para isso, o principal obstáculo deriva do fato de que sua trajetória vem sendo reconstituída a partir dos resultados mais significativos de sua vida intelectual, particularmente, sua formulação da teoria do subdesenvolvimento. Por outro lado, a herança de Celso Furtado nos estudos sobre economia brasileira e na história do pensamento econômico no Brasil ainda modula grande parte das interpretações sobre sua obra, tornando difícil ao intérprete deslindar as escolhas e os percalços que o levaram a se dedicar à economia e, mesmo, a forma como compreendeu esse território do saber. Uma circunstância dificulta ainda mais esse processo: a necessidade incontornável de recorrer aos escritos autobiográficos de Celso Furtado, que reconstituem e organizam sua trajetória, inevitavelmente sinalizando ao intérprete os momentos-chave de sua vida, as circunstâncias formadoras, as decisões importantes e as escolhas definitivas em seu percurso. Estes escritos autobiográficos, mesmo que iluminem o contexto imediato da atuação de Celso Furtado, quando não confrontados com outros documentos e fontes sobretudo com seus próprios textos, muitos dos quais não mencionados ou referidos apenas alusivamente em sua obra autobiográfica — de alguma maneira prenderam os intérpretes numa espécie de camisa de força conceitual ${ }^{13}$, de forma que as reconstituições de sua trajetória se associam ao próprio relato autobiográfico, gerando

\footnotetext{
${ }^{13}$ Para fins comparativos, indicamos duas reconstituições baseadas nos escritos autobiográficos e que chegam a conclusões quase idênticas, variando unicamente em ênfase: GUIMARÃES NETO, Leonardo: "Itinerário de Celso Furtado até Formação econômica do Brasil". In: ARAÚJO, Tarcisio Patricio de; WERNECK VIANNA, Salvador Teixeira; MACAMBIRA, Júnior. (orgs) 50 anos de Formação Econômica do Brasil: ensaios sobre a obra clássica de Celso Furtado. Rio de Janeiro: Ipea, 2009, pp. 247 270; MENDONÇA, Marina Gusmão de. "A formação intelectual de Celso Furtado". In: CORSI, Francisco Luiz; CAMARGO, José Marangoni (orgs). Celso Furtado e os desafios do desenvolvimento. Marília-SP: Oficina Universitária, 2010, pp. 1-19. Entretanto, fique subentendido que muitos estudos de fôlego também utilizaram quase como fonte única de sua reconstituição os volumes autobiográficos de Celso Furtado.
} 
um curto-circuito que nubla a inteligibilidade de alguns momentos cruciais na vida de Celso Furtado. ${ }^{14}$

Embora não pretendamos solucionar essas questões de fundo, propomos localizar o momento decisivo na trajetória de Celso Furtado em que suas preocupações se voltaram predominantemente ao campo da Economia. Essa mudança pode ser captada com a passagem de suas reflexões sobre Teoria Geral da Administração, o papel do Estado em vias de crescente burocratização e suas análises de política econômica para a discussão sobre teoria econômica e, em seguida, para o estudo da economia brasileira.

Para tanto, além dos textos de Celso Furtado escritos no período entre 1946 e 1948 - e que refletem as preocupações mencionadas - nos deteremos em duas resenhas publicadas na Revista Brasileira de Economia, a primeira no final de 1948 e a segunda no primeiro trimestre de 1949, ou seja, os últimos escritos anteriores à sua entrada na Comissão Econômica para América Latina e Caribe (CEPAL). A ênfase nos comentários críticos às obras Les mecanismes de prix de Jean Marchal ${ }^{15}$ e Trustes y carteles, sus orígenes y influencia en la economia mundial, de Richard Lewinsohn ${ }^{16}$ permite discutir a abordagem segundo a qual a dedicação ao campo econômico, assinalada por alguns interpretes, se iniciou após seu trabalho na Cepal ou em período posterior. Támas Szmrecsányi, por exemplo, pontua que após o ingresso na Comissão da ONU, os temas presentes na tese de doutorado "foram mantidos apenas em parte nas obras subsequentes de Celso Furtado", enquanto os objetivos gerais:

acabaram sendo descartados por ele já nos primeiros trabalhos que publicou após a sua volta da França e seu ingresso na Cepal. Tais preocupações foram substituídas por uma visão de mundo essencialmente econômica, para não dizer economicista e tecnocrática, tornando mais difícil o entendimento de seus trabalhos para os leitores desprovidos de maiores conhecimentos de Economia $^{17}$

\footnotetext{
${ }^{14}$ Para uma abordagem crítica sobre a autobiografia: BOURDIEU, Pierre. “A Ilusão Biográfica” [1986]. In: AMADO, Janaína; FERREIRA, Marieta de Moraes (coord). Usos e abusos da história oral. Rio de Janeiro, Editora FGV, 2006, p. 183-191; uma crítica a essa abordagem, é empreendida por, DOSSE, François. O desafio biográfico: São Paulo: Edusp, 2010. Uma análise dos escritos autobiográficos de Celso Furtado que incorpora essas reflexões e as confronta com os trabalhos sobre retórica na economia pode ser encontrada em: VIEIRA, Rosa Maria. "Celso Furtado: autorretrato e retórica". In: BRESSERPEREIRA, L. C. \& REGO, J. M. A grande esperança em Celso Furtado. Ensaios em homenagem aos seus 80 anos. São Paulo: Editora 34, 2001, pp. 157-165.

${ }^{15}$ FURTADO, Celso. Resenha de Jean Marchal, Les mecanismes de prix. Librarie de Médicis, 1948. Revista Brasileira de Economia, v. 2; n. 4, 1948, pp. 174-177.

${ }^{16}$ FURTADO, Celso. Resenha de Richard Lewinsohn, Trustes y carteles, sus orígenes y influencia en la economia mundial. Editorial Claridad: Buenos Aires, 1948. Revista Brasileira de Economia, v. 3; n. 1, 1949, pp. 103-106.

17 SZMRECSÁNYI, Tamás. Sobre a formação da Formação econômica do Brasil de C. Furtado. In: Estudos Avançados. São Paulo: EDUSP, 13(37), 1999, pp. 210-211. Em outro texto, “dedicado apenas ao pensamento propriamente econômico de Furtado", Támas Szmrecsányi encontra no ensaio de 1952,
} 
O período referido entre "sua volta da França e seu ingresso na Cepal" compreende os meses em que Celso Furtado trabalhou na revista Conjuntura Econômica, editada pela Fundação Getúlio Vargas, e durante os quais publicou as duas resenhas que iremos analisar. Esse intervalo entre sua estadia na França e sua viagem para Santiago tornou-se um hiato para grande parte da bibliografia, ${ }^{18}$ ou apenas uma menção sem grandes consequências ${ }^{19}$ para a trajetória de Celso Furtado, não suscitando análises mais detidas sobre os textos desse período. Maurício Coutinho, raciocinando a partir dos textos posteriores de Celso Furtado sobre teoria econômica, sobretudo a partir de 1954, afirma que:

os estudos de doutoramento em Paris, concluídos em 1948, ofereceram-lhe a oportunidade de obter um aprendizado mais sistemático em teoria econômica. De fato, apesar de haver escolhido como objeto de tese um tema histórico, e de tê-lo desenvolvido sob a supervisão de um historiador, Maurice Byé, os estudos doutorais envolveram a realização de uma revisão ampla da teoria econômica ${ }^{20}$

Essa hipótese aventada por Coutinho destaca o aprendizado de teoria econômica, o que explicaria a ampla revisão sobre a história do pensamento econômico e da teoria econômica que Celso Furtado iniciará no livro Economia Brasileira [1954] e que receberá um tratamento aprofundado em Desenvolvimento e subdesenvolvimento [1961]. Por outro lado, a importância da teoria econômica pode ser ainda mais enfatizada se considerarmos que Maurice Byé, nessa época, já se preocupava com as

\footnotetext{
"Formação de capital e desenvolvimento econômico", traduzido em 1954 para o inglês na International Economic Papers o "surgimento de Celso Furtado como um economista de renome internacional": SZMRECSÁNYI, Támas. Celso Furtado. Estudos Avançados. vol.15 no. 43. São Paulo: Sept./ Dec. 2001, p. 347.

${ }^{18}$ Carlos Mallorquin, autor de uma das interpretações mais densas da obra de Celso Furtado, assim elipsa o período: "sin haber mediado mucho tempo entre su tesis y retorno a Brasil en 1948, toma vuelo para Santiago de Chile...". MALLORQUIN, Carlos, "Celso Furtado el hacedor del estruturalismo latinoamericano". In: CORSI, Francisco Luiz; CAMARGO, José Marangoni (orgs). Celso Furtado e os desafios do desenvolvimento. Marília-SP: Oficina Universitária, 2010, p, 58; em seu grande estudo sobre a trajetória intelectual de Celso Furtado, ao analisar "os primeiros trabalhos e aproximações de Furtado na cena econômica", inicia se detendo nas diversas versões do texto de 1952, "Formação de capital e desenvolvimento econômico", como já o fizera Szmrecsányi. MALLORQUIN, Carlos. Celso Furtado: um retrato intelectual. [1993] São Paulo: Xamã; Rio de Janeiro: Contraponto, 2005, pp. 49-52;

${ }^{19}$ Por exemplo: LOVE, Joseph. A Construção do Terceiro Mundo. Teorias do subdesenvolvimento no Brasil e na Romênia. Rio de Janeiro: Paz e Terra, 1995, pp. 361-362; MENDONÇA, Marina Gusmão de. "A formação intelectual de Celso Furtado". In: CORSI, Francisco Luiz; CAMARGO, José Marangoni (orgs). Celso Furtado e os desafios do desenvolvimento. Marília-SP: Oficina Universitária, 2010, pp. 8-9.

${ }^{20}$ COUTINHO, Maurício C. "A teoria econômica de Celso Furtado: formação econômica do Brasil." In: LIMA, Marcos Costa. \& DAVID, Maurício Dias (orgs). A atualidade do Pensamento de Celso Furtado. Goiás: Verbena Editora, 2008, p. 141.
} 
teorias do comércio internacional, um tema que tem seus fundamentos na obra de David Ricardo. $^{21}$

Apenas em trabalho recente de Afrânio Garcia encontramos uma ponderação sobre a passagem de Celso Furtado na Fundação Getúlio Vargas e uma hipótese sobre sua partida para a Cepal em 1949. O antropólogo, examinando as narrativas autobiográficas de Celso Furtado, chama a atenção para o período que iremos examinar:

sua entrada no espaço dos economistas brasileiros se deu através do polo cosmopolita e neoclássico, de quem se demarcaria nos anos 50, pois na FGV pontificavam Eugênio Gudin e Otávio Gouveia de Bulhões, grandes herdeiros de famílias tradicionais instaladas na capital e ferrenhos adeptos dos dogmas neoclássicos e partidários da especialização do Brasil em exportações de produtos agrícolas ou minerais, por crença no "teorema das vantagens comparativas" 22

Afrânio Garcia deslinda um elemento importante na problemática que pretendemos analisar ao assinalar o trabalho de Celso Furtado no espaço da Fundação Getúlio Vargas, entre os economistas cosmopolitas e neoclássicos ${ }^{23}$, cujas concepções sobre a teoria e o ensino de economia no Brasil serão contestadas, nos anos subsequentes, pela Cepal e por Celso Furtado. Nesse sentido, destacamos não apenas o período entre a volta do Brasil e embarque para a Cepal, como enfatizamos a necessidade de compreender sua relação com os economistas brasileiros ligados à FGV. Por outro lado, dada essa inserção institucional, caberia perguntar também sobre os motivos que o levaram, alguns meses depois, a abandonar o posto e embarcar para uma comissão da ONU, então em caráter temporário ${ }^{24}$, sem um grande economista que lhe

\footnotetext{
${ }^{21}$ Sobre as preocupações de Maurice Byé, consulte-se: ALCOUFFE, Alain. "Furtado, o Brasil e os economistas franceses: influências cruzadas". In: COELHO, Francisco Silva \& GRANZIERA, Rui Guilherme (orgs). Celso Furtado e a Formação econômica do Brasil (Edição comemorativa dos 50 anos de publicação (1959-2009)). Prefácio Fernando Henrique Cardoso. São Paulo, Editora Atlas, 2009, p. 44 45.

${ }^{22}$ GARCIA, Afrânio. Entre fardas, fantasias e figurinos matemáticos para simbolizar condutas humanas: a "obra autobiográfica de Celso Furtado". Trabalho apresentado no Simpósio El recuerdo letrado: escritura memorialistica de artistas e intelectuales latinoamericanos del siglo XX. Buenos Aires, 23-35 de noviembre de 2011. [Texto provisório], fl. 8.

${ }^{23}$ As denominações para as escolas de pensamento econômico no Brasil são divergentes. Hélio Jaguaribe utiliza a oposição entre cosmopolitas e desenvolvimentistas nacionalistas. Ricardo Bielschowsky, entretanto, identifica cinco correntes de pensamento no Brasil: socialista, neoliberal e três correntes desenvolvimentista (do setor privado, desenvolvimentista não-nacionalista do setor público e desenvolvimentista nacionalista do setor público). Adotaremos esta distinção de Ricardo Bielschowsky, porém preferindo designar a corrente neoliberal apenas como liberal, para evitar confusão com o movimento surgido após o Consenso de Washington. BIELSCHOWSKY, Ricardo. Pensamento econômico Brasileiro. O ciclo ideológico do desenvolvimentismo. 1930-1964. Rio de Janeiro: Contraponto, 2003.

${ }^{24}$ Seguindo a narrativa de Edgar Dosman, em 1946, os EUA propuseram "duas comissões regionais dentro do Conselho Econômico e Social da ONU: a Comissão Econômica para a Europa (ECE), com secretariado em Genebra, e a Comissão Econômica para a Ásia e o Extremo Oriente (Ecafe)." O governo do Chile, com apoio de Cuba, Peru e Venezuela, propuseram a criação de uma CEPAL. A criação da Cepal foi contestada pela existência da União Pan-Americana, que contava com um Conselho Econômico
} 
garantisse o mesmo prestígio que a Comissão Econômica para a Europa, sob a direção do economista sueco Gunnar Myrdal, por exemplo. Refletindo sobre os motivos que o levaram a tomar essa decisão, Afrânio Garcia pondera que:

\begin{abstract}
não demonstra haver sido contrariado em sua passagem pela FGV, nem de estar sendo mal remunerado. Diferentemente da diversidade de motivos adiantados para a segunda viagem à Europa, onde todos têm sua pertinência, a simples desilusão, com o nível dos debates intelectuais no Brasil, não parece ser suficiente para tantos investimentos materiais e emocionais implicados nessa mudança de rumos. [...] Possivelmente a residência em Santiago, meio caminho entre Buenos Aires e o Rio, tivesse atrativos outros que razões de ordem intelectual ou profissional ${ }^{25}$
\end{abstract}

Ao final da citação, Garcia refere-se ao casamento com a argentina Lucia Tosi e o nascimento do primeiro filho do casal. Entretanto, sem desconsiderar esses fatores de ordem pessoal, talvez seja possível aventar que sua estadia no Brasil e os trabalhos que publicou enquanto funcionário da Fundação Getúlio Vargas tenham contribuído para a formação e o estabelecimento de alianças e de confrontos com outros economistas no Brasil, além de ter permitido ao jovem recém-doutorado em economia uma visada sobre as transformações pelas quais passava o Estado brasileiro no que se refere à produção de conhecimento e à intervenção na economia, bem como aos grupos que coordenavam e protagonizavam essas tarefas. Assim, a partir das resenhas publicadas na Revista Brasileira de Economia, pretendemos levantar algumas hipóteses para interpretar as escolhas e adesões intelectuais que formulou, seja como consequência e resultado da consolidação de seus estudos anteriores, seja como posicionamento frente a algumas questões importantes do período.

Para tanto, iremos: assinalar a posição ocupada pela Fundação Getúlio Vargas na produção de conhecimento econômico e sua importância no auxílio à elaboração da política econômica do Estado brasileiro; retomar brevemente as reflexões sobre Teoria Geral da Administração e política econômica escritas por Celso Furtado entre 1946 e 1948, período imediatamente anterior às resenhas publicadas na Revista Brasileira de Economia. Em seguida, examinamos as resenhas, destacando em que medida iluminam o direcionamento de Celso Furtado para o campo econômico e, também, a decisão de

e Social. Uma comissão foi criada para analisar o caso e argumentou sobre a "utilização excessiva de equipamentos de capital nos tempos de guerra, a necessidade de assistência externa para fortalecer o desenvolvimento na região e o alto custo de reparação das perdas econômicas". DOSMAN, J. Raúl Prebisch (1901-1986): a construção da América Latina e do terceiro mundo. Rio de Janeiro: Contraponto, 2011, p. 273-273. Sobre o assunto, ver também: MORAIS, Reginaldo. Celso Furtado: o subdesenvolvimento e as ideais da Cepal. São Paulo: Editora Ática, 1995.

${ }^{25}$ GARCIA, Afrânio. Entre fardas, fantasias e figurinos matemáticos para simbolizar condutas humanas: a "obra autobiográfica de Celso Furtado". op. cit., fls. 8-9. 
aceitar a proposta de trabalho na Comissão Econômica para a América Latina. Finalmente, apontamos uma mudança em seu enfoque, vislumbrada em alguns trechos do primeiro relatório da Cepal, onde discutiu as relações entre industrialização e comércio exterior e, em seguida, na reformulação de sua interpretação sobre a economia brasileira no período recente, para a qual os influxos cepalinos tiveram grande relevância.

A importância das instituições de intervenção econômica criadas no bojo da crise econômica internacional de 1929 e da Revolução de 1930 é apontada por diversos estudiosos como o campo de aprendizagem, discussão e explicitação mais imediata da formação do pensamento econômico no Brasil, enfatizando que este se constituiu a partir de posições e oposições que são definidas, contrapostas e redesenhadas por questões práticas e objetivas. ${ }^{26}$

A crise mundial do capitalismo inaugurada em 24 de outubro de 1929 com o crack da Bolsa de Nova York e cujas repercussões nos Estados Unidos se prolongaram até 1938, atingiu fortemente os países da América Latina, produtores de bens primários dependentes da demanda dos centros industriais. Dadas as condições impostas pela crise, a queda dos preços das commodities e a adoção de medidas recessivas de desvalorização cambial e abandono do padrão ouro-libra pelos países industrializados europeus (salvo a França, que o manteve até 1938), a reação de alguns países latinoamericanos, México, Brasil, Chile e Argentina, se concentrou no esforço de superação do modelo de crescimento econômico baseado na agroexportação e a construção de um novo padrão de acumulação, agora baseado no crescimento industrial. ${ }^{27}$

\footnotetext{
${ }^{26}$ A compreensão de que as escolas de pensamento econômico se definem não apenas por princípios gerais, mas a partir de contradições e dilemas que se manifestam objetivamente no tratamento da política econômica é desenvolvida por Eduardo Scaletsky, ao assinalar que "a ortodoxia, convém ressaltarmos, só pode ser pensada historicamente, ou seja, "não existe ortodoxia senão em oposição à heterodoxia. Assim, considerarmos ortodoxo o posicionamento da Missão Abbink, implica, por oposição, comprovar-se a existência de alternativa viável de política econômica, na qual não predomine o abandono dos objetivos desenvolvimentistas ou, por outro caminho: mostramos que a vitória das propostas de saneamento implicariam em negligenciar-se os planos de médio e longo prazos". SCALETSKY, Eduardo Carnos. Dois projetos para o Brasil: 1945-1954. Uma análise dos Projetos da Missão Abbink, da Comissão Mista Brasil-Estados Unidos e do Grupo Misto BNDE-Cepal. Dissertação de Mestrado, UFRGS, 1988, fls. 3839; SOLA, Lourdes. Ideias econômicas, decisões políticas. Desenvolvimento, estabilidade e populismo: São Paulo: Fapesp, Edusp, 1998; LOUREIRO, M. R. Economistas no Governo. Rio de Janeiro: FGV, 1997. BIELSCHOWSKY, R. Pensamento econômico brasileiro. O ciclo ideológico do desenvolvimentismo 1930-1964. Rio de Janeiro: Contraponto, 2000.

${ }^{27}$ Wilson Cano vê ainda na década de 1920 uma expressiva capacidade produtiva industrial, seja na diversificação da produção de bens de consumo, seja no de bens de produção, nos ramos têxtil, material elétrico, metalurgia, cimento, etc. Veja-se: CANO, Wilson. "Crise de 29, soberania na política econômica e industrialização". In: BASTOS \& FONSECA (orgs). A era Vargas: desenvolvimentismo, economia e sociedade. São Paulo: Editora da Unesp, 2012, pp. 130-135; BASTOS, P. P. Z. "Ortodoxia e heterodoxia
} 
Nesse processo de crise econômica do sistema capitalista, cuja repercussão mais importante no Brasil foi evidenciar o esgotamento da dinâmica econômica de crescimento baseado nas exportações, emerge como expressão desse momento de crise a alteração do poder político representado pela Revolução de $1930 .{ }^{28}$

A Revolução de 30 e, mais especificamente, a ampliação da participação do Executivo em diversos setores da vida social, sobretudo na condução econômica do Brasil após 1937, deu ensejo a um processo de demanda crescente por técnicos, em particular, os economistas. Ao mesmo tempo, a própria intervenção do Estado na economia foi produzindo as condições para que esse saber se consolidasse. ${ }^{29}$ Desse conjunto de necessidades para a superação da crise econômica, surgiram as primeiras experiências de planejamento econômico, com a finalidade de mapear os recursos naturais e humanos disponíveis na economia brasileira, bem como sugerir formas de utilização desses recursos que elevassem a eficiência da economia brasileira. Para tanto, diversos órgãos, técnicos, consultivos e associações de classe foram constituídos ${ }^{30}$, cabendo salientar que representavam interesses díspares, configurando zonas de conflitos entre projetos sociais, muitas vezes expressos por meio do discurso econômico. Assim, seja no Estado, seja nas associações de classe, o saber e as técnicas de organização e execução de medidas econômicas emergiam como requisitos fundamentais. Num país onde os primeiros cursos de economia estavam sendo implementados, as atividades nesses órgãos executivos se tornaram verdadeiras "escolas práticas”, e o saber econômico surge diretamente envolvido com a prática e a execução da política econômica.

econômica antes e durante a era Vargas". In: BASTOS \& FONSECA (orgs). A era Vargas... op. cit., pp.183-184.

${ }^{28}$ DRAIBE, Sonia. Rumos e metamorfoses. Um estudo sobre a constituição do Estado e as alternativas da industrialização no Brasil , 1930-1960. Rio de Janeiro: Paz e Terra, 2004; FONSECA, Pedro Cezar Dutra Fonseca. Vargas: o capitalismo em construção, 1906-1954. São Paulo: Editora Brasiliense, 1999; IANNI, Octavio. Estado e planejamento econômico no Brasil. 2a ed. Rio de Janeiro, Civilização Brasileira, 1977. ${ }^{29}$ LOUREIRO, M. R. Economistas no governo. op. cit.

${ }^{30}$ Entre os principais órgãos criados com o objetivo de intervir na realidade econômica, podemos elencar o Conselho Federal de Comércio Exterior [1934], o Conselho Técnico de Economia e Finanças [1937], a Coordenação de Mobilização Econômica [1942], Conselho Nacional de Política Industrial e Comercial [1944], Comissão de Planejamento Econômico [1944]. A esses órgãos ligados ao executivo, destaca-se, também o Departamento de Administração do Serviço Público [1938], responsável pela elaboração do Plano de Obras e Equipamentos [1943] e o Plano Salte [1949]. Somam-se também as missões firmadas em cooperação com os Estados Unidos, como a Missão Cooke [1942] e a Missão Abbink [1948]. A apreciação detalhada desses órgãos e comissões está além das possibilidades deste trabalho. Veja-se: PAULA, Christiane Jalles; LATTMAN-WELTMAN, Fernando (Coord). Dicionário Histórico Biográfico Brasileiro Pós -30: Rio de Janeiro: CPDOC/FGV. Disponível em http://cpdoc.fgv.br/acervo/dhbb. Acesso em 25/09/2012; MONTEIRO, Jorge Vianna; CUNHA, Luiz Roberto Azevedo. Alguns aspectos da evolução do planejamento econômico no Brasil. Pesquisa e Planejamento econômico. Rio de Janeiro, V. 4, N. 1, Fevereiro de 1974, pp. 1-24. 
Esse conjunto de preocupações com a questão do Estado não foi capaz de criar um consenso entre os diversos órgãos de execução da política econômica, explicitando, por outro lado, um processo de disputa por projetos político-econômicos. Assim, sob o ponto de vista da compreensão das tensões no debate econômico vivenciadas por Celso Furtado no momento de seu regresso ao Brasil, importa destacar a corrente "neoliberal" 31 , caracterizada pela defesa da "prioridade da livre movimentação das forças de mercado". Embora seus principais representantes reconheçam a importância da industrialização e a legitimidade das propostas desenvolvimentistas, o cerne de suas proposições residia no esforço em "estabelecer as condições de equilíbrio monetário e financeiro" ${ }^{32}$, constituindo-se, no período, como "uma ativa participante do debate, seja como formuladora de políticas econômicas criticadas pelos desenvolvimentistas, seja como formuladora de críticas às proposições destes últimos". ${ }^{33}$ Entre seus aspectos fundamentais estavam a redução da intervenção estatal, a defesa de políticas de equilíbrio monetário e financeiro sem consideração para seus reflexos sobre o emprego e a renda e a recusa de uma política deliberada de apoio e proteção à indústria. ${ }^{34}$ Ainda cabe notar que "o principal núcleo de militância intelectual dos economistas neoliberais foi a Fundação Getúlio Vargas. Pouco depois da sua fundação, em 1944, Eugênio Gudin e Otavio Gouvêa de Bulhões lograram formar uma sólida divisão de pesquisas econômicas que, em 1950, ganhou o nome de Instituto Brasileiro de Economia (Ibre)". 35

Criada por ex-funcionários do DASP em 1946, e dirigida por Luis Simões Lopes até 1992, a Fundação Getúlio Vargas tinha como principal objetivo "a formação dos quadros necessários à modernização do Estado". ${ }^{36}$ As discussões sobre economia, comandadas por Eugênio Gudin ${ }^{37}$, ganharam fôlego e se desenvolveram a partir de

\footnotetext{
${ }^{31} \mathrm{O}$ prefixo neo, segundo Bielschowsky, "representa o fato de que os liberais brasileiros, em sua maioria, passavam a admitir, na nova realidade posterior a 1930, a necessidade de alguma intervenção estatal....". Ver: BIELSCHOWSKY, Ricardo. Ideologia e desenvolvimento: Brasil, 1930-1964. In: LOUREIRO, Maria Rita. 50 anos de ciência econômica no Brasil. Pensamento, instituições, depoimentos. Rio de Janeiro: Editora Vozes, 1997, p. 71.

32 BIELSCHOWSKY, Ricardo. Pensamento econômico brasileiro. O ciclo ideológico do desenvolvimentismo, 1930-1964. Rio de Janeiro: Contraponto Editora, 2000, p. 33.

${ }^{33}$ Idem, p. 37.

${ }^{34}$ Idem, p. 38-39.

${ }^{35}$ Idem, pp. 37-38.

${ }^{36}$ LOUREIRO, Maria Rita. Economistas no Governo. Rio de Janeiro, FGV, 1997, p. 38.

${ }^{37}$ Os dados biográficos de Eugênio Gudin, extraídos do $D H B B$, permitem vislumbrar a importância deste engenheiro em diversas comissões governamentais, que incluía até esse momento a Comissão de Estudos Financeiros e Econômicos do Ministério da Fazenda (1931), Comissão Mista de Reforma Econômica e Financeira (1935), Conselho Técnico de Economia e Finanças do Ministério da Fazenda, Conselho Nacional de economia (1944). Além disso, fora delegado brasileiro nas conferências de Bretton Woods e
} 
1947 com a criação da Revista Brasileira de Economia, de periodicidade trimestral, e a publicação mensal Conjuntura Econômica, ambas lançadas neste mesmo ano. A última, organizada pelo Centro de Análise da Conjuntura Econômica do Núcleo de Economia da Fundação Getúlio Vargas, sob a direção de Richard Lewinsohn, e tendo como redator-chefe Américo Barbosa de Oliveira, dedicou-se ao estudo e elaboração de índices econômicos: contas nacionais, balanço de pagamentos, índices de produção, preços, dados monetários e bancários. No número inaugural de Conjuntura Econômica, Eugênio Gudin ressalta a necessidade, sobretudo após a Guerra, da "observação contínua e vigilante da conjuntura econômica nacional e internacional". ${ }^{38}$ Cabe notar, também, como o esforço da Fundação insere-se num amplo movimento realizado por diversos setores do Estado e de associações privadas brasileiras: "com a cooperação de vários departamentos públicos e de organizações particulares, pode, agora, aquele Centro, depois de árduos trabalhos preparatórios, iniciar a publicação deste Boletim Mensal, destinado a divulgar, sob forma condensada, e a todos acessível, os principais índices de produção, do comércio, das finanças, do movimento bancário, etc., acompanhados de indispensáveis comentários e interpretações”. ${ }^{39}$ Esforço, portanto, sob os auspícios da Fundação Getúlio Vargas, mas que certamente encontra eco nas necessidades de diversos setores produtivos, servindo, também, como um instrumento imprescindível de trabalho nos cursos de economia que estavam sendo criados. Ainda sobre a Conjuntura Econômica, é preciso notar que, segundo Ricardo Bielschowsky, a influência de Eugênio Gudin e Otávio Gouveia de Bulhões ${ }^{40}$ apenas se consolidou em 1952. Antes disso, a revista "estivera sob a direção de intelectuais da linha

membro integrante da Missão Abbink, junto com Octávio Gouveia de Bulhões. Veja: "Eugênio Gudin". In: PAULA, Christiane Jalles; LATTMAN-WELTMAN, Fernando (Coord). Dicionário Histórico Biográfico Brasileiro Pós -30. Rio de Janeiro: CPDOC/FGV. Disponível em http://cpdoc.fgv.br/acervo/dhbb. Acesso em 02/10/2012.

${ }^{38}$ GUDIN, Eugênio. Apresentação. Conjuntura Econômica. Ano 1. Número 1, Novembro de 1947, p. 1.

${ }^{39}$ Idem, ibidem.

${ }^{40}$ Octávio Gouvêa de Bulhões, bacharel em direito, de início autodidata no estudo da economia, depois consolidando sua formação com uma especialização em economia na American University, exerceu diversos cargos executivos na área econômica, sendo funcionário de carreira do Ministério da fazenda, tendo também uma importante participação na criação da FNCE. Sua inserção e o cerne de suas preocupações econômicas estiveram dirigidas para as questões monetárias, tendo tido também papel crucial na criação de órgãos e instrumentos reguladores, com destaque para a SUMOC. Pensando na relação entre Eugênio Gudin e Octávio Gouvêa de Bulhões, Fausto Saretta destaca que "o que unia esses economistas, e dava maior substrato ao pensamento e à atuação deles, foi a ênfase nas questões monetárias, vale dizer, na estabilidade da economia". SARETTA, Fausto. Octavio Gouvea de Bulhões. In: SZMRECSÁNYI, T; COELHO, F. S. Ensaios de história do pensamento econômico no Brasil contemporâneo. São Paulo: Atlas, 2005, p. 323. 
desenvolvimentista" ${ }^{41}$, referindo-se sobretudo a Américo Barbosa de Oliveira e ao próprio Lewinhson.

A ênfase que atribuímos à Fundação Getúlio Vargas, ao Núcleo de Economia e à revista Conjuntura Econômica permite situar o local institucional onde Celso Furtado publicou suas primeiras resenhas no campo da teoria econômica. Por outro lado, essa inserção colocou-o em contato com as instituições responsáveis pela implementação e instrumentalização da ciência econômica no Brasil e, também, com as correntes de pensamento econômico brasileiro em processo de consolidação e diferenciação, para as quais os locais de produção, difusão e reprodução do conhecimento econômico adquirem papel relevante.

Entretanto, para compreender o significado dessas resenhas no processo de formação intelectual de Celso Furtado, é preciso retomar, ainda que brevemente, a trajetória de Celso Furtado e seus escritos até esse momento.

Celso Furtado, ainda estudante na Faculdade Nacional de Direito, foi aprovado em concurso público para a função de Assistente de Organização no DASP em 1943 e no ano seguinte se tornou Técnico de Administração. ${ }^{42} \mathrm{O}$ aprendizado técnico ampliado pelo interesse em Ciências Sociais pode ser notado nos quatro artigos que publicou na Revista do Serviço Público entre 1944 e 1946. ${ }^{43}$ Esse período foi interrompido pelo engajamento no Corpo de Preparação de Oficiais da Reserva em 1944 e o recrutamento e embarque para a Itália em janeiro de 1945 na Força Expedicionária Brasileira. Permanece no Brasil de agosto de 1945 a janeiro de 1946 quando retorna à Europa, desta vez para a França, onde se matricula no doutorado em economia na Faculdade de Direito e Ciências Econômicas da Universidade de Paris. Durante o tempo em que viveu na capital francesa, Celso Furtado colaborou nas revistas Observador econômico e financeiro $^{44}$, Panfleto e Revista da semana com artigos sobre a vida cultural da juventude europeia, bem como análises de política econômica, as quais iremos dedicar

\footnotetext{
${ }^{41}$ BIELSCHOWSKY, R. op. cit., p. 38.

${ }^{42}$ Para os dados biográficos de Celso Furtado, utilizamos a cronologia disponível em: FURTADO, Celso. Obra autobiográfica. Três Tomos. Organização de Rosa Freire d'Aguiar. São Paulo, Paz e Terra, 1997.

${ }^{43}$ FURTADO, Celso. A estrutura da Comissão do Serviço Civil dos Estados Unidos. In: Revista do Serviço Público, Brasil, ano VII, v. I, n. 2, fevereiro de 1944ª , pp. 66-69; Notas sobre a administração de pessoal no Governo Federal Americano. In: Revista do Serviço Público, Brasil, ano VII, v. III, n. 1, julho de 1944b, pp. 49-53; Teoria da estrutura em organização. In: Revista do Serviço Público, Brasil, ano IX, v. I, n. 2. Brasil, fevereiro de 1946a, pp.17-26; Teoria do Departamento de Administração Geral. In: Revista do Serviço Público, Brasil, Ano, IX, v. II, n. 2. Brasil, maio de 1946b, pp. 25-32.

${ }^{44}$ CORRÊA, Maria Letícia. Um estudo sobre o debate desenvolvimentista nas páginas de O Observador Econômico e Financeiro (1936 - 1954). Anais do XXVI Simpósio Nacional de História - ANPUH, São Paulo, julho 2011.
} 
atenção adiante. Sua tese de doutorado foi defendida em 1 de julho de 1948, retornando ao Brasil no mês seguinte e reassumindo seu cargo no Departamento Administrativo do Serviço Público (DASP). Em seguida, liga-se à redação da revista mensal Conjuntura Econômica, e é nesse momento que publica as duas resenhas que iremos examinar. Para melhor compreendê-las, é necessário contrastá-las com seus textos anteriores, captando, assim, a especificidade desses dois trabalhos.

O tema geral dos artigos da Revista do Serviço Público refere-se à reforma administrativa brasileira iniciada em 1935 com a Comissão Mista da Reforma Econômico-Financeira e a lei do Reajustamento de 1937 e que culminou com a criação do DASP, previsto na Carta de 37 e implantado no ano seguinte. ${ }^{45}$ Artigos técnicos, centrados em conceitos da Teoria da Administração e suas possibilidades de adaptação ao contexto brasileiro, apenas no ultimo deles, Teoria do Departamento Geral de Administração, Celso Furtado procurou contextualizar, a nível internacional, as transformações políticas que originaram a organização racional e técnica do Estado para, em seguida, refletir sobre a experiência brasileira em administração. Quanto ao surgimento dessa ciência, temos que:

foi no momento em que o Estado - debatendo-se entre suas novas e
complexas funções e uma velha instrumentalidade - lançou mão desse
corpo de conhecimentos elaborado pelos pesquisadores das indústrias
privadas, que teve início a reforma da administração pública.
A revolução política impusera aos governos a necessidade de uma
atitude dinâmica, de um programa sistemático de ação. A reforma da
administração pública teria início, consequentemente, não na análise do
trabalho e do grupamento das tarefas, como ocorreu na indústria privada, mas
na transformação das cúpulas, na remodelação dos aparelhamentos diretores.
Ocorria, assim, no campo governamental, uma inoculação de ideias, uma
aceitação de técnicas elaboradas fora - um processo endógeno de
renovação ${ }^{46}$

Aqui, as relações entre a Teoria da Administração e a política aparecem ao relacionar o surgimento do Estado burocrático ao influxo dos processos racionais de organização e produção das empresas privadas, e sua manifestação particular no âmbito governamental na organização das cúpulas e dos aparelhos diretores. É precisamente nesse sentido que Celso Furtado analisa a reforma administrativa no Brasil:

após os primeiros dez anos de experiência, podemos hoje dizer que as soluções apresentadas para os problemas técnicos foram as mais acertadas, se

\footnotetext{
${ }^{45}$ Para informações sobre a Reforma Administrativa no Brasil, o trabalho mais completo continua sendo: WAHRLICH, Beatriz. Reforma administrativa na era Vargas. Rio de Janeiro: Ed. FGV, 1985.

${ }^{46}$ FURTADO, Celso. "Teoria do Departamento de Administração Geral”. Revista do Serviço Público. Ano, IX, Vol. II, no 2. Brasil, maio de 1946 p. 26.
} 
se tem em vista o clima igualmente revolucionário e construtivo em que se desenvolvia a reforma administrativa no Brasil $^{47}$

Cumpre ressaltar o caráter ao mesmo tempo de testemunha e de agente que Celso Furtado ocupa, ainda que em posição subordinada, nas transformações do Estado brasileiro que indicamos anteriormente. Note-se que o elogio aos "primeiros dez anos de experiência" da reforma administrativa brasileira não se aproxima da apologia. Ao contrário, o relevo dado às transformações na estrutura política e à origem empresarial da reforma administrativa indica a compreensão do caráter ideológico e conservador desta.

Essa preocupação com o Estado e as origens sociais e econômicas de suas transformações foi objeto também de outro estudo, Trajetória da democracia na América, publicado em 1947, como artigo vencedor de um concurso promovido pelo Instituto Brasil - Estados Unidos (IBEU) sobre a cultura norte-americana. Prosseguindo na mesma problemática, porém abordando o problema do Estado racional e burocrático em contraposição às origens locais do sistema político norte-americano, afirma que, "os problemas sociais acarretados pela centralização industrial tendem a exigir da ação governamental medidas igualmente centralizadas. E, à semelhança da indústria, o governo vai se tornando igualmente 'eficiente' e 'centralizado", 48 Compromete-se assim a tradição do governo local norte-americano, pois, “à proporção que o governo passa a ser estritamente uma organização de prestação de serviços, o cidadão se desinteressa pelos problemas políticos". 49 Indo às últimas consequências, Celso Furtado expõe o aspecto autoritário do moderno Estado burocrático:

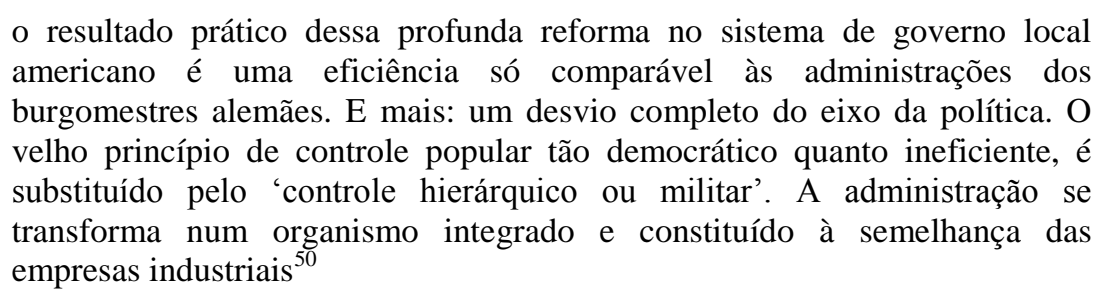

Importa, uma vez mais, destacar as reflexões de Celso Furtado sobre o Estado, aqui em seu aspecto mais geral, mas também a referência às forças sociais e econômicas

\footnotetext{
${ }^{47}$ Idem, p. 32.

${ }^{48}$ Furtado, Celso. "Trajetória da democracia na América". Revista do Instituto Brasil-Estados Unidos. Rio de Janeiro, vol. V, $\mathrm{N}^{\circ} 11,1947$, p. 18. Uma análise desse artigo, diferente da nossa, pode ser encontrada em: GUIMARÃES, M. E. Celso Furtado: A utopia da Razão. Um estudo sobre o conceito de subdesenvolvimento (1945-1964). (Tese de Doutorado). Departamento de Sociologia da FFLCH-USP, 1999.

${ }^{49}$ Idem, Furtado, Celso. "Trajetória da democracia na América”. op. cit., p. 19.

${ }^{50}$ Idem, ibidem.
} 
que pressionam as decisões políticas, com tendências cada vez mais antidemocráticas. Entretanto, o que pretendemos ressaltar nessa recapitulação é que as forças sociais e econômicas têm um papel importante nas transformações do Estado moderno, enquanto a economia ainda não apareceu como a principal esfera de explicação nas análises de Celso Furtado, manifestando-se apenas como geradora de tensões, demandando respostas do Estado.

A Economia surgirá como um objeto específico nas análises da política econômica adotadas pela Inglaterra e a França, objeto de dois artigos de Celso Furtado publicados no Observador econômico e financeiro no ano de 1948. ${ }^{51}$ Sobre a Inglaterra, a origem da sua crise econômica no pós-Segunda Guerra está na passagem dos investimentos produtivos ingleses em diversos países do mundo para um portfólio crescente de empréstimos e financiamentos às colônias e nações independentes para cobrir serviços financeiros e investimentos públicos, assumindo uma posição rentista e não mais industrial. Esse processo desenvolve-se no século XX, quando a exportação de capitais ultrapassa a de mercadorias, tendo uma série de consequências no nível e na estrutura do emprego. Nesse quadro, o objetivo específico do artigo é analisar o empréstimo norte-americano firmado em 1945, com prazo de cinco anos e que representou, na análise de Furtado, a imposição da supremacia estadunidense ao comércio e às finanças inglesas. O empréstimo foi consumido pelo governo em dois anos e agravou a situação da economia, pois entre suas cláusulas estava a exigência de conversibilidade da libra. A opção que se abria ao governo britânico em 1947 se apresentava como:

uma brusca diminuição do nível de vida indubitavelmente reforçaria a
posição da indústria inglesa no comércio internacional. Uma forma de
conseguir isso seria a desvalorização da libra. O sacrifício caberia, entretanto,
todo à classe trabalhadora. Nenhum fator será mais significativo para
elevação do nível de produtividade da indústria inglesa do que a cooperação
decisiva da classe trabalhadora. Neste sentido, todas as medidas propostas
pelos economistas acadêmicos - desemprego, rebaixamento do nível de
vida - terão um efeito extremamente negativo

Ora, interpretando as considerações de Celso Furtado, percebe-se o posicionamento antirrecessivo na orientação da política econômica. A política cambial: desvalorização da libra, inflação interna e reajustamento das exportações [já que a indústria inglesa havia perdido dinamismo desde finais do século XIX] é rechaçado pelo

\footnotetext{
${ }^{51}$ FURTADO, Celso. A crise econômica inglesa. In: Observador econômico e financeiro. Ano XII, n. ${ }^{\circ}$ 144, janeiro de 1948; França: evolução da política financeira. Observador econômico e financeiro. Ano XIII, n. ${ }^{\circ}$ 152, setembro de 1948.

${ }^{52}$ FURTADO, Celso. A crise econômica inglesa. op. cit., p. 57.
} 
seu impacto na "classe trabalhadora". Nesse sentido, contrapõe à solução monetarista proposta "pelos economistas acadêmicos" o impacto que poderia causar nos trabalhadores, justamente a classe cuja cooperação seria "decisiva" para a elevação do nível de produtividade.

Interpretação semelhante é lançada por Furtado ao examinar os problemas econômicos do pós-guerra na França. Neste país, o problema da reconstrução se colocava pela possibilidade de formação de capital para estimular as atividades. Dado o nível de renda nacional estimada em 360 bilhões de francos em 1947, a margem de investimentos só poderia ser aumentada com redução do consumo. Importante nesse sentido é a análise do Plano Meyer, iniciado em dezembro do mesmo ano, que diagnosticou o problema inflacionário como derivado do excesso de demanda e implantou uma política recessiva. Novamente, Celso Furtado alerta para os problemas que a redução do consumo traz para a classe trabalhadora.

Esses dois artigos de análise da conjuntura e da política econômica rejeitam as políticas ortodoxas de redução do consumo das massas ou de desvalorização cambial como forma de ampliar as exportações, em detrimento da manutenção do nível de emprego. Não é preciso dizer, por outro lado, que problemas cambiais, inflacionários e financeiros também eram enfrentados pelo Governo Dutra, sobretudo após o período de livre conversão de moedas, que gerou uma crise cambial, imponto o estabelecimento de controle sobre as importações, e medidas recessivas para conter o aumento no nível de preços. ${ }^{53} \mathrm{O}$ que importa destacar, nessa breve retomada dos artigos de Celso Furtado no período em que esteve na França, é justamente o interesse e a crescente presença da economia como elemento explicativo dos problemas específicos das sociedades contemporâneas. Assim, vimos como a preocupação inicial de Celso Furtado esteve voltada para a organização e a administração; esta, logo foi compreendida no âmbito da alteração das forças sociais: aumento da escala e do poder econômico das grandes empresas, reaparelhamento e burocratização do Estado para gerenciar conflitos e ampliar sua escala de atuação. Finalmente, os últimos artigos que repassamos dedicamse exclusivamente a analise de política econômica, em sua relação com os diversos

\footnotetext{
${ }^{53}$ A Inflação, decorrente do período de Guerra, porém agravada após 1945 com volta da conversibilidade do cruzeiro ao anterior ao conflito mundial, foi contida através de forte política contracionista a partir de final de 1947, impactando negativamente no nível de produção industrial e no emprego. VIANNA, S. B. "Política econômica externa e industrialização: 1946-1951". In: PAIVA, M. A. (org) A ordem do progresso. Cem anos de política econômica republicana: 1889-1989. Rio de Janeiro, Campus, p. 119; MALAN, P., Et ali. Política econômica externa e industrialização no Brasil (1939-52). Rio de Janeiro: IPEA, INPES, 1977.
} 
setores da sociedade, porém, priorizando as consequências das decisões econômicas para os trabalhadores. ${ }^{54}$

O retorno de Celso Furtado ao Brasil, em finais de 1948 e o trabalho na revista Conjuntura Econômica, marcam o início de uma inserção institucional focalizada na área econômica. É preciso recordar que o doutorado em Ciências Econômicas na Universidade de Paris era um importante fator de distinção entre os economistas de então, grande parte deles autodidata. ${ }^{55}$ Adquire, portanto, um status diferente daquele do "técnico em administração" do DASP, como assinara seus primeiros artigos. ${ }^{56}$

Com isso, examinaremos, em seguida, a publicação de seus primeiros textos após o retorno ao Brasil na Revista Brasileira de Economia, ilustrando o direcionamento à discussão da teoria econômica, sem deixar de aproveitar os resultados de seus estudos e preocupações anteriores.

\section{A primeira publicação de Celso Furtado na Revista Brasileira de Economia} apareceu no número IV, setembro/dezembro de 1948: uma resenha de quatro paginas do

\footnotetext{
54 Nesse conjunto de preocupações, apenas limites espaciais nos impedem de fazer uma discussão aprofundada da tese de doutorado de Celso Furtado, Economia colonial brasileira nos séculos XVI $e$ XVII, defendida em 1 de julho de 1948 na Faculdade de Direito da Universidade de Paris. Ressaltem-se, apenas, seus temas gerais: a preocupação em compreender o processo de formação do Estado português como resultado de uma revolução burguesa, que deu ensejo às Grandes Navegações e, em seguida ao povoamento e colonização do Brasil no âmbito de uma empresa comercial baseada na grande propriedade monocultora escravista destinada a produzir artigos de grande valor no comércio internacional. Nesse sentido, cumpre destacar as consequências do regime de propriedade e de trabalho para a formação da futura nação brasileira, devido aos problemas estruturais que legou, tais como diversas regiões de subsistência desintegradas, atraso técnico e a criação de fortes interesses regionais localizados que impediram a consolidação da nação no Brasil. Do ponto de vista teórico, cumpre ressaltar a presença dos trabalhos de François Perroux sobre as assimetrias de poder no comércio internacional e a análise da plantation escravista empreendida por Caio Prado Júnior. Sobre a tese de doutorado de Celso Furtado, consulte-se: GUIMARÃES, Maria Eugênia. Celso Furtado: A utopia da Razão. Um estudo sobre o conceito de subdesenvolvimento (1945-1964). (Tese de Doutorado. Departamento de Sociologia da FFLCH-USP, 1999); SZMRECSÁNYI, Tamás. Sobre a formação da Formação econômica do Brasil de C. Furtado. In: Estudos Avançados. São Paulo: EDUSP, 13(37), 1999, pp. 207-214; SILVA, Roberto Pereira. O jovem Celso Furtado. História, política e ideologia (1941-1948). Bauru/SP. Edusc, 2011.

${ }^{55}$ A peculiaridade do título de doutor em economia de Celso Furtado é ressaltado por: GARCIA, Afrânio. Entre fardas, fantasias e figurinos matemáticos para simbolizar condutas humanas: a "obra autobiográfica de Celso Furtado". op. cit. Maria Rita Loureiro, analisando a relação entre a circulação internacional dos economistas como fator determinante da posição que eles irão adquirir no debate econômico, esclarece que: “entre les années 1940-1960, la circulation internationale dans le champ des économistes vise, notamment, la formation des cadres du gouvernement pour qu'ils puissent intervenir dans des organes de gestion économique (régulation, planification, contrôle monétaire, politiques de change ou encore des banques de développement)". LOUREIRO, Maria Rita. Circulation internationale des économistes brésilienes. Cahiers du Brésil contemporain, 2004-2005; nº 57/58 - 59/60, p. 153.

${ }^{56}$ No segundo dos artigos que publicou na revista Observador Econômico e Financeiro, sobre a situação econômica da França, em julho de 1948, Celso Furtado é assim apresentado: "O autor acaba de regressar da Europa, onde esteve por vários meses realizando um curso na Sorbonne. Nessa oportunidade, visitou os principais países europeus, entrando em contato íntimo com seus problemas.Sobre a crise inglesa escreveu Celso Furtado valioso trabalho já publicado pelo OBSERVADOR, que agora oferece a seus leitores uma análise da evolução da política financeira inglesa (sic)": FURTADO, Celso. A crise econômica inglesa. In: Observador econômico e financeiro. Ano XII, n. ${ }^{\circ}$ 144, janeiro de 1948 [nota do editor]
} 
livro Le mécanisme des prix, de Jean Marchal, em sua segunda edição, do mesmo ano. A escolha do livro pode ser atribuída aos estudos de Celso Furtado em Paris, pois Jean Marchal ministrou dois cursos no Institute des Sciences Politiques nos anos 1947 e 1948: Économie Financière e Problèmes Économiques Contemporaines ${ }^{57}$ no período em que Celso Furtado lá esteve matriculado como auditeur.

Entretanto, para além da retomada e aproveitamento dos estudos franceses, é preciso considerar a peculiaridade do tema selecionado por Celso Furtado: um tratado de teoria monetária. Diferentemente das análises da conjuntura europeia feitas até então, e distante da história econômica colonial brasileira examinada na tese de doutorado, o autor concentra-se na teoria econômica, e, dentro desta, na economia monetária, aspecto que esteve presente, porém não de forma explícita e sob o ponto de vista teórico, nas discussões sobre a política econômica inglesa e francesa.

A mudança de perspectiva, embora já aponte para sua concentração no campo da economia, não o distancia, como poderia aparecer a primeira vista, dos problemas especificamente brasileiros; estes, afinal, são elementos que orientam a avaliação do livro, explicando algumas ênfases e análises do comentário crítico.

O primeiro aspecto que surpreende Celso Furtado neste "trabalho com objetivos didáticos" é a abordagem dos sistemas de preço, colocando a moeda "como um elemento neutro", sobretudo considerando-se a origem francesa do trabalho, "onde, desde a famosa polêmica do século XVI de Jean Bodin e M. de Malestroit, as teorias econômicas tenham ocupado o primeiro plano dos estudos econômicos". 58 Dessa forma, a escolha do tratado de Jean Marchal permite a introdução da discussão da moeda na teoria econômica, destacando a necessidade do estudo dos preços e considerando a "análise das estruturas de mercado". 59

Seguindo a arquitetura do livro, cuja primeira parte investiga a teoria estática e dinâmica dos preços, chama a atenção de Celso Furtado a "magnífica exposição introdutória em que são analisados os fundamentos dessas teorias: as condições de

\footnotetext{
${ }^{57}$ Lista dos cursos ministrados na Science Po entre 1946-1948, enviada por solicitação do autor e sem referências bibliográficas.

${ }^{58}$ FURTADO, Celso. Resenha de Jean Marchal, Les mecanismes de prix. Librarie de Médicis, 1948. Revista Brasileira de Economia, v. 2; n. 4, 1948, p. 174. A observação guarda uma crítica à Jean Marchal, cuja tese de doutorado, defendida em 1931 em Nancy, La conception de l'économie nationale et des rapports internationaux chez les mercantilistes français et chez leurs contemporains, demonstra precisamente sua proximidade com a tradição monetarista francesa. Sobre o autor, consultamos: LECAILLON, Jacques. Regards sur l'oeuvre de Jean Marchal. Revиe économique. Volume 48, n $4,1997$. pp. 781-804.

${ }^{59}$ Idem, ibidem.
} 
concorrência perfeita e os períodos da análise [grifos do autor]". ${ }^{60}$ O livro, como exigido pelo resenhista, agrupa as estruturas econômicas na análise do mecanismo de preço,. Em consonância com a definição de Marchal da concorrência perfeita pela "fluidez" e "atomicidade" da oferta e da procura, Celso Furtado resgata os aspectos mais críticos ao liberalismo econômico, sobretudo o momento em que "o autor insiste no fato de que a ausência de regulamentação governamental não significa necessariamente concorrência, como pretendiam os clássicos. Nem o fato de que os produtores renunciem a se associar implica concorrência”. ${ }^{61}$ Assim, nota-se a ênfase na arbitrariedade da identificação Mercado/ Livre Concorrência, pois esta dependeria de arranjos institucionais que passam conjuntamente pela iniciativa privada e pelo Estado, inexistindo automatismos econômicos ou controles estatais a priori.

Essa ênfase se amplia no momento em que Celso Furtado dá voz ao autor: “contrariamente à opinião dos autores clássicos, acrescenta Jean Marchal, a concorrência perfeita de nenhuma maneira é um regime natural ou espontâneo. É, no pleno sentido da palavra, um regime construído". ${ }^{62}$ Ou seja, o movimento da resenha destaca um elemento presente nas preocupações de Celso Furtado, a relação entre Estado e concorrência, muito embora isto pareça não ter sido o foco principal de Jean Marchal, uma vez que a importância do Estado nesse processo de estímulo à concorrência não tenha sido desenvolvida no livro resenhado: "não obstante uma interessante observação, que aparece na introdução, alusiva à importância da ação do Estado que, em certos casos, prepara a concorrência e em outros elimina-a, o autor ignora em todo o desenvolvimento de sua construção teórica esse importante fator". 63

Esse aspecto crítico à identificação do regime concorrencial com a ausência de intervenção estatal, típica dos “autores clássicos" e do liberalismo econômico, é retomado quando Celso Furtado analisa a concorrência imperfeita. Ao examinar o papel do mecanismo de preço do ponto de vista da dinâmica econômica, Jean Marchal procurou "dar ao tempo um conteúdo de ordem conjuntural". ${ }^{64}$ Essa densidade temporal, do ponto de vista dos modelos econômicos, se apresenta como cenários nos quais se altera o comportamento de uma variável-chave. Furtado dá como exemplo "o caso da Conjuntura D (inflação galopante) - curva da procura de bens de produção:

\footnotetext{
${ }^{60}$ Idem, p. 175.

${ }^{61}$ Idem, ibidem.

${ }^{62}$ Idem, ibidem.

${ }^{63}$ Idem, ibidem.

${ }^{64}$ Idem, ibidem.
} 
deslocamento muito acentuado da esquerda para a direita: curva da procura de bens de consumo: igual comportamento: deslocamento muito acentuado de baixo para cima; clima psicológico: expectativa de alta indefinida". ${ }^{65}$ Nesse trecho, para além da capacidade do modelo explicar a realidade, cumpre destacar o exemplo escolhido por Celso Furtado: inflação galopante, num momento em que o nível de preços no Brasil não dava sinais de reduzir sua ascensão. ${ }^{66}$

Outro elemento que remete a seleção de temas às preocupações de Celso Furtado com a economia brasileira é a questão dos preços agrícolas, ponto-chave numa economia em processo de industrialização, com problemas de oferta de alimentos. Embora não discuta a análise elaborada por Jean Marchal, critica os trabalhos atuais sobre a questão, enfatizando que "os estudos desse tipo de mercado têm sido, entretanto, prejudicados pela tendência dos autores modernos a utilizarem nesse setor os mesmos métodos abstratos que aplicam na análise dos preços industriais". ${ }^{67}$

Com isso, percebe-se como o recorte da discussão aponta para problemas contemporâneos: inflação galopante, que analisara na França do pós-guerra, e a questão da aplicação de modelos gerais para situações específicas. Por outro lado, é preciso destacar a distinção entre análise econômica estática e dinâmica e as possibilidades de introdução da temporalidade nos modelos.

Por sua vez, a segunda parte da obra, voltada aos problemas da teoria dos preços em relação à estrutura da economia, dedica-se ao "estudo dos mercados ditos de concorrência imperfeita". Celso Furtado retoma as considerações sobre a "formação, no início do século XIX, do mito da concorrência e à crença de que este era um regime natural. Demonstra-nos, finalmente, como a própria evolução tecnológica e também o desenvolvimento dos princípios mesmos do liberalismo político limitaram mais e mais a concorrência no campo econômico". Assim, Celso Furtado novamente enfatiza o caráter construído, não-espontâneo do regime de concorrência perfeita. Ora, apenas nesse regime é possível considerar a moeda como um elemento neutro, abordagem já rechaçada no início da resenha. Entretanto, ao retomar esse argumento esboçado no livro de Marchal, a estratégia do resenhista avança para a crítica não só da estrutura

\footnotetext{
${ }^{65}$ Idem, p. 176.

66 "A inflação, que chegara a $11 \%$ e $22 \%$ em 1945 e 1946, respectivamente, foi identificada como o principal problema a ser enfrentado e diagnosticada oficialmente como derivada de excesso de demanda agregada". Com uma política monetária contracionista, porém contrabalançada pelas emissões do Banco do Brasil, a inflação atingiu 12,4\% em 1950. Ver: VIANNA, Sergio Bresserman \& VILLELA, André. O pós-Guerra (1945-1955). GIAMBIAGI, Fábio (et. alli). Economia brasileira contemporânea 1945-2004). Rio de Janeiro, Elsevier, 2005, p. 27.

${ }^{67}$ Idem, ibidem.
} 
argumentativa do livro, mas para a constatação de uma contradição na teoria econômica:

\begin{abstract}
As observações finais do livro de Jean Marchal fazem-nos pensar em que há talvez um certo exagero em levar tão longe o emprego do método dedutivo numa ciência que trabalha com fatos essencialmente mutáveis, como são os econômicos. A simples necessidade de partir de um postulado que não encontra correspondência na realidade, tal o da concorrência perfeita, torna necessária a formulação de todos os problemas em um nível de abstração extremamente elevado. Por outro lado, toda aproximação da realidade se traduz por uma 'imperfeição', ou deformação da teoria. Até que ponto essa espécie de teoria econômica é um simples 'instrumento pedagógico' como pretende Pietro Sraffa, ou chega a ser um instrumento de utilidade prática, como afirma J. Robinson, não seria fácil dizê-lo ${ }^{68}$
\end{abstract}

Celso Furtado refere-se às contradições entre o método dedutivo - a partir do qual se elaboram as teorias econômicas modernas - e as aproximações da realidade, que apareceriam ao economista teórico como uma "imperfeição' ou deformação da teoria". Destaque-se, ainda, as referências à Piero Sraffa, Joan Robinson e John Hicks, autores que abordaram essas questões, mas cujas soluções oferecidas aparentam não satisfazer Celso Furtado, pois encaram a teoria econômica como "instrumento pedagógico" ou instrumento de utilidade prática, e não como uma via de acesso a problemas concretos.

A resenha se encerra apontando a esterilidade que pode resultar do tipo de teoria econômica criticada: "uma economia essencialmente dedutiva, tornar-se-ia muito cedo uma ciência estéril. O perigo principal do método exposto por Jean Marchal é que leva muita gente a confundir certas construções abstratas com a realidade". ${ }^{69}$

Depreende-se desta primeira resenha a discussão, partindo da teoria monetária, dos pressupostos da teoria econômica no âmbito da concorrência imperfeita e a contradição entre o método dedutivo e a realidade empírica que se procura explicar. Mais ainda, observemos que a crítica aos fundamentos epistemológicos da economia toma como exemplo justamente a economia monetária e a teoria dos preços, o campo por excelência do pensamento econômico liberal.

Cabe notar, também, em comparação com os textos sobre política econômica francesa e inglesa (ambas enfrentando e se debatendo com soluções monetárias para resolver a situação do pós-guerra), que Furtado avançou sua análise — talvez tendo já refletido e testemunhado o fracasso das políticas econômicas recessivas - para o

\footnotetext{
${ }^{68}$ Idem, p. 176-177.

${ }^{69}$ Idem, p. 177.
} 
exame dos pressupostos teóricos que dariam embasamento às opções adotadas pelos países europeus examinados nos artigos de $O$ observador econômico e financeiro.

Dessa forma, podemos apreciar esses primeiros passos de Celso Furtado na Fundação Getúlio Vargas enfatizando sua tomada de posição não apenas frente aos temas de teoria econômica, mas também estabelecendo e selando aproximações intelectuais ao redor de pessoas dentro da Fundação e nas revistas onde trabalhava e publicava. Empenho este que não deixava de ligar-se aos seus desenvolvimentos intelectuais. Sob esse prisma, cabe examinar a resenha de Trustes y carteles, sus origenes y influencia en la economia mundial, de Richard Lewinsohn, publicado na Argentina em 1948.

Diretor da revista Conjuntura Econômica, onde Celso Furtado trabalhava, Lewinsohn antes fora contratado pelo DASP e participara da elaboração do Plano Salte em 1947, "em sua parte financeira". ${ }^{70}$ Escrevia seus artigos em francês e quem os traduzia era o próprio economista paraibano recém-chegado da França. Ora, é possível afirmar que na escolha do livro a ser resenhado, para além da familiaridade com o tema, tenha pesado a possibilidade de diálogo e a diminuição da distância hierárquica pela proximidade intelectual. Empreendimento exitoso, já que: "um dia, ele viu na Revista Brasileira de Economia uma resenha minha à recém-publicada edição brasileira de seu Trustes e cartéis, e passou a dar mais atenção a mim".71

O livro traz uma afinidade temática com um aspecto sublinhado na resenha de Jean Marchal: a concorrência imperfeita; e também retoma os processos de coordenação econômica que atingem tanto as organizações privadas como o Estado, tal como esboçadas nos artigos anteriores: "Teoria Geral da Administração" e "Trajetória da Democracia na América".

Esta resenha se inicia revisitando a problemática abordada ao final da anterior: a característica do pensamento econômico liberal, com seus postulados abstratos, de compreender as transformações sociais e econômicas como desvios da teoria abstrata. Concentrando-se nas diversas evidências de "ententes e coalizões para eliminar a concorrência" surgidas desde o século XIX, Celso Furtado destaca a lentidão dos economistas em incorporarem essas transformações na teoria econômica. Apenas "em

\footnotetext{
${ }^{70}$ FURTADO, Celso. A Fantasia Organizada, p. 137; "Plano Salte". In: Dicionário Histórico - Biográfico Brasileiro Pós -30 Rio de Janeiro: CPDOC/FGV. Disponível em http://cpdoc.fgv.br/acervo/dhbb. Acesso em 25/09/2012.

${ }^{71}$ FURTADO, A Fantasia Organizada, op. cit, p. 137. Embora seja a edição argentina de 1948 que conste na resenha de Celso Furtado, o livro havia sido publicado pela editora do Globo, Rio de Janeiro, em 1945.
} 
face, finalmente, da realidade insofismável de um mercado estratificado e rígido, os economistas liberais - e seus seguidores atuais da escola austro-inglesa marginalista passaram a encarar o fenômeno como manifestações de 'concorrência imperfeita', ou seja, desvios em torno de um eixo ideal de equilíbrio instável”. ${ }^{72}$ Assim, a crítica ao irrealismo que vimos na resenha anterior é amplificada aos fundamentos da economia neoclássica, nominalmente na obra de Menger: "a metodologia abstrata de Carlos Menger não comportava a aproximação ao vivo da realidade, que impunha o estudo dos fenômenos 'trusts' e cartéis". ${ }^{73}$ Essa relutância dos economistas, associados à "escola austro-inglesa marginalista", permite expor a contradição entre o método dedutivo e a realidade "impura", agora assimilada a uma corrente específica da teoria econômica. Esta, não se colocava o problema - ou o superava pela predominância da dedução — da confrontação da teoria com a realidade. Nesse sentido, o contraste serve de introito à importância do livro resenhado, derivada justamente da pesquisa histórica e empírica: "Richard Lewinsohn é um desses economistas que acreditam no valor da pesquisa histórica e do contato com a realidade presente. Seu livro [...] é, a um tempo, obra de análise histórica e econômica”. ${ }^{74} \mathrm{O}$ autor retoma a formação dos trusts e dos conglomerados inserindo-os na história do capitalismo e relacionando-os aos "fenômenos de concentração do poder econômico", assim como à "influência desses fenômenos de concentração na economia mundial". ${ }^{75}$ Dessa forma, as propostas de Lewinsohn se coadunam com as análises de Celso Furtado no ensaio Trajetória da Democracia na América, quando ressaltou o crescente poder econômico das corporações e a crescente capacidade do poder econômico influenciar a política. A origem dos trustes e cartéis é encontrada na "separação entre o controle econômico e a propriedade". ${ }^{76}$ Essa separação marca o momento em que o "poder econômico já não seria apenas independente do trabalho, mas igualmente da propriedade". ${ }^{77}$ Para captar esse processo, Lewinsohn estudou a constituição história destes conglomerados, destacando suas diferenças continentais e nacionais, as interferências nos mecanismos de preço e no mercado de trabalho, bem como a legislação para coibir essas práticas.

Entretanto, a despeito do reconhecimento desta reconstituição histórica, Celso Furtado critica alguns pontos resultantes dessa escolha, pois Lewinsohn "prende-se

\footnotetext{
${ }^{72}$ Idem, p 104.

${ }^{73}$ Idem, ibidem.

${ }^{74}$ Idem, ibidem.

${ }^{75}$ Idem, p. 104.

${ }^{76}$ Idem, ibidem.

${ }^{77}$ Idem, p. 105
} 
mesmo, talvez demasiadamente, aos fatos de comprovação irrefutável”. Aqui, portanto, enfatiza o outro aspecto da tensão entre dedução e observação empírica: a pletora de dados e a excessiva confiança nestes ocasionam problemas teóricos, que Celso Furtado destaca ao discordar do próprio conceito de trustes e cartéis utilizados por Lewinsohn, pois este "limita o campo de suas observações partindo de definições restritivas dos conceitos de 'trust' e cartel". ${ }^{78}$ Por outro lado, a crítica aos limites estritos da observação é retomada através do trabalho de Robert A. Brady, Business as a sistem of power de 1943, apontando o espraiamento dos comandos econômicos para além dos conselhos das empresas, alcançando as "associações de cúpula", elemento que Celso Furtado aprofunda pelo trabalho de David Lynch, The concentration of economic power de 1946. A conclusão a que chega, a partir dessa discussão é que "o problema do poder econômico já não pode hoje ser formulado independentemente do poder político". 79 Nesse sentido, a crescente interdependência entre ambos se deve à centralidade da tecnologia, de forma que "o denominador comum dos fenômenos econômicos e políticos é o desenvolvimento tecnológico, de onde deriva o imperativo da concentração". As saídas apontadas para esse processo retomam a conclusão já apresentada em Trajetória da democracia na América, emergindo a necessidade de um planejamento capaz de coordenar o desenvolvimento tecnológico e a concentração econômica com um Estado capaz de distribuir os benefícios dos crescentes aumentos de produtividade e preservar a participação política. Daí que "a aproximação desses fatos levou alguns autores modernos, particularmente ingleses, a apresentarem a necessidade de uma planificação democrática da ordem econômica como única forma de fazer sobreviverem as instituições políticas democráticas". ${ }^{80}$

Dessa forma, a resenha reforça a crítica ao liberalismo econômico e o reconhecimento do necessário papel do Estado na economia, bem como propõe novos e recentes desdobramentos aos problemas da concentração econômica tratados no livro, que o seu "caráter pré-guerra" não captou. Por sua vez, a afinidade com o autor (e seu diretor na Conjuntura Econômica) é reiterada pelo exame e discussão aprofundada dos temas, mostrando a atualização do economista recém-chegado da França.

Sob um certo sentido, a ênfase dessa resenha nas consequências do processo de concentração econômica reforça a impossibilidade de sustentação de uma teoria

\footnotetext{
${ }^{78}$ Idem, p. 105.

${ }^{79}$ p. 106.

${ }^{80}$ Idem, ibidem.
} 
econômica baseada exclusivamente no liberalismo e na livre concorrência. Mais ainda, podemos considerar o reconhecimento da centralidade da tecnologia no mundo moderno e a simbiose entre economia e poder político como a transposição, em seu aspecto teórico, das decisões estatais tomadas sob a pressão de forças econômicas. Dessa forma, se retomarmos o conjunto de textos que acabamos de analisar, talvez não seja difícil identificar que a discussão sobre a neutralidade da moeda procurou destacar como esta serviu de justificativa para as políticas recessivas adotadas pela França e Inglaterra no pós-guerra, ao mesmo tempo em que as discussões sobre a concentração do poder econômico incidem sobre a impossibilidade daquelas nações de contemplar os interesses das classes trabalhadoras, fazendo valer os pactos de democracia política. As duas resenhas marcam a consolidação e o aprofundamento dos estudos de Celso Furtado. Emerge desses dois trabalhos a imbricação das pressões econômicas na atuação estatal, implodindo a cientificidade da teoria econômica. Isso decorre da (ou é corroborada pela) identificação da contradição entre o método dedutivo da teoria econômica e sua impossibilidade de explicar o caráter histórico e mutável das realidades econômicas e sociais.

Finalmente, essas resenhas evidenciam o direcionamento de Celso Furtado para a teoria econômica. Notemos, não qualquer teoria econômica, mas sim um corpo de proposições conflitantes com o liberalismo da Fundação Getúlio Vargas. Nesse sentido, a afinidade intelectual, que não exime a crítica objetiva, com Richard Lewinsohn foi reforçada ao custo da exposição de divergências com os princípios liberais encampados por Eugênio Gudin e, em menor medida, por Octávio Gouveia de Bulhões. Por sua vez, fica patente nesses primeiros escritos a vontade combativa aliada ao empenho em discutir os fundamentos da teoria econômica. E, nessa discussão, vemos como a questão do confronto entre o método dedutivo e a validação da realidade formam os dois polos de crítica: se Jean Marchal excedeu-se na construção de modelos teóricos, a minúcia história fez com que Richard Lewinsohn não conseguisse encontrar uma base conceitual para examinar os trustes e cartéis. Dessa forma, surge um conjunto de preocupações que apontam para os perigos da teoria econômica, caso esta se descuide de confrontar seus fundamentos e explicações com a realidade imediata.

Finalmente, não podemos sugerir que as resenhas de Furtado tenham causado espécie no corpo editorial da Revista Brasileira de Economia. Entretanto, mais do que medir seus efeitos na cúpula econômica da Fundação Getúlio Vargas, a experiência no Centro de Análise da Conjuntura Econômica e na redação da Conjuntura Econômica 
permitiu a Celso Furtado mapear as linhas de força que comandavam e direcionavam a produção do conhecimento econômico e a discussão sobre a economia brasileira. A experiência pode ter revelado os limites da posição de Celso Furtado, sem possibilidades de ascender intelectual e profissionalmente, ainda que dotado do título de doutor em ciências econômicas e trabalhando na principal instituição de formulação e elaboração de conhecimento econômico sobre o Brasil no período.

Dentro desse conjunto de perspectivas, a possibilidade de trabalhar em uma Comissão da Organização das Nações Unidas sobre a América Latina pode ter aparecido como algo promissor, despertando em Celso Furtado seu "amor da aventura". A notícia, nos relataria em A Fantasia organizada, "foi o suficiente para que o ambiente brasileiro, com sua compartimentação de ideias, me parecesse asfixiante". Tomado pelo entusiasmo, desconsiderou a "visão negativa" de Richard Lewinsohn pelas organizações internacionais, bem como os prognósticos de ascensão profissional que Otávio Gouveia de Bulhões lhe observou, e aceitou o convite para ir trabalhar em Santiago do Chile, na Cepal. ${ }^{81}$

De todo modo, o período em que permaneceu no Brasil permitiu a Furtado conhecer o modus operandi da Fundação Getúlio Vargas e lhe deu o treinamento no levantamento, coleta e preparação de dados que seriam extremamente relevantes da Cepal.

\section{A Cepal e as armadilhas da teoria econômica na América Latina}

O ingresso na Cepal irá estimular uma nova mudança nas preocupações de Celso Furtado, para a pesquisa com dados empíricos, focalizando em comércio internacional e economia industrial na América Latina, especialmente, no Brasil.

Incorporado ao grupo de economia industrial, teve como supervisor o economista "norte americano de origem checo-mexicana" Milic Kybal. Encarregados de elaborar a seção sobre a indústria manufatureira na América Latina, a Celso Furtado coube "preparar alguns quadros e esboçar uma análise em torno da situação habitacional e de saneamento básico". A tarefa, por sua vez, colocava em tela o tema das "relações entre industrialização e comércio exterior", problemática que explicava a

\footnotetext{
${ }^{81}$ FURTADO, Celso. A Fantasia organizada. op. cit., pp. 139-142.
} 
industrialização latino-americana em decorrência da conjuntura específica configurada pelo conflito mundial.

Celso Furtado, no âmbito dos trabalhos preliminares para o relatório da Cepal, com data de apresentação para maio do mesmo ano, "encontra" no estudo preparado pela Sociedade das Nações em 1945, Industrialização e comércio exterior, uma comprovação empírica de que o processo de industrialização, no caso específico do Canadá, proporcionou um aumento concomitante da importação de manufaturas, em razão da melhoria geral do poder de compra da população. Celso Furtado propõe, então, aquilatar qual o volume de importações de produtos manufaturados seria necessário para aumentar a disponibilidade desses bens nos quatro países mais industrializados da América Latina - Argentina, Brasil, México e Chile - e como isso impactaria no comércio internacional. A questão, que ocupa o quinto item do capítulo "Manufaturas" do relatório de 1949, intitulado "Industrialização e Comercio Exterior", é um dos poucos trechos do relatório em que Celso Furtado reivindica autoria. ${ }^{82}$ Nesse sentido, vale a pena considerar esse item, também pela importância que a questão da industrialização e do comércio exterior vai adquirir para Cepal e para a obra do economista paraibano.

O excerto mencionado enfatiza a manutenção da importação de produtos manufaturados pelas economias em processo de industrialização, muito embora haja uma alteração em sua composição, a depender do nível de renda alcançado pela população. Há uma descrição das consequências da Segunda Guerra Mundial para a produção manufatureira, tendo como base a indústria têxtil no Brasil. A princípio, a interrupção das importações de têxteis causou um aumento da demanda, beneficiando as empresas estabelecidas e, em consequência, um aumento do emprego e da renda monetária, revertida em demanda por manufaturas nacionais. ${ }^{83}$ Num quadro de diminuição da concorrência estrangeira, a indústria operou com altos lucros e baixa produtividade. Depois da guerra, a retomada das importações da América Latina contou com grande participação de bens de produção em sua pauta, ao passo que problemas no

82 "O problema que mais preocupava na época, e que não podia ser eludido, era o das relações entre industrialização e comércio exterior. Kybal se sentia aí como pisando em ovos. [...] propus dar um passo adiante nesse terreno. Preparei uma estimativa da possibilidade de consumo dos produtos manufaturados (excluídos alimentos, bebidas e fumo) nos quatro maiores mercados latino-americanos referente ao ano de 1939 e comparei o resultado com o mesmo dado obtido para o Canadá. [...] Como os dados eram precisos e o raciocínio, rigoroso, o texto foi aprovado em todas as instâncias. FURTADO, Celso. A fantasia organizada. op. cit., pp. 149-151. [grifo nosso]

${ }^{83}$ Comissão Econômica para América Latina. Estudio Económico de América Latina, 1948. Nações Unidas, Departamento de Assuntos Econômicos, Nova York, 1949. (E/CN. 12/82: Número de venda: 1949. II. G. I) p. 57. 
balanço de pagamentos desses países exigiram a instituição de uma série de controles sobre importações de bens de consumo que ajudou a manter a alta lucratividade das empresas nacionais durante a década de 1940. ${ }^{84}$ Finalmente, o relatório procura demonstrar que, nos países onde não houve rígidos controles de importações, tais como a Colômbia, México, as importações de bens de consumo tenderam a retornar aos níveis do pré-Guerra. Por outro lado, nos países que iniciaram um processo de industrialização de bens de capital, como o Brasil, a pauta de importações recuperou o nível de bens de consumo do pré-guerra, em virtude da melhora na renda. O raciocínio, portanto, está engajado nas discussões sobre comércio internacional e procura refutar o argumento de que a industrialização dos países da América Latina diminuiria o nível do comércio internacional, sobretudo de manufaturas das nações industrializadas.

Estabelecida a relação entre industrialização e comércio exterior, Celso Furtado se pergunta, ainda baseado no estudo da Sociedade das Nações, quanto seria necessário importar em bens manufaturados para que os quatro países mais desenvolvidos da América Latina alcançassem a disponibilidade de bens manufaturados correspondente a 50\% do mesmo nível do Canadá em 1939. Celso Furtado chega à cifra de 7,2 bilhões de dólares, o equivalente a $30 \%$ do total mundial de importações. ${ }^{85}$ Ao mesmo tempo, os países latino-americanos não teriam condições de aumentar sua produção primária nesse nível, devido à baixa elasticidade-renda das matérias-primas e produtos agrícolas do subcontinente. Assim, países como Austrália, Canadá, Nova Zelândia e União Sulafricana, conseguiram aumentar sua disponibilidade de bens manufaturados pois seu comércio exterior se desenvolveu com um "amplo processo de industrialização", financiado pela Inglaterra. Dessa forma, a consequência apontada pelo relatório indica que a única possibilidade de melhora do nível de vida e de disponibilidade de bens manufaturados nos países latino-americanos é a industrialização:

de este modo, la industrialización parece ser a largo plazo el medio principal para conseguir una elevación sensible de los niveles de vida de América Latina. Si la finalidad primordial de la actividad y de la política económica consiste en producir mayor cuantidad de bienes y servicios, y lograr estabilidad en su suministro, la actividad fabril no puede ser el único medio utilizable, pues la industrialización significa

\footnotetext{
${ }^{84}$ Sobre isso, podemos encontrar no relatório: “esta orientación de las importaciones hacia los bienes de producción impidió, en parte, el restabelecimiento de una competencia efectiva en aquellos setores de la industria nacional desarrollados durante la guerra. Los altos precios, a veces condición esencial de la subsistencia de tales empresas, se mantuvieron. A partir de 1947, el creciente rigor del control de importaciones restringió las de artículos no esenciales en numerosos países. La escasez de divisas actuó por lo tanto como protección suplementaria de las industrias nacionales". Comissão Econômica para América Latina. Estudio Economico de América Latina, 1948, op. cit., p. 58.

${ }^{85}$ Idem, pp. 63-64.
} 
el uso de técnicas y mecanismos que ahorren mano de obra en todas las esferas de la producción. Sería difícil, por ejemplo, concebir un desarrollo económico armonioso en cualquier país, sin el mejoramiento de la técnica agrícola, de los transportes, suministro de energía y un sistema moderno de distribución. El testimonio de la historia y la interdependencia entre todas las actividades económicas indican que es un proceso mucho más complejo que la mera instalación de fábricas y el establecimiento de una política que asegure la perduración de las mismas. ${ }^{86}$

Aqui, Celso Furtado já avançava na reflexão sobre os problemas da industrialização latino-americana, extravasando as atribuições técnicas que lhe cabiam. Merece destaque no texto, também, o diagnóstico de altos lucros e baixa produtividade com os quais opera a indústria têxtil brasileira. Finalmente, o elemento principal dessas páginas é sua redação ter acontecido já nos primeiros meses de $1949 .{ }^{87}$ Assim, as colocações do jovem economista brasileiro na Comissão revelam o interesse nos problemas do grupo, ao mesmo tempo em que avançava no diagnóstico da situação latino-americana, detectando algumas características da situação brasileira.

Os trabalhos para a preparação do primeiro relatório, iniciados em fevereiro de 1949, contaram, também, com a colaboração de técnicos da ONU, do FMI, além de economistas latino-americanos contratados pela Cepal. ${ }^{88}$ Entretanto, ainda faltava uma diretriz teórica geral para o relatório, cuja redação coube a Raúl Prebisch. Um texto preliminar foi divulgado no início de abril mas, segundo Celso Furtado, não causou grande entusiasmo. Foi apenas após Prebisch ter recebido o estudo de Hans Singer, Post-war price relations between under-development and industrialized countries, escrito para a Subcomissão de Desenvolvimento Econômico da ONU, que finalmente elaborou a introdução definitiva ao relatório da Cepal, intitulada: $O$ desenvolvimento econômico da América Latina e alguns de seus principais problemas.

\footnotetext{
${ }^{86}$ Idem, p. 65.

87 A notícia da criação da Cepal e o convite para Prebisch assumir a secretaria executiva, não lhe entusiasmou. Prebisch tinha acertado um conjunto de dez palestras na Universidade Nacional do México para fevereiro de 1949, além de ter recebido o convite para se tornar assessor permanente do diretor-geral do FMI, com salário de US\$ 14 mil. Entretanto, houve oposição à sua contratação em Washington, a qual foi ampliada pela oposição à sua contratação pela Argentina e o Brasil. Edgar Dosman inclusive aponta a intervenção de Bulhões junto ao Ministro da Fazenda para vetar sua nomeação no Fundo, num momento em que era impossível a intervenção de Eugênio Gudin, que passava por uma cirurgia em Washington e se ressentiu da posição brasileira contra o amigo argentino. Finalmente, Prebisch inicia os trabalhos na Cepal em 10 de março, porém, tanto seu biógrafo quanto Celso Furtado destacam seu pouco envolvimento com a equipe nos primeiros meses. DOSMAN, J. E. Raúl Prebisch..., op. cit., p. 270.

${ }^{88}$ A primeira reunião da Cepal aconteceu em julho de 1948, onde os governos aprovaram um plano de trabalho, na forma de um documento intitulado Investigación económica de América Latina, a ser apresentado na segunda seção, marcada para maio e junho de 1949, em Havana, sob a secretaria executiva de Gustavo Martinez-Cabanãs.
} 
Este texto, fundador do estruturalismo latino-americano, denominado por Albert Hirschman de "manifesto dos periféricos", adquiriu vida própria e identificou permanentemente a Cepal com a deterioração dos termos de troca do comércio internacional e com a defesa da industrialização como forma de romper a estrutura que perpetua a condição subdesenvolvida dos países da América Latina. A relação da introdução com o conjunto do relatório elaborado pelos técnicos da Cepal, no entanto, precisa ser esclarecida, devido à independência que adquiriu.

Algumas interpretações ${ }^{89}$ sobre a trajetória intelectual de Raúl Prebisch destacam a ligação deste texto com reflexões anteriores, iniciadas já nos anos 1920. Essas avaliações, longe de retirarem a importância do texto, nos fornecem uma chave interpretativa que permite identificar o cerne das preocupações de Prebisch, evidenciando o papel fundamental dos ciclos econômicos e suas consequências nos países da América Latina. Dessa forma, o elemento estruturante de $O$ desenvolvimento econômico da América Latina e alguns de seus principais problemas é resultado de estudos sobre a teoria dos ciclos econômicos nas economias capitalistas e seus efeitos não apenas para os países industrializados, mas também nos produtores de matériasprimas e alimentos para exportação. ${ }^{90}$

\footnotetext{
${ }^{89}$ GURRIERI, Adolfo. Las ideas del joven Prebisch. Revista de la Cepal, n. 75, diciembre 2001, pp. 6982; GONZÁLEZ, Norberto \& POLLOCK, David. Del ortodoxo al conservador ilustrado. Raúl Prebisch en la Argentina, 1923-1943. Desarrollo económico. Vol. 30, n. 120, Jan-Mar, 1991, PP. 455-486.

${ }_{90} \mathrm{O}$ texto, por outro lado, deriva das preocupações de Raúl Prebisch com os problemas do ciclo econômico dos países latino-americanos, sobretudo da Argentina desde os anos de 1940, quando presidente do Banco Central. Com efeito, após sair da instituição em 1943, resolveu escrever um livro sobre sua experiência à frente da política econômica argentina. Projetado para se chamar La moneda y el ritmo de la actividad econónica, o livro trataria de "cinco proposições inter-relacionadas sobre os mercados e o Estado. Nele defendia: 1) a intervenção ativa do Estado na economia para evitar as grandes flutuações cíclicas dos preços agrícolas, fortalecimento do comércio exterior e, igualmente, fomento ao desenvolvimento e ao nível de emprego; 2) estímulo ao desenvolvimento "hacia dentro", ou seja, promoção da industrialização via substituição de importações para contrabalançar a relação desigual da Argentina com os países industrializados, numa primeira formulação das crítica à teoria das vantagens comparativas, incluindo a percepção do papel dos ciclos econômicos nos países centrais como geradores de instabilidades na periferia; 3) por outro lado, limites ao papel do Estado na industrialização, permitindo que a economia como um todo continuasse operando pelas forças de mercado; 4) importância da retomada de um comércio internacional aberto, de forma que permitisse a exportação de produtos primários; 5) finalmente, seria necessário contar com um setor privado saudável e viável, ao custo de empresas menos competitivas, bem como os gastos governamentais deveriam manter-se não inflacionários. Dessas proposições, ficava implícita a crítica à teoria econômica liberal, uma vez que o funcionamento da economia internacional apresentava "características tão distintas em nossa vida econômica que requer uma explicação teórica alternativa àquela que é apropriada para os países industrializados". O projeto, rejeitado pelas editoras argentinas não foi concluído e Prebisch manteria essas ideias pelos próximos anos, em aulas na universidade de Buenos Aires e em conferências na América Latina. A oportunidade para concluí-las apenas surgiu nos meses em que Prebisch esteve na Cepal, premido pelo tempo para redigir um texto que sugeriria as principais características das economias do subcontinente nos últimos 20 anos. DOSMAN, E. J. Raul Prebisch... op. cit., PP. 173-176.
} 
Esse caráter de síntese de reflexões, de hierarquização de problemas monetários desenvolvidas em período anterior é uma chave importante para a percepção da apropriação desse texto seminal no primeiro trabalho de Celso Furtado após seu ingresso na Cepal, intitulado "Características gerais da economia brasileira", escrito em meados de 1949 e publicado em 1950 na Revista brasileira de economia. Assim, iremos, no que segue, fazer uma breve retomada do ensaio de Prebisch para, em seguida, perceber quais ideias foram retomadas por Celso Furtado neste artigo, onde a preocupação com a industrialização e as possibilidades de ruptura da especialização primário-exportadora ganham importância.

$\mathrm{O}$ ensaio se abre com uma crítica à Teoria das Vantagens Comparativas no comércio internacional. Esta seria negada pela própria "realidade na América Latina", pela imposição "dos fatos", colocando-a no rol das "ideologias" que "costumam seguir, com atraso, os acontecimentos ou sobreviver-lhes demasiadamente". Embora de "validade teórica inobjetável", "se baseia numa premissa terminantemente negada pelos fatos", a saber, de que "o fruto do progresso técnico tende a repartir-se igualmente em toda a coletividade". Assim, "o erro dessa premissa consiste em atribuir um caráter geral ao que de si mesmo é muito circunscrito", já que "as grandes vantagens do desenvolvimento da produtividade não chegaram à periferia em medida comparável ao que lograram desfrutar as populações dos grandes países”. Dessa forma, as nações latino-americanas encontram-se envolvidas em uma série de problemas que precisam ser elucidados em termos próprios, sem apelo às teorias elaboradas nos países centrais.

A dificuldade para isso é reconhecida por Prebisch:

há que reconhecer-se que, nos países latino-americanos, resta muito por fazer
nesta matéria, tanto no que diz respeito ao conhecimento dos fatos mesmo,
quanto à sua correta interpretação teórica. [...] Não se conseguiu, sequer,
abordar em conjunto seu exame e elucidação. Não é de estranhar, portanto,
que prevaleça, frequentemente, nos estudos que se publicam sobre os países
da América Latina, o critério ou a experiência especial dos grandes centros
da economia mundial. Dificilmente poder-se-ia esperar de tais estudos
soluções diretamente voltadas para nós ${ }^{91}$

Cabe ressaltar aqui uma preocupação convergente aos problemas de teoria econômica levantados por Celso Furtado nas resenhas publicadas na Revista brasileira de economia. Com efeito, da teoria econômica abstrata decorre sua incapacidade para explicar as principais transformações do sistema capitalista. Já nesse texto, do

\footnotetext{
91 PREBISCH, Raúl. O desenvolvimento econômico da América Latina e alguns de seus principais problemas. In: BIELSCHOWSKY, Ricardo. Cinquenta anos de pensamento na Cepal. Rio de Janeiro, Record, 2000, volume 1, p. 48.
} 
diagnóstico dos problemas reais surge a necessidade de formular uma teoria nova, sem o recurso às já existentes, capaz de compreender os "principais problemas" dos países latino-americanos.

A questão da desigualdade na propagação do progresso técnico é constatada pela deterioração dos termos de troca dos produtos primários em relação aos manufaturados, processo interpretado como inerente ao movimento cíclico da economia capitalista, que afeta de forma desigual países centrais e periféricos e cujo epicentro é os Estados Unidos, "principal centro cíclico do mundo", com grande produtividade industrial, reservas monetárias crescentes e elevado nível de protecionismo. Em outros termos, o comércio mundial produz uma perda do poder aquisitivo para os países da periferia, pois os preços dos produtos primários têm queda mais acentuada que os industriais. Isso agrava-se em uma fase descendente do ciclo econômico, pois os países periféricos mantêm sua dependência de produtos manufaturados, enquanto seu poder de compra declina, devido à contração da demanda dos países industriais. Por sua vez, a política econômica estadunidense do pós-guerra agrava o quadro pela redução de importações e aumento das reservas monetárias, causando instabilidade nos países periféricos, dependentes do mercado norte-americano.

O início do processo de industrialização em alguns países da América Latina coincidiu com a consolidação do poder econômico dos Estados Unidos, que fechou sua economia aplicando medidas protecionistas e absorvendo crescentes quantidades do ouro mundial. Dessa forma, o mais importante mercado comprador para os produtos primários latino-americanos retraía suas compras. As consequências monetárias desse processo são: nos momentos de baixa cíclica o hiato temporal que as economias periféricas experimentam até se adaptarem a um nível menor de comércio acarreta o envio de dólares e ouro aos Estados Unidos. Essa contração no centro, por sua vez, ocasiona diminuição das importações, desvalorização monetária e aumento da proteção tarifária e cambial nos países latino-americanos, como forma de equilibrar seu balanço de pagamentos.

Dessa forma, Prebisch identifica uma série de problemas típicos das economias subdesenvolvidas latino-americanas: balanço de pagamentos, desvalorizações cambiais, inflação, oscilação da renda decorrente da dependência da demanda externa. Entende a política econômica latino-americana como reflexa ao movimento geral do capitalismo em sua fase atual, na qual o deslocamento do centro cíclico, da Grã-Bretanha para os Estados Unidos resultou em uma diminuição no fluxo internacional de matérias-primas 
e concentração de meio monetário na América do Norte. Com isso, a situação dos países latino-americanos deixa de ser vista a partir de erros e acertos pontuais de política econômica, mas na estrutura de funcionamento do capitalismo, onde as determinações nacionais encontram constrições internacionais.

Outro aspecto abordado por Prebisch refere-se à relação entre formação de capital e aumento de produtividade. O problema da captação de recursos para financiar incrementos na relação produto-capital deriva da elevada taxa de consumo de produtos importados, sobretudo artigos de luxo. O comprometimento de divisas com esses gastos restringe a importação de bens de capital e equipamentos. Para ampliar o consumo destes últimos, torna-se necessário canalizar receitas de exportação, ganhando relevo a ação do Estado, direcionando a poupança para a ampliação de recursos produtivos. Por sua vez, a etapa de adaptação a uma nova estrutura de importação pode gerar conflitos distributivos, manifestos pela inflação, e ocasionar lucros elevados em alguns setores industriais.

Entretanto, aumentos de produtividade poderiam ser alcançados pela transferência de mão-de-obra para atividades mais produtivas, sobretudo industriais, bem como aumentando a proporção de capital por trabalhador, seja na indústria seja na agricultura. Por outro lado, o esforço de industrialização não poderia ser feito em detrimento da agricultura; ao contrário, ela é essencial para obter as divisas necessárias para a importação de bens de capital. Finalmente, Prebisch retoma as questões relativas ao ciclo econômico e seus efeitos no centro e na periferia. Nesta última, a política econômica deve se pautar pela redução das importações supérfluas e estimular as atividades internas, contando com proteção tarifária e direcionamento específico à importação de bens de capital.

Esse conjunto de reflexões que compõe o texto de Prebisch, no qual o ciclo econômico e os fluxos de ouro têm papel central, ao lado das relações comerciais entre países centrais e periféricos, e onde a saída dessa cadeia estrutural exigiria um processo de industrialização como forma de incorporar progresso técnico, aumentar o nível da renda e criar condições para o desenvolvimento terá impacto nas análises de Celso Furtado, seja por reforçar a crítica ao caráter abstrato da teoria econômica, seja por fornecer instrumentos para captar a situação dos países latino-americanos e seus processos de industrialização ou de perpetuação do modelo primário-exportador, sobretudo o Brasil. 


\section{As armadilhas da teoria econômica no Brasil}

A recepção efusiva do relatório em Havana, bem como os debates que ensejou e que posicionaram a Cepal como uma importante agência no debate econômico mundial, não foram presenciados por Celso Furtado. Ainda subordinado dentro da nova hierarquia da Comissão, foi afetado pela decisão dos superiores em deixá-lo em Santiago. ${ }^{92}$ Nesta situação traduz o texto de Prebisch para o português e o envia à Revista brasileira de economia, mobilizando seus contatos no Brasil e dando continuidade às relações de Prebisch com os dois principais economistas da Fundação Getúlio Vargas, Eugênio Gudin e Otávio Gouveia de Bulhões. ${ }^{93}$ Mas, como não pensar a tradução do texto como uma maneira de estabelecer uma relação mais próxima com a figura central da Cepal? Por outro lado, embora o texto dialogue com o relatório preparado pelo staff técnico ${ }^{94}$, traz uma profusão de ideias estimulantes para as preocupações de Celso Furtado. Ora, se para Prebisch o documento expressa a síntese de suas reflexões sobre o ciclo econômico, para o economista brasileiro o novo instrumental analítico, convergente com o tratamento estatístico dos dados industriais dos principais países latino-americanos já trabalhados no relatório, estimularam-no a avançar a pesquisa por conta própria, utilizando seus conhecimentos em economia, incorporando o escopo referencial da Cepal, sem, contudo, abandonar a problemática desenvolvida em estudos anteriores, sobretudo na tese de doutorado. Dessa forma, o período em que permaneceu em Santiago permitiu canalizar energias no estudo do texto de Prebisch e incorporá-lo em suas reflexões.

Além da tradução do texto, Celso Furtado regressou ao Brasil para cuidar de sua publicação na Revista Brasileira de Economia, então dirigida por Arízio Viana, embora as decisões "sobre o que valia ou não publicar eram tomadas pelo professor Eugenio Gudin". ${ }^{95}$ Este acolheu o texto de Prebisch com interesse, publicando-o no número de setembro de 1949. Além disso, editou longos trechos do trabalho de Hans Singer sobre

\footnotetext{
92 “O sr. Castilho, que tinha em suas mãos a administração e em tudo intervinha (Martinez-Cabañas quase sempre estava ausente) seguramente estimou que meus serviços eram dispensáveis, o que me valeu ficar em Santiago na companhia de um outro técnico do secretariado, o engenheiro Bruno Leuschener" FURTADO, Celso. A fantasia organizada. op. cit., p. 159.

93 As relações entre Prebisch e Eugênio Gudin se iniciaram com uma visita deste à Buenos Aires em 1947. Meses depois, quando, junto com Otávio Gouvêa de Bulhões, debatiam a criação de um Banco Central no Brasil, solicitaram o aconselhamento de Prebisch sobre o assunto. DOSMAN, J. E. Raul Prebisch... op. cit., pp. 221-222.

${ }^{94}$ Com efeito, não há menção, no texto de Prebisch ao relatório ao qual servia de introdução. De resto, este é outro indício de que o texto sintetiza preocupações anteriores de seu autor.

${ }^{95}$ FURTADO, Celso Fantasia organizada, op. cit., p. 160.
} 
comércio internacional, base empírica da argumentação sobre a deterioração dos termos de troca de Prebisch. ${ }^{96}$ A visita foi também uma oportunidade para colher material sobre o Brasil, coletado sob o ímpeto de "estudar a economia de nosso país, de deslindar as causas de seu singular atraso". 97

Os resultados desse elã aparecem na publicação, também na Revista brasileira de economia, de "Características gerais da economia brasileira", em março de 1950, assinado por Celso Furtado, "economista da Comissão Econômica para a América Latina", informando, como de costume, que "o presente trabalho, entretanto, é de estrita responsabilidade do autor". 98

O texto permite apreender os influxos cepalinos na abordagem de Celso Furtado. Com efeito, é possível captar um novo deslocamento em suas preocupações, agora centradas na industrialização como forma de alterar a estrutura da economia colonial e estimular o surgimento do mercado interno no Brasil. Além disso, como veremos, a experiência na Cepal promove um redimensionamento dos instrumentos de apreensão da realidade econômica, revelando, do ponto de vista analítico e temático, outra face da reviravolta já apreendida do ponto de vista teórico das relações entre a o presente concreto e a teoria econômica. Consciente da contradição entre teoria e realidade, ou seja, de que o excesso de qualquer um dos polos pode afetar a compreensão dos problemas latino-americanos, retoma alguns temas examinados em sua tese de doutorado, porém redirecionando-os a partir das reflexões cepalinas.

Sem pretender introduzir uma grande digressão em nosso trabalho, notemos que Celso Furtado dedicou a última parte de Economia colonial no Brasil nos séculos XVI e XVII, sintomaticamente intitulada "Atavismos coloniais do Brasil Atual", a analisar "algumas das sobrevivências desse sistema [de economia colonial] na estrutura econômica e social do Brasil de nossos dias", 99 as quais permitem estabelecer um

\footnotetext{
96 PREBISCH, Raúl. O desenvolvimento econômico da América Latina e alguns de seus principais problemas. Revista brasileira de economia. Tradução de Celso Furtado. Rio de Janeiro, v. 3, n. 3, 1949. p. 47. No mesmo número da revista também foram publicados trechos do relatório de Hans Singer, sem indicação do tradutor, porém com indicação do editor que sua publicação se justifica "simply by the reason that the subsequente article of this issue starts its argument from the conclusions arrived at by the referred study", bem como dois artigos de Eugênio Gudin, "Estabilização de preços" e "A desvalorização da libra". Revista Brasileira de Economia. N. 3; v. 3, setembro de 1949.

${ }^{97}$ FURTADO, Celso Fantasia organizada, op. cit., p. 162.

${ }^{98}$ FURTADO, Celso. Características gerais da economia brasileira. Revista Brasileira de Economia. Rio de Janeiro, Fundação Getúlio Vargas, Ano 4, N. 1, março de 1950, p. 7

${ }^{99}$ FURTADO, Celso. Economia colonial no Brasil nos séculos XVI e XVII. São Paulo: Hucitec; ABPHE, 2001, p. 141.
} 
diálogo não apenas com o texto de Prebisch, mas também com o artigo "Características gerais da economia brasileira".

Na tese de 1948, a economia colonial é definida como um sistema no qual "o centro de gravidade da economia do país estará fora dele", e apenas uma parte do lucro gerado pela produção monocultora fica no país, ainda que concentrada em poder dos grandes proprietários, que consomem suas rendas no exterior. A partir dessa definição, três fatores são analisados por Celso Furtado, enquanto permanências desta economia colonial no século XX.

O primeiro deles é a persistência da monocultura e seu comportamento cíclico, cujo principal problema reside na passagem de um ciclo para outro: a alteração geográfica das regiões monocultoras, os deslocamentos de mão-de-obra e o surgimento de uma nova classe de proprietários a cada novo produto de exportação. Dessa forma, a superação da monocultura e a criação de uma dinâmica interna apareciam como o grande problema brasileiro. ${ }^{100}$ Deve-se assinalar que, ao contrário de Prebisch, os ciclos na tese de doutorado referem-se à oscilação nos preços e demanda de um produto primário-exportador e, sobretudo, às consequências do abandono do cultivo de produtos agrícolas para regiões anteriormente especializadas nessa produção monocultora. Nesse sentido, Celso Furtado se refere tangencialmente à dinâmica cíclica das economias capitalistas, cujo movimento é dado pelo processo de acumulação de capital e no qual se inter-relacionam fatores produtivos, monetários e fiscais.

Em segundo lugar, temos como consequência da monocultura o atraso técnico na agricultura, decorrente da escravidão e do isolamento em que a metrópole portuguesa manteve sua colônia. Dessa conjunção de agricultura de exportação e situação colonial resultou a existência de dois ramos na agricultura brasileira: a grande lavoura de exportação e a pequena lavoura de subsistência. Esta, que por séculos "se desenvolveu desarticulada, ao acaso das necessidades flutuantes dos núcleos urbanos ou de mineração", sofreu as consequências do desenvolvimento industrial "consequente às grandes guerras e crises deste século [XX]”, que absorveu a mão-de-obra nos núcleos urbano-industriais. Dessa forma, "as consequências não se fizeram esperar: a crise de gêneros de primeira necessidade se tornou mais e mais aguda nos principais centros

\footnotetext{
100 "A eliminação desse atavismo colonial — a monocultura — se apresenta hoje como um problema fundamental para o Brasil. Transplantar para dentro do país o eixo de sua vida econômica, superar o regime de colônia agrícola estritamente exportadora de alimentos exóticos: eis o problema brasileiro". FURTADO, Celso. Economia colonial... op. cit., p. 147.
} 
urbanos do país". ${ }^{101}$ Assim, voltando-se para "o problema agrário brasileiro", encontra "duas faces inteiramente diversas". A agricultura de exportação necessita de incorporação tecnológica que aumente sua produtividade, já que "forçar o mercado internacional, contraído em seguida às crises e guerras sucessivas e tornado inelástico pelo sistema de contingenciamento já não é possível”. ${ }^{102}$ Já a agricultura de subsistência deverá ser ampliada pela "multiplicação de pequenas unidades de trabalho", através da redistribuição de terras entre agricultores que trabalham em arrendamento, como forma de estancar sua migração para as cidades em busca de melhores salários.

Finalmente, temos a relação entre o domínio patriarcal e o município brasileiro. Celso Furtado destaca a polarização social decorrente do "domínio colonial brasileiro", na qual existe "de um lado, uma minoria senhorial; de outro, a massa achatada dos escravos". Este domínio persistiu no Brasil como "célula social", 103 e a vida política e social dos municípios brasileiros é expressão dos interesses do senhor patriarcal, subordinando os demais habitantes. A tese de doutorado se fecha com a constatação da impossibilidade de coesão social que unifique o país enquanto Nação:

\footnotetext{
a inexistência de interesses comuns que liguem os domínios semiautônomos e a tendência ao mandonismo resultante da herança escravista dificultam qualquer entendimento ou colaboração entre os senhores patriarcais. Por outro lado, esse isolamento de grupos semiautônomos fechará o caminho à formação de uma mentalidade política e de uma consciência de coletividade
}

Assim, depreendemos da tese de doutorado o entendimento da economia colonial enquanto um sistema subordinado a uma dinâmica externa. Por outro lado, a monocultura escravista - unidade econômica, social e cultural - criou estruturas que se perpetuaram no século XX: a produção em larga escala de algum produto de grande valor no mercado internacional e os custos causados pela alternância de regiões a cada ciclo produtivo, as transferências de mão-de-obra e a consolidação de fortes interesses sociais vinculados a cada novo produto de exportação. Por outro lado, o atraso técnico da agricultura brasileira e sua dualidade entre uma grande agricultura de exportação e uma agricultura de subsistência frágil, por não dispor de terras e operar com baixa produtividade, sem mecanismos para reter mão-de-obra, facilmente atraída para os centros urbanos e industriais. Nesse diagnóstico, o grande problema do Brasil reside,

\footnotetext{
${ }^{101}$ Idem, p. 161 e 162, respectivamente.

${ }^{102}$ Idem, p. 162.

${ }^{103}$ Idem, p. 165.

${ }^{104}$ Idem, p. 169.
} 
precisamente, em sua estrutura agrária. Ou seja, embora reconheça as transformações ocasionadas pelo surgimento de um núcleo industrial no século $\mathrm{XX}$, este apenas pressiona a mão-de-obra concentrada na agricultura de subsistência e não aparece como transformador do caráter colonial da economia brasileira. Finalmente, também decorre da monocultura o domínio patriarcal e sua estrutura de poder, que se perpetua no sistema político, impedindo a formação de interesses nacionais coesos.

Esse diagnóstico revela, por sua vez, a preocupação de Celso Furtado em investigar o passado brasileiro. De fato, a indagação sobre os "atavismos coloniais no Brasil atual" revela que o interesse pela história econômica brasileira estava no horizonte explicativo dos problemas contemporâneos de seu autor. Nesse sentido, é importante ressaltar que, decorrente de um exame da monocultura canavieira nordestina, os principais problemas que tenha detectado estão localizados, seja no atraso técnico da agricultura, seja na separação rígida entre exportação e subsistência e nos próprios efeitos da monocultura, cujos rastros de decomposição têm uma força centrípeta que dificulta a integração do país.

É preciso considerar, ainda, como Celso Furtado opera a transtemporalidade, pois já se descortina nesse diagnóstico uma proposta de reforma e transformação, via mudança na propriedade fundiária. Em suas palavras: "a medida mais urgente a ser tomada é a entrega da terra a quem nela trabalha", ${ }^{105}$ o cultivo nas propriedades abandonadas pelo latifúndio monocultor e a reorganização das correntes migratórias para ocupá-las. Dito de outro modo, o olhar ao passado tem como ponto de fuga os problemas do presente e, de sua compreensão histórica surgem as propostas de reforma, a preocupação em alterar o curso dos acontecimentos, rompendo os atavismos coloniais. Essa operacionalização da transtemporalidade, entretanto, revela todo seu alcance se apreendermos como, alterando-se os dilemas do presente e os instrumentos de conhecimento, tanto a apreensão do passado quanto os projetos de futuro também serão modificados por esse presente cognitivo que dá inteligibilidade ao passado e labora expectativas de futuro.

De posse desses elementos, examinaremos o artigo "Características gerais da economia brasileira" identificando os influxos teóricos oriundos da Cepal e sua relação com a problemática tratada na tese de doutorado. Assim, propomos avaliar como o texto "O desenvolvimento econômico da América Latina e alguns de seus principais problemas" reorientou as balizas analíticas de Celso Furtado. Em que medida os 
problemas formulados sobre a economia brasileira foram mantidos, de forma que os novos instrumentos se adaptaram a questões pré-existentes? Haveria um tensionamento no discurso do técnico das Nações Unidas entre uma problemática histórica identificada na economia brasileira e os objetivos de formulação de política econômica para os países latino-americanos da instituição em que trabalhava? Ou, teria ocorrido uma reformulação conceitual na obra de Celso Furtado, em decorrência do instrumental analítico proposto pela Cepal e imposto pela identificação de novas perspectivas para os problemas da economia brasileira? Questões essas que só poderão ser respondidas se compreendermos a interação entre formulação conceitual e problemas práticos.

Celso Furtado inicia o texto identificando "três fatores" no desenvolvimento da economia brasileira que persistiram ao longo do século XX: "a) uma persistente piora na relação de trocas; b) uma elevação não menos persistente da taxa cambial; e c) uma inflação crônica do meio circulante, motivada em grande parte por déficits orçamentários". Embora relacionados entre si, o primeiro é "a principal força de desequilíbrio", embora haja espaço para a "atuação independente de fatores internos em períodos curtos". 106

Essa preeminência do setor externo, a despeito de já estar consolidada nos estudos sobre a economia brasileira, destaca-se pela ênfase atribuída não mais à inserção do Brasil na economia mundial desde a Era dos Descobrimentos, mas é captada, agora, pelas formulações cepalinas sobre a conjuntura cíclica do capitalismo industrial, e suas implicações econômicas específicas: a defasagem entre os preços dos produtos primários e as manufaturas industrializadas, desfavorecendo os primeiros em benefício dos segundos. Essa perda, ainda, "parece ser uma característica específica do desenvolvimento econômico capitalista", como bem mostrou, nos diz Furtado, o artigo de Hans Singer, escrito no âmbito da ONU e traduzido parcialmente no número de dezembro de 1949 da Revista Brasileira de Economia. ${ }^{107}$ Nessas condições, o poder de compra no exterior poderia ser contrabalançado pelo aumento do volume físico das exportações ou, no que se refere especificamente aos grupos exportadores, essa piora na relação de trocas fora "neutralizada", através de elevações da taxa cambial. Da conjunção da deterioração dos termos de troca, agravada pelo movimento cíclico das

\footnotetext{
${ }^{106}$ FURTADO, Celso. Características gerais da economia brasileira. Revista Brasileira de Economia. Rio de Janeiro, Fundação Getúlio Vargas, Ano 4, N. 1, março de 1950, p. 7.

${ }^{107}$ Reforça a vinculação entre a Cepal e este primeiro artigo de Celso Furtado, a própria circulação restrita desse documento nos organismos internacionais, mas cuja cópia chegou às mãos de Prebisch quando este estava trabalhando em sua nova visão sobre o comércio internacional. Veja-se: DOSMAN, J. Prebisch: a formação do América Latina. Rio de Janeiro: Editora Contraponto; Centro Celso Furtado, 2011, p. 279.
} 
economias capitalistas, e da observação de suas consequências na economia brasileira, Celso Furtado vai caracterizá-la não como uma economia periférica - conceituação prebischiana que procura dar conta da inserção das economias na divisão internacional do trabalho - , mas sim como uma economia colonial:

a economia de tipo colonial que prevaleceu no país até 1914 e que somente a
partir da década passada vem sofrendo transformações substanciais, se baseia
na exportação de uns poucos produtos primários e na importação de grande
número de artigos de consumo, sobretudo manufaturas leves, como tecidos e
alimentos semielaborados. Esse tipo de estrutura econômica facilita a
transferência - através do mecanismo de câmbio - da perda resultante da
piora na relação de troca, que se exerce secularmente, e das baixas bruscas
dos preços dos produtos primários por ocasião das crises, dos reduzidos
grupos exportadores para as amplas massas importadoras ${ }^{108}$

Chama atenção, para além da incorporação da deterioração dos termos de intercâmbio no conceito de economia colonial, ausente em sua tese de doutorado, a própria escolha terminológica, que recusa o termo cunhado por Prebisch, Periferia, e que busca dar conta, sobretudo do aspecto econômico desigual da subordinação derivada da estrutura da Divisão Internacional do Trabalho. Nesse sentido, é possível perceber que há uma tensão conceitual entre os ensinamentos e corolários cepalinos e os instrumentos analíticos que Celso Furtado utilizou em sua tese de doutorado, de onde extrai sua concepção de economia colonial como uma dissimetria de poder político e econômico, como já fora assinalado por François Perroux. Mais certo, no entanto, assinalar a incorporação da deterioração dos termos de troca no conceito de economia colonial. Por isso, também, uma vez que sua elaboração engloba uma caracterização mais precisa das classes sociais, Celso Furtado pôde avançar rumo a implicações mais amplas, incluindo na análise do comportamento da taxa de câmbio no Brasil, o mecanismo de socialização das perdas, destacando suas consequências para os grupos de exportadores, industriais e as camadas urbanas.

Aqui, portanto, para além do mecanismo econômico, Celso Furtado acrescenta um elemento sócio-político, a "transferência da perda resultante da piora na relação de troca" para "as amplas massas importadoras" ou, como ficaria conhecida, a "socialização das perdas". A interpretação incorpora os efeitos sociais, bem como as relações de poder entre grupos econômicos brasileiros e delimita a forma como se manifestam os conflitos econômico-sociais entre os exportadores e os demais grupos sociais, redefinindo as bases da interpretação da tese de doutorado, agora não mais focalizada na influência dos senhores na vida política, mas sim na possibilidade de

$\overline{{ }^{108} \text { FURTADO, Celso. Características gerais da economia brasileira. op. cit., p. } 8 .}$ 
concentrar os ganhos e redistribuir os prejuízos econômicos através do acesso ao Estado. Por sua vez, a política econômica eleva-se como o principal elemento capaz de reproduzir e redistribuir os privilégios econômicos, em detrimento do controle do acesso aos canais eleitorais de mando político e a perpetuação de relações de poder, como aparecia na tese de doutorado. Não que a política se torne epifenômeno da economia, mas passa ser captada em sua expressão de interesses econômicos.

Por outro lado, as consequências dessa dinâmica cíclica para o caso brasileiro também são analisadas considerando as características da estrutura produtiva, constatando que a economia não cresce por aumento da produtividade e ampliação do mercado interno, mas sim através do mercado externo, de forma expansiva. ${ }^{109}$

Isso se torna um elemento fundamental para a caracterização da economia brasileira: "a chave para um grande número de problemas". Pois, "dado que o crescimento da economia se processava por solicitação externa, nenhuma correlação se estabeleceu entre o ritmo de crescimento e o aumento da produtividade. Seja, entre a produção nacional e o nível dos salários reais". ${ }^{110}$ O impulso externo não cria aumentos de produtividade fora de seu setor, nem repercute positivamente no nível de renda da economia, produzindo, mesmo, uma diminuição dos salários reais. Esse conjunto de fatores está na origem de dois traços característicos da economia brasileira: "a) a tendência para a concentração das rendas em exíguo número de mãos, e b) a lentidão na formação do mercado interno". 111

Essas considerações levam Celso Furtado a destacar outra consequência não mencionada no estudo de Prebisch, mas que compõe seu diagnóstico dos atavismos coloniais, qual seja: a dificuldade de formação do mercado interno, cuja explicação se dá pela ausência de aumentos no salário real e pela mão-de-obra disponível a preços baixos, uma herança da monocultura. Assim, embora se valendo dos conceitos dinâmicos de comércio internacional e da importância do setor externo na análise de Prebisch, recoloca essas conclusões sob a ótica da formação do mercado interno e da distribuição da renda. Como já fora assinalado, na economia colonial há "uma tendência à concentração das rendas nas fases de prosperidade e à socialização das perdas nas

\footnotetext{
${ }^{109} \mathrm{Na}$ formulação furtadiana: "ao contrário do que se passa nos países industriais, em que o crescimento da economia se faz através de aumento de produtividade e consequente ampliação do mercado interno, no Brasil a economia nacional se expandia exclusivamente sob a forma de aumento de envios ao exterior". FURTADO, Celso. Características gerais da economia brasileira. op. cit., p. 10.

110 Idem, ibidem.

111 Idem, p. 11.
} 
fases de depressão". ${ }^{112}$ Essa concentração se dá pelo reduzido número de exportadores que se beneficiam da expansão dos preços internacionais e consomem grande parte dos lucros em produtos importados.

Assim, podemos perceber como, ao mesmo tempo em que o instrumental cepalino revela conceitos de análise econômica, sobretudo a política econômica e suas repercussões no nível de renda dos grupos sociais, esses elementos ficam subordinados ao interesse de Celso Furtado de examinar os principais problemas da economia brasileira. Sua interpretação do passado, sua compreensão do processo histórico tensiona, questiona, direciona o instrumental da Cepal para a inteligibilidade dos dilemas econômicos do Brasil.

Dentro desse quadro, Celso Furtado retoma outro argumento da tese de doutorado: a consequência dos ciclos econômicos de produtos de exportação para o mercado de trabalho, que ensejou a formação de um excesso de mão-de-obra disponível, que se deslocava pelo território nacional "na proporção que se fazia necessária". 113 Dessa forma, a ausência de estímulos para a expansão dos salários reais ocasionou que “o crescimento desse mercado [interno] se processava apenas em extensão, seja pelo aumento de uma massa de ínfimo poder de compra". 114

O diagnóstico se completa e Celso Furtado extrai suas principais consequências ao elencar "certos traços fundamentais da economia brasileira", resumidos como:

os lucros excessivamente elevados, a socialização das perdas, o controle
parcial das atividades agroexportadoras por grupos financeiros estrangeiros, o
elevado preço do dinheiro e a debilidade do mercado interno - todos estes
fatores concorrerão para retardar a formação no país de um autêntico espírito
de empresa, condição básica do desenvolvimento de uma economia
capitalista 115

De fato, o principal efeito do funcionamento da economia colonial é a ausência de incrementos de produtividade e, em consequência, um baixo nível de salários. Esse conjunto de circunstâncias torna a formação do mercado interno lenta, por inexistir uma massa de consumo expressiva e pela elevada lucratividade do setor externo garantido por desvalorizações cambiais, as quais são inerentes à forma como as economias coloniais se ligam às industriais e ao movimento dos ciclos econômicos, e se traduzem também, num elevado consumo de produtos de luxo importados. Finalmente, Celso Furtado menciona a ausência de um espírito de empresa, ou seja, uma organização

\footnotetext{
112 Idem, ibidem.

${ }^{113}$ Idem, ibidem.

${ }^{114}$ Idem, p. 12.

115 Idem, ibidem.
} 
racional baseada em aumentos de produtividade e redução de custos, operando em condições de concorrência.

Essas características gerais da economia colonial brasileira sofrerão alterações decorrentes do "desenvolvimento de um núcleo industrial", que se forma no final do século XIX, quando "certos acontecimentos concomitantes", a abolição da escravidão, a proclamação da República e a Depressão nos Estados Unidos “iriam forçar a formação dentro do país de um primeiro núcleo industrial, o qual, como veremos, será mais bem um recurso de sobrevivência que um mecanismo de expansão". 116

A indústria têxtil, "primeiro grupo a desenvolver-se e que tem ocupado maior número de operários" é o setor privilegiado na análise. Celso Furtado detecta as conexões desse setor com as atividades de exportação, de forma que "as crises da indústria têxtil têm lugar em épocas de alta conjuntura mundial, seja, em fases de elevados preços dos produtos primários no mercado internacional e, portanto, de expansão da renda nacional real". 117

Essa dinâmica fez com que algumas características da economia colonial se perpetuem: a tendência ao sobrelucro e à cartelização, embora a coincidência de crises com a diminuição da capacidade para importar, permita aos industriais "apelar para medidas de caráter protecionista". Em consequência, "a crise perde, em razão disso, sua efetividade saneadora. E isto em parte explica a forma de crescimento tipicamente em extensão da indústria têxtil brasileira". ${ }^{118}$ Assim, Celso Furtado encontra no protecionismo à indústria nas fases de auge cíclico a origem dos lucros extraordinários do setor industrial e a manutenção de unidades ineficientes, garantindo "uma elevada taxa de sobrelucros"119, decorrendo "certos aspectos do desenvolvimento do núcleo industrial. Entre estes poderíamos citar a ausência de um vigoroso espírito de empresa, a qual se traduz numa tendência à cartelização". ${ }^{120}$ Em consequência, não havendo estímulos para a diminuição dos custos via aumento da produtividade: "esse tipo de

\footnotetext{
${ }^{116}$ Idem, p. 13. Entre os fatores que estimularam o surgimento deste núcleo industrial estão: a moeda desvalorizada, a mão-de-obra assalariada imigrante empregada na lavoura cafeeira, baixo custo da mãode-obra nacional e abundância de matérias-primas como atrativos às indústrias leves estrangeiras, e o elevado grau de proteção industrial decorrente do sistema fiscal e aduaneiro brasileiro, centrado nos impostos de importação e exportação. Esses fatores, por sua vez, não são capazes de unificar o mercado interno: "o núcleo industrial que assim começa a desenvolver-se não tem caráter nacional: está disseminado pelas diversas regiões do país que constituem mercados autônomos. Seu principal ramo é a indústria têxtil algodoeira, que conta com matéria prima de baixo preço nas diversas regiões do país". FURTADO, idem, p. 14

${ }^{117}$ Idem, p. 15.

${ }^{118}$ Idem, p. 18.

${ }^{119}$ Idem, p. 19.

${ }^{120}$ Idem, p. 23.
} 
expansão industrial contribui muito pouco para ampliação do mercado interno, pois se a massa dos salários pagos aumenta um pouco momentaneamente, os salários reais individuais nada crescem. Na realidade esses salários deveriam baixar porque a produtividade do trabalhador marginal diminuiu". 121

Nesse ponto, o aporte cepalino revela desdobramentos importantes na obra de Celso Furtado. Se a conexão da economia brasileira nos ciclos do capitalismo mundial tem repercussões diversas para os setores exportadores e industriais, este último também impõe dificuldades para a formação do mercado interno. Ora, ao funcionar com grandes lucros e ter uma capacidade de proteção nos períodos de crise do setor exportador, os centros industriais não repassam esses lucros aos salários, devido à abundância de mão-de-obra e à possibilidade da indústria crescer de forma extensiva, sem investimentos intensivos em capital e, portanto, incapaz de elevar a produtividade do trabalho. Dessa forma, ao expandir a produção mediante uso intensivo do equipamento, a produtividade e renda média tendem a decrescer, de forma que não há estímulo, do ponto de vista do consumo, para a consolidação de um mercado interno forte.

O diagnóstico, portanto, incorpora a contribuição da Cepal e, ao mesmo tempo, revela que os problemas de formação do mercado interno têm origem múltipla: a abundância de mão-de-obra, a elevada taxa de importações e a forma de operação do setor industrial. Aplicados à economia brasileira, os conceitos cepalinos conformam uma nova problemática no horizonte de inquietações de Celso Furtado e, também, para as economias latino-americanas.

Os setores industriais, prossegue, até os anos de 1930, apresentavam uma "incapacidade para superar dentro das regras do jogo capitalista as crises com que se enfrentavam". ${ }^{122}$ Ou seja, mantinham um crescimento extensivo, dependente de proteção, com sobrelucros e ausência de aumentos de produtividade, uma vez que o reinvestimento dos lucros exigiria um mercado interno amplo, precisamente o que os setores exportador e industrial barravam pela ausência de incrementos nos salários reais.

\footnotetext{
${ }^{121}$ Idem, p. 19. Esse ponto é importante para matizar a ideologia industrialista e se coaduna com o diagnóstico dos altos lucros industriais expresso pelos liberais. Por outro lado, essa crítica aos industriais provavelmente derive muito de sua racionalidade ao relatório da Missão Abbink, citado também por Prebisch.

${ }^{122}$ Idem, p. 23.
} 
Daí a importância da "ruptura do ritmo de atividade do setor colonial, cujas repercussões se fariam sentir em toda a estrutura econômica do país". ${ }^{123}$ Iniciada com a Crise de 1929, considerada "como o término de uma fase evolutiva da economia brasileira" ${ }^{24}$, as principais consequências da crise foram a impossibilidade da agricultura de exportação manter sua renda e gerar divisas para o país, sendo necessário "não somente reduzir o ritmo das inversões nesse setor, mas ainda adotar um regime de autodestruição". ${ }^{125}$ Com isso, a redução das importações dará impulso à produção interna.

Constatando a crise do setor exportador e o início do processo de industrialização, Celso Furtado nota três consequências desses acontecimentos: “a) maior grau de independência da economia do país, vis-a-vis das flutuações do mercado internacional de produtos primários; b) as mudanças na estrutura agrícola e c) a integração das diversas economias do país em uma unidade econômica". ${ }^{126}$ A importância do mercado interno atua na diminuição da participação da renda nacional vinculada às flutuações cíclicas da economia internacional e na constituição de núcleos urbanos que pressionam pela diversificação agrícola para atender seu mercado consumidor. Assim, o processo de industrialização iria "transformar o país em um só mercado, integrando as diversas regiões agrícolas anteriormente voltadas para o exterior". Dessa forma, "o Brasil, ao entrar em sua nova fase de desenvolvimento econômico, não só encerrava seu ciclo colonial, mas ainda fundia todos os 'ciclos' anteriores em uma unidade econômica integrada, e concluía o processo histórico de sua formação nacional”. ${ }^{127}$

O movimento do texto, portanto, se dá pela constatação da deterioração dos termos de troca como o principal fator desestabilizador da economia brasileira em sua fase colonial. É desse mecanismo inerente à dinâmica das economias capitalistas que Celso Furtado detecta a origem dos constantes problemas inflacionários e de balanço de pagamentos. Por outro lado, também aparece no texto as formas internas de reação a esse problemas: desvalorização cambial, que protege o setor exportador e transfere para o conjunto da população as consequências da diminuição do poder de compra da moeda nacional. Por outro lado, preocupado em captar as características da economia brasileira

\footnotetext{
${ }^{123}$ Idem, p. 23.

${ }^{124}$ Idem, ibidem.

${ }^{125}$ Idem, p. 27.

${ }^{126}$ Idem, p. 28.

${ }^{127}$ Idem, p. 31.
} 
em perspectiva histórica, Celso Furtado destaca as transformações ocorridas na passagem do século XIX, com o surgimento de um núcleo industrial. Este, dependente de proteção tarifária e cambial, operando com alta lucratividade e crescendo unicamente em extensão e não por aumentos de produtividade, não é capaz de estimular aumentos nos salários reais, condição fundamental para o surgimento de um mercado interno.

A crise de 1929 e seu impacto em todo o capitalismo global impõem barreiras intransponíveis ao funcionamento das estruturas da economia colonial. O destaque desse acontecimento remete, também, ao relatório de Prebisch, pois é considerado pelo economista argentino como uma ruptura no desenrolar dos ciclos econômicos, exigindo novas respostas de todos os países integrados no comércio internacional. A partir desse momento, portanto, a economia brasileira reage com a diminuição da participação do café, seu principal produto na pauta de exportações e responsável por grande parte da riqueza produzida no país. Por sua vez, as restrições à capacidade de importar dão um impulso prolongado para os setores industriais, bem como resultam em uma maior diversificação agrícola, visando o mercado interno.

Considerando a relação de "Características gerais da economia brasileira" com o texto do economista argentino, nota-se sua presença na análise dos ciclos econômicos dos países capitalistas e suas repercussões sobre os países periféricos, ou sobre as economias coloniais. ${ }^{128}$ Aqui, o principal elemento a ser destacado é que o ciclo econômico de Prebisch, baseado nas flutuações da produção e nas taxas de câmbio, é diferente daquele esboçado por Celso Furtado em sua tese de doutorado. Aquele que explica as flutuações cambiais não é mesmo que explica a formação da reserva de mãode-obra constituída historicamente na economia brasileira. Assim, afastando-se da consideração dos longos ciclos de produtos primários em sua sucessão histórica, Celso Furtado incorpora uma definição oriunda das preocupações de Prebisch com a dinâmica econômica, não mais centrada nas mudanças de produtos agrícolas, mas sim nos efeitos das relações de troca internacionais sobre a taxa de câmbio, a concentração de renda e a inflação.

Outro ponto que merece destaque nesse texto é o papel transformador do surgimento de um núcleo industrial e a imposição de uma ruptura com a economia

\footnotetext{
${ }^{128}$ Para Rosa Maria Vieira, há, também nesse ponto, uma divergência com Prebisch: "diversamente do economista argentino, sua atenção volta-se, sobretudo, para a procura das determinantes históricas desse processo, para os efeitos dos ciclos entre os diversos grupos sociais e suas consequências para o mercado interno". VIEIRA, Rosa Maria. Celso Furtado: reforma, política e ideologia (1950-1964). São Paulo: Educ, 2007, p. 51.
} 
colonial ensejada pela Crise de 1929. Embora seja preciso considerar que na tese de doutorado a preocupação principal com o diagnóstico do presente resultou na ênfase das continuidades entre o passado e o presente, a instrumentalização econômica proporcionada pela Cepal forneceu ferramentas para compreender os problemas brasileiros decorrentes do surgimento e expansão da indústria e suas relações com o comércio exportador. Nesse sentido, a Comissão e o texto de Prebisch tiveram papel fundamental para reinterpretar a problemática da economia brasileira em sua etapa atual.

O diagnóstico das transformações da economia brasileira, que em 1948 apontava para os problemas de concentração fundiária e baixo nível de produtividade agrícola como herança da monocultura, surge, menos de dois anos depois, identificando as principais alterações na estrutura produtiva como decorrentes da industrialização, em resposta à crise econômica mundial, cujo resultado é a ruptura com a condição colonial pela formação de um mercado interno integrando o território nacional, possibilitado pelo surgimento de um núcleo de produção industrial.

Finalmente, essa conversão à economia que tentamos retraçar com a reformulação das questões colocadas na tese de doutorado a partir do novo instrumental cepalino remete, também, àquelas considerações sobre o caráter abstrato da teoria econômica examinado nas resenhas. O esforço intelectual empreendido no texto “Características gerais da economia brasileira” mostra, na prática, a tentativa de apontar uma solução para aquela questão, na medida em que reformula sua interpretação exposta em Economia colonial no Brasil nos séculos XVI e XVII, utilizando conceitos capazes de captar com maior precisão as transformações na economia brasileira. Dessa forma, a tensão entre os conceitos cepalinos de deterioração dos termos de troca convivendo com a conceitualização da economia colonial indica uma integração do esforço teórico para a explicação da realidade. Dito de outra forma, pode expressar o empenho de Celso Furtado em se mover entre os dois polos examinados nas resenhas. Ou seja, procura incorporar os desenvolvimentos da teoria econômicas na explicação de problemas específicos sem, todavia, subordinar os elementos conceituais a um conjunto de dados empíricos. Nesse sentido, este texto de 1950 apresenta uma primeira tentativa de resolução das relações entre história e teoria econômica, apreensível no esforço de compreender a economia brasileira, não em seu desenvolvimento desde o século XVI, mas, sim, conceitualmente, enquanto uma economia colonial cujos fatores definidores começaram a ser superados com a Primeira Guerra Mundial. A partir desse momento, o 
exame passa a se voltar aos dois setores que melhor expressam essas transformações: 0 exportador e o industrial, este último examinado a partir da atividade mais importante no Brasil, a produção têxtil. Com isso, conseguimos compreender como a inovação conceitual trazida pela Cepal foi absorvida por um conjunto de preocupações já delimitadas sob a perspectiva histórica, que, entretanto, foi capaz de modificá-la e tensioná-la para solucionar os problemas da economia brasileira. Esse movimento de absorção e reorientação de problemáticas, tendo como critério último a compreensão da realidade brasileira e latino-americana é uma característica do pensamento de Celso Furtado, e estará presente no artigo que publicará em 1952, na Revista brasileira de economia.

\section{Ragnar Nurkse, Celso Furtado e o debate sobre desenvolvimento}

\section{econômico}

$\mathrm{O}$ artigo "Formação de capital e desenvolvimento econômico" é considerado por grande parte dos intérpretes de Celso Furtado sua primeira elaboração teórica sobre desenvolvimento econômico. Neste trabalho encontramos pontos centrais, tais como: a distinção entre países desenvolvidos e subdesenvolvidos, a importância do setor externo como elemento dinamizador nos estágios iniciais de desenvolvimento, o papel do Estado canalizando a poupança e transformando-a em investimentos, via planejamento, em concomitância com o controle sobre as importações e política industrial substitutiva.

O texto permite, também, a leitura de Celso Furtado enquanto um propositor da teoria do desenvolvimento econômico, temática que deu origem a uma pletora de contribuições desde o final da Segunda Guerra Mundial. ${ }^{129}$ Nesta interpretação,

\footnotetext{
129 As relações entre as primeiras teorias do desenvolvimento econômico e os relatórios oficiais das Nações Unidas, Comissão de Assuntos Econômicos e outras instituições criadas após a Segunda Guerra são apontadas por Reginaldo Moraes, Celso Furtado: a Cepal e a teoria do subdesenvolvimento. São Paulo: Ática, 1995. Ver, também, Aloísio Teixeira, Desenvolvimento econômico: a arqueologia do debate e a contribuição original de Celso Furtado. In: ARAÚJO, Tarcisio Patricio de; WERNECK VIANNA, Salvador Teixeira; MACAMBIRA, Júnior. (orgs) 50 anos de Formação Econômica do Brasil: ensaios sobre a obra clássica de Celso Furtado. Rio de Janeiro: IPEA, 2009. Bruno Borja, A formação da teoria do subdesenvolvimento de Celso Furtado. Rio de Janeiro, IE-UFRJ, 2013 (tese de doutorado). No que segue, cabe uma consideração importante. A contextualização do debate sobre desenvolvimento econômico no pós-guerra, do qual Celso Furtado faz parte, tem sido reconstituído de acordo com alguns elementos anacrônicos. Elegem-se alguns debatedores, sobretudo economistas consagrados nesta teoria, mas que não o eram necessariamente no momento da intervenção de Celso Furtado. Basta, para tanto, constatar que essa reconstituição é feita a partir de duas coletâneas de texto, uma delas organizada em 1969 por Agarwala e Singh, e outra publicada em 1984, por Meyer e Seers. Essas coletâneas, ao depurar os contendores, avaliando as contribuições com o distanciamento que o tempo permite, não nos parecem um procedimento adequado para a recuperação do debate. No caso específico de Celso Furtado,
} 
"Formação de capital e desenvolvimento econômico" intervém no debate internacional, já que foi escrito como resposta a um conjunto de conferências pronunciadas na Fundação Getúlio Vargas pelo economista estoniano Ragnar Nurske - professor da Universidade de Columbia e membro do Conselho Econômico e Social das Nações Unidas - a convite de Eugênio Gudin e publicadas, assim como o artigo de Celso Furtado, na Revista Brasileira de Economia.

As duas interpretações estão interligadas. $O$ texto, mesmo enquanto peça constituinte de um debate internacional sobre desenvolvimento econômico remete, ao mesmo tempo, à evolução das ideias de Celso Furtado e, portanto, ao contexto nacional no qual formula suas preocupações e no veículo escolhido para difundi-las. Em outras palavras: o trabalho aponta para a discussão sobre desenvolvimento econômico a nível internacional e nacional, pois envolve o maior centro de produção de conhecimento econômico no Brasil da época, inserindo-se num conjunto de conferências patrocinadas pela Fundação Getúlio Vargas, iniciadas em 1950 com H. W. Singer; Jacob Viener e Ragnar Nurkse em 1951, Arthur Burns e Alain Barrère em 1953 e Kenneth E. Boulding em 1954, seguindo-se outros conferencistas nos anos seguintes. Note-se, ainda, que, conectada com os trabalhos produzidos no exterior sobre a temática do desenvolvimento econômico, a linha editorial da revista aponta para a redução de espaço aos economistas latino-americanos ligados à Cepal, sendo que apenas mais um artigo de Raúl Prebisch será publicado na revista em 1956 e o último publicado por Celso Furtado será este que analisaremos, em 1952. Reforça esta afirmação a publicação de autores críticos às proposições da Cepal, a exemplo do próprio Eugênio Gudin, mas contando também com a artilharia de Gottfried Harbeler e Robert E. Baldwin. ${ }^{130}$

avaliações sobre sua intervenção deveriam ser feitas a partir dos autores citados por Celso Furtado, ou cujas proposições poderiam ser identificadas. Daí nossa ênfase, no que se seguirá, na polêmica com Ragnar Nurkse. Ainda sobre esse autor, boa parte dos estudiosos que se dedicaram a analisar esta polêmica apresentou parcialmente o oponente estoniano, resumindo sua teoria ao círculo vicioso da pobreza, ou então assumindo as próprias críticas, nem sempre justas, que lhe dirigiu o economista brasileiro. Dessa forma, a exposição, talvez excessiva, das propostas de Nurkse que serão encontradas na sequência do texto, visa captar os termos do debate, explicitando que não apenas os pontos selecionados por Celso Furtado para comentário, mas também seus silêncios, omissões e desentendimentos têm interesse especial para o historiador.

130 Sobre essa perda de espaço, Celso Furtado, lembrando a repercussão do texto de Prebisch que traduzira em 1949, esclarece: “já em dezembro de 1949, me havia escrito Arízio Viana, diretor da Revista brasileira de economia, informando da grande repercussão que tivera a publicação do primeiro ensaio de Prebisch. E acrescentara: 'Esperamos que Haberler, e posteriormente Jacob Viner, nos remetam dos Estados Unidos alguns comentários, conforme prometeram ao dr. Gudin’. Assim, a partir de 1950 abriuse por iniciativa deste uma ofensiva no plano acadêmico contra as ideias da Cepal". FURTADO, Celso. A fantasia organizada. In: Obra autobiográfica. Três Tomos. Organização de Rosa Freire d'Aguiar. São Paulo, Paz e Terra, 1997, p. 249. Está para ser feito um estudo da linha editorial da Revista Brasileira de Economia, procurando perceber as alterações na linha editorial à medida que a discussão sobre 
Com efeito, Celso Furtado percebe essa conformação de linhagens teóricas em disputa no debate sobre economia no Brasil, como já indicamos na análise de suas resenhas publicadas anos antes. Nesse momento, como explica em sua autobiografia, a vinda de Ragnar Nurkse representou uma oportunidade excepcional, devido à concepção dos problemas dos países subdesenvolvidos e sua possibilidade de superação. Para Celso Furtado, "os termos do debate, que pareciam haver sido definitivamente estabelecidos pelo ciclo de conferências de Viner em 1950, foram de alguma forma tumultuados com a visita do professor Ragnar Nurkse no ano seguinte". ${ }^{131}$ Numa caracterização retrospectiva desse debate, a autobiografia identifica a vivência do economista estoniano e seu trabalho na Liga das Nações como um ambiente que lhe forneceu "experiência em lidar com a economia internacional real [grifo de Celso Furtado], ademais de ter amplo conhecimento teórico da matéria, traço comum entre os grandes economistas suecos de sua geração". ${ }^{132}$ Características estas que permitem contornar a principal dificuldade da teoria econômica, tal como delineada nas resenhas publicadas alguns anos atrás, qual seja, a conciliação entre a teoria econômica e sua capacidade de explicação das experiências históricas concretas. Celso Furtado, no entanto, nega a existência de uma proposta original nas conferências, pois "a importância da contribuição de Nurkse não esteve em sua originalidade, e sim em apresentar de forma elegante e convincente, e em linguagem acadêmica, ideias que estavam brotando aqui e acolá, mas ainda não haviam sido reunidas em um todo articulado". Um dos locais onde essas ideias brotavam era, claro, o Chile, onde a Cepal estava ganhando importância na reflexão sobre os problemas latino-americanos.

A importância do artigo Formação de capital e desenvolvimento econômico deve ser colocada, portanto, seja sob a perspectiva dos debates sobre teoria do desenvolvimento econômico, seja nos embates teóricos reunidos na Revista Brasileira de Economia. Dito de outra forma, é preciso captar nessas duas vertentes, nacional e internacional, a maneira peculiar como Celso Furtado unificou-as, formulando uma crítica ao trabalho de Nurkse a partir de uma conceitualização, em algumas passagens,

desenvolvimento econômico no Brasil ganhava corpo, sobretudo durante os Governos Vargas e Juscelino Kubtschek. Essa virada editorial foi percebida por Ricardo Bielschowsky. Pensamento econômico Brasileiro. O ciclo ideológico do desenvolvimentismo. 1930-1964. Rio de Janeiro: Contraponto, 2003, p. 38.

${ }^{131}$ FURTADO, Celso. A fantasia organizada. In: Obra autobiográfica. Três Tomos. Organização de Rosa Freire d'Aguiar. São Paulo, Paz e Terra, 1997, p. 259.

${ }^{132}$ Idem, ibidem. 
cepalina, em outras lançando algumas "ideias pessoais" "133, partindo do exame e do conhecimento da realidade brasileira e latino-americana, mas atingindo repercussão internacional. Assim, propomos uma leitura que extrapole a compreensão do texto como um momento exclusivo de elaboração teórica, deslocado das problemáticas imediatas de seu tempo. Com efeito, analisado sob o ponto de vista da evolução do pensamento do autor, o texto marca um avanço e se torna um ponto de referência em sua produção. ${ }^{134}$ Entretanto, é preciso atentar para as circunstâncias da elaboração do artigo, seu objetivo imediato de intervenção no debate econômico, bem como a estruturação formal do trabalho e os pontos escolhidos para discussão.

Escrito como uma crítica às conferências de Ragnar Nurkse, o texto recebeu uma resposta do autor, argumentando que Celso Furtado não teria compreendido sua exposição e mesmo demonstrando uma maior proximidade com o crítico brasileiro do que o trabalho deste deixaria entrever. Dessa perspectiva, a pergunta sobre o primeiro texto de teoria do desenvolvimento de Celso Furtado se amplia para uma tentativa de compreender qual leitura fizera das conferências e por que se apoiou em críticas a argumentos que não eram tão opostos quanto sugeriu em seu artigo.

Algumas pistas para captar os propósitos de Furtado podem ser encontradas em sua autobiografia. As conferências chamavam a atenção, no Brasil, para o problema do subdesenvolvimento. Assim, "se este não aparecia nos livros que lia Viner, não era difícil encontrá-lo no mundo real. Abria-se novo espaço ao trabalho de teorização, que convinha ocupar". ${ }^{135} \mathrm{Ou}$ seja, as conferências eram uma oportunidade de ocupar um espaço no debate nacional, no qual (subentende-se) o problema do subdesenvolvimento em suas especificidades não era objeto das formulações teóricas por parte dos conferencistas convidados pela Fundação Getúlio Vargas, nem da teoria econômica tal como praticada no Brasil. Dessa forma, continua:

decidi-me a comentá-las, aproveitando a oportunidade para expor algumas ideias pessoais. Rompia-se o diálogo de surdos: deixávamos de lado as caixas vazias das teorias puramente dedutivas para abordar a realidade do subdesenvolvimento de um ângulo teórico. ${ }^{136}$

\footnotetext{
${ }^{133}$ Idem, p. 261.

${ }^{134}$ É esta a perspectiva de Támas Szmracsányi, que elege este texto como "seu artigo de estreia no campo da Teoria Econômica". Ver: SZMRECSÁNYI, T "Celso Furtado (1920-2004) e a Economia do Desenvolvimento". In: SZMRECSÁNYI, T; COELHO, F. S. Ensaios de história do pensamento econômico no Brasil contemporâneo. São Paulo: ATLAS, 2004, p. 388.

${ }^{135}$ FURTADO, Celso Fantasia Organizada. op. cit., p. 261.

${ }^{136}$ Idem, ibidem.
} 
A opção em comentar as conferências aparece, retrospectivamente, como uma tomada de posição no debate nacional, saturado de intervenções críticas à Cepal, formuladas em sua maioria por economistas de países desenvolvidos. E, nesses comentários que se propõe a lançar, ressaltar que "minhas discordâncias com Nurkse não tinham maior importância, se bem que ele não pensou assim, pois lhe dedicou uma longa resposta, publicada na mesma revista". ${ }^{137}$ As discordâncias, ao menos para Celso Furtado, não eram o elemento principal, mas sim a possibilidade de, por meio de considerações próprias ensejadas pelas palestras, inserir-se no debate sobre os problemas do subdesenvolvimento.

Entretanto, a opção de Celso Furtado não foi percebida dessa forma por alguns intérpretes. Com efeito, tomaram o texto pelo seu valor de face, ou seja, admitiram que fosse uma crítica à totalidade das conferências de Nurkse (veremos que não é isto) e a consideraram exclusivamente como uma primeira formulação da teoria do desenvolvimento econômico de Celso Furtado. ${ }^{138}$

Para Támas Szmeracsanyi, o artigo seria responsável pelo surgimento de seu autor "como economista de renome internacional", devido à sua tradução em inglês em 1954, podendo "ser considerado seu artigo de estreia no campo da Teoria Econômica, tendo tido um sucesso instantâneo e ganho de imediato ampla circulação”. Além disso, caracteriza-o como "uma resenha crítica" das conferências de Nurkse. ${ }^{139}$ Aloísio Teixeira, também vê no texto "a primeira contribuição de Celso Furtado" para o "debate sobre os temas do desenvolvimento econômico" no pós-Segunda Guerra Mundial ou, noutros termos, "sua primeira contribuição relevante para o debate da teoria do desenvolvimento". 140

Reginaldo Moraes, embora reconheça que Celso Furtado "recorta e interpreta os textos de Nurkse", analisa apenas a questão do círculo vicioso da pobreza. ${ }^{141}$ Nesse ponto, podemos adentrar em uma característica das interpretações do debate: a assunção

\footnotetext{
${ }^{137}$ Idem, ibidem.

${ }^{138}$ Curiosamente, basta consultar os trabalhos que, propondo-se a sintetizar as conferências de Nurkse, formulam apenas temas ressaltados pela própria crítica de Celso Furtado, deixando de lado importantes considerações do economista estoniano sobre transações internacionais, política industrial e fiscal, protecionismo, etc. Isso fica, ainda mais notório nos trabalhos que sintetizam as proposições de Nurkse como sendo unicamente o círculo vicioso da pobreza ou desenvolvimento equilibrado.

139 SZMERACSÁNYI, Támas. Celso Furtado. Estudos avançados, pp. 347-348.

140 TEIXEIRA, Aloísio. Desenvolvimento econômico: a arqueologia do debate e a contribuição original de Celso Furtado. In: ARAÚJO, T. P., et alli. (orgs) 50 anos de Formação Econômica do Brasil: ensaios sobre a obra clássica de Celso Furtado. Rio de Janeiro: Ipea, 2009, pp. 71 e 75, n. 7.

${ }^{141}$ MORAES, Reginaldo. Celso Furtado: o subdesenvolvimento e as ideias da Cepal. São Paulo: editora Ática, 1995, p. 30.
} 
de que Celso Furtado faria uma crítica ao conjunto das conferências de Nurkse e que estas estariam centradas nas dificuldades dos países subdesenvolvidos em acumular capital e transformá-lo em investimentos devido ao tamanho reduzido do mercado interno.

Para evitar essa interpretação — pois só assim poderemos compreender como Celso Furtado utilizou-se do texto de Nurkse, destacando pontos específicos, relevando outros, enfatizando críticas, contornando contradições — nossa análise será direcionada a uma reconstituição das proposições gerais das conferências, mapeando as possíveis convergências e distanciamentos de Celso Furado, para, em seguida, nos concentrar no objeto das críticas. Finalmente, examinaremos a réplica escrita por Nurkse, evidenciando os pontos que Celso Furtado selecionou, explicitando o caráter combativo do texto e as formas como, a partir das críticas, o economista brasileiro levantou questões importantes para a sua compreensão dos países subdesenvolvidos. Só assim poderemos aquilatar o lugar do texto na produção pessoal de Celso Furtado, entendo-a como indissociável dos debates nacionais e internacionais, embora com alvos e aproveitamentos diversos em cada território.

\section{Ragnar Nurkse e os Problemas da formação de capital em países subdesenvolvidos} (1951)

Para Ragnar Nurkse, o tema da formação de capitais "constitui o centro do problema do desenvolvimento em países economicamente atrasados". ${ }^{142}$ Reconhece, também, que o problema do desenvolvimento não se restringe ao campo estritamente econômico, mas "é ligado a aptidões humanas, atitudes sociais, condições políticas e acontecimentos históricos. A formação de capitais é parte importante, mas não todo o problema". 143

Constatando dificuldades envolvidas na abordagem da questão da formação de capitais, escolheu algumas ramificações "para estudo mais minucioso nesta série de conferências", alertando que "os tópicos selecionados serão de caráter geral", de forma que não se deve esperar "um tratamento sistemático e equilibrado do assunto, nem que

\footnotetext{
${ }^{142}$ NURKSE, Ragnar., Problemas da formação de capital em países subdesenvolvidos. In: Memórias do desenvolvimento. Ano 1; N. 1, junho de 2007. Rio de Janeiro: Centro Internacional Celso Furtado de Políticas para o Desenvolvimento, p. 19 (primeira conferência, "As dimensões do mercado e o incentivo à inversão"). No que segue, indicaremos em algarismos romanos o número da conferência, o nome da mesma apenas na primeira aparição na exposição e o número da página.

${ }^{143}$ NURKSE, Ragnar, I, p. 19.
} 
se relacione especificamente com as condições de qualquer país em particular". Com isso, a problemática da generalidade de uma teoria do desenvolvimento está colocada: nem o tema será esgotado, nem será possível atingir o nível histórico/concreto das experiências nacionais. 144 Por outro lado, a superação da generalidade pela incorporação dos circunstanciamentos específicos da realidade brasileira será um dos propósitos principais de Celso Furtado, não somente para contrapor-se ao economista estoniano, mas como forma de superar a dicotomia entre teoria econômica e histórica, incorporando as condições específicas na própria formulação da teoria econômica.

Após esta introdução, a ênfase recairá sobre "alguns aspectos internacionais do problema da formação de capitais em países menos desenvolvidos", ou seja, "somente em duas das minhas seis conferências, isto é, na primeira e na terceira, a atenção é focalizada no quadro nacional". ${ }^{145}$ Nesse ponto, podemos compreender que a abordagem segue caminho semelhante à da Cepal, ao enfatizar o comércio internacional. ${ }^{146}$

Como definiçãa geral para a compreensão das conferências, temos que:

formação de capital quer dizer que a sociedade se abstém de aplicar o total de suas atividades produtivas correntes à satisfação de necessidades e desejos de consumo imediatos, mas dirige uma parte das mesmas para a produção de bens de produção: - ferramentas e instrumentos, máquinas e meios de transporte, instalações e equipamento - todas as espécies de capital real que aumenta, e pode aumentar extraordinariamente, a eficiência do esforço produtivo [grifos do autor] ${ }^{147}$

\footnotetext{
${ }^{144}$ Idem, ibidem. A ressalva sobre o caráter geral do texto reaparece na réplica a Celso Furtado: "Minhas conferências foram de caráter geral, não se relacionando especificamente com qualquer país ou países". NURKSE, Ragnar. "Notas sobre o trabalho do Sr. Furtado relativo a 'Formação de Capitais e Desenvolvimento Econômico. In: Memórias do desenvolvimento. op. cit., p. 235.

${ }^{145}$ Nurkse, Ragnar, I, p. 19 . E acrescenta em seguida, retomando as dificuldades de interação entre os aspectos gerais e particulares em uma teoria do desenvolvimento: "minha desculpa, em parte, é que uma descrição mais completa dos problemas internos conduzir-nos-ia logo a particularidades para as quais não temos tempo e, de outra parte, porque os aspectos internacionais são de especial interesse nos Estados Unidos". Idem, p. 20

${ }^{146}$ Com efeito, a teoria da Cepal surge da análise da deterioração dos termos de intercâmbio entre produtos primários e manufaturados entre os países especializados na produção de cada um deles. Segundo Octávio Rodriguez, a constatação inicial da Cepal aparece em duas formulações: numa delas, chamada de "versão contábil", enfatiza-se os aspectos teóricos das trocas comerciais e detecta-se, do ponto de vista estático, a propensão à perda do valor de troca dos produtos primários frente aos industriais. Numa segunda formulação, chamada "versão ciclos", a apreende-se de forma dinâmica como a deterioração opera a partir do ciclo econômico das economias industriais e suas repercussões na periferia do sistema. Ver: RODRIGUEZ, O. Teoria do subdesenvolvimento da Cepal. Rio de Janeiro: Forense Universitária, 1981, pp. 51-66.

${ }^{147}$ Nurkse, Ragnar, I, p. 20. Reginaldo Moraes conclui que Ragnar Nurkse, ao defender um esforço das economias para ampliar a poupança em detrimento do consumo, se filia à economia política clássica, em sua concepção de abstinência. Ver. MORAES, R. Celso Furtado: o subdesenvolvimento e as ideias da Cepal. São Paulo: Editora Ática, 1995, p. 25.
} 
Trata-se, portanto, de um processo de transferência de recursos disponíveis para consumo no presente para o gasto com bens de produção, "de modo a tornar possível uma expansão da produção de bens consumíveis no futuro". Assim, caracterizada a problemática em seu aspecto mais geral, a primeira conferência versará sobre "as condições que determinam a procura de capital para uso no processo da produção", pelo “capitalista individual" ou "entrepreneur". ${ }^{148}$

O principal problema do lado da procura de capital reside "nas limitadas dimensões do mercado interno nos estágios iniciais do desenvolvimento econômico do país". ${ }^{149}$ Nos países menos desenvolvidos, "o uso de equipamento moderno na produção de bens para o consumo nacional é limitado pelo pequeno tamanho do mercado, pela falta de poder aquisitivo do mercado interno - não em termos monetários, mas em termos reais". ${ }^{150}$ Da constatação desse problema, descarta soluções como expansão monetária, intensificação de métodos de promoção de vendas e propaganda, aumento da população ou mesmo do território. Com efeito, "a determinante crucial do tamanho do mercado é a produtividade", ou seja, "a produção total depende da capacidade de produção per capita; isto é, da produtividade". ${ }^{151}$ Assim, a problemática da formação de capital sob o aspecto da procura interna do país se apresenta como: "a produtividade depende em grande parte (de nenhum modo inteiramente, mas grandemente) da quantidade de capitais usados na produção [...] Como vimos, porém, a aplicação de capitais é obstada e cerceada inicialmente pelo pequeno tamanho do mercado. Temos, claramente, uma relação recíproca entre o tamanho do mercado e o incentivo para investir". ${ }^{152}$ Para romper esse "círculo vicioso", é preciso que se explique "as forças necessárias, ou que foram observadas no passado, capazes de sacudir e fazer saltar fora a economia do estado de equilíbrio estagnante no qual, de outro modo, tenderia a permanecer". ${ }^{153}$ Para isso, Nurkse nos remete ao trabalho de Schumpeter, Teoria do desenvolvimento econômico. Considerando que este livro é "precipuamente uma teoria do crescimento econômico e só secundariamente uma

\footnotetext{
${ }^{148}$ Nurkse, Ragnar, I, p. 20.

${ }^{149}$ Idem, I, p. 22.

${ }^{150}$ Idem, ibidem.

${ }^{151}$ Idem, I, p. 24. Cumpre ressaltar que a questão da produtividade também é fundamental para a Cepal: "de acordo com as ideias gerais da Cepal, contidas em seus primeiros documentos, o desenvolvimento econômico se expressa no aumento do bem-estar material, normalmente refletido pela elevação da renda real por habitante e condicionado pelo crescimento da produtividade média do trabalho". Ver: RODRIGUEZ, O. op. cit., p. 36.

${ }^{152}$ Idem, I, p. 25.

${ }^{153}$ Idem, I, p. 26.
} 
teoria dos ciclos econômicos", destaca o papel central do empreendedor e das ondas de inovação. Nesse sentido,

o ponto principal aqui é o de reconhecer como um ataque frontal desta espécie, uma onda de investimentos de capital em muitas indústrias simultaneamente, pode ser bem sucedido, ao passo que a aplicação de capital por qualquer investidor individual, em qualquer indústria isolada, pode ser bloqueada, ou desencorajada pelas limitações preexistentes do mercado em conjunto ${ }^{154}$

Entretanto, Nurkse reconhece a aplicação limitada desse mecanismo de inovação dependente do empresário privado:

a teoria do desenvolvimento econômico de Schumpeter destinava-se a ser aplicada principalmente ao surto de crescimento do capitalismo ocidental. Não é necessariamente aplicável a outros tipos de sociedade. É possível que em outros tipos de sociedade as forças que devem derrotar os efeitos da estagnação econômica precisem ser deliberadamente organizadas pelo Estado, por meio de alguma forma de ação coordenada e empreendimento coletivo, pelo menos inicialmente $^{155}$

Nesse ponto, cabe destacar não apenas o reconhecimento do caráter particularista do texto de Schumpeter, mas a necessidade de intervenção estatal para iniciar um processo de formação de capital e aumento da produtividade na economia. Por outro lado, as formas de intervenção ou mesmo sua necessidade, estão fora do escopo de Nurkse, para quem "se as forças do progresso econômico devem ser organizadas pela iniciativa privada ou pelo Estado é essencialmente uma questão de método". 156

Retomando ainda os problemas do mercado interno, ressalte-se a baixa produtividade e sua contrapartida, a diminuta renda real. Como consequência disso,

\footnotetext{
${ }^{154}$ Idem, I, p. 27. Retomado mais adiante, "uma onda de novos investimentos em diferentes ramos da produção pode ser economicamente bem sucedida, aumentando o mercado total e quebrando, assim, a cadeia do equilíbrio estacionário do subdesenvolvimento". Idem, I, p. 29.

${ }^{155}$ Idem, I, p. 29. A questão da necessidade do Estado organizar os investimentos e a poupança, mesmo que deixando a execução para a iniciativa privada é um ponto destacado por Reginaldo Moraes: "não é difícil identificar o projeto de sociedade que a análise de Nurkse julga adequado à 'maturação' dos países subdesenvolvidos. Ele implicaria um alto grau de estatização: os investimentos feitos pelas autoridades públicas são decisivos, assim como a "poupança coletiva tornada obrigatória pelo Estado"'. Ver: MORAES, R. op. cit., p. 27. Ver, também, MALLORQUIN, C. op. cit., p. 55. Por outro lado, Bruno Borja, que reconstitui as ideias de Nurkse e do debate com Celso Furtado por outros textos, excluindo, inclusive, as conferências, chega a uma conclusão diversa: "Nurkse não toma partido do planejamento estatal, argumentando ser indiferente entre a ação governamental e a empresa privada, contanto que se busque o crescimento equilibrado". BORJA, Bruno. A formação... op. cit., f. 124.

${ }^{156}$ Idem, idem. Cumpre notar que Nurkse reconhece a necessidade de coordenação do Estado, embora tenda a acreditar que essa coordenação deva sinalizar os investimentos, que deveriam ser deixados para a iniciativa privada. A necessidade do Estado direcionar a ação da iniciativa privada têm levado alguns interpretes a considerar Nurkse como não favorável á intervenção do Estado. Veja-se BORJA, Bruno op.cit.
} 
temos um reduzido volume de poupança nacional e seu emprego em consumo improdutivo, o qual não estaria ligado a problemas monetário-financeiros, mas sim é "um reflexo direto do pequeno incentivo para investir capitais na produção para o mercado interno". ${ }^{157}$ Finalmente, dialogando com H. W. Singer, que constatou que os investimentos estrangeiros em países subdesenvolvidos, no passado, se concentraram nos setores de exportação, aventa a explicação geral de que essa concentração confirma a tese do reduzido mercado desses países, de forma que não haveria incentivos para investimentos.

Ragnar Nurkse não descarta a ajuda dos capitais estrangeiros, embora enfatize que estes tendam, sob condições de livre mercado, a se concentrar no setor exportador. Nesse ponto, o argumento a favor de um crescimento equilibrado é reforçado, pois estaria "criando economias externas que possibilitem alta produtividade social do capital ainda que, para qualquer empreendimento isolado, as perspectivas de lucro possam desencorajar bastante, ou, de qualquer modo, encorajar tão insuficientemente a ponto de não tornar compensadora a instalação de equipamento melhor e mais abundante". 158

Esses limites aos investimentos, ou seja, a ausência de estímulos econômicos para canalizar recursos para empreendimentos direcionados ao mercado interno tem outro obstáculo, externo, dado pela disparidade de renda entre as nações. Nurkse, em sua segunda conferência, aborda os problemas do balanço de pagamentos como um fator estrutural, compreensível teoricamente pela generalização, a nível nacional, da teoria do comportamento do consumidor de Duesenberry, o efeito demonstração. ${ }^{159}$ Nesta reformulação, "a intensidade da atração exercida pelos níveis de consumo dos países adiantados - o "efeito de demonstração" - no plano internacional é determinado por dois fatores. Um deles é o tamanho das disparidades da renda real e dos padrões de consumo; o outro é a extensão em que o povo tem consciência disso". 160 Utilizando estatísticas das Nações Unidas e os trabalhos de Simon Kuznets para os Estados Unidos, Nurkse constata que esses dois fatores estão ampliando seu efeito nas áreas subdesenvolvidas. Uma importante consequência dessa disparidade é seu reflexo

\footnotetext{
${ }^{157}$ NURKSE, Ragnar, I, p. 34.

${ }^{158}$ Idem, I, p. 38.

${ }^{159}$ Nurkse explica o efeito demonstração nos seguintes termos: "quando indivíduos estabelecem contato com bens superiores ou padrões superiores de consumo, como artigos novos ou novos meios de satisfazer velhas necessidades, ficam depois de algum tempo, sujeitos a uma certa inquietação e insatisfação; a sua imaginação é estimulada, seus desejos aumentados, suas propensões de consumo deslocam-se para um nível superior". Idem, Conferência II, p. 55

${ }^{160}$ Idem, II, p. 60.
} 
no balanço de pagamentos. Com efeito, "os países pobres, em contato com os mais ricos, estão sujeitos a constantes pressões para manterem suas rendas monetárias e despesas monetárias acima do nível assegurado por seus padrões de produtividade. $\mathrm{O}$ resultado tende a ser um desequilíbrio nos seus balanços de pagamentos internacionais". 161 Dessa forma, não bastariam medidas de caráter monetário e cambial para conter a inflação e os déficits governamentais ${ }^{162}$ seria preciso contornar o problema dos limites impostos à formação de capital nos países subdesenvolvidos. Para isso, retoma algumas considerações de Prebisch, a saber, "o nível de produtividade na América Latina é baixo por causa da falta de capital, e o capital é escasso por causa da pequena margem de poupança, a qual é devida à baixa renda e à baixa produtividade". ${ }^{163}$ Nurkse, entretanto, ressalta apenas este último ponto, ou seja, não necessariamente a falta de capital se deve ao baixo nível de renda mas, sobretudo, à propensão a consumir. A superação desta requer considerar a ineficácia das transferências unilaterais, internacionais e interregionais, pois a receita extra não seria automaticamente gasta em formação de capital, mas poderia contribuir para o consumo improdutivo. O mesmo vale para o capital privado estrangeiro, que não é atraído para países com problemas de balanço de pagamentos. Daí a necessidade desses recursos serem direcionados para investimentos produtivos, muito embora Nurkse continue tratando as formas de planejamento dos recursos como um aspecto de "método" e de "política econômica".

Na terceira conferência, Nurkse retoma as possibilidades de formação de capital com recursos internos. Para tanto, elabora uma tipologia dos países subdesenvolvidos, baseada na população, propondo "uma distinção entre dois tipos de países subdesenvolvidos, que poderão ser superficialmente designados 'superpopulados' e 'subpopulados"'. 164

\footnotetext{
${ }^{161}$ Idem, II, p. 61.

${ }^{162}$ Nurkse esclarece: “a prescrição clássica - paralisar a inflação e ajustar a taxa de cambio - não parece dar resultado [...] As pressões inflacionárias e as dificuldades do balanço de pagamentos, que tendem a resultar hoje das disparidades de renda e dos níveis de consumo, não constituem intrinsecamente a dificuldade básica. São sintomas. Poderiam resultar tanto de dispêndios de capital quanto de aumentos nos gastos de consumidores" idem, II, pp. 62-64.

${ }^{163}$ Idem, II, p. 65.

${ }^{164}$ Idem, III, p. 87. Essa distinção, diversa da cepalina e de Celso Furtado, não é objeto de análise na crítica que faz das conferências. Entretanto, a distinção foi vista como um dos aspectos mais problemáticos da teoria de Nurkse. Helen Makower, resenhando as conferências publicadas em livro em 1953, diz: "with a subject as complex as that about which Professor Nurkse is writing, it would be surprising if one found oneself in agreement with everything that he says. Perhaps my most general criticism would be that I think a sharper distinction between 'underdeveloped' countries and 'undevelopable' countries is needed. This distinction is partially contained in the author's dichotomy between densely populated and sparsely populated countries. However, I do not think it is wholly
} 
Nos países superpopulados existe um desemprego disfarçado, pois "mesmo sem modificação dos métodos de produção na agricultura, uma grande parte da população empregada nesse setor poderia ser transferida sem reduzir a produção agrícola". ${ }^{165}$ Essa distinção no âmbito dos países subdesenvolvidos implica em diferentes alternativas de soluções para o problema do subdesenvolvimento. No caso em exame, seria possível transferir o excesso populacional para a produção em outras áreas ou para o setor de infraestrutura. Assim, o problema da formação de capital aparece no financiamento. Discutindo fontes internas e externas, Nurkse reconhece, novamente, que "alguma forma de poupança coletiva, tornada obrigatória pelo Estado, é provavelmente indispensável para a mobilização dos potenciais implícitos no desemprego disfarçado". Porém, mais uma vez, trata-se de uma "questão de método", muito embora, seja "perfeitamente possível deixar-se a função do investimento em mãos de particulares", de forma que "apenas a função de economizar que deve ser executada de um modo compulsório pelo Estado". 166

No entanto, do ponto de vista das críticas que Celso Furtado fará à Nurkse, interessa-nos mais sua exposição do segundo tipo de países subdesenvolvidos, aqueles de população esparsa ou "subpopulados". Nestes países há uma taxa de crescimento populacional mais alta e, por estarem mais próximos dos centros internacionais, "ficam sujeitos, talvez, a maior pressão para aumentar seus níveis de consumo, do que resulta, portanto, maior 'handicap' em relação à respectiva capacidade interna de poupança”. ${ }^{167}$ A maior taxa de crescimento populacional implica aumento do consumo e consequentemente, do efeito demonstração. Dessa forma, os dois aspectos internos, tamanho restritivo do mercado e subpopulação, impactam no consumo e na ampliação dos problemas do balanço de pagamento. Em consequência, esses países têm "urgente necessidade de capital para atender ao crescimento da sua população. De outro lado, não sofrem de desemprego disfarçado em larga escala, que possa ser mobilizado para a formação interna de capital". Ou seja, de um lado, necessidade de capital e, de outro, ausência de fontes internas de poupança. A solução para esses países não seria uma transferência do setor agrícola para o industrial, pois o problema central é justamente a formação de capital. $\mathrm{O}$ ataque ao problema deveria sair de uma melhora técnica na

contained therein". MAKOWER, Helen. Review of Problems of capital formation in underdevelopment countries, by Ragnar Nurkse. The Economic Journal, V. 63, N. 252, (dec. 1953), p. 899.

165 Nurkse, Ragnar, III, 87.

166 Idem, III, pp. 92-93.

167 Idem, III, p. 98. 
agricultura, seja pela grande parcela da população que absorve, seja pela menor unidade de capital necessário para ocasionar melhorias de produtividade. Com esse aumento seria possível liberar mão-de-obra para as atividades de "formação de capital real", sendo preciso, também, disponibilidade de poupança para alimentar a parcela que irá fornecer os bens de produção. Para tanto, Nurkse examina o papel das finanças públicas, enfatizando a ausência de automatismos de mercado capaz de garantir que aumentos na renda sejam canalizados para poupança. Daí a necessidade de um controle sobre o aumente do poder de compra. ${ }^{168}$ Descarta a poupança compulsória viabilizada pela inflação, pois pode desviar recursos dos investimentos produtivos para setores de luxo, em detrimento de necessidades prioritárias de infraestrutura. As alternativas propostas seriam um imposto sobre o consumo - e não sobre a renda - e empréstimos compulsórios na forma de títulos e outros mecanismos. ${ }^{169}$

Assim, da exposição até aqui realizada, os principais elementos do diagnóstico de Nurkse sobre os países subdesenvolvidos são: 1) o reduzido tamanho do mercado interno, desestimulando o investimento e 2) a elevada propensão a consumir desses países, estimulada pela disparidade internacional de renda. Desse diagnóstico surge a necessidade de intervenção do Estado: a) planejando e coordenando uma onda de investimentos simultâneos, rompendo os limites setoriais e individuais do mercado interno; b) elaborando formas de poupança compulsória para financiar esses investimentos, os quais teriam diferentes objetivos e prioridades de acordo com a realidade específica de cada país. Finalmente, o fator trabalho nessas economias tem papel importante na definição dos meios de formação de capital: via alocação de fatores em países superpoulosos, via formas compulsórias de poupança para os países subpopulosos. Cumpre notar, ademais, que a intervenção do Estado não interferiria na iniciativa privada, embora o autor reconheça os limites e os problemas decorrentes de automatismos econômicos e soluções de caráter monetário para os problemas do desenvolvimento. Examinaremos, agora, outros elementos daquilo que o autor se referiu, no início, como os problemas da formação de capital do ponto de vista da oferta.

\footnotetext{
${ }^{168}$ Para Nurkse, "todas as forças automáticas atuam no sentido de desviar para o consumo todos os aumentos da renda". Em comparação com os países hoje desenvolvidos, "manter um controle firme sobre o aumento do consumo deveria ser mais fácil do que lhe reduzir efetivamente o nível. Este é o modo normal pelo qual o capital foi acumulado no passado. Não obstante, é um método bastante difícil em virtude das forças que atuam no sentido de um maior consumo imediato". Idem, III, p. 101.

${ }^{169}$ Novamente ao enfatizar a ação do Estado para a formação de capital, temos que "a poupança compulsória por meio da taxação é perfeitamente compatível com os investimentos privados. É o ato de economizar que o Estado torna compulsório. $\mathrm{O}$ ato de investimento pode ser deixado em mãos de particulares, embora, talvez, não sem alguma orientação e coordenação central” Idem, III, p. 107.
} 
Na quarta conferência, são analisados os investimentos externos sob o ponto de vista da sua contribuição para a formação de capital. Como sinalizado anteriormente, as restrições da demanda do mercado interno levaram o capital estrangeiro privado a se dirigir para indústrias fornecedoras de matérias-primas para os países industrializados, contribuindo para a especialização em produtos primários. ${ }^{170}$ Dessa forma, as economias subdesenvolvidas, expostas às livres forças do mercado, ao baixo nível de demanda do mercado interno em conjunto com a ausência de infraestrutura para escoar internamente a produção e intensificar o uso do fator trabalho, fez com que o capital estrangeiro privado não incrementasse a formação de capital na direção necessária para romper os limites impostos pelo tamanho restrito do mercado interno. Outro aspecto importante constatado por Nurkse é que, para além deste problema, os investimentos estrangeiros estavam diminuindo no século XX. Dessa forma, "a confiança em investimentos privados comerciais como fonte dos capitais necessários para 0 desenvolvimento econômico, é sujeita a um duplo desapontamento. Primeiro, não virão para a expansão do mercado interno. Segundo, mesmo para a expansão da produção para exportar, poderão deixar de vir em volume apreciável”. 171

Por outro lado, os empréstimos e donativos internacionais não necessariamente aumentarão o capital a ser investido em atividades produtivas. Como demonstrado na segunda conferência, podem simplesmente contribuir para o aumento do consumo de bens manufaturados dos países desenvolvidos. Mesmo a vinculação de empréstimos estrangeiros a projetos específicos de investimento não é considerado pelo autor como um "método infalível de aumentar o ritmo de investimento". ${ }^{172}$

Um terceiro elemento discutido refere-se a um aumento de poupança decorrente de uma alteração nas relações de troca com o exterior. Também nesse caso, enfatiza que "uma melhoria na relação de trocas não contribui, de nenhum modo automaticamente, para um aumento da formação de capital, através de um aumento da importação de bens de produção". De início, porque o aumento da renda pode ser canalizado para consumo no exterior ou gerar inflação interna. Assim, a ampliação da poupança deve ser canalizada para a formação de capital adotando-se, quando necessário, "medidas muito

\footnotetext{
170 "Os investimentos estrangeiros, em vez de desenvolverem as economias dos países agrícolas, serviram para enrijar e fortalecer o sistema sob o qual esses países se especializaram na produção de matériasprimas e gêneros alimentícios para exportação. Os investimentos estrangeiros, de acordo com este ponto de vista, têm tendido a promover um padrão especial de especialização baseado num esquema estático de vantagens comparativas no comércio internacional”. Idem, IV, p. 121.

${ }^{171}$ Idem, IV, p. 124.

${ }^{172}$ Nurkse menciona a possibilidade dos governos nacionais redirecionarem recursos produtivos para atividades improdutivas, contando com os recursos externos para substituí-los. Idem, IV, p. 128.
} 
definidas e deliberadas por parte das autoridades fiscais e monetárias". ${ }^{173}$ Nesse ponto, Nurse propõe claramente a implantação de taxação como mecanismo para criar poupança, de forma que

o incremento da exportação é, assim, contrabalançado por uma economia compulsória. Somente desta maneira pode-se evitar duas coisas: primeiro, inflação na economia doméstica e, segundo, a utilização de incremento da receita de exportação para a importação de bens de consumo corrente ${ }^{174}$

Implícita nessa proposta de formação de poupança está a ideia de que a taxação seria um mecanismo melhor do que as restrições à importação de bens não-essenciais. 175

A quinta conferência inicia a discussão de tarifas aduaneiras para proteger as indústrias nascentes. Com efeito, menos que uma questão de proteção aduaneira, o problema dos países subdesenvolvidos está no "suprimento de capitais"176, ou seja, reside na criação de indústrias, e não na proteção. Para Nurkse, o efeito da proteção aduaneira num economia com falta de capital seria um aumento do crédito com consequências inflacionárias. Além disso, a proteção tarifária teria como consequências: 1) que o aumento da renda no setor é contrabalançado pela diminuição daquela dos consumidores dessas indústrias; 2) um subsídio para o setor protegido que poderia ser feito via fundo de taxação sobre a possibilidade de contribuição dos consumidores em geral, e não de um setor específico e 3) não há garantia de que o aumento da renda no setor produtivo será reinvestido ou disponibilizado para a formação de capital futura. Dessa forma, Nurkse é taxativo ao afirmar que "a proteção tarifária por si só não fornece capital". 177

Outro ponto questionado de forma mais sistemática nesta conferência é a restrição às importações, sobretudo de produtos supérfluos ou de luxo. Nurkse observa que essa restrição pode não ser acompanhada por uma maior importação de bens de

\footnotetext{
${ }^{173}$ Idem, IV, p. 131.

${ }^{174}$ Idem, IV, p. 132.

175 Cumpre ressaltar que este é um ponto de divergência com a Cepal. Segundo Octavio Rodriguez, a questão da proteção ao mercado interno é elemento fundamental na política econômica proposta pela instituição: "destacam-se nesta matéria três aspectos principais: a necessidade, a amplitude e dimensão da proteção e, finalmente, o critério de não-reciprocidade entre a periferia e o centro, também chamado assimetria da proteção". RODRIGUEZ, O. O pensamento da Cepal... op. cit., p. 158.

${ }^{176}$ NURKSE, Ragnar, V, p. 146. Analisando do ponto de vista histórico e admitindo que os países subdesenvolvidos possuem tarifas protecionistas, afirma: "a proteção aduaneira às indústrias nascentes falhou na promoção do desenvolvimento industrial porque fez muito pouco, ou quase nada, para a criação do capital necessário a esse desenvolvimento". Idem, ibidem.

${ }^{177}$ Idem, V, p. 149.
} 
capital, mas ser gasta no mercado doméstico, ocasionando inflação, distorcendo os incentivos a investir e dificultando a formação de capital para o país. ${ }^{178}$ Dessa forma,

parece-me inteiramente inadequado que o Governo procure impor a sua decisão em relação ao investimento e consumo somente pela regulamentação das importações [...] Não podemos extrair mais capital do comércio externo, simplesmente obtendo mais importações de bens de produção. $\mathrm{O}$ problema verdadeiro é extrair mais poupança da renda nacional. É somente com uma política complementar de aumento da poupança interna, quer voluntária, quer compulsória, que as restrições à importação podem ser usadas eficientemente, e com êxito, para obter maiores importações de bens de produção no comércio exterior ${ }^{179}$

Com isso, Nurkse intervém no debate sobre as formas de política econômica necessárias ao desenvolvimento. Ao criticar o modelo de substituição de importações e propor, alternativamente, formas de captação internas de poupança para evitar mecanismos inflacionários, o alvo principal de sua crítica pode ser entendido como a política econômica cepalina. Assim, embora concorde em termos gerais com os pressupostos do diagnóstico daquela - deterioração dos termos de troca, dependência do setor externo, tendência ao consumo imitativo - Nurkse diverge a respeito das soluções, sobretudo a política comercial proposta pela Comissão. Isso será reiterado na última conferência, que versará sobre os movimentos internacionais de capital.

Nesta sexta conferência, Ragnar Nurkse, assim como Prebisch, destaca a dificuldade da teoria econômica em captar a dinâmica e as transformações reais, sobretudo os movimentos internacionais de capital; tema tanto mais interessante, pois esses movimentos foram a base empírica da crítica cepalina e seu ataque aos pressupostos abstratos das teorias do comércio internacional existentes. Para Nurkse, "a teoria econômica atrasa-se natural e inevitavelmente em relação ao curso real dos acontecimentos internacionais. Mas, em nenhum outro setor esse atraso tem sido tão grande como no campo dos movimentos internacionais de capital". ${ }^{180}$ A abordagem de

\footnotetext{
${ }^{178}$ Claro está que se pressupõe aqui uma situação de pleno emprego, no qual a oferta de produtos e de fatores de produção é inelástica.

${ }^{179}$ Idem, V, pp. 156-157. Mais adiante, Nurkse ainda esclarece: "sob a influência da inflação e restrições às importações de luxo, ambas as quais são muito comuns na América Latina, o investimento nos últimos anos tem tendido a concentrar-se em construções residenciais, principalmente para os grupos superiores da renda, e em indústrias de luxo ou semi-luxo, enquanto as instalações públicas essenciais, tais como estradas de ferro e portos, em alguns casos mostram sinais de decadência. Não se pode negar que esteja se verificando desenvolvimento econômico, mas parece um método de desenvolvimento desnecessariamente penoso e às avessas". Idem, V, p. 158.

${ }^{180}$ Idem, p. VI, p. 171. Para Nurkse, o atraso na discussão se deu pela premissa teórica da imobilidade dos fatores de produção; hipótese desmentida pelos acontecimentos do século XIX, mas que recobra sua importância na sequência da Crise de 1929 e durante a II Guerra Mundial. Nesse ponto, as relações entre
} 
Nurkse nessa conferência é, sobretudo, panorâmica, discutindo diversas interpretações, tal como a teoria keynesiana, que considera os movimentos internacionais de capital sob o ponto de vista dos efeitos dos investimentos estrangeiros nos países emprestadores/credores. Para Keynes, as exportações de capital estão associadas ao aumento da procura e do emprego no país exportador de recursos. Entretanto, Nurkse rejeita (assim como Prebisch) a hipótese de uma necessidade dos países industriais exportarem capital para manter o nível de emprego e renda. Keynes, ao desvincular o investimento estrangeiro como única forma de política anticíclica, abriu espaço para a relação entre investimentos internacionais e desenvolvimento. Finalmente, pensando na criação de externalidades para as economias tomadoras de empréstimo, Nurkse mais uma vez retoma, do ponto de vista das consequências internas dos pagamentos de empréstimos feitos pelos países subdesenvolvidos, que não há nada que impeça, do ponto de vista fiscal, que os investimentos estrangeiros sejam feitos no setor interno. Ainda assim, continua, o investimento estrangeiro se concentrará no setor externo, pelas razões apontadas nas outras conferências. Nesse sentido, Nurkse reafirma que o livre fluxo de capitais não é uma variável autônoma, seja para política anticíclica no centro, seja como estabilizador e gerador de expansão do mercado interno, nos países subdesenvolvidos. Dessa forma, as considerações de Nurkse estão próximas do diagnóstico elaborado por Prebisch, no sentido de reivindicar maior autonomia e direcionamento dos investimentos pelo Estado como forma de criar a acumulação de capital capaz de gerar aumentos de produtividade na economia.

\section{Celso Furtado e a Formação de capital e desenvolvimento econômico (1952)}

Como pudemos depreender dessa longa releitura, os temas abordados nas conferências de Nurkse ultrapassam a interpretação de sua teoria do desenvolvimento econômico como, simplesmente, o "círculo vicioso da pobreza"; uma leitura de transposição da teoria de Schumpeter; uma teoria do desenvolvimento equilibrado, ou; uma generalização do efeito demonstração de Duesenberry, muito embora esses sejam

as teorias e os movimentos reais da economia são percebidos por Nurkse, por exemplo ao se debruçar sobre a obra de Ohlin, que incorporou a mobilidade dos fatores de produção na teoria num contexto de estancamento das transferências destes fatores pós 1929. Outro fator que chama atenção foi a dificuldade de comprovação empíricas das teorias de Ohlin e Harbeler. 
elementos cruciais. Abordadas em seu conjunto, as conferências revelam uma pletora de temas, concernentes às dificuldades de formação de capital nos países subdesenvolvidos. A começar pela distinção desses países entre subpopulosos e superpopulosos, abordam-se: formas compulsórias de poupança, necessidade de intervenção do Estado, políticas cambiais e fiscais, mecanismos de proteção tarifária, etc.

Alguns tópicos tratados por Nurkse procuram desenvolver ou discutir aspectos da teoria de Prebisch, sobretudo a questão da tendência às altas taxas de importação nos países subdesenvolvidos. Entretanto, o tratamento da política comercial diverge substancialmente das propostas da Cepal, sobretudo na argumentação de que políticas de proteção às indústrias nascentes não são eficazes pois criam sobrelucros e/ou geram problemas no balanço de pagamentos. Ainda assim, se nesse aspecto Nurkse faz coro aos argumentos de caráter liberal e crítico às ideias da Cepal, por outro lado os diagnósticos e soluções monetaristas para os problemas de balanço de pagamentos e da inflação são igualmente rechaçados.

Para nosso argumento, caberia perguntar: quais desses aspectos Celso Furtado poderia - seja pelo seu trabalho na Cepal, seja nas discussões que vimos que estava se dedicando - criticar?

Um leitor que não esteja saturado com as interpretações e com os desdobramentos da obra de Celso Furtado apostaria na política comercial, na defesa da intervenção do Estado para promover a industrialização, na tipologia entre países superpopulosos e subpopulosos e no círculo vicioso da pobreza. Ademais, Celso Furtado poderia se valer das consequências que Nurkse retira da baixa demanda do mercado interno - a concentração dos investimentos estrangeiros nos setores exportadores, com baixa propensão a se expandir aos setores internos — para enfatizar a necessidade de industrialização dos países latino-americanos. Consequência tanto mais importante, pois alerta para as dificuldades que surgem em canalizar investimentos aos setores ligados ao mercado interno, cujos mecanismos que possam viabilizá-lo foram examinados nas últimas quatro conferências, onde o papel do Estado como coordenador desse esforço é fundamental.

Essa linha seria tanto mais provável se considerássemos o lugar específico de onde Celso Furtado estava falando. Com efeito, meses antes da conferência de Nurkse, o destino da Cepal havia mudado consideravelmente. As manobras diplomáticas dos EUA para encerrar os trabalhos da Comissão e manter as análises sobre a economia da 
América Latina restrita à Organização dos Estados Americanos fora derrotada pela intervenção decisiva das delegações do Brasil, Chile e México. Com isso, a Cepal se tornou um órgão permanente da ONU. Ainda em junho de 1951, a Comissão cria uma diretoria de desenvolvimento econômico, sob a direção de Celso Furtado. Dois meses depois, traduziu os capítulos teóricos que Prebisch redigiu para a conferência do México, publicando-os no terceiro trimestre, na Revista brasileira de economia. Dessa forma, temos um movimento de Celso Furtado divulgando as ideias sobre política econômica da Cepal no Brasil, ao mesmo tempo em que ascende a um cargo de direção na instituição. Assim, por mais que a resposta a Nurkse seja exclusivamente de Celso Furtado (não há registro, ao menos na autobiografia, de que tenha discutido o texto com os colegas de Santiago), seria temerário esquecer que "Formação de capital e desenvolvimento econômico" é escrito pelo diretor da divisão de desenvolvimento econômico da Cepal. ${ }^{181}$

No entanto, a estratégia encampada por Celso Furtado não poderia ser mais diversa. Cabe, agora, examinar não apenas a crítica dirigida aos textos de Nurkse e, mais importante, qual foi sua opção argumentativa. Iremos atentar para os pontos do debate e, sobretudo, os critérios que adota e sua contraposição de argumentos e soluções aos problemas levantados. Dessa forma, o artigo "Formação de capital e desenvolvimento econômico" pode revelar seu sentido mais imediato: intervenção no debate sobre desenvolvimento econômico, internacional e nacional a um só tempo, evidenciando como a crítica de Furtado posiciona-o em relação à agenda teórica e política da Cepal (onde trabalha), às proposições de Nurkse (o adversário) e à orientação e compromisso editorial da Revista Brasileira de Economia (local onde o debate efetivamente acontece).

O início do texto oferece um interessante contraponto com a retomada memorialista do debate na autobiografia, onde Ragnar Nurkse foi caracterizado pela sua "experiência em lidar com a economia internacional real [grifo de Celso Furtado], ademais de ter amplo conhecimento teórico da matéria”. ${ }^{182}$ Numa direção oposta, este artigo de 1952 abre-se com uma contraposição entre os economistas e a teoria

${ }^{181}$ Sobre a mudança institucional da Cepal, para além da autobiografia de Celso Furtado, pode-se consultar com proveito a narrativa que consta em Edgar J. Dosman, Raul Prebisch: A construção da América Latina e do Terceiro Mundo. op. cit. Por outro lado, sobre o texto de Celso Furtado como portador das ideias da Cepal, precisamos considerar que dois anos depois, com a publicação do $A$ economia brasileira, em 1954, a Comissão resolveu editar uma série de normas cerceando publicações autorais de seus membros. Talvez a preocupação com os trabalhos de seus integrantes possa ter surgido com esse trabalho de Celso Furtado.

${ }^{182}$ FURTADO, Celso. A fantasia organizada. op. cit., 259. 
econômica formulada nos países desenvolvidos e subdesenvolvidos. Temos, de um lado, os "economistas de países "desenvolvidos"” e seus esforços para "compreender os problemas que enfrentam atualmente as economias subdesenvolvidas"; de outro, "a inexistência de material informativo de base e o resultante desconhecimento da realidade econômica [que] criaram nos economistas dos países subdesenvolvidos o hábito de raciocinar por analogia, na ilusão de que a um determinado grau de generalidade os fenômenos econômicos seriam iguais em toda parte". ${ }^{183}$

Nessa distinção aparece a separação de recursos e meios de compreender os países subdesenvolvidos. A despeito dos esforços dos economistas de países avançados em termos de elaboração teórica e reflexão sobre a problemática do desenvolvimento, nestes países, devido à falta de dados, seus economistas raciocinam "por analogia", o que implicaria, seja a ausência de um pensamento "autóctone", seja a incompreensão da dificuldade de conciliação — próprio do método da economia, como já vimos — entre a realidade a ser explicada e a teoria que procura explicá-la ${ }^{184}$, o que coloca no cerne da problemática a questão da generalidade da teoria econômica para abarcar realidades diversas. Assim, atenuada na autobiografia, o debate não gira em torno de conceitos e formulações teóricas isentas, mas revela concepções divergentes sobre a teoria econômica e disputas sobre a forma de interpretar a realidade dos países subdesenvolvidos, o que, se exige conceitos e dados para acercar-se do objeto, necessita, ao mesmo tempo, de um arcabouço interpretativo adequado.

No fundo, é isso que está posto: criticar o internacional a partir do nacional, legitimando os esforços de compreender a realidade econômica do subdesenvolvimento em seus próprios termos: como faz a Cepal e como fará Celso Furtado e, em sua visão, reluta em fazer a Fundação Getúlio Vargas e seus economistas liberais.

Elaborada a distinção, Celso Furtado passa a enumerar os temas que serão objeto de apreciação e que, pela "extraordinária atualidade", "merecem ser assinalados para maior discussão". Neste trabalho, se detém em três deles: “a teoria do desenvolvimento

\footnotetext{
183 FURTADO, Celso. Formação de capital e desenvolvimento econômico. In: Memórias do desenvolvimento, op. cit, p. 195. Publicado pela primeira vez na Revista Brasileira de Economia, (set. 1952). Rio de Janeiro, ano 6, número 3.

184 “Infelizmente, nem sempre é possível tirar conclusões aplicáveis a situações concretas de teorias que, se bem apresentam uma grande consistência lógica, estão construídas num elevado nível de abstração". Furtado, Celso, idem, p. 195. Aqui, portanto, a crítica que vimos aos trabalhos de Jean Marchal e Richard Lewinsohn a respeito justamente da dificuldade de conciliação entre teoria e realidade aparece agora amplificada na relação entre a América Latina (realidade) e a teoria econômica que os economistas, dos países desenvolvidos e subdesenvolvidos, usam sem a adequação à realidade, seja pela inexistência de dados, seja por mimetismo ou, mesmo, pela abstração e generalização de um conjunto de teorias formuladas para uma realidade específica.
} 
econômico", "o problema das relações entre a propensão a consumir e a intensidade do desenvolvimento", e "a questão dos efeitos das inversões sobre o balanço de pagamentos". 185

Celso Furtado ressalta a passagem, das teorias do ciclo econômico e de medidas anticíclicas, à compreensão do processo de crescimento econômico, chegando a uma elaboração teórica do desenvolvimento econômico. Retoma a apreciação do próprio Nurkse sobre esse tema, complementando que "anteriormente o desenvolvimento econômico havia sido matéria de preocupação de historiadores, filósofos sociais e sociólogos no campo da dinâmica social" e indica, em seguida, "as magníficas obras de Max Weber, Henri Pirenne, H.[enri] Sée e outros, sobre as origens do capitalismo". ${ }^{186}$

Para Furtado, a passagem da política anticíclica se conclui com a percepção de que o desenvolvimento econômico não pode estar desvinculado de estudos e projetos de orientação das variáveis econômicas. Dito de outra forma: "uma das modalidades mais recentes de política anticíclica consiste na determinação de objetivos a serem alcançados, em função do tempo, por determinados setores da atividade econômica, aos quais se atribui um papel dinâmico". ${ }^{187}$ Ou seja, dentro das tendências de reflexão sobre o desenvolvimento econômico, o planejamento, ou melhor, a possibilidade de lidar com variáveis agregadas para estimular o produto aparece nesse texto como algo consonante "uma das modalidades mais recentes de política anticíclica". Dessa forma, "compreende-se, portanto, o grande interesse que despertam atualmente os estudos sobre a acumulação de capital, as relações entre o montante das inversões e a renda nacional e finalmente o renovado empenho em levantamentos da riqueza nacional, que se observam particularmente nos Estados Unidos”. 188

Após essas considerações gerais, Furtado direciona o artigo para as críticas às conferências. Considera que

o prof. Nukse aborda a teoria do desenvolvimento econômico dentro do quadro geral do pensamento de Schumpeter. Sua versão desse pensamento é, entretanto, extremamente pessoal, razão pela qual consideraremos em separado sua contribuição para em seguida fazer algumas observações sobre a teoria schumpeteriana ${ }^{189}$

\footnotetext{
185 Idem, ibidem.

${ }^{186}$ Idem, p. 196, nota 2. A referência a esses autores será retomada mais tarde.

${ }^{187}$ Idem, ibidem, 196.

${ }^{188}$ Idem, p. 197. Lembremos que o Centro de Análise da Conjuntura Econômica da Fundação Getúlio Vargas, onde Celso Furtado trabalho entre 1948 e 1949 era o órgão nacional responsável pela elaboração desses dados. Mas, mais importante, na segunda metade de 1952 reúne esforços para a elaboração de suas técnicas de planificação, cujo relatório será apresentado em maio de 1953, no Rio de Janeiro, durante a conferência anual da Cepal.

${ }^{189}$ Idem, ibidem.
} 
Aqui, nesse primeiro trecho, podemos perceber a estratégia de Furtado: resumir o conteúdo das conferências a uma observação que se encontra apenas na primeira delas. ${ }^{190}$ E ainda mais, de identificar em Nurkse uma teoria do desenvolvimento econômico que este não reivindica, bem como fazê-la derivar da obra de Schumpeter. Sobretudo por que, como acompanhamos, a menção ao economista austríaco é ilustrativa das dificuldades de incorporação de progresso técnico em economias subdesenvolvidas e Nurkse alerta que "destinava-se a ser aplicada principalmente ao surto de crescimento do capitalismo ocidental. Não é necessariamente aplicável a outros tipos de sociedade". ${ }^{191}$ Ainda sobre essa definição dos objetivos das conferências, para Furtado, "o ponto central do pensamento de Nurkse se refere à pequenez do mercado como fator limitante do desenvolvimento econômico". ${ }^{192}$ Essa caracterização centrada na ausência de procura de capitais para expandir as atividades internas como um fator característico dos países subdesenvolvidos - permite que Celso Furtado proponha uma alternativa de desenvolvimento econômico que superaria o restrito tamanho de mercado. Percebamos o movimento: ao reinterpretar um aspecto das conferências como o núcleo central do pensamento de Nurkse, pode valorizar sua proposição alternativa, qual seja: "sempre que os países subdesenvolvidos tivessem oportunidade de realizar suas inversões com vista ao mercado externo, o problema não existiria”. Assim, ao contrário de Nurkse, para quem a concentração dos investimentos no setor externo não dinamiza a economia ${ }^{193}$, segundo Celso Furtado, “a questão fundamental está na inexistência de um mercado externo em expansão. Haveria, assim, que distinguir entre desenvolvimento com comércio externo em expansão e desenvolvimento com estancamento ou contração do intercâmbio exterior". ${ }^{194}$ Dessa

\footnotetext{
${ }^{190}$ Com efeito, Nurkse caracteriza as dificuldades típicas de uma economia com escassez de poupança e reduzido mercado interno de obter capitais para iniciar um processo de aumento da produtividade. Dificuldade agravada pela abundância do fator trabalho, de forma que a incorporação de uma maior quantidade de capital não poderia gerar efeitos nos outros setores econômicos (seja porque poderia ampliar a oferta de mão-de-obra na economia [se a tecnologia é capital-intensiva] seja porque não há mercado para absorver aumentos da produção), sendo necessário investimentos em diversos setores econômicos ao mesmo tempo, para gerar demanda global.

${ }^{191}$ NURKSE, Ragnar. Problemas da formação de capital em países subdesenvolvidos. In: Memórias do desenvolvimento. op. cit., Primeira Conferência, p. 29.

${ }_{192}$ FURTADO, Formação de capital.. op. cit., p. 197.

${ }^{193}$ Idem, p. 198. Ainda sobre Nurkse, não podemos esquecer que este se vale do estudo de Hans Singer sobre os investimentos estrangeiros nos países subdesenvolvidos, incorporando sua análise da pequenez do mercado interno para explicar que os investimentos estrangeiros concentram-se no setor externo da economia e não ampliam seus efeitos para o resto da economia. Ver, sobre isso, NURKSE, op. cit., I, pp. 34-36.

${ }^{194}$ FURTADO, Formação de capital.. op. cit., p. 198. Podemos pensar que a insistência de Celso Furtado nessa variável externa possa ligar-se, em alguma medida ao conceito de crescimiento hacia afuera, da
} 
forma, a onda de inovações em diversos setores da economia não é a única via para o desenvolvimento econômico, já que o mercado exterior pode suprir essa função. Por outro lado, ainda em termos da dimensão restrita do mercado interno, é preciso observar que "um mercado é pequeno com relação a alguma coisa. E no caso em questão o mercado dos países subdesenvolvidos é pequeno com relação ao tipo de equipamento que se usa nos países desenvolvidos. Não é essa uma dificuldade fundamental no processo de desenvolvimento econômico e sim acidental". ${ }^{195}$ Aqui, portanto, a crítica a Nurkse prossegue ao afirmar que a indivisibilidade técnica não é um fator importante para bloquear o desenvolvimento econômico, já que pequenas melhorias na alocação dos recursos nos países subdesenvolvidos já ocasionaria uma elevação da produtividade, contudo, aspecto reconhecido por seu oponente. ${ }^{196}$

Nesse momento, a leitura atenta das conferências nos revela que Celso Furtado está contrapondo-se a Nurkse, ainda que se valendo dos argumentos deste último, ou seja, refuta a tese da pequenez do mercado com ponderações que o próprio economista estoniano fizera a respeito da indivisibilidade, e que contribui para desestimular os investimentos.

Outro ponto onde essa estratégia aparece é na crítica que dirige a Schumpeter, à não historicidade do "empresário inovador", bem como a ausência de explicação das bases sociais desse indivíduo. Embora Nurkse houvesse explicitado que as afirmativas de Schumpeter não são aplicáveis aos países subdesenvolvidos, mas serviriam apenas de indicativo das possibilidades de romper o círculo vicioso da pobreza, em sua crítica, Celso Furtado vai indicar que

\begin{abstract}
em realidade o problema do desenvolvimento econômico é um aspecto do problema geral de mudança social em nossa sociedade, e não poderá ser totalmente compreendido se não se lhe devolve o conteúdo histórico. Seria necessário considerar todo o complexo cultural que se formou na Europa, com seus elementos de racionalidade, sua mobilidade social, sua escala de prestígio em grande parte refletindo a escala da riqueza pessoal, para explicar a dinâmica do processo econômico capitalista.
\end{abstract}

Cepal. Entretanto, do ponto de vista conceitual, haveria um problema em sua suposição de um "desenvolvimento com estancamento ou contração do intercâmbio exterior", já que este aconteceria quando a dinâmica do setor externo deixasse de ser dominante. Por outro lado, essa formulação não incorpora a teoria dos ciclos cepalina.

195 Idem, ibidem.

${ }^{196}$ Cumpre notar que essa crítica é reconhecida pelo próprio Nurkse: "Muitos artigos de uso comum nos Estados Unidos da América só podem ser vendidos em quantidades tão pequenas em países subdesenvolvidos que uma única máquina, trabalhando apenas uns poucos dias ou semanas, poderia produzir o suficiente para o consumo de um ano todo; o resto do tempo teria que permanecer parada". NURKSE, R. op. cit., I, p. 23.

${ }^{197}$ FURTADO, Formação de capital.. op. cit., p. 200. 
Essa crítica ao caráter abstrato do "empresário schumpeteriano" será ampliada ao conceito de "ondas de inovação", pois:

utilizar essa teoria como explicação do ponto de partida de um processo de crescimento numa economia subdesenvolvida nos parece afastar-se muito da realidade. Para uma economia subdesenvolvida, começar um processo de desenvolvimento com seus próprios recursos e pela ação espontânea de seus próprios empresários é, para usar uma frase corrente, como levantar-se pelos próprios cabelos ${ }^{198}$

Aqui, a crítica pressupõe que o processo de desenvolvimento fosse comandado unicamente pela classe de empresários privados do país subdesenvolvido e que a "onda de inovação" surgiria de forma espontânea. Essa suposição, cara à visão liberal, não consta das conferências, onde esse esforço de inovação não seria obra da iniciativa privada individual, mas coordenado pelo Estado. ${ }^{199}$

Para além dessas críticas, Celso Furtado vai, em seguida, analisar o processo de desenvolvimento econômico. Esse momento do texto merece uma discussão detalhada, sobretudo para investigar a estratégia argumentativa de, através de Nurkse, apresentar sua própria definição de desenvolvimento econômico. ${ }^{200}$ Pois, aqui, o foco se altera. Não mais uma discussão sobre a formação de capital mas, agora, na pena de Furtado, uma teoria do desenvolvimento econômico ou, em formulação sinônima, o processo de desenvolvimento.

Este, "consiste fundamentalmente numa série de mudanças na forma e proporções como se combinam os fatores de produção" pois, "o objetivo da teoria do desenvolvimento econômico, portanto, não é explicar por que a economia está mudando permanentemente, e sim como em nossa economia o fator trabalho vai progressivamente aumentando sua produtividade". ${ }^{201}$

\footnotetext{
${ }^{198}$ Idem, p. 201.

${ }^{199}$ Nurkse, ao tratar das "ondas de inovação", não o faz de forma abstrata, mas se refere à experiência japonesa, onde "o Estado foi o grande inovador e o pioneiro industrial em uma larga frente. O desenvolvimento industrial inicial do Japão parece ter sido planejado e realizado principalmente pelo Estado. Mais tarde, quando os principais obstáculos tinham sido removidos, o Estado pode confiar a interesses privados alguns projetos que haviam iniciado”. Nurkse, op. cit., I, p. 20. Na sua réplica a Celso Furtado, Nurkse defende que isolou o problema das ondas de inovação dos estímulos do setor externo, analisados nas demais conferências, sob o ponto de vista metodológico: "tratar dos diversos aspectos de determinado problema separadamente é um procedimento legítimo, habitual e inevitável, em análise econômica". FURTADO, Formação de capital.. op. cit.,p. 233.

200 Ainda sobre essa estratégia, cumpre ressaltar que a republicação desse trabalho em $A$ economia brasileira [1954], cortou a crítica a Nurkse, corroborando nossa interpretação de uma independência entre a crítica ao economista da ONU e a apresentação de uma teoria do desenvolvimento econômico por Celso Furtado.

${ }^{201}$ FURTADO, Formação de capital.. op. cit.,p. 202.
} 


\section{Para Celso Furtado,}

o processo de desenvolvimento se realiza seja através de combinações novas dos fatores existentes ao nível da técnica conhecida, seja através de inovações técnicas. Numa simplificação teórica se poderia admitir como sendo plenamente desenvolvidas, num dado momento, aquelas regiões em que, não havendo desocupação de fatores, só é possível aumentar a produtividade (a renda real per capta) introduzindo novas técnicas. Por outro lado, as regiões cuja produtividade aumenta ou poderia aumentar pela simples implantação de técnicas já conhecidas seriam consideradas em graus diversos de subdesenvolvimento. ${ }^{202}$

Aqui, temos uma nova tipologia a respeito dos países desenvolvidos e subdesenvolvidos. Substitui-se pela primeira vez, nos escritos de Celso Furtado, o conceito de economia colonial, o qual remetia aos determinantes externos da economia em clara referência às impossibilidades de autonomia econômica e política que o conceito guardava, para uma definição centrada em elementos econômicos, os fatores de produção e incorporação de progresso técnico, muito embora o conceito de economia colonial ainda reapareça em sua obra. ${ }^{203}$ Ainda assim, a passagem acima, inserida no processo de formulação de conceitos econômicos que estamos acompanhando desde as resenhas da Revista brasileira de economia, oferece, agora, um novo elemento, uma concepção e conceitualização alternativa das economias subdesenvolvidas, agora referenciadas a categorias da teoria econômica.

Entretanto, ainda nessa definição, o problema da formação de capital subsiste, embora Celso Furtado o desloque. Nas regiões subdesenvolvidas ocorre uma "deficiente utilização dos fatores de produção", de forma que "desperdiça-se um fator - mão-deobra - porque outro é insuficiente - capital”. Assim, retoma-se a questão da ausência de capital. Porém, para Furtado, "esse círculo vicioso, conforme explicaremos em

\footnotetext{
${ }^{202}$ Carlos Mallorquin, Celso Furtado: um retrato intelectual. [1993] São Paulo: Xamã; Rio de Janeiro: Contraponto, 2005, pp. 52-53, examina este trecho salientando a proximidade de Celso Furtado com as "concepções convencionais sobre o crescimento e sua equiparação com o 'desenvolvimento". Desta forma, "o desenvolvimento apareci simplesmente como um problema de assimilação tecnológica e não se tentavam especificar as particularidades do subdesenvolvimento, fenômeno que de toda maneira seria superado por meio do crescimento e da assimilação de processos econômicos conhecidos". Sob esse ponto de vista, é possível reiterar como as proposições de Celso Furtado neste momento, em que pesem as críticas à Ragnar Nurkse, não obstante ainda não se cristalizaram numa concepção que permite resolver o dilema das formulações teóricas com os problemas das peculiaridades dos países subdesenvolvidos. Notese ainda, que, a ênfase muda, mas persiste o problema da formação de capital para os países subdesenvolvidos.

${ }^{203}$ A discussão sobre o conceito de economia colonial e sua substituição é feita por Carlos Mallorquin, para quem o conceito se refere não a um aspecto de dominação política, mas sim, a "um espaço amplo de recursos naturais e humanos subutilizados, onde tanto os recursos financeiros aplicados para produzir e exportar alguns de seus possíveis itens como os lucros ou excedentes provêm e se filtram para o exterior devido à ausência de condições internas para sua acumulação posterior.” MALLORQUIN, c. Celso Furtado: um retrato intelectual. op. cit, p. 58. Mallorquin nota, ainda, que a noção de economia colonial será suplantada pela de economia subdesenvolvida, em Formação Econômica do Brasil.
} 
seguida, nas economias mais rudimentares quase sempre é quebrado pela ação de fatores externos". ${ }^{204}$ Dessa forma, dada a existência de uma corrente de comércio externo, abre-se a possibilidade de ocorrer um aumento de produtividade pela melhor utilização do fator trabalho, gerando acumulação de capital. Com isso, a melhora da produtividade aumenta a renda real social que, por sua vez, modifica a estrutura da procura. Entretanto, pode ocorrer que, em comunidades com baixa produtividade, nas quais grande parcela da população está ocupada em atividades de alimentação e vestuário, não seja possível uma elevação automática da acumulação de capital. Nesse momento, Celso Furtado retoma sua crítica ao círculo vicioso da pobreza de Nurkse:

as grandes dificuldades do desenvolvimento se encontram, portanto, nos níveis mais baixos de produtividade ${ }^{205}[\ldots] \mathrm{O}$ impulso inicial para ultrapassar essas dificuldades veio historicamente de fora da comunidade. [Nota de rodapé: isto é verdade não somente para os povos atualmente subdesenvolvidos. A passagem, na Europa, em fins da Idade Média, de uma economia constituída de unidades quase totalmente fechadas e estancadas, para outra em processo de crescimento, se deveu, em grande parte, ao intercâmbio que os povos levantinos - particularmente Bizâncio depois das invasões árabes impuseram às populações costeiras da Itália e sul da França. Uma vez iniciado, o processo tendeu a se propagar através dos grandes rios a todo o continente, criando possibilidades crescentes de divisão do trabalho, aumento de produtividade e acumulação de capital. Ver Henri Pirenne, "La civilization occidentale au Moyen Âge, tomo VIII da coleção "Histoire Générale", dirigida por Glotz, Presses Universitaire, Paris.]

O estabelecimento de uma corrente de intercâmbio externo cria para uma economia de baixos níveis de produtividade a possibilidade de iniciar um processo de desenvolvimento sem prévia acumulação de capital $^{206}$

Com isso, Celso Furtado aponta que “em determinadas circunstâncias é possível introduzir combinações mais produtivas sem aumentar a disponibilidade de capital, sempre que se possa integrar a economia em questão num mercado maior", ${ }^{207}$ pois poderá utilizar seus fatores abundantes "mais a fundo e mais racionalmente". Com isso, criar-se-ia o aumento de produtividade capaz de se converter em acumulação de capital.

\footnotetext{
${ }^{204}$ FURTADO, Formação de capital.. op. cit., pp. 202-203.

205 Procurando delimitar esse período da produção furtadiana sobre o crescimento/desenvolvimento como ligada com as teorias convencionais ou ortodoxas do crescimento, Carlos Mallorquin destaca que a interpretação das dificuldades iniciais do crescimento e que são superadas com o passar do tempo permite identificá-lo "com ideias similares às de Rosenstein/Rodan sobre a necessidade de um "primeiro empurrão" (push) para iniciar o processo de desenvolvimento, ou romper com os "círculos viciosos"”. Assim, "Furtado expõe uma noção de crescimento cujas características denotam um processo automático e mecânico, fluindo quanto a seus efeitos multiplicadores". MALLORQUIN, op.cit., pp. 54-55.

${ }^{206}$ FURTADO, Formação de capital.. op. cit., p. 204-205.

${ }^{207}$ Idem, p. 205.
} 
Daí, também, "a grande importância que tem para os países subdesenvolvidos a expansão do comércio mundial”. ${ }^{208}$

Aqui, temos um passo importante na argumentação. De fato, ao mesmo tempo em que critica o círculo vicioso da pobreza de Nurkse, Celso Furtado justifica a análise do setor externo feita pela Cepal, ou seja, a importância deste para o dinamismo das economias bem como as consequências que a crise do mercado mundial pode trazer aos países subdesenvolvidos. Entretanto, esta passagem não aprofunda as diferenças que os ciclos econômicos industriais trazem para as economias centrais e periféricas.

Note-se, ademais, que Celso Furtado considera a importância do mercado externo sem historicizá-lo. ${ }^{209}$ No exemplo citado, temos que, assim como a Europa saiu do feudalismo através da retomada comercial com o oriente cristão, as economias subdesenvolvidas também podem crescer por uma demanda externa. Além disso, está implícita nesta formulação que as correntes de comércio são fatores impulsionadores em qualquer período histórico. Ora, ao igualar as experiências históricas, perguntamos: por que o comércio com o exterior, que causou a recuperação da Europa ocidental, levou à segunda servidão em sua parte oriental, por exemplo? Por outro lado, na hipótese de Celso Furtado, tanto a Europa medieval quanto o Brasil no século XIX seriam subdesenvolvidos, hipótese que, aliás, ecoa em outros textos sobre teoria do desenvolvimento econômico, que marca a superação do subdesenvolvimento europeu após a Revolução Industrial. ${ }^{210}$ Embora ainda não aprofundada nessa passagem, a própria petição de princípio sobre a consideração de elementos sociais, econômicos, históricos e culturais reivindicados como necessários para compreender $\mathrm{o}$ desenvolvimento econômico é implodida nesse trecho, uma vez que iguala o mercado exterior em economias diversas geográfica, cultural, social e historicamente.

Continua Furtado, se o impulso externo é persistente,

haverá estímulo para que aumente a produção através de inversão dos lucros recém-criados. Começa então a série de reações conhecidas, pelas quais a acumulação de capital e as melhoras técnicas que aquela

\footnotetext{
${ }^{208}$ Idem, ibidem.

209 Essa generalização de Celso Furtado, foi assim tratada por Carlos Mallorquin: “a interpretação histórica da evolução econômica de tão díspares âmbitos geográficos que Furtado oferece demonstra uma concepção unilinear ou teleológica da História”. Ver MALLORQUIN, Carlos. op. cit., p. 51.

${ }^{210}$ Um exemplo entre tantos outros, Kuznets, procurando entender o pode impulsionar o desenvolvimento dos países subdesenvolvidos, investiga qual a configuração econômica da Inglaterra antes da revolução industrial. Ver: Simon Kuznets, "Os países subdesenvolvidos e a fase pré-industrial nos países avançados”. In: AGARWALA, A. N \& SINGH, S. (orgs). A economia do subdesenvolvimento. Rio de Janeiro: Forense Universitária, 1969, pp. 141-158.
} 
traz consigo vão libertando trabalho e terra por um lado e absorvendoos por outro, com aumento da produtividade média social ${ }^{211}$

Entretanto, esse impulso pode ser refreado "por alguns fatores que podem atuar em sentido contrário". Fatores como a forma cíclica de crescimento das economias de livre empresa, condições climáticas da agricultura ou, mesmo - e aqui a análise cepalina é importante - o aumento de produtividade pode ser anulado por uma queda no preço de exportação. Porém, "com exceções de casos particulares como os citados, pode-se admitir que a renda real acompanha muito de perto a evolução da produtividade física média do fator trabalho". ${ }^{212}$

Cumpre ressaltar que Celso Furtado considera as duas maiores constrições ao desenvolvimento latino-americano como "casos particulares". A citação desvela, assim como a anterior, que a importância do setor externo não é examinada de forma histórica. ${ }^{213}$ Dessa forma, a evolução da procura tende a se propagar para o resto da economia, ao contrário das teses de Nurkse e de Singer, que enfatizam que este impulso fica concentrado no setor externo.

Ressalte-se, ainda, para melhor distinguir as formulações de Celso Furtado, que o não-dinamismo do investimento no setor externo dos países subdesenvolvidos foi uma formulação importante para a Cepal, servindo como justificativa para a defesa do processo de substituições de importações, e que é relativizada nesta argumentação.

Aqui, a formulação de Carlos Mallorquin é esclarecedora, pois percebemos Celso Furtado muito próximo das visões mais tradicionais sobre crescimento econômico. Acrescentaríamos, somente, que essa proximidade é apresentada pelo próprio Furtado como um elemento crítico às teorias ortodoxas do crescimento econômico, Nurkse incluso. Note-se ademais, que estes economistas estão preocupados com a alocação das inversões, enquanto Furtado está se referindo à evolução da procura. Esta, como já havia alertado Nurkse, "é em boa parte determinada por fatores

\footnotetext{
${ }^{211}$ FURTADO, Formação de capital.. op. cit., p. 205.

212 Idem, p. 206.

${ }^{213}$ Esse ponto passou despercebido, mesmo para intérpretes como Aloísio Teixeira, que interpreta esse trecho de maneira oposta: "o argumento de Furtado vai muito além da contestação formal às ideias de Nurkse. Na verdade, ao distinguir a natureza específica da realidade econômica dos países atrasados, abre caminho para considerar o subdesenvolvimento não como uma etapa do desenvolvimento, mas como seu subproduto". TEIXEIRA, Aloísio. "Arqueologia do debate...” op. cit., p. 80. Por outro lado, a explicitação da diferença entre o desenvolvimento europeu na Idade Moderna e o subdesenvolvimento do século XX deveria ser distinguido também levando em consideração as condições internas ou "todo o complexo cultural que se formou na Europa, com seus elementos de racionalidade, sua mobilidade social, sua escala de prestígio em grande parte refletindo a escala da riqueza pessoal, para explicar a dinâmica do processo econômico capitalista”. FURTADO, idem, p. 200.
} 
institucionais". ${ }^{214}$ Com efeito, em economias onde os aumentos da renda se concentram em grupos fechados, o estímulo decorrente da pressão externa não terá desdobramentos. Entretanto, se o setor externo criar uma demanda por mão-de-obra pagando salários mais altos do que o restante da economia, "o processo de desenvolvimento tende a se expandir". ${ }^{215}$ Para corroborar seu argumento, Celso Furtado enfatiza que "é fato comprovado pela experiência que a procura tenda a modificar-se no sentido da diversificação, sempre que numa economia se eleva o salário real médio. Inquéritos realizados entre os mais variados grupos sociais confirmam essa tendência à diversificação da procura".

Aqui nesse ponto, a crítica a Nurkse é retomada, pois para o estoniano essa diversificação da procura é canalizada para a importação e não é revertida em estímulo para outros setores da economia, embora a afirmação seja atenuada em seguida, quando Celso Furtado analisa mais detalhadamente a hipótese sobre a propensão a consumir. Com efeito, concorda com a teoria de Nurkse, pontuando que o "fenômeno foi destacado em muitos estudos da Cepal" e que "a importância da contribuição do prof. Nurkse nesta matéria deve-se a que ele deu maior generalidade ao fenômeno, colocando-o dentro de uma teoria geral do comportamento do consumidor". ${ }^{216}$

Reconhece, também, que "a tendência a aumentar da propensão a consumir, resultante das disparidades internacionais de renda real, determina uma redução progressiva no ritmo do crescimento espontâneo dos países que ficaram atrasados no processo de desenvolvimento". ${ }^{217}$ Entretanto, Celso Furtado propõe algumas ressalvas a esta hipótese, procurando elaborar "algumas considerações suplementares sobre o mecanismo do desenvolvimento econômico". ${ }^{218}$ Para ele, "a intensidade de crescimento de uma economia é função de duas relações: $a$ ) inversões-renda nacional, e $b$ ) riqueza reprodutível empregada no processo produtivo-renda nacional”. Com a distinção,

\footnotetext{
214 Idem, p. 207.

215 Idem, p. 207. Cumpre notar, entretanto, a ressalva de Celso Furtado: "não nos deteremos a analisar como historicamente foram eliminados os fatores institucionais que impediam a ampliação do processo de desenvolvimento". Ora, a eliminação desses fatores seria fundamental para uma explicação do processo de desenvolvimento e poderia, ainda, reforçar as analogias e as diferenças com a situação da Europa medieval. Parece-nos, entretanto, que esse argumento, cujo desenvolvimento permitiria, efetivamente, justificar a crítica ao ciclo vicioso da pobreza de Nurkse, marca os passos ainda incompletos de Celso Furtado no campo da teoria do desenvolvimento econômico. Se não por menos, seriam esses fatores institucionais que explicariam porque os países em contato com o comércio mundial continuam subdesenvolvidos. A resposta de Nurkse, baseada em Singer, enfatiza, justamente, que os efeitos do comércio internacional se concentraram, historicamente, unicamente no setor externo, não se expandindo para o conjunto da economia.

216 Idem, p. 208.

${ }^{217}$ Idem, p. 209.

218 Idem, ibidem.
} 
Furtado faz um aparte na teoria de Nurkse, pois nem sempre a renda real per capita indica acumulação de capital, ou seja, o nível de capitalização (medido pela relação entre inversões e renda gerada). Para Furtado, é preciso considerar a produtividade do capital invertido, ou seja, uma unidade de capital pode gerar aumento de produtividade maior em uma região de terras férteis, comparativamente a uma região desértica. Dessa forma, deve-se, para a compreensão a taxa de crescimento da economia, observar não apenas a produtividade dos capitais invertidos, mas também a relação, não considerada por Nurkse, das inversões como porcentagem sobre o produto. Apoiando-se nos estudos da Cepal, a produtividade do capital é estável em cada economia: "a intensidade do crescimento de ano para ano é principalmente determinada pela relação inversões-renda nacional, à qual denominaremos de coeficiente de inversão". ${ }^{219}$ Esse coeficiente, como já apontara anteriormente, é "grandemente influenciado por fatores institucionais e de outras ordens que atuam sobre a propensão a consumir". ${ }^{220}$ Entretanto, Celso Furtado considera que nos primeiros passos do processo de desenvolvimento, a propensão a investir é maior que a de consumir, de forma que "o desenvolvimento pode apoiar-se em si mesmo, uma vez iniciado". ${ }^{221}$ Daí que insista:

esse processo teve sua origem nos contatos culturais resultantes das correntes de comércio que, vindas de fora, foram criando na Europa ocidental uma classe empresária. Essa classe, dotada de espírito de lucro, se constituiu em elemento social dinâmico, em choque com comunidades feudais. Os hábitos de consumo, influenciados por tradições religiosas e sociais, só lentamente foram se transformando ${ }^{222}$

E aqui, Celso Furtado distingue o papel do mercado externo nos estertores do feudalismo e na economia atual, onde, reconhecendo a generalização do efeito demonstração de Nurkse, temos que

graças à enorme força dos meios de propaganda e comunicações, os hábitos de consumo vão na frente, como o carro diante dos bois. Há em razão disso motivos para crer que o desenvolvimento espontâneo dos países subdesenvolvidos atuais se realiza com ritmo muito inferior ao que seria de esperar das potencialidades dessas economias e do progresso alcançado pela técnica. Como superar essa dificuldade é, por certo, um dos problemas mais sérios que se apresentam aos economistas de nossa época 223

\footnotetext{
${ }^{219}$ Idem, p. 211.

${ }^{220}$ Idem, p. 211.

${ }^{221}$ Idem, p. 212.

222 Idem, ibidem.

${ }^{223}$ Idem, p. 213.
} 
Cumpre notar a ambiguidade da formulação de Furtado. Ao criticar o círculo vicioso da pobreza, considera que o comércio exterior pode impulsionar a acumulação de capital, via aumento da produtividade, elevação da renda social real e diversificação da demanda por consumo, garantindo a rentabilidade para investimentos no conjunto da economia. Nessa crítica, Celso Furtado se vale da experiência histórica da Europa medieval. No entanto, essa formulação gera algumas complicações adicionais. Ora, se a corrente de comércio exterior é capaz de produzir os primeiros impulsos para o desenvolvimento, por que os países latino-americanos não se desenvolveram? A resposta se direciona para as mudanças históricas nesse mercado externo, mudanças históricas captadas precisamente pelos conceitos de Nurkse, através da generalização da função de consumo, do efeito demonstração. Ou seja, o problema que Celso Furtado tentou atacar — as possibilidades de desenvolvimento autônomo dos países subdesenvolvidos via comércio exterior (uma forma de criticar o círculo vicioso da pobreza) - coloca sua negação, uma vez que os países que se ligaram, a partir do século XIX, ao comércio exterior europeu, não se desenvolveram, e nem se desenvolverão, segundo a Cepal. Assim, critica a formulação sobre os países subdesenvolvidos com o exemplo da Europa medieval mas, ao abordar os países latinoamericanos, corrobora Nurkse. A experiência histórica europeia nega a teoria destepreocupada, entretanto, com os países subdesenvolvidos —, mas a experiência latinoamericana confirma-a e invalida ou fragiliza a contraposição que Celso Furtado está fazendo. Contradições, estas, oriundas da tentativa de conciliar a explicação do subdesenvolvimento com a experiência histórica, europeia e latino-americana. No entanto, o que cabe destacar desta proposta é sua possibilidade de levantar problemas e questões novas, não colocadas pelo economista estoniano e que Furtado, reconhecendo as dificuldades de conciliação entre a teoria econômica e a história, busca encontrar caminhos de conciliação.

A sequência do texto aborda alguns aspectos de política econômica, concentrando-se nos critérios de inversão. Há consenso entre os dois economistas sobre o principal critério ser a "produtividade social marginal" 224 , em contraposição aos critérios microeconômicos, pois "a adoção desse critério leva à conclusão de que o simples mecanismo de preços do mercado não possibilita utilização ótima dos

\footnotetext{
${ }^{224}$ Esse ponto corrobora nossa impressão de que o debate entre Furtado e Nurkse foi feito assumindo o ponto de vista do primeiro. O critério de produtividade social, presente nas conferências de Nurkse, é tratado como uma originalidade de Celso Furtado por Aloísio Teixeira. "Desenvolvimento econômico: a arqueologia do debate e a contribuição original de Celso Furtado”, op. cit., p. 80.
} 
recursos". ${ }^{225}$ Entretanto, se nas economias desenvolvidas a produtividade social tende a igualar-se em todos os setores, nas subdesenvolvidas, "existe uma grande disparidade no grau de utilização dos fatores produtivos, de um setor para outro". Celso Furtado, assim como Nurkse, considera que "existem fortes razões para crer que o ritmo de desenvolvimento pode ser intensificado se se corrige a insuficiência do mercado como mecanismo diretor do processo econômico e se se imprime às inversões uma orientação geral coordenadora". ${ }^{226}$ Dessa forma, reconhecendo a impossibilidade da alocação de recursos pelo mercado impulsionar o desenvolvimento econômico, Furtado estabelece a necessidade de redirecionamento do consumo via coordenação, para dirigi-lo aos investimentos que possam aumentar a produtividade social média da economia.

Ainda relacionado com o capital necessário para iniciar o processo de desenvolvimento, Furtado discute as repercussões das inversões estrangeiras sobre o balanço de pagamentos. Como vimos, Nurkse examinou, na sexta conferência, essas repercussões sob seu efeito sobre a renda, qual seja: “o aumento das importações como consequência do aumento da renda real". Furtado, entretanto, aponta que o efeito-renda também atua nas “inversões de capitais nacionais". ${ }^{227}$ Essa consideração é importante pois, retomando os estudos da Cepal, Celso Furtado indica: "essa tendência ao desequilíbrio, conforme temos afirmado, é imanente ao processo de desenvolvimento espontâneo em certas condições de evolução da economia internacional”. Porém, as repercussões sobre o balanço de pagamentos não se fariam sentir enquanto houvesse um fluxo constante de capitais ou expansão do mercado internacional. Entretanto, "a realidade dos últimos dois decênios foi inteiramente distinta: o quantum do comércio mundial declinou firmemente e ainda nos anos recentes, entre 1947 e 1949, havia voltado a declinar". ${ }^{228}$ Com isso, destaca que nos países em etapas iniciais de desenvolvimento a tendência à importação é alta, gerando problemas para o balanço de pagamentos. Dito de outra forma, está recolocando o problema que a Cepal vem tentando resolver: "como conciliar essa tendência a aumentar as importações, resultante do próprio desenvolvimento, com a impossibilidade de aumentar a capacidade para importar? Na verdade foi essa a situação que conhecemos desde 1930 até muito

\footnotetext{
${ }^{225}$ Idem, p. 215.

${ }^{226}$ Idem, p. 215.

${ }^{227}$ Idem, p. 215.

${ }^{228}$ Idem, p. 217.
} 
recentemente". ${ }^{229}$ Tratando-se, portanto, de um problema estrutural dos países em desenvolvimento, é preciso compreender que:

sempre que as exportações (considerada constante a relação de intercâmbio) não cresçam paralelamente com a procura de importações, o processo de crescimento criará desequilíbrios, que se manifestam em excedentes de produção interna e em saldos desfavoráveis no balanço de pagamentos. Esses desequilíbrios vão sendo corrigidos com atraso e quase sempre de forma dolorosa. E isso contribui para dificultar a política de estabilização e para tornar a inflação inseparável do processo de desenvolvimento ${ }^{230}$

Dessa forma, o elemento dinamizador do desenvolvimento aparece agora também como causador de instabilidade, pois as importações necessárias para os investimentos ou o consumo de produtos importados (quando não dirigidos pelo Estado) ocasionam desequilíbrios estruturais na economia e a manifestação desse desequilíbrio se dá pela inflação.

Assim, Celso Furtado não apenas faz coro com Nurkse, como admite claramente que a inflação é um processo inerente às etapas iniciais de desenvolvimento econômico, não podendo, portanto, ser combatida com medidas monetárias:

a inflação que acompanha o desenvolvimento econômico em nosso país não é, portanto, fundamentalmente, um problema monetário. A causa última do desequilíbrio está na disparidade entre o crescimento da renda e o da capacidade para importar. É, portanto, indispensável, se se quer corrigir o desequilíbrio, que se modifique a estrutura da produção no sentido de aumentar as exportações ou de substituir importações.

Nesse ponto, Celso Furtado está unindo pela primeira vez o diagnóstico dos problemas estruturais da economia, com uma solução clara de política econômica via planejamento. Assim,

para evitar que surjam esses desajustamentos é necessário que se tomem com antecipação certas medidas relativas à orientação das inversões. Se é possível, até certo ponto, prever esses desequilíbrios, também será possível evitá-los [...] Uma ação coordenadora se faz imprescindível e isso reconhece implicitamente o prof. Nurkse quando põe em primeiro plano o papel da política fiscal no desenvolvimento econômico atual. ${ }^{231}$

Com efeito, aqui podemos perceber que a ação coordenadora do Estado não decorre de uma orientação política ou da adoção de princípios abstratos. Ao

\footnotetext{
${ }^{229}$ Idem, p. 220.

${ }^{230}$ Idem, p. 220.

${ }^{231}$ Idem, p. 220-221.
} 
diagnosticar as dificuldades dos países em orientar suas inversões para o desenvolvimento econômico e ao indicar os problemas de balanço de pagamentos como decorrentes, não de problemas monetários, mas da própria tendência das economias subdesenvolvidas em importar uma grande quantidade de produtos manufaturados, Celso Furtado coloca o planejamento não como opção política, mas sim, como uma necessidade econômica, decorrente do próprio funcionamento da economia.

Nesse ponto, cabe destacar que Celso Furtado está inserindo uma temática em discussão na Cepal, e que ficará evidente no Estudio preliminar sobre la técnicca de programacion del desarrollo económico, de 1953. Há, aqui, uma convergência com Nurkse, ao apontar a inevitabilidade técnica da coordenação econômica. Já sobre a questão da inflação, radicaliza sua posição em relação ao conferencista, estabelecendo uma correlação entre a estrutura produtiva e a forma de crescimento econômico dos países subdesenvolvidos, com elevações nos níveis de preços.

Contudo, mesmo essas afirmações não nos explicam por que Celso Furtado deixou de defender pontos importantes das propostas da Cepal, tais como o protecionismo para indústrias nascentes e a questão da substituição de importações. Para tentar responder a esta lacuna, cabe abordar a resposta que Nurkse deu ao artigo de Celso Furtado, procurando deslindar, a partir desta, a abordagem seletiva e interessada que este fez das conferências.

\section{Resposta de Ragnar Nurkse a Celso Furtado}

Ragnar Nurkse publicou suas "Notas sobre o trabalho do sr. Furtado relativo a 'Formação de capitais e desenvolvimento econômico"', no primeiro número de 1953 da Revista brasileira de economia. Nele podemos ler que o trabalho de Celso Furtado "representa um estudo interessante, mas contém uma série de afirmações que parecem interpretar erradamente certas ideias minhas expostas em conferências também publicadas na mesma revista...". ${ }^{232}$

Primeiramente, Nurkse rebate a interpretação de que o tema central de suas conferências seria a questão do círculo vicioso da pobreza, revelando, assim, o caráter seletivo da crítica de Furtado.

\footnotetext{
232 NURKSE, Ragnar. "Notas sobre o trabalho do Sr. Furtado relativo a 'Formação de Capitais e Desenvolvimento Econômico. In: Memórias do desenvolvimento. op. cit., p 233.
} 
Outro ponto, não diretamente ligado às críticas recebidas, mas sim às proposições de desenvolvimento de Celso Furtado, é a questão do estímulo externo como fator impulsionador do crescimento de uma economia subdesenvolvida, e a afirmação de que esse influxo não foi maior pois o comércio internacional está em declínio. Para Nurkse, “colocar a ênfase analítica principalmente no comércio exterior e afirmar que esse comércio não está se expandido com bastante rapidez, pode dar lugar a uma atitude desnecessariamente pessimista". ${ }^{233}$ Divergindo de Celso Furtado — para quem "a realidade dos últimos dois decênios foi inteiramente distinta: o quantum do comércio mundial declinou firmemente e ainda nos anos recente, entre 1947 e 1949, havia voltado a declinar"234 — Nurkse sustenta que "no após-guerra, o comércio tem crescido rapidamente. A afirmação de Furtado que esse comércio teria declinado de 47 a 49 não concorda com o índice de quantum do comércio mundial que aumentou de 96, em 1947, para 108 em 1949 e para o nível recorde de 134 em 1951, na base de 100 em 1937. Ver United Nations, Monthly Bulletin of statistics, august, 1952." 235 Assim, utilizando as estatísticas das Nações Unidas, - e aqui aparece a importância dos dados econômicos - rebate o argumento de Celso Furtado, evidenciando que sua proposta alternativa, o impulso do comércio exterior, não está produzindo os efeitos esperados.

Dessa forma, Nurkse reitera como alternativa para os impulsos iniciais de desenvolvimento, o crescimento equilibrado. Este poderia, ao ser distribuído em diversos setores ao mesmo tempo, aumentar a produtividade da economia.

Já sobre o economista austríaco, embora Nurkse reconheça que, historicamente, o empresário schumpeteriano teve o papel de ampliar os investimentos nos países hoje desenvolvidos, contesta a interpretação do economista brasileiro, ao afirmar que

Furtado considera com ceticismo a utilidade da teoria de Schumpeter para os países menos desenvolvidos da atualidade - e eu concordo com ele. Não é necessariamente aplicável a outros tipos de sociedade, onde é bem possível que as forças que devem derrotar os efeitos da estagnação econômica necessitem ser deliberadamente organizadas pelo Estado, pelo menos inicialmente, por meio de alguma forma de ação coordenada e empreendimento coletivo ${ }^{236}$

O trecho nos parece ilustrativo da leitura que estamos propondo, pois Nurkse explicita que um dos pontos principais da crítica de Celso Furtado é, de fato, um ponto

\footnotetext{
${ }^{233}$ Idem, p. 236.

${ }^{234}$ FURTADO, Formação de capital.. op. cit., p. 217.

235 NURKSE, Ragnar. "Notas sobre o trabalho do Sr. Furtado...". op. cit., p. 236, nota 1. Nessa nota, revela-se outro aspecto da controvérsia, ou seja as fontes e os dados para as afirmações.

${ }^{236}$ Idem, p. 237.
} 
de concordância. Ressalte-se, também, o reconhecimento da necessidade da ação do Estado para estimular esses investimentos simultâneos, outro elemento de convergência entre os autores. Dentro dessa ação planificadora do Estado, Nurkse retoma um tema tratado na sua quinta conferência, onde abordou a questão da proteção do mercado interno para as indústrias substitutivas de importação — tópico, aliás, de importância crucial para a Cepal, mas que Celso Furtado não abordou em sua crítica. Para Nurkse, “é sumamente duvidoso que esse procedimento por si só, possa dar início a um processo de crescimento equilibrado da economia", pois, não contando com o crescimento equilibrado proposto, "o incentivo à inversão em determinada indústria protegida não irá além do ponto em que todas as importações tenham sido substituídas pela produção nacional. Nesse ponto, poderá cessar a expansão da nova indústria, e nada terá sido conseguido em termos de aumento da renda real". ${ }^{237}$ A menos, é claro, que o incentivo aos novos investimentos conte, também, com a ajuda do Estado. Muito embora Nurkse não considere que a proteção tarifária e a indústria substitutiva possam, ao aumentar o nível dos salários reais, gerar incentivos para investir em outros setores de consumo assalariado, o argumento parece ter um alvo bem definido: as políticas protecionistas que a Cepal vinha propondo. Ora, a retomada desse tema, entre tantos outros não comentados, reforça a crítica do economista estoniano aos estudos da Cepal. Mas, uma análise detalhada nos mostra outros elementos da polêmica com Celso Furtado. Explicita que o economista brasileiro deixou escapar um ponto crítico. Daí que Ragnar Nurkse tenha voltado à carga na resposta, indicando os assuntos sobre os quais esperava a resposta de outros economistas.

Agora, examinando o outro lado, Celso Furtado, identificado com a instituição na qual trabalhava, recuou da possibilidade (necessidade?) de defendê-la, num momento crítico, momento em que julgava necessário marcar posição num debate que estava ficando cada vez mais fechado e polarizado. Não teria Celso Furtado percebido o teor e o alvo da crítica? A recusa em tomar ciência desse ponto indicaria que estava se afastando da posição e das propostas da Cepal? Quais as consequências de seu silêncio numa controvérsia que, evidentemente, tinha efeito importante no debate econômico brasileiro? Embora ainda haja elementos para responder categoricamente estas questões, o resultado evidente dessa omissão foi justamente que o argumento de Nurkse tenha saído reforçado com sua resposta.

${ }^{237}$ Idem, p. 238. 
No que se refere a necessidade do Estado garantir os estímulos, ou nas palavras de Nurkse, a procura de capitais, ambos estão de acordo. Entretanto, o ponto nodal é que os investimentos industriais nos países subdesenvolvidos se concentraram, unicamente, no setor externo. E isso reitera o fraco dinamismo das indústrias para o mercado interno, corroborando sua interpretação anterior sobre o reduzido tamanho deste mercado. Com isso, Nurkse critica as considerações de Furtado sobre o dinamismo dos investimentos nos setores de exportação e nas indústrias substitutivas de importação, para superar os problemas de balanço de pagamento e de aumento constante do nível de preços.

Outro ponto importante nesta resposta é a questão da inflação. Nurkse, a despeito de alguns momentos em que se mostra crítico às soluções monetaristas, elege a política fiscal do governo como única forma de garantir o financiamento dos investimentos de forma não inflacionária. Essa política fiscal poderia ser implantada retirando recursos do consumo de luxo ou - e nesse ponto se utiliza da experiência histórica do Japão - canalizando para o conjunto da economia os aumentos de produtividade da agricultura, uma das principais fontes de ampliação de capital dos países subdesenvolvidos. Nesse sentido, a inflação surge como "a tendência da renda monetária de crescer mais rapidamente do que a capacidade de produção", ${ }^{238}$ o que difere da leitura de Furtado, que afirma ser a inflação a expressão de um desequilíbrio estrutural entre o consumo de importações com a baixa capacidade de gerar divisas característica dos países subdesenvolvidos. Para este último, portanto, a inflação não é um problema monetário, mas a expressão de desequilíbrios fundamentais das economias subdesenvolvidas.

Dessa forma, na réplica de Nurkse fica exposta a forma como Celso Furtado conduziu suas críticas: selecionou alguns elementos das conferências e, através deles, desenvolveu uma distinção entre países desenvolvidos e subdesenvolvidos, enfatizando, em sua distinção, a importância do setor externo. Nessa ênfase, deixou de considerar aspectos críticos à Cepal que estavam contidos nas conferências, e que Nurkse fez questão de recolocar na resposta, enfatizando, portanto, em sua perspectiva, os aspectos que julgava importantes em seu trabalho.

Para além disso, se nosso objetivo era relativizar o texto de Furtado como um texto exclusivamente teórico do desenvolvimento econômico, a proposta conseguiu levantar alguns elementos nesta direção, perceptíveis através da ênfase em criticar ${ }^{238}$ Idem, p. 239. 
aspectos parciais das conferências. O principal deles, nos parece, foi enfatizar (teoricamente) o caráter dinamizador do mercado externo, ao mesmo tempo reconhecendo que seu impulso não se efetivou nos países subdesenvolvidos, pelas próprias razões aventadas por Nurkse.

Nesse sentido, o texto explicita a constituição de uma teoria do desenvolvimento econômico ou do subdesenvolvimento ainda incompleta. Com efeito, a tentativa de Celso Furtado explicá-lo englobando não apenas a economia, mas também as ciências sociais e a história — utilizadas como ponto de partida para a crítica à Nurkse — foi feita recorrendo à historia da Europa medieval, enfatizando a importância do comércio exterior para seu desenvolvimento. Entretanto, ao mobilizar esse argumento para refutar as considerações de Ragnar Nurkse sobre a formação de capital nos países subdesenvolvidos, Celso Furtado não historicizou as diferenças do comércio, sob o capitalismo comercial e industrial, nem as relações sociais e econômicas que se estabeleceram na Idade Moderna e Contemporânea. A principal consequência disto ficou explícita pela incapacidade do comércio exterior desenvolver as economias latinoamericanas, a qual teve que admitir mais adiante no texto. Por outro lado, um elemento inovador nesse trabalho é a distinção entre países desenvolvidos e subdesenvolvidos, baseada nas diferentes formas de incorporar aumentos de produtividade. Essa distinção, que não está presente em seus textos anteriores e não consta dos trabalhos oficiais da Cepal, pode ser considerado um esforço inovador de Celso Furtado, muito embora, ao se concentrar unicamente na produtividade, perca a possibilidade de captar as peculiaridades históricas. Finalmente, o texto aponta para outra preocupação que irá desenvolver nos próximos trabalhos publicados em sua autoria. Trata-se da questão do planejamento econômico como decorrência necessária do diagnóstico da economia brasileira.

Assim, a variedade de pontos trabalhados por Celso Furtado, longe de ser exaustiva ou completa, indica sua seleção. Quanto a isso, nem um mistério. Importante, agora, é apontar o critério subjacente à escolha. Para tanto, imbricam-se os aspectos nacionais e internacionais do debate que estamos propondo. Se pensarmos na tomada de espaço pretendida tanto por Nurkse como Furtado, perceberemos que as ênfases de cada autor expressam interesses teóricos particulares: Nurkse, propondo o crescimento equilibrado, a opção pela intervenção estatal via coordenação de investimentos e execução de política físcal para estimular a formação de poupança; Furtado, enfatizando a ação propulsora do comércio exterior, capaz de gerar os efeitos internos que podem 
levar ao desenvolvimento. Quanto ao mecanismo de desenvolvimento, o simples contato comercial já iniciaria o processo, cabendo ao Estado a coordenação dos investimentos para os setores que tenham maior efetividade para aumentar a produtividade social média. Colocadas em confronto essas visões, entretanto, percebemos que Celso Furtado deixou de responder às críticas dirigidas à Cepal, instituição onde trabalhava e para a qual assumiu o papel de divulgador no Brasil, através das traduções dos textos de Raúl Prebisch para a Revista brasileira de economia. Por certo, é possível argumentar que "Formação de capital e desenvolvimento econômico" não se liga à instituição, cabendo, unicamente à pena e à responsabilidade do jovem economista brasileiro. Entretanto, a pergunta persiste: como angariar espaço no debate sobre desenvolvimento econômico deixando flancos abertos e sub-repticiamente aceitando críticas a formulações cruciais de política econômica, como a proteção às indústrias substitutivas, mecanismo fundamental para a industrialização da periferia latino-americana? Mais ainda, por que aceitar as críticas, deixando-as explícitas num dos únicos periódicos brasileiro de economia - e sem dúvida o mais importante - num momento de virada editorial rumo à ortodoxia econômica tão explícita que Celso Furtado e Raúl Prebisch não terão mais nenhum artigo publicado na revista a partir de $1952 ?^{239}$

Mais ainda, não podemos deixar de considerar outro aspecto: retirado de seu contexto imediato de polêmica, o artigo de Celso Furtado teve uma recepção internacional favorável, sendo publicado em inglês nos International economic papers, em 1954. A pergunta, então, se complexifica: teria ele a preocupação de formular uma teoria própria do desenvolvimento econômico, abrindo mão da visão cepalina? A questão é complexa, pois elementos de política econômica da Comissão continuarão sendo defendidos pelo economista brasileiro, inclusive a política de protecionismo industrial.

Mas, por hora, constatemos: inserida na linha formativa do pensamento do autor, a definição de países desenvolvidos e subdesenvolvidos, a partir de uma classificação baseada em fatores de produção e formas de incorporação de progresso técnico, embora não se distancie da teoria econômica tradicional, é crítica à Nurkse e, ainda, dá substância ao processo que analisamos nas resenhas, de uma reflexão que se dirige cada

\footnotetext{
${ }^{239}$ Não cabe agora adiantar exames posteriores, mas fica registrado que em 1955 Celso Furtado e um conjunto de economistas heterodoxos irão fundar um periódico alternativo a Econômica Brasileira, justamente para publicar trabalhos que não tinham espaço em outras revistas.
} 
vez mais para o campo da teoria econômica, muito embora com diversas críticas e ressalvas a esta.

Outro passo importante para nós é entender a ênfase que Celso Furtado deu ao comércio exterior como fator dinamizador das economias subdesenvolvidas e de como utilizou-se, como exemplo, da experiência do Europa ocidental durante a Idade Média.

Nesse ponto, chamamos atenção para as consequências da comparação. Ao igualar a Europa do medievo à América Latina dos séculos XIX e XX, perde-se a historicidade e as características sociais profundamente distintas destas economias. Podemos entender essa estratégia argumentativa, no entanto, como um procedimento metodológico que procurou solucionar a difícil relação entre a teoria econômica abstrata e as realidades históricas que pretende analisar. A comparação aparece como uma defesa do dinamismo do setor exportador (algo evidente nas análises cepalinas), contrapondo-se à ênfase de Nurkse no bloco dos investimentos nos setores internos da economia. Dessa perspectiva, Celso Furtado defende um ponto fundamental da Comissão - o crescimento hacia afuera —, embora na mobilização de sua argumentação deixe abertas outras questões ensejadas pela comparação entre períodos históricos distintos. Ao fazê-lo, portanto, procurou uma justificativa que permite, também, a possibilidade de conciliação de sua hipótese com a realidade histórica: a referência à Europa medieval é justificada pela preocupação de Celso Furtado em conciliar teoria e realidade histórica. Em sua visão, o fim do feudalismo se deu pela abertura do comércio do Mediterrâneo, seguindo as sugestões de Henri Pirenne e Henri Sée, de forma que o exemplo histórico confirma a teoria. Entretanto, o flanco fica aberto, uma vez que o comércio exterior, não conseguiu desenvolver as economias subdesenvolvidas. Aqui, há uma assunção subjacente: a mesma experiência de desenvolvimento europeu poderia ser repetida nas economias subdesenvolvidas dos séculos XIX e XX. Evidentemente, em outra passagem do texto, Celso Furtado vai marcar as principais diferenças do comércio exterior nos dois momentos, mas, de toda forma, a comparação persistirá em sua obra, como veremos. Mas, reparemos: onde a experiência histórica contrariou ou não conseguiu apoiar a compreensão da realidade específica das economias latino-americanas, a primeira foi sacrificada pela explicação do presente.

Finalmente, as considerações que Celso Furtado faz sobre o papel do Estado como coordenador dos investimentos e agente de política econômica nos permite, uma vez mais, explicitar a relação conflituosa com a Cepal, já expressa na crítica de Nurkse 
às políticas de industrialização protecionistas. Embora ambos concordem com a importância do Estado, Celso Furtado, ao enfatizar a relação estrutural entre desenvolvimento e inflação, não mais coloca o Estado como uma opção de coordenação dos investimentos, como destacou em diversas passagens o conferencista. Ao contrário, o papel do Estado surge como imprescindível, fruto do próprio diagnóstico do funcionamento das economias subdesenvolvidas com sua tendência aos desequilíbrios no balanço de pagamentos decorrentes de uma industrialização seletiva que, ainda que estabelecida obedecendo ao critério de produtividade social média, ocasiona problemas cuja expressão aparece na elevação do nível de preços. Nesse ponto, o diagnóstico de Celso Furtado tem uma coerência muito grande em termos de política econômica: ao mesmo tempo em que refuta as interpretações monetaristas (o que Nurkse também faz, em parte) coloca como elementos integrados num mesmo processo: os benefícios da industrialização, a inevitabilidade da inflação e a necessidade intrínseca de planejamento para comandar a primeira e controlar a segunda.

E aqui retornamos à relação com a Cepal. Com efeito, nesse momento a Comissão está trabalhando num conjunto de ferramentas econômicas que permitirão às economias subdesenvolvidas identificar seus pontos de debilidade, formular projeções de crescimento do produto e da renda, definir setores prioritários para investimento, detectar áreas para a reformulação de políticas fiscal e tributária, estabelecer formas de manipulação de taxas de câmbio e controle monetário. Dessa forma, a intervenção no debate sobre desenvolvimento econômico conclui com uma enunciação das preocupações da Cepal no momento: a operacionalização da intervenção na economia.

Assim, diante do exposto, resta, finalmente, a pergunta: qual o sentido do texto "Formação de capital e desenvolvimento econômico"? Em nossa análise, não um texto precursor da teoria do desenvolvimento econômico nem, tão somente, uma intervenção nos debates internacionais. Um momento importante nas formulações de Celso Furtado, sem dúvida. Entretanto, guardando ainda uma relação ambígua com a Cepal, mantendo lacunas que o debate nacional pode ter percebido como um recuo dos economistas que procuram propostas alternativas de desenvolvimento econômico. Mais significativo talvez, seja a tentativa de resolver a relação entre teoria econômica e realidade concreta, diferenciando-se do texto "Características gerais da economia brasileira", no qual o segundo polo teve prioridade, e também das discussões exclusivamente teóricas das resenhas que vimos. Afluem preocupações diversas a este texto: a procura de uma voz individual, um local de expressão nos debates nacionais e internacionais, dentro e fora 
da instituição para a qual trabalha, bem como a busca de resolução para um problema específico, a relação entre teoria econômica e história. É ainda sob o influxo dessas questões, que se avolumam, emergem e submergem ao sabor das circunstâncias que Celso Furtado vai procurando respostas.

É nessa busca que podemos compreender que o final do texto aponte para a questão da intervenção do Estado no planejamento econômico, problema que vem à tona na Cepal, mas que também está presente no Brasil, durante o Segundo Governo Vargas. Assim, é para este tema que temos que nos voltar agora, procurando deslindar as formulações de Celso Furtado e da Cepal, e captar as repercussões destas questões nos debates brasileiros, seja no confronto com outros economistas, seja (ainda que em menor escala) na política econômica adotada pelo Brasil e alguns países da América Latina. 
Capítulo 2: A educação prática 


\section{O Planejamento econômico da Cepal no Brasil}

Os antecedentes do estudo sobre a técnica de planejamento da Cepal remontam, segundo Celso Furtado, à intenção da Comissão de indicar diretrizes de política econômica para os países da América Latina, algo já iniciado no relatório apresentado no México em 1951. Internamente, isso se manifestou na criação, em 1952, do programa de treinamento em desenvolvimento da Cepal, de início na sede, em Santiago, depois com turmas nos próprios países interessados. ${ }^{240}$

Segundo Dosman, "as unidades mais poderosas da Cepal eram a divisão de desenvolvimento, chefiada por Celso Furtado, e a divisão de treinamento, dirigida por Jorge Ahumada. Furtado tinha uma equipe de nove pessoas que incluía Regino Boti e o mexicano Juan Noyola, recrutado após a conferência da Cepal de 1951. Essa divisão era o centro do pensamento sobre teoria do desenvolvimento e planejamento na organização". ${ }^{241}$ A Cepal, uma vez institucionalizada, ampliava sua esfera de influência, do trabalho teórico à prática, formando quadros técnicos familiarizados com os objetivos, as técnicas e as ideias da instituição no continente. No Brasil, para além daqueles que se dirigiram à Santiago, como Américo Barbosa de Oliveira, foi criado em 1952 o convênio Cepal-BNDE que, sob a direção de Celso Furtado do lado cepalino e de Roberto Campos no Banco, estabeleceu um grupo de trabalho formado por técnicos das duas instituições para mapear os setores prioritários no recebimento de investimentos industriais e de infraestrutura para atender aos objetivos da industrialização de Getúlio Vargas. No entanto, a despeito dessa ampliação do escopo teórico e prático da instituição no continente, anteviam-se dificuldades na recepção do relatório cepalino no Brasil, em 1953.

Por outro lado, é preciso notar que os inícios de 1950 assinalam a presença crescente do tema do planejamento econômico no Brasil. Nesse sentido, cabe destaque à Comissão Mista Brasil-Estados Unidos (CMBEU), assinada em dezembro de 1950,

\footnotetext{
${ }^{240}$ Em 1952 "foi criado o programa de treinamento em problemas de desenvolvimento econômico, sob a direção de Jorge Ahumada, com o objetivo de formar especialistas em política de desenvolvimento, para os governos latino-americanos. De início era um pequeno grupo de pessoas, selecionadas com muito critério, que passavam oito meses em Santiago [...] A esses cursos, pelos quais passaram muitas centenas de estudantes, deve-se a difusão continental do pensamento da Cepal. Sem eles, a penetração das novas ideias ter-se-ia circunscrito, em muitos países, ao mundo acadêmico. Foram numerosos os formuladores de política econômica na América Latina, inclusive membros de muitos governos, que passaram pelos cursos organizados pela Cepal" FURTADO, C. A fantasia organizada, op. cit., p. 246.

${ }^{241}$ DOSMAN, J. Raúl Prebisch (1901-1986): a construção da América Latina e do terceiro mundo op. cit., p. 320.
} 
iniciando seus trabalhos em julho do ano seguinte. ${ }^{242}$ Uma decorrência direta dos trabalhos da Comissão foi a criação do Banco Nacional de Desenvolvimento Econômico (BNDE), em 1952, com a finalidade de administrar os créditos em moeda estrangeira recebidos no âmbito do financiamento norte-americano, bem como preparar e analisar projetos específicos da Comissão. ${ }^{243}$

Portanto, se, por uma lado, a intenção da Cepal de desenvolver um método de programação econômica vem ao encontro de ações do governo brasileiro para implementá-las, não podemos deixar de notar que, em termos do pensamento econômico no Brasil, não havia um consenso sobre a necessidade da planificação.

Celso Furtado, chefiando a direção do convênio Cepal-BNDE, já se encontrava no país desde inícios de 1953. Neste momento percebia uma movimentação contra as teorias cepalinas, sobretudo na Fundação Getúlio Vargas. Se, dois anos antes, ele e Prebisch visitaram Rio de Janeiro e São Paulo - contando com o apoio entusiasmado do setor empresarial reunido na Fiesp e no Conselho Nacional da Indústria ${ }^{244}$ — o momento agora era de fechamento de espaço. Celso Furtado assim manifestou sua impressão sobre as dificuldades de disseminação das ideias da Cepal:

\begin{abstract}
quando estivemos no Rio de Janeiro, em setembro de 1951, Prebisch e eu tomamos conhecimento desse grande festival de doutrina ortodoxa. O professor Gudin havia recuperado a sua segurança e foi extremamente gentil, convidando Prebisch para uma conferência na Escola de Economia. Falando de improviso, Prebisch divertiu o público dizendo que o professor Viner se havia esmerado em construir um boneco que, em seguida, passou a destruir. Tratava-se, evidentemente, de um diálogo de surdos, que ocultava uma real confrontação no plano das ideias, em um campo de claras implicações práticas $^{245}$
\end{abstract}

\footnotetext{
${ }^{242}$ A CMBEU foi resultado da mudança da política externa norte-americana no sentido de auxiliar o desenvolvimento dos países do Terceiro Mundo, em confluência com os objetivos de Getúlio Vargas de ampliar os setores de infraestrutura básica. Considerada como "uma mudança qualitativa fundamental na posição norte-americana", a Comissão "se propunha a elaborar projetos concretos que deveriam ser financiados por instituições como o Banco de Exportação e Importação (Eximbank) e o Banco Internacional de Reconstrução e Desenvolvimento (Banco Mundial)". VIANNA, Sergio Bresserman. Duas tentativas de estabilização: 1951-1954. PAIVA, Marcelo de Abreu (orgs). A ordem do progresso. Cem anos de política econômica republicana (1889-1989. Rio de Janeiro, Campus, 1994, p. 124.

${ }^{243}$ Para tanto foi criado um Fundo de Aparelhamento Econômico no início de 1952, que receberia os recursos do Eximbank e do Banco Mundial, devendo ser repassado para os projetos no âmbito do Programa de Reaparelhamento Econômico. Ver: VIANNA, Sergio Bresserman \& VILLELA, André. O pós-Guerra (1945-1955). GIANBIAGI, Fábio (et. alli). Economia brasileira contemporânea 1945-2004). Rio de Janeiro, Elsevier, 2005, pp. 30-31.
}

${ }^{244}$ COLISTETE, Renato Perin. A Cepal e os industriais paulistas na primeira metade da década de 1950. História Econômica \& História de Empresas, XI, 2, jul./dez., 2006.

${ }^{245}$ FURTADO, Celso, A Fantasia organizada, op. cit., p. 252. 
Descrevendo os artigos que acompanharam seus comentários às conferências de Nurkse no número de setembro de 1952 da Revista Brasileira de Economia, todos eles críticos à teoria cepalina, um deles assinado por E. M. Berstein, uma das referências monetaristas do FMI, afirma:

as baterias ortodoxas estavam sendo assestadas de todos os lados. Coroando essas posições, e pretendendo deixar claro que o debate devia ser dado como encerrado, aparecia um artigo do professor Gudin com o título ' $\mathrm{O}$ caso das nações subdesenvolvidas'. $\mathrm{O}$ autor começava advertindo os economistas que não devem intrometer-se em seara alheia. Cabe aos engenheiros, dizia, discutir os 'aspectos tecnológicos do problema do desenvolvimento. ${ }^{246}$

Tendo em vista esse quadro de disputa teórica e de fogo acirrado, continua Furtado, "tratava-se de ocupar um espaço no mundo das ideias e de influir em círculos onde se tomavam as decisões. O que eu dizia tinha repercussão em São Paulo, mas no Rio de Janeiro o que se ouvia era a ressonância dos artigos de Gudin”. ${ }^{247}$

Ora, em se tratando de uma busca por espaço, a conferência da Cepal no Brasil ofereceria uma oportunidade para a Comissão expor suas propostas de política econômica, tendo já mapeado a adesão entre o empresariado industrial e procurando agora sensibilizar os setores ortodoxos do pensamento econômico brasileiro. Por outro lado, a estes não poderia escapar a oportunidade de escrutinar o relatório e criticá-lo.

Entretanto, como relembra Celso Furtado, alguns fatores obscureceram os debates da Cepal, sobretudo a grave crise cambial que se iniciara em finais de $1952 .{ }^{248}$ Frente ao clima político de imediata reforma ministerial,

a conferência da Cepal no Quitandinha foi relegada à sombra. Mas isso não impediu que os ataques à Técnica de programação surgissem de vários lados. Já não se tratava de um debate confinado a páginas de revistas especializadas. Pretendia-se chamar a atenção de setores mais amplos para a ameaça que constituía a doutrina industrialista da Cepal. Entre 29 de maio e 11 de junho, portanto, logo em seguida à conferência, o professor Gudin publicou no Correio da Manhã uma série de cinco artigos, com o título 'a mística do planejamento', com ataques diretos à nossa Técnica de programação. O que escrevia

\footnotetext{
${ }^{246}$ FURTADO, A fantasia organizada, p. 270.

247 Idem, p. 275. Essa divergência na aceitação das ideias é explicitada por Celso Furtado pelas características sócio-econômicas dos dois estados: São Paulo, centro econômico e industrial e Rio de Janeiro, capital federal concentrando as elites comerciais ligadas aos setores de comércio exterior. Essa polarização é percebida também nas instituições de pensamento criadas no Rio de Janeiro, permeadas pela burocracia estatal e vinculada à corrente ortodoxa. Ver, sobre isso. FURTADO, C. A fantasia organizada. op.cit., p. 276-277.

${ }^{248}$ Como relembra Celso Furtado: "Foi num clima de grande tensão política e sob cerrado fogo na frente ideológica que a Técnica de planificação ... foi apresentada... A delegação brasileira era chefiada por Euvaldo Lodi, presidente da Confederação Nacional da Indústria, homem com um clara percepção dos difíceis momentos que atravessa o governo". Idem, A fantasia organizada, op. cit., p. 273.
} 
deixava transparecer que lera pouco atentamente o texto que criticava. O seu verdadeiro propósito era desacreditar certo tipo de política que vinha sendo adotada pelo governo Vargas ${ }^{24}$

Nesse contexto de ataques e ressalvas às propostas cepalinas, podemos recuperar a expressão usada por Celso Furtado referindo-se à palestras de Nurkse: "ocupar espaço". Com efeito, a discussão do relatório é indício dessa polarização que tomava conta do pensamento econômico no Brasil.

Ricardo Bielschowisky, examinando o período entre 1953 e 1955 sob a perspectiva do pensamento econômico brasileiro, destaca que este triênio "pode ser considerado o ponto de maturidade do debate desenvolvimentista, também porque nele se registram a renovação e a ampliação do quadro de instituições de produção intelectual”. ${ }^{250}$ Nesse aspecto, cabe destacar o retorno de Richard Lewinsohn à Europa e a oportunidade da "equipe de Eugênio Gudin e Octávio Bulhões - que já controlava o Instituto Brasileiro de Economia (e editava a Revista Brasileira de Economia) - de passar a controlar a revista Conjuntura Econômica, desalojando os desenvolvimentistas como Américo Barbosa de Oliveira e Thomaz Accioly Borges". ${ }^{251}$ Nesse fechamento de espaço, é preciso notar que os economistas heterodoxos levarão mais tempo para organizarem-se em instituições próprias, como o Clube dos Economistas, fundado apenas em 1955, e que publicará a revista Econômica Brasileira.

Ainda assim, e embora o debate sobre planejamento econômico ensejado pelo relatório da Cepal possa aparecer como um, entre outros do período, o que pretendemos com seu exame é avaliar em que medida essa discussão, ou melhor, os termos dessa disputa foram interiorizados nos escritos de Celso Furtado, pois só assim podemos evidenciar os contingenciamentos que marcam sua obra. Embora a discussão apresentese como debate entre formas de planejamento e toque em questões técnicas, o problema de fundo pode ser assim formulado: afinal, é necessário o planejamento econômico no Brasil? Responder a esta pergunta, que é o objeto e o tema do debate, requer uma compreensão da economia brasileira, de sua dinâmica e evolução, pois é deste diagnóstico que surgirão as críticas e as defesas do planejamento cepalino. Não é a toa que ao longo das respostas há a acusação de que Bulhões e Gudin não compreenderam o

\footnotetext{
${ }^{249}$ Idem, A fantasia organizada. op. cit., p. 274.

250 BIELSCHOWSKY, Ricardo. Pensamento econômico Brasileiro. O ciclo ideológico do desenvolvimentismo. 1930-1964. op.cit., p. 368.

251 Idem, ibidem. Lembremos que Celso Furtado iniciou sua carreira como economista no Brasil trabalhando na revista Conjuntura Econômica, sob a direção de Lewinsohn, de quem resenhou o livro Trustes e cartéis.
} 
relatório (o segundo talvez não o tenha lido). E nem seria preciso, pois é o diagnóstico da evolução econômica brasileira que está em jogo. Por isso, é preciso compreender a interiorização desse debate (das disputas ideológicas) e seus desdobramentos nos escritos de Celso Furtado.

Dentro desse conjunto de questões, e para uma compreensão do debate sobre planejamento econômico no Brasil, uma análise detalhada do texto da Cepal, "Estudio preliminar sobre la técnica de programación”, está fora de nosso escopo, cabendo-nos unicamente uma explanação geral do texto. ${ }^{252}$ Com efeito, mais importante que o exame de seu conteúdo, é necessário nos centrar nas críticas que a ele dirigiu Octávio Gouveia de Bulhões e a resposta de Celso Furtado. Como viemos acompanhando, o economista paraibano estava orientando sua análise da economia brasileira (e dos países subdesenvolvidos) à necessidade de intervenção estatal para acelerar e direcionar o desenvolvimento econômico. O texto da Cepal explicitou exatamente as técnicas possíveis para implantá-la, com forte ênfase na previsão e interligação dos diversos setores da economia, sem negar o auxílio do capital privado, nacional ou estrangeiro. ${ }^{253}$

Com a intenção de ser um instrumento neutro de política econômica, sem propor a autarquia ou o comando da produção pelos governos, o texto, ainda assim, causou espécie entre os economistas ortodoxos. Nossa proposta, para a leitura da polêmica com Bulhões é a de que, assim como as resenhas e a atuação de Celso Furtado na Fundação Getúlio Vargas em 1948 e 1949 permitiram-lhe mapear as correntes de pensamento econômico no Brasil, o debate com Bulhões irá confirmar uma tendência que já aparece de forma germinal nos comentários ao trabalho de Ragnar Nurkse: a percepção da inocuidade das discussões em termos políticos e a busca por uma imbricação entre diagnóstico da economia e necessidade de intervenção, subsidiadas

\footnotetext{
${ }^{252}$ Um exame da discussão sobre a programação econômica da Cepal pode ser encontrada em: LOPES, Tiago Camarinha. Planejamento para a industrialização e o desenvolvimento: o Brasil entre as lógicas de mercado e controle (1930-1956). Uberlândia: UFU (Dissertação de mestrado), 2011.

253 Cumpre notar que, neste período, no Brasil, aparecem duas propostas de planejamento: "O planejamento "seccional" [que daria origem ao Plano de Metas e teve origem nos trabalhos da CMBEU] corresponde à localização de alguns setores que constituem 'pontos de estrangulamento' e/ou 'pontos de germinação da economia e à definição de objetivos setoriais, de modo que o Estado, através de uma série de mecanismos, promova uma política econômica visando garantir as taxas de investimento necessárias. Já o método da Cepal, utilizado por Celso Furtado, pretende-se muito mais abrangente. O objetivo subjacente aos trabalhos do órgão é o planejamento global da economia. Parte-se de uma meta macroeconômica de crescimento, pré-definida de acordo com o levantamento das possibilidades de expansão do sistema como um todo e calculada com base em estimativas da relação capital-produto, da taxa de poupança e dos termos de troca. As projeções setoriais são então feitas de acordo com as taxas de crescimento previstas e levando em consideração a dinâmica da procura final e das relações intersetoriais". BIELSCHOWISKY, Ricardo. Pensamento econômico Brasileiro. O ciclo ideológico do desenvolvimentismo. 1930-1964. Op.cit., p 153.
} 
por uma formulação de teoria econômica consistente e atualizada. Ou seja, não mais discutir princípios e doutrinas econômicas, mas, no campo da prática, evidenciar caminhos inequívocos para a política econômica em direção ao desenvolvimento.

\section{A Cepal e a Técnica de programação}

O documento da Cepal, "Estudio preliminar sobre la tecnica de programacion del desarollo economico", apresentado no Rio de Janeiro na sessão de 6 de abril de 1953, divide-se em duas partes. A primeira, "Esboço de uma técnica de programação", com um total de 119 folhas, expõe os principais conceitos e ferramentas da programação desenvolvidos pela Comissão. A segunda parte "Aplicação das projeções por setores a um caso concreto", dedica-se exclusivamente à economia chilena, somando 279 folhas. Embora não nos caiba um estudo exaustivo deste trabalho, iremos retomar, na intenção de levantar alguns subsídios para análise do debate brasileiro, unicamente a introdução geral do relatório.

O texto apresenta uma distinção entre "programa de desenvolvimento" e a "regulamentação rigorosa da economia pelo Estado". Programa significa: "aumentar e ordenar criteriosamente os investimentos de capital, com o objetivo de imprimir mais força e regularidade ao crescimento de um país”. ${ }^{254}$ Evitando qualquer assimilação precipitada entre os termos programação e programa totalitário, o relatório esclarece que o objetivo último da proposta é incentivar o desenvolvimento, sendo o programa o meio necessário para isso:

um programa requer a aplicação firme de uma política de desenvolvimento, mas isso poderia ser feito sem travar a iniciativa privada, antes lhe oferecendo estímulos para que ela se oriente num determinado sentido e lhe dando acesso aos recursos indispensáveis. $\mathrm{O}$ Estado tem em seu poder instrumentos eficazes para tanto - a política fiscal e alfandegária, a política monetária e creditícia e os empréstimos internos ou externos - , sem prejuízo de sua participação direta em investimentos básicos que, por uma ou outra razão, não sejam realizáveis pela iniciativa privada. ${ }^{255}$

Assim, de antemão, o relatório procura evitar uma possível assimilação de sua proposta com o planejamento total da economia, como ocorria na União Soviética. Além disso, enfatiza o papel ativo da iniciativa privada, que manteria seu dinamismo

\footnotetext{
${ }^{254}$ A introdução ao relatório foi publicada no Brasil em: PREBISCH, Raúl. Os principais problemas da técnica preliminar de programação. In: PREBISCH, Raúl, O manifesto latino-americano e outros ensaios. Adolfo Gurrieri (org). Rio de Janeiro: Contraponto, Centro Celso Furtado, 2011, p. 299.

${ }^{255}$ Idem, ibidem.
} 
mesmo respondendo aos estímulos da programação. Por outro lado, distingue também dois tipos de política econômica, ou dois tipos de intervenção que o Estado dispõe para promover o desenvolvimento econômico. No primeiro, pode utilizar os instrumentos acima [“a política fiscal e alfandegária, a política monetária e creditícia e os empréstimos internos ou externos"] para criar "um ambiente propício ao desenvolvimento da iniciativa privada e encaminhando esta para o cumprimento de certas metas ou objetivos", o que garante a atuação da iniciativa privada, mas indicando, através de incentivos, as melhores fontes de lucratividade, bem como os pontos necessários para a política de desenvolvimento.

Há, entretanto, outra forma de intervenção, que o relatório nega. ${ }^{256} \mathrm{Nesta,} \mathrm{o}$ Estado

prescreve o que a iniciativa privada pode fazer - ou deve abster-se de fazer. O regime de licenças de câmbio e o controle de preços são característicos desse último tipo de intervenção. Um bom programa, longe de reforçar ou tornar indispensável a continuidade desse tipo de ação reguladora da conduta individual dos empresários, pode, ao contrário, criar condições favoráveis à sua eliminação, mediante o crescimento mais ordenado e intenso da economia ${ }^{257}$

Afastando uma interpretação da programação para o desenvolvimento como intervenção total do Estado na economia, o relatório avança "para um campo mais concreto" e discute "a técnica dessa programação". Pela sua complexidade, limitar-se-á a:

considerar a técnica preliminar de um programa, ou seja, o conjunto de processos de análise e projeção que permite determinar os elementos básicos nos quais terão que se fundamentar os objetivos, projetos e medidas de política econômica que integram um programa

Dessa forma, fica explícito o caráter a um só tempo técnico e aplicado do documento, procurando discutir processos de análise, formas de elaboração e de interpretação de índices que possam nortear caminhos ou evidenciar instrumentos

\footnotetext{
${ }^{256}$ Esse ponto, num relatório elaborado com grande generalidade, pode ter o efeito de desferir críticas ao regime cambial vigente no Brasil. De fato, houve no Brasil a adoção do sistema de contingenciamento de importações e controle cambial, a partir de meados de 1947. As medidas de política cambial sofreram novas alterações em 1953, frente a uma grave crise cambial, quando se estabeleceu um regime de leilões cambiais e controle de importações. Sobre isso, ver: VIANNA, Sergio Bresserman \& VILLELA, André. O pós-Guerra (1945-1955). GIAMBIAGI, Fábio (et. alli). Economia brasileira contemporânea (19452004). Rio de Janeiro, Elsevier, 2005, pp. 25 e segs. VIANNA, Sergio Bresserman. Política econômica externa e industrialização: 1946-1951. PAIVA, Marcelo de Abreu (orgs.). A ordem do progresso. Cem anos de política econômica republicana (1889-1989. Rio de Janeiro, Campus, 1994; VIANNA, Sergio Bresserman. Duas tentativas de estabilização: 1951-1954. PAIVA, M. de A. op, cit..

${ }^{257}$ PREBISCH, Raúl, O manifesto latino-americano e outros ensaios, op. cit., pp. 299-300.

${ }^{258}$ Idem, p. 300.
} 
necessários à realização de uma política de desenvolvimento. Para tanto, o texto aborda os principais problemas que envolvem a técnica de planejamento. Neste aspecto, é preciso considerar algo que terá desdobramentos importantes na análise que se seguirá. Com efeito, a formulação da técnica de programação que a Cepal propõe não é fruto ou resultado unicamente de uma reflexão teórica, nem está desconectada dos demais trabalhos da Comissão. Ao contrário, esta "Introdução à Técnica da Programação Econômica" é a tentativa de formalizar uma série de recomendações de política econômica aos países latino-americanos que resultam do estudo sistemático e contínuo da realidade do subcontinente, procurando compreender o desenvolvimento econômico que ocorre na região desde a Primeira Guerra Mundial. Dessa forma, longe de uma imparcialidade dos meios técnicos que está propondo, são eles resultado de análises e diagnósticos do presente.

Isso fica claro ao apresentar o primeiro problema que a técnica de planificação precisa resolver, a saber, "determinar quais são as metas de crescimento possíveis para uma dada economia”. Para isso, é preciso examinar a evolução recente do país, quais os fatores dinâmicos de seu desenvolvimento; ou seja, elaborar um "diagnóstico da economia nacional", captando "a taxa de crescimento obtida no período mais recente" e estudar "as possíveis tendências futuras e as possibilidades de variação ou persistência de fatores internos e externos que atuaram nesse último período". ${ }^{259}$ Com este diagnóstico é possível estabelecer as metas, o ritmo e as necessidades de crescimento da economia, abrindo-se um leque de possibilidades futuras. Um dos elementos fundamentais para isto é a determinação do volume de investimentos necessários para alcançar a meta desejada. A Cepal já possui estudos que indicam a relação entre o capital existente e a renda, de forma que é possível, pela experiência passada, determinar "a quantidade de novos investimentos requeridos para se chegar a um determinado aumento da renda", ${ }^{260}$ calculando-se o processo ano a ano. Desse processo, passo inicial que exigirá correções posteriores e apreciações para cada setor da economia, surgem os primeiros limites aos quais as economias latino-americanas estão sujeitas: aumentar o coeficiente de investimentos implica um aumento da poupança, com consequências sobre o consumo presente da população. Assim, cabe também à técnica de planificação, "discorrer sobre os meios de que o Estado dispõe para trabalhar sobre o coeficiente de poupança, em função dos dados disponíveis a

\footnotetext{
${ }^{259}$ Idem, p. 301.

${ }^{260}$ Idem, p. 301.
} 
respeito da composição da receita". ${ }^{261}$ Nesse sentido, o texto indica medidas de política fiscal como forma de incentivar o reinvestimento dos lucros privados e diminuir o poder de consumo das classes de altas rendas para que o Estado possa disponibilizar esses recursos aos empresários para novos investimentos. Com isso, seria possível evitar o financiamento inflacionário que, em última instância, compromete grande parte da renda com o consumo corrente.

Outro problema importante é a questão da relação entre consumo e importações substitutivas para diminuir a dependência de compras de bens de consumo e de capital no exterior. A necessidade de canalização dos recursos para a importação de bens de produção é alta em relação ao consumo, constata o relatório. A solução pode ser pensada a partir da técnica do planejamento econômico, determinando-se "o montante das substituições a serem feitas para possibilitar uma determinada taxa de crescimento da receita". Para tanto, é necessário fazer alguns "cálculos hipotéticos": qual será "o crescimento provável das necessidades de bens importados", e, também, estimar "o crescimento provável da capacidade para importar, em função das exportações e de seus preços relativos, bem como da quantidade de capital estrangeiro que se considera necessária para a realização do programa”. ${ }^{262}$ Com isso, será possível visualizar a quantidade de importações a substituir, abrindo-se a possibilidade de determinar o tamanho e a magnitude do esforço de substituição de importações. Nesse ponto, continua o relatório, "o critério fundamental deverá ser o aumento da renda obtido nas diferentes alternativas; quanto maior for o incremento alcançado com um certo acréscimo de capital, maior será a massa de bens e serviços disponíveis para a coletividade". 263

Aqui, aparece o caráter instrumental da planificação, capaz de orientar alternativas de política econômica. Por outro lado, fica evidente que as soluções que oferece derivam de diagnósticos que a Cepal elaborou. Isso explicita uma característica fundamental, que irá aparecer adiante: a técnica de planificação não é uma ferramenta puramente teórica com objetivos pré-estabelecidos: trata-se de mecanismos capazes de instrumentalizar soluções de há muito detectadas pela observação do comportamento de variáveis-chave dos países da América Latina: evolução da renda, exportações, importações e capacidade para importar, observação das políticas monetária, fiscal e

\footnotetext{
${ }^{261}$ Idem, p. 304.

262 Idem, ibidem.

${ }^{263}$ Idem, ibidem.
} 
cambial adotadas pelos países, bem como projeções elaboradas considerando a evolução recente dessas economias.

Com isso, a questão da planificação aparece em seu aspecto mais abrangente: o "problema geral concerne à estimativa do crescimento da demanda por bens e serviços, a fim de calcular o montante dos investimentos nos diferentes setores da atividade econômica e nos diferentes ramos de cada setor". ${ }^{264}$ Assim, se num primeiro momento estima-se o capital necessário para uma dada taxa de crescimento, é preciso que esses cálculos avancem para as estimativas de capital em cada setor e, a partir disso, sejam feitos ajustes nas primeiras estimativas. A questão do planejamento é, fundamentalmente, uma escolha entre possibilidades: de vez que se estabeleça o crescimento desejado para o todo, deve-se reunir especialistas para elaborar as projeções necessárias a cada setor, determinando-se, desde já, o esforço e a participação de cada um deles; em seguida, retorna-se às projeções gerais, com os ajustes necessários.

Outra questão, agora ligada à interdependência entre os setores produtivos, é a da mão-de-obra, para a qual será preciso adequar a incorporação de capital nas atividades produtivas de forma que se consiga, ao mesmo tempo, prever os deslocamentos de mão-de-obra e a capacidade intersetorial de absorvê-los.

Um último ponto que deve ser destacado é o conceito de produtividade, critério orientador "na distribuição do capital entre os diferentes setores e entre os diferentes ramos de cada setor da atividade econômica". ${ }^{265}$ Com efeito, uma vez que a programação é um instrumento que abre opções aos planejadores, que envolve distribuir incentivos ou implementar políticas com pesos específicos para cada setor dependendo dos objetivos gerais, a produtividade assume um papel importante como critério de decisão de política econômica, embora não seja o único. O relatório chama atenção para duas formas principais de aumento da produtividade: a produtividade por pessoa ativa e a produtividade por unidade de capital. A primeira delas, que seria aumentar a produtividade por trabalhador sem aumentar o investimento em capital, seria a melhor opção para países latino-americanos, com um histórico de excesso de mão-de-obra e baixa produtividade em alguns setores. Entretanto, a forma como a técnica moderna evoluiu e está disponível agora apresenta como solução para o aumento de produtividade a elevação da intensidade de capital por unidade de trabalho. Ou seja, consomem-se os recursos na ampliação do capital poupador de mão-de-obra. A solução

\footnotetext{
${ }^{264}$ Idem, p. 308.

265 Idem, p. 311.
} 
desse problema, que depende da evolução tecnológica dos últimos cento e cinquenta anos, não está nas mãos dos países latino-americanos. Entretanto, prossegue o relatório, é um problema que deve ser avaliado em um programa de desenvolvimento econômico, pois exige que se leve em conta os efeitos de uma elevação do capital em cada setor da economia, considerando-se, sobretudo, as repercussões sobre a mobilidade e a disponibilidade de mão-de-obra, bem como os efeitos sobre o consumo no conjunto, pois a utilização de recursos em capital pode diminuir o consumo de outros setores, sobretudo de bens-salário.

Finalmente, o relatório toca na importante questão do papel do economista na formulação de um programa de desenvolvimento econômico. Este deverá diagnosticar as possíveis soluções e apresentá-las

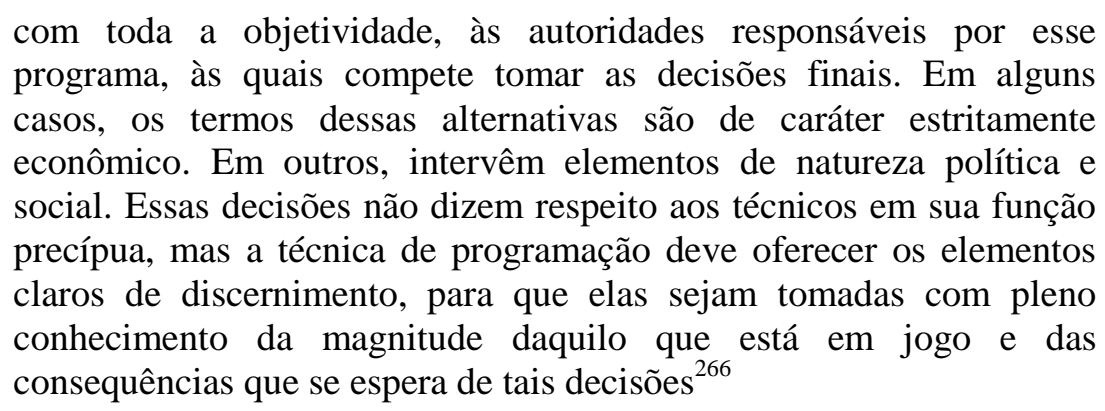

O que aparece aqui, portanto, é a delimitação precisa do economista trabalhando com um instrumental capaz de oferecer opções de política econômica, cujas decisões e formas de implantação têm natureza política e sob as quais não exerce controle. Nesse sentido, "o papel da técnica é apresentar com objetiva imparcialidade as diferentes alternativas, aquilo que cada uma delas exige e seus efeitos prováveis". ${ }^{267}$ Mas ainda aqui, cabe um esclarecimento importante, não apenas para a compreensão do documento, mas também de sua recepção no Brasil e as estratégias de defesa que Celso Furtado e Raúl Prebisch adotaram. Com efeito, no plano instrumental, a técnica de planificação trata unicamente do cálculo das projeções, de estimativas de impacto nos diversos setores econômicos e as alternativas de desenvolvimento econômico considerando-se a possiblidade de ampliar o investimento e, em consequência, a renda per capta. Para isso, vale-se do comportamento recente da economia, cujo escrutínio foi o principal objetivo da Cepal desde sua criação em 1948 e cujos relatórios gerais procuraram aprofundar e ampliar. Entretanto, nesta instrumentalização, está implícito o diagnóstico da necessidade de industrialização dos países latino-americanos. Ao

\footnotetext{
${ }^{266}$ Idem, p. 316.

${ }^{267}$ Idem, ibidem.
} 
detectar e ao trabalhar no relatório como elaborar as estimativas para ampliar a capacidade de importar e a seleção dos setores onde os aumentos de produtividade terão maiores repercussões na economia como todo, tem-se implícita a preponderância do setor exportador, as dificuldades no balanço de pagamento decorrente da dependência das importações de bens de consumo e de capital, os problemas da agricultura e de excesso de mão-de-obra. Assim, sob a forma de isenção e imparcialidade técnica, o relatório da Cepal efetivamente operacionaliza seu diagnóstico e seu programa de industrialização para a América Latina.

Com isso, cabe-nos, agora, averiguar como o relatório foi recebido nos meios liberais brasileiros, dando origem à controvérsia sobre o planejamento econômico na qual discutiram Celso Furtado e Otávio Gouveia de Bulhões e, num debate semelhante, Raúl Prebisch e Eugênio Gudin.

\section{O debate sobre planejamento econômico no Brasil}

Uma das primeiras reações no Brasil ao relatório da Cepal sobre a técnica de planificação econômica apareceu no Jornal do Comércio, do Rio de Janeiro, no dia 24 de maio de 1953 — ou seja, poucos dias após a reunião no hotel Quitandinha, em Petrópolis — assinada por Octávio Gouveia de Bulhões. A resposta de Furtado, bem como a réplica de Bulhões foram republicadas no número de novembro/dezembro do mesmo ano da Revista do Conselho Nacional de Economia. ${ }^{268}$

Paralelamente a essa discussão, Eugênio Gudin publicou uma série de cinco artigos no Correio da Manhã, entre maio e julho, aos quais Raúl Prebisch respondeu com dois textos no Diário de Notícias, de São Paulo, em novembro do mesmo ano. ${ }^{269}$

\footnotetext{
268 Ricardo Bielschowisky, enumerando as instituições em que os "economistas e intelectuais" se agrupariam para definir seus projetos refere-se ao Conselho Nacional de Economia: "o predomínio dos neoliberais nessa instituição é grande, no período em questão [o triênio 1953-1955]. O prof. Octávio Bulhões assume a presidência entre 1953-1954, e o chefe do departamento técnico, Denio Nogueira, terá destacada participação intelectual na defesa das posições da equipe Gudin-Bulhões. A Revista do CNE passa a sair com regularidade (desde meados de 1952) e alcança um bom padrão". BIELSCHOWSKY, Ricardo. Pensamento econômico Brasileiro. O ciclo ideológico do desenvolvimentismo. 1930-1964. Rio de Janeiro: Contraponto, 2003, pp. 368-369.

${ }^{269}$ Sobre o papel de Eugênio Gudin no pensamento econômico brasileiro e sua discussão com a corrente
desenvolvimentista: "esta se via continuamente impelida à obrigação do exercício de crítica às análises de
Gudin, não só pela importância prática que tinham essas análises, de ampla divulgação pública, mas
também pelo conhecimento da firmeza e coerência de sua linha de argumentação. Diante da segurança
com que divulgava os postulados neoliberais, é difícil imaginar que o debate sobre desenvolvimento
econômico tivesse ficado mais ou menos balanceado, como ficou, se não fosse a riqueza da interpretação
antiliberal inspirada em Prebisch e nos textos da Cepal, de um modo geral". BIELSCHOWSKY, Ricardo.
} 
Esses debates assumem relevância em nosso trabalho pois explicitam as clivagens do pensamento econômico no Brasil, cujas consequências extrapolam esses artigos e irão ressoar na própria formulação dos diagnósticos sobre a economia brasileira e latino-americana que Celso Furtado produzirá nos próximos anos. Trata-se, portanto, de momento importante para compreender uma inflexão no pensamento de Celso Furtado, pois a partir deste momento irá incorporar em suas reflexões as possíveis críticas liberais e buscar estratégias de contra-argumentação que as tornem ineficazes. $\mathrm{O}$ principal mecanismo para tanto será imbricar ainda mais as propostas de política econômica nos diagnósticos sobre o presente, retirando o caráter ideológico daquelas e apontando sua necessidade intrínseca, secundarizando as discussões ideológicas.

Para chegar a essa solução, estes debates constituem peças-chave, pois evidenciam que as reações à técnica da planificação se deram a partir dos diagnósticos sobre o presente, muito embora tenham se traduzido em linguagem teórica e, em alguns, momentos, ideológica. Serão esses elementos que iremos examinar em seguida.

O editor da Revista do Conselho Nacional de Economia anuncia que está publicando "três artigos de interesse no momento em que se debatem nos congressos e conferências econômicas, as questões referentes ao desenvolvimento da economia dos países latino-americanos". Destaca, ainda, a intenção de "publicar outros, de análise e comentário às conferências que, sobre o momentoso tema do desenvolvimento econômico da América Latina, vêm pronunciando nesta capital alguns dos mais eminentes economistas estrangeiros, vindos ao Brasil a convite do Instituto Brasileiro de Economia da Fundação Getúlio Vargas”. ${ }^{270}$

No editorial, portanto, constatamos a ampliação do debate sobre temas econômicos que vinha acontecendo no Brasil, sobressaindo o papel ativo da Fundação Getúlio Vargas. ${ }^{271}$ Esse interesse, no entanto, não deixa de ser apresentado de forma a diminuir as divergências, talvez resguardando o caráter oficioso de uma revista que

Eugênio Gudin (1886-1986). In: SZMRECSÁNYI, T; COELHO, F. S. Ensaios de história do pensamento econômico no Brasil contemporâneo. São Paulo: ATLAS, 2004, p. 307.

270 REVISTA DO CONSELHO NACIONAL DE ECONOMIA. "Problemas do desenvolvimento." [editorial]. Revista do conselho Nacional de Economia. Rio de Janeiro, Ano II, Números 19-20, Novembro-dezembro de 1953, p. 1

${ }^{271} \mathrm{O}$ artigo de Bulhões, ainda, tem um caráter coletivo pois, como explica logo de início: "o Instituto Brasileiro de Economia, da Fundação Getúlio Vargas, examinou com muita atenção o documento intitulado 'Estudo Preliminar Sobre a Técnica de Programação do Desenvolvimento Econômico / O trabalho foi discutido em várias reuniões da Comissão Diretora e, de certo modo, as considerações aqui expedidas como que refletem um resumo dos debates". BULHÕES, Octavio Gouveia de. Estudos sobre a programação do desenvolvimento econômico. Revista do conselho Nacional de Economia. Rio de Janeiro, Ano II, Números 19-20, Novembro-dezembro de 1953, p. 3. 
expressa as visões de uma instância governamental: "terão os leitores dessa Revista ocasião de verificar que embora divirjam as opiniões quanto à questão de método, de sistema ou de instrumental, uma coisa persiste íntegra, e não sofre dúvida ou impugnação: é que se faz imperioso o desenvolvimento econômico desta parte do continente americano.". ${ }^{272}$

Assim, nesta apresentação, fica explícita a concepção do próprio editor, de que a discussão é de método, mas a questão de fundo parece ser consensual: há necessidade de desenvolvimento. Nesse sentido, o debate é sobre o tipo de promoção deste, e qual a sua intensidade e limites.

\section{A crítica de Otávio Gouveia de Bulhões}

Segundo Bulhões, a Cepal entende por programação "a escolha de uma taxa de aceleração de crescimento da renda nacional", ou seja, "um sistema de investimentos tendentes a propulsionar as diferentes produções de um país, de modo a imprimirem à economia um ritmo de crescimento pré-estabelecido". ${ }^{273}$ Esta definição inicia sua crítica. Com efeito, "a fixação a priori de progresso é o cerne da programação da Cepal [grifo do autor]" e resulta em um "processo exógeno de desenvolvimento". Em outras palavras, "em vez de pressupor-se a existência de ânimo de progresso entre os produtores [...] os autores da teoria da programação partem da hipótese da inexistência desse espírito de empreendimento", ou "parte-se do pressuposto de uma economia com tendência à estagnação". ${ }^{274}$

A argumentação de Bulhões, ao contrário, enfatiza o dinamismo interno. Para isso, resgata as conferências de Ragnar Nurkse, sobretudo as considerações sobre as possibilidades de ruptura do círculo vicioso da pobreza, a avaliação de Schumpeter e os

\footnotetext{
${ }^{272}$ Idem, p. 2. Intenção semelhante tem o editor do Diário de Notícias, que apresenta a resposta de Prebisch como parte de um esforço para "elucidar um dos mais apaixonantes aspectos do debate sobre o conceito que deve prevalecer na solução dos problemas econômicos das nações latino-americanas, inclusive o Brasil". Diário de Notícias. Editorial. São Paulo, domingo, 8 de novembro de 1953, terceira seção, p. 8.

${ }^{273}$ BULHÕES, Estudos sobre a programação... op. cit., p. 3.

${ }^{274}$ Idem, p. 4. Por outro lado, Eugênio Gudin, tem uma definição restrita de planejamento, "no sentido elementar de estudo e reflexão sobre o que se vai fazer". GUDIN, Eugênio. A mística do planejamento IV - A órbita do Estado. Correio da manhã. Rio de Janeiro, terça-feira, dia 9 de junho de 1953, $1^{\circ}$ Caderno, fl. 2. Por outro lado, também considera que a fixação de uma taxa de investimentos transforma a programação num instrumento de política totalitário. GUDIN, Eugênio. A mística do planejamento V As Forças de Equilíbrio. Correio da manhã. Rio de Janeiro, quinta-feira, 11 de junho de 1953, $1^{\circ}$ Caderno, fl. 2.
} 
exemplos de desenvolvimento com o apoio do Estado, como no caso japonês. Entretanto, ao contrário do economista esloveno, para Bulhões:

basta um ligeiro relance sobre nossa história econômica para compreendermos que a evolução brasileira tem mais afinidade com o chamado desenvolvimento schumpeteriano do que com o desenvolvimento processado no Japão [...] $O$ que são, economicamente, a grande produção açucareira, a seu tempo, e, posteriormente, os surtos da expansão cafeeira, senão expressões inovadoras? Valem como produções novas no mercado internacional e, acima de tudo, provocaram em nosso país ondas sucessivas de expansão industrial, no Estado de São Paulo e no Distrito Federal ${ }^{275}$

Aqui, percebe-se que Bulhões vai à contramão de Nurkse $e$ de Furtado, pois ambos reconhecem que o desenvolvimento schumpeteriano tem validade exclusiva para os países desenvolvidos. Aquele, entretanto, mobiliza episódios da história econômica do Brasil sob a ótica do empresário privado, pressupondo que este opera em condições econômicas semelhantes e independente de apoio estatal, seja no período colonial (produção açucareira), seja após a Independência, a despeito da forte intervenção do governo no mercado mundial de café.

Mesmo reconhecendo que o desenvolvimento econômico brasileiro "encontra enormes obstáculos", nega que sejam "mais substanciais do que realmente o são", ou mesmo que "tais obstáculos tinham raízes demasiado profundas". ${ }^{276}$ Para corroborar sua visão, utiliza alguns dados publicados pela FGV para mostrar a dinâmica do setor privado brasileiro, indicando a superioridade do investimento privado sobre o público, no período de 1947 a 1951, ressaltando que só não foram maiores porque os serviços públicos eram monopolizados pelo Estado, restringindo, assim, a esfera de atuação dos empresários. Em suas palavras: “observe-se que a iniciativa particular foi enxotada dos serviços públicos, nestes últimos 30 ou 40 anos, por força de uma incompreensão de política econômica". 277

A crítica se estende à administração das empresas estatais, pois, "os governos, persuadidos de que bem serviam ao povo fixando tarifas baixas, acabaram por inutilizar

\footnotetext{
${ }^{275}$ BULHÕES, Estudos sobre a programação... op. cit., p. 5.

${ }^{276}$ Idem, p. 5.

${ }^{277}$ Idem, p. 6. A discussão sobre a passagem do setor de energia elétrica para a iniciativa privada nos anos de 1940 e 1950 é examinada em: BASTOS, Pedro Paulo Zahluth. A construção do nacionalismo econômico de Vargas. In: BASTOS, P. P. Z; FONSECA, P. C. D (orgs). A Era Vargas. Desenvolvimentismo, economia e sociedade. São Paulo, Editora Unesp, 2013, pp. 274 e segs.
} 
toda a possibilidade de expansão das empresas, quer dirigidas diretamente por particulares, quer pelo próprio governo". ${ }^{278}$

Nesse ponto, é preciso considerar que Gudin e Bulhões estiveram empenhados em reduzir a atuação do Estado nesses setores. O primeiro, em um de seus artigos, relata a discussão que se dava no CNE [do qual fazia parte] a respeito de um "anteprojeto da lei reguladora do equilíbrio econômico das empresas de produção e distribuição de energia elétrica", que foi rejeitado pela proposta alternativa de criação de um fundo público para conceder empréstimos e administrar o sistema elétrico nacional. O projeto, na visão de Gudin, recusava "às empresas privadas os mecanismos indispensáveis de equilíbrio econômico". 279

Em contraposição aos monopólios estatais, Bulhões apresenta o conceito de economias externas, emprestado de Marshall, para destacar a importância dos serviços públicos suprirem não apenas a demanda da população, mas também das regiões industriais, pois estas têm capacidade de irradiação de benefícios via aumento de produtividade.

A ideia de economia externa é relacionada com a expansão do consumo, pois permite que se amplie a escala da produção. Bulhões, retomando a proposta de Nurkse - um ciclo de investimentos em diversos setores simultaneamente, como forma de romper a estagnação do círculo vicioso da pobreza - descarta essa solução como não válida para o Brasil, onde é possível perceber "a existência de certa uniformidade de expansão manufatureira e acentuada multiplicidade de indústrias no curso dos últimos anos", 280 sem a necessidade de investimentos estatais.

Para Bulhões, o país já teria saído de seu círculo vicioso da pobreza e:

para uma economia como a do Brasil, que já atingiu determinado estágio de evolução, com um mercado dotado de satisfatórias condições de procura, seja para bens de consumo, seja para bens de produção, mais importante do que a preocupação do aumento do âmbito do consumo é a da conquista da generalização da eficiência da produção. Somente através de um sistema de núcleos de irradiação de produtividade é que poderemos alcançar essa almejada generalização

\footnotetext{
${ }^{278}$ Idem, p. 6. A questão do Estado cerceando a iniciativa privada é também alvo das críticas de Gudin. Suas restrições ao planejamento, escreve, surgem "quando se pretende invadir o setor da iniciativa privada desnecessariamente". Citando caso da estrada de ferro Great Western e da recente criação do fundo para eletrificação, Gudin descreve a estratégia de atuação do governo como recusando "às empresas, repetidamente, os elementos de justa remuneração para seu capital e, diante da consequente impossibilidade de manter e ampliar seus serviços, declarar a falência da iniciativa privada". GUDIN, Eugênio. A mística do planejamento IV - A órbita do Estado. Correio da manhã. Op.cit., fl.2.

${ }^{279}$ GUDIN, Eugênio. A mística do planejamento. Correio da manhã. Rio de Janeiro, sexta-feira, dia 29 de maio de $1953,1^{\circ}$ Caderno, fl. 2.

${ }^{280}$ BULHÕES, Estudos sobre a programação... op. cit., p. 7.
} 
de eficiência. É a falta da 'economia externa' na real acepção marshalliana, ou sejam os transportes prontos e regulares e a difusão da assistência técnica na indústria e, notadamente na agricultura, que, fundamentalmente, está prejudicando o progresso do Brasil ${ }^{281}$

Desse ponto de vista, o principal elemento para o desenvolvimento econômico brasileiro reside no melhoramento da estrutura produtiva privada brasileira.

Percebe-se que o diagnóstico de Bulhões pressupõe: 1) o dinamismo da iniciativa privada; 2) um processo de desenvolvimento econômico em curso, sob o comando do empresariado; 3) a necessidade de aumentar a eficiência produtiva da economia direcionando a área de atuação do Estado para promover economias externas e excluir sua participação de setores monopolísticos, ampliando as possibilidades de inversão do setor privado que se encontram bloqueadas. Entretanto, neste diagnóstico, algumas questões ficam sem resposta: como definir esse núcleo de irradiação e como determinar os setores que devem ter preferência no aumento de produtividade?

Não há uma discussão sobre como identificar os pontos de irradiação necessários, ou como estabelecer sua capacidade dinamizadora para o conjunto da economia. Ao contrário da Cepal, que adota o conceito de produtividade social média, Bulhões preocupa-se mais com os agentes que irão operacionalizar esses investimentos de que com a definição da prioridade dos mesmos.

Em seu diagnóstico, o setor privado nacional é dinâmico e capaz de promover o desenvolvimento econômico, mas o monopólio estatal de serviços públicos restringe sua ação ao cercear as frentes de investimento e não fornecer as economias externas necessárias à expansão das atividades produtivas. Para Bulhões, a atuação estatal nesses setores prejudica o setor privado, pois impede que seus lucros sejam investidos em infraestrutura e serviços públicos, ao mesmo tempo em que a estrutura tributária não permite ao Estado custear os investimentos necessários. Em suas palavras:

como, entretanto, o sistema tributário não é adequado ao programa de socialização dos serviços públicos, os particulares aplicam suas disponibilidades, não taxadas, na expansão das 'economias internas' ou em construções urbanas, enquanto que o Governo também realiza investimentos, sem uma provisão de fundos decorrentes de somas provenientes de tributos, nos empreendimentos de 'economias externas'. Ele o faz mediante apelos inflacionários, ostensivos ou disfarçados, mas sempre com resultados funestos sobre os preços, que estão provocando uma intranquilidade social cada vez mais aguda". ${ }^{282}$

\footnotetext{
${ }^{281}$ Idem, p. 8.

${ }^{282}$ Idem, pp. 8-9.
} 
Aqui, portanto, emerge outro elemento importante do diagnóstico de Bulhões sobre a economia brasileira. Por encontrar-se num período de expansão, "efervescência" dos investimentos, os principais problemas atuais derivam da atuação governamental, que deveria ser restringida. O monopólio de serviços públicos impede ou inibe o campo de investimento dos empresários ao mesmo tempo em que o Estado não é capaz de ampliar esses serviços, pois the falta uma base de arrecadação para novos investimentos; já a operacionalização dos serviços, por sua vez, ao funcionar com taxas subsidiadas, impede o equilíbrio orçamentário. Dessa forma, a necessidade de investimentos e de manutenção dos preços administrados é feita via emissão monetária, causando da inflação.

Dentro desse conjunto de problemas, Bulhões retoma a ideia de programação econômica. Para ele, diferentemente da Cepal, trata-se de indicar caminhos, via incentivos, para a iniciativa privada decidir seus investimentos:

o fundamento da orientação reside num dilema, que pode não ser rígido, isto é, que admite certa fluidez, mas que, de qualquer modo, positiva a definição de propósitos: ou enveredamos pelo caminho dos investimentos governamentais, no setor das 'economias externas', mas, nesse caso, devemos reduzir as possibilidades de investimentos particulares no setor das 'economias internas', por meio de substancial intensificação tributária, ou então, o que parece de resultados muito mais seguros, embora mais remotos, voltamos a adotar um clima favorável aos investimentos particulares nos serviços públicos, estimulando a aplicação de capitais nesses setores ${ }^{283}$

Assim, ao contrário do relatório da Cepal - preocupado em distinguir as ferramentas, a metodologia para analisar cada setor econômico e captar suas interdependências - para Bulhões, trata-se de definir os agentes que se incumbirão de realizar os investimentos. A dinâmica do setor empresarial tem condições de impulsionar o desenvolvimento, cabendo apenas uma planificação capaz de criar oportunidades e promova economias externas para os empresários. Sua preferência, claro está, reside no setor privado, dinâmico, com lucros disponíveis para investimento, ao contrário do Estado, sem receita tributária para executá-los e carecendo de uma administração econômica racional de suas tarifas. ${ }^{284}$

\footnotetext{
${ }^{283}$ Idem, p. 9.

${ }^{284}$ Essa, na verdade, é também a visão do Conselho Nacional de Economia, que preside: "o conselho Nacional de Economia apontou o dilema e sugeriu a aplicação de capitais particulares no campo dos serviços públicos, com as medidas legislativas e administrativas que julgou acertado alvitrar. Cabe, agora, às autoridades e aos homens públicos escolherem o processo de investimento. E, se digo que cabe agora a escolha é porque se impõe uma solução urgente". Idem, ibidem.
} 
Finalmente, Bulhões explicita sua discordância com a Cepal retomando um ponto do relatório que suas considerações vinham deixando de lado: como definir os critérios para o investimento, ainda que estes sejam deixados unicamente para a iniciativa privada. Em suas palavras:

a Cepal, ao formular uma programação, visa a fixação do coeficiente de aumento da renda nacional, preocupando-se em escolher aqueles investimentos que requeiram menor densidade de capital e que ofereçam uma produção de maior elasticidade da procura, em função do acréscimo da renda. Dentro dessa base, podem ser deixados para um plano secundário o problema dos preços relativos e os problemas monetários $^{285}$

Aqui aparece, pela primeira vez, um ponto central da programação: o critério para os investimentos é automático, dado pelos preços relativos da economia. Com isso, a própria ideia de programação cai por terra: não é necessário ou recomendável que o Estado intervenha diretamente na economia e, tampouco, o planejamento, pois este já está dado pelo sistema de preços. Dito de outra forma, a principal crítica de Bulhões ao relatório da Cepal está na fixação da taxa de crescimento da renda. Argumenta, em defesa de um livre mercado, que as decisões de investir estão baseadas nos preços relativos das mercadorias, bem como na produtividade de cada mercadoria ou ramo produtivo. Notemos: ao enfatizar os preços relativos, desloca o foco do aumento da renda e da repartição entre consumo e investimento, para as iniciativas individuais dentro do sistema de preços; desaparece a necessidade direta do Estado agir criando poupança e canalizando-a para os investimentos que julgar mais adequados ao sistema econômico como um todo.

Para Bulhões, o sistema de preços é o melhor indicador, ou, corrigindo, um indicador espontâneo para os investimentos, não sendo necessária, numa economia em expansão como a brasileira, a programação econômica. ${ }^{286}$

Dessa forma, a argumentação desliza para a conclusão de que, uma vez rejeitado o sistema de preços, o planejamento da Cepal está tolhendo a iniciativa privada e desconsiderando a atividade dinâmica da classe empresarial. Com isso, "o afastamento do problema dos preços e, também, dos problemas monetários, que se observa na teoria da programação da Cepal, não é mero processo analítico de aproximações [...] $\mathrm{Na}$ verdade, os preços relativos não foram imediatamente focalizados porque desempenham

\footnotetext{
${ }^{285}$ Idem, p. 9.

286 "Num regime econômico de progresso espontâneo, a relação de preços é a base essencial de realização do investimento, enquanto que no regime de planejamento a relação de preços resulta dos investimentos projetados". Idem, ibidem.
} 
papel de secundária importância, nessa teoria”. ${ }^{287}$ A desconsideração dos problemas monetários só é viável, nos termos da programação cepalina, se ocorrer uma absorção prévia da poupança que será canalizada para os investimentos, também definidos previamente pelo programador. Contudo, e aqui a crítica atinge outro patamar: "nessa ordem de considerações estamos, ao que parece, em pleno regime de economia totalitária" e, ${ }^{288}$ prossegue, inflacionária, uma vez que trabalha com a projeção de um aumento da renda, mas não quantifica em termos monetários o montante de poupança a ser criado, nem os investimentos a serem realizados.

Nesse sentido, Bulhões, examinando os critérios de investimento da Cepal resumidos como: "a) investimentos com diminuta aplicação de capital; b) investimentos que determinem a produção de artigos de elevada procura"289 — reconhece a virtude do primeiro, embora não aplicável ao caso do Brasil, e nota que o segundo elemento irá ocasionar desequilíbrios dos fatores de produção, devido à expansão de produtos com procura elástica, desestimulando o investimento em outras áreas.

Finalmente, os problemas examinados e a solução proposta pela técnica de programação da Cepal, como já anunciado anteriormente, não têm razão de ser, sobretudo num país como o Brasil, “onde há provas de existência de surtos de progresso espontâneo. A tendência de desenvolvimento está assegurada pelo ânimo de progresso dos empreendedores particulares [...] Estão, pois, asseguradas as forças propulsoras da formação da renda e de sua multiplicação". ${ }^{290}$ Com efeito, argumenta, o problema principal está na criação de "economias externas", de "pontos de irradiação de produtividade", de forma que "o sistema de política de intervenção indireta do Estado assuma papel importante e muito complexo, mas certamente menos difícil e provavelmente mais eficaz do que a intervenção direta de outros gêneros de programação". 291

Assim, percebemos que Bulhões restringiu sua análise predominantemente ao caso brasileiro. Neste, afirma, a dinâmica do empresariado é alta, operam com superlucros e só não os reinvestem em infraestrutura e serviços públicos pois esses setores estão monopolizados pelo Estado. De outro lado, fica explícita também a sua compreensão do papel do Estado na economia, que não deve ser de total ausência de

\footnotetext{
${ }^{287}$ Idem, ibidem.

${ }^{288}$ Idem, ibidem.

${ }^{289}$ Idem, p. 10.

${ }^{290}$ Idem, p. 11.

${ }^{291}$ Idem, ibidem.
} 
intervenção, mas restrita à criação de economias externas que baixem o custo de produção e permitam que a iniciativa privada amplie seus investimentos e busque incrementos de produtividade. Finalmente, o sistema de preços, e não o Estado, assume papel central na coordenação da economia, aspecto que a Cepal prescinde e situa em segundo plano, colocando a programação em termos de uma prévia fixação da taxa de crescimento da renda e, a partir disso, dos investimentos necessários para alcançar aquela projeção. Posto em outros termos, enquanto a Cepal trabalha com variáveis macroeconômicas, operacionalizando-as a objetivos prévios e específicos, Bulhões, ao enfatizar o sistema de preços, trabalha com variáveis microeconômicas, considerando a economia um conjunto de agentes individuais respondendo ao incentivo dos preços. Essa ênfase permite-lhe acusar a programação cepalina de totalitária e inflacionária, por não quantificar em termos monetários os investimentos e a poupança necessária para sua execução.

\section{A Resposta de Celso Furtado}

O exame do artigo de Bulhões permitiu captar a polarização do pensamento econômico no Brasil, identificando também a inserção institucional de seu autor em organismos de difusão do pensamento econômico ortodoxo, sobretudo a Fundação Getúlio Vargas e o Conselho Nacional de Economia. A resposta de Celso Furtado também explicita sua participação e engajamento na Cepal, pois inicia seu texto referindo-se ao conjunto de problemas aos quais a Comissão dedicou-se nos últimos anos. Primeiramente, a instituição se preocupou com a "análise do processo histórico de desenvolvimento dos países latino-americanos", em seguida, procurou identificar "os fatores que têm dificultado esse processo e são responsáveis pelo atraso relativo desses países" e, no momento atual, apresentadas no relatório discutido no Quitandinha, "como acelerar o ritmo de desenvolvimento". 292

Celso Furtado afirma que o documento não é um exercício econômico. Ao contrário, resulta de um trabalho constante de estudo e compreensão do processo de desenvolvimento econômico da América Latina e da formulação dos problemas que este processo veio acarretando para o subcontinente. O diagnóstico do presente está pressuposto na proposta de planificação ou, de forma inversa, a planificação surge para

\footnotetext{
${ }^{292}$ FURTADO, Celso. A programação do desenvolvimento econômico. Revista do Conselho Nacional de Economia, Rio de Janeiro, Ano II, Números 19-20, Novembro-dezembro de 1953, p. 11.
} 
corrigir problemas detectados nos relatórios anteriores, em concomitância com um esforço de formulação de conceitos econômicos que expliquem a realidade latinoamericana. $^{293}$

Destaca, também, o caráter generalizante do relatório, admitindo - e ecoando a crítica de Bulhões - que embora alguns países da América Latina já possuam uma dinâmica de desenvolvimento, enquanto outros ainda não se iniciaram nesse processo, é forçoso admitir que "mesmo naqueles países em que o ritmo de desenvolvimento é considerado satisfatório, existe generalizada a preocupação do enorme desperdício de recursos que vem caracterizando esse desenvolvimento". 294

Celso Furtado retoma as considerações de Bulhões sobre a necessidade de uma programação para o desenvolvimento que estimule os investimentos $\operatorname{privados}^{295}$, cabendo ao Estado a criação de economias externas e pontos de irradiação para favorecer os setores empresariais. Bulhões, continua, recomenda que esse desenvolvimento seja feito sem inflação — ou seja, sem que o Estado assuma compromissos de investimento além de sua capacidade tributária, o que o obrigaria a recorrer a emissões monetárias — deixando que os investidores privados, via incentivos, ocupem o lugar do Estado nos investimentos. Mas, pergunta Furtado: “como seria possível empreender um programa dessa natureza sem antes cercear a iniciativa privada?”. ${ }^{296}$ É necessária alguma transferência de recurso, argumenta, seja entre o setor público, seja do setor privado para este, sem que com isso a estrutura da demanda como um todo sofra alterações.

É preciso, continua Furtado, pensar como essas transferências e esse programa de desenvolvimento poderiam ser feitos sem inflação. Para explicar como essa questão, não apenas está colocada, mas também resolvida no estudo da Cepal, reforça novamente que o principal objetivo do estudo foi fazer um amplo mapeamento do "processo total de formação de capital dentro da economia", pois, "sem essa análise seria impossível

\footnotetext{
293 A relação entre a questão do planejamento e os trabalhos sobre a conjuntura latino-americana da é examinada em RODRÍGUEZ, Octávio. Teoria do subdesenvolvimento da Cepal. Rio de Janeiro: Forense Universitária, 1981, pp. 167-170.

${ }^{294}$ Idem, ibidem.

295 Prebisch também enfatiza como viável um programa de investimentos do Estado no qual o setor privado seja estimulado a alcançar "determinados objetivos e o volume das inversões atinja determinado nível. São vários os mecanismos pelos quais o Estado influi nos investimentos privados. A diferença da programação está em coordenar essa atuação para objetivos convergentes e não contraditórios. Ou seja, um programa pressupõe a análise de todas essas formas de ação governamental e a fim de conjuga-las de tal maneira que, sem prejuízo de seus objetivos diretos e parciais, contribuam para alcançar uma determinada meta de desenvolvimento". PREBISCH, Raúl. A mística do equilíbrio espontâneo na economia. Diário de Notícias. São Paulo, domingo, 8 de novembro de 1953, terceira seção, oitava página ${ }^{296}$ FURTADO, Celso. A programação do desenvolvimento econômico. op.cit., p. 12.
} 
dispor dos critérios gerais para localizar os 'núcleos de irradiação de produtividade', a que se refere o prof. Bulhões”. Explicando essa mapeamento:

trabalha-se aí com hipóteses sobre o crescimento da renda e sua distribuição. Trata-se em seguida de quantificar os efeitos daquele crescimento sobre a estrutura e o montante do consumo. Como se está raciocinando em termos reais, procura-se determinar quanto teria que crescer a capacidade produtiva de cada setor (isto é, a quanto deveriam montar os investimentos e aproximadamente que estrutura deveriam apresentar estes) para atender àquele consumo. Esse modelo dinâmico de desenvolvimento equilibrado, é que servirá de base para a orientação dos investimentos privados e para a suplementação destes pelos investimentos públicos. ${ }^{297}$

Somente a partir desse mapeamento seria possível detectar os núcleos de irradiação que defende o crítico, ademais que a aparente ausência de considerações monetárias no estudo se deve ao fato de ter-se optado por trabalhar a análise em termos reais. Ou seja, evitando o automatismo do mercado (que existe ao nível individual e não para o conjunto da economia) é somente com o levantamento e identificação não apenas dos recursos disponíveis, mas também da interdependência entre os setores produtivos que se pode avaliar os pontos de irradiação e as possibilidades de maior aumento de produtividade setorial que terão maiores repercussões para o conjunto da economia.

Rebatida a crítica principal, do ponto de vista teórico, e que ainda será retomada mais a frente, Celso Furtado irá se deter na afirmação de que a Cepal desconsiderou a dinâmica do desenvolvimento econômico brasileiro, bem como seu setor empresarial, capacitado para conduzir esse desenvolvimento. Celso Furtado insiste em que o dinamismo do empresário não é algo endógeno ou espontâneo, podendo ser criado, seja por condições externas (aumento da demanda internacional por um produto) ou pelo próprio governo (controle sobre taxas de câmbio), concluindo que

a análise econômica não deve assentar em princípios de fé. É necessário conhecer e quantificar os estímulos a que responde o empresário, se se pretendem criar as condições propícias à sua atuação mais efetiva. Não basta crer no progresso espontâneo. É indispensável conhecer o mecanismo do mesmo, se pretendemos orientá-lo e, quando necessário, acelerá-lo 298

Com isto, Celso Furtado, retomando considerações que remontam às resenhas publicadas em 1948, desvela um dos pressupostos da análise de Bulhões: concorrência significaria ausência de intervenção estatal. Ao contrário, argumenta, é o Estado que

\footnotetext{
${ }^{297}$ Idem, idem.

${ }^{298}$ FURTADO, Celso. A programação do desenvolvimento econômico. op.cit., p. 12.
} 
cria as condições de concorrência e o que está em jogo é qual tipo de intervenção será feita e com qual finalidade. Notemos, ainda, como a crítica elevou o tom ao distinguir a crença na concorrência com o conhecimento de seu mecanismo, nos revelando um Celso Furtado combativo e pouco conciliador. ${ }^{299}$

Cabe, ainda, discutir a identificação que Bulhões faz entre o planejamento totalitário e a determinação de uma poupança prévia aos investimentos planejados, supondo-se que esta implicaria o controle governamental de todos os recursos da economia. Ao contrário, para Furtado a coincidência da poupança prévia com o investimento é fruto do estudo da estrutura de consumo da coletividade. Ora, "se se concorda que é possível estatisticamente prever o consumo, é necessariamente possível antecipar a poupança. Estamos aqui no terreno corriqueiro da análise econômica e não vejo por que tenhamos que nos assustar com nenhum fantasma totalitário", afirma Furtado, não sem ironia. ${ }^{300}$

Claro está que o esforço de qualquer programa de investimento que se pretenda não inflacionário deve equilibrar, no momento de sua execução, "o fluxo de poupança às necessidades de investimento". Neste momento, entretanto, é que se retoma um ponto de divergência que ficara implícito na crítica de Bulhões: o desenvolvimento espontâneo, a partir da dinâmica empresarial, prescinde do planejamento econômico, pois os empresários, orientados pelo sistema de preços, alocariam seus investimentos, sem que ocorresse desperdício, onde a lucratividade e a produtividade fossem maiores, evitando-se, inclusive, o risco de inflação. Nesse sentido, contra-argumenta Celso Furtado:

Não há nenhuma razão para que um plano de desenvolvimento seja mais inflacionário que um desenvolvimento sem plano. A experiência está aí para demonstrar que o desenvolvimento sem plano, com a função de consumo que hoje dispomos, cria fortes tendências inflacionárias. Não vejo como se possam combater essas tendências sem determinar todos os fatores que entram no problema sem

\footnotetext{
299 Essa crítica aos princípios de fé, bem como outros pontos podem relativizar o chamado "estilo furtadiano", de Francisco de Oliveira, definido como "a ausência de qualquer polêmica explícita e a busca constante de procurar manter-se, e aparecer, como estritamente científico". OLIVEIRA, Francisco. Viagem ao olho do furacão: Celso Furtado e o desafio do pensamento autoritário brasileiro. In, idem., $A$ navegação venturosa. Ensaios sobre Celso Furtado. São Paulo: Editora Boitempo, 2003, p. 65.

300 Idem, p. 15. Prebisch enfatiza, ainda, que "o total das inversões públicas não pode existir independentemente do ritmo de crescimento da produção resultante das inversões privadas. Não só devem existir certas relações funcionais entre estas inversões como também a determinação da soma total de poupança que será utilizada pelo Estado para realizar inversões públicas deve ter em contra as necessidades de inversão do setor privado, a fim de não debilitar a corrente de poupança que a elas se dirige”. PREBISCH, Raúl. A mística do equilíbrio espontâneo na economia [segundo artigo]. Diário de Notícias. São Paulo, domingo, 15 de novembro de 1953, terceira seção, oitava página.
} 
acompanhar a ação de cada um deles, o que evidentemente exige uma orientação geral do processo econômico ${ }^{301}$

Eis aqui, portanto, o que pode ser o cerne da divergência entre os dois economistas. Enquanto Bulhões contrapõe ao relatório da Cepal a dinâmica do empresariado nacional, a qual, por si só, seria capaz de promover o desenvolvimento econômico sem um planejamento da economia, Celso Furtado enfatiza que a proposta de programação parte dos desequilíbrios econômicos gerados pelas livres forças de mercado, cuja possibilidade de discipliná-las exige o mapeamento dos recursos produtivos e formas de estimular o crescimento da renda, via investimentos, sob a coordenação estatal, ainda que não se prescinda da dinâmica e dos recursos acumulados pela inciativa particular.

Finalmente, é preciso considerar a questão do critério de orientação dos investimentos. Também aqui, Celso Furtado reafirma um elemento constante no relatório da Cepal e também um ponto de convergência com Nurkse:

O critério básico da orientação dos investimentos que está no espírito e na letra do texto é o da produtividade marginal social. Qualquer critério secundário terá que estar subordinado a este. $\mathrm{O}$ que se pode dizer é que, sendo escasso o capital, sua maior produtividade marginal social de preferência estará ali onde se obtenha maior quantidade de produto por unidade de capital invertido ${ }^{302}$

Após esclarecer essa questão, Celso Furtado conclui seu artigo:

Todas estas são afirmações de sentido comum. Os comentários que faz o prof. Bulhões sobre esta matéria escapam totalmente a minha compreensão. Contudo não é demais acrescentar que existe uma tendência do crítico para pensar em termos monetários problemas que no estudo da Cepal estão explicitamente formulados em termos reais $^{303}$

A resposta de Furtado, portanto, procura desfazer dois equívocos da crítica de Bulhões: a desconsideração dos preços relativos, implícita no relatório da Cepal — que

\footnotetext{
${ }^{301}$ FURTADO, Celso. A programação do desenvolvimento econômico. op.cit., p. 15. Prebisch, argumentando contra Gudin, é mais incisivo na ênfase de que o desenvolvimento com iniciativa privada vem causando desequilíbrios nas economias latino-americanas. A necessidade da programação deriva de duas razões: "em primeiro lugar, é necessário aumentar o volume das inversões a fim de acelerar a taxa de crescimento; e, em segundo lugar, é mister orientá-las de maneira a evitar os desequilíbrios que tão frequentemente se observam durante a evolução econômica dos países latino-americanos". Para Prebisch, as divergências com Gudin surgem porque este "parece não reconhecer a necessidade de acelerar o ritmo do crescimento latino-americano, nem haver percebido as razões que a justificam e que se encontram em nosso relatório". PREBISCH, Raúl. A mística do equilíbrio espontâneo na economia. Diário de Notícias. São Paulo, domingo, 8 de novembro de 1953, terceira seção, oitava página.

${ }_{302}$ FURTADO, Celso. A programação do desenvolvimento econômico. op.cit., p. 15.

${ }^{303}$ Idem, ibidem.
} 
entretanto foi elaborado em termos reais — não é indicativo do caráter totalitário de um programa econômico. Por outro lado, considerar a necessidade de programação não significa desconhecer a dinâmica do setor privado nem, tampouco, tratar $o$ desenvolvimento enquanto um processo exógeno: ao contrário, foi pela Cepal detectar os problemas estruturais do desenvolvimento espontâneo que surgiu a necessidade de planejamento. Assim, os autores divergem na técnica, nos agentes da programação e, sobretudo, no diagnóstico que elaboram sobre a economia brasileira: se para Bulhões, o empresariado, dinâmico, não amplia o desenvolvimento porque o Estado cerceia suas possibilidades de investimento, para Furtado e a Cepal, a expansão econômica recente agravou problemas estruturais, tais como balanço de pagamentos, capacidade para importar e a inflação decorrente dos desequilíbrios comerciais, etc.. No entanto, antes de avançarmos conclusões gerais, é necessário percorrermos a réplica de Bulhões.

\section{A Réplica de Otávio Gouveia de Bulhões}

Octávio Gouveia de Bulhões redigiria, ainda, uma avaliação da defesa do relatório da Cepal feita por Celso Furtado. Embora não traga novos elementos ao debate, reafirma seu pontos mais importantes. Assim, retoma sua crítica ao pressuposto de um desenvolvimento "exógeno" para o Brasil no relatório: "no plano da Cepal, os particulares participam, sem dúvida, da produção, mas o surto do progresso não é de sua iniciativa - vem da esfera governamental. O Governo é que se torna o verdadeiro empreendedor e, além disso, é o supremo distribuidor dos fatores de produção". 304

Com isso, reconhece Bulhões que a defesa feita por Celso Furtado ${ }^{305}$ consistiu, num primeiro momento, uma justificativa do relatório como um estudo do processo de formação de capital dentro da economia, ou seja, de um mapeamento das interligações entre recursos disponíveis e seus repercussões nas atividades produtivas e nos fatores de produção. Entretanto, reafirma sua oposição, uma vez que:

dá o Sr. Furtado por assentado o acréscimo da renda e procura ver seus efeitos sobre o aumento da procura dos bens de consumo. Mas,

\footnotetext{
${ }^{304}$ BULHÕES, Octavio Gouveia de. Considerações adicionais sobre a programação do desenvolvimento econômico. Revista do conselho Nacional de Economia. Rio de Janeiro, Ano II, Números 19-20, Novembro-dezembro de 1953, p. 16.

305 Importante assinalar a maneira elegante como Bulhões apresenta seu interlocutor: "o Sr. Celso Furtado, que é um dos mais brilhantes componentes do Secretariado da Cepal, economista que se impõe desde a Faculdade e muito se tem firmado pela segurança com que escreve ou discute nossos problemas, julgou oportuno oferecer alguns esclarecimentos". Idem, p. 16-17.
} 
esse desdobramento não tira a característica de ser um plano elaborado fora e acima da esfera da iniciativa particular.

Os particulares aparecem em cena depois que a renda foi devidamente propulsionada. E com receio de que, mesmo nesta segunda fase, eles ainda não tenham uma iniciativa de ordem econômica adequada". ${ }^{306}$

Aqui, mais uma vez fica explícita a posição de Bulhões: pelo mapeamento dos setores e atividades capazes de proporcionar o aumento da renda, via investimentos, já está excluída a ação da iniciativa privada, pois fica subordinada às decisões do planejamento. Essas considerações só caberiam em economias subdesenvolvidas num longo processo de estagnação, ou numa baixa cíclica de uma economia desenvolvida: “todavia, muito outra é a situação dos principais países da América Latina e, notadamente, a do Brasil. Há em nosso país notório ímpeto de progresso, realizado e desenvolvido pela iniciativa particular”. ${ }^{307}$ Ou seja, a programação só se justificaria na ausência de estímulos econômicos e de dinamismo da iniciativa privada, o que não é o caso para o Brasil.

Da mesma forma, reitera a importância dos preços relativos como o principal estímulo para a iniciativa particular. Nas considerações de Bulhões só pode haver programação que leve em consideração a atividade do setor privado, se esta considerar o sistema de preços relativos. A Cepal, por partir da fixação de uma taxa de crescimento da renda, implicitamente subordina a iniciativa individual ao plano econômico. Finalmente, argumenta, um plano que não leva em consideração a iniciativa particular é um plano totalitário.

Essa discussão sobre a natureza da programação e os mecanismos de sua operacionalização, como vimos, tem como elemento subjacente os diferentes diagnósticos formulados pelos economistas, presentes no tratamento de questões como inflação, problemas de balanço de pagamentos, a natureza e os agentes responsáveis pelo desenvolvimento econômico, delimitações entre as esferas pública e privada.

Configura-se, portanto, neste debate, os temas norteadores da discussão sobre o desenvolvimento: papel do Estado e da iniciativa privada, diagnóstico sobre inflação e possibilidades de desenvolvimento econômico, espontâneo ou planejado. Cumpre notar, entretanto, que a discussão, embora tenha se revestido de argumentos teóricos (sobretudo, aqui, o papel dos preços relativos na programação econômica) o elemento norteador das discussões é o diagnóstico da economia brasileira. É este, afinal, que irá

\footnotetext{
${ }^{306}$ Idem, p. 17.

${ }^{307}$ Idem, ibidem.
} 
sustentar as discussões. Assim, nos cabe reter em que medida essas características dos debates foram introjetadas na obra de Celso Furtado.

Pudemos acompanhar esses temas através da discussão entre Otávio Gouveia de Bulhões e Celso Furtado e, marginalmente, num debate, em muitos pontos semelhantes, entre Eugênio Gudin e Raúl Prebisch. Esta segunda controvérsia revela outro elemento importante na delimitação das linhas de força do pensamento econômico brasileiro. Com efeito, nos artigos de Eugênio Gudin, para além das críticas à política econômica preconizada pela Cepal, há injunções sobre as motivações econômicas, políticas e ideológicas que distingue o que estamos chamando de economistas liberais e heterodoxos.

Por isso, nos caberá, nas próximas páginas, retomar esse perfil delineado por Gudin, pois ele é um índice - uma vez que se insere numa disputa que abarca muitos outros autores e veículos de difusão de conhecimento - dos rumos que tomará a discussão econômica no Brasil, sendo, também, uma chave importante para compreendermos as escolhas e os caminhos, teóricos e práticos, que a obra de Celso Furtado irá tomar.

\section{O debate entre Eugênio Gudin e Raúl Prebisch}

Eugênio Gudin não discute apenas a programação e/ou o planejamento econômico. Como veremos, discute muito pouco esses temas. Mas, seus artigos têm uma força retórica elevada, quando procura delinear as motivações e os objetivos dos planejadores. Segundo Ricardo Bielschowisky, o posicionamento político de Gudin, liberal e conservador, emprestou um aspecto peculiar ao tema da programação, ponderando que, "talvez por isso sua discussão relativa à questão do planejamento econômico seja algo incompleta se comparada a outras questões essenciais. Predominou nessa questão sua obsessiva oposição política a intervenções do Estado na economia, que considerava corresponderem a perigosas concessões ao socialismo". ${ }^{308}$ Dito de outra forma, transforma a questão do planejamento em uma disputa de ordem ideológica.

\footnotetext{
${ }^{308}$ BIELSCHOWSKY, Ricardo. Eugênio Gudin (1886-1986). In: SZMRECSÁNYI, T; COELHO, F. S. Ensaios de história do pensamento econômico no Brasil contemporâneo. São Paulo: ATLAS, 2004, p. 308.
} 
Para Eugênio Gudin, a relação existente entre Estado e economia é permeada pelos agentes governamentais, que possuem interesses próprios que entram em conflito com a racionalidade dos processos econômicos. Seus argumentos, ao se dirigirem para a extinção da participação do Estado na economia, visa anular esses interesses pessoais, resguardando a neutralidade da esfera estatal, alcançada unicamente com a não-atuação dos agentes na esfera econômica. Esses interesses estão alojados na "burocracia e demais órgãos governamentais, que detêm as alavancas controladoras da economia e do poder político através do poder econômico e que só visam atingir a soma considerável de poder ( e às vezes de proventos) a que se apegam com todas as garras". ${ }^{309}$ De outro lado, existem também, "certos grupos econômicos que esperam servir-se do planejamento estatal para eliminar a liberdade de concorrência e consolidar situações monopolísticas, explorando a escassez" ${ }^{310}$; e, finalmente, "socialistas e comunistas, sinceros ou oportunistas, que vêem no plano de economia totalitária e da supressão da livre iniciativa o melhor instrumento de conquista do poder". 311 Aqui, portanto, se repete o viés ideológico.

Temos, portanto, uma tipologia e uma compreensão de que o planejamento econômico, longe de ser um mecanismo técnico, imparcial, como afirma a Cepal, configura-se como um instrumento capaz de viabilizar interesses que estão alojados no Estado. Dentro dessa tipologia, Gudin insere também os planejadores cepalinos. Referindo-se ao "comando avassalador da burocracia onipotente", classifica-os como uma "nova geração" de intelectuais, avessos ao passado e imbuídos de "novos ideais sustentados por ideias-força, 'weltanschaung', existencialismo e outros institutos de boa sonoridade". 312

Essas ideias-força foram gestadas durante o New Deal - definido como um programa provisório —, de forma que “a substância pragmática é suprida pelo desenvolvimento econômico, para o qual importa (segundo a Cepal) abandonar a velha

\footnotetext{
${ }^{309}$ GUDIN, Eugênio. A mística do planejamento. Correio da manhã. Rio de Janeiro, terça-feira, dia 29 de maio de $1953,1^{\circ}$ Caderno, fl. 2.

GUDIN, Eugênio. A mística do planejamento V - As Forças de Equilíbrio. Correio da manhã. Rio de Janeiro, quinta-feira, 11 de junho de $1953,1^{\circ}$ Caderno, fl. 2

${ }^{310}$ Idem, ibidem. Em outro artigo, esse mesmo grupo é caracterizado como "os que se servem do plano, pelos métodos indiretos que indicamos no artigo anterior, não só para ampliar o campo econômico do Estado como para controlar cada vez mais, as atividades privadas, colocando-as na dependência financeira de órgãos governamentais". GUDIN, Eugênio. A mística do planejamento V - As Forças de Equilíbrio. Correio da manhã. Rio de Janeiro, quinta-feira, 11 de junho de 1953, $1^{\circ}$ Caderno, fl. 2.

${ }^{311}$ GUDIN, Eugênio. A mística do planejamento. Correio da manhã. Rio de Janeiro, terça-feira, dia 29 de maio de $1953,1^{\circ}$ Caderno, fl. 2.

${ }^{312}$ GUDIN, Eugênio. A mística do planejamento III - A filosofia. Correio da manhã. Rio de Janeiro, terça-feira, dia 2 de julho de $1953,1^{\circ}$ Caderno, fl. 2.
} 
teoria econômica e construir teorias novas de origem puramente autóctone (quem não tiver pelo menos uma avó índia não poderá colaborar) e o elemento místico pelas ideiasforça, as Weltanschaunng, etc". 313

Essa caracterização, segundo Gudin, desqualifica o esforço teórico da Cepal devido à sua inspiração em um episódio transitório da história econômica mundial. Por outro lado, o que aparece como imitação daquelas ideias é contraposta, paradoxalmente, com a acusação de que a Comissão pretende criar uma nova teoria econômica, “autóctone", cujo critério não estaria em sua validade científica e sim na nacionalidade e origem de seus formuladores. Ampliando ainda mais o paradoxo, "confesso que não é fácil descortinar a gênese dessa formação mental, senão como um produto da cultura hermética, autogâmica e desajeitada dos velhos seminários ou das prisões". 314

Dessa forma, a teoria cepalina aparece como desatualizada teoricamente, nãocientífica, pois baseada em princípios nacionalistas (autóctone) ao invés de seguir o rigor da ciência e, sem fundamentos práticos, já que não está inserida "numa formação cultural arejada, ao contato da realidade econômica do mundo dos empreendimentos". 315

Esta tipologia, portanto, longe de examinar e discutir os argumentos cepalinos, traz implícita uma avaliação desqualificadora dos argumentos dos adversários, colocando-os no plano dos interesses pessoais. E nesta caracterização explicita-se também o polo oposto, valorativo, a respeito do tipo de economia, de inserção social e interesses específicos que devem ter os tomadores de decisões sobre política econômica no Brasil. Isso pode ser captado no último artigo assinado por Gudin, onde discute a “função social do economista". Esta,

não é fabricar modelos para o progresso econômico do país em ritmo pautado. Seu primeiro dever é o de alertar os dirigentes (quando estes condescendem em ouvi-los) contra as consequências das medidas em projeto ou em curso, contra as escolhas que se podem apresentar, explicando-lhes as relações de causa e efeito (teoria) dos fenômenos econômicos. Além disso, o dever de acompanhar a 'conjuntura' mês a mês se possível, com dados e índices os mais recentes e expressivos, à maneira do médico que acompanha continuadamente a temperatura, a

\footnotetext{
313 Idem, ibidem. Esse posicionamento de Eugênio Gudin é esclarecido por Bielschowisky: "essencialmente, considerava que a teoria econômica era uma só - a mesma para economias desenvolvidas e atrasadas - , mas pensava que, do ponto de vista da formulação de políticas econômicas, 'as diversidades de estrutura são bastante marcadas para que seja preferível tratar de cada caso separadamente"”. BIELSCHOWSKY, Ricardo. Eugênio Gudin (1886-1986). In: SZMRECSÁNYI, T; COELHO, F. S. Ensaios de história do pensamento econômico no Brasil contemporâneo. São Paulo: ATLAS, 2004, p. 313.

314 Idem, ibidem.

315 Idem, ibidem.
} 
pressão e demais sintomas do paciente para 'replanejar a cada momento' o tratamento em função das variáveis verificadas.

É isso que nos esforçamos por fazer no Instituto de Economia da Fundação Getúlio Vargas"316

Contrapondo-se aos interesses dos "burocratas" e aos favorecimentos possíveis que o planejamento lhes proporcionaria, Eugênio Gudin reduz significativamente o papel e a função do economista, politizando o problema. Este deve apenas aconselhar os dirigentes, alertá-los sobre as relações de causa e efeito das medidas econômicas e acompanhá-las através de indicadores. Assim, o economista surge isento dos vícios dos planejadores caracterizados acima. Mas, examinemos um pouco mais as implicações dessa missão do economista. Ela pressupõe uma completa isenção, um nãopertencimento às classes sociais que podem beneficiar-se com os rumos das medidas de política econômica. Finalmente, que o corpo da teoria econômica é um todo completo, bem articulado, universal, previsível e instrumentalizável, de forma que ao profissional caberia apenas a explicitação de relações de causa e efeito entre medidas de política econômica. Ademais, sua função principal não é ser intervencionista: ao economista não cabe definir os rumos da política econômica, mas apenas acompanhar a conjuntura, confrontando-a com a teoria e aconselhando os dirigentes sobre as relações de causa e efeito que a situação exige. Finalmente, pressupõe, ou aceita, que a esfera política possa agir de forma imparcial quando não está imbuída do ideal de planificação, sendo de responsabilidade dos agentes o desvio dos interesses governamentais para os pessoais.

Temos, portanto, nesse conjunto de artigos de Eugênio Gudin a cristalização, no campo ideológico, de uma das principais correntes de pensamento econômico no Brasil. Essa disputa, traduzida nas visões da ciência econômica e, claro, nas relações entre Estado e economia e nos projetos para atingir o desenvolvimento econômico aparece também na resposta que Raúl Prebisch deu a esses artigos. Resposta defensiva, como relembra Celso Furtado em sua autobiografia, mas que não poderia ser feita de outra forma, pois Gudin não atacou o cerne das propostas e das teorias da Cepal, mas privilegiou a crítica ideológica. Esta resposta tem dois pontos:

primeiramente, recomendarei ao dr. Gudin que estude o referido relatório, pois tenho a convicção de que suas múltiplas tarefas não lhe terão permitido fazê-lo por completo, a julgar pela natureza de algumas de suas críticas. Evidentemente teria sido mais fácil para o

\footnotetext{
${ }^{316}$ GUDIN, Eugênio. A mística do planejamento II. Correio da manhãa. Rio de Janeiro, terça-feira, dia 2 de julho de $1953,1^{\circ}$ Caderno, fl. 2.
} 
ilustre mestre averiguar diretamente na fonte nossa maneira de pensar, em vez de repetir o que ouviu dizer de nossa tese

Em seguida, Prebisch se propõe a

discutir com ele alguns dos fundamentos teóricos da programação do desenvolvimento. Confesso que esta última me seria mais difícil que a primeira, mas não impossível, pois a posição teórica do dr. Gudin não é em absoluto ortodoxa [...] Há nele um herege em potencial e isto, aliado à sua reconhecida aptidão para o raciocínio científico, leva-me a alimentar a esperança de poder incliná-lo mais para o nosso lado ${ }^{317}$

Nessa introdução, já é possível perceber o que viemos dizendo sobre o caráter ideológico dos artigos de Gudin. Para Prebisch, é notório que o economista brasileiro não lera o relatório; ${ }^{318}$ daí que inicie sua resposta qualificando seu interlocutor que, imerso em "múltiplas tarefas", não estudou o trabalho "por completo", tendo que "repetir o que ouviu dizer de nossa tese". Retenhamos: se se trata de rebater uma crítica feita ao relatório da Cepal por alguém que não estudou o referido trabalho, a discussão teria que tocar em pontos externos a este. É exatamente com isso em mente que Prebisch apresenta como estratégia expor as teses da Cepal para atrair Gudin ao posicionamento heterodoxo da Comissão. Isso seria facilitado "pois a posição teórica do dr. Gudin não é em absoluto ortodoxa", ademais, "há nele um herege em potencial". Ou seja, uma vez que o adversário compreenda o posicionamento da Cepal (o pressuposto é que ele ainda não o conheça), suas qualidades intelectuais facilitarão que Prebisch faça com que incline-se "mais para o nosso lado". Aqui, também, é possível perceber como o economista argentino está assumindo a existência da disputa, e que se trata, para além da argumentação técnica, de angariar espaço e conseguir adesões para as posições heterodoxas da Cepal, num verdadeiro exercício de cooptação. Evidentemente, essa empreitada requer não apenas estratégias retóricas ou tomada de princípios, mas uma fundamentação teórica, elemento que irá se empenhar em discutir com Gudin na sequência do artigo.

Para tanto, inicia uma reflexão sobre a natureza do conhecimento econômico: "não nos empenhamos na vã tarefa de criar uma teoria econômica autóctone". No

\footnotetext{
${ }^{317}$ PREBISCH, Raúl. A mística do equilíbrio espontâneo na economia. Diário de Notícias. São Paulo, domingo, 8 de novembro de 1953, terceira seção, oitava página

${ }^{318}$ De fato, em determinada passagem do quinto artigo, Gudin, resumindo a concepção de planejamento da Cepal, escreve: "seria, ao que me dizem, o caso dos planos da Cepal". GUDIN, Eugênio. A mística do planejamento V - As Forças de Equilíbrio. Correio da manhã. Rio de Janeiro, quinta-feira, 11 de junho de $1953,1^{\circ}$ Caderno, fl. 2. Isso, também nos leva a ponderar a afirmação de Bulhões de que discutira o relatório da Cepal no IBRE.
} 
entanto, "recusamo-nos a ver o sentido de universalidade que frequentemente se pretende atribuir às teorias formuladas nos grandes centros mundiais...". O estudo da Cepal, "se propõe contribuir para a elucidação teórica dos fenômenos da periferia, não somente com fins científicos, mas também para que se chegue a formular princípios de ação prática". Nesse sentido a investigação deverá integrar-se "no corpo daquelas teorias formuladas nos grandes centros" o que "naturalmente", "requererá mais de uma modificação de algumas das teorias vigentes e mesmo a rejeição de certas dentre elas". Fato normal no âmbito da teoria econômica, "que ainda se encontra em incipiente elaboração". 319

Assim, o que aparecia na crítica de Gudin como uma petição de princípios de cunho nacionalista e descolado da realidade, surge na resposta do economista argentino como o andamento normal da produção do conhecimento científico no campo da teoria econômica. Prebisch contesta o pressuposto de universalidade da teoria econômica através do estudo científico dos problemas da periferia, propondo que seus resultados sejam incorporados ao núcleo da teoria e que esta seja modificada, caso necessário, para exprimir essas novas realidades. Isso, porque "a investigação sistemática dos fenômenos da periferia poderia contribuir vantajosamente a introduzir elementos dinâmicos nas teorias vigentes, sem os quais seguiriam elas um tanto afastadas da realidade". ${ }^{320}$ Esse procedimento normal do conhecimento científico é acompanhado por outro, o de que estes conhecimentos se revertam num saber prático, para auxiliar a formulação de política econômica capaz de enfrentar os problemas específicos com os quais se defrontam as economias periféricas.

Ora, ao recusar a universalidade da teoria econômica, admitir a especificidade da problemática periférica e que sua compreensão não apenas pode abarcar as teorias disponíveis, como deve também orientar a ação prática, Prebisch está propondo uma visão do papel do economista completamente diverso daquele proposto por Gudin. Para explicitar essa divergência, Prebisch utiliza outro recurso retórico: o depoimento sobre sua experiência profissional:

também já fui um ortodoxo, meu caro amigo, mas isto nos anos vinte, quando, recém-formado, tive de ensinar na mesma cátedra universitária o que havia aprendido nos textos anglo-saxões. Veio então, a crise econômica mundial e, com ela, a responsabilidade de atuar na própria realidade, e foi esse contato com feitos econômicos

\footnotetext{
${ }^{319}$ PREBISCH, Raúl. A mística do equilíbrio espontâneo na economia. Diário de Notícias. Op. cit., p. 8.

${ }^{320}$ Idem, ibidem.
} 
que me obrigou a afastar-me de boa parte da teoria tradicional. Mais tarde me foi necessário um imenso esforço mental para não deixar-me seduzir pelas generalizações keynesianas em plena periferia latinoamericana. Espero que este fato não leve o meu eminente colega a negar-me, como professor universitário, a mesma virtude que no fim de um dos seus artigos atribui a outro - a de não ter perdido o contato com o solo - apesar de meus largos anos de cátedra.

Se alguma aspiração teórica, se alguma ideia nova surgiu de tudo isso, fique certo o dr. Gudin, não se trata de "um produto da cultura hermética, autogâmica e desajeitada dos velhos seminários ou das prisões". Ignoro, naturalmente, o processo mental pelo qual o grupo brilhante de jovens economistas brasileiros preconiza a programação do desenvolvimento em seu país. Folgo, porém ao saber que nos encontramos no mesmo campo e compartilhamos os mesmos ideais ${ }^{321}$

Aqui, portanto, a contraposição maior de Prebisch é feita resgatando sua experiência profissional a frente de instituições como o Banco da Nação Argentina e, depois, o Banco Central do qual foi formulador e primeiro diretor durante a crise dos anos de 1930. Portanto, um caminho inverso ao apontado por Gudin: não um economista seduzido por ideias passadas assimiladas fora do contato com a realidade. Ao contrário, o lento e progressivo abandono das teorias ortodoxas à medida que o contato e as possiblidades de formulação de política econômica foram expondo a inadequação destas, sobretudo no momento em que a situação econômica mundial deu mostras de que a teoria econômica clássica não era capaz de fornecer saídas aos problemas engendrados pela quebra da bolsa de valores de Nova York. Dessa forma, a crise econômica de 1929, e as respostas adotadas pelos Estados Unidos - o ultrapassado New Deal, segundo Gudin — aparecem no depoimento de Prebisch como evento decisivo para explicitar as possibilidades da teoria econômica responder às depressões do sistema capitalista. Dito de outra forma, a teoria da Cepal (que se confunde com a trajetória intelectual de Prebisch), origina-se do contato com a realidade econômica de crise e necessidade de formulação de política econômica para lhe fazer frente. Nesse sentido, foram as imposições conjunturais, contrapondo-se à teoria econômica consolidada, que forçou modificações nesta última. Com isso, Raul Prebisch inverte o raciocínio de Gudin, ao mesmo tempo em que justifica sua visão teórica. Ademais, o texto se encerra com um apelo geracional (ambos economistas tinha quase a mesma idade) aos “jovens economistas brasileiros", engajados no planejamento econômico.

${ }^{321}$ PREBISCH, Raúl. A mística do equilíbrio espontâneo na economia [segundo artigo]. Diário de Notícias. São Paulo, domingo, 15 de novembro de 1953, terceira seção, oitava página. 
Ao ressaltarmos esta discussão entre os dois economistas, nosso objetivo principal foi captar o elemento ideológico da oposição entre ortodoxos e heterodoxos. Com isto, foi possível perceber como o debate, sob o pretexto de versar sobre planejamento econômico, resvalou para caracterizações sobre interesses pessoais, utilização da maquina pública e, mesmo, questionou o próprio conhecimento econômico dos participantes do debate. Ou seja, emerge um conjunto de elementos que ultrapassam a discussão estritamente conceitual, adentrando a arena política. Por outro lado, fica também explícita que uma das formas de conduzir esse debate foi questionando o fundamento da teoria econômica.

Por outro lado, o diagnóstico do presente e as sugestões de política econômica pressupõem certa interpretação sobre a teoria econômica, sua universalidade e aplicabilidade para cada situação avaliada. E, aqui, percebemos o ponto comum entre as duas polêmicas: a discussão sobre o planejamento girou sobre o eixo do diagnóstico do presente e suas implicações, arguindo-se sobre a necessidade da programação na economia brasileira. Em decorrência, ganhou relevo o papel do Estado, do empresariado privado e dos preços relativos como formas de apoiar ou descartar a necessidade de planejamento. Ora, a discussão, para além de evidenciar o lugar institucional dos protagonistas, demonstrou que a concepção de ciência econômica, bem como os pressupostos teóricos aceitos, teve peso fundamental no debate. Por sua vez, o fim da polêmica, tal como a apresentamos, não esgotou as questões levantadas, e reaparecerá ao longo dos anos de 1950, a partir de novas formulações à medida que a conjuntura econômica se modifica e surjam, também, novas instituições e projetos econômicos.

Evidentemente, é impossível avaliarmos o grau em que esses debates impressionaram Celso Furtado. No entanto, talvez essa discussão entre Gudin e Prebisch, pelos termos em que foi colocada, possa ter sugerido uma estratégia de argumentação a ser incorporada em sua obra. Se retomarmos a afirmação do editor da Revista do Conselho Nacional de Economia, de que o debate sobre programação expressa divergência de método e concordância de objetivo, qual seja, a necessidade de programação para o desenvolvimento, podemos considerar se esta opinião se sustenta. De fato, a reiteração, por parte de Bulhões, do caráter autoritário da programação e da eficácia do sistema de preços relativos conduz, no limite, a descartar a programação. Por outro lado, os esclarecimentos de Celso Furtado, implicando um diagnóstico desfavorável à alocação de recursos através do mercado, não foi reconsiderado por 
Bulhões em termos teóricos. No entanto, e aqui está o mais importante, o texto de Eugênio Gudin, de fato muito virulento, foi escrito em completa desconexão com a análise do relatório, centrando-se em aspectos extra-econômicos. Para Celso Furtado, jovem economista, a resposta de Gudin sinalizava que o confronto estava se dando, sobretudo, no plano político-ideológico, de forma que os argumentos teóricos teriam pouca eficácia. Esta deve ter sido, também, a percepção de Prebisch, que, no entanto, adotou uma estratégia de resposta que retoma a importância decisiva do conhecimento econômico. Essa opção do diretor executivo da Cepal pode ter sugerido a Celso Furtado um caminho a seguir, reiterando o papel inquestionável das verdades científicas como forma de condução das discussões sobre economia no Brasil. Assim, nos cabe perguntar: o que Celso Furtado absorveu destas polêmicas? Quais elementos ele aproveitou ou consolidou de seus trabalhos anteriores? Em suma, em que medida introjetou os tópicos e temas desses debates? Como sua obra procurou responder às críticas dos economistas ortodoxos brasileiros? O início dessa resposta pode ser encontrada na palestra que Celso Furtado proferiu na Escola Superior de Guerra, chamada "A técnica do Planejamento Econômico".

Como relata em sua autobiografia, fora procurado pelo coronel Jurandir Bizarria Mamede que o "sondava" para pronunciar uma conferência sobre o tema. O convite, entretanto, foi repetido nos anos posteriores. Rememorando os motivos para ter aceitado a invitação, afirma que "a importância que estava adquirindo essa instituição [a Escola Superior de Guerra] era um sinal dos tempos. Aceitei, inicialmente, por curiosidade, nos anos seguintes, porque logo me convenci da importância que teria na crise em gestação uma instituição dedicada a influenciar as elites militares e civis". ${ }^{322}$ Assim, notemos, na decisão de proferir a palestra sobre planejamento pesou não apenas a preocupação com os rumos políticos e econômicos do país, mas, sobretudo, a percepção de que a Escola Superior de Guerra pudesse ser um local de divulgação de suas ideias, atingindo um público não apenas militar, mas também, civil. Dito de outra forma, a oportunidade apareceu justamente em um período no qual o espaço público de discussão para os economistas desenvolvimentistas estava se restringindo.

\section{A lição prática: A técnica do planejamento econômico}

\footnotetext{
${ }^{322}$ FURTADO, Celso. A Fantasia organizada. op. cit., p. 279.
} 
Logo de início, Celso Furtado apresenta a ligação do tema com a Cepal:

a técnica de planejamento econômico a que vou referir-me na presente conferência, é fundamentalmente o resultado dos estudos e trabalhos realizados pela Comissão para a América Latina, das Nações Unidas, na qual tenho a honra de trabalhar como economista, praticamente desde sua fundação em $1948^{323}$

Destacando sua relação com a instituição, cuja participação é afirmada em termos militares (a "honra" de trabalhar na Comissão), enfatiza que a conferência insere-se no âmbito das repercussões da reunião da Cepal no Rio de Janeiro, em maio do mesmo ano. Mas, se os artigos até agora examinados foram publicados em jornais de grande circulação em São Paulo e Rio de Janeiro, o público dessas palestras é diverso, tratando-se, agora, unicamente de militares. Ressalte-se, ainda, que a trajetória de Celso Furtado como ex-combatente na Força Expedicionária Brasileira acabava por estabelecer algum tipo de relação de confiança por ter já circulado nos meios militares.

No entanto, o que mais nos interessa captar como consequência dos debates é o reforço da imbricação indissociável entre o diagnóstico da economia e a necessidade do planejamento, descartando-o como uma opção de política econômica entre outras:

os nossos estudos de planejamento estão intimamente ligados aos relativos (sic) ao desenvolvimento econômico. Observando o processo de crescimento das atuais economias chamadas subdesenvolvidas, somos levados a concluir que se as coisas marcham no futuro como no último quarto de século, essas economias subdesenvolvidas estarão condenadas a uma situação de pobreza relativa cada vez maior" [grifo nosso]. ${ }^{324}$

A mensagem é reveladora. Parte da observação da realidade, e não da aplicação de alguma teoria econômica. Por outro lado, indica que essa observação procura dar conta de temporalidades distintas: estuda-se o passado (último quarto de século) para alterar o futuro. A planificação, portanto, pode modificar o curso da economia, ao mesmo tempo em que, implicitamente, supõe que seu funcionamento é passível de previsão e pode ser estudado pelas suas linhas de continuidade. Assim, o diagnóstico do presente aponta uma situação real que não é capaz de conduzir ao desenvolvimento econômico esperado, ou mesmo em potencial. Para acelerar esse processo, para alterar suas linhas de evolução, recorre-se ao planejamento econômico.

\footnotetext{
${ }^{323}$ FURTADO, Celso. A técnica do planejamento econômico. Palestra proferida na Escola Superior de Guerra, em 26 de outubro de 1953. Documento reservado A28-53., fl. 1.

${ }^{324}$ Idem, ibidem.
} 
Portanto, deste estudo do presente surge a percepção de que é preciso acelerar o ritmo de crescimento do produto real brasileiro como única forma de diminuir o hiato com relação aos países desenvolvidos. ${ }^{325}$ Elimina-se do plano argumentativo a discussão da necessidade ou não do planejamento econômico, ou seja, um dos temas principais dos debates anteriores é neutralizado nestas palestras.

O mesmo pode ser dito a respeito do tipo de planejamento que Celso Furtado apresenta. Este, "refere-se diretamente ao desenvolvimento econômico e consiste basicamente na coordenação e intensificação das inversões e numa política encaminhada a lograr a racionalização do uso dos recursos humanos e materiais que a economia tem à sua disposição". ${ }^{326}$ Este objetivo é um, entre outros e, prossegue, assemelha-se ao planejamento para a guerra, considerando-se que "têm em comum a necessidade de exigir um maior esforço do sistema econômico, num caso para intensificar a formação de capital e noutro para aumentar a produção bélica". ${ }^{327}$ Dessa forma, Celso Furtado esclarece que a técnica de planejamento proposta pela Cepal também pode ser usada para fins militares, pois permite agir no conjunto dos setores econômicos evitando grandes desequilíbrios. Ao conceituar a programação como uma técnica para melhorar o aproveitamento dos recursos disponíveis de uma economia, a discussão sobre o nível de crescimento econômico e a participação do setor empresarial neste fica diminuída, pois não se trata de criar novos recursos produtivos ou suplantar a iniciativa privada, mas unicamente de intensificar e coordenar os bens disponíveis. Esse aspecto, ainda, ganha maior força pela ampliação do escopo de programação econômica para o esforço de guerra, uma tentativa, também, de conseguir a adesão dos setores militares para a técnica de planificação cepalina.

Por outro lado, destaca a "neutralidade da técnica de planejamento", que tanto pode ampliar como restringir "a posição da empresa privada como elemento organizador do sistema produtivo", muito embora o elemento central do planejamento, a coordenação das inversões, "é perfeitamente compatível com a organização privada da produção". ${ }^{328}$ Esta defesa da neutralidade do planejamento é apresentada como ponto passivo, esclarecendo que não há incompatibilidade entre planejamento e atividades

\footnotetext{
${ }^{325}$ Nesta palestra, como aliás também no relatório da Cepal, comparando-se a taxa de crescimento da renda real no Brasil e nos Estados Unidos, temos que "dentro de 250 anos apenas teremos alcançado um renda per capta igual à terça parte da que disfrutará a população norte-americana". FURTADO, op. cit., pp. 1-2.

${ }_{326}^{32}$ Idem, fl. 2.

${ }^{327} \mathrm{Idem}$, ibidem.

${ }^{328}$ Idem, fl. 3.
} 
particulares. Assim, e para não deixar dúvidas sobre a compatibilidade de sua proposta com a democracia e a iniciativa privada, assinala que um dos elementos técnicos fundamentais do plano, o qual poderia ser assimilado ao planejamento totalitário, faz parte dos temas mais recentes desenvolvidos pela teoria econômica atual: a previsão do comportamento do consumidor. ${ }^{329}$ Com isso, Celso Furtado reafirma que o planejamento não interfere na vontade dos consumidores e visa, unicamente, através do estudo de suas preferências, adequar os objetivos de intensificação da produção com as necessidades e demandas do consumo, evitando desequilíbrios.

Feito esses esclarecimentos, que agora percebemos como formas de evitar imputações totalitaristas ao planejamento cepalino, retoma o cerne de sua argumentação para justificar a planificação, a saber: a relação entre o estudo da situação econômica e a necessidade planejamento. Celso Furtado nos explica que: “os estudos preliminares exigidos pela técnica de planejamento, devem basear-se numa análise de conjunto do processo econômico, isto é, numa análise que nos dê uma visão agregativa das atividades econômicas". ${ }^{330}$ Para tanto, os estudos necessários para essa visão consistem na estimativa da renda ou do produto nacional. As duas formas se igualam, e o importante "é que a atividade econômica pode ser observada do ponto de vista da produção dos bens e serviços e do ponto de vista da criação de um fluxo monetário de poder de compra". 331

A discussão sobre a técnica de programação e a estimativa da renda nacional utilizando as matrizes insumo-produto de Leontief que a Cepal vinha elaborando há alguns anos, leva Celso Furtado, inevitavelmente, para o campo da teoria econômica, como forma de legitimar esse instrumento de planificação. E, aqui, portanto, emerge um aspecto que apontamos: a técnica do planejamento implica, também, uma visão sobre a teoria econômica. A partir dessa relação, justifica o aparecimento desse instrumental como forma de suprir as lacunas da teoria econômica clássica e neoclássica. Com isso, introduz uma breve, mas significativa, incursão pela história do pensamento econômico, que será reforçada posteriormente em sua obra.

Para Celso Furtado, a economia clássica se preocupou unicamente em desenvolver técnicas que equilibrassem o fluxo de renda à quantidade de bens e

\footnotetext{
${ }^{329}$ Nesse ponto, Furtado enfatiza que "a técnica de previsão da procura é um dos setores em que a análise econômica alcançou maior refinamento". Idem. fl. 4.

${ }_{330}^{330}$ Idem, fl. 4.

${ }^{331}$ Idem, fl. 5.
} 
serviços, tendo como principais mecanismos de ajuste a política monetária, principalmente alterações no nível do crédito e os déficits orçamentários:

foi a luta contra os desequilíbrios cíclicos que induziu os economistas a abandonar as preocupações de natureza puramente monetária - isto é, os desajustamentos entre o fluxo de renda e a disponibilidade real de bens e serviços - para analisar os mecanismos mais profundos da vida econômica. Dentre esses mecanismos, tem importância básica o processo de formação de capital, isto é, a forma pela qual a coletividade poupa uma parte de sua renda e por outro lado logra transformar essa renda poupada em capacidade produtiva. ${ }^{332}$

Nessa transformação, Celso Furtado identifica preocupações e formas diversas dos economistas observarem e intervirem na realidade econômica:

o economista monetário se havia habituado a observar o sistema econômico como um processo de ajustamentos e desajustamentos e tinha como preocupação única amortecer esses desajustamentos e lograr um grau relativo de estabilidade para o sistema.

De sua nova posição o economista moderno percebeu que a faixa de maior sensibilidade do sistema econômico é o processo de formação de capital. Nessa faixa se concentra uma quantidade de renda, em forma contínua, a qual deve encontrar aplicação. Se a economia não consegue absorver essa quantidade de renda que está sendo formada permanentemente fora da faixa de consumo, o nível de atividade não poderá ser mantido e haverá uma contração de todo o sistema. Dessa forma o economista é levado a comprovar que o sistema só se mantém em equilíbrio quando está crescendo. A teoria dos ciclos tende, portanto, a transformar-se quase necessariamente numa teoria do desenvolvimento econômico ${ }^{333}$

Assim, a distinção entre os dois tipos de economista, diferente daquela elaborada por Gudin, não surge de preferências pessoais ou da inserção dos agentes no Estado ou seu pertencimento a determinados extratos sociais: a divergência reflete os próprios desenvolvimentos da teoria econômica. Nessa genealogia, portanto, a técnica de planejamento da Cepal está de acordo com os principais problemas práticos com os quais lida a teoria do desenvolvimento econômico e, portanto, os dilemas que enfrentam as economias atuais. Celso Furtado reitera a clivagem no território do pensamento econômico no Brasil nos inícios dos anos de 1950, mas o faz esclarecendo que a própria teoria econômica aponta para abordagens preocupadas em resolver os problemas do desenvolvimento econômico no presente. Nesta caracterização, portanto, vemos a imbricação entre diagnóstico do presente e necessidade de intervenção, ambos balizados pela técnica do planejamento que aparece como corolário da própria teoria econômica

\footnotetext{
${ }^{332}$ Idem, ibidem.

${ }^{333}$ Idem, fl. 6.
} 
em sua preocupação recente com o desenvolvimento econômico. Por outro lado, atrás da objetividade da técnica do planejamento, coloca-se uma distinção que reflete o campo de disputas e os debates sobre desenvolvimento econômico do Brasil. Claro está que todo economista lida com problemas monetários e de formação de capital, com ênfases diferentes. Entretanto, a distinção marca precisamente o debate brasileiro, que Celso Furtado consegue transpor como uma clivagem teórica, esclarecendo, através de um retorno à teoria econômica desde suas raízes na economia política clássica, que a compreensão da economia subjacente às propostas de planejamento da Cepal possui um poder explicativo e uma capacidade de estabilizar os sistemas econômicos (via crescimento) mais efetivos do que a economia ortodoxa (via persecução do equilíbrio).

O que cumpre destacar, portanto, e retomando nossa hipótese inicial, é que nesta conferência, menos que uma alteração dos pontos de vista de Celso Furtado apresentados no debate com Bulhões, houve uma modificação, estratégica, na forma de apresentar os argumentos. Ao enfatizar: a necessidade de programação como uma decorrência dos próprios problemas que apresentam as economias latino-americanas nas últimas décadas; a questão da indução e previsão do consumo como parte dos desdobramentos da teoria econômica; e ao introjetar a discussão entre monetaristas e estruturalistas como consequência do próprio desenvolvimento da teoria econômica o que confere legitimidade ao polo estruturalista - Celso Furtado não se vale de argumentos políticos e ideológicos, mas apresenta-os no campo da ciência econômica. Se pudermos falar em um aprendizado que é também um reconhecimento de projetos em disputa, de concepções conflitantes sobre os rumos da economia brasileira, é certo que Celso Furtado interiorizou esse cenário e percebeu que a única forma de defender sua proposta seria eludir-se das disputas político-ideológicas, inserindo suas proposições em um quadro de exposição teórica que exija do interlocutor a discussão de aspectos objetivos. Por perceber, nesses debates, que o conhecimento econômico foi mobilizado de forma secundária para expor posições políticas, a estratégia de Furtado foi apagar esse aspecto de sua argumentação, restringindo-a ao campo econômico. As palestras na Escola Superior de Guerra nos parecem, por isso, significativas, pois é evidente a intenção de convencer esta instituição do projeto de desenvolvimento econômico no Brasil. Paradoxalmente, o maior esforço retórico de Celso Furtado é expresso em linguagem estritamente científica, pois esta é a única forma, para ele, de avançar propostas concretas sem perder-se em questões de princípio, elidindo o propósito intervencionista que passa a entranhar sua posição. 
Capítulo 3: 0 desenvolvimento econômico na história e a economia brasileira 


\title{
O livro A economia brasileira (1954) e a relação entre história e teoria econômica
}

Agora é o momento de retomarmos as considerações sobre desenvolvimento econômico que se encontram na resposta de Celso Furtado à Ragnar Nurkse. Nela, percebemos sua dificuldade em explicar por que, uma vez que o setor externo pode iniciar um processo de desenvolvimento econômico, isso não se verificou para os países subdesenvolvidos. Em outras palavras, por que o impulso externo não foi capaz conduzir à superação do subdesenvolvimento? A resposta a essa pergunta concentrará os esforços de Celso Furtado. Implicará na reformulação de sua primeira definição de desenvolvimento econômico, exigindo uma abordagem que pense a relação entre história e teoria econômica e aprofunde os termos nos quais elaborou suas resenhas na Revista Brasileira de Economia. Mas, com uma diferença: se antes essa reflexão se fazia como uma crítica a outros autores, agora Celso Furtado oferecerá uma resposta direta para a questão.

Nesta linha, não é demais reafirmar nossa interpretação: Celso Furtado se empenha em refutar as propostas liberais e justificar políticas econômicas que visem à industrialização e à superação da condição subdesenvolvida. Isso implica uma epistemologia que valide seus diagnósticos, prescrições e fundamentos teóricos. Ou seja, Celso Furtado está pensando fundamentos teóricos e ação prática como indissociáveis. ${ }^{334}$ Esses problemas definiram seu programa de trabalho. Em sua autobiografia, podemos ler que

\begin{abstract}
a essa altura dos acontecimentos [meados de 1953], pareceu-me que se fazia necessário clarificar posições. Trabalhava em três frentes: a) teoria do desenvolvimento: gênese histórica e mecanismos de acumulação; b) a economia brasileira: perspectiva histórica e problemas atuais; e c) crítica das ideias sobre desenvolvimento econômico. ${ }^{335}$
\end{abstract}

De fato, esses três pontos de interesse são inteligíveis à luz do que tratamos até o momento. A teoria do desenvolvimento econômico é o campo para a discussão não

\footnotetext{
${ }^{334}$ A Junção entre teoria e prática e estreitamento da formulação epistemológica conformada aos circunstanciamentos do presente recebeu uma reflexão teórica em: ARRUDA, José Jobson de Andrade. Historiografia: consciência crítica da produção histórica. In: idem, Historiografia: teoria e prática. op. cit., pp. 19 e segs. Um exemplo prático dessa leitura, abordando o Visconde de Cairu pode ser encontrado na mesma obra. Ver: idem, "José da Silva Lisboa: texto e contexto". In: idem, Historiografia: teoria e prática. op. cit., pp. 305-349.

${ }^{335}$ FURTADO, Celso. A Fantasia Organizada. op. cit., p. 287.
} 
apenas da economia, mas o que lhe permite, também, fundamentar seu diagnóstico sobre o presente. Por sua vez, relacionando-se com o terceiro dos temas, são os elementos históricos e a especificidade da problemática brasileira e latino-americana que possibilita discutir a teoria do desenvolvimento econômico e, ao mesmo tempo, intervir nos debates brasileiros e internacionais sobre o desenvolvimento. Dito de outra forma, o projeto de Celso Furtado trabalha com a transtemporalidade. Ora, buscar a gênese histórica da teoria do desenvolvimento é mobilizar o passado; o recurso à história, interagindo com os conceitos e categorias da teoria, permite uma formulação conceitual vazada pelo passado e cuja verificação reside na demanda explicativa do presente, sobretudo, explicar a economia brasileira unificando a "perspectiva histórica" que reatualiza o passado, com os "problemas atuais", que, no entanto, projetam-se ao futuro, momento da intervenção, da implantação da política econômica cujos fundamentos teóricos e históricos propõe estabelecer. Os três elementos desta problemática se completam, também, porque "as ideias sobre desenvolvimento econômico" são submetidas a uma crítica de seus fundamentos lógicos, confrontados por sua incapacidade de responder aos dilemas, às preocupações do presente.

Esta tríade de preocupações vinha sendo trabalhada nos últimos anos. Assim, é da necessidade de manter o debate sobre os rumos da economia brasileira, bem como integrar seus trabalhos que teremos o primeiro livro de Celso Furtado na área econômica:

decidi reunir em livro minhas reflexões sobre o conjunto desses temas, consciente que estava de que a contraofensiva ortodoxa ganhava terreno. Utilizei o título de A economia brasileira, para que não houvesse dúvida de que minha preocupação central era aprofundar o conhecimento da problemática de meu país ${ }^{336}$

Aqui, novamente, percebemos como os debates que ocorriam no Brasil influem na resolução de publicá-lo. De fato, como veremos, o livro examina os três pontos citados, com densidades diversas, centrando-se no exame da economia brasileira em perspectiva histórica. Esta era "pensada no quadro amplo da expansão europeia e dominação e exploração de outros povos; daí que fosse necessário teorizar sobre o todo, captando a lógica de sua evolução". 337 Essa preocupação em colocar a economia brasileira na tela ampliada da Época Moderna, algo que já fora realizado a partir de outra problemática em sua tese de doutorado, aparece não apenas no livro, mas também

\footnotetext{
${ }^{336}$ Idem, ibidem.

${ }^{337}$ Idem, ibidem.
} 
em um artigo que publicará no ano seguinte, mas que é resultado da "condensação" de conferências proferidas no Instituto Superior de Estudos Brasileiros (ISEB). ${ }^{338}$ Intitulado "Desenvolvimento Econômico (ensaio de desenvolvimento históricoanalítico)" ${ }^{339}$, o artigo, embora não abordando diretamente a economia brasileira, retoma a evolução da história europeia desde a Antiguidade para elaborar as categorias econômicas que permitam formular o que é o desenvolvimento econômico. Estas, derivadas de uma nova tentativa de junção de história com análise socioeconômica permitiram a Celso Furtado conceitualizar sistemas econômicos e descrever seu funcionamento. Essa análise, por sua vez, está subentendida no exame apresentado no primeiro capítulo de A economia brasileira.

Assim, os três eixos de preocupação de Celso Furtado serão o objeto principal de nosso exame neste capítulo. Nos concentraremos no livro "A economia Brasileira (contribuição ao estudo de se desenvolvimento)" - publicado em 1954, mas com prefácio de setembro-outubro de 1953 - e no artigo "Desenvolvimento Econômico (Ensaio de Interpretação histórico-analítica)", publicado somente em 1955 na revista Econômica Brasileira.

Pelo escopo adotado, o livro não é apenas uma reunião de artigos ou de reflexões esparsas de Celso Furtado. Procura reequacionar os problemas e as soluções que o comentário às palestras de Ragnar Nurkse deixou em aberto, bem como afinar sua interpretação do diagnóstico dos problemas da economia brasileira, adotando uma estratégia baseada no exame dos problemas atuais a partir de uma interpretação histórica, que mostre a conjuntura como resultado de um longo processo. Finalmente, a união de um exame histórico da economia brasileira com a retomada da problemática do desenvolvimento econômico é confrontada com a história da ciência econômica, buscando fundamentar teoricamente o esforço realizado ao longo do livro.

Essencial para compreender a solução metodológica que oferece para essas questões, o prefácio do livro, que analisaremos em seguida, é considerado por Rosa

\footnotetext{
${ }^{338}$ Idem, p. 284.

${ }^{339}$ Este artigo, reelaboração das palestras, terá uma longa vida na obra de Furtado. Acreditamos que o artigo seja uma reprodução, com acréscimos e revisões, das palestras. Estas foram consideravelmente reorganizadas a partir de uma problemática diferente, e apareceram no primeiro capítulo do livro de 1954. Em sua versão de artigo ele reaparecerá, com acréscimos, no livro Desenvolvimento $e$ subdesenvolvimento, assim como na reedição deste livro com o título de Teoria e política do desenvolvimento econômico, tanto na edição original de 1967 quanto na modificada de 1979. Para as edições do livro, ver: GONÇALVES, José Sergio R. C. Apresentação. In: FURTADO, Celso. Teoria e política do desenvolvimento econômico. São Paulo: Abril Cultura, 1983 (Os Economistas). Sobre o artigo e as modificações que sofreu: MALLORQUIN, Carlos. Celso Furtado: um retrato intelectual. São Paulo: Xamã; Rio de Janeiro: Contraponto, 2005, cap. 2.
} 
Maria Vieira, "um dos raros momentos em que Furtado permite manter, à vista dos leitores, os andaimes de sua construção analítica ou, em outras palavras, a explicação do método". ${ }^{340}$

Nele, um primeiro ponto ganha destaque, sobretudo porque permite, de início, perceber a imersão do livro nos debates sobre desenvolvimento econômico. Trata-se de uma apresentação da figura do economista; diferente, tanto daquela de Eugênio Gudin, quanto de Prebisch mas, ainda assim, permeada por aquelas disputas. Ao contrário da ênfase no caráter prático da profissão e de suas qualificações teóricas para intervir na realidade a partir dos diagnósticos do presente, o que é colocado em questão é o substrato teórico não tanto do economista, mas sim da ciência econômica. Substrato este, como não poderia deixar de ser dentro do projeto furtadiano, relacionado com outros campos do saber:

no campo das ciências sociais o rigor metodológico parece ser função inversa do alcance de observação. $O$ que se ganha em exatidão científica, paga-se em horizonte visual. O economista logrou uma série de instrumentos de trabalho que lhe permitem analisar os fenômenos sociais num nível de abstração em que já é possível obter resultados de elevado rigor científico. Essa, talvez, a razão pela qual seja ele, dentre os estudiosos da sociedade humana, o menos capacitado para observar o processo histórico em seu conjunto. Afeito a lidar com fenômenos quantificáveis e a avançar na observação sobre uma base de dados, que lhe permite pensar em termos de grandes números, sente-se incômodo e inábil quando é chamado a observar a corrente heterogênea e indócil a qualquer disciplina, do complexo de fenômenos que constituem o processo da vida social ${ }^{341}$

Construído a partir de uma oposição entre abstração e realidade, o texto plasma como um dos problemas das ciências sociais precisamente a necessidade de compreensão da realidade. Esta, entretanto, é obstaculizada pelo método, pois não pode prescindir de generalização e abstração. A questão aparece de forma mais extremada no caso do economista, "o menos capacitado para observar o processo histórico em seu conjunto", já que seus instrumentos possibilitam "obter resultados de elevado rigor científico" devido ao "nível de abstração" alcançado através do trabalho com "fenômenos quantificáveis" e a observação a partir de "grandes números". Essa metodologia, portanto, limita a observação e a compreensão da "corrente heterogênea e indócil a qualquer disciplina" que constitui "o processo da vida social".

${ }^{340}$ VIEIRA, Rosa Maria. Celso Furtado. Reforma, política e ideologia (1950-1964). São Paulo: Educ., 2007 , p. 55.

${ }^{341}$ FURTADO, Celso. A economia brasileira. (Contribuição à análise de seu desenvolvimento). Rio de Janeiro: A noite, 1954, p. 13. 
A formulação de Celso Furtado precede o alvo das críticas de Eugênio Gudin e da resposta de Prebisch, pois, previamente aos interesses pessoais dos economistas, de suas funções de aconselhamento, da validade das teorias que utilizam para justificar a intervenção na realidade ou, mesmo da existência ou não de teorias universais, $o$ problema aqui colocado concerne à própria epistemologia da ciência, que impõe, de saída, um paradoxo entre abstração e realidade que cabe às ciências sociais unicamente encontrar pontos de equilíbrio entre um e outro, mas nunca superar a dicotomia. Dentro desse quadro, a economia aparece em posição específica: embora voltada para a intervenção na realidade concreta, seus métodos e categorias foram constituídos em elevado nível de abstração. É para este aspecto metodológico que Celso Furtado chama atenção, novamente colocando os termos do debate em outro patamar que, no entanto, não o torna isento de assumir posição crítica.

Ora, essa problemática não se restringe ao caso brasileiro, uma vez que "esse esforço de visão compreensiva dos fenômenos sociais será cada vez mais exigido aos economistas, à medida que estes se preocupem com o comportamento de conjunto das economias nacionais e com suas interações". ${ }^{342}$ Neste ponto, alguns pressupostos implícitos chamam a atenção. A preocupação dos economistas está se alterando; agora há um esforço direcionado não mais para deslindar o comportamento atomístico dos agentes, mas sim para o conjunto da economia nacional e suas articulações. Dessa forma, o objetivo e a missão do economista, ao se debruçar sobre o conjunto da economia terá, necessariamente, de valer-se de procedimentos que envolvem o mapeamento de todo o funcionamento desses setores. Um conjunto de "preocupações desse tipo vão ganhando terreno dia a dia entre os economistas modernos", e um de seus campos mais recentes é, precisamente, a "análise do desenvolvimento econômico". 343

O leitor atento pode completar a observação de Celso Furtado afirmando que a Cepal e sua técnica de planificação fazem parte desses desdobramentos da ciência econômica. De fato, nesta nova problemática, para que o economista "possa abarcar com a percepção lógica — quando não com seus instrumentos de análise — o conjunto do processo social, será indispensável que primeiramente se esforce para pensar em conjunto os próprios fenômenos econômicos". ${ }^{344}$ A preocupação com o conjunto, não apenas da economia, mas também da vida social, orienta o propósito do livro de Celso

\footnotetext{
342 Idem, ibidem.

${ }^{343}$ Idem, ibidem.

${ }^{344}$ Idem, p. 13-14.
} 
Furtado. Preocupação esta que decorre de seu trabalho na Cepal e do trato com os problemas econômicos, mas cujo horizonte disciplinar procura ampliar: "depois de haver, durante anos, manuseado dados concretos relativos a todos os aspectos da economia brasileira, propusemo-nos abandonar por uns momentos esse maremagno de estatísticas, e tentar ver o processo em seu conjunto". ${ }^{345}$ Sem dispensar suas qualificações de economista, que lhe permitiram uma visão de diversos aspectos da economia brasileira, o objetivo do livro, portanto, é propor uma visão de conjunto. Celso Furtado irá articular como pretende solucionar a relação entre teoria econômica e história buscando uma explicação mais totalizante.

Para sua proposta, explica,

foi indispensável que nos colocássemos em distintas posições no tempo, e das mesmas tentássemos um corte vertical no processo histórico. Neste sentido formos levados a adotar, em suas linhas gerais, a técnica de análise que os economistas chamam de construção de modelos [...] A técnica de análise aqui adotada consiste substancialmente em uma tentativa de reconstituição da realidade através de uma caracterização de uma série de pontos estratégicos. Não nos interessa reproduzir aquilo que sucedeu em um dado momento histórico senão como elemento subsidiário que esclarece a forma como funcionava o sistema. É o mecanismo mesmo desse sistema que nos preocupa. Como se forma o fluxo de renda em cada um dos sistemas econômicos que se sucederam no território do país, isto é, como se agregam os fatores produtivos para criar essa massa de bens e serviços que é o lastro da vida social. Como é distribuída e utilizada essa massa de bens e serviços e que conexões existem entre o processo de utilização e aquele de produção. Dessa forma, reconstituímos em abstrato as linhas básicas dos distintos sistemas econômicos brasileiros e, observando o seu funcionamento, tentamos comprovar as possibilidades reais de expansão de cada um deles ${ }^{346}$

O trecho expõe o principal da solução metodológica oferecida por Celso Furtado. Primeiramente, a forma de encarar o tempo é diversa, em comparação com sua tese de doutorado. Abandona a baliza cronológica para buscar recortes de sentido no processo histórico. Por outro lado, marca que sua abordagem não rompe com os procedimentos da ciência econômica, pois adota a "construção de modelos". Estes, têm uma elaboração vazada pela história. No entanto, não se propõe a uma reconstituição, mais sim uma "caracterização de uma série de pontos estratégicos". Dessa forma, a reprodução "daquilo que sucedeu em um dado momento histórico" aparecerá "senão como elemento subsidiário que esclarece a forma como funcionava o sistema".

\footnotetext{
${ }^{345}$ Idem, p. 14.

${ }^{346}$ Idem, p. 14-15.
} 
Essa relação com a história guarda muitas das ambiguidades que Furtado veio assinalando em outros momentos, e sua tentativa de resolução está ancorada na elaboração de modelos econômicos que, embora referenciados ao processo histórico da economia brasileira, terão como elemento principal a caracterização de seu “mecanismo" de funcionamento. É possível apreender sua operação, a despeito das especificidades históricas, a partir de algumas categorias econômicas tais como o "fluxo de renda", as formas de agregação dos "fatores produtivos para criar essa massa de bens e serviços", sua distribuição e utilização, bem como as "conexões" existentes "entre o processo de utilização e aquele de produção". É, portanto, de suas "linhas básicas", reconstituídas "em abstrato", que é possível observar o "funcionamento" dos sistemas econômicos e averiguar as "possibilidades reais de expansão de cada um deles".

A proposta de Celso Furtado consiste na articulação entre as realidades históricas e a sua possibilidade de figuração como modelos ou sistemas econômicos. Vemos, portanto, que não é possível descartar os "instrumentos de trabalho" do economista, mas, sim, reduzir seu nível de abstração circunscrevendo-os a modelos construídos a partir da detecção de traços gerais oriundos de processos históricos. Por sua vez, não se restringe a uma simples reconstituição do passado, pois nesse caso a explicação ficaria comprometida pela ausência dos conceitos das ciências sociais. Esse objetivo de compreender a realidade a partir de modelos e sua funcionalidade, por sua vez, é marcado pela definição de economia colonial que apresenta neste livro e que difere substancialmente do conteúdo histórico-político apresentado em sua tese de doutorado:

a qualificação de sistema colonial que aqui damos, aplica-se àquele que não pode crescer senão por indução do crescimento de um outro sistema, melhor ainda, àquele que não é capaz de criar o seu próprio impulso de crescimento. Esta peculiaridade é consequência do fato de que a produção em uma economia colonial só chega a completar-se economicamente quando a mercadoria produzida é exportada ${ }^{347}$

Dessa forma, a economia colonial é apresentada não por sua peculiaridade histórica, mas pelo funcionamento de seu mecanismo econômico: o processo de crescimento. É justamente a partir desse mecanismo fundamental que Celso Furtado irá examinar, ao longo do livro, as possibilidades e os limites que cada modelo econômico detectado na história brasileira tem para se desenvolver, bem como os fatores que levam à transição de um a outro. Celso Furtado ressalta, também, que está apresentando

${ }^{347}$ Idem, p. 15. 
unicamente "hipóteses de trabalho", uma vez que "a esse nível de generalidade, o economista sente que seus instrumentos de análise se tornam imprecisos quando não inúteis". ${ }^{348}$ Ainda assim, justifica seus esforços, pois "sua simples formulação teve para nós a virtude de permitir-nos abarcar um horizonte mais amplo", conseguindo captar "algumas faixas do processo econômico que a observação direta de uma realidade fragmentada nos havia deixado escapar". 349

Dessa forma, o esforço metodológico tem o objetivo não de resolver as questões apresentadas, mas, de permitir uma ampliação do horizonte da análise. Nesse sentido, podemos considerar que a proposta de Celso Furtado tem sua principal contribuição ao iluminar aspectos da realidade presente, examinados, agora, a partir de uma abordagem que considera o acúmulo histórico dos sistemas econômicos anteriores, abrindo uma maior permeabilidade à história. Essa preocupação com o presente, entretanto, é o objetivo principal do livro, sobretudo a apresentação de um diagnóstico dos problemas da economia brasileira. E, nesse ponto, Furtado retoma sua posição de economista em voltas com a elaboração e exame de dados estatísticos, bem como sua filiação com a Comissão da ONU, ao oferecer seus "agradecimentos aos economistas da Cepal, meus colegas, cujo espírito crítico tem sido para um prova de todas as ideias". ${ }^{350}$

Fica marcado, assim, seu pertencimento à Cepal, bem como a preocupação de lançar um conjunto de hipóteses sobre o funcionamento da economia brasileira em seu processo de desenvolvimento. Além disso, não podemos deixar de chamar atenção à intenção de dissociar a imagem do economista enquanto um profissional, mas, sim para sua metodologia e as possibilidades de interação com as outras ciências sociais.

\section{História e teoria econômica no processo de desenvolvimento europeu}

Neste passo, analisaremos como Celso Furtado propôs a conciliação entre história e teoria econômica, primeiramente em seu aspecto mais geral, em seguida no exame concreto da economia brasileira. Em sua autobiografia, Celso Furtado relembra que sua preocupação neste momento era:

encontrar fórmulas metodológicas que permitissem conjugar os recursos da história e da análise. Sem haver tomado conhecimento dos trabalhos da École des Annales, eu buscava, na mesma época, o

\footnotetext{
${ }^{348}$ Idem, p. 16.

${ }^{349}$ Idem, ibidem.

${ }^{350}$ Idem, p. 16-17.
} 
entrosamento da história com as ciências sociais, partindo destas últimas, enquanto os membros dessa escola partiam da primeira. [...] $\mathrm{O}$ que eu tinha em vista era iluminar áreas pouco visíveis, aumentar a percepção da História, fazendo apelo aos recursos das ciências sociais, particularmente à economia. As relações entre a ocupação do espaço, o intercâmbio externo, a diferenciação das estruturas produtivas internas e a evolução da produtividade poderiam ser detectadas como tendências para cada período do qual tivéssemos uma visão global dada pela história. ${ }^{351}$

Aqui, é preciso perceber a intenção de Celso Furtado de conciliar história enquanto uma experiência singular - e análise — definida como uma forma de ordenar o conjunto de dados empíricos a partir de conceitos cuja abrangência permita compreendê-lo e ampliá-los além de sua especificidade. Por outro lado, a menção e a afirmação do desconhecimento da École des Annales, pode ser relativizada, pois acreditamos que há algumas conexões, temas e procedimentos metodológicos na tese de doutorado de Celso Furtado que podem ser relacionados a esta escola. ${ }^{352}$ Cabe, ainda, chamar atenção para a compreensão de que as ciências sociais, em especial a economia, são capazes de lançar luz sobre a história, deslindando tendências gerais. Dessa forma, é possível detectar no diálogo entre história e ciências sociais, que as últimas têm a função de esclarecer e ampliar o escopo compreensivo da história através de seus conceitos. Por outro lado, a história permitiria uma visão global de cada sociedade, dando amplitude e, ao mesmo tempo, esclarecendo o meio no qual as relações econômicas têm lugar, reduzindo seu grau de abstração.

Neste movimento, cumpre observar os aspectos econômicos que Furtado destaca em sua rememoração: "ocupação do espaço, o intercâmbio externo, a diferenciação das estruturas produtivas internas e a evolução da produtividade". Aspectos estes que nortearão a exploração que fará da história econômica europeia e, veremos, terá uma permanência duradoura em sua obra. Finalmente, notemos a relação entre a reformulação de sua concepção de desenvolvimento econômico e a reinterpretação da história brasileira como um só movimento integrado, que se inicia, podemos dizer, em 1953.

Em nossa análise de "Desenvolvimento econômico (Ensaio de interpretação histórico-analítico)" iremos nos deter principalmente nas categorias econômicas que

\footnotetext{
${ }^{351}$ FURTADO, Celso. A Fantasia Organizada. op. cit., p. 284.

352 A influência da vida intelectual francesa, bem como a importância da École des Annales para Celso Furtado durante o período de elaboração de sua tese de doutorado foram analisadas em: SILVA, R. P. $O$ Jovem Celso Furtado: História, política e economia: 1941-1948. São Paulo: Bauru; Edusc, 2011.
} 
Celso Furtado propôs e no modo pelo qual as utilizou para interpretar analiticamente o desenvolvimento econômico a partir da história. Para tanto, é preciso destacar um conceito fundamental para sua análise histórica sobre as formas de desenvolvimento econômico. Trata-se de sua concepção de excedente.

Para Celso Furtado (ainda de acordo com a autobiografia), o desenvolvimento econômico faz parte de "um amplo processo de mudança cultural". Essa ideia de mudança cultural, entretanto, é desdobrada: "se há mudança, é porque existe a possibilidade de escolha, o que pressupõe uma margem na disponibilidade de recursos, um excedente com respeito ao estritamente necessário à sobrevivência da coletividade". ${ }^{353} \mathrm{O}$ excedente abre a possibilidade de compreensão do desenvolvimento econômico como experiência singular, pois resulta de escolhas e opções de cada sociedade no tempo e do espaço. Celso Furtado, em outro momento memorialístico, enfatiza a possibilidade aberta pelo conceito de excedente econômico de integrar a análise do desenvolvimento com fatores políticos e sociais. Com efeito, "a teoria do excedente liga-se à teoria da estratificação social e, por intermédio desta, ao estudo das formas de dominação que engendram as desigualdades na repartição do produto social, ou definem as opções a tomar na utilização do excedente". ${ }^{354}$ Essa dupla função do excedente para explicar o desenvolvimento econômico, a um só tempo abertura para a história e meio de incorporação das ciências sociais na formulação dos problemas do desenvolvimento econômico, nos leva, agora, a nos concentrar no artigo destacando as principais categorias elaboradas por Celso Furtado e a forma como as mobilizou em sua interpretação da história.

Para Celso Furtado, o desenvolvimento econômico pode ser observado a partir do "aumento do fluxo de renda real, isto é, um incremento da quantidade de bens e serviços que à sua disposição tem uma determinada coletividade". Por outro lado, "nosso objetivo central consistirá em observar esse fluxo, que não é outro senão o fluxo da renda social". ${ }^{355}$ O problema a ser observado no processo de desenvolvimento econômico é "o de indagar que relações existem entre o fluxo de renda e a capacidade

\footnotetext{
${ }^{353}$ FURTADO, Celso. A fantasia organizada. op. cit., p. 285.

${ }^{354}$ FURTADO, Celso. Entre inconformismo e reformismo. [1987] In: FURTADO, Celso. Essencial Celso Furtado. Organização de Rosa Freire d'Aguiar. São Paulo: Cia das Letras, 2013, p. 65.

${ }^{355}$ FURTADO, Celso. Desenvolvimento Econômico (Ensaio de Interpretação histórico-analítica). Revista Econômica Brasileira, v. 1. N. 1, jan-mar., 1955, p. 3.
} 
produtiva; que fatores determinam o crescimento dessa capacidade produtiva; que interdependência há entre esse crescimento e a estrutura econômico-social, etc.,". 356

Nesta primeira definição já fica claro o procedimento heterodoxo de Celso Furtado, pois assimila quantidade de bens ao fluxo de renda social valendo-se de um conceito econômico (fluxo de renda), porém, imbricando-o na estrutura social, através de sua relação com o sistema produtivo. Dito de outro modo, não apenas define o ângulo a partir do qual irá observar a realidade, como postula a existência de uma relação entre o fenômeno econômico (fluxo de renda) e o social (a distribuição do excedente, ou da renda social entre as classes). Com isso, percebe-se sua preocupação em incorporar elementos da teoria econômica e ao mesmo tempo abri-los às ciências sociais pela observação da distribuição da renda social entre as classes.

Para consolidar essa compreensão, Celso Furtado utiliza a categoria processo econômico como junção de três aspectos: produção, distribuição e acumulação. ${ }^{357}$ No entanto, essa compreensão do processo econômico, por si só, não permite explicar as diferenças entre os países desenvolvidos e subdesenvolvidos senão sob um aspecto descritivo e tipológico. ${ }^{358}$ Justamente para prosseguir nesse problema, Celso Furtado irá utilizar o conceito de excedente.

Em qualquer sistema econômico ocorre algum excedente de produção. Se este é totalmente consumido pela comunidade, temos apenas um breve aumento na renda social. Mas, se olharmos do ponto de vista do conjunto social, "em todas as sociedades houve sempre grupos minoritários que, por uma forma ou outra, souberam apropriar-se

\footnotetext{
${ }_{356}^{356}$ Idem, p. 3.

${ }^{357}$ Assim, nessa caracterização do que é o desenvolvimento econômico, Celso Furtado reivindica uma análise integrada da produção, distribuição e acumulação, ao mesmo tempo em que complementa sua definição de desenvolvimento enquanto aumento da renda social, relacionando-a com a acumulação de capital, ou seja, o aumento dos bens e serviços de uma comunidade. Resumindo: "essa visão rápida já nos permite identificar os três aspectos fundamentais do processo econômico: a produção, a distribuição e a acumulação. Não se deve perder de vista que são, estes, três aspectos de um mesmo processo, não sendo possível dissociar totalmente um dos outros. Vimos que a população está organizada de acordo com a função de cada indivíduo dentro do aparelho produtivo social. Ora, como a estrutura do aparelho produtivo reflete basicamente o grau de acumulação alcançado e o nível da técnica, o processo acumulativo impõe permanentes modificações na organização social. Por outro lado, a forma como se distribui o produto reflete o grau de acumulação e o regime de propriedade. Finalmente, a acumulação está condicionada pela forma como se distribui o produto. Destarte, para explicar um dos aspectos temos que partir de uma explicação dos outros dois, o que nos obriga a circular num campo de indeterminação. É indispensável, portanto, partir de uma visão de conjunto do processo econômico, sendo impossível compreendê-lo através de uma simples agregação de análises parciais". Idem, pp. 3-4.

${ }^{358}$ É possível perceber como produção, distribuição e acumulação funcionam num sistema econômico subdesenvolvido, ou seja, a) a produção guarda discrepâncias quanto ao nível técnico e emprego de fatores; b) a distribuição é extremamente desigual e, c) a acumulação é limitada pela própria impossibilidade do sistema produtivo satisfazer todas as necessidades da comunidade, sendo necessária a importação de bens e serviços, etc. Dessa forma, essa tipologia descreve, mas não explica as diferenças.
} 
do excedente de produção, permanente ou ocasional, do conjunto da coletividade. Este fato, extremamente simples e de observação universal, está na base do processo acumulativo". 359

Com isso, é possível perceber não apenas os diferentes destinos da apropriação do excedente e suas repercussões nos sistemas econômicos, mas também a elaboração da relação entre história e análise econômica que Celso Furtado está empreendendo. Partindo de categorias abstratas da teoria econômica tradicional —produção, distribuição e acumulação - inter-relaciona-os e introduz o conceito de excedente de produção para compreender as variações no funcionamento dos sistemas econômicos e, mais importante, explicar as divergências em termos históricos e sociais. Ou seja, capta na formação dos sistemas econômicos as formas peculiares de apropriação do excedente, permitindo que a explicação, embora se valendo de conceitos abstratos e convencionais, considere as peculiaridades históricas das sociedades, já que a apropriação da produção por um grupo específico é resultado de formas de dominação, explicitando que elementos políticos e sociais conjugam-se para explicar o fenômeno do desenvolvimento. Se recuperarmos as afirmações de Eugênio Gudin sobre os interesses privados dos agentes públicos, podemos entender também que Celso Furtado lhe responde em outro patamar, imbricando economia e sociedade, explicitando que o conflito distributivo entre as classes sociais deve estar integrado na própria formulação da teoria do desenvolvimento econômico.

Cabe, portanto, examinar de forma mais detida a aproximação que Celso Furtado está propondo, sobretudo o nível de penetração da história nos conceitos econômicos. Este esforço para considerar as experiências históricas e as formas de dominação social expressa um alargamento da análise econômica para a história e as ciências sociais. Ainda assim, é preciso considerar, na sequência do ensaio, que Celso Furtado não está propondo uma reconstituição histórica do desenvolvimento econômico. Encontraremos referências a categorias tais como sociedades primitivas, economia escravista, comercial e industrial. Estas, embora referidas e ordenadas em sucessão temporal, possuem balizas cronológicas e geográficas amplas, com um elevadíssimo grau de generalidade.

Para Furtado, o processo de acumulação tem início com a escravidão. Este é o primeiro sistema econômico que impôs o aumento da produção além das necessidades da comunidade e sua apropriação por pequenos grupos. Ainda que nem sempre essa acumulação se revertesse em aumento da produtividade técnica, ocasionou, no entanto,

\footnotetext{
${ }^{359}$ Idem, p. 4.
} 
uma diversificação do consumo pelos grupos dominantes, estimulando novas atividades e melhorando outras já existentes. Foi essa diversificação do consumo, oriunda da acumulação de capital dentro de uma comunidade que deu início ao comércio. ${ }^{360}$

O desenvolvimento econômico nas economias comerciais, por sua vez, não é um processo progressivo e linear. As diversas regiões têm diferentes níveis de capital, de técnica e de recursos produtivos, de forma que, ao integrarem-se através do comércio, abrem-se inúmeras possibilidades de desenvolvimento: aplicação de capitais em novos processos produtivos, especialização, realocação de fatores, de forma que "o desenvolvimento nessas primeiras etapas é, portanto, um processo de expansão geográfica do universo econômico", 361 ou, dito de outra forma, "o crescimento, numa economia comercial, é, em última instância, um problema de abertura de mercados". ${ }^{362}$ Por outro lado, uma vez que as possibilidades de expansão dos mercados estejam esgotadas, os lucros serão revertidos em tesouros ou obras improdutivas, mantendo-se a economia comercial num longo equilíbrio com os mercados já existentes. ${ }^{363}$

Assim, Celso Furtado passa da destinação do excedente na economia comercial para o exame do mecanismo de distribuição social, pois “o problema da forma de utilização do excedente de produção e da posição social do grupo que dele se apropria está no centro mesmo do processo social que engendra o desenvolvimento". ${ }^{364}$ Nesse movimento, podemos ver como opera a análise de Furtado. Ao relacionar o desenvolvimento econômico com aumento da produção e sua manifestação na renda social e, ao mesmo tempo, a apropriação desse aumento por um grupo específico, a análise recai, em seguida, no uso que a classe social que se apropria desse excedente faz, pois esta é a chave para captar o caráter aberto do desenvolvimento econômico:

\footnotetext{
360 "uma vez encontrada a possibilidade de diversificar o consumo através comércio estava dado o passo decisivo para o processo de aumento da produtividade. A alavanca mestra do sistema já não está na compressão do consumo de alguns grupos à custa de reduzi-los à escravidão, e sim, na apropriação do fruto do aumento de produtividade trazido pelo comércio [...] Essa especialização facilitará a concentração de riqueza, pois, por uma série de razões fáceis de perceber, os benefícios do aumento de produtividade tendiam a concentrar-se em mãos dos comerciantes". Idem, p. 5.

${ }^{361}$ Idem, p. 7.

${ }^{362}$ Idem p. 8.

363 "Alcançada a expansão máxima do comércio, o mecanismo de acumulação de capital dentro da economia de base comercial tendia a dissociar-se do processo produtivo. Mesmo sem expandir-se, o comércio continuava a criar uma grande massa de excedente de riqueza, isto é, de bens que não eram utilizados pelos povos que produziam e que ficavam em mãos dos controladores das atividades comerciais. Essa riqueza era desviada do sistema produtivo — onde não havia possibilidade de introduzila para ser aplicada em outros setores da atividade humana. Explicam-se por essa forma as ingentes aplicações de recursos em obras improdutivas que realizaram os empórios comerciais em todas as épocas". FURTADO, Celso. A economia brasileira (Contribuição à análise do seu desenvolvimento). Rio de Janeiro: A Noite, 1954, p. 28.

${ }^{364}$ Idem, p. 8.
} 
como o funciona o fluxo de renda, quem se apropria dele e se o utiliza para gerar aumentos de produtividade e realimentar o processo econômico até encontrar seus limites. E com isso podemos perceber a imbricação que existe entre o mecanismo de funcionamento e a estrutura social na qual ele opera. Dito de outra forma, Celso Furtado passa a compreender o desenvolvimento econômico a partir de fatores sociais e políticos, mas não no sentido de que esses elementos sejam constituídos como variáveis exógenas; ao contrário, é a partir destes que se pode compreender o funcionamento das categorias econômicas.

Outro ponto que ganha destaque na análise de Celso Furtado é a transição entre sistemas econômicos. Essa problemática é examinada a partir da crise do Império Romano do Ocidente. ${ }^{365}$ Esta resultou em um processo de "involução econômica": o fim da organização administrativo-militar ocasionou redução da oferta de produtos agrícolas nas cidades; uma crescente insegurança desestimulou o comércio; por sua vez, a redução dos lucros dos comerciantes diminuiu a demanda por bens e serviços urbanos. Dessa forma, "se reduzem as transações, aumenta relativamente a produção destinada ao autoconsumo, reduz-se a produtividade, atrofia-se a renda social". No entanto, esse retrocesso não equivale à regressão a um sistema econômico anterior. Celso Furtado assinala a assimetria deste retrocesso, uma vez que essa involução, esse atrofiamento tem características peculiares. Com efeito, diz,

uma economia atrofiada possui um nível técnico superior àquele que normalmente corresponderia a seu nível de renda e a sua constelação de recursos naturais. Em outras palavras: a redução da produção per capita motivada pela desarticulação do sistema econômico, não traz consigo uma reversão às formas primitivas de produção, isto é, não implica num abandono total das técnicas mais avançadas ${ }^{366}$

Dessa caracterização de atrofiamento e/ou involução, surge a definição de feudalismo de Celso Furtado: "a economia feudal representava, portanto, uma forma regressiva de organização social, com técnica em decadência mas, ainda assim, de nível

\footnotetext{
${ }^{365}$ Aqui, podemos perceber de forma mais evidente o que dissemos a respeito da abrangência de alguns elementos históricos mobilizados. Com efeito, Celso Furtado trabalha com conceitos globais, tais como: Império Romano do Ocidente e Feudalismo sem nenhuma historicização de suas mudanças, nem das suas diversas manifestações regionais, no caso deste último. Entretanto, cabe destacar que não é intenção de Furtado elaborar uma história econômica da Europa ocidental, mas apenas frisar o tipo de recorte e análise que está empreendendo. Como ressalta: "não é nosso objetivo apresentar uma pretensa interpretação da história. Seria essa uma tarefa demasiadamente complexa e que evidentemente não poderia ser acometida com o simples instrumental de análise de que dispõe um economista. O problema que estamos discutindo é, porém, daqueles que exigem para a compreensão do fato econômico a consideração de outros aspectos do processo social". Ou seja, neste trecho, que o foco principal é a consideração do "fato econômico" e não da história, que aparece como elemento auxiliar. Idem, p. 10.

${ }^{366}$ Idem, pp. 10-11.
} 
relativamente superior". ${ }^{367}$ Essa caracterização teve uma importância fundamental na tese de doutorado de Celso Furtado e permanecerá em sua obra. Ela delimita a experiência histórica de um sistema econômico que perde seu dinamismo econômico, mas mantém sua estrutura social e técnica. Essa involução permite que o sistema econômico funcione com baixíssima produtividade, mas, ainda assim, por preservar o nível técnico, é sensível a novas alterações na demanda que permitiriam uma resposta rápida e uma retomada do desenvolvimento econômico, recuperando o nível técnico já alcançado. Como assinala em A Economia Brasileira,

o feudalismo é essencialmente uma forma regressiva de organização social. Não pode ser compreendido, se se parte para analisá-lo, de formas mais simples de organização social, pois resulta de um processo involutivo. Seria erro de sérias consequências para a análise histórica, confundir o tipo de organização econômica da sociedade feudal com aquele correspondente às comunidades primitivas de 'economia natural' ou de autoconsumo. A economia feudal é uma economia que se fechou sobre si mesma por impossibilidade de utilizar toda sua capacidade produtiva. Seu nível técnico pode, portanto, estar muito acima do mínimo requerido para a simples subsistência da comunidade. Destarte, essa economia está em condições de reagir rapidamente ante o primeiro reatamento de atividades comerciais ${ }^{368}$

Por outro lado, essa resistência com baixa produtividade faz com que a estrutura social e política permaneçam, revelando, uma vez mais, uma relação intricada entre economia e sociedade.

Por sua vez, se o fim do comércio ocasionou o atrofiamento da economia feudal europeia e, se esta se caracteriza pela subutilização da técnica produtiva, o renascimento do comércio, por volta do século XI fará com que o desenvolvimento retorne rapidamente no continente. Esse retorno, próximo à interpretação de Henri Pirenne, foi um fator exógeno, decorrente da expulsão dos mulçumanos e suas repercussões na Europa e no Oriente. ${ }^{369}$ Com isso, há novamente uma “expansão do universo

\footnotetext{
367 Idem, p. 11. Na explicação de Celso Furtado, a passagem da escravidão para a servidão é que a primeira, sendo um regime de uso intensivo de mão-de-obra para extração do excedente, sua necessidade num sistema atrofiado se fez dispensável, daí o surgimento da servidão, onde as necessidades de consumo podiam ser atendidas com autoconsumo, ou seja, com menor utilização da mão-de-obra.

${ }^{368}$ FURTADO, Celso. A Economia brasileira. op. cit., p. 26.

${ }^{369}$ Não estamos interessados, neste estudo, numa genealogia das ideias de Celso Furtado, embora seja um esforço importante e que, até o momento, foi realizado muito parcialmente. Em relação à obra de Henri Pirenne, seria de grande interesse um estudo que mostrasse como Celso Furtado se apropria da interpretação do processo econômico social da Europa medieval e, a partir disso, o reinterpreta a partir das categorias econômicas que está desenvolvendo, tais como apropriação do excedente, fluxo de renda social, expansão do universo econômico, aumentos de produtividade ocasionados pelo comércio, etc.
} 
econômico sob a pressão de correntes comerciais que encontram uma grande receptividade". 370

Ou seja, aqui podemos perceber a importância de sua definição de feudalismo como resultado de uma involução econômica: por ter preservado um nível técnico superior, porém subutilizado, a retomada do comércio se fez de forma rápida. Por outro lado, esse desenvolvimento do comércio cria uma nova classe de comerciantes, os burgueses, situados nas cidades medievais e em tensão com os proprietários de terra. $\mathrm{O}$ comércio amplia seu raio de influência, seja nas cidades, seja no campo, dando origem à unificação política dos diversos feudos como forma de, em última instância, garantir, proteger e expandir essas atividades mercantis. A própria formação dos Estados nacionais europeus obedece a uma lógica mercantil, uma vez que "surgirão na Europa, destarte, não como uma aglutinação de unidades feudais, e sim como uma armadura para proteger e regulamentar a nova sociedade de base urbana que estava se formando". 371 Por outro lado, essa junção entre interesses comerciais e políticos permitiu que os mercadores se aliassem ao poder real para ampliar a contraposição aos interesses feudais baseados na posse da terra e na produção agrícola.

Aqui, também, é importante, ainda em consonância com Pirenne, a ênfase no surgimento de uma nova classe social, a burguesia. A proximidade da análise com o historiador belga fica patente pois este também marca o surgimento desses "habitantes dos burgos" como um fator que produzirá uma ruptura no equilíbrio social da Europa medieval. ${ }^{372}$

Com esses elementos, podemos perceber como a proposta de Celso Furtado de "iluminar a história a partir das ciências sociais", sobretudo a economia é operacionalizada. O principal conceito emprestado da sociologia é o de excedente social e sua relação com a apropriação pelos grupos dominantes. Por sua vez, esse conceito é trabalhado pelo economista. É preciso notar quando o excedente se transforma em

\footnotetext{
${ }^{370}$ Como assinala no texto: "esta economia estava preparada pra receber as correntes de comércio, as quais vinham possibilitar uma melhor utilização dos recursos já existentes e uma diversificação do consumo, sem exigir modificações no sistema produtivo". Idem, p. 12.

${ }^{371}$ Idem, p. 13. Uma discussão sobre a natureza da monarquia feudal é objeto de disputa ainda hoje na historiografia. Sem adentrarmos nesse debate, cumpre apenas ressaltar que, ao entender o Estado absolutista como burguês, a própria ideia de revolução burguesa, em termos marxistas, fica comprometida. A ressalva é importante pois, na tese de doutorado, Celso Furtado interpretou a Revolução de Avis como Revolução Burguesa. Neste texto, portanto, a categoria parece que deixou de ter validade em sua interpretação, o que tem consequências para os intérpretes que procuram ver uma influência implícita do marxismo em Celso Furtado.

372 Note-se, ademais, que para os períodos anteriores, Celso Furtado se refere aos comerciantes, ressaltando a especificidade da burguesia para o final do feudalismo.
} 
capital, ou seja, atentar para as formas de acumulação. É neste sentido que surge a questão do fluxo de renda dentro do sistema econômico (distribuição), pois é a partir dele que se identifica a possibilidade e as formas pelas quais os grupos econômicos transformam o capital em aumento de produtividade (produção).

Pudemos acompanhar, portanto, como esses conceitos foram utilizados na caracterização do sistema econômico comercial. Neste sentido, ressalte-se, também, que a iluminação da história aparece justamente na delimitação e formulação dos conceitos e categorias apresentados. Ou seja, Celso Furtado não se propõe a realizar uma história econômica, nem, tampouco, uma econometria retrospectiva da história europeia. ${ }^{373} \mathrm{De}$ fato, sua caracterização ilumina a estrutura geral de funcionamento das economias comerciais, cabendo a outros pesquisadores a verificação das categorias em sociedades, regiões, comunidades específicas no tempo e no espaço. Mesmo sua definição de feudalismo, também elaborada a partir das categorias que desenvolveu, não tem a pretensão de abarcar a complexidade espacial e temporal do feudalismo.

Entretanto, é preciso destacar que as categorias que utiliza não são abstratas. Nesse sentido, o esforço de Celso Furtado vai contra a pretensão de universalidade da ciência econômica.

Reflitamos. Se, como procuramos argumentar ao longo do texto, as proposições de diagnóstico e política econômica devem ter um embasamento teórico último, como Celso Furado fundamenta sua teoria? Ora, ao balizar sua análise do desenvolvimento econômico pelo conceito de excedente em relação com a estrutura social, sua compreensão do desenvolvimento econômico adquire um fundamento necessariamente histórico, pois sua compreensão pressupõe e exige o conhecimento de elementos sociais e políticos.

No entanto, esta historicidade dos conceitos econômicos, ao permitir uma compreensão mais global da economia que analisa, não implica que sua análise seja sempre histórica no sentido de uma reconstituição do passado. Nesse sentido, o esforço de Celso Furtado não resulta na elaboração de uma história econômica, mas na fundamentação histórica dos conceitos de desenvolvimento econômico. Com isso, sua elaboração e análise já traz em si a necessidade de dar conta das peculiaridades de cada economia analisada, mas não como variáveis exógenas, mas como uma necessidade

${ }^{373}$ Uma discussão sobre a diferença entre Economia retrospectiva e história econômica aparece em NOVAIS, F. \& FORASTIERI. R. S. Introdução. In: idem (orgs), Nova história em perspectiva. São Paulo: Cosac e Naify, 2013, volume. Ver também, FOGEL, \& Elton. Qual de los caminhos al passado. México: Fondo de Cultura Económica 1983. 
intrínseca das categorias e conceitos do desenvolvimento econômico. Daí que seja fundamental na sequência do texto, o exame da economia industrial.

A passagem dessa economia comercial para a industrial foi um período longo, estendendo-se do século XV ao XVIII. Compreender essa transição implica um olhar sobre a economia que surgiu paralela à feudal, ou, como diz Celso Furtado: "por um processo de enxerto na economia feudal pré-existente". 374

Com efeito, o desenvolvimento do comércio gerou duas economias distintas: uma agropecuária e outra, comercial-urbana. Entretanto, essa separação geográfica e produtiva, longe de criar dois sistemas econômicos estanques, conformou uma série de interesses comuns e dinamizadores: enquanto o setor urbano era o grande consumidor dos produtos agrícolas, melhorou a produtividade e especializou o campo no fornecimento de gêneros para a cidade. Por outro lado, a economia urbana foi a grande fornecedora de todos os outros bens e serviços que a zona rural deixava de produzir. ${ }^{375}$ Cabe ressaltar, ainda, que essa interdependência foi possível pela existência de um mercado comum, interno, entre as regiões, funcionando a despeito dos interesses do grande comércio de exportação. Nessa caracterização, portanto, Celso Furtado está analisando a interdependência de duas economias distintas. Essa possibilidade de intercomunicação e de estímulo e desenvolvimento (aumento da produtividade e da renda social) só é possível pela existência de um mercado interno, interdependente, no qual há uma reciprocidade entre produção e consumo. Este também é abordado em $A$ Economia Brasileira:

alguns centros urbanos eram, ademais, centros de produção artesanal. Por outro lado existia uma grande quantidade de mão-de-obra aplicada permanentemente em obras públicas. Muitas dessas obras estavam ligadas ao processo produtivo: construção e manutenção de estradas, aquedutos, etc. Outras se destinavam ao bem-estar das populações urbanas. Toda essa mão-de-obra dedicada a trabalhos não agrícolas era alimentada com o excedente de produção daquela parte considerável de gente que ficava nos campos. Esse excedente, por seu lado, constituía o fruto do aumento de produtividade que o comércio engendrava. Ora, esse comércio não seria possível sem a existência de uma população urbana nele especializada, parte da qual se dedicava, aliás, à construção de navios e estradas e outros instrumentos exigidos pelas atividades comerciais ${ }^{376}$

\footnotetext{
${ }^{374}$ Idem, p. 13.

375 Segundo Furtado: "ao invés de uma economia rural fechada, teremos agora uma economia rural que dedica parte de sua produção ao mercado externo e que deste recebe — através do entreposto urbano uma série de produtos que de outra forma não seriam acessíveis". p. 14.

${ }^{376}$ FURTADO, Celso. A Economia Brasileira. (Contribuição à análise de seu desenvolvimento). op. cit., p. 25 .
} 
O tema é tanto mais importante pois ecoa as considerações já presentes no debate com Nurkse sobre a não-comunicação entre os sistemas econômicos direcionados ao mercado externo e à subsistência. Neste caso específico, a experiência histórica europeia é um contraponto, pois mostra como, na economia medieval, devido a sua caracterização de um sistema econômico atrofiado, a retomada do comércio teve um efeito dinamizador no setor agrícola, ou seja, de subsistência, retomando e aprofundando as técnicas produtivas já existentes. Dessa forma, o comércio e os centros urbanos irão impulsionar a especialização produtiva no campo. Por sua vez, é a partir dessa interdependência ${ }^{377}$ que Celso Furtado vai observar os movimentos da renda no sistema. Com efeito, os excedentes de produção rural eram consumidos nos centros urbanos. Por outro lado, embora estes também consumissem os produtos agropecuários, parcela importante dos rendimentos do comércio eram gastos "dentro da cidade com bens e serviços aí produzidos". Assim, ao mesmo tempo em que a cidade passa a ocupar o lugar de centro dinâmico do sistema, surgem os conflitos sobre a distribuição dos recursos, que se revela nos preços relativos, pois "sempre que um grupo conseguisse aumentar os preços daquilo que vendia com relação ao nível médio de preços, lograria aumentar sua participação na renda global". 378

Esse conflito foi resolvido com a formação de dois sistemas de organização da produção: de um lado, o comércio de longa distância, sob o controle dos grandes comerciantes, permaneceu livre de regulamentação. Já a produção artesanal e corporativa da cidade passou a ser estritamente regulada, seja em relação ao preço dos produtos, seja quanto às possibilidades de entrada de novos produtores. Celso Furtado chama a atenção para as relações entre regulamentação e laissez-faire, como já havia feito na resenha sobre a concorrência imperfeita, bem como na discussão com Bulhões:

a livre concorrência, ao contrário do que comumente se supõe, exige, mais que qualquer outro regime, uma total regulamentação e um estrito controle. O regime de laisser faire não cria a livre concorrência, pois dá oportunidade ao mais forte de organizar o mercado da forma que mais lhe convém. A concorrência perfeita, na forma em que existiu nos mercados de gêneros alimentícios das cidades medievais, não é propícia ao desenvolvimento da economia

\footnotetext{
377 “A produção agropecuária não só terá que aumentar para dar origem ao excedente exigido pelo pagamento dos novos produtos, como ainda terá que crescer para alimentar a população urbana. Em verdade, no preço pago pelos produtos importados nas zonas rurais estava incluído o valor do serviço que prestava o comerciante como intermediário, isto é, estava incluída a remuneração ou renda da classe comercial". Idem, p. 12.

378 "Por exemplo: se os padeiros conseguiam aumentar o preço do pão, como o nível global da renda estava pré-estabelecido, a quota dos referidos padeiros aumentaria em detrimento da dos demais grupos". Idem, p 14.
} 
capitalista, pois reduz os lucros ao mínimo. É no regime do laisser faire que as margens de lucro crescem suficientemente para acelerar a capitalização $^{379}$

Celso Furtado está novamente chamando a atenção para a indissociabilidade entre economia e política, ou seja, como o poder político é um elemento assegurador e regulador da esfera econômica, tanto do ponto de vista da planificação, quanto da concorrência perfeita. Ademais, as duas formas coexistem na economia medieval, evidenciando, que não pode haver uma separação nítida entre a regulamentação estatal e a iniciativa particular. No entanto, notemos que a argumentação, aqui, situa-se em um plano diverso daquele apresentado na defesa do relatório da Cepal, pois agora está ancorada em perspectiva histórica.

Entretanto, o que Celso Furtado mais destaca sobre a economia medieval é que o setor urbano é dinâmico, por contar com "a grande classe comerciante". Esta, com o desenvolvimento e expansão de suas linhas comerciais, passou a exportar não apenas produtos agropecuários, mas, cada vez mais, artigos manufaturados, especialmente tecidos. Essa produção passa a ser incentivada pelos comerciantes, originando regiões especializadas no norte da França e nos Países Baixos. Daí, também, surgir, ao lado das corporações urbanas, centradas no mercado local, uma especialização produtiva destinada ao comércio de longa distância, onde prevalece o laissez-faire e a aventura. Dessa forma; "dentro das comunidades urbanas a produção tende a organizar-se em forma a que todos os imprevistos sejam eliminados; entre essas mesmas comunidades urbanas o comércio se realiza em condições totalmente aleatórias e de aventura. É este segundo comércio que, com sua instabilidade, provocará rupturas sucessivas e cada vez mais profundas no arcabouço geral do sistema". 380

No século XIV ocorre o que Celso Furtado havia chamado de limites de expansão do sistema econômico comercial, ou seja, o término da expansão geográfica e incorporação de novas áreas. As rotas encontram-se saturadas de produtos. Aumenta a concorrência entre os comerciantes, ocorre a unificação política dos Estados nacionais europeus, patrocinada pela burguesia comercial e inicia-se uma série de políticas protecionistas dentro das fronteiras nacionais. De forma que:

essa tensão crescente no comércio europeu, acarretada por uma concorrência cada vez maior, terá necessariamente que repercutir no regime de organização da produção. Entramos agora em um sistema

\footnotetext{
${ }^{379}$ Idem, p. 15.

${ }^{380}$ Idem, p. 16.
} 

econômico em que os custos passam a ter uma significação crescente.
381

Essa passagem de um sistema econômico cujo excedente era extraído através do comércio entre regiões distantes para outro no qual o próprio processo produtivo tornase o fator-chave na obtenção do excedente econômico via redução de custos é fundamental para compreender as economias industriais e o processo de desenvolvimento econômico. ${ }^{382}$ Com efeito:

o surgimento de uma economia industrial na Europa ocidental é, de todos os pontos de vista, um fenômeno cuja compreensão apresenta extraordinária importância. Mas, é do ponto de vista da teoria do desenvolvimento econômico que esse fenômeno se configura como verdadeiramente transcendental, pois se lograrmos bem compreendêlo estaremos capacitados para penetrar a fundo na análise do sistema econômico atual, identificar as diferenças fundamentais que apresenta esse sistema em seus diversos graus de desenvolvimento, e perscrutar as potencialidades que o mesmo apresenta como instrumento propulsor do progresso econômico. ${ }^{383}$

A partir do momento em que os custos de produção passam a preocupar os comerciantes, seus investimentos serão direcionados para modificações na produção e na forma de organização técnica ou espacial do trabalho, com vistas a diminuir os custos e vencer a concorrência cada vez maior que impera no comércio de longa distância. Independentemente das maneiras como cada região, ou mesmo cada atividade produtiva foi impactada por esta mudança, "o importante a reter em tudo isso é que surgira um novo sistema de organização da produção em que o custo de produção desempenhava um papel fundamental”. ${ }^{384}$ Esse processo irá desencadear as tentativas de baixar os salários dos trabalhadores e modificar os "métodos de produção, dividindo melhor o trabalho, introduzindo instrumentos mais adequados". 385

Celso Furtado resume esse processo da seguinte forma:

o estacionamento da fronteira econômica na Europa provoca uma intensificação da concorrência. Esta leva a tensões crescentes que aceleram a aglutinação do sistema político, a formação de economias nacionais, provoca o surgimento da política mercantilista de proteção das burguesias nacionais, etc. Para manter suas linhas de comércio, particularmente as de exportações de tecidos entre regiões vizinhas, os

\footnotetext{
${ }^{381}$ Idem, p. 17.

382 "Passamos assim insensivelmente de um sistema econômico em que a margem de lucro é extremamente elevada ou os prejuízos são totais, para um outro em que prevalece maior segurança nas transações e maior regularidade nas operações, e ao mesmo tempo em que as margens de lucro são menores". Idem, p. 17.

${ }^{383}$ Idem, p. 13.

${ }^{384}$ Idem, p. 17.

${ }^{385}$ Idem, p. 18.
} 
comerciantes exigem dos mestres-artesãos organizadores da produção, custos mais e mais baixos. Cria-se por essa forma uma classe de artesãos empresários cuja subsistência depende de uma permanente vigilância para reduzir os custos. Essa política de redução dos custos leva a uma enorme pressão sobre os salários reais e à criação de uma massa trabalhadora submetida a um regime comparável ao da escravidão. Por outro lado essa política de redução de custos induz a modificações na técnica de produção. Abre-se assim um caminho de possibilidades extraordinárias, passando a tecnologia a ocupar o ponto focal de todo o sistema econômico ${ }^{386}$

Neste trecho podemos perceber o projeto de utilização dos conceitos da teoria econômica para iluminar a história, patente nesta passagem da economia comercial para a industrial - explicada pelo surgimento de um sistema econômico baseado nos custos de produção como decorrência do estancamento da expansão comercial e da concorrência pelos canais existentes. De fato, Celso Furtado está trabalhando com os mesmos conceitos econômicos apresentados anteriormente, vazados pela experiência histórica e as formas peculiares de organização e dominação social. Ora, se fôssemos abordar este texto sob a perspectiva da história econômica, ainda que utilizássemos como parâmetro de análise a tese de doutorado de Celso Furtado (para evitar uma crítica externa), uma pergunta surgiria: qual o lugar, nesse processo de estancamento das rotas de comércio, da expansão europeia e da incorporação de grandes regiões da África, Ásia e América ao intercâmbio comercial-marítimo, a partir do século XIV? Nesse mesmo sentido, fica a necessidade de dar conta do seguinte problema: a redução dos custos se apresentou de diferentes formas nessa economia global agora articulada: nas metrópoles, se resolve com a baixa dos salários e modificações na produção; nas colônias, regrediu para formas de trabalho compulsório cujo limite foi a escravidão e cujo método produtivo eram os mais arcaicos — como ademais, Celso Furtado mostrara em sua tese de doutorado. ${ }^{387}$ Por outro lado, o problema dos custos apareceu de forma lenta na Inglaterra, ou seja, enquanto foi possível a simples extração de excedente e a manutenção do exclusivo metropolitano e dos grandes canais de exportação, a lucratividade era garantida por fatores extra-econômicos, não se colocando o problema dos custos.

Dessa forma, a leitura do desenvolvimento econômico a partir de uma análise histórica deixa um flanco aberto. Ainda assim, notemos: o objetivo do texto é iluminar a

\footnotetext{
${ }^{386}$ Idem, ibidem.

387 A expansão comercial abre a tese de Celso Furtado sobre a economia colonial brasileira. Sobre as formas de extração do excedente econômico no Pacto Colonial durante a Época Moderna, ver: NOVAIS, Fernando. Portugal e Brasil na crise do Antigo Sistema Colonial (1777-1808). São Paulo: Hucitec., 2000.
} 
história a partir de conceitos econômicos e das ciências sociais. Na medida em que estes têm a preponderância sobre a história, a análise se sustenta. Por outro lado, a pergunta sobre a expansão comercial da Idade Moderna não pode ser descartada. Voltaremos a esta questão mais tarde. Concertarmo-nos, agora, na conclusão do exame do texto.

Notemos que a passagem é fundamental para estabelecer o contraste entre economia comercial e industrial. Com efeito, é quando o comércio passa a se fazer, não mais com produtos de grande valor unitário - especiarias, tecidos finos - mas com produtos de baixo valor, porém em grande quantidade - o que se efetivou com a fabricação têxtil —, a forma de organização se torna um elemento importante para vencer a concorrência entre diversos mercadores e produtores para diminuir seus custos. Assim, a partir da busca de alterações na produção surge uma série de transformações técnicas. Celso Furtado marca esse processo nos séculos XVII e XVIII, quando se chega ao limite da compressão da folha de salários e os comerciantes empenham-se em "reduzir os custos através de melhoras na técnica de produção, as quais significam aumento de produtividade". ${ }^{388}$

Sob o ponto de vista da acumulação, o processo se dá pela aplicação de quantidades crescentes de capital na produção. Agora, na economia industrial, segundo Furtado, não é mais necessária a abertura de novas frentes de comércio, podendo os investimentos ser feitos dentro das fronteiras econômicas já conhecidas, uma vez atingidas modificações na produção:

reduzindo os seus custos sem reduzir a folha de salários, o empresário poderá baratear os seus produtos sem reduzir na mesma quantidade a renda dos seus operários. Desta forma, os lucros que afluem às mãos da classe empresária serão aplicados de maneira crescente no sistema produtivo para aumentar a produtividade, isto é, para expandir a renda global e, portanto, para incrementar o mercado interno. ${ }^{389}$

Dessa forma, mais do que ampliar o número de consumidores, como era feito com a expansão comercial, passa-se a ampliar o número de produtos consumidos, mantendo-se a renda dos trabalhadores, ou seja, retroalimentado o fluxo de renda. ${ }^{390}$

\footnotetext{
${ }^{388}$ O processo em que isso ocorre é descrito como: "o trabalho domiciliar tende a ser substituído pelo trabalho coletivo em fábricas. Os instrumentos de produção passam a ser principalmente instrumentos de uso coletivo. O capital, que na época do artesanato era um simples complemento do trabalho, passa a ser agora a peça principal na organização da produção". Idem, p. 19.

${ }^{389}$ Idem, p. 20.

${ }^{390}$ Cumpre notar, por outro lado, que o mercado interno só passou a ter importância fundamental a partir do século XIX. Com efeito, até então, a busca por mercados era um elemento mais importante, cujas independências na América dão testemunho. Ver, sobre isso: HOBSBAWM, Eric. Da revolução industrial inglesa ao imperialismo. Rio de Janeiro, Forense Universitária, 2009, especialmente, capítulo 3.
} 
Surge, portanto, nesse novo sistema econômico, o empresário tomador de preços, investidor e organizador da produção, pois é "na organização e na técnica de produção que está o elemento focal do novo sistema econômico". Agindo assim, o empresário está repondo no circuito produtivo os lucros que obtém com a produção e venda de seus artigos. Por sua vez, essa gênese do papel do empresário schumpeteriano no sistema industrial, cuja dinâmica de desenvolvimento é dada pela diminuição dos custos, aparece agora em nova luz, para explicar o que fora argumentado na polêmica com Ragnar Nurkse: as inovações e o papel do empresário no desenvolvimento econômico apenas tem validade para as economias industriais desenvolvidas.

$\mathrm{Na}$ economia industrial os limites de expansão não são exógenos, podendo prosseguir sempre que haja reinversão de lucros no processo produtivo e que este se modifique para ampliar a quantidade produzida ou reduzir o seu custo unitário. Dito de outra forma:

\begin{abstract}
A economia industrial, ao contrário do que ocorria com as economias comerciais, não necessita de uma fronteira geográfica para crescer. $\mathrm{O}$ seu desenvolvimento opera-se, basicamente, em profundidade, isto é, traduz a intensificação da capitalização no processo produtivo. Mas, não é somente isso. Demais, é necessário ter em conta que o crescimento na economia industrial é imanente ao sistema e não contingente, como ocorre com a economia comercial. Não seria possível conceber uma economia industrial senão crescendo, pois as peças fundamentais de seus mecanismos só tomam corpo e se individualizam através do crescimento. Uma teoria econômica industrial tem necessariamente que trazer dentro de si uma explicação do crescimento econômico. Em outras palavras, a teoria do desenvolvimento teria que anteceder a toda explicação geral da economia moderna ${ }^{391}$
\end{abstract}

Nesse ponto, ao retomar a relação entre economia industrial e a teoria do desenvolvimento econômico, os propósitos de Celso Furtado ficam mais claros. Ora, se pensarmos que há uma relação intrínseca entre as formulações teóricas e a elaboração de diagnósticos do presente, o percurso analítico de compreensão da economia industrial (com seus contrastes com a economia comercial) é, ao mesmo tempo, o procedimento heurístico de formação de sua teoria do desenvolvimento econômico. Dito de outra forma, os conceitos que Celso Furtado veio formulando e operacionalizando para deslindar o funcionamento dos sistemas econômicos, ao ser válido, também, para a economia industrial, revela a formulação de uma teoria do desenvolvimento econômico que, ao surgir transpassada pelas ciências sociais e a

${ }^{391}$ Idem, p. 20-21. 
história, é capaz de compreender as especificidades de diferentes países. A viabilidade de sua teoria, portanto, depende do aprofundamento de sua compreensão das economias industriais. Daí que as economias industriais são as únicas nas quais o processo de desenvolvimento é intrínseco. Por isso, também, não é possível encontrar uma teoria do desenvolvimento anterior a este sistema, ou, ao menos, nos outros sistemas, o desenvolvimento econômico tem um caráter ocasional, ou parcial.

Assim, uma vez caracterizado como funciona o processo de desenvolvimento econômico, Celso Furtado, retoma as considerações sobre o fluxo de renda nas economias comercial e industrial. $\mathrm{Na}$ economia comercial, a renda era determinada pelos lucros dos comerciantes: enquanto uma parte dos lucros eram reinvestidos no comércio (dados o seu limite de expansão e a possibilidade de uma ampliação das vendas gerar uma queda dos preços), e outra era entesourada ou gasta em obras improdutivas ou artigos de luxo. Está implícita nesta colocação que, uma vez atingido seus limites, a economia pode funcionar sem novas inversões produtivas, apenas mantendo o comércio existente. O contrário ocorre numa economia industrial, onde o lucro é residual e no preço de um artigo industrial já está computado o pagamento a outros fatores de produção. Se esse lucro não retorna à produção, uma parte desses fatores ficará sem pagamento e, em consequência, reduzirá sua atividade, atingindo o sistema como um todo. Assim, delimitam-se mais nitidamente as características da economia industrial: "nela o empresário procura reinverter os seus lucros aperfeiçoando os métodos de produção. Entretanto, se se tem em conta o que vem de ser dito, comprovamos que não é menos específico do sistema industrial o fato de que nele o empresário não pode negar-se a inverter os seus lucros, isto é, a aplicar aquela parte de sua renda que não chega a consumir". 392 Daí surge, também, a instabilidade característica das economias industriais. Uma vez que seu crescimento não tem limites, pois exige a constante reinversão do capital ao processo produtivo, a tomada de decisão dos empresários, num contexto de ausência de informações para orientar-se, ocasiona períodos de alta e de baixa na acumulação de capital. Com efeito:

a forma normal de crescimento dessa economia se caracteriza pela sucessão de etapas de descapitalização. Essa ampla pulsação do

\footnotetext{
${ }^{392}$ Idem, p. 22. "Como um aumento de produção cria automaticamente um aumento de procura, sempre que um número de empresários estejam invertendo nos distintos setores da atividade econômica simultaneamente, cada um deles estará seguro de que encontrará mercado para seu aumento de produção. Os lucros obtidos através desse aumento de produção encontrarão nova oportunidade de ser aplicados e assim por diante. / O importante a observar no mecanismo da economia industrial é que a mesma necessita organicamente de crescer. Ao contrário da economia comercial, ela não se pode manter estável a um determinado nível de atividade". FURTADO, Celso. A Economia Brasileira. op. cit., p. 42.
} 
sistema econômico, a qual os economistas desde o século passado chamam de ciclo, é a manifestação externa do processo de crescimento da economia industrial de livre-empresa ${ }^{393}$

Essa conclusão do texto, ressaltando a instabilidade cíclica das economias industriais, pode nos sugerir um retorno às considerações do debate com Ragnar Nurkse, onde afirmara que a teoria do desenvolvimento econômico surgiu das tentativas de compreender e atenuar os ciclos econômicos. No entanto, neste artigo, ao refazer as principais características dos sistemas econômicos, Celso Furtado deixa a análise em aberto, pois não apresenta a discussão sobre planejamento econômico que poderia eliminar e diminuir o caráter cíclico da economia. Por outro lado, vimos ao longo do texto que sua caracterização, ao enfatizar muito diretamente a relação entre política e economia, possível através do conceito de excedente econômico, deixou de considerar algumas questões que, embora não invalidem sua elaboração conceitual do desenvolvimento econômico, carecem de explicação.

De fato, em sua empreitada histórico-analítica para deslindar o mecanismo de desenvolvimento, não considerou a expansão comercial europeia para África, Ásia e América e sua relação com o desenvolvimento econômico. Isso, acreditamos, deixa patente, não uma falha factual em sua exposição mas, antes, evidencia a dificuldade da empresa a que Celso Furtado está se dedicando: desemaranhar a história de seu fluxo caótico e procurar os conceitos-chave que permitam ao pesquisador compreender os grandes movimentos econômicos. Ressaltemos: do ponto de vista da elaboração conceitual, essa ausência pode ser compreendida a partir da dificuldade da proposta teórico-metodológica. No entanto, para os objetivos práticos de Celso Furtado, a ausência implica a não-incorporação das economias subdesenvolvidas no modelo. Ora, isso teria graves consequências para o debate econômico-político da época, pois poderia sugerir que a proposta não dá conta de responder aos problemas econômicos brasileiros a partir de uma conceitualização vazada pela história e as ciências sociais.

A solução para esse impasse está no livro A economia brasileira, que incorpora os principais resultados conceituais deste artigo que acabamos de examinar, e os utiliza para explicar o funcionamento das economias coloniais. É para esta solução que nos dirigiremos agora.

${ }^{393}$ Idem, p. 23. 


\section{O desenvolvimento econômico na América Latina e no Brasil: a economia colonial}

Se, como acabamos de ver, no estancamento da economia comercial europeia origem do surgimento do sistema econômico industrial - Celso Furtado deixou de considerar as grandes navegações como uma nova frente de expansão geográfica, ou em suas palavras, de "expansão do universo econômico", o que não compromete sua interpretação conceitual do desenvolvimento econômico, mas deixa de considerar um momento fundamental na história europeia, essa questão será abordada, não do ponto de vista da transição da economia comercial para industrial, mas, procurando estabelecer uma tipologia das relações econômicas iniciadas com as grandes navegações. Neste passo como no anterior, cabe chamarmos a atenção para a grande generalidade temporal com que trabalha Celso Furtado, sem podermos definir especificamente o quadro histórico mais concreto desse novo sistema econômico que será objeto do capítulo II de A economia brasileira, intitulado "A unidade colonial exportadora-escravocrata".

Neste, temos um exame do sistema da economia colonial. Naqueles abordados até aqui - comercial e industrial - houve algum tipo de colonização econômica. No primeiro, a colônia surge como um entreposto comercial, podendo, em condições excepcionais, tornar-se um foco de irradiação e desenvolver-se até competir com a antiga metrópole.

A colonização das economias industriais visa, sobretudo, a busca de matériasprimas. Diferentemente da comercial, implica em "exportações de capital e técnica e na utilização dos fatores locais constituídos pelos recursos naturais e humanos". ${ }^{394}$ Dentro desse quadro, a principal distinção que pode ocorrer nessas colônias industriais dependerá da existência de "recursos humanos locais em quantidade suficiente". ${ }^{395} \mathrm{Se}$ estes não existem, a colônia exigirá a exportação, para além de capital e técnica, de força de trabalho, tornando-se um prolongamento da economia metropolitana, com

\footnotetext{
${ }^{394}$ A questão da importância de capital e técnica para caracterizar a colonização já fora discutido na tese de doutorado de Celso Furtado a partir de Paul Leroy-Beaulieu e René Maunier. Para isso, ver: FURTADO, Celso. A economia colonial no brasil nos séculos XVI e XVII. São Paulo, Hucitec; ABPHE, 2001. Ver, também, SILVA, Roberto Pereira. O Jovem Celso Furtado. História, política e economia. Bauru-SP: Edusc, pp. 188-194.

${ }^{395}$ Lembremos, apenas para marcar as proximidades entre Furtado e Ragnar Nurkse, de que o economista búlgaro dividiu as economias subdesenvolvidas em superpopulosas ou subpopulosas.
} 
tendência a manter as formas culturais de suas metrópoles e a melhorar o salário real, como no caso da Austrália, Nova Zelândia e EUA, a partir da marcha para o Oeste. ${ }^{396}$

No segundo caso, no qual existem recursos humanos e mesmo uma organização produtiva, "forma-se uma segunda economia e tem início um processo de absorção da preexistente" pela economia industrial, numa intensidade que depende da velocidade de propagação do progresso técnico. O ponto central nesse tipo de colônia é a possibilidade de absorção da economia nativa. Aqui, portanto, surge a consideração dos efeitos do contato de uma economia industrial com uma colônia que possui recursos locais:

o capital e a técnica exportados para essa região visam à obtenção de um determinado produto primário que será utilizado no centro industrial. Se, para obter uma dada quantidade desse produto, apenas uma pequena fração da mão-de-obra disponível é utilizada, será necessário que a exportação de capital e técnica alcance grandes proporções, para que o processo de absorção da economia preexistente alcance um ritmo rápido. Isto porque a renda criada no processo produtivo não é outra coisa senão a soma dos pagamentos aos fatores de produção. Constantes outros fatores, quanto menor é a quantidade de trabalho que se utiliza para obter uma unidade de determinado produto, maior é a de capital. Como a renda do capital vai para o exterior, é evidente que quanto menor seja a quantidade de trabalho absorvido, menor será a quantidade de renda que permanecerá dentro do território e que, portanto, poderá contribuir para transformar a economia estacionária preexistente ${ }^{397}$

Dessa forma, temos que somente em condições excepcionais será possível que essa absorção aconteça. Aqui, podemos encontrar os principais elementos que serão mobilizados no exame de Celso Furtado. Primeiramente, ele redimensiona a questão da colonização, dos aspectos de contatos culturais para o funcionamento econômico. $\mathrm{O}$ contato entre culturas é abordado enquanto migração de fatores de produção. O mesmo pode ser dito quanto à exportação de capital como fator determinante da colonização. Posto nesses termos, ela aparece como uma relação entre economias com fatores produtivos (capital e trabalho) diversos, mas também sob a perspectiva de que uma é auxiliar, subordinada à outra. $\mathrm{O}$ problema que se coloca, portanto, é a possibilidade e a velocidade de absorção de uma pela outra. Ora, também nesse aspecto, a forma como essa assimilação pode ocorrer é examinada a partir das mesmas categorias do desenvolvimento econômico, sobretudo a observação da distribuição, não mais do excedente (este é canalizado para a economia industrial), mas da renda e sua

\footnotetext{
${ }^{396}$ Notemos, para marcar as largas balizas temporais, que estes exemplos que Celso Furtado utiliza ocorreram em meados do século XIX.

${ }^{397}$ Idem, p. 52-53.
} 
possibilidade de circulação dentro da economia colonial e sua capacidade de gerar aumentos de produtividade pela acumulação de capital. ${ }^{398}$

Nesse quadro teórico, portanto, Furtado já apresenta a hipótese de uma economia não receber um impulso para o seu desenvolvimento. Lembremos: se até agora, sua interpretação tratou o comércio exterior como um fator dinamizador, capaz de gerar aumentos de produtividade e ampliar a renda social, agora trabalha com efeitos econômicos diversos, o que lhe permite delinear o funcionamento das economias subdesenvolvidas, porém integrando-as no quadro geral, analítico e histórico, do desenvolvimento econômico que está empreendendo. A economia subdesenvolvida, apesar de suas características objetivas: tipo de produção, população, organização social, formas de produção ou não de excedente econômico, aparece interligada ao processo de colonização das economias industriais.

Essa nova configuração é apreendida na formulação de um "equilíbrio com subdesenvolvimento", que busca captar o que pode acontecer com uma economia que recebe um impulso externo, mas este não se sustenta:

\begin{abstract}
se o impulso externo não alcança certo grau de intensidade, com relação à extensão da economia preexistente, e se esse impulso não se prolonga, o mais provável é que se estabeleça um equilíbrio relativamente estável entre as duas economias que coexistem no mesmo território. É o que se tem observado em muitos países, onde através de decênios coexistem uma economia de exportação e outra de subsistência, sem que aquela tenda a absorver esta ${ }^{399}$
\end{abstract}

Isso ocorre por que numa economia colonial com um núcleo industrial, este não necessariamente consegue modificar o setor tradicional, ou preexistente, "o núcleo criado pela imigração de capital e técnica não apresenta as mesmas características de uma economia industrial autônoma", ${ }^{400}$ na qual os lucros do empresário são reinvertidos na produção. Ao contrário, numa economia colonial, estes são direcionados para a metrópole, ou seja, não são gastos em sua totalidade no setor colonial, quebrando seus efeitos sobre o consumo dos trabalhadores e as possibilidades de dinamização do consumo interno.

\footnotetext{
${ }^{398}$ Celso Furtado usa como exemplo a mineração, na Venezuela, cuja atividade ocupou 5\% da força de trabalho do país. O contrário ocorre com a busca por produtos que exigem muita mão-de-obra, como café, açúcar, cacau. Nesta, o efeito dinamizador é mais rápido. Resultando que "a colonização agrícola tem efeitos mais rápidos e profundos, para iguais volumes de exportação de capital, que a colonização com vista à exploração dos recursos minerais". Idem, p. 54.

399 Idem, p. 54.

${ }^{400}$ Idem, p. 55.
} 
Outro problema que afeta a economia colonial são as duas formas de aumentos de produtividade, que possuem consequências inteiramente distintas. A produtividade pode crescer através de um aumento de capital e, com isso, do produto por hora trabalhada ou, por outro lado, via redução de mão-de-obra por unidade produzida, acrescentando capital e o trabalho. Essa distinção é importante pois, se ocorre um aumento de produtividade com diminuição de mão-de-obra na economia colonial, ocorre simultaneamente um aumento dos lucros do empresário, que será canalizado para o exterior e, ao mesmo tempo, desemprego e diminuição da renda na economia colonial, pois uma parte da população ficará desocupada. Ora, é precisamente esta última forma, facilitada pela exportação de capital da economia metropolitana, a forma mais comum de aumento de produtividade na economia colonial. Temos, portanto, nessa explicação, que tanto a utilização e envio de lucros para a metrópole, quanto a forma de incorporação de progresso técnico dificultam a dinamização da economia colonial.

Por outro lado, o processo de formação de capital também é diverso. Na economia industrial, o empresário reinveste os seus lucros na produção prevendo aumentos da demanda. Neste caso, o reinvestimento é feito dentro do sistema econômico, ampliando a renda e o consumo. Além disso, o empresário ainda tem à sua disposição o mercado de capitais, que redistribui seus lucros para outros setores. Numa economia colonial, a decisão de investimento é feita prevendo-se aumento do consumo fora desta economia, ou seja, para atender uma demanda externa, de forma que também o lucro do empresário será realizado fora do sistema econômico colonial. E, ainda, são poucas as opções de diversificação de investimentos internos — pois os setores tradicionais estão estagnados —, de forma que a alternativa para o empresário do setor exportador é emigrar para o mercado de capitais metropolitano. Agrava isso, e aqui temos uma evidência empírica fornecida pelos trabalhas da Cepal, que a demanda por produtos primários tem baixa elasticidade à aumentos da renda nos países compradores, de forma que há sérios limites para sua expansão indefinida. Dessa forma,

numa economia colonial, o processo de formação de capital não se comporta como uma peça integrante do sistema econômico. Os estímulos que induzem os empresários a inverter não refletem as flutuações e perspectivas do nível de gastos realizados dentro da economia. É neste sentido que a economia colonial não constitui, propriamente falando, um 'sistema econômico' e sim parte dependente de um sistema. Mas, como não existe mobilidade total de fatores entre a colônia e a metrópole, seria impróprio considerar a economia colonial para todos os efeitos parte integrante da 
metropolitana. Para que cresça aquela, de maneira geral é necessário que cresça esta última. Entretanto, a recíproca não é verdadeira ${ }^{401}$

Com isso, estão caracterizados os limites e as restrições que o comércio externo impõe à economia colonial, de forma que esta não consegue o mesmo dinamismo dos sistemas comerciais analisados há pouco. A explicação para isso é a orientação externa da produção, controlada pelos capitais metropolitanos a não absorção do setor econômico preexistente, que permanece desligado do resto da economia. Ao contrário da simbiose entre o setor comercial e rural que existiu no Império Romano e no feudalismo, esta não se configura na economia colonial, pois a técnica e o capital se dirigem a um setor específico, para atender uma demanda externa à economia, não sendo possível, portanto, colocar os dois sistemas em contato. Destaquemos, ainda, que, assim como foi importante na análise anterior, determinar o lugar ocupado pela classe que se apropria do excedente econômico na produção, o mesmo é feito aqui, identificando-se que o empresário da economia colonial tem conexões com o setor produtivo apenas na medida em que ele pode atender aos interesses metropolitanos. São estes que lhe oferecem os parâmetros de inversão, fazendo que esta se canalize seja no setor financeiro metropolitano, seja nos investimentos que visam unicamente atender as expectativas dessa demanda externa.

Estabelecidas as causas do não-dinamismo do setor externo nas economias coloniais, Celso Furtado vai aprofundar suas consequências discutindo um tema já debatido por Prebisch e a Cepal: a Teoria das Vantagens Comparativas e a Divisão Internacional do Trabalho. Esta retomada ultrapassa o objetivo imediato do livro, mas pode ser lida à luz das disputa do período, sobretudo porque a Fundação Getúlio Vargas direcionou suas críticas à Cepal refutando uma de suas principais inovações teóricas: a distinção entre Centro e Periferia e a tendência à deterioração dos termos de troca.

Celso Furtado argumenta que a Divisão Internacional do Trabalho não garante o crescimento permanente da economia colonial. Ou melhor, não garante a distribuição dos frutos do progresso técnico. Entretanto, esta sua refutação não está assentada na metodologia cepalina que se debruçou sobre o intercâmbio entre países produtores de matérias primas e de manufaturas. Dessa forma, ainda corroborando a hipótese central de Prebisch, critica a Teoria das Vantagens Comparativas a partir das categorias que desenvolveu para compreender o processo de desenvolvimento econômico. Ora, como a

${ }^{401}$ Idem, p. 63. 
Cepal já mostrara, não é possível expandir a produção primária devido à baixa elasticidade-renda desses artigos. Por outro lado, outra vantagem comparativa que as economias coloniais teriam e que poderia promover uma melhor distribuição de recursos a seu favor, é o nível menor dos salários quando confrontado com os países industrializados. Entretanto, argumenta Furtado, as vantagens comparativas não são iguais para todos os fatores, sobretudo não é igual para recursos naturais e salários.

Isso, pois, nas economias coloniais, a vantagem comparativa do nível salarial mais baixo é acompanhada pela ausência de infraestrutura e serviços essenciais que, por sua vez, tornam mais caro o custo de operação de investimentos industriais alternativos à produção para exportação. Dessa forma, há limites dentro da própria economia que impedem a efetivação das vantagens comparativas. Assim, ao refutá-las a partir dos próprios fundamentos da economia colonial, Celso Furtado estabelece um quadro geral de suas características:

a) recursos naturais não utilizados, porque não é possível aumentar a exportação dos produtos primários que podem ser produzidos com vantagem relativa; b) recursos humanos subutilizados, porque não está crescendo a produção no setor primário exportador e porque, não obstante o custo relativamente baixo da mão-de-obra, a economia não poderia competir no setor manufatureiro com os países industrializados; c) recursos financeiros sem encontrar aplicação dentro da economia, pelas razões indicadas nos dois itens anteriores, devendo portanto emigrar. Esse quadro poderia perfeitamente ser identificado com a situação que prevalece atualmente em numerosos países de economia colonial. Trata-se, na verdade, de uma situação de equilíbrio com subutilização de todos os fatores. O impulso de crescimento resultante da criação de um núcleo colonial estaria, destarte, totalmente arrefecido ${ }^{402}$

Com isso, podemos perceber melhor a preocupação de Celso Furtado em expor o funcionamento das economias coloniais, valendo-se dos mesmos conceitos utilizados na compreensão dos sistemas comerciais e industriais: formação de capital, distribuição da renda e técnicas de produção de cada sistema. A economia colonial, diferente das anteriores, é caracterizada como dependente da industrial, e em razão disso, sem autonomia e dinamismo.

Por outro lado, sua análise não opera unicamente com uma comparação, mas também com contrastes. Uma decorrência fundamental do surgimento da economia comercial e do estabelecimento de um setor agropecuário e outro manufatureiro foi as inter-relações dinâmicas entre eles, que deu origem ao mercado interno. Ora, é

\footnotetext{
${ }^{402}$ Idem, pp. 66-67.
} 
precisamente isso que não ocorre na economia colonial, pois a distribuição da renda fica com um grupo que a canaliza para o exterior. Por outro lado, a produção também tem um destino externo, não estabelecendo relações com o setor tradicional ou de subsistência. Dessa forma, no procedimento metodológico de Celso Furtado, ao inserir a economia colonial como um subsistema dependente de outro, as categorias analíticas são novamente mobilizadas, demonstrando-se seu poder explicativo. A possibilidade destas categorias abarcarem as especificidades nacionais será colocada, a partir de agora, com o exame da economia colonial brasileira. Esse exame mobilizará aqueles conceitos vazados de historicidade, e serão aplicados a este caso específico. Antes de passarmos para esse ponto, cumpre ainda destacar que a partir do conceito de economia colonial, pudemos perceber a inserção peculiar que o comércio exterior ocasiona nestes sistemas econômicos, não criando dinamismo e desenvolvimento econômico. Se precisássemos, uma vez ainda, sintetizar as características da economia colonial, destacaríamos: 1) posição de fornecedora de matérias primas para uma economia industrial; 2) existência de um setor econômico de subsistência e de mão-de-obra incapaz de ser absorvida pelo setor de exportação; 3) realização dos lucros comerciais se dá fora da economia colonial; 4) as decisões e volume de investimento são dados pela demanda externa, sem influir ou dinamizar o mercado interno. É preciso considerar, ainda, que grande parte dessa caracterização foi possível através da compreensão do desenvolvimento econômico europeu. Isso significa, como já assinalamos em outra parte, que o esforço de Celso Furtado tem uma conexão com o objetivo principal de interpretar e fornecer um diagnóstico para as economias subdesenvolvidas. Com isso, toda a incursão "histórico-analítica" que empreendeu e que fundamenta suas categorias de compreensão do desenvolvimento econômico aparecem como necessárias e, mesmo, imprescindíveis para o estudo das economias coloniais. Notemos, ainda, que neste empreendimento intelectual, Celso Furtado incorporou elementos importantes das ciências sociais, tais como a noção de grupos dominantes, e inseriu seus conceitos econômicos numa perspectiva histórica. Ao fazê-lo, deu maior abrangência e conteúdo às suas categorias, ao mesmo tempo estabelecendo que os problemas do desenvolvimento não podem ser vistos em bases exclusivamente econômicas.

Vejamos, agora, como Celso Furtado examina, a partir dessas categorias fundamentais, a economia colonial brasileira.

Sua explanação do caso brasileiro retoma considerações já desenvolvidas em Economia colonial no Brasil nos séculos XVI e XVII. Porém, ao contrário da tese, cujo 
recorte temporal liga-se à formação do Estado português e sua relação como os descobrimentos no século XV, neste livro, a colonização é introduzida por um recorte lógico, a partir da discussão conceitual sobre as categorias do desenvolvimento e uma tipologia das formas de colonização. Com isso, o esforço de Celso Furtado adere ao trabalho desenvolvido na França pois, agora, elaborou um conjunto de conceitos e categorias econômicas que lhe permitem empreender uma grande interpretação analítica. Nesta, assume importância o diálogo com as ciências sociais, sobretudo a economia. Mas não só, pois vimos como sua análise da apropriação do excedente traz em si uma apreciação das formas de dominação capazes de transformar essa apropriação em elemento gerador de desenvolvimento econômico. Finalmente, nesse recorte lógico não há uma apreensão da evolução econômica brasileira, de forma que se refere, ao longo de sua análise, à economia açucareira sem precisar suas transformações temporais nem, tampouco, suas variações regionais. Por outro lado, a economia mineradora brasileira aparecerá de forma extremamente pontual ao longo das reflexões. Mas, repetimos, ao não se propor uma reconstituição histórico-fatual, o objetivo de descrever o funcionamento dos sistemas econômicos, embora imbuídos de historicidade, prescindem, no projeto furtadiano, do repertório factual.

Essas balizas temporais aparecem unicamente em alguns momentos, por exemplo, quando Furtado retoma a peculiaridade portuguesa implantando e dirigindo a produção tropical de açúcar, mobilizando sua experiência nas ilhas do Atlântico, bem como os elevados preços do produto, que estimularam essa empresa e garantiram a possibilidade de autofinanciamento de sua expansão, "por mais de um século". 403

Esta contextualização da experiência portuguesa de colonização, dissemos, não é o foco do livro, mas sim a compreensão do mecanismo de funcionamento da economia colonial brasileira, a partir dos conceitos elaborados para a compreensão do desenvolvimento econômico. Daí que se concentre nas "linhas gerais do mecanismo econômico dessa enorme empresa comercial que está na base de ocupação do território brasileiro". 404

Assim inicia sua caracterização:

a unidade produtora, localizada em território brasileiro, funcionava como uma unidade contábil independente da empresa comercializadora. $\mathrm{O}$ produto se vendia a preço fixado no porto de exportação, e era esse preço que determinava o nível de renda criado dentro da colônia. Com esta o empresário local remunerava os

\footnotetext{
${ }^{403}$ Idem, p. 72.

${ }^{404}$ Idem, p. 72.
} 
distintos fatores de produção, constituindo sua parte o elemento residual. A semelhança com uma empresa produtora moderna é, entretanto, apenas aparente. Todos os fatores de produção eram de propriedade do empresário, e a remuneração dos mesmos poderia ser considerada como gastos fixos. Sendo assim, as oscilações nos preços de venda e mesmo na escala de produção, afetavam apenas a remuneração do empresário, isto é, a massa de lucros. Numa economia desse tipo inexiste, como expressão econômica, o mercado interno. Se cresce a procura externa, os lucros poderão ser reinvertidos para expandir a capacidade produtiva. Essa inversão não tem, entretanto, nenhum efeito sobre a renda da coletividade, isto é, não altera o nível dos gastos monetários, conforme demonstraremos em seguida $^{405}$

Com efeito, aqui podemos perceber como sua análise incorpora as categorias do desenvolvimento econômico. Interessa-lhe destacar o papel do empresário no processo produtivo e as repercussões de seus investimentos no nível de renda. Este comercializava diretamente com o exterior. Por outro lado, os fatores de produção (elementos dinamizadores do fluxo de renda) não eram assalariados, não participavam do fluxo de renda, pois eram sua propriedade, ou seja, considerados, contabilmente, como gastos fixos da empresa açucareira. Dessa forma, o pagamento ao empresário, por não ser a contrapartida de pagamento aos outros fatores de produção (como na economia industrial), não dinamiza a renda e a economia, mas unicamente influi na taxa de lucro. Implícito nesta análise está, também, a percepção de que o empresário privado não possui as propriedades requeridas por Otávio Gouveia de Bulhões, ao afirmar que este seria um impulsionador de desenvolvimento desde a etapa colonial da história do Brasil.

A economia colonial, portanto, não possui formas de dinamizar-se a partir do comércio exterior. Dito de outro modo, Celso Furtado desconstrói a aparência contábil da economia açucareira, demonstrando sua dependência do setor externo. Por sua vez, destaca quais fatores impedem o dinamismo da economia colonial: além de sua ligação subordinada ao setor externo, a utilização de trabalho escravo bloqueia a possibilidade de um fluxo de renda dinâmico.

Ressaltemos, ainda, a ocorrência de uma alteração conceitual, pois a economia colonial brasileira será chamada de "economia escravocrata-exportadora" ou de “economia colonial-escravocrata". Essa alteração, longe de ser unicamente nominal, expressa uma mudança conceitual. Com efeito, no conceito de economia colonial está presente, para além dos aspectos já mencionados de dependência externa e ausência de 
impulso interno de desenvolvimento, a dominação política exercida pela metrópole. Por outro lado, ao caracterizá-la como "escravocrata-exportadora", traz ao primeiro plano as características principais de um sistema econômico produtivo, no qual a forma de utilização da mão-de-obra, bem como o direcionamento da produção ganham destaque. Claro que do caráter exportador é possível supor a dominação política, mas, o binômio escravocrata e exportador plasma as características distintivas do sistema econômico colonial e suas dificuldades de se desenvolver, sobretudo a escravidão, principal limitador da expansão do mercado interno.

Essa ênfase fica patente quando Celso Furtado passa a examinar a economia sob o ponto de vista da inversão, onde o empresário importa equipamentos e a mão-de-obra, tanto para a construção, como também, num estágio posterior, para produção de alimentos e tarefas complementares. ${ }^{406}$ Nesse quadro, o investimento (feito no exterior) na compra de equipamentos e mão-de-obra escrava não aumenta a renda monetária da coletividade. Assim, diversamente da economia industrial — onde o investimento é pagamento a outros fatores de produção no mercado interno, ocasionando aumento da renda da coletividade - , numa economia "colonial-escravocrata", o pagamento aos fatores é feito no exterior. É fácil concluir que, deduzidos os gastos com a manutenção e reposição dos fatores, o que sobra é lucro para o empresário.

Por sua vez, observando o funcionamento da economia colonial-escravocrata sob a perspectiva do fluxo monetário percebe-se que o proprietário dos fatores de produção fazia seus gastos (pessoais e de reposição e inversão) no exterior e, em contrapartida, sua renda era determinada pelo valor das exportações. Dessa forma: "o fluxo de renda se estabelecia, portanto, entre a unidade produtiva, considerada em seu conjunto, e o exterior". ${ }^{407}$ Entretanto, lembra Furtado, retomando sua tese de doutorado, embora esse fluxo de renda tivesse uma natureza puramente contábil, não significava isso a ausência de circulação monetária da economia, ou mesmo um sistema econômico in natura.

Nesse ponto, Celso Furtado também intervém no debate sobre a existência de feudalismo no Brasil, retomando as considerações, já presentes na tese de doutorado, mas desenvolvidas no artigo $O$ desenvolvimento econômico. De acordo com Furtado,

\footnotetext{
${ }^{406}$ A exposição a seguir foi transposta, com algumas alterações, no capítulo 9 de Formação econômica do Brasil. Desta forma, é possível perceber a relação entre este livro de 1959 e as discussões sobre o desenvolvimento econômico nos anos de 1950.

${ }^{407}$ Idem, p. 76.
} 
como vimos, o feudalismo resulta da regressão e atrofiamento de um sistema econômico que deixa de operar no nível técnico e de produtividade que havia atingido. Por sua vez,

a unidade colonial, cujas características indicamos em suas linhas gerais, pode ser apresentada como um caso extremado de especialização econômica. Ao contrário da unidade feudal, ela vive totalmente voltada para o mercado externo. A suposta similitude está na existência de pagamentos in natura em uma e outra. Mas ainda aqui existe um total equívoco, pois na unidade colonial os pagamentos a fatores são todos de natureza monetária, devendo-se ter em conta que o pagamento ao escravo é aquele que se faz no ato de compra deste. O pagamento corrente ao escravo seria um simples gasto de manutenção que pode ficar implícito na contabilidade (real ou virtual), sem que por isso perca sua natureza monetária ${ }^{408}$

Aqui, portanto, fica claro o esforço comparativo dos sistemas econômicos empreendido por Celso Furtado. Neste caso específico, as características e os fatores limitadores do desenvolvimento da economia colonial ganham inteligibilidade pela ausência de elementos que permitiram o desenvolvimento econômico da Europa medieval a partir da retomada do comércio exterior. Se, neste sistema, a retomada do intercâmbio teve efeitos dinâmicos, pois gerou especialização e aumento da produtividade no campo e nas atividades manufatureiras, criando um mercado interno que retinha e ampliava a renda social, na economia escravocrata-exportadora, o trabalho escravo aliado à demanda externa, impedia o impulso dinâmico.

Sintetizando, o movimento de Celso Furtado até agora foi caracterizar uma tipologia dos sistemas econômicos, as formas de economia colonial que se relacionam com esses sistemas e, ainda, as peculiaridades da economia colonial-escravista brasileira. Considerou nessa caracterização, o papel central da apropriação do excedente, as formas de aumento de produtividade e sua relação com a tecnologia, a formação de capital e seu fluxo de renda dentro dos sistemas e, finalmente, seu potencial de dinamizar ou estabilizá-los, em situações específicas.

Para concluir sua caracterização do sistema brasileiro, faltou, no entanto, examinar as possibilidades de expansão e estabilidade desta economia.

O crescimento de economia colonial se faria, unicamente em extensão. Com efeito, argumenta Furtado — agora restringindo-se, especificamente, à economia açucareira - supondo-se a demanda por açúcar crescente no mercado internacional, "a economia colonial poderia crescer, sempre que a oferta externa de força de trabalho

${ }^{408}$ Idem, p. 77. 
fosse elástica, até ocupar todas as terras disponíveis". 409 Por outro lado, esse crescimento não causaria alterações na estrutura econômica, que apresentava um "elevado grau de estabilidade, pois, mesmo que a unidade produtiva se paralisasse ocasionalmente, o empresário não incorria em grandes perdas, uma vez que os gastos de manutenção se faziam com o simples aproveitamento da força de trabalho que produzia seus próprios alimentos e cuidava dos equipamentos". ${ }^{410}$ Mas, prossegue, mesmo em momentos de desaceleração econômica, a estrutura permaneceria, pois os custos de reposição podem ser efetuados, em grande parte, pela própria mão-de-obra disponibilizada pela diminuição da produção. Assim, depreende-se das

\begin{abstract}
características da empresa colonial que seu crescimento tendia a ser puramente em extensão, isto é, sem quaisquer modificações estruturais, e, ademais, que as paralizações ou retrocessos nesse crescimento não tendiam a criar tensões capazes de modificar essa estrutura. O crescimento significava ocupação de novas terras e aumento das importações de bens de consumo. A decadência significava redução dos gastos em bens de consumo importados e redução na reposição da força de trabalho (também importada), com diminuição progressiva, mas lenta, no ativo da empresa, que assim minguava sem se transformar estruturalmente. ${ }^{411}$
\end{abstract}

Assim, Celso furtado reconhece que não havia "nenhuma possibilidade de que o crescimento com base no impulso externo desse lugar a um processo de desenvolvimento com autopropulsão". 412 Ora, com isso, percebemos que estamos tratando de um sistema econômico completamente diferente daqueles examinados anteriormente na história europeia. Nas economias comerciais era possível se expandir e dinamizar a economia até o estancamento das fronteiras geográficas ou das rotas comerciais. Uma vez esgotadas essas possibilidades, restava ainda a modificação dos bens comercializados, de produtos de luxo para artigos de consumo corrente, o que induziu modificações na produção que deram início à passagem para a economia industrial, na qual o dinamismo e o desenvolvimento econômico eram intrínsecos. Nesse ponto, Celso Furtado estabeleceu, inclusive, que toda explicação do funcionamento de uma economia industrial deve trazer, consigo, uma teoria do desenvolvimento econômico.

Por sua vez, a economia colonial surge como um sistema completamente diferente em seu funcionamento. No entanto, e aqui chegamos ao ponto central da

\footnotetext{
${ }^{409}$ Idem, p. 77.

${ }^{410}$ Idem, p. 77.

${ }^{411}$ Idem, p. 78.

412 Idem, ibidem.
} 
exposição de Furtado, as categorias que desenvolveu para compreender o desenvolvimento econômico da Europa ocidental permitem, também, explicar os motivos da limitação do comércio exterior como fator dinâmico dessas economias coloniais, cuja situação de "equilíbrio com subdesenvolvimento" caracteriza esse sistema econômico. De fato, a explicação da economia colonial brasileira - ou, da economia escravocrata-exportadora ou colonial-escravocrata - nada mais é do que a explicação de um sistema que não consegue expandir-se de forma autônoma, nem internalizar o consumo e dinamizar-se a partir do impulso externo.

Finalmente, e ainda usando as "categorias fundamentais do crescimento econômico", Celso Furtado caracteriza a forma como a renda circulava internamente, sem permitir "que se articulassem o sistema de produção e o de consumo". ${ }^{413}$ Devido à própria organização produtiva voltada ao exterior e sem pagamento a fatores internos, os sistemas de produção (interno) e de consumo (no exterior, ou dentro da unidade produtiva), ficavam desarticulados, não resultando qualquer dinamismo para a economia. Dessa forma, fica claro que

a unidade produtiva colonial era fundamentalmente um sistema independente, no que respeita às demais unidades que com ela coexistiam no mesmo território. Todos os seus canais de ligação básicos estavam voltados para o exterior. $\mathrm{O}$ conjunto dessas unidades produtivas não chegava a constituir, portanto, um sistema econômico. Não existia entre as mesmas o grau de interdependência que é a característica de um sistema. Observadas dentro de uma perspectiva ampla, aquelas unidades produtivas vinham a ser, cada uma delas, pontos terminais de uma corrente comercial. Era do ponto de vista dessa corrente que as distintas unidades produtivas podiam ser consideradas como um todo. Não é para estranhar, portanto, que a peça mestra desse sistema econômico consistisse nas atividades comerciais. O sistema de preços era totalmente controlado de dentro da posição comercial, o que evidentemente criava para o comerciante a possibilidade de absorver a maior parte de qualquer aumento de produtividade. Todo o tempo que a atividade econômica no território colonial consistisse num simples complemento da atividade comercial externa, perduraria essa situação. Os frutos do aumento de produtividade podiam ser total ou quase totalmente retidos no exterior. Ademais, a parte dessa melhora de produtividade que retivesse o produtor interno, teria que ser invertida para aumentar a corrente comercial, e portanto reverteria necessariamente em benefício do próprio comércio ${ }^{414}$

Aqui, portanto, as características do sistema produtivo recebem uma visão dinâmica, pois são examinados a partir do fluxo de renda, articulando os elementos que

\footnotetext{
${ }^{413}$ Idem, p. 78.

${ }^{414}$ Idem, p. 79.
} 
discutimos. De fato, podemos perceber agora o caráter "independente" dos setores econômico exportador em relação ao conjunto do sistema colonial. O setor agrícola de subsistência, ao estabelecer "canais de ligação" com o setor exportador, não se dinamiza. Com isso, a própria noção de sistema econômico é questionada, em face da ausência de interdependência entre os setores. Por sua vez, o não-dinamismo do setor de exportação, seu crescimento unicamente em extensão, revela, também, sua dependência de mercado e demanda externas. Daí que o comerciante retenha a maior parte do lucro, pouco restando ao produtor colonial que, de toda maneira, só poderia expandir ou aumentar a produtividade dos bens exportados ainda em subordinação ao comerciante externo.

Mas, ressaltemos: com essa caraterização da economia brasileira podemos compreender, também, o mecanismo explicativo do surgimento das economias subdesenvolvidas. Entretanto, caberia, ainda, destacar melhor como esta definição de economia colonial ou escravocrata-exportadora, ou colonial-escravocrata, dialoga com outros textos de Celso Furtado. Isso permitira captar o impacto de suas preocupações econômicas nos anos de 1950, e como elas levaram a alterações em seu pensamento. O leitor iniciado na obra de Celso Furtado sabe da importância dessa distinção, pois enquanto está trabalhando com o conceito de economia colonial, a temporalidade implícita na definição de subdesenvolvimento entendido como a reprodução históricoestrutural das diferenças históricas de desenvolvimento econômico fica opaca, pois o conceito de economia colonial não dá conta dessa especificidade.

Com efeito, se observarmos sua definição em "Características gerais da economia brasileira", vemos que economia colonial se refere a um tipo de estrutura produtiva e comercial. De fato, refere-se à "economia de tipo colonial que prevaleceu no país até 1914", que tem como base a "exportação de uns poucos produtos primários" e a "importação de grande número de artigos de consumo" 415; "as atividades tipicamente coloniais de exportação de produtos primários". ${ }^{416}$ Essa estrutura produtiva é contraposta a outra, voltada ao mercado interno e que começa a se desenvolver a partir de 1914, "em função do mercado interno". ${ }^{417}$ Por sua vez, "o núcleo agrícola de tipo colonial é essencialmente monoprodutor", de forma que "a estrutura econômica colonial resistira à formação desse mercado interno". ${ }^{418}$ Sob o ponto de vista do fluxo de renda,

\footnotetext{
${ }^{415}$ FURTADO, Celso. Características Gerais da economia brasileira... op. cit., p. 9.

${ }^{416}$ Idem, p. 15.

${ }^{417}$ Idem, p. 20.

${ }^{418}$ Idem, p. 29.
} 
a economia colonial "se caracteriza pela tendência à concentração das rendas nas fases de prosperidade e à socialização das perdas nas fases de depressão". 419

Com isso, podemos perceber que a análise sobre a economia colonial avança em relação ao texto "Características gerais da economia brasileira", pois agora parte da incorporação dos conceitos de fluxo de renda, as formas de aumento de produtividade e, ainda, a relação entre a economia colonial com sua contraface industrial, que explica como os lucros, as reinversões e as possibilidades de diversificação ficam restritas.

Ademais, ao ressaltar as expressões "economia colonial" "escravocrataexportadora" ou "colonial-escravocrata", Celso Furtado destaca os fatores que produzem o "equilíbrio com subdesenvolvimento": um setor produtivo subordinado ao exterior sob a ótica dos investimentos e do comércio; quanto ao fluxo de renda, destaca a barreira causada pela escravidão, que impede que haja uma propagação da renda para as outras atividades internas. Mas, o que importa ressaltar nessa interpretação, é que as características estruturais e os principais problemas da economia brasileira compõem um quadro totalizante. Aqui, notemos ainda, o termo estrutura é relevante, pois, como vimos, essa economia colonial não se refere à relação política entre metrópoles e colônias, mas sim à sistema de produção e sua relação com o exterior.

Com isso, podemos dar como concluída a primeira etapa do projeto de Celso Furtado: fundar as categorias que lhe permitam explicar as economias subdesenvolvidas como forma de justificar seus diagnósticos dos problemas atuais da economia brasileira. Esse esforço se expressou numa revisão da história europeia, procurando captar as categorias básicas do processo de desenvolvimento econômico. A partir disso, estabeleceu os elementos diferenciadores das economias subdesenvolvidas, encontrando os principais entraves na orientação e natureza do comércio, que não geram dinamismo, bem como na composição social da mão-de-obra, no caso brasileiro, composta por trabalho escravo.

Da construção desses diversos elementos, Celso Furtado poderá dar o passo adiante: fornecer um diagnóstico sobre os problemas do presente. Nesse aspecto, fica evidente que sua explicação operacionaliza as categorias que formulara, permitindo-lhe, ao mesmo tempo, unificar esses dois elementos, pois só será possível explicar o presente pelas modificações que a economia colonial sofreu. Ou seja, o diagnóstico do presente se torna inteligível a partir das categorias selecionadas para a sua compreensão. Assim, veremos em seu diagnóstico do presente que sua explicação para crise do setor ${ }^{419}$ Idem, p. 11. 
colonial teve sua originalidade teórica na produção histórica brasileira pois operacionalizou os conceitos histórico-analíticos que desenvolvera para entender o subdesenvolvimento, e não pode ser entendida separadamente com risco de tomar uma série de influências externas e parciais - keynesianismo, estruturalismo - como o fundamento teórico da interpretação. Ao contrário, é a imbricação de inovação epistemológica voltada para o presente que explica a originalidade furtadiana, que permite a seleção e incorporação de influências parciais, unificando-as, não numa perspectiva eclética, mas na preocupação principal de fundamentar um diagnóstico do presente que rompa com as análises liberais e, ao mesmo tempo, coloquem a indissociável necessidade de intervenção do Estado para orientar o desenvolvimento econômico brasileiro.

Para demonstrarmos essa hipótese, nos cabe, agora, retomar a análise da crise da economia colonial feita por Celso Furtado em A economia brasileira.

\section{Fim da economia colonial, cafeicultura e a crise do nascimento do mercado interno}

Em toda a análise que viemos acompanhando, Celso Furtado referiu-se a um sistema econômico preexistente, ou tradicional, ou de subsistência, que não era atingido pelo setor exportador e, por isso mesmo, não consegue se integrar, dificultando a formação de um mercado interno capaz de ampliar ou, ao menos, dar continuidade aos aumentos de produtividades para o conjunto da economia. Este setor será examinado agora, completando o objetivo de compreensão da economia colonial.

Este exame, como não poderia deixar de ser, está referido, também, à possibilidade de conciliação entre história e teoria econômica, mas concentrando-se, agora, no setor de subsistência complementar à economia açucareira, a pecuária. Reconhecendo em seu trabalho a extrema simplificação da realidade, "destinada a por em evidência o mecanismo básico da empresa colonizadora", ${ }^{420}$ Celso Furtado completa sua análise pelo surgimento de uma economia de subsistência, "cuja atividade básica era a criação". Embora houvesse um fluxo monetário triangular entre o setor de subsistência, o de exportação e o comércio de importação, aquele representava "uma

${ }^{420}$ Idem, p. 83 
parte insignificante da atividade econômica geral”, seja pela quase autossuficiência do setor exportador, seja pela baixa ocupação de mão-de-obra no setor de subsistência.

A importância desse setor de subsistência está ligada à ocupação territorial, pois abriu vias de comunicação e exploração de regiões não tocadas pela cultura de exportação.

No entanto, Celso Furtado preocupa-se em examinar a relação que os dois sistemas econômicos estabelecem entre si. De fato, nos períodos de crise do setor externo, unicamente os lucros do empresário contraíam-se, compensando para este continuar operando a despeito da baixa dos preços, até o limite do custo de reposição dos equipamentos e da força de trabalho. Mesmo nesta situação, a "redução de capacidade teria que ser um processo muito lento", de forma que a atividade exportadora "estava assim capacitada para preservar a sua estrutura", como ressalta o comprova o caso da economia açucareira nordestina que "resistiu durante três séculos e meio às mais prolongadas depressões". ${ }^{421}$

Esses períodos de decadência geravam transferência de fatores produtivos, seja para outras atividades de exportação, seja para o setor de subsistência, pois, não surgindo uma atividade alternativa, ou o empresário emigrava para outra atividade exportadora ou esperava uma nova expansão cíclica. Neste último caso, ocorreria a reversão para atividades de subsistência. Como assinala Furtado:

naquelas regiões do país onde floresceram os ciclos de economia colonial de exportação, surgiram como resíduos de atividades ligadas ao mercado externo e que tenderam a atrofiar-se, grandes massas de população dedicadas a atividades de subsistência. Apresentando todas as características de uma economia estacionária pré-capitalista: a parte principal da força de trabalho estava absorvida em atividades destinadas a satisfazer as necessidades primárias da população e as inversões líquidas se limitavam a atender ao crescimento desta ${ }^{422}$

\footnotetext{
${ }^{421}$ Idem, pp. 84-85. Essa questão da resistência estrutural às mudanças já está presente na tese de doutorado. Ela é construída a partir da identificação de que os reveses econômicos das classes exportadoras não correspondem à sua influência política. É possível observar que o declínio das atividades de exportação não é acompanhado de uma renovação das classes dirigentes, mas estas conseguem manter mecanismos de reprodução em grande parte devido ao acesso que têm às diferentes instâncias do Estado. Com isso, há uma dissociação entre as esferas política e econômica, de forma que a decadência desta última não altera a situação da primeira. Cumpre ressaltar que a interpretação que Celso Furtado fará dos anos de 1930 tem sua abrangência e originalidade precisamente por identificar esse momento único no qual a crise econômica foi também uma crise política na medida em que alterou os objetivos do Estado na condução da política econômica e na redistribuição dos recursos econômicos. ${ }^{422}$ Idem, p. 85.
} 
Com isso, Celso Furtado estabelece um quadro no qual é possível perceber a relação entre os dois setores da economia colonial, sob o ponto de vista da mão-de-obra. Esse legado é importante para marcar a passagem na análise de Celso Furtado:

a característica principal da economia brasileira ao concluir-se o ciclo da economia colonial exportadora-escravocrata, consistia na existência dessa considerável força de trabalho. Das distintas empresas colonizadoras comerciais, cada uma das quais a seu tempo havia sido um êxito econômico, havia resultado como elemento derivado uma extensa economia de subsistência ${ }^{423}$

Essa consideração é importante para a identificação de um problema econômico fundamental no Brasil: o excedente de mão-de-obra ocupado na subsistência e que, a um só tempo, pressiona para baixo os salários urbanos e, ao mesmo tempo, os encarece, pois não é capaz de produzir alimentos para os trabalhadores do setor urbano. Celso Furtado, ainda extraindo as consequências da sua caracterização da economia colonial e de seu funcionamento peculiar, agora adensando a interdependência entre os dois setores, traça um dos problemas fundamentais que se acumularam ao longo dos séculos: um excesso de mão-de-obra aplicada em atividades de baixa produtividade voltadas para a subsistência:

de país praticamente desprovido de mão-de-obra, o Brasil transformara-se em região dotada de uma extensa economia de subsistência que poderia constituir uma fonte de força de trabalho. A colonização comercial dos três primeiros séculos tivera como principal consequência, do ponto de vista econômico, o povoamento de parte do extenso território brasileiro. Essa população não estava organizada numa economia capaz de transformar-se por suas próprias forças. Era um simples reservatório de mão-de-obra que, graças às forças da economia mundial em expansão, iria enfrentar nova experiência de desenvolvimento ${ }^{424}$

Aqui, não basta o diagnóstico sobre a constituição de um reservatório de mãode-obra decorrente da desarticulação das atividades exportadoras. Ao contrário, é preciso considerar, também, a ocupação em atividades de subsistência de baixa produtividade. Essas duas características, como vimos, impedem a formação e dinamização de um mercado interno, seja pela ausência de transações monetárias resultantes de um mercado organizado, seja pela manutenção em alguns casos, como o brasileiro, da escravidão. Daí que é o surgimento de uma economia baseada no trabalho assalariado que dará início às modificações da economia colonial. Ou seja, com a organização de um mercado de trabalho, a economia colonial, embora ainda não perca

\footnotetext{
${ }^{423}$ Idem, p. 86.

${ }^{424}$ Idem, p. 86.
} 
sua dependência do setor externo, conta com um fator capaz de dinamizar a renda e a produção interna, pois, a partir de agora, os aumentos de produtividade do setor dinâmico serão redistribuídos em parte através dos salários. Forma-se, portanto, um mecanismo fundamental que ensejou a passagem da economia comercial para a industrial: o surgimento do mercado interno, ainda que em escala reduzida. Dito de outra forma: o pagamento de salários inicia um fluxo de renda que se realizará em consumo tanto pelos trabalhadores do setor exportador como, também, nos sistemas econômicos dele dependentes.

Embora esse momento do texto ultrapasse o segundo capítulo do livro Economia brasileira, o consideramos como a finalização da intenção de Furtado de compreender o funcionamento de uma economia colonial e identificar os fatores que impediram que o comércio exterior impulsionasse um processo de desenvolvimento econômico. Com isso, podemos dizer que Celso Furtado concluiu, para a economia colonial o que já havia feito para a economia europeia: através de uma análise histórica conseguiu extrair os conceitos econômicos fundamentais que lhe dão inteligibilidade.

Concluída esta etapa de retomada histórica e formulação dos conceitos fundamentais tanto das economias industriais quanto das coloniais, o propósito de Celso Furtado irá se desdobrar no exame da crise da economia colonial e no surgimento de uma economia que poderíamos chamar de nacional, embora o termo mais frequente que utiliza neste livro seja economia brasileira. Notemos o que já viemos assinalando: por compreender a economia colonial sob o ponto de vista econômico, da dependência do setor externo, também a explicação de sua crise, será a explicitação da ruína do setor exportador e do surgimento de uma forma alternativa de dinâmica econômica. Aqui, também, adentramos no segundo momento da empreitada de Celso Furtado que viemos examinando: se, até o momento ele procurou elaborar conceitos que lhe permitissem compreender o desenvolvimento econômico incorporando a história e as ciências sociais como parte de seu instrumental teórico, seu desdobramento óbvio é a utilização destes, não mais para o processo histórico, mas para realizar o diagnóstico dos problemas da economia brasileira. De fato, a partir de agora será possível perceber a imbricação que apontamos entre elaboração conceitual e diagnóstico para a ação, na qual a interpretação dos problemas da economia brasileira deve trazer as soluções a serem adotadas.

Para compreendermos essa análise, entretanto, será necessário, antes, precisarmos o momento específico sobre o qual Celso Furtado irá trabalhar e quais as relações que podemos estabelecer com as interpretações correntes sobre seu 
pensamento. Ora, a crise da economia colonial, seguindo sua construção teórica, é o momento em que o setor externo deixou de dinamizar a economia e, em consequência, o do surgimento e expansão do mercado interno. Neste processo emerge a importância fundamental do trabalho assalariado alterando o fluxo de renda, concluindo-se com a diminuição do peso do comércio exterior na geração de renda e no produto.

Celso Furtado, portanto, passa a ocupar-se agora, da política econômica cafeeira no século XIX e XX, a crise de 1929 e seus desdobramentos para a economia brasileira. Já vimos uma primeira análise dessas transformações no artigo "Características gerais da economia brasileira”, ao qual faremos referência em seguida.

No entanto, antes de adentrarmos na análise da interpretação sobre a crise de 1929 e seus efeitos para a economia brasileira, cabe observar que esse tema é trabalhado pela bibliografia como uma das grandes inovações teóricas de Formação econômica do Brasil, de 1959. Esta leitura, constitutiva da fortuna crítica de Celso Furtado, não deu todo o destaque ao fato de que esta interpretação está toda neste livro de 1953, publicado em 1954, e que será reproduzido mais tarde como os capítulos 26, 27 e 28 e de 30 a 35. Por sua vez, partes do capítulo III de A economia brasileira irão reaparecer, no capítulo 9. Esta permanência faz com que o livro de 1959 tenha uma estrutura dupla, pois reaproveita os capítulos de 1954 e elabora novos. Ou seja, Formação econômica do Brasil possui datas diferentes de redação, o que pode ser captado no próprio teor dos capítulos. Entretanto, como iremos aprofundar mais a frente, a principal dívida deste é com o livro A economia Brasileira, já que as formulações encontradas na tese de doutorado foram alteradas em termos teóricos, restando entre os dois livros unicamente uma coincidência temporal no período estudado, os séculos XVI e XVII. Sobre a estrutura de Formação Econômica do Brasil, alguns intérpretes, tais como Ricardo Bielschowsky, Rosa Maria Vieira, Tamás Szmeracsányi e Francisco de Oliveira, propuseram, para fins de analíticos, dividi-lo em duas grandes partes, indicando preocupações teórico-metodológicas diferentes.

Cabe-nos, então, antes de avançar na leitura do texto, procurar investigar se há alguma consequência, para captar as transformações do pensamento de Celso Furtado, no fato da interpretação sobre a crise de 1929 já estar presente neste livro de 1954.

Ricardo Bielschowsky relaciona Formação econômica do Brasil com o engajamento de Furtado nos debates sobre a intervenção na economia brasileira. Em suas palavras, o livro foi "instrumento da militância intelectual de Furtado no sentido da consolidação da consciência desenvolvimentista brasileira, que requeria uma 
argumentação histórica. O esforço de elaboração dessa argumentação, que ocupou o autor por muitos anos - a versão preliminar da obra fora publicada já em 1954, sob o título A Economia brasileira — resultou num avanço da própria abordagem estruturalista". 425

Aqui, encontramos uma concordância a respeito da relação entre a legitimação dos diagnósticos do presente e a obra de 1959. Com uma diferença de ênfase: se $A$ economia brasileira aparece para Bielschowsky como um precursor do livro de Formação, para nós, a problemática deste último é tributária dos debates do início da década de 1950.

Refletindo sobre os fundamentos analíticos de Formação econômica do Brasil, Ricardo Bielschowsky, aponta que "as primeiras considerações do autor sobre a história econômica brasileira aparecem num artigo publicado na Revista Brasileira de Economia, de 1950, no qual já constam algumas ideias mestras da análise posterior, como a de 'deslocamento do centro dinâmico', e a de 'concentração de renda nas fases de prosperidade e socialização das perdas nas fases de depressão"”. ${ }^{426}$ Por sua vez, "o livro A Economia Brasileira já contém o arranjo conceitual básico de análise histórica que figuraria no trabalho final, isto é, Formação econômica do Brasil'. Este, prossegue, “corresponde ao A Economia Brasileira, destituído desses capítulos mais abstratos, modificado em algumas partes e acrescido de alguns capítulos”. ${ }^{427}$ Dessa forma, a interpretação de Bielschowsky, reconhece a continuidade entre os dois livros em termos analíticos, mas não enfatiza as consequências temporais das continuidades e rupturas nos diagnósticos da economia brasileira elaborados por Celso Furtado. Mais ainda, como pretendemos examinar ao longo deste capítulo, é preciso relativizar, também, uma continuidade muito estreita entre o artigo de 1950 e o livro de 1954, bem como em relação à Formação.

\footnotetext{
${ }^{425}$ BIELSCHOWSKY, Ricardo. Formação econômica do Brasil: uma obra prima do estruturalismo cepalino. In: ARAÚJO, Tarcisio Patricio de; WERNECK VIANNA, Salvador Teixeira; MACAMBIRA, Júnior. (orgs) 50 anos de Formação Econômica do Brasil: ensaios sobre a obra clássica de Celso Furtado. Rio de Janeiro: Ipea, 2009, p p. 49.

${ }^{426}$ Idem, p. 51.

${ }^{427}$ Idem, p. 52. Ainda sobre esse reaproveitamento, explica que "o texto definitivo [de Formação econômica do Brasil] é aproximadamente o mesmo que os outros dois capítulos finais da parte IV, referentes à 'economia de transição para o trabalho assalariado' e nos capítulos da parte V, em que o autor analisa o colapso da economia cafeeira e a transição para a economia industrial. No entanto, é consideravelmente mais aprofundado em todos os capítulos anteriores, precisamente aqueles que dão suporte à caracterização da estrutura brasileira como subdesenvolvida e à análise dos problemas que lhe são específicos". Idem, p. 52-53. Isso corresponderia aos capítulos 28 a 36. Como apontamos, os capítulos reaproveitados foram 8 e 9,26 a 28 e 30 a 35 .
} 
Da mesma forma, Tamás Szmeracsányi reconhece a importância do livro por ser “precursor, tanto de sua obra-prima, Formação Econômica do Brasil, publicado cinco anos mais tarde, como de seu livro Desenvolvimento e subdesenvolvimento, de 1961". ${ }^{428}$ Em outra ocasião, assinala que neste livro de 1954 Celso Furtado "apresenta, pela primeira vez, as suas ideias sobre a evolução da economia cafeeira e da crise dos anos 30, acompanhada pelo desenvolvimento industrial na mesma época”, cujos capítulos mais importantes, em relação à Formação econômica do Brasil, "são o terceiro, relativo à evolução da economia cafeeira, e o quarto, a respeito de sua crise e do desenvolvimento industrial subsequente a partir dos anos 30". ${ }^{429}$ Aqui também, do caráter precursor não se extrai as consequências em termos da problemática que ocupa Celso Furtado na primeira metade de 1950.

Francisco de Oliveira, por sua vez, examina a relação entre os livros nos seguintes termos: “já em seu primeiro livro, A economia brasileira, a aplicação da teoria cepalina ao caso do Brasil dava mostras do que viria a ser. Retomando basicamente os mesmos temas, com abrangência e aprofundamento histórico maiores, Furtado escreverá, depois de um período em Cambridge, Formação econômica do Brasil". Sobre esta última obra, acrescenta que "o forte do livro é a explicação que apresenta da economia exportadora de café para a economia industrial que emerge da Segunda Guerra Mundial”. ${ }^{430}$ Nesta interpretação, há a continuidade dos temas entre as duas obras, ressaltando que a interpretação sobre a crise de 1929 e a solução adotada pelo Brasil é o ponto forte de Formação econômica do Brasil.

Por sua vez, Pedro Cezar Dutra Fonseca, partindo de outra problemática, a questão da intencionalidade da política industrialista na década de 1930, afirma que “deve-se fundamentalmente a Celso Furtado, e a Formação econômica do Brasil, a tese clássica de que o Brasil foi um dos primeiros países ocidentais a sair da crise iniciada em 1929 e que tal fato deveu-se à política intervencionista empreendida pelo governo para sustentar as exportações de café". ${ }^{431}$ A relação entre a interpretação da crise

\footnotetext{
${ }^{428}$ SZMRECSÁNYI, Tamás. Cinquentenário de A Economia brasileira de Celso Furtado. Boletim Informativo da ABPHE, dezembro de 2003.

${ }^{429}$ SZMRECSÁNYI, Tamás. As raízes, a estrutura e o conteúdo da Formação econômica do Brasil. In: COELHO; GRANZIERA, (orgs). Celso Furtado e a Formação econômica do Brasil (Edição comemorativa dos 50 anos de publicação (1959-2009). Prefácio Fernando Henrique Cardoso. São Paulo, Editora Atlas, 2009, p. 50.

${ }^{430}$ OLIVEIRA, Francisco. A navegação venturosa. In: Idem. A navegação venturosa. Ensaios sobre Celso Furtado. São Paulo, Boitempo Editorial, 2003, p. 19.

${ }^{431}$ FONSECA, Pedro Cezar Dutra. Instituições e política econômica: crise e crescimento do Brasil na década de 1930. In: BASTOS, P. P. Z. e FONSECA, P. C. D (orgs). A Era Vargas. Desenvolvimentismo, economia e sociedade. São Paulo, Editora Unesp, 2013, p. 159.
} 
mundial de 1929 feita por Celso Furtado e seu aparecimento especificamente no livro Formação econômica do Brasil, é enfatizada ao ressaltar que os capítulos 30 a 33 do livro "constituem sua parte considerada mais criativa e que propiciou maior debate". 432

Nesta leitura como na anterior, novamente a produção e o contexto são diluídos, dando maior destaque à originalidade da interpretação furtadiana da economia brasileira a partir da década de 1930.

Dessa forma, é preciso considerar, que, de um lado, existe uma visão teleológica do livro de 1954, no sentido de que este aparece unicamente como precursor de Formação econômica do Brasil, o que implica que a temática abordada se sobrepõe aos circunstanciamentos que lhe deram origem ou, por outro lado, a origem da interpretação sobre a crise de 1929 e a resposta da política econômica brasileira não são problematizadas. Dentro desse conjunto de perspectivas, portanto, nosso exame, alternativamente, centra-se na conjuntura específica desta primeira metade dos anos de 1950, sob dois aspectos: primeiramente, a partir dos debates sobre planejamento econômico no qual Celso Furtado se insere, e, também, considerando a formulação conceitual que elabora como forma de intervir neste debate, não apenas do ponto de vista do diagnóstico sobre os problemas correntes da economia brasileira, mas sob a perspectiva da fundamentação teórica dos conceitos e das categorias do desenvolvimento econômico como um instrumental unificado que lhe permite, não apenas examinar o presente, mas indagar o processo de desenvolvimento econômico do conjunto da evolução da economia brasileira.

Com isso, podemos passar à análise de A economia brasileira.

Celso Furtado distingue as particularidades da agricultura cafeeira em relação à economia exportadora-escravocrata, pois a primeira "toma impulso exatamente na época em que se abolia no país o regime de trabalho escravo", ${ }^{433}$ e sua expansão no final do XIX tem "base no trabalho assalariado", contando com "um grande reservatório de mão-de-obra" no setor de subsistência, além da possibilidade de importar mão-de-obra de países europeus que passavam por uma crise neste período. Nesta análise, embora Celso Furtado tenha presente a experiência da economia açucareira no Nordeste e as formas de colonização dos Estados Unidos, sua explicação para a adoção do trabalho livre se deve à pré-existência de mão-de-obra abundante,

\footnotetext{
432 Idem, p. 162.

${ }^{433}$ Idem, p. 87.
} 
interna e externa, o que deprimiu os salários e diminuiu os custos de sua adoção para o empresário. ${ }^{434}$

Entretanto, o que merece destaque nesta interpretação é precisamente o fato de marcar a alteração da economia colonial com o surgimento do trabalho assalariado, pois estabelece a importância da modificação de um de seus entraves principais, o trabalho escravo e a ausência de fluxo de renda baseado no salário e no consumo dos trabalhadores. É por esse fato, inédito na economia brasileira, que é possível compreender as alterações na economia e suas repercussões no fluxo de renda.

A economia cafeeira é analisada, como não poderia deixar de ser, desde seu fluxo de renda. Nela, uma vez vendida a produção no exterior, o empresário paga os fatores de produção, cobre os custos de depreciação e reposição e aufere seu lucro. A renda, portanto, pode ser dividida entre "renda dos assalariados e renda dos proprietários”. ${ }^{435}$ Os fatores de produção pagos pelos empresários dispendem sua renda em bens de consumo internos ou em importações, estimulando pequenos produtores que, por sua vez, gastam seus rendimentos da mesma forma em bens de consumo interno e externo. Mas a principal característica desta economia aparece ao analisar "o fluxo de renda do ponto de vista dinâmico", pois o aumento da procura externa leva a um aumento da massa de salários no setor cafeeiro e, consequentemente, na procura de artigos de consumo fora da economia exportadora, mas dentro do país. Ora, uma vez operando com trabalho assalariado,

o aumento do impulso externo pode determinar uma melhor utilização dos fatores já existentes no país. Esse aumento de produtividade, efeito secundário do impulso externo, vai beneficiar um setor da economia fora da unidade produtora-exportadora, isto é, ligado ao mercado interno. A massa de salários paga no setor exportador vem a ser, portanto, o núcleo central de uma economia de mercado interno. Esta economia, quando convergem os efeitos da ação de certos fatores que referiremos em seguida, poderá crescer com maior intensidade

\footnotetext{
${ }^{434}$ Nesta análise, é preciso notar que agricultura cafeeira assume importância desde 1830 e que a adoção de mão-de-obra assalariada não foi decorrente do cálculo econômico do fazendeiro num cenário de mãode-obra disponível em grande quantidade. Foram fatores sociais e econômicos, dentre dos quais se destaca o fim do tráfico externo e interno, e a constante elevação dos preços do café no mercado internacional que forçaram os cafeicultores a buscar saídas para o problema da mão-de-obra. Este problema será desenvolvido, nesta perspectiva, em Formação econômica do Brasil. Aliás, nesta obra, a segunda metade do século XIX é caracterizada como um período de "inelasticidade da oferta de trabalho" (173). Por sua vez, a insistência de Celso Furtado nesta argumentação está ligada à distinção entre colônias com e sem fatores de produção disponíveis. Nesta perspectiva, a economia colonial brasileira se iniciou com a importação de mão-de-obra, seja de Portugal, da África ou indígena e alterou essa condição no século XIX.

435 Idem, p. 89. Nesta distinção, os assalariados gastam a "totalidade ou quase totalidade" de seus rendimentos em consumo, enquanto os empresários "retém parte de sua renda para aumentar o seu capital que é a fonte dessa mesma renda”. Idem, p. 89-90.
} 
que a economia de exportação, se bem que o impulso último de crescimento venha desta última [Grifo nosso] ${ }^{436}$

Com isso, Celso Furtado não apenas destaca a principal característica diferenciadora da cultura cafeeira no Brasil, vis-à-vis as outras culturas de exportação, como também marca a semelhança com as economias comerciais e industriais. Neste aspecto, percebemos que o trabalho assalariado é o fator que pode impulsionar o setor ligado ao mercado interno, melhorando sua produtividade, encadeamento inexistente na economia colonial e, como vimos, característica do desenvolvimento dos sistemas comerciais e industriais. Podemos perceber, também, o conteúdo da denominação de "economia escravocrata-exportadora", pois o que dava a peculiaridade ao setor exportador colonial era a escravidão, elemento que não constava dos sistemas econômicos examinados anteriormente. Por outro lado, percebe-se uma diferenciação importante ao texto de 1950, no qual o eixo de análise das transformações da economia brasileira não é dado pelo fluxo de renda, mas sim pelos problemas de balanço de pagamentos e sua resolução pela desvalorização cambial. ${ }^{437} \mathrm{Ou}$, dito de outra forma, se no texto "Características gerais da economia brasileira" a interpretação está consideravelmente enraizada na interpretação cepalina, sobretudo em questões como deterioração dos termos de troca, tendência ao desequilíbrio do balanço de pagamentos, desvalorização cambial e inflação, neste momento, as categorias fundamentais do desenvolvimento econômico redirecionam a observação para o fluxo de renda e, neste aspecto, a questão do trabalho assalariado (uma elemento interno ao sistema econômico) passa a adquirir importância interpretativa. Por outro lado, no artigo, há uma preocupação mais acentuada na criação do mercado interno, dificultada pelo baixo nível dos salários. Neste caso, não muda o diagnóstico, mas sim o instrumental: este deixa de ligar-se visceralmente ao trabalho cepalino, incorporando o esforço de Celso Furtado de formular historicamente conceitos e categorias que possam explicar a peculiaridade da economia brasileira. Cumpre assinalar, também, que se as teses cepalinas de Centro e Periferia e Deterioração dos Termos de Troca estavam sob o ataque dos economistas liberais, os conceitos de Celso Furtado dão uma nova base epistemológica para a sustentação de seu diagnóstico da economia brasileira.

\footnotetext{
${ }^{436}$ Idem, p. 90.

${ }^{437}$ Esse aspecto é examinado em COUTINHO, Maurício C. A política cambial: instrumento privilegiado na análise da Formação econômica do Brasil In: COELHO; GRANZIERA, (orgs). Celso Furtado e a Formação econômica do Brasil (Edição comemorativa dos 50 anos de publicação (1959-2009)). Prefácio Fernando Henrique Cardoso. São Paulo, Editora Atlas, 2009, pp. 160-170.
} 
Essa singularidade da economia cafeeira vai operar, ainda com relação ao fluxo de renda, atraindo mão-de-obra do setor de subsistência para o exportador, uma vez que o impulso externo aumenta os lucros do empresário e, consequentemente, estimula sua reinversão na expansão da produção, contratando trabalhadores do setor de subsistência e ampliando a produção em termos extensivos, ainda que mantendo a renda estável neste setor. ${ }^{438}$ Por outro lado, a expansão do setor externo, absorvendo o setor de subsistência, aumenta a produtividade média da economia, embora abaixo do aumento no setor cafeeiro, pois o aumento de produtividade fica retido pelo empresário. Isso significava, entretanto, que nesta economia o problema dos custos não se apresentava ao cafeicultor, mas apenas o de suas margens de lucro. ${ }^{439}$ Dado que a economia funcionava a partir do movimento dos preços no mercado internacional, e que os salários já estavam abaixo da produtividade, as flutuações dos preços se traduziriam em oscilações no lucro dos empresários. Entretanto, argumenta Furtado, algumas características específicas desta "nova economia colonial” forçavam uma alteração neste mecanismo.

Uma destas alterações resultava na "impossibilidade de adaptar-se ao mecanismo do padrão-ouro", ${ }^{440}$ sobretudo a manutenção de uma reserva em ouro para cobrir déficits na balança de pagamentos. ${ }^{441}$ Numa economia colonial a base de trabalho assalariado, a renda cresce muito além das receitas de exportação devido ao efeito multiplicador atuante sobre os salários, sendo que parte desse aumento era satisfeito com importações. Nas etapas de crise, os preços de exportação caem bruscamente, enquanto a redução das importações ocorre de forma lenta, causando pressão no balanço de pagamentos no momento em que a entrada de divisas diminui. Some-se a isso, a fuga de capitais e a consideração bastante desenvolvida nos trabalhos da Cepal, de que nas etapas de crise os preços de produtos primários caem mais de que os manufaturados. Dessa forma, a economia que passa a operar com trabalho

\footnotetext{
${ }^{438}$ Isso se explica pois não é preciso que os salários subam no setor exportador para atrair mão-de-obra do setor de subsistência. Basta, unicamente, que seja superior à deste setor. Por outro lado, essa mesma transferência de fatores de produção, aumentando a oferta de trabalho, contribui para que o salário permaneça estável.

${ }^{439}$ Lembremos, o problema dos custos foi fundamental para a passagem da economia comercial para a industrial. Com isso, portanto, Celso Furtado está marcando os limites que economia colonial brasileira em sua transição encontra em direção à implantação de uma lógica industrial.

${ }^{440}$ Idem, p. 94.

${ }^{441}$ Segundo Celso Furtado, essas reservas deveriam ser proporcionais à participação de cada país no comércio internacional. Assim, "um país pobre - tais os de economia colonial - mas muito dependente do comércio exterior, deveria possuir enormes reservas metálicas. Sempre que fossem insuficientes essas reservas, a economia estaria sujeita a desequilíbrios externos intermitentes que se traduziriam em flutuações da taxa cambial”. Idem, p. 95.
} 
assalariado mas ainda é dependente do setor externo terá uma tendência a desequilíbrios no balanço de pagamentos, agravados pelo funcionamento do padrão-ouro. Entretanto, será preciso compreender que, se a economia brasileira não tinha condições de operar de forma "saudável", no padrão-ouro, a manutenção deste sistema monetário tinha uma função específica, que será trabalhada mais a frente. Aqui, também, embora a interpretação deste movimento geral já estivesse presente no artigo de 1950, sua formulação, agora, retoma o polêmico, pois vai de encontro a um dos dogmas da economia ortodoxa e do saneamento das finanças, qual seja, a inserção no Padrão-Ouro, uma obsessão da política econômica durante a Primeira República (1889-1930). Mais ainda, aqui Celso Furtado destaca as implicações políticas e sociais de adesão ao Sistema Monetário Internacional, e quais os grupos que saem beneficiados.

Outro ponto discutido por Celso Furtado é que, se os aumentos de produtividade, fruto da melhora dos preços internacionais, não eram revertidos em melhores salários, não havia, consequentemente, pressão para que o empresário ampliasse o capital investido e economizasse mão-de-obra. Assim, a economia cafeeira crescia unicamente em extensão, dado que havia grande disponibilidade de terras:

as condições econômicas em que se desenvolvia a cultura do café não criavam, portanto, nenhum estímulo ao empresário para aumentar a produtividade física, seja da mão-de-obra, seja da terra por ele utilizadas. Era essa, aliás, a forma racional de crescimento de uma economia onde existiam desocupadas ou subocupadas terra e mão-deobra, e onde era escasso o capital ${ }^{442}$

Dessa forma, não havia aumentos da produtividade física no setor exportador. Ora, a afirmação ganha força precisamente por demonstrar que o empresário cafeeiro não seguia a lógica de inovação e progresso técnico na visão schumpeteriana defendida por Bulhões. As condições específicas da nova economia colonial permitiam, a um só tempo, a ampliação dos lucros e a manutenção do nível técnico de produção, pois os salários não eram valorizados suficientemente para estimular uma alteração na organização da produção. Dessa forma, Celso Furtado vai destacar a possibilidade de conciliação de uma economia com altas taxas de lucro e estagnação da produtividade.

Retomando o funcionamento dessa economia, uma vez que os aumentos nos lucros eram decorrentes de elevações cíclicas da procura externa, poderia esperar-se que "o empresário devolvesse, através de lucros mais baixos, aquilo que ganhara em lucros

${ }^{442}$ Idem, p. 100. 
extraordinários na etapa cíclica anterior”. ${ }^{443}$ Entretanto, isso não ocorria na prática e a explicação deste fato liga-se ao problema já mencionado do funcionamento do padrãoouro e à dependência de importações do conjunto da economia. De fato, já que a dinâmica econômica estava dada pela procura externa do café e que os períodos de auge cíclico se traduziam em elevação das margens de lucro do empresário, era de se esperar que as fases de baixa cíclica se traduzissem numa redução das rendas dessa classe nãoassalariada. Com isso, ocorreria uma queda nas importações e, também, no ritmo das inversões dentro da economia.

Entretanto, a correção dos desequilíbrios externos não era feita pela contração dos lucros e redução do consumo, mas através de alterações na taxa cambial, com distintas consequências para o conjunto da economia. Ao reduzir-se o valor externo da moeda, diminuía o poder de compra de produtos importados e desestimulavam-se as remessas ao exterior. A principal consequência desse mecanismo é beneficiar o setor que operava com divisas estrangeiras, ou seja, o setor exportador, pois, com a desvalorização cambial, era possível trocar suas divisas em uma maior quantidade de moeda nacional. Segundo Furtado, essa manobra cambial era um mecanismo de “socialização de prejuízos do setor exportador":

O processo de correção do desequilíbrio externo significava, em última instância, uma transferência de renda daqueles que pagavam as importações para aqueles que vendiam as exportações. Como as importações eram pagas pela coletividade em seu conjunto, os empresários exportadores estavam na realidade logrando socializar as perdas que a ação dos fatores econômicos tendia a concentrar em seus lucros [...] Durante a depressão, as importações que se contraiam menos - dada a baixa elasticidade-renda de sua procura - eram aquelas de produtos essenciais utilizados pela grande massa consumidora. Os produtos de consumo de importação exclusiva das classes não assalariadas, apresentavam elevada elasticidade, dado seu caráter de não-essencialidade. ${ }^{444}$

Aqui, portanto, temos um aspecto fundamental da interpretação de Celso Furtado, que nos permite ligar seu diagnóstico do presente com as categorias econômicas do desenvolvimento econômico que veio elaborando. Nesta interpretação da "socialização das perdas" - como ficará conhecida a partir de Formação Econômica do Brasil, embora já esteja presente no artigo "Características gerais da economia brasileira" - reside um dos aspectos inovadores de sua força analítica e explicativa, por chamar a atenção a alguns aspectos fundamentais: 1) o grupo dominante que se

\footnotetext{
${ }^{443}$ Idem, p. 101.

${ }^{444}$ Idem, p. 103-104.
} 
apropria do excedente (lucros) e o destino que lhe dá; 2) a caraterística das economias coloniais de manter sua estrutura mesmo em momentos de crise; 3) a atenção dada ao fluxo de renda dentro do sistema econômico e, 4) o acesso dos grupos dominantes à orientação da política econômica nacional. Por outro lado, cumpre notar também, uma alteração de ênfase do texto de 1950, já que em "Características gerais da economia brasileira”, a principal consequência da socialização das perdas foi a ausência de efeito saneador da crise, de forma que "o crescimento da economia do país não se efetuou, assim, através de uma seleção interna". 445

Ora, essas três características foram objeto de reflexão de Celso Furtado em seus escritos anteriores, mas com ênfases e tratamentos diversos, que a análise até aqui já permitiu identificar. Neste sentido, queremos salientar, uma vez mais, a imbricação entre a formulação conceitual e análise do presente como o ponto forte para explicar a originalidade da interpretação furtadiana. Ressaltemos ainda nossa opção por construir nossa análise da elaboração dos conceitos para sua aplicação, muito embora o movimento pudesse ser invertido, pois se trata, de fato, de uma relação dialética entre observação da realidade e formulação conceitual. O que queremos enfatizar, no entanto, é que não pode haver separação, compartimentação entre as duas, constituindo-se parte de um mesmo movimento. Assim, observando o conjunto até aqui examinado, podemos perceber melhor o encadeamento dos passos analíticos de Furtado: 1) marcar o surgimento do trabalho assalariado; 2) examinar suas consequências para o fluxo de renda; 3) assinalar os entraves para o desenvolvimento econômico da economia brasileira. Ora, o foco nesses pontos pode ser compreendido a partir de: I) exame do desenvolvimento econômico nas economias comercial e industrial, na qual o impulso externo se propaga pela economia através dos salários; II) o fluxo de renda é a forma de observar como o desenvolvimento econômico se propaga e transforma a economia; III) nas economias comerciais, os entraves ocorreram devido ao surgimento problema dos custos, inexistentes, como vimos, na economia cafeeira. Ora, elaboração conceitual e análise da economia brasileira andam juntas e, veremos, ainda, estarão imbricados no diagnóstico dos problemas recentes da economia brasileira, subsidiando a interpretação estruturalista que irá se contrapor à visão liberal.

\footnotetext{
${ }^{445}$ FURTADO, Celso. Características Gerais da Economia Brasileira. op. cit., p. 10. Desse ponto de vista, podemos perceber que Celso Furtado estava mais próximo de uma análise que levava em consideração os aspectos microeconômicos. Sobretudo porque, em alguns momentos do texto, parece identificar fatores que acabam toldando a iniciativa do empresário schumpeteriano, que criticará alguns anos depois.
} 
Para Furtado, "a lógica de todo esse sistema estava no esforço de sobrevivência de um organismo econômico que contava com escassos meios de defesa". "446 Numa economia industrial, as crises funcionavam como mecanismo de correção, no sentido de criar as bases para um novo ciclo de crescimento e aumento de produtividade. Ao contrário, na economia colonial a crise não se manifestava na eliminação dos produtores menos eficientes e, tampouco, na paralização de parte da produção. Embora as peculiaridades da produção de café contribuíssem para isso, seja devido ao longo tempo de florescimento, seja pela impossibilidade de intercalação com outras culturas, não havia alternativa para a economia senão a manutenção da produção, sob o risco de fortes consequências negativas para o conjunto da economia. Vejamos:

qualquer que fosse a redução no preço internacional do café, era
vantajoso para o conjunto da economia continuar exportando o
produto. Mantinha-se, assim, o nível de emprego dentro do país e
evitavam-se os efeitos secundários da crise. Mas para manter o nível
de emprego era necessário que o impacto da crise não se concentrasse
nos lucros dos empresários, pois do contrário parte destes últimos
seriam forçados a paralisar as suas atividades, por impossibilidade
financeira de enfrentar maiores reduções em suas receitas. Desde o
momento em que o empresário lograva transferir para o conjunto da
coletividade as suas perdas, ficava em condições de continuar
operando, qualquer que fosse a baixa real do preço de exportação. Não
resta dúvida que, do ponto de vista da defesa do nível da renda, valia a
pena pagar o preço. ${ }^{447}$

Aqui também, é possível perceber que a análise aponta os aspectos positivos do mecanismo de defesa que a economia cafeeira possuía, não porque favorecia os empresários, mas sim porque, mantinha em funcionamento o conjunto da economia colonial e diminuía as consequências da queda no fluxo de renda do conjunto do sistema. Ressaltamos novamente: é a partir das categorias elaboradas, que Celso Furtado analisa a economia brasileira. Ou seja, vista anteriormente unicamente pela ausência de mecanismos saneadores da economia, agora, a saída pela socialização das perdas "distribuía", também, um pouco dos ganhos do setor exportador ao conjunto da economia ao impedir uma queda mais acentuada na renda. A alteração da interpretação, insistiremos, decorre da incorporação da perspectiva do fluxo de renda no sistema econômico, cujo mecanismo tem maior possibilidade de propagação a partir do trabalho assalariado. Visto, portanto, menos sob a ótica da produção e mais sobre a ótica da

\footnotetext{
446 Idem, p. 105.

${ }^{447}$ Idem, p. 107.
} 
distribuição, a socialização das perdas amplia sua abrangência explicativa, da microeconomia do setor exportador para a macroeconomia da renda nacional.

Entretanto, disso decorrem, também, as consequências negativas da defesa para a economia. De fato, ao manter a oferta, os preços eram pressionados para baixo, pois os empresários pretendiam compensar o efeito baixista pela ampliação da quantidade vendida. Nessa situação, ficou evidente a ausência de coordenação entre os empresários para superar a crise mantendo a produção e financiando a retenção dos estoques para não afetar os preços internacionais. Daí resultou a necessidade de mobilização de recursos governamentais ou, nas palavras de Furtado: "a mancomunação da direção dos negócios econômicos com as atividades políticas amadureceu precocemente". ${ }^{448}$ A junção da "maquinaria estatal" com os "interesses dos exportadores facilitou a consolidação desses interesses, em prejuízo de outros grupos que estavam começando a desenvolver-se”. Ora, também aqui nessa análise, podemos perceber que Celso Furtado está destacando os limites que a defesa do setor externo colocou para criação de um setor voltado ao mercado interno. Por outro lado, o próprio funcionamento da economia cafeeira, sob o aspecto das decisões de investimento, ou seja, sob o comando da iniciativa privada, carecia de coordenação e planejamento. A intervenção estatal, como foi feita, via financiamento de estoques crescentes, tinha uma função dupla: se, de um lado, corroborava as decisões de investimento dos empresários, de outro garantia o funcionamento da economia como um todo, evitando uma crise maior, dada pelo abandono das plantações de café, num cenário de impossibilidade de absorção das quantidades produzidas. Mas, ao mesmo tempo, transformações ocorriam no setor de subsistência cada vez mais interligado ao setor exportador, ao absorver este setor, o sistema de exportação criou uma demanda por bens de consumo, resultado da expansão dos salários na economia, que começava a ser atendida pela produção interna. No entanto, a economia cafeeira, "na luta de sobrevivência contra as crises externas, criou condições que dificultaram a transformação espontânea da economia colonial em economia industrial". 449 Esse conjunto de impasses, crises periódicas, alterações cambiais e socialização das perdas, intervenções no mercado financiando estoques e ampliando a quantidade produzida, pressionando o setor produtor de alimentos fez com a que a economia cafeeira vivesse décadas de instabilidade que, no entanto, foram incapazes de produzir uma crise e transformação definitiva, prolongando a vida do

\footnotetext{
${ }^{448}$ Idem, p. 109.

${ }^{449}$ Idem, p. 109.
} 
sistema econômico, embora agudizando as contradições e conflitos inerentes a esta perpetuação. Dessa forma, importará, na sequência analisar

a combinação de fatores que provocou a crise profunda da economia colonial, a qual se estendeu por todo o último quarto de século. $\mathrm{O}$ processo de transformação estrutural que nesse período se opera na economia brasileira, reflete em grande parte o grau de eficácia com que atuaram os mecanismos de defesa a que antes nos referimos. Diante de uma crise de grandes proporções, as doses subministradas ao organismo enfermo tiveram de ser tão fortes, que os efeitos obtidos resultaram totalmente distintos daqueles que se buscavam. ${ }^{450}$

Esse acúmulo de contradições, formado, lembremos, a partir dessa nova produção exportadora organizada com trabalho assalariado iria pressionar para romper aqueles limites que fizeram com que a economia colonial permanecesse imóvel em sua estrutura, mas oscilante em sua extensão e expansão nos três séculos anteriores.

Cabe, agora, examinar como Celso Furtado irá interpretar a crise da economia cafeeira. Suas bases estão delineadas: é a partir da persistência e proteção dos interesses do setor exportador, confrontados com uma crise de grandes proporções, que as consequências da defesa do setor contra a situação econômica internacional irão adquirir uma nova direção. Se o mecanismo de defesa funcionou até o terceiro decênio do século XX, a crise de 1929 encontra a economia cafeeira numa situação vulnerável em decorrência da própria manutenção desse mecanismo por um período prolongado.

Com efeito, embora a defesa do café se baseasse no controle da oferta, a grande disponibilidade de terras e mão-de-obra nos países produtores, bem como a ausência de culturas alternativas à rubiácea criava uma tendência para safras cada vez maiores, ampliando a oferta além dos limites de absorção pelo mercado internacional. ${ }^{451}$ Dessa forma: "o mecanismo de defesa da economia cafeeira era, em última instância, um processo de transferência para o futuro da solução de um problema que se tornaria cada vez mais grave". 452

De fato, a produção cresceu mais de $100 \%$ na segunda metade dos anos de 1920, enquanto a demanda se manteve estável, devido à baixa elasticidade-renda, formando "uma situação perfeitamente caracterizada de desequilíbrio entre oferta e procura". ${ }^{453} \mathrm{~A}$ correção deste desequilíbrio, aponta Furtado, deveria ter sido feita com restrições à

\footnotetext{
${ }^{450}$ Idem, pp. 109-110.

${ }^{451}$ Notemos, ademais, que a oferta internacional de café se deu a partir, quase exclusivamente, do Brasil, que controlava $75 \%$ da oferta mundial do produto. Idem, p. 114.

452 Idem, p. 115.

453 Idem, p. 117.
} 
ampliação da capacidade produtiva, o que não era factível numa economia colonial, pois seu limite do lado da oferta é a ocupação de todas as terras disponíveis e/ou de toda a mão-de-obra, uma vez que não se apresentava nenhum investimento alternativo para os grandes lucros da produção cafeeira.

Aprofundando as características do problema, Celso Furtado chama a atenção para a forma de financiamento dos estoques de café, feitos em bancos estrangeiros e convertidos em moeda local. Essa operação tinha um caráter inflacionário, pois representava uma ampliação dos meios de pagamento, elevando a procura no setor cafeeiro e encontrando uma oferta interna reduzida para a produção de alimentos e inelástica para manufaturados, um e outro sendo atendidos com importações, e/ou pressionando os preços internos. Nesse quadro, se junta uma grande expansão das plantações de café nos anos de 1927-1928 e a afluência de capital estrangeiro para financiá-la, gerando uma situação cambial favorável que levou o governo a aderir ao padrão-ouro. Uma vez iniciada a crise internacional de 1929, "não foram necessários mais do que alguns meses para que todas as reservas metálicas acumuladas à custa de empréstimos externos fossem tragadas pelos capitais em fuga do país”. ${ }^{454}$

Nesse quadro, Celso Furtado apresenta a situação da economia cafeeira: crescimento da produção até 1933, devido aos investimentos de 1927-28 e, ao mesmo tempo, impossibilidade de obtenção de financiamento externo para a retenção de estoques. O problema aparecia, portanto, como:

1. Que conviria mais, colher o café ou deixá-lo apodrecer nas árvores, abandonando parte das plantações como uma fábrica cujas portas se fecham durante a crise?

2. Caso se colhesse o café, que destino deveria dar-se ao mesmo? Forçar o mercado mundial, retê-lo em estoques ou destruí-lo?

3. Como seria financiada essa operação? Isto é, sobre quem recairia a carga, caso fosse colhido o café? ${ }^{455}$

Não se tratava, simplesmente, de abandonar os cafezais, mas sim de saber "quem iria pagar pela perda". Por outro lado, o duradouro processo de defesa do setor cafeeiro já indicava que não recairiam sobre ele os custos da crise. Assim, "o problema que se apresentava, destarte, era como adaptar esse mecanismo às condições, inéditas por sua gravidade, surgidas com a nova crise". 456

\footnotetext{
${ }^{454}$ Idem, p. 121.

${ }^{455}$ Idem, p. 122

${ }^{456}$ Idem, p. 123.
} 
De início, é preciso considerar que a queda foi muito maior no preço do café vendido no porto, enquanto o preço pago pelo consumidor norte-americano se reduziu de maneira mais leve, o que indica a existência de duas crises: uma de oferta e outra de comercialização, que favoreceu as organizações intermediárias no comércio do café. A baixa do preço do café pode ser aliviada pela desvalorização da moeda nacional, que compensou um pouco aquela perda, enquanto o problema dos estoques foi em parte diminuído pela ampliação das vendas. Por sua vez, a atenuação da crise através mecanismo cambial continuava estimulando o produtor a colher o café e pressionar o mercado para baixo. Dessa forma, a única maneira de restabelecer o equilíbrio entre oferta e demanda e, ao mesmo tempo, não fazer recair as perdas sobre o setor cafeeiro seria o financiamento dos estoques com expansão monetária, o que, a um só tempo, contribuía para depreciar ainda mais a moeda e, ao mesmo tempo, socializar os prejuízos para o conjunto da economia. Apesar desses esforços, os estoques não poderiam ser vendidos num futuro próximo. Daí que a solução adotada foi a destruição dos estoques como forma de obter-se "o equilíbrio entre a oferta e a procura a nível mais elevado de preços". ${ }^{457}$ Com essas medidas, o café atravessou toda a década de 1930 com seu preço estável, comprovando a estabilidade da oferta após essas medidas.

Entretanto, importa a Celso Furtado "observar o grau de efetividade dos mecanismos de defesa que se haviam desenvolvido na economia e as modificações estruturais que acarretou a ação dos referidos mecanismos nas condições especiais criadas pela grande depressão". ${ }^{458}$

De fato, o principal efeito da política de defesa do setor cafeeiro durante a crise de 1929 foi que, “ao garantir preços mínimos de compra, remuneradores para a grande maioria dos produtores, estava-se na realidade mantendo o nível de emprego para a economia exportadora e, indiretamente, para os setores ligados ao mercado interno". 459 Ou seja, aqui, é possível perceber as mudanças que o surgimento do trabalho assalariado trouxe para a economia: a possibilidade de transferir, multiplicar, a renda do setor exportador. A colheita de café continuou durante a década de 1930, mantendo-se a renda dos trabalhadores e a demanda para a produção interna. Com isso, e aqui Celso Furtado está trabalhando com multiplicador keynesiano, sustentou-se a procura em um nível de renda maior, para o conjunto da economia, do que se fossem abandonadas as

\footnotetext{
${ }^{457}$ Idem, p. 126.

${ }^{458}$ Idem, p. 128.

${ }^{459}$ Idem, p. 128.
} 
plantações de café. No período da crise até seu ponto mais baixo, a renda monetária teve uma redução entre 25 e 30\%, "relativamente pequena se se compara com a de outros países", a exemplo dos Estados Unidos, onde a queda atingiu 50\%. ${ }^{460}$

A explicação para este fato é assim apresentada por Celso Furtado:

a diferença está em que nos Estados Unidos a baixa de preços acarretava enorme desemprego, ao contrário do que estava ocorrendo no Brasil, onde se mantinha o nível de emprego se bem que se tivesse de destruir o fruto da produção. O que importa ter em conta é que o valor do produto que se destruía era muito inferior ao montante da renda que se criava. Estávamos, em verdade, construindo as famosas pirâmides que anos depois preconizaria Keynes. ${ }^{461}$

Com isso, Celso Furtado delineia, em suas linhas gerais, a interpretação sobre a crise da economia cafeeira na década de 1930. Quase nada se pode acrescentar que possa alterá-la na versão de Formação Econômica do Brasil. Entretanto, é preciso considerar a estrutura conceitual com a qual está trabalhando para visualizar a crise e seus desdobramentos. Com efeito, Celso Furtado vinha apontando a peculiaridade das economias coloniais e a ausência de mecanismos saneadores durante as crises, tal como ocorria nas economias industriais. Ora, é precisamente a diferença estrutural da economia cafeeira brasileira, com sua dinâmica dada pelo setor externo, porém utilizando-se de trabalho assalariado, que permitiu que a absorção da crise se fizesse também de forma diversa, pois a manutenção da renda no único setor dinâmico da economia teve repercussão em seu conjunto. Repercussão que, através do mecanismo cambial e da velocidade de expansão da renda, ativaram e estimularam os outros setores da economia, abrindo possibilidades de investimento, estímulos estes que as forças de mercado — que atendiam unicamente à demanda e à lucratividade do setor exportador - não conseguiam produzir. Dito de outro modo, a defesa do setor cafeeiro, paradoxalmente, foi o mecanismo propulsor do mercado interno e, como veremos, do setor manufatureiro. Os impulsos e os encadeamentos entre setores econômicos operaram na economia brasileira como resultado da defesa de seu setor externo colonial. Atentemos, portanto, uma vez mais, como a tipologia econômica de Celso Furtado para compreender o processo de desenvolvimento econômico opera em sua interpretação e

\footnotetext{
${ }^{460}$ Idem, p. 130-131.

${ }^{461}$ Idem, p. 131. A análise segue: "a política de defesa do setor cafeeiro nos anos da grande depressão concretiza-se num verdadeiro programa de fomento da renda nacional. Chega-se a praticar no Brasil, inconscientemente, uma política anticíclica de maior amplitude que a que se tenha sequer preconizado em qualquer dos países industriais".
} 
lhe fornece os achados para as transformações econômicas, bem como fundamentará seu diagnóstico sobre o presente.

Finalmente, fica indicada, para ser discutido mais a frente, sob o ponto de vista da evolução do pensamento de Celso Furtado, o significado dessa interpretação sobre a crise de 1929 e seus mecanismos de defesa já estar presente neste livro de 1953. Por hora, iremos seguir a exposição, intentando reunir os elementos para desenvolvermos essa discussão.

A contração das inversões durante a crise foi contrabalançada pela retenção dos estoques de café, que funcionavam como um investimento, mantendo a renda e a demanda. Dessa forma, "a recuperação da economia brasileira, que se manifesta a partir de 1933, não se deve a nenhum fator externo e sim à política de fomento seguida inconscientemente no país e que era um subproduto da defesa dos interesses cafeeiros". 462 Com isso, Celso Furtado está justificando a importância, para a análise econômica, de se considerar a atuação dos grupos dominantes e observar as direções do fluxo de renda na economia, temas já tratados anteriormente e para os quais dedicara grande esforço conceitual. Por outro lado, destaca uma consequência inesperada do nãofuncionamento do mecanismo de crise típico das economias industriais - onde a interdependência entre os diversos setores da economia transmitiria o impulso recessivo para o conjunto da economia. Como a economia brasileira ainda tinha sua dinâmica baseada na produção de exportação, a ação governamental nesse setor específico conseguiu garantir resultados para a economia como um todo. Ou seja, de uma socialização das perdas, houve, neste momento, uma socialização da política econômica, que, agora passou a ter diferentes resultados à medida que atingiu outros setores sociais. Essa constatação é o fundamento da interpretação furtadiana de que a intensidade da crise e a forma de defesa tiveram repercussões diferentes dos outros programas de valorização e iniciou um conjunto de mudanças na própria estrutura da economia brasileira. Dito de outro modo, o cerne da explicação é colocado na solução da crise: a intervenção do Estado para favorecer um grupo social específico. Essa atuação, por sua vez, aparece não comprometida por uma valorização positiva ou negativa, pois, se num primeiro momento (planos de valorização) aguçou as tensões da "nova economia colonial", num segundo momento ofereceu uma política econômica que, ao proteger um setor social especifico, teve efeito "benéfico" para o conjunto da economia.

\footnotetext{
${ }^{462}$ Idem, p. 132.
} 
Isso pode ser notado ao se considerar os resultados da política de defesa do café e "o que significou isso como pressão sobre a estrutura do sistema econômico". ${ }^{463}$ A forma como se financiou a manutenção da produção e a queima dos estoques — através de expansão monetária - ao manter a renda, manteve também a pressão sobre as importações, ocasionando "um desequilíbrio externo que tendia a profundar-se". A depreciação do valor externo da moeda foi a forma como se buscou um equilíbrio, reduzindo a procura por importações. A operação do mecanismo cambial, em concomitância à uma queda menos acentuada na renda total, pressionou o sistema econômico interno, de forma que

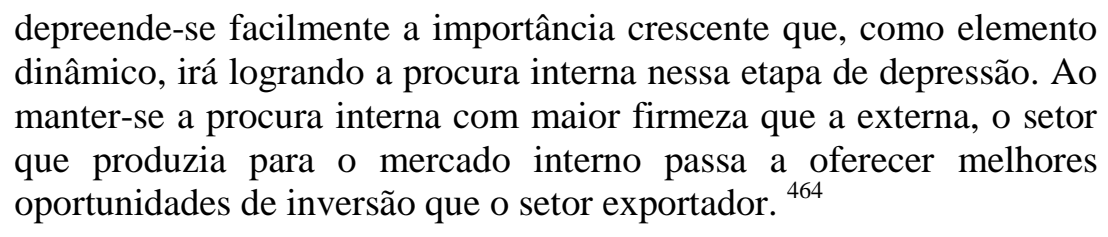

Ora, a crise e sua forma de defesa, atuando em um cenário permeado pelo trabalho assalariado e expansão dos serviços urbanos gerados pelo café, tiveram o efeito de romper o peso excessivo do setor exportador como catalisador dos investimentos. De fato, se o principal problema da defesa foi a impossibilidade de diminuir a produção devido à falta de investimentos alternativos, a depreciação cambial aliada à expansão da renda derivada da forma de financiamento e destruição dos estoques irão atuar direcionando-a para a procura interna. Assim, a crise, em seu conjunto, ao mesmo tempo em que ocasiona a diminuição da produção cafeeira, cujas reinversões e gastos de manutenção das plantações cessam a partir de 1930, estimula os setores ligados ao mercado interno. Uma alteração sem precedentes e que irá ocasionar o fim da economia colonial:

O fator dinâmico principal, nos anos que se seguem à crise, passa a ser, sem nenhuma dúvida, o mercado interno. A produção industrial, que se destinava em sua totalidade ao mercado interno, sofre durante a depressão uma queda de menos de 10 por cento, e já em 1933 recupera o nível de 1929. A produção agrícola para o mercado interno supera com igual rapidez os efeitos da crise. É evidente que, mantendo-se elevado o nível da procura e represando-se uma maior parte dessa procura dentro do país, através do corte das importações, as atividades ligadas ao mercado interno puderam manter, na maioria dos casos, e em alguns aumentar, a sua taxa de rentabilidade. Esse aumento da taxa de rentabilidade se fazia concomitantemente com a queda dos lucros no setor ligado ao mercado externo. Explica-se,

\footnotetext{
463 Idem, p. 133.

${ }^{464}$ Idem, p. 137.
} 
portanto, a preocupação de desviar capitais de um para outro setor. As atividades ligadas ao mercado interno não somente cresciam impulsionadas por seus maiores lucros, mas ainda recebiam um maior impulso atraindo capitais que se formavam ou desinvertiam no setor de exportação ${ }^{465}$

Aqui, portanto, o cerne dos resultados da crise de 1929 e seu efeito sobre o conjunto da economia. Destaquemos, nesse sentido, o surgimento do mercado interno e a sua capacidade de absorver a renda disponível do setor exportador em depressão, seja do ponto de vista do aumento da taxa de lucratividade dos investimentos, seja do fornecimento de bens de consumo devido à queda das importações. Cumpre destacar, ainda, o seu significado do ponto de vista do processo de desenvolvimento econômico. Neste aspecto, as categorias construídas a partir da análise da história europeia trouxeram os elementos principais para a inteligibilidade da crise da economia colonial. Se esta se caracterizava pela dependência do setor exportador, organizava produtivamente a partir do trabalho escravo, e esses elementos bloqueavam a transmissão de um impulso gerador de aumento de produtividade, o exame de Furtado vai se colocar tanto no surgimento de uma economia de exportação baseada no trabalho assalariado, quanto os fatores que se aliaram para reverter a exclusividade desse setor voltado para o comercio exterior receber todos os investimentos. Assim, a crise de 1929 é analisada como o processo que resultava na formação do mercado interno.

Essa pressão sobre a produção nacional não poderia ser respondida com uma rápida expansão, pois o setor manufatureiro também era dependente da importação de máquinas e equipamentos. Dessa forma, ocorreu uma intensificação da utilização da capacidade instalada na indústria, ocasionando elevação dos lucros e acumulação de capital para ser direcionada aos investimentos, num período posterior. Celso Furtado chama atenção, também, para o surgimento e expansão, durante a crise, de uma indústria de bens de capital no país, para fazer frente à demanda e aos altos custos que a situação cambial impunha para a importação.

Finalmente, Furtado avalia as consequências que o conjunto desses fatores ocasionou para a economia. Em primeiro lugar, e aqui ele retoma uma categoria que desenvolvera na Cepal e que está presente em seu primeiro artigo, "a capacidade para importar não se recuperou nos anos trinta". Por outro lado, houve uma diminuição da participação do setor exportador na formação da renda agrícola, caindo de 70 para 57 por cento entre 1929 e 1937.

${ }^{465}$ Idem, p. 137-138. 
Por outro lado, no que se refere à economia como um todo, "a recuperação, entretanto, veio rápida e comparativamente forte. A produção industrial cresceu em cerca de 50 por cento entre 1929 e 1937 e a produção primária para o mercado interno cresceu em mais de 40 por cento, no mesmo período". ${ }^{466}$ Houve, ainda, um aumento de $20 \%$ da renda nacional e de $7 \%$ per capita.

Ressaltando novamente o ineditismo das consequências da política econômica pós-crise de 1929, sobretudo a manutenção da renda e da procura interna em uma conjuntura de estancamento e crise do setor exportador ( o setor dinâmico de uma economia colonial), Celso Furtado irá indagar:

\begin{abstract}
por que meio logrou a economia brasileira, nos anos trinta, subverter a ação mais ou menos automática desses mecanismos? Por que forma foram compensados os efeitos depressivos da contração persistente da procura externa? Melhor ainda: a que se deve o fato de que a procura interna não tenha entrado em colapso com a contração da procura externa? Esses resultados, de grande significação para o futuro imediato da economia brasileira, estão ligados às dimensões catastróficas da crise do café e à persistência com que foram defendidos os interesses da economia cafeeira. ${ }^{467}$
\end{abstract}

Com isto, fica explícita, ainda uma vez, como a interpretação de Celso Furtado deriva das categorias desenvolvidas anteriormente. Com efeito, somente pela identificação dos mecanismos que operam em uma economia colonial é possível caracterizar a intensidade da crise e, ao mesmo tempo, relacioná-la com os grupos que dirigiam o setor exportador. Dessa forma, está implícita na interpretação o funcionamento da economia colonial e o papel dos grupos dirigentes em fazer valer os seus interesses. Notemos, ainda, como o arcabouço cepalino e furtadiano (coeficiente de importações, tendência ao desequilíbrio externo, dificuldades de funcionamento do padrão-ouro) foram mobilizados para comprovar e subsidiar a interpretação da política econômica que, entretanto, deriva sua força explicativa das categorias fundamentais do desenvolvimento econômico formuladas neste período. $\mathrm{O}$ mesmo se poderia dizer do multiplicador keynesiano, operacional na medida em que permite explicar ou elucidar o raciocínio segundo o qual a excepcionalidade da crise transformou os resultados da política de valorização do café. Mas, vejamos, transformou, mas não alterou seu sentido básico, a preservação dos interesses do setor cafeeiro. Daí, também que a interpretação da política econômica de manutenção da renda atribua inconsciência dos formuladores no que concerte aos resultados econômicos, pois a ação foi, exclusivamente, política e

\footnotetext{
${ }^{466}$ Idem, p. 141.

${ }^{467}$ Idem, p. 142.
} 
operou dentro da margem de manobra existente na economia para preservar os interesses cafeeiros. Finalmente, a intepretação da crise de 1929 e suas repercussões no conjunto da economia dão início ao exame da economia brasileira recente. Isso significa, em nossa proposta analítica - qual seja, existe uma imbricação entre a formulação das categorias de compreensão do desenvolvimento econômico como fundamento para a formulação e legitimação dos diagnósticos sobre o presente —, que a partir de agora o exame da economia brasileira também é feito partindo-se do mesmo substrato analítico, as consequências da crise econômicas e de sua superação ainda nos anos de 1930.

Assim, seguindo as considerações de Celso Furtado, "essas modificações bruscas na estrutura econômica não podiam deixar de trazer persistentes desequilíbrios. O mais significativo talvez seja o que afeta a balança de pagamentos". "468 Foi esse desequilíbrio que acabou por reduzir as importações e estabelecer um novo nível de preços relativos entre produtos importados e nacionais, favorecendo estes últimos, que elevou a rentabilidade deste setor e canalizou os investimentos até a sua plena ocupação e posterior expansão. Com isso, a taxa de câmbio passa a ser um elemento-chave, não apenas para o setor exportador, mas também para o setor interno. De fato, uma vez que melhorasse a situação das exportações, ocorreria uma valorização cambial e um aumento das importações. Isso, evidentemente, iria diminuir a renda do setor interno, ocasionando desemprego e diminuição da renda. Dessa forma,

ao passarem a concorrer os dois setores, as modificações na taxa cambial passam a ter repercussões demasiado sérias, para que possam ser abandonadas às contingências do momento. Perdia-se, assim, um dos mecanismos de ajuste mais amplos de que dispunha a economia e ao mesmo tempo um dos instrumentos mais eficazes de defesa da estrutura econômica colonial ${ }^{469}$

Com isso, está dada a condicionante fundamental para a alteração da economia brasileira. Ou seja, a perda de um dos mecanismos básico de manutenção da reprodução da economia colonial irá aprofundar o sentido das modificações da economia brasileira. Vale notar, também, que a concorrência entre o setor externo e interno e, sobretudo, a origem deste último, foi gestada no bojo da política econômica cafeeira, e teve esse resultado pela conjugação, peculiar deste sistema econômico, de funcionar com trabalho assalariado. De fato, uma política de manutenção dos interesses das classes exportadoras foi empreendida também pela produção açucareira no Nordeste,

\footnotetext{
${ }^{468}$ Idem, p. 143.

${ }^{469}$ Idem, p. 144.
} 
entretanto, o predomínio do trabalho escravo permitiu que aquela estrutura fosse mantida, ainda que com a expulsão de trabalhadores e a formação de uma economia de subsistência de baixíssima produtividade. Entretanto, o que cabe perceber é que enquanto os interesses dos produtores de açúcar foram mantidos, na economia cafeeira, sua defesa teve resultados diversos. Entretanto, uma ilumina a outra. Em outras palavras,

as consequências da perda desse mecanismo serão profundas e respondem em boa parte pelas modificações estruturais que continuarão a operar-se. Ao lograr sobrepor-se à profunda crise dos anos trinta, a economia brasileira comprometia certos elementos básicos de seu mecanismo. As consequências últimas desses desajustamentos do sistema só se manifestarão com plenitude após a economia de guerra da primeira metade do século ${ }^{470}$

Com isso, Celso Furtado não apenas sinaliza a natureza das modificações da economia brasileira como explicita que, a partir deste momento, e correndo o risco de parecermos desrespeitosamente didáticos, as modificações da taxa cambial não são neutras, ou seja, têm implicações diretas sobre os setores da economia. Dito de outra forma, não é possível ajustarem-se os desequilíbrios externos (balanço de pagamentos) e internos (inflação) através deste mecanismo. De fato, a política cambial deve, a partir de agora, considerar as repercussões que a variação da taxa de câmbio acarreta para o conjunto da economia brasileira: socializam-se, também, as repercussões e os encadeamentos no conjunto da economia brasileira.

Observando em seu conjunto, a preocupação de Celso Furtado em compreender a crise de 1929 é, ao mesmo tempo, detectar as constrições que sua superação lega à economia brasileira. Dessa forma, o diagnóstico sobre o presente está imbuído dessa interpretação, lançando os termos a partir dos quais será possível formular políticas econômicas. Importante, neste sentido, é a percepção de que a economia desenvolve um outro setor, ligado ao mercado interno, e que opera em sinal trocado com o exportador. Nesse sentido, a formulação dos conceitos do desenvolvimento econômico levou a uma modificação na interpretação da crise, pois, como vimos em "Características gerais da economia brasileira", a interpretação da industrialização fora feita através dos "choques adversos" ocorridos no setor exportador, não levando em consideração as pressões que o novo setor interno impunha por uma solução de política econômica que contemplasse seus interesses. Assim, a industrialização perde o caráter tão diretamente reflexo,

${ }^{470}$ Idem, p. 145. 
sobretudo a partir do momento em que este setor passa a ganhar importância e deve ser levado em consideração na política cambial.

Entretanto, a imbricação entre a intepretação sobre o passado da economia brasileira e seu diagnóstico sobre o presente aparecerão de forma nítida no próximo capítulo de Economia brasileira, onde irá investigar o surgimento e expansão do setor industrial voltado para o mercado interno.

A queda do poder de compra da moeda brasileira no exterior e a consequente alteração dos preços relativos em favor da produção interna de manufaturas e bens de consumo foram responsáveis pelo "desenvolvimento industrial dos anos trinta". 471

Como já vimos, a taxa de câmbio adquiriu importância fundamental, tanto para os produtores internos, quanto para os importadores e exportadores. A oscilação cambial, argumenta Furtado, passa a ser um fator de grande instabilidade para os setores que agora disputam o mesmo mercado, dificultando "subsistir dentro da indisciplina do sistema de preços que havia antes prevalecido". ${ }^{472}$ A situação se modificou, no entanto, na década de 1940, com o início da Segunda Guerra Mundial, o que ocasionou uma grande entrada de divisas no país, pressionando a valorização do cruzeiro. Essa valorização iria contra os interesses dos exportadores (que receberiam menos em moeda nacional) e dos produtores ligados ao mercado interno (que poderiam enfrentar concorrência para seus produtos, com a queda no preço das importações) A solução adotada, como se sabe, foi a fixação da taxa de câmbio, em um nível sobrevalorizado, o que acabou por beneficiar o setor exportador, ainda que o mercado mundial tenha alterado sua demanda devido ao esforço de guerra.

A medida cambial, ao favorecer o setor exportador, mais uma vez logrou manter o nível de renda. Por outro lado, a conjuntura de retração da disponibilidade de importações devido à guerra e a intensa utilização da capacidade produtiva interna desde os anos 1930, configuraram "o extremo esforço a que foi submetido o sistema econômico e a estagnação em que esteve submerso nesse período". ${ }^{473}$ Conjugavam-se, portanto, fixação da taxa cambial, manutenção da renda e pressão para o consumo interno num período de bloqueio de importações; o resultado foi um aumento do nível de preços decorrente da pressão do consumo em contraposição às restrições que o

\footnotetext{
${ }^{471}$ Idem, p. 150.

${ }^{472}$ Idem, p. 150.

${ }^{473}$ Idem, p. 154. Celso Furtado mostra a dificuldade das autoridades de política econômica do período pois o setor externo não suportaria uma desvalorização da moeda nacional, pois os valores que recebia pelas exportações era o mesmo que de 1935, enquanto nível de preços internos havia aumentado em mais de $40 \%$, o que tornava impraticável uma redução maior em seu poder de compra interno. Idem, p. 155.
} 
período da Segunda Guerra Mundial impõe à economia. Com isso, Celso Furtado indica as dificuldades de operação do sistema econômico sob o esforço de guerra, sobretudo com a ausência de orientação e planejamento econômico:

a ação poderia ter sido orientada, seja no sentido de reduzir diretamente o fluxo de renda nacional - cortando salários e outras remunerações - ou no sentido de esterilizar parte da renda que se criava. Numa economia de livre iniciativa, este segundo método é de aplicação mais fácil e de resultados menos imprevisíveis ${ }^{474}$

Dessa maneira, podemos perceber, outra vez, a relação direta que os diagnósticos sobre a economia brasileira guardam com as preocupações de Celso Furtado em sua disputa com os economistas liberais em favor do planejamento. A análise que elabora da conjuntura brasileira, para além de identificar as restrições mais prementes da economia, oferece, em seu bojo, alternativas erigidas sob a necessidade da coordenação e planejamento da economia. De fato, aqui, pela primeira vez, e sintomaticamente, a política econômica deixa de ser vista como a persecução de salvaguarda dos interesses cafeicultores e, sim, pela identificação dos vários setores que disputam a política econômica. Ora, a partir do momento em que concorrem os setores externo e interno, o mercado deixa ser um elemento regulador (o mercado só poderia regular para um dos lados), sendo necessária a intervenção do planejador, pois a forma de manifestação da disputa se dá com desequilíbrios econômicos, por vezes nas contas externas, por vezes no nível de preços internos. Dito de outra forma, diagnóstico e prescrição se juntam agora fundamentados e balizados nos conceitos econômicos: não apenas os desenvolvidos na Cepal, mas estes derivados da interpretação das categorias do desenvolvimento econômico.

Por outro lado, Celso Furtado não deixa de assinalar as dificuldades de coordenação durante o esforço de guerra. A principal razão disso, paradoxalmente, foi o sucesso da recuperação econômica brasileira ainda na primeira metade da década de 1930. Como vimos, esta, ao reduzir o papel do setor externo e dinamizar a agricultura interna, a produção manufatureira e a nascente indústria de bens de capital, já no final da década havia resultado numa série de pressões sobre o sistema econômico, enquanto os países centrais encontravam-se em plena recessão. Na Europa e nos Estados Unidos, a Guerra veio ser um fator de estímulo para a retomada do crescimento econômico, dando tempo e abrindo algumas possibilidades para essas economias organizarem-se, pois contavam com capacidade ociosa durante os dois primeiros anos do conflito. No

\footnotetext{
${ }^{474}$ Idem, p. 158. Ver, também, p. 157
} 
Brasil, ao contrário, a deflagração da guerra veio impor maiores dificuldades para a economia, manifestando-se na elevação no nível de preços de 78\% entre 1940 e 1944, dificultando qualquer política corretora. ${ }^{475}$ Dentro deste quadro, está claro um elemento já presente nos debates sobre planejamento, a respeito da inflação. Esta não é resultado de uma má gestão da política monetária, como queriam os liberais, mas é expressão de problemas reais da economia; conjuntura de grande demanda, restrição às importações, queda de exportações. Dessa forma, a elevação dos preços nada mais é que a explicitação do conflito distributivo através da inflação, pois "a alta dos preços não é outra coisa senão um sintoma de que a forma de distribuição da renda se está modificando com rapidez". De fato, uma vez que ocorre uma grande pressão por bens reais, concomitante à expansão monetária, a forma de equilíbrio tende a ser a alta dos preços, pois é a única forma dos agentes protegerem seus ativos. Nessa perspectiva, os empresários se beneficiam de um aumento de seus lucros em detrimento dos assalariados.

Examinando a década de 1940, Celso Furtado destaca que a estabilidade cambial favoreceu o setor exportador até 1945, pois os preços de exportação subiram mais que o nível de preços internos. Já no período do pós-guerra, ocorreu o contrário, havendo uma diminuição no preço das importações. Dessa forma, a conjuntura dos anos 1930 favoreceu o setor industrial, enquanto a década se seguinte reverteu essa tendência. Isso fica patente no final da guerra, com a liberação das importações, fazendo com que seu coeficiente praticamente duplique já em 1947. Essa medida de liberação das importações, adotada no contexto de final do conflito e de acúmulo de saldos comerciais (a maioria deles em moedas não-conversíveis, fez com que surgissem desequilíbrios no balanço de pagamentos cuja solução foi a adoção de controles seletivos de importação. Essa medida, "teria profunda significação para o futuro imediato se bem que foi tomada aparentemente com desconhecimento de seu verdadeiro alcance". ${ }^{476}$ De fato,

a consequência prática da política cambial adotada com vista a combater a alta de preços, foi que se reduziram relativamente as importações de manufaturas acabadas de consumo, e se incrementaram as de bens de capital e de matérias-primas. $\mathrm{O}$ setor industrial era assim favorecido duplamente: por um lado, porque a possibilidade de concorrência externa se reduzia ao mínimo através do

\footnotetext{
475 Idem, p. 160.

476 Idem, p. 166. Celso Furtado ressalta o "desconhecimento" do alcance das medidas pois, para os exportadores, o objetivo era conter a alta dos preços internos, enquanto os industriais julgaram que a medida iria contrariar seus interesses, ao regular os setores em que haveria concorrência.
} 
controle das importações; por outro, porque as matérias-primas e os equipamentos podiam ser adquiridos a preços relativamente baixos. ${ }^{477}$

Dessa forma, ampliou-se ainda mais o incentivo aos investimentos nas indústrias voltadas ao mercado interno, numa conjuntura em que as importações de bens de capital e equipamentos poderiam ser compradas a preços praticamente constantes entre 1948 e 1951. Vejamos, uma vez mais, e para não sermos levados pelo diagnóstico, quais são os elementos que compõe o exame de Celso Furtado. Ora, o objetivo principal, como vimos, é marcar o surgimento e as consequências da expansão do setor interno. Para tanto, vai observar os mecanismos com os quais os setores disputam espaço e recursos econômicos. Vimos que até a crise de 1929, o principal mecanismo de defesa do setor dominante da economia foi a política cambial, responsável pela "socialização das perdas". A profundidade da crise econômica mundial colocou em xeque esse mecanismo, pois o surgimento do mercado interno e de produção industrial passa a ter peso maior na determinação do fluxo de renda e na composição do nível de preços. Disso resultou, ainda segundo Furtado, que o confronto entre os setores aparecesse através da inflação. A forma de resolução ou de equilíbrio entre os setores passa, portanto, a exigir outras medidas além da política cambial, daí a necessidade de considerar, na análise furtadiana, as políticas de comércio exterior, sobretudo de exportação.

Entretanto, caberia perguntar, qual foi a consequência do aumento da produtividade do setor industrial, beneficiado com essas políticas de proteção e incentivo aos investimentos. Ou seja, "houve, no período, uma redistribuição de renda para o setor industrial". ${ }^{478}$ A questão é complexa, pois, como explica, "numa economia de livre-empresa o processo de capitalização tem que correr paralelo com o crescimento do mercado". ${ }^{479}$ Argumenta que não houve uma redistribuição entre setores ${ }^{480}$, e tampouco, dos consumidores em geral, pois isso afetaria o tamanho do mercado e o nível de consumo.

Para Celso Furtado, ao contrário

o benefício que usufruíram os empresários industriais através das importações a baixos preços dos equipamentos e das matérias-primas representa não o fruto de uma redistribuição de renda no sentido

\footnotetext{
${ }^{477}$ Idem, p. 168.

${ }^{478}$ Idem, p. 170.

${ }^{479}$ Idem, p. 170.

${ }^{480}$ Durante a década de 1940 os preços pagos ao produtor agrícola, de exportação e interno, subiram mais que o nível geral de preços.
} 
estático, e sim de uma apropriação por aqueles empresários de parte substancial do aumento da renda real da coletividade que resultou da melhora na relação de preços do intercâmbio externo. A baixa relativa nos preços dos produtos importados, em vez de beneficiar igualmente a todos os setores, ia concentrar-se no setor industrial, pela simples razão de que este setor era o maior absorvedor de divisas ${ }^{481}$

Isso significa, na interpretação de Celso Furtado, que o setor industrial conseguiu se expandir sem restringir os outros setores ou o consumo. Com efeito, unicamente se apropriou do excedente de divisas gerado pelo setor exportador (que, por sua vez, não poderia usá-lo em sua totalidade em importações, devido ao regime de licenças), ao mesmo tempo em que se beneficiou e, em alguma medida o socializou, do aumento de produtividade da indústria, agora protegida pela disparidade entre os preços internos e os de importação. Esta conjuntura permitiu ao setor industrial absorver o aumento de produtividade decorrente da diminuição dos preços dos bens de capital e equipamentos. O que a política cambial fez $-\mathrm{e}$ aqui se justifica o termo inconscientemente que o autor emprega - foi canalizar o aumento da produtividade para a acumulação de capital e não para o consumo, algo que já era reivindicado na resposta à Otávio Gouveia de Bulhões e estava presente nos trabalhos da Cepal. Mais importante ainda, é que nesta interpretação Celso Furtado recusa o diagnóstico de que as inversões industriais foram possibilitadas pela inflação. Em suas palavras, "os capitais adicionais de que dispuseram os industriais para intensificar suas inversões não foram fruto de uma simples redistribuição de renda e, portanto, não resultaram do processo inflacionário". Ao contrário, "esses capitais foram criados por assim dizer fora da economia, através do aumento geral de produtividade econômica que advinha da baixa relativa dos preços de importação". ${ }^{482}$ Assim, a disputa pelo diagnóstico sobe de tom, pois "atribuir à inflação uma aumento de capitalização da magnitude do que teve lugar no Brasil entre 1948 e 1952 é uma simplificação grosseira do problema que em nada contribui para esclarecê-lo". ${ }^{483}$ Dessa forma, nesse momento, o exame da situação da economia brasileira aparece imbricado à disputa pelos diagnósticos sobre o movimento geral e as alternativas de política econômica a ser seguidas na economia brasileira. Isso fica tanto mais claro quanto o diagnóstico apresentado em "Características gerais da economia brasileira" explica o surgimento e desenvolvimento industrial devido aos

\footnotetext{
${ }^{481}$ Idem p. 172.

482 Idem, p. 174.

${ }^{483}$ Idem, ibidem.
} 
sobrelucros do setor industrial, muito embora tenha se baseado unicamente no setor têxtil, —ainda que fosse o mais importante da economia — no período.

Dentro deste quadro e_ainda no âmbito da disputa pelos diagnósticos da economia brasileira, Celso Furtado vai abordar a questão da inflação, situando-a nos seguintes termos: "existem aqui dois problemas distintos: a razão pela qual os preços se elevam persistentemente, e os efeitos dessa elevação no processo econômico". 484

Sobre o segundo ponto, a inflação, por si só, como demonstra a experiência de outros países latino-americanos, não é capaz de elevar a capitalização permanentemente na economia. A capitalização aumentou respondendo à melhora da produtividade marginal do capital, ou seja, havia uma perspectiva de maior rentabilidade para os novos capitais investidos. Isso ocorreu devido à conjunção de cambio fixo e ascensão dos preços internos, o que barateava a compra de equipamentos. Entretanto, isso não quer dizer que o aumento da produtividade veio da inflação, pois, "para que a inflação pudesse desempenhar um papel positivo, no sentido de intensificar as inversões e o crescimento da economia, foi necessário que houvesse algo a redistribuir, cuja origem independia dela". ${ }^{485}$ Esse "algo" nada mais foi de que o aumento da massa de renda da economia como um todo, resultado da melhora dos preços de exportação, dos incentivos internos para investir e da ampliação e diversificação das atividades agrícolas. Com isso, Celso Furtado desfaz um dos mal-entendidos da interpretação liberal, que atribui a excessiva intervenção do Estado e emissão de moeda (para os liberais, a inflação é um problema monetário) ao interesse em beneficiar o setor industrial, tornando a inflação um mecanismo de poupança forçada. Com essa análise, portanto, o foco é deslocado da inflação como causa do aumento da capitalização do setor industrial para aparecer como a manifestação da disputa pelos recursos disponibilizados pela melhora de produtividade do setor industrial.

Isso leva ao primeiro ponto: qual a origem da persistente elevação dos preços na economia brasileira?

Celso Furtado observa o período de estabilidade no nível de preços entre 1947 e 1949 (adoção das medidas de seleção de importações), e sua aceleração em seguida. O principal fator nesse caso, argumenta, foi a elevação das receitas e, consequentemente, da renda do setor agropecuário, sobretudo a agricultura de exportação. Essa elevação da renda disponível, entretanto, ao não ser canalizada para o consumo de importados,

\footnotetext{
${ }^{484}$ Idem, p. 175.

${ }^{485}$ Idem p. 176.
} 
pressionou a oferta interna. Naquela conjuntura específica, explica, "em primeiro lugar, o aumento da oferta depende de importações, as quais exigem tempo para concretizarse. Em segundo, a necessidade de selecionar os pedidos dos importadores e a preferência às importações de bens de capital tornarão ainda mais longo o período requerido para aumento da oferta de bens de consumo". ${ }^{486}$

Com isso, já se pode perceber que o diagnóstico sobre a inflação que Celso Furtado irá propor recusa a interpretação monetarista. Ora, "a palavra inflação induz a esse erro [a separação entre elevação do nível de preços e redistribuição de renda], pondo em primeiro plano o aspecto monetário do processo, isto é, a expansão da renda monetária". ${ }^{487}$ Ao contrário, continua Furtado, "a inflação é fundamentalmente uma luta entre grupos pela redistribuição da renda real e que a elevação do nível de preços é apenas a manifestação exterior desse fenômeno". ${ }^{488}$ Esse diagnóstico, já presente em outros trabalhos, será comprovado por Celso Furtado, observando-se a economia brasileira a partir de 1949. De fato, a origem do conflito distributivo ocorre com a elevação dos preços do café, ocasionando um aumento da renda e da procura do setor exportador que se propaga para o conjunto da economia. ${ }^{489}$

Entretanto, essa elevação da renda não beneficia o setor exportador, pois, ao propagar-se para o conjunto da economia, desencadeia uma série de reações que "abrem oportunidade a outros grupos para absorverem uma parte do aumento da renda real". $\mathrm{Na}$ conjuntura de bloqueio de importações de bens de consumo, o resultado de aumento da renda passa a pressionar a oferta interna, seja de bens de consumo, seja de manufaturas. Com isso, ocorre um aumento dos investimentos e da renda nos setores industriais, que por sua vez, pelo mecanismo multiplicador, torna a pressionar o nível de preços. Ora, uma vez que o sistema bancário brasileiro atua de forma passiva, transferindo a liquidez gerada no setor externo para o conjunto da economia, o processo inflacionário se alastra. Mas, continua Furtado, não é o sistema bancário o responsável pela inflação, pois o desequilíbrio surge da pressão sobre a oferta interna. Houvesse o setor bancário contido a oferta monetária necessária para acompanhar o aumento da pressão e ele estaria, explicitamente, adotando uma política de favorecimento do setor exportador. Nessa análise, portanto, para além da explicação do funcionamento da inflação a partir

\footnotetext{
${ }^{486}$ Idem, pp .178-179.

${ }^{487}$ Idem, p. 179.

488 Idem, p. 181.

489 Celso Furtado observa: “essa elevação não pode, tecnicamente, ser qualificada de fenômeno inflacionário, uma vez que houve elevação concomitante da renda real”. Idem, p. 181.
} 
do resultado das transformações da economia brasileira a partir da crise de 1929 e as formas como ela foi enfrentada, Celso Furtado, ao compreendê-la sob a ótica de um conflito distributivo, conclui explicando quais setores uma política de contenção monetária beneficiaria.

Essa questão se complexifica ao considerar a situação da agricultura interna, que também tem que responder ao aumento de renda do setor exportador. Isso é dificultado, ainda, pois o aumento dos lucros neste setor tende a atrair fatores de produção da agricultura interna, influenciando em seu nível de preços, que responderá com novo aumento. Assim, "a forma como a agricultura se adapta a essa economia de mercado duplo, é em parte responsável pela instabilidade crônica da economia brasileira". 490 Disso resultam os crescentes desequilíbrios da economia brasileira em sua etapa de superação da economia colonial.

Neste diagnóstico fica patente, por um lado, a perda de mecanismos de ajustes importantes para a economia brasileira, bem como a contraposição e diversificação dos interesses econômicos. É a partir destes conflitos que se pode entender a real natureza da inflação: a tradução monetária de desequilíbrios no conjunto da economia brasileira. Dessa forma,

pretender alcançar essa estabilidade sem ter em conta a natureza e as dimensões do problema, que pode ser totalmente contraproducente do ponto de vista do crescimento da economia. E numa economia de grandes potencialidades e de baixo nível de desenvolvimento, a última coisa a sacrificar deve ser o ritmo do seu crescimento ${ }^{491}$

Assim, o diagnóstico de Celso Furtado sobre a economia brasileira atual, ao destacar o conjunto de desequilíbrios causados por fatores externos (balanço de pagamentos) e internos (inflação) são lidos como resultados de problemas estruturais, alguns dos quais poderiam ser remediados por uma política macroeconômica ativa, por exemplo: 1) continuação do processo de substituição de importações via incentivos à capitalização do setor industrial; 2) incentivos para a expansão e aumento da produtividade da agricultura interna. Entretanto, o que fica patente nesse diagnóstico é que as medidas só poderiam ser tomadas via planejamento econômico. Por outro lado, a complexificação da leitura sobre a inflação, não mais em seu aspecto monetário, mas como um conflito distributivo, ao um só tempo rebate teoricamente as interpretações

\footnotetext{
${ }^{490}$ Idem, p. 186.

${ }^{491}$ Idem, p. 187.
} 
monetaristas como coloca no horizonte que a resolução desse problema deve ser encontrada na esfera produtiva, no lado real da economia.

Ao final desse esforço explicativo da economia brasileira desde sua formação até a compreensão de seus problemas atuais, fica patente o caráter de intervenção direta no debate econômico que o livro propõe e que será mantido (e, em algumas partes, ampliado, mas não alterado), em Formação Econômica do Brasil. Dessa forma, embora grande parte da bibliografia já tenha indicado a relação entre os dois livros, procuramos argumentar, nesta parte, que não se trata unicamente de aproveitamento da redação, mas que o diagnóstico sobre a economia brasileira — iniciado, mas consideravelmente modificado, de "Características gerais da economia brasileira" - tem raízes no início dos anos de 1953, quando Celso Furtado está preocupado com as categorias gerais do desenvolvimento econômico, bem como defendendo a proposta de planejamento econômico da Cepal. Nesse sentido, mais do que buscar suas referências teóricas neste momento, sobretudo a Cepal e Keynes - quisemos demonstrar como a formulação do problema do desenvolvimento econômico ou, do subdesenvolvimento, através do fluxo de renda, da comparação entre as economias comerciais, industriais e coloniais foi de fundamental importância para iluminar as peculiaridades da economia brasileira. Por sua vez, aventamos a hipótese de que foi a partir delas, juntamente com a instrumentalização de conceitos cepalinos e keynesianos, que Celso Furtado construiu a interpretação sobre a crise dos anos de 1930, as formas de superação e o legado para economia brasileira, que deveria ser corrigido através do planejamento econômico.

Com isso, podemos aventar outro aspecto de nossa hipótese, de que o livro Formação econômica do Brasil é tão tributário dos trabalhos históricos de Celso Furtado quanto de suas reflexões sobre desenvolvimento econômico. A principal consequência disso é que a interpretação desse clássico de 1959 e de sua gênese não deve ser feita unicamente buscando-se as referências históricas de Celso Furtado, mas também e, quiçá, sobretudo, o desenvolvimento de sua teoria do subdesenvolvimento. 492

\footnotetext{
${ }^{492}$ A primeira dessas propostas foi feita em: SZMRECSÁNYI, Tamás. Sobre a formação da Formação econômica do Brasil de C. Furtado. Estudos Avançados 13 (37), 1999, pp. 207-214. Levantamos algumas considerações a respeito da relação entre os dois livros em: SILVA, Roberto Pereira. O jovem Celso Furtado. História, política e economia. Bauru-SP: Edusc, 2011.
} 
Olhado em perspectiva, o trabalho furtadiano iniciado com os comentários às conferências de Ragnar Nurkse foi desenvolvimento em A Economia Brasileira, sobretudo para dar maior densidade conceitual e explicativa à dinâmica do setor externo para a dinamização de uma economia subdesenvolvida. Para tanto, foi fundamental que ele recriasse (trata-se de uma recriação, pois é diversa de sua tese de doutorado) $a$ categoria de economia colonial, não a partir de uma teoria da colonização, mas elaborando uma comparação entre as economias comerciais e industriais, buscando demonstrar a dinâmica e os limites do setor externo. Daí que tenha assumido importância neste livro, em comparação à "Características gerais da economia brasileira”, a questão do surgimento da mão-de-obra assalariada. Esse aspecto, dinamizador efetivo do impulso externo para o conjunto da economia, é decorrente da comparação com as economias comerciais e industriais, e traz em seu bojo a marca da elaboração conceitual de Celso Furtado, que ultrapassa as influências cepalinas e keynesianas, que figuram de forma instrumental em sua teoria.

Finalmente, não esqueçamos, ainda, que esse esforço de teorização foi feito em disputa com outros economistas, e cujos problemas teóricos só poderiam ser resolvidos na interpretação do movimento recente da economia brasileira. Isso explica os três capítulos do livro se dedicarem a explicar os últimos cinquenta anos da economia brasileira.

Mas, ainda que se conteste esse caráter de disputa, é possível prosseguir argumentando neste sentido, uma vez que o último capítulo do livro, a ser analisado em seguida, é a cristalização do esforço de legitimação do diagnóstico, agora em termos teóricos.

Isso é feito de dois modos: primeiramente, retomando o texto da polêmica de Nurkse, mas retirando as referências diretas às conferências e, portanto, dando um acabamento estritamente teórico ao trabalho. Nesse sentido vejamos: foi possível a Celso Furtado retomar o texto, destituído de seu caráter de polêmica porque ele resolveu, ao longo de A economia brasileira, as principais lacunas teóricas e, sobretudo, elaborando uma melhor qualificação do funcionamento do setor externo em economias desenvolvidas (industriais) e subdesenvolvidas (coloniais). Esse andamento, de retomar uma discussão teórica após haver clarificado sua validade a partir da análise do presente, mostra o movimento dialético de Celso Furtado, no qual teoria e prática interagem, sendo que uma alimenta a outra. Isso significa, como iremos examinar mais a frente, que a ordem dos capítulos do livro poderia ser outra: da teoria (também do 
primeiro texto cronologicamente produzido) para a análise da economia brasileira. Dessa forma, também esse problema deverá ser discutido.

Por outro lado, há também um outro texto teórico neste livro, no qual Celso Furtado argumenta que a ciência econômica tradicional não é capaz de enfrentar conceitualmente o problema do desenvolvimento econômico, sendo necessária uma nova teoria econômica, a teoria que Celso Furtado está propondo. Dessa forma, para concluirmos a discussão de A economia brasileira, cabe perceber, agora, a forma como reincorporou o artigo de 1954, bem como a leitura do sub-item do sexto capítulo: $A$ teoria do desenvolvimento na ciência econômica.

\section{Intermezzo: de Formação de capital e desenvolvimento econômico a $O$ mecanismo do desenvolvimento.}

Diversos autores anotaram que Celso Furtado reaproveitou o texto em que polemizou com Ragnar Nurkse, retirando as referências mais diretas às conferências, mas guardando e em alguns casos aprofundando a discussão da teoria do desenvolvimento econômico. Com efeito, no artigo de 1952, Celso Furtado expressou sua insatisfação com a teoria proposta pelo economista estoniano, e aproveitou o ensejo das palestras da Fundação Getúlio Vargas para apresentar suas próprias ideias sobre o tema. Vimos, também, que Furtado retomou e assimilou algumas ideias de Nurke, de forma que seu texto não foi uma crítica incisiva, mas sim uma espécie de diálogo, paralelo, criticando alguns elementos quiçá subsidiários, e assimilando outros mais densos.

A republicação deste texto, agora com o título "O mecanismo do desenvolvimento" excluiu, também, a longa crítica à Schumpeter, inapropriadamente entendida como um pressuposto teórico de Nurkse, como vimos. No entanto, ela será reaproveitada, novamente, no segundo subitem do sexto capítulo de A economia brasileira, intitulado "A teoria do desenvolvimento econômico na ciência econômica". Celso Furtado também reescreveu, embora sem mudar seu sentido geral, a parte referente à intensidade do crescimento ${ }^{493}$, alterando a denominação "renda nacional"

\footnotetext{
493 A parte referente à intensidade do crescimento corresponde às paginas 208 a 211, o termo rendanacional em 208 e nas seguintes. Ver: FURTADO, Celso. Formação de capital e desenvolvimento econômico.
} 
para "renda territorial". ${ }^{494}$ A distinção, entretanto, não altera o argumento central, precisamente: a renda nacional/territorial não pode ser utilizada como único indicador do nível de acumulação de capital de um país. ${ }^{495}$ Entretanto, a parte final dos artigos têm diferenças mais fundamentais. Com efeito, Celso Furtado dedica a parte final de Formação de capital e desenvolvimento econômico examinando como o coeficiente de inversões, ao ocasionar um crescimento maior no produto final de que no consumo, é capaz de dar origem ao processo de desenvolvimento. Entretanto, nos países subdesenvolvidos, devido à forte propensão a consumir e ao efeito demonstração, grande parte do aumento da renda é convertido em consumo improdutivo. Disso, Celso Furtado concluiu que “o desenvolvimento espontâneo dos países subdesenvolvidos atuais se realiza com ritmo muito inferior ao que seria de esperar das potencialidades dessas economias e do progresso alcançado pela técnica". 496

Em seguida, passa a discutir a questão do investimento externo, um tema ao qual Nurkse dedicara sua última conferência. Esta parte, foi retirada do livro de 1954, e a discussão sobre o coeficiente de inversões chega a conclusões que apontam para outro caminho. Vejamos.

Celso Furtado afirma, que a taxa de capitalização (termo que substitui “coeficiente de inversão") não pode elevar-se além de certo nível, pois, numa economia de livre-empresa, é preciso que o crescimento crie seu próprio mercado. Ou seja, há um teto para a taxa de inversão, acima da qual ela não terá mercado correspondente. O que Celso Furtado nota, no entanto, é que "o teto da taxa de inversões parece haver-se elevado no Brasil, se comparamos o período de intenso crescimento recente (19481952) com outras etapas de rápido desenvolvimento da economia brasileira". ${ }^{497}$ Atribui esse fato, a uma diminuição da dívida externa e da propriedade de não-residentes no Brasil. Ou seja, se no texto de 1952 foi detectada uma desaceleração dos investimentos num período de aumento da renda, agora Celso Furtado detecta uma elevação da taxa de investimentos no país, resultado de uma ampliação da renda territorial.

\footnotetext{
${ }^{494}$ Celso Furtado escreve uma nota para explicar a distinção: "a renda territorial é a renda total gerada em um dado território, diferenciando-se da renda nacional, que, a rigor, é a renda dos nacionais de um dado país. Assim, a renda territorial brasileira inclui a renda das companhias estrangeiras que operam no país e exclui a renda das companhias brasileiras que operam no estrangeiro. Na análise do desenvolvimento econômico é de toda conveniência tratar dos conceitos territoriais". FURTADO, Celso. A economia brasileira (contribuição à análise de se desenvolvimento), op. cit., p. 201, n.1.

${ }^{495}$ Discutimos isto no capítulo 1.

${ }^{496}$ FURTADO, C. Formação de capital e desenvolvimento econômico. Op. cit., p. 213.

${ }^{497}$ FURTADO, C. A economia Brasileira. op. cit., p. 208.
} 
De fato, esse diagnóstico pode estar balizado, também, na implantação de projetos de desenvolvimento econômico que estavam no horizonte em 1951 e começavam a avançar em 1953, sobretudo, a partir da Comissão Mista Brasil-Estados Unidos e do Convênio Cepal-Bnde, este último dirigido por Celso Furtado e que servirá de base para o Plano de Metas.

Se nossa percepção está correta, é possível explicar a alteração deste texto "teórico" para captar as injunções e a conjuntura do presente, de forma que a teoria serve de base para estes diagnósticos, ao mesmo tempo em que é modificada por eles.

Por outro lado, se atentarmos para estrutura de A Economia Brasileira, essa dialética fica explícita na própria organização do livro. Como vimos, os dois primeiros capítulos empreendem um esforço de derivar historicamente as categorias e os conceitos para explicar o desenvolvimento econômico, aí incluído o funcionamento da economia colonial brasileira. Os três seguintes fazem um exame das transformações da economia brasileira desde finais do século XIX até o início dos anos de 1950. O sexto e último capítulo, "Formulação teórica do problema do crescimento econômico", é composto de duas partes. A primeira é o reaproveitamento de "Formação de capital $e$ desenvolvimento econômico". A segunda, por sua vez, intitulada "A teoria do desenvolvimento na ciência econômica", apresenta um exame da história do pensamento econômico, desde os clássicos dos séculos XVIII, inquirindo como os economistas pensaram o desenvolvimento econômico.

Sem procurar adiantar as conclusões, passemos ao exame desta última parte do livro, intitulada A teoria do desenvolvimento na ciência econômica, e que apareceu como segundo parte do capítulo VI, Formulação teórica do problema do crescimento econômico.

\section{Completando o aprendizado: A teoria do desenvolvimento na ciência econômica}

Antes de adentrar no tema propriamente dito, Celso Furtado tece alguns comentários que procuram desenvolver aspectos discutidos no prefácio, sobretudo a relação que se pode estabelecer entre história e teoria econômica no exame específico do desenvolvimento econômico. 
Retomando a consideração de que a teoria do desenvolvimento tem como objetivo central explicar "o processo de expansão da produtividade do fator trabalho", Celso Furtado explica que este objetivo deve ser perseguido em dois planos:

No primeiro - que poderíamos chamar de plano abstrato - cabe analisar o mecanismo propriamente dito do processo de crescimento. No segundo, que seria o plano histórico - tem lugar o estudo crítico, em confronto com a realidade, das categorias básicas utilizadas na análise abstrata. Não basta construir um modelo abstrato e explicar como ele funciona. É indispensável, ademais, criticar em termos de realidade histórica, as variáveis estratégicas desse modelo. A duplicidade fundamental da ciência econômica - seu caráter abstrato e histórico - aparece, assim, com toda a plenitude na teoria do desenvolvimento econômico. ${ }^{498}$

Aqui podemos encontrar, com variações, o problema que preocupa Celso Furtado desde o final dos anos 1940 e que se apresenta como a relação entre história e teoria econômica. Agora, ela aparece a partir de uma problemática específica: a teoria do desenvolvimento econômico. Ao distinguir entre o caráter abstrato e o histórico, inevitavelmente pensamos no próprio livro A economia brasileira e nos procedimentos que adotou em sua escritura. De fato, os capítulos 1 e 2 poderiam ser considerados capítulos mais abstratos, muito embora uma abstração pura dificilmente encontra-se neste livro. Por sua vez, a primeira parte do sexto capítulo, também pode ser considerada um esforço abstrato. Mas, aqui também, já vemos como Celso Furtado procurou superar essa dicotomia pois, ao examinar a economia colonial brasileira, o próprio funcionamento desta já está inserida em seu desenrolar histórico. Por sua vez, os capítulos históricos, o exame do desenvolvimento da economia brasileira em sua superação da posição colonial não traz um "confronto com a realidade, das categorias básicas utilizadas na análise abstrata”, pois as categorias já nasceram imbuídas de temporalidade. Nesse sentido, ao mesmo tempo em que delimita o problema, Celso Furtado já ofereceu uma forma de superá-lo. No entanto, a ordem de apresentação não é decorrente de modéstia ou timidez teórica, mas sim, uma estratégia para adentrar no cerne de sua problemática, a saber, a crítica ao universalismo da ciência econômica e a necessidade de elaboração de teorias específicas para dar conta de realidades subdesenvolvidas. Daí enfatizar que o economista trabalhe unicamente no plano

\footnotetext{
${ }^{498}$ FURTADO, Celso. A economia Brasileira. op. cit., p. 211.
} 
abstrato, "essa generalidade induz o analista a emprestar validez universal às teorias que formule, se bem que a base de suas observações seja extremamente limitada". 499

Mas, não é somente uma escolha teórica entre abstração e história que origina esta dicotomia. Ao contrário, ela é uma imposição do próprio objeto de pesquisa. De fato, "o problema da natureza abstrata ou histórica do método com que trabalha o economista não é independente, destarte, da natureza dos problemas que o preocupam". Isso deve ser levado em consideração, sobretudo, pois "o desenvolvimento econômico é essencialmente um fenômeno histórico". 500

Ora, aqui, também, está reformulada uma questão já levantada no texto Formação de capital e desenvolvimento econômico, de que "uma teoria científica pressupõe a existência de um ou mais problemas cuja solução é motivo de preocupação de algum grupo social". ${ }^{501}$ É preciso, portanto, detectar um problema, a partir de condições objetivas da sociedade e dos grupos sociais e entender sua natureza para, em seguida, procurar formas de compreendê-lo teoricamente. Nesse sentido, Celso Furtado destaca que o aspecto histórico é intrínseco, constitutivo da problemática do desenvolvimento econômico, esclarecendo que não é possível atingir sua natureza e características unicamente do ponto de vista abstrato.

Mas, entendamos. Essa característica não levou Celso Furtado a fazer uma reconstituição histórica do processo de desenvolvimento econômico. Ao contrário, o que vimos foi um esforço para captar, historicamente, as categorias gerais do processo de desenvolvimento. Esse ponto também recebe uma reflexão:

não se deduza do que vimos de dizer, entretanto, que o economista deva limitar-se a uma simples descrição de casos históricos. Jamais ele lograria compreender o verdadeiro papel que desempenham as flutuações da procura externa do açúcar no processo de formação de capital da economia cubana se não dispusesse de um instrumental analítico adequado, o que não poderia existir se a ciência econômica não houvesse alcançado certo gral de universalidade na definição de uma série de conceitos básicos ${ }^{502}$

Aqui, portanto, está a elaboração conceitual do próprio procedimento adotado por Celso Furtado em Desenvolvimento econômico - ensaio de interpretação históricoanalítico, bem como no livro A economia brasileira. Com efeito, ao apontarmos como

\footnotetext{
${ }^{499}$ Idem, p. 212. Celso Furtado usa como exemplo a teoria da renda da terra em Ricardo, cuja validade em "um condado da Inglaterra" não pode ser generalizada como uma "evidência universal".

${ }^{500}$ Idem, p. 213.

${ }^{501}$ FURTADO, Celso. Formação de capital e desenvolvimento econômico. op. cit., p. 196. Reaparece em: FURTADO, C. A economia brasileira. op. cit., p. 191.

502 Idem, p. 213.
} 
nessa derivação das categorias centrais para o desenvolvimento econômico, alguns elementos históricos foram deixados de lado - tal como a questão da expansão marítima do século XV e a integração dos espaços africanos, asiáticos e americanos à economia europeia —, quisemos chamar atenção para o propósito específico de Celso Furtado: encontrar os conceitos e as categorias que lhe permitissem compreender o processo de desenvolvimento econômico. Dessa forma, repetimos, o recurso à história foi feito não com o intuito de reconstituição, mas partindo de uma problemática específica - o desenvolvimento econômico — aplicada a um caso também restrito — a economia brasileira em seu desenvolvimento histórico. Assim, podemos perceber melhor as opções teóricas de Celso Furtado e como elas aparecem aplicadas em seus textos. Por sua vez, fica mais compreensível o sentido das afirmações que fizera no prefácio, a respeito do posicionamento e do corte em momentos específicos para analisar o funcionamento dos sistemas econômicos, de maneira que a história entraria como elemento subsidiário na análise. Dessa forma, tendo como elemento norteador a problemática do desenvolvimento irá reler a história do pensamento econômico.

Primeiramente, Celso Furtado identifica como o problema do desenvolvimento econômico apareceu na teoria econômica. A indagação não é trivial, uma vez que esta questão, como ele mesmo reconhece, surgiu apenas no século XX. Dessa forma, cabe se perguntar, será possível identificar, a partir de problemáticas diversas, elementos que possam subsidiar uma teoria do desenvolvimento econômico?

Para responder esta pergunta, retoma a característica central do desenvolvimento, qual seja, o aumento de produtividade. Mas, lembremos, a elevação ocorrendo não "nesta ou naquela empresa", mas sim "aqueles aumentos que se traduzem em elevação da produtividade do conjunto da economia". ${ }^{503}$ Pois bem, uma vez que se considere "produtividade como produção por unidade de tempo e produtividade social como produto total por unidade de tempo de ocupação da força de trabalho, vemos que a teoria do desenvolvimento não é outra coisa senão um aspecto da teoria da produção". Dessa forma, "ao formularem a teoria das variações a longo prazo da produção os economistas estariam, portanto, subministrando-nos uma teoria do desenvolvimento econômico". 504

\footnotetext{
${ }^{503}$ Idem, p. 214. Mais adiante, "não se deve, portanto, confundir aumento de produtividade — no plano microeconômico - com desenvolvimento, o qual dificilmente se poderia conceber sem elevação da renda real per capta". Idem, p. 215.

${ }^{504}$ Idem, p. 215.
} 
Entretanto, argumenta Furtado, “a grande maioria dos economistas não só não se preocuparam com esse tipo de problema, como algumas vezes declararam explicitamente que os mesmos escapam aos objetivos da ciência econômica", referindose à Edwin Cannan. ${ }^{505}$ Algumas exceções seriam Adam Smith, que encarou os aumentos de produtividade como resultados da divisão do trabalho. Ricardo, por outro lado, "concentrou-se totalmente no estudo dos problemas relacionados com a distribuição". 506 No entanto, argumenta, "o problema da produção, relegado a segundo plano, vai, entretanto reaparecer na ciência econômica, entrando pela porta dos fundos, conforme veremos". 507 Reaparecerá, paradoxalmente, para demonstrar que "o desenvolvimento que se observava era um fenômeno fugaz". ${ }^{508}$ De fato, os economistas clássicos, ao dividirem os elementos da produção em terra, capital e trabalho, atribuíram a produção de valor unicamente a este último. A quantidade de trabalho realizado era função da acumulação de capital e, o nível do salário, por sua vez, dependente do capital disponível e da oferta de trabalho. Nessa concepção, entretanto, ao crescer o uso de equipamento e aumentar a relação capital fixo/variável, o valor criado por operário diminuiria, levando a um decréscimo da taxa de lucros. Dessa forma, Celso Furtado identifica, nessas teorias, a ausência de uma reflexão sobre o papel do progresso técnico. Com efeito, para J. S. Mill, o progresso técnico retardaria a "vinda do estado estacionário, mas não pode evita-la". Para Ricardo, o progresso técnico seria “o meio de defesa da classe capitalista contra a elevação dos salários". Ou seja, ao vincularem a teoria do valor trabalho à ideia de equilíbrio entre acumulação de capital e nível de salários, os economistas clássicos viram no progresso técnico apenas um instrumento de luta entre os industriais e arrendatários e não conseguiram enquadrá-lo numa teoria do desenvolvimento econômico, ou numa teoria da produção. Dito de outro modo, ao abordarem o problema de forma secundária, ou "pela porta dos fundos", os economistas clássicos não conseguiram desenvolver um corpo de conceitos para pensar o desenvolvimento econômico.

Em seguida, Celso Furtado vai investigar o mesmo problema nos "economistas neoclássicos”. Definida pelo esforço dos economistas, no último quartel do século XIX em superar os problemas herdados da teoria do valor trabalho, a economia neoclássica caracterizou-se pela criação de "um instrumental analítico novo", a reformulação "de

\footnotetext{
505 Idem, p. 216.

${ }^{506}$ Idem, p. 216.

${ }^{507}$ Idem, ibidem.

${ }^{508}$ Idem, p217.
} 
uma série de conceitos", culminando na "teoria do equilíbrio geral". ${ }^{509}$ Nela, "o enfoque distributivista vai dominar ainda mais fortemente que entre os clássicos". Procurando sair dos problemas da teoria do valor-trabalho, os neoclássicos negaram a existência de um excedente econômico que pudesse ser apropriado pelos trabalhadores. Para eles, os salários não eram determinados pela oferta e demanda da força de trabalho, mas sim, um pagamento exato pela participação do trabalhador no processo produtivo, ou seja, pela disponibilidade relativa de fatores. ${ }^{510}$ Nesse sentido, o aumento do estoque de capital, ou da acumulação de capital promove aumentos na produtividade do trabalho e, com isso, elevações nos salários reais. Ora, uma vez que o estoque de capital é dado pela oferta e a procura de capital, confundindo-se, portanto, com a taxa de juros, "a teoria do desenvolvimento que se pode extrair do modelo neoclássico é simples e se formula como segue: o aumento de produtividade (que se reflete na elevação do salário real) é uma consequência da acumulação de capital, a qual, por sua vez, está na dependência da taxa antecipada de remuneração dos novos capitais". ${ }^{511}$ Nesse ponto, segundo Celso Furtado, os neoclássicos recolocam o problema da estagnação pois, o aumento dos salários reais diminui a lucratividade do capital, ao passo que a queda da taxa de juros do capital desestimularia a poupança, comprometendo a acumulação. ${ }^{512}$

Dessa forma, Celso Furtado reencontra o problema da ausência de uma teoria da produção ou, da preocupação com "o conceito de progresso econômico". 513 Ao centrarse na oferta de poupança, não há uma explicação sobre o processo de desenvolvimento econômico. De fato, constata: "a explicação última do progresso econômico estaria na boa disposição de alguns cidadãos beneméritos para uma forma ou outra de sacrifício". Daí, também, que tenham surgido para explicar a relação entre oferta e procura de poupança, “os conceitos de espera (Marshall), sacrifício (Cassel)., etc., que em nada constituem progresso com respeito à abstinência de Senior”. ${ }^{514}$ Ou seja, por se preocupar com uma teoria do equilíbrio do sistema econômico, regulando a produção e o consumo a partir da taxa de juros, os economistas neoclássicos não investigaram o

\footnotetext{
${ }^{509}$ Idem, p. 221.

${ }^{510}$ Idem, p. 222. Vale ressaltar o cruzamento que Celso Furtado faz entre esta formulação teórica e a realidade econômica observada no final do século XIX: "essa construção tão abstrata e tão longe da realidade num mundo de desemprego como era o século XIX, surgiu aos economistas neoclássicos como a verdade científica irrefutável”. Idem, pp. 222-223.

${ }^{511}$ Idem, p. 224.

512 Daí a centralidade da taxa de juros na teoria neoclássica: "a taxa de juros está na cúpula do sistema do equilíbrio geral. Ela por um lado induz o sistema econômico a criar poupança, e por outro regula e submete às reais possibilidades do sistema os impulsos dos inversionistas". Idem, p. 225.

${ }^{513}$ Idem, p. 224.

${ }^{514}$ Idem, p. 226. Grifos de Celso Furtado.
} 
problema do desenvolvimento econômico, pois não adentraram no exame das formas de organização da produção e nem captaram as consequências da incorporação do progresso técnico. Ora, nesse exame das teorias clássica e neoclássica, é preciso esclarecer melhor os fundamentos da crítica de Celso Furtado. Primeiramente, quanto à formulação da problemática e o procedimento investigativo, não há nada de errado em revisar a história do pensamento econômico buscando elementos que permitam a elaboração de uma nova problemática, tal qual a do desenvolvimento econômico. No entanto, é preciso atentar para o recorte e a crítica que Celso Furtado faz destas duas escolas de pensamento. Ela partiu de dois pontos: primeiramente, uma teoria do desenvolvimento econômico poderia ser buscada se este fosse encarado a partir de uma teoria da produção. É a partir desta que se buscaria a problemática da acumulação de capital, bem como a forma como os recursos se distribuem entre a sociedade. O segundo ponto, correlato ao primeiro, refere-se ao papel do progresso técnico. Ora é a partir dessas duas ausências na economia clássica e neoclássica que Celso Furtado elabora sua crítica. Pois, também esses dois elementos derivam, como vimos, de sua formulação dos conceitos do desenvolvimento econômico. Eles são a base da caracterização da economia industrial. Esse sistema, como foi descrito, sobretudo no artigo "Desenvolvimento econômico (ensaio de interpretação histórico-analítico)", caracteriza-se pelo papel fundamental do progresso técnico como única forma de diminuir os custos e tornar endógena a acumulação de capital e os investimentos, tornando o crescimento algo automático nestas economias. Dessa forma, é precisamente essas características da economia industrial que os economistas do século XVIII e XIX (contemporâneos do processo de industrialização), não incluíram em sua teoria. Podemos perceber como o esforço de Celso Furtado, também neste momento de revisão dos fundamentos da ciência econômica, chama a atenção para a ausência de uma teoria do desenvolvimento econômico.

Entretanto, Celso Furtado dedica a maior parte do ensaio à teoria do empresário, exposta por Schumpeter, assunto que já fora objeto de reflexão no texto Formação de capital e desenvolvimento econômico.

Considera, primeiramente, o processo de acumulação de capital e sua transformação em produção e, consequentemente, em fonte de renda para quem o utiliza. A teoria neoclássica não apresentou uma teoria dos lucros, mas apenas o justificou. Nesse sentido, "Schumpeter representa um enorme progresso dentro da economia neoclássica. Ao pretender proporcionar-nos uma verdadeira teoria da 
formação do lucro, ele, se bem que permanecendo nos quadros da teoria do equilíbrio geral, provocou uma verdadeira subversão desta". ${ }^{515}$ Para o economista austríaco, a ação do empresário é capaz de "transformar o processo produtivo. É, portanto, na ação criadora do empresário que está o motor do progresso econômico". ${ }^{516} \mathrm{Ou}$ seja, com Schumpeter, ainda que se valendo do instrumental neoclássico, segundo Furtado, o processo produtivo passa a ser objeto de escrutínio, e sua teoria dos lucros é, também, uma teoria da produção, captada através da ação inovadora do empresário. Por outro lado, a "importância do progresso tecnológico como fator dinâmico da economia capitalista" ganha destaque na teoria schumpeteriana.

Entretanto, em que pesem esses avanços, continua Furtado, retomando as considerações sobre o economista austríaco já desenvolvidas no texto de 1952, sua teoria "está longe de nos dar uma explicação satisfatória do processo de desenvolvimento econômico". ${ }^{517}$ Um dos problemas da análise de Schumpeter é "sua falsa universalidade. O espírito de empresa surge como uma categoria abstrata, independente do tempo e de toda ordem institucional", ${ }^{518}$ aparecendo como unicamente "um complemento da teoria do equilíbrio geral". ${ }^{519}$ Celso Furtado, embora reconheça a preocupação com a questão do progresso técnico, considera a teoria de Schumpeter "mais uma teoria do lucro que uma explicação do progresso econômico". 520

Outro ponto de crítica foi "haver isolado o empresário do mundo em que este vive". Nesse ponto, Celso Furtado retoma o primeiro capítulo e o ensaio Desenvolvimento econômico, considerando as condições objetivas a partir das quais o empresário aumenta seu capital e o reinveste na produção. Celso Furtado assinala que "a inovação não é necessariamente um fruto do 'espírito de empresa' como o concebe Schumpeter. É muitas vezes o resultado do esforço das empresas para encontrar aplicações para os recursos que se lhes acumulam automaticamente". ${ }^{521}$ Ou dito de outra forma, o reinvestimento dos lucros no processo produtivo e a busca por inovações técnicas que reduzam os custos e aumentem a produtividade é algo normal, endógeno, das economias industriais. Como foi visto, neste sistema "o lucro é um elemento residual" e a forma mais evidente de ampliar esse lucro é a "redução dos custos".

\footnotetext{
515 Idem, p. 229.

${ }^{516}$ Idem, p. 231.

517 Idem, p. 231.

518 Idem, p. 231.

${ }^{519}$ Idem, p. 232.

${ }^{520}$ Idem, p. 232.

${ }^{521}$ Idem, p. 235.
} 
Assim, "a introdução de novas técnicas ou combinações encontra aí um grande estímulo". ${ }^{522}$ Com isso, Celso Furtado está situando o empresário inovador schumpeteriano no que denominou de economia industrial. Ao mesmo tempo em que critica o universalismo da teoria de Schumpeter e o caráter a-histórico que atribui ao empresário e às inovações, corrobora as características da economia industrial que examinara: sobretudo o problema da redução dos custos como um fator que cria um processo de auto-propulsão da economia, e o papel importante que a técnica assume nessas economias.

Outro ponto examinado é a questão do elemento dinâmico no processo de desenvolvimento. Enquanto Schumpeter localiza este na inovação, Furtado considera que a acumulação de capital é o fator importante para desencadear e manter esse processo. Isso, pois, “acumular capital, significa, as mais das vezes, difundir em um setor ou estender a novos setores uma técnica superior já disponível". ${ }^{523}$ Dessa forma, relaciona a acumulação de capital e sua aplicação ao processo produtivo com suas repercussões no fluxo de renda, a exemplo que do que veio fazendo ao longo de todo o livro. Por outro lado, ressalta que as inovações pressupõem acumulação de capital, bem como condições específicas para que tal inovação seja aceita e se propague para o conjunto da economia. ${ }^{524}$

Dessa forma, argumenta Furtado, "uma teoria do desenvolvimento tem que ter por base uma explicação do processo de acumulação de capital”. ${ }^{525} \mathrm{Com}$ isso, reforça a crítica à Schumpeter, como também justifica sua proposição de que o desenvolvimento é um fenômeno eminentemente histórico. Ora,

o processo de acumulação de capital não pode ser explicado com uma formulação puramente abstrata, pois está intimamente ligado à forma por que se organiza a produção. E não somente isso: é indispensável descer à observação de cada caso concreto pois não existem duas economias com tão grandes similitudes que seja factível esperar delas reações idênticas diante de uma determinada situação. Não há dúvida que existe uma série de categorias comuns a todas as economias, e um

\footnotetext{
522 Idem, ibidem.

${ }^{523}$ Idem, p. 236.

${ }^{524}$ Utilizando o exemplo do tear automático, Celso Furtado elabora uma série de ressalvas ao caráter espontâneo e individual da inovação: "a introdução de um tear automático numa economia não é um puro ato de inovação, pois exige a convergência de determinadas condições que a justifiquem economicamente. Tanto é assim que muitos anos depois da aparição do tear automático ainda se continua a fabricar teares manuais, os quais são preferidos em determinadas economias. Para que o tear automático seja mais econômico é necessário que os salários tenham alcançado determinado nível, o que pressupõe para o conjunto da economia um certo avanço no grau de acumulação de capital”. Idem, p. 236.

${ }^{525}$ Idem, p. 237.
} 
número ainda maior de outras comuns a certos grupos de economia. $\mathrm{E}$ é somente por isso que existe uma ciência econômica ${ }^{526}$

Aqui, portanto, podemos ver uma clara justificação do método que Celso Furtado desenvolveu ao longo do livro, concomitante a uma crítica à Schumpeter. De fato, ao reforçar sua argumentação a respeito do caráter histórico do desenvolvimento, o que não exclui, evidentemente, as categorias generalizáveis da ciência econômica, coloca-se como portador de uma explicação para o desenvolvimento econômico que pretende superar os problemas apresentados pela teoria do economista austríaco. Nesse sentido, embora essas categorias generalizáveis, "apenas nos capacita para descrever alguns mecanismos gerais do processo econômico", Celso Furtado detalha seu método e expõe os principais problemas da teoria do desenvolvimento econômico, justificando suas opções conceituais:

a teoria do desenvolvimento tem que baixar ao plano histórico, o qual comporta o agrupamento das economias de acordo com certas categorias relevantes no caso. É nesse sentido que falamos de economias desenvolvidas e subdesenvolvidas; de economias autônomas e dependentes, etc. Consequentemente, a teoria do desenvolvimento, após haver sido apresentada em termos muito gerais, para adquirir maior precisão deverá assumir formulações especiais relativas a determinados processos históricos de desenvolvimento. Assim, quando nos reportamos hoje em dia à teoria do desenvolvimento, referimo-nos aos problemas específicos daquelas economias, tais as latino-americanas, que permaneceram atrasadas com relação às demais economias que se desenvolveram nos últimos 150 anos. Seria totalmente irreal assimilar os problemas dessas economias àqueles que conheceram outras, atualmente mais desenvolvidas, em etapas anteriores de seu crescimento ${ }^{527}$

Aqui, portanto, percebemos que no cerne de suas reflexões está a distinção entre economias desenvolvidas e subdesenvolvidas que, como vimos, diferem pela forma como incorporam aumentos de produtividade. Mais ainda, destaca a inexistência de uma teoria do desenvolvimento geral e universal, que valesse para qualquer tipo de economia. Daí, também, que suas considerações refiram-se, precisamente, às economias latino-americanas, incorporando em sua própria metodologia o pressuposto da especificidade. Finalmente, uma última consideração importante refere-se à caracterização que faz das economias subdesenvolvidas e sua peculiaridade em relação aos estágios anteriores das economias desenvolvidas. Essa afirmação, ainda que não se aproxime de sua formulação da diferença histórica entre países desenvolvidos e

\footnotetext{
${ }^{526}$ Idem, p. 237.

${ }^{527}$ Idem, p. 238.
} 
subdesenvolvidos e os limites que os primeiros impõem aos segundos, já deixa patente sua preocupação em conceituar as economias subdesenvolvidas como um tipo específico.

Por sua vez, o texto vai assumindo, cada vez mais, uma característica polêmica. De fato, sutilmente Celso Furtado passa a considerar o uso que os economistas fazem das teorias disponíveis e se este uso é o mais adequado. Para ele, é preciso perceber que "uma teoria só se justifica quando nos arma para conhecer e explicar a realidade. A aplicação de qualquer teoria exige um trabalho preliminar de 'identificação de problemas"”. Por vezes, prossegue, o erro está nesta identificação, ou seja, no diagnóstico. O exemplo utilizado por Celso Furtado é revelador:

\begin{abstract}
admite-se, por exemplo, em abstrato, o princípio do livre-câmbio; em seguida se condena a industrialização de um país subdesenvolvido porque, dado o baixo nível de produtividade relativa das novas indústrias estas não resistem à concorrência externa e, portanto, são artificiais. O erro aí não está em aceitar ou não o princípio do livrecambismo, e sim na identificação do problema, o qual consiste em saber se, dadas as condições de livre-cambismo, é ou não vantajosa a instalação de uma certa indústria em certo país. O problema consiste em saber se, dadas as condições que prevalecem no mundo real - as quais não têm nada que ver com o livre-câmbio — justifica-se ou não, etc. ${ }^{528}$
\end{abstract}

A escolha do livre-cambismo e sua contraposição à industrialização dos países subdesenvolvidos evidencia a polarização do debate econômico brasileiro. No exemplo utilizado, ainda que não conteste a doutrina liberal em si, dirige a crítica àqueles economistas que a tomam por referência para o diagnóstico e a proposição de política econômica. Esses economistas erram ao diagnosticar o problema das economias subdesenvolvidas, que não é uma questão de adequação ou não ao livre-cambismo em detrimento das atividades produtivas, mas sim — e este é o sentido do "etc" com que termina a citação — de implantação de um parque industrial para diminuir a dependência de importações, a especialização produtiva em bens primários como única forma de obtenção de divisas, bem como a criação de mercado interno de bens de consumo assalariado, que também impulsionaria uma diversificação e ampliação da agricultura interna. ${ }^{529}$ Dessa forma, a partir de um exemplo de equívoco entre

\footnotetext{
${ }^{528}$ Idem, p. 239.

${ }^{529}$ Celso Furtado amplia ainda mais o tom da crítica: "quem estuda a história econômica se surpreende a cada passo com a luta do sentido comum contra a falsa ciência. Tivessem os governantes de muitos países, e entre estes o Brasil, seguido à risca os conselhos daqueles que se supunham conhecedores da ciência econômica, e esses países provavelmente se teriam desenvolvido muito menos. Essa observação
} 
identificação de diagnóstico e aplicação da teoria econômica, Celso Furtado não apenas dirige a crítica aos economistas liberais mas, ao mesmo tempo, contrapõe o diagnóstico apresentado ao longo do livro, este sim capaz de identificar os problemas da economia brasileira.

Entretanto, a crítica fica um tanto quanto diluída na sequência do texto, ao retomar a problemática da teoria econômica. Celso Furtado novamente ressoa algo já afirmado em suas resenhas de final dos anos 1940. Para ele, o problema entre abstração e realidade histórica

reflete o choque - que em economia é maior que em qualquer outra ciência - entre a possibilidade de generalizar e a capacidade de explicar. Deve-se isto ao fato de que o economista, para não perder o 'rigor científico' e a elegância expositiva, refugia-se num elevado plano de generalidade, no qual os problemas concretos quando aparecem perde completamente seus contornos e se transformam em imagens vagas ${ }^{530}$

Nessa afirmação está patente que a explicação e a compreensão dos problemas econômicos não devem estar subordinadas aos preceitos das teorias econômicas, mas devem adaptar-se ao objeto que pretende explicar. Do contrário, a realidade é falseada e o princípio teórico que, como vimos, é um guia, torna-se um elemento abstrato e perde sua função compreensiva. Nesse sentido, Celso Furtado finaliza afirmando: "o que é totalmente anticientífico é pretender preservar a todo custo uma teoria e transformá-la em um leito de Procusto para os problemas que transbordam de seus limites". ${ }^{531}$ Ora, levando em consideração todo o esforço compreensivo exposto em A Economia Brasileira, Celso Furtado deixa implícito que sua proposta não incorreu nesses métodos anticientíficos.

Tendo intercalado sua exposição e crítica à teoria de Schumpeter com um conjunto de reflexões sobre os métodos e objetivos da teoria econômica, bem como suas possibilidades, condições e formas de apropriação e aplicação pelos economistas, cabenos, ainda, perguntar sobre o sentido e o ordenamento dessas considerações no conjunto do texto. Expliquemos: o objetivo de Celso Furtado neste item, perceber como a história do pensamento econômico refletiu sobre o desenvolvimento não se encerra com o exame da obra do economista austríaco mas, ainda assim, esse objetivo foi de certa forma interrompido pelas considerações sobre a relação entre história e teoria

se aplica inclusiva a países como os Estados Unidos e a Austrália, para ficar apenas com aqueles que liam em sua língua os livros dos economistas ingleses". Idem, p. 239.

${ }^{530}$ Idem, p. 230 ..

${ }^{531}$ Idem, p. 240. 
econômica. Somos levados a pensar que esse procedimento corrobora nossa interpretação de que esse exame do pensamento econômico tem o objetivo de justificar o próprio trabalho teórico, metodológico e de análise da conjuntura da economia brasileira que Celso Furtado vem fazendo. Por outro lado, o aparecimento dessas considerações justamente ao examinar a obra de Schumpeter pode revelar o propósito de ampliar as críticas a uma das teorias mobilizadas pelos liberais brasileiros, como por exemplo, Otávio Gouveia de Bulhões, na polêmica sobre planejamento econômico que acompanhamos. Se nossa hipótese estiver correta, ela também pode justificar a ênfase que a crítica à teoria do empresário e dos lucros recebeu na polêmica com Ragnar Nurkse, uma vez que há uma concordância de fundo entre o economista estoniano e Celso Furtado a respeito do caráter restrito aos países desenvolvidos das teorias de Schumpeter.

Voltemos, no entanto, ao texto de Celso Furtado.

A última teoria examinada é chamada de "'maturidade' econômica". Para ele, é "um caso típico de teoria especial no campo do desenvolvimento", pois, a partir da “explicação do desemprego", nos países desenvolvidos, surgiu "uma teoria do desenvolvimento". Seu principal formulador foi Alvin Hansen, na esteira do pensamento keynesiano. ${ }^{532}$ Para Keynes, a dinâmica econômica é dada pelo investimento. No entanto, este, assim como as decisões dos empresários, não levam em conta apenas os fatores disponíveis da economia, mão-de-obra incluso, mas sobretudo sua expectativa em relação à "capacidade de absorção do mercado", 533 ou, nos termos do economista inglês, a procura efetiva. Uma vez que o crescimento "é principalmente influenciado pelas oscilações no volume das inversões", "sempre que numa economia o impulso para inverter não seja suficientemente forte para absorver toda a poupança que se forma, haverá desemprego". ${ }^{534}$ Dessa forma, somente em condições excepcionais, expectativa de expansão da demanda, baixa na taxa de juros e aumento das inversões, a economia alcança o pleno emprego, ou seja, utiliza todos os fatores produtivos. Do contrário, ela procura um equilíbrio com desemprego. Nesta explicação dos fatores dinâmicos da economia e do nível de desemprego atingido nos anos de 1930, Keynes, investigando os fatores que induzem o empresário a investir, abriu caminho para a

\footnotetext{
${ }^{532}$ Idem, p. 240.

${ }^{533}$ Idem, p. 241.

${ }^{534}$ Idem, p. 242.
} 
considerações de longo prazo, permitindo o surgimento de uma teoria do desenvolvimento.

Alvin Hansen, ao examinar a crise dos anos trinta, lança uma explicação que vai além da questão da insuficiência da procura efetiva. Examinando o desenvolvimento econômico no século XIX, destaca como fatores importantes para estimular o investimento: o deslocamento da fronteira agrícola, crescimento da população e progresso técnico. No século XX, ao contrário, assiste-se a um declínio da população em idade produtiva e de estabilização das fronteiras. Esses fatores, ao reduzir o estímulo ao progresso técnico, direciona-o para o aumento da produtividade do capital, em detrimento do trabalho.

Para Celso Furtado, esta teoria tem valor unicamente como um "caso especial", pois suas "limitações são mais ou menos evidentes", de forma que "pretender atribuirlhe universalidade seria totalmente equívoco, pois, em muitos países, nos anos trinta, a fronteira ainda não estava estabilizada, a população continuava crescendo com intensidade e, o que é mais importante, a economia de tipo capitalista ainda não havia absorvido a totalidade da população existente". Dessa forma, conclui, "suas dimensões históricas [da teoria de Hansen] estão perfeitamente definidas". ${ }^{535}$ Cumpre notar, no entanto, que ao restringir o alcance da teoria da "maturidade econômica", Celso Furtado está colocando em cheque o desenvolvimento mais recente da teoria econômica, que orientara, inclusive, a recuperação econômica dos EUA, e se constituiu em referência importante para os trabalhos da Cepal. Mais, alguns aspectos da teoria keynesiana foram incorporados inclusive na análise de Celso Furtado sobre a economia cafeeira, utilizando-se do mecanismo do multiplicador e tomando-a como referência de política anticíclica. Esta crítica tem, também, outro aspecto que precisa ser destacado. Ao localizar historicamente a realidade que procura explicar, a teoria não poderá explicar os países subdesenvolvidos, a menos que seja submetida a uma crítica de seus pressupostos. Essa avaliação corrobora o projeto furtadiano de revisão do pensamento econômico pois, ao relativizar o keynesianismo enquanto uma teoria do desenvolvimento, ressalta o aspecto inovador da própria teoria e interpretação do movimento recente da economia brasileira que o livro traz. Dessa forma, podemos compreender a revisão da teoria do desenvolvimento econômico como uma justificativa para os argumentos apresentados por Furtado ao longo de A economia brasileira.

${ }^{535}$ Idem, p. 244. 
Isso fica patente nas páginas finais do livro, em que destaca, uma vez mais, que "o problema do desenvolvimento econômico ocupou sempre um segundo plano na ciência econômica". ${ }^{536}$ A principal consequência da inexistência de uma teoria específica para os problemas dos países subdesenvolvidos aparece no diagnóstico e na proposição de políticas econômicas equivocadas. Para Furtado:

\begin{abstract}
as atenções dos economistas, até o presente, têm-se concentrado nos problemas relativos à repartição do produto social, às flutuações do nível dos preços e à insuficiência periódica do grau de ocupação da capacidade produtiva. A análise desses problemas tem levado, uma vez ou outra, algum teórico a tecer considerações marginais sobre o problema do crescimento a longo prazo. E de uma maneira geral essas considerações têm conduzido antes à formulação de uma teoria da estagnação que do desenvolvimento ${ }^{537}$
\end{abstract}

A necessidade de uma teoria do desenvolvimento econômico surge, aqui, com vigor, uma vez que tem sido apagada por considerações de curto prazo. Entretanto, ao criticar esses diagnósticos, Celso Furtado ancora-se dentro dos problemas da própria teoria econômica, pois, como vimos, tanto as teorias clássicas, neoclássicas e keynesianas apontam para a inevitabilidade da estagnação. É contra a avaliação de estancamento, no período em que algumas economias da América Latina estão se industrializando e alcançando índices consideráveis de crescimento econômico que Furtado pergunta: "de onde arrancaram os economistas essa ideia de estagnação se a realidade tem sido totalmente outra? Aparentemente ela é uma resultante das insuficiências das próprias formulações teóricas." ${ }^{538}$ Com isso, desvela a relação causal entre a filiação aos preceitos teóricos e os diagnósticos equivocados sobre os problemas dos países subdesenvolvidos. Dito de outra forma, por se prenderem a formulações teóricas que não dão conta dos problemas do desenvolvimento, por utilizarem instrumentais analíticos que têm como corolário a estagnação, os economistas não conseguem captar o movimento geral da economia atual nem, sobretudo, diagnosticar e implementar políticas econômicas que ampliem o desenvolvimento. Em suas palavras

antes de abandonar seus preconceitos e posições estabelecidas a priori, os economistas de maneira geral vêm preferindo aceitar a ideia milenária de uma tendência à estagnação. Essa atitude é responsável pelo atraso dos trabalhos de caráter científico com enfoque direto nos problemas do desenvolvimento. $\mathrm{O}$ grande esforço que atualmente se

\footnotetext{
${ }^{536}$ Idem, p. 245.

${ }^{537}$ Idem, p. 245.

${ }^{538}$ Idem, p. 245.
} 
realiza para sanar essa enorme lacuna poderá abrir perspectivas inteiramente novas à ciência econômica. ${ }^{539}$

Com isso, também, fica explícita a inserção de A Economia Brasileira. Sob o ponto de vista teórico, procurou apresentar em termos históricos as principais categorias que utilizou para compreender o desenvolvimento econômico. Esse esforço resultou numa tipologia dos principais tipos de economia: comercial, industrial e colonial. A partir da comparação e da identificação das inter-relações entre elas, examinou o desenvolvimento da economia brasileira, enfatizando o período compreendido entre o final do século XIX e os anos de 1950. Neste exame, demonstrou como as categorias anteriormente derivadas foram aplicadas para uma análise histórica específica. Somente após a construção dessa interligação entre conceitos e análise histórica, apresentou aspectos mais gerais para uma teoria do desenvolvimento econômico. Esta teoria, por sua vez, foi justificada a partir de um vazio teórico na história do pensamento econômico e na ineficácia real de sua aplicação para as economias subdesenvolvidas. Nesse sentido, o livro desvela todo seu caráter de intervenção no debate econômico nos inícios dos anos de 1950.

Por sua vez, vale nos determos, um pouco mais, na estrutura e organização de $A$ Economia Brasileira. Com efeito, o fechamento do livro com um capítulo teórico subdividido em duas partes, uma sobre desenvolvimento econômico e outra revisando a história do pensamento econômico procurando a formulação teórica deste problema é contra-intuitiva, mas não inesperada. De fato, por que não iniciar o livro com a discussão teórica mais geral e, em seguida, dotar de ossatura histórica os princípios da teoria do desenvolvimento econômico? Ou, por outro lado, por que não fazê-los de forma concomitante, apresentando problemas teóricos e examinando-os em casos concretos, como, ademais, boa parte dos trabalhos de teoria do desenvolvimento?

Ora, se nossa argumentação está correta, há a preocupação de Celso Furtado em intervir no debate sobre desenvolvimento econômico e nos diagnósticos da economia brasileira. Foi esse propósito que, como vimos, orientou suas intervenções anteriores, seja a discussão com Nurkse - que, a bem da verdade, era um diálogo com os economistas liberais brasileiros -, ou a defesa do relatório da Cepal sobre planejamento econômico. O livro A Economia Brasileira insere-se na mesma proposta, e sua organização interna tem um propósito claro de convencer o leitor para uma nova

${ }^{539}$ Idem, p, 246. 
proposta de desenvolvimento econômico. Nesse sentido, iniciar o livro partindo das categorias históricas distancia-se dos métodos da teoria do desenvolvimento econômico e consegue atrair público de outras áreas das ciências sociais e, sobretudo, historiadores. Por sua vez, o diagnóstico da economia brasileira, na qual efetivamente mobiliza uma série de conhecimentos e termos econômicos, faz parte de um conjunto de discussão que permeia o espaço público de debates no Brasil dos anos cinquenta. Dessa forma, apenas após o leitor estar familiarizado com as categorias históricas, pelas quais é possível entender as peculiaridades da economia brasileira, Celso Furtado apresenta o diagnóstico do presente. Somente ao final do livro, quando o leitor já está familiarizado com as análises, é que surgem os princípios teóricos do desenvolvimento econômico. Nessa altura, a teoria perdeu seu caráter abstrato, pois já foi perpassada pela análise histórica, expondo sua aplicação para o caso da economia brasileira.

Dessa forma, o livro se encerra, de forma aparentemente modesta, mas efetivamente contundente: reafirmando a originalidade de suas preocupações, demonstrando que toda a teoria econômica, desde o final do século XVIII, não pensou o problema do desenvolvimento econômico ou formulou categorias (como as que o livro de Celso Furtado apresenta) para compreender as nações subdesenvolvidas. A Economia Brasileira não apresenta um programa teórico em suas primeiras páginas. Ao contrário, seu fecho é muito mais do que o que chamaríamos hoje de uma revisão bibliográfica. É, de fato, uma demonstração de que não é possível pensar o desenvolvimento econômico dos países atrasados com as categorias da ciência econômica tradicional. Com isso, combate, não apenas no diagnóstico, mas também em nível teórico, as propostas dos economistas liberais brasileiros. 
Capítulo 4: A maturação dos conceitos: a herança do passado e as perspectivas de futuro 


\section{A revista Econômica Brasileira e a teoria do desenvolvimento econômico examinada sob o crivo da economia brasileira}

Ainda no ano de 1955, Celso Furtado irá publicar uma série de resenhas e intervenções na revista Econômica Brasileira. Uma vez delimitada nossa interpretação sobre a formulação de sua teoria do desenvolvimento econômico e a relação com os debates brasileiros, caberá, agora, investigar em que medida esses textos alteram ou reiteram diagnósticos, perspectivas e formulações conceituais estabelecidas no livro $A$ economia brasileira. Já indicamos que o primeiro número da revista trouxe a publicação de suas palestras na Escola Superior de Guerra em 1953, reescritas sob o título de "Desenvolvimento econômico (ensaio de interpretação histórico-analítica)", que forneceu o arcabouço histórico para o primeiro capítulo do livro. No entanto, como o propósito da revista foi, precisamente, criar um fórum de discussão e divulgação das propostas desenvolvimentistas — em face do fechamento de espaço na Revista brasileira de economia e em jornais diários do Rio de Janeiro - será preciso encarar esses comentários e resenhas sob esse aspecto: a um só tempo, divulgar e comentar trabalhos científicos, como, também, examiná-los a partir de um conjunto de conceitos e categorias próprias para compreender a realidade das economias subdesenvolvidas, sobretudo, a economia brasileira.

A primeira resenha publicada nesta revista é sobre o livro de Brinley Thomas, Migration and economic growth, de 1954. Nela, Celso Furtado destaca dois elementos que reforçam seus pontos de vista. $\mathrm{O}$ primeiro deles diz respeito à universalidade da teoria econômica, no que concerne à teoria das vantagens comparativas do comércio internacional, tema largamente trabalhado nos relatórios da Cepal: "a teoria clássica do comércio internacional não somente ignorou o fenômeno das migrações como, demais, assentou no postulado básico da imobilidade internacional dos fatores da produção". 540 Brinley Thomas explicita a existência deste problema nos próprios teóricos da economia política clássica, a exemplo de J. S. Mill. Em seu conjunto, esses autores consideraram apenas o comércio da Inglaterra com outros países do continente europeu ou com outras partes do Atlântico. Entretanto, prossegue, como neste último caso, considerava-se o

\footnotetext{
${ }^{540}$ FURTADO, Celso. Resenha de Migration and economic growth de Brinley Thomas. Econômica Brasileira. Rio de Janeiro: Clube dos Economistas, N.1, V. 1, janeiro-março, 1955, p. 51.
} 
comércio nos termos de uma "comunidade maior", britânica, não houve espaço para uma teorização da mobilidade de fatores no pensamento clássico. Esse ponto é importante, pois o livro estabelece, de início, uma relação entre o problema das migrações e as teorias do comércio internacional, as quais eram alvo dos trabalhos cepalinos preocupados em deslindar as consequências para os países subdesenvolvidos da hipótese da teoria das vantagens comparativas, base das teorias clássicas.

Do exame deste problema, Thomas "abre caminho para uma teoria do desenvolvimento econômico fundada na expansão dos mercados, na dinâmica dos rendimentos crescentes, e na mobilidade internacional da mão-de-obra e do capital”. ${ }^{541}$ Para tanto, supõe um modelo simplificado com um país desenvolvido possuindo “população densa, indústria desenvolvida, alta propensão a poupar" e "dividido em duas classes, trabalhadores e empresários, sendo praticamente nula a mobilidade entre as mesmas". Este país, ao estabelecer comércio com outro, caracterizado por "uma elevada mobilidade social, amplas áreas inexploradas, riquezas potenciais, escassez de mão-deobra e capital", especializa-se na produção industrial enquanto o último, em produção primária. ${ }^{542}$ Nas etapas iniciais ocorrerá migração do país desenvolvido para o outro. Com o tempo, à medida que o país primário-exportador desenvolver-se, aumentando a renda da terra, adotará medidas para industrializar-se.

Para Furtado, o interesse do livro está na transição do desenvolvimento agrícola para o industrial: "tendo em vista, basicamente, economias como a dos Estados Unidos e do Canadá, isto é, economias que se desenvolveram dentro de um quadro de escassez de mão-de-obra, o modelo do prof. Thomas não se aplica exatamente à grande maioria dos países latino-americanos. A Argentina e o Uruguai constituem possivelmente exceções, no caso". 543

Com isso, podemos perceber que Celso Furtado marca seu interesse pelo livro condicionando-o aos elementos passíveis de esclarecer a realidade latino-americana. É interessante notar que a tipologia utilizada por Thomas converge para a utilizada no livro A economia brasileira - a saber, países com escassez ou excesso de mão-de-obra —, muito embora no livro resenhado essa questão repercuta diretamente na mobilidade social, uma vez que a dinamização e a transição da agricultura para indústria estão condicionadas à ascensão dos primeiros imigrantes e suas formas de proteger o mercado

\footnotetext{
${ }^{541}$ Idem, p. 52.

542 Idem, p. 52.

${ }^{543}$ Idem, p. 52.
} 
da renda da terra, incorporando ou desenvolvendo tecnologia para ampliar a produtividade do capital em detrimento da mão-de-obra.

Por outro lado, notando a importância do protecionismo para a industrialização nos países com escassez de mão-de-obra como um argumento válido na explicação do desenvolvimento da América do Norte, Celso Furtado expande essa argumentação para os países subdesenvolvidos latino-americanos:

Como se poderia observar que, se o argumento em favor do protecionismo que o professor Thomas recolhe de Wicksell, é verdadeiro para os países de escassa mão-de-obra, com dobrada razão o será para aqueles que dispõem de mão-de-obra abundante. A penetração do capital estrangeiro e a criação de uma agricultura de exportação nestes países dá origem a um fenômeno de refluxo de renda idêntico àquele referido pelo professor Thomas. A abundância relativa de mão-de-obra cria uma situação privilegiada para o capital. Quando este capital se aplica em atividades que absorvem pouca mãode-obra, como a mineração, sua contribuição para o desenvolvimento econômico da região é mínima, como o demonstram a experiência da Bolívia e de outros países. ${ }^{544}$

De fato, neste trecho vemos Celso Furtado retomando suas considerações sobre o fluxo de renda e suas repercussões no conjunto da economia, quando a mão-de-obra é assalariada. Vimos que sua análise da economia cafeeira descreve, basicamente, como a dinâmica do setor externo comandada pela agricultura de exportação cafeeira gerou um fluxo de renda. Por sua vez, dado que esta agricultura repercutia grandemente no conjunto da economia, seja pela mão-de-obra utilizada nas plantações ou pelos encadeamentos na agricultura de subsistência e nos serviços urbanos dela decorrentes, a passagem para uma economia industrial, processo em curso na economia brasileira, como vimos, vem contando com formas indiretas de proteção à indústria característicos dos anos de após-guerra. O destaque para a situação brasileira aparece, também, na comparação com a economia boliviana, onde os investimentos em mineração são poupadores de mão-de-obra e os recursos gerados, canalizados para o exterior. Nesse caso, o processo que vem ocorrendo no Brasil, de ampliação do mercado consumidor e expansão do setor industrial, aparecem como elementos geradores de desenvolvimento econômico.

Finalmente, conclui a resenha com uma consideração sobre a utilidade da teoria do comércio e da imigração internacional para os países subdesenvolvidos. Isso, pois, “para os países de abundante mão-de-obra e baixo grau de desenvolvimento, a teoria do

${ }^{544}$ Idem, p. 52. 
livre câmbio constituiu sempre uma falácia. Para os países que lideraram a industrialização, essa teoria apresentou sempre um lado positivo". ${ }^{545}$ Por sua vez, e aqui Celso Furtado retoma novamente as críticas às teorias do comércio internacional, "para aqueles países que já possuíam abundantes reservas de mão-de-obra trabalhando com baixa produtividade numa economia de subsistência, a referida teoria jamais apresentou qualquer aspecto positivo. Este fenômeno talvez não seja estranho ao fato de que os níveis de vida das populações deste último grupo de países hajam declinado persistentemente no último século, comparativamente ao das populações dos dois primeiros grupos de países". ${ }^{546}$ Nesse ponto, também, Celso Furtado extrai uma consequência que pode ser compreendida a partir de seu esforço de teorização do desenvolvimento econômico e sua preocupação em entendê-lo enquanto um fenômeno complexo, no qual se conjugam aspectos econômicos, sociais e culturais que balizam a afirmação e o desvelamento dos grupos e dos países que se beneficiam da teoria das vantagens comparativas do comércio internacional. Mas, notemos, a afirmação foi feita, não sob um ponto de vista ideológico, mas a partir da comparação e análise de como essa teoria não consegue dar conta dos problemas e da realidade dos países latinoamericanos.

Dessa forma, o livro de Brinley Thomas, que procurou dar conta da relação da imigração nos séculos XIX e sua compreensão nas teorias do comércio internacional, com especial atenção para países como Estados Unidos e Canadá, é abordado por Celso Furtado a partir de sua capacidade de explicitar problemas específicos das economias subdesenvolvidas latino-americanas. Suas principais conclusões, portanto, são uma ressalva da importância de protecionismo - tratado de forma geral na resenha — para impulsionar a transição para economias industriais.

No mesmo número da revista, Celso Furtado faz, ainda, um comentário à "Exposição geral da situação econômica do Brasil”, relatório elaborado pelo Conselho Nacional de Economia para o ano de 1954. Como sabemos, o Conselho, presidido por Otávio Gouveia de Bulhões, editava a revista em que saíram publicadas sua discussão com Celso Furtado a respeito do trabalho sobre as técnicas de planificação apresentado pela Cepal no ano anterior. Dessa forma, é possível considerar suas observações como continuidade dessa polêmica, trazendo consigo alguns dos mesmos aspectos da disputa.

\footnotetext{
545 Idem, p. 52-53.

${ }^{546}$ Idem, p. 53.
} 
Como vimos, as considerações teóricas que fundamentam os diagnósticos sobre a economia brasileira foi uma preocupação constante de Celso Furtado. De fato, sua ênfase em aspectos teóricos, seja sua teoria do desenvolvimento econômico, a formulação das categorias centrais para compreender o subdesenvolvimento e, mesmo, sua revisão da história do pensamento econômico têm um objetivo preciso de lançar os alicerces para sua interpretação do movimento corrente da economia.

É este viés que aparece logo no inicio da resenha: "um dos aspectos mais saudáveis do desenvolvimento recente dos estudos de economia no Brasil é esse reconhecimento da necessidade de fundamentar em critérios objetivos e o quanto possível científicos as decisões governamentais no campo da política econômica [grifo nosso]" ${ }^{547}$ Assim, dirigindo-se ao Conselho Nacional de Economia, estabelece uma ligação entre os fundamentos teóricos subjacentes às recomendações de política econômica. Percebe-se, implicitamente, que se a premissa teórica não decorre de critérios "objetivos" e "científicos", certamente a política econômica fíca comprometida. Enfatizando que estas exposições anuais "constituem sem lugar a dúvida o documento de maior repercussão elaborado por uma agência do governo no setor econômico", chama atenção, também, ao tema central deste relatório, a inflação. A crítica de Celso Furtado irá se deter neste fenômeno, ou seja, "analisar o diagnóstico que se fez, na Exposição, do desequilíbrio inflacionário que existe atualmente na economia brasileira", ${ }^{548}$ limitando-se ao primeiro capítulo do documento e anunciando comentários posteriores na revista.

A primeira discussão é metodológica. Celso Furtado discorda da forma como o relatório organizou os agregados econômicos, sobretudo o fato de não se "caracterizar adequadamente o produto, e em particular diferenciá-lo do dispêndio ou gasto global". ${ }^{549}$ Essa confusão é atribuída ao uso inadequado das igualdades keynesianas em uma economia aberta. O melhor seria, prossegue, "comparar as inversões com o dispêndio, pois a diferença entre esses dois agregados está constituída pelo consumo". 550

\footnotetext{
${ }^{547}$ FURTADO, Celso. Comentário sobre a Exposição Geral da Situação econômica do Brasil (1954). Conselho Nacional de Economia. Econômica Brasileira. Rio de Janeiro: Clube dos Economistas, N.1, V. 1, janeiro-março, 1955, p. 55.

${ }^{548}$ Idem, p. 55.

${ }^{549}$ Idem, p. 55.

${ }^{550}$ Idem, p. 55. Para Furtado "grande parte da confusão no uso destes conceitos resulta da aplicação indiscriminada de igualdades keynesianas, pois somente numa economia fechada poupança e inversão podem ser tomadas uma pela outra". Idem, ibidem.
} 
O mesmo acontece na "divisão que se faz do produto em consumo, inversões privadas e gastos públicos", a qual coloca sob a mesma rubrica "os gastos correntes do governo e das inversões públicas". Para Celso Furtado, não é possível desconsiderar os investimentos públicos do governo brasileiro, que "representam cerca de 30 por cento das inversões totais", 551 nem tampouco desconsiderar o papel do gasto corrente no consumo total. A crítica, entretanto, sobe de tom ao examinar o tipo de análise e de comparação que o relatório extrai desses agregados: "isolar o setor público totalmente do privado e ignorar que este, tanto quanto o primeiro, contribui para o consumo e para a inversão, é algo cujo alcance analítico não compreendemos. Mas, o que em verdade carece totalmente de fundamento lógico, a nosso ver, é agregar inversões privadas com o montante dos gastos públicos e comparar com o total do produto [grifos nossos]" 552 Da incompreensão do "alcance analítico" à carência de "fundamento lógico" do relatório, percebemos como Celso Furtado está minando em suas bases a validade "objetiva" e o caráter "científico" do trabalho elaborado pelo Conselho Nacional de Economia. Entretanto, essa crítica é feita a partir dos próprios postulados científicos que o relatório utiliza. Dessa forma, a crítica dirige-se à tentativa de aplicação da teoria keynesiana considerando a especificidade da economia brasileira. ${ }^{553} \mathrm{Ou}$ seja, da correta intepretação da realidade e do conhecimento da teoria de Keynes, a crítica aparece não apenas questionando os fundamentos teóricos, mas também a sua adequação ao objeto de estudo, a economia brasileira. Ademais, da imprecisão dos agregados utilizados pelo relatório, Celso Furtado explicita a tentativa de minimizar o papel dos gastos e investimentos públicos para a dinâmica da economia brasileira.

A despeito dessas críticas, que por vezes constata "erros de cálculo" em quadros do relatório, Celso Furtado, ainda antes de enfrentar o problema da inflação, examina a interpretação sobre a "importância do consumo individual na formação da renda" postulado fundamental de um diagnóstico sobre inflação de consumo gerada pela renda e salários e cuja solução mais provável seria a desaceleração do consumo da classe trabalhadora - , argumentando a discussão elaborada pelo relatório decorre da forma de agregação já discutida, além de fato de o setor público brasileiro ser "relativamente pequeno". No entanto, um outro postulado é criticado, a saber, "quanto mais baixo em

\footnotetext{
${ }^{551}$ Idem, ibidem.

${ }^{552}$ Idem, p. 56.

${ }^{553}$ Ainda sobre a questão sobre agregar os gastos correntes do governo com as inversões públicas, temos: "que se faça isso nas publicações oficiais norte-americanas, compreende-se, uma vez que a maior parcela dos gastos públicos norte-americanos são as despesas militares, as quais dificilmente poderiam ser classificadas como inversão ou consumo". Idem, p. 55.
} 
um país é o nível de renda per capta, tanto mais elevada a parte de sua renda que se destina ao consumo". Segundo Furtado, "temos aí uma negação peremptória de uma das observações empíricas de maior alcance feitas pela pesquisa econômica moderna, que é a da estabilidade da função consumo", ${ }^{554}$ referindo-se, especificamente, aos estudos de Kuznets sobre os Estados Unidos. Aqui, portanto, uma vez mais, o confronto se estabelece a partir do conhecimento da teoria econômica e de suas aplicações. Ademais, como vimos, os estudos de Kuznets têm papel central no âmbito da programação econômica apresentada pela Cepal, pois embasa a metodologia capaz de operar as previsões de consumo para cada nível de produto e de investimentos.

Feitas essas considerações, Celso Furtado se detém na questão da inflação. O diagnóstico do Conselho Nacional de Economia é de que
Através da redução do consumo (em termos reais) que se processa em face da elevação dos preços, aumentam os recursos monetários em mãos dos empreendedores privados e do governo, que assim exercem maior procura de bens de produção, iniciando-se a espiral inflacionária. Quanto mais sobem os preços mais as despesas de consumo crescem em termos monetários, se bem que diminua o consumo real. Resulta daí um aumento da propensão a investir que, por sua vez, acelera ainda mais a elevação dos $\operatorname{preços~}^{555}$

Este diagnóstico, portanto, de um excesso de demanda de bens de capital devido ao aumento dos preços, que canaliza os recursos do consumo para a poupança é criticado por Celso Furtado afirmando que "o analista da Exposição se fechou dentro de um raciocínio keynesiano estático" ${ }^{556}$, pois não há relação entre aumento dos preços e redução do consumo e sua transformação em investimentos. Por outro lado, um aumento no coeficiente de poupança não necessariamente se traduz em propensão a investir, uma vez que a retração do consumo diminui as expectativas de lucro dos empresários.

Deste primeiro diagnóstico o relatório afirma que o financiamento dos investimentos, a partir de 1949 foi feito por meio de redução do consumo, ou seja, com poupança forçada. Celso Furtado, corrigindo os próprios dados apresentados, aponta que no período, não apenas se elevou a participação do consumo privado no produto nacional, como isso ocorreu numa etapa de estabilidade do nível de preços. Dessa forma, o diagnóstico da redução do consumo devido à inflação fica invalidada, assim

\footnotetext{
${ }^{554}$ Idem, p. 56.

555 Idem, p. 56.

${ }^{556}$ Idem, p. 56.
} 
como sua consequência imediata que seria desacelerar a economia para estabilizar o nível de preços.

Essa recusa do diagnóstico e da proposta de política econômica do relatório fica explícita no seguinte trecho:

Não pretendemos negar validade à tese central desse primeiro capítulo da Exposição, segundo a qual a inflação é o principal problema que enfrenta a economia brasileira no momento atual. Nossa opinião é que o principal problema do país consiste em manter e, se possível, aumentar a taxa de crescimento. Entretanto não pretendemos discutir esta questão, pois ela é muito mais de política do que de ciência econômica. ${ }^{557}$

Aqui, portanto, Celso Furtado clarifica o que está em jogo na análise do Relatório. Com efeito, a discordância reside na caracterização do principal problema da economia brasileira: inflação ou manutenção do crescimento. A exposição do Conselho, ao priorizar a inflação, apresentou como solução a redução do ritmo de crescimento econômico, pois o desequilíbrio monetário estaria sinalizando para o aumento contínuo das inversões, gerando uma espiral inflacionária. Ao contrário, Celso Furtado discorda da solução apontada, priorizando o crescimento econômico, como, ademais, já fizera no debate com Otávio Gouveia de Bulhões no ano anterior. Entretanto, esta solução não é apresentada sob o aspecto concernente à "política", mas sim a partir da crítica aos pressupostos teóricos que sustentam o diagnóstico sobre a inflação brasileira. Ao reivindicar uma correta utilização dos agregados macroeconômicos keynesianos, ao refazer os dados do relatório, ao enfatizar a estabilidade da "função consumo" de Kuznetz, em suma, ao ressaltar que os pressupostos teóricos devem adequar-se às características da economia brasileira e apontar que, uma vez alcançada essa formulação, o diagnóstico apresentado pelo Conselho perde validade cientifica, Celso Furtado estabelece, no plano teórico, a validade de sua posição política, ainda que recuse colocar a discussão nestes termos.

Com isso, podemos retomar nossa hipótese de que, a partir das polêmicas com os economistas liberais, Celso Furtado modifica suas estratégias argumentativas, dando relevo aos aspectos teóricos para justificar seus diagnósticos. Uma das formas de executar esse procedimento é, justamente, apontar o caráter seletivo dos argumentos utilizados por seus adversários: "apenas queremos chamar a atenção para o fato de que a argumentação utilizada na exposição é extremamente inconsistente, deixando demasiadamente claro que se pretende justificar à outrance, uma tese apriorística". E

${ }^{557}$ Idem, p. 57. 
prossegue, "os desequilíbrios inflacionários que apresenta no momento atual a economia brasileira, não são passíveis de dissecação com o simples uso do instrumental analítico keynesiano". 558

Ressaltada, portanto, a estratégia argumentativa dos liberais, e constatada sua inadequação metodológica, Celso Furtado irá retomar o diagnóstico da inflação já apresentado em A economia brasileira, destacando os problemas estruturais da economia brasileira.

Uma economia subdesenvolvida como a nossa, apresenta duas características que são de fundamental importância. A primeira é que a oferta de bens de capital está basicamente ligada à capacidade para importar; a segunda é que a oferta de mão-de-obra apresenta uma elevada elasticidade mesmo em condições de pleno emprego do estoque de capital. Se meditamos sobre estes dois pontos vemos que a análise keynesiana dificilmente poderia alcançar todos os aspectos de nosso problema. ${ }^{559}$

Dessa forma, não apenas a análise keynesiana não dá conta dos problemas da economia brasileira, como é preciso considerar dois aspectos constitutivos das características subdesenvolvidas da economia brasileira e que já foram objeto de estudo no livro A economia brasileira, o que evidencia a importância e o alcance das análises apresentadas. Celso Furtado ressalta a dependência de divisas para efetuar as compras de bens de capital, dessa forma desligando os problemas do investimento do nível de preços internos. Por sua vez, o problema da elevada elasticidade da mão-de-obra reforça sua argumentação, pois não há uma disputa pelos fatores de produção entre os setores de bens de capital e de consumo, que poderia gerar a espiral inflacionária diagnosticada no Relatório. Com isso, Celso Furtado invalida o diagnóstico e a receita para eliminar a inflação. Entretanto, a crítica não formula uma proposta alternativa de maneira evidente, embora indique que a prioridade da política econômica deva residir na manutenção do crescimento econômico. Daí que conclua retomando a inadequação do diagnóstico do Relatório:

Não pretendemos de nenhuma forma defender a inflação. Apenas queremos indicar que a análise da exposição está longe de contribuir para esclarecer o problema. Enquanto nos mantivermos dentro de raciocínios simplistas, os autênticos objetivos do combate à inflação não serão compreendidos e persistirá a desconfiança de que o que se pretende com esse combate é favorecer grupos de interesse. Muito esforço ainda teremos que fazer para aprender a cingir-nos dentro de uma verdadeira objetividade científica. Se não soubermos resistir a

\footnotetext{
${ }^{558}$ Idem, p. 57.

${ }^{559}$ Idem, p. 57.
} 
utilizar nossos conhecimentos econômicos ancilarrmente para justificar pontos de vista apriorístico, estaremos justificando a ironia daqueles que atribuem à economia - como à razão se atribuiu no século XIX - o comportamento de uma volúvel atriz de ópera. ${ }^{560}$

Aqui, também, os resultados da reflexão sobre o desenvolvimento econômico reaparecem, sobretudo o aspecto de favorecimento dos grupos de interesses, algo que parece cada vez mais incorporado à análise de Celso Furtado e que surge como um aspecto importante na crítica aos economistas liberais. Essa crítica, ao estar acompanhada pela constatação de uso de "pontos de vista apriorísticos", reforça ainda mais os aspectos "científicos" da crítica furtadiana, pois ao mesmo tempo em que invalida teoricamente os fundamentos do relatório, explicita que essa invalidação é decorrente não apenas de fragilidades no campo da ciência econômica, mas também na orientação e posicionamento político dos autores criticados. Ao examinar os pressupostos teóricos, acentua suas preferências práticas.

Vemos, portanto, como a crítica sobe de tom no encerramento do texto, destacando uma vez mais o uso apriorístico das teorias econômicas e as possíveis consequências sociais desse problema, sobretudo ao favorecer grupos de interesse.

Esta estratégia de confronto com os economistas liberais é retomada em outra resenha, no número seguinte da revista, desta vez direcionada à figura mais importante desta corrente de pensamento, Eugênio Gudin, e ao segundo volume de seu livro Princípios de Economia Monetária, um dos primeiros manuais de economia escritos no Brasil.

Isso, ademais, é ressaltado por Celso Furtado na introdução da resenha, destacando a importância de Gudin "entre os estudiosos da ciência econômica no Brasil", seu "prestígio como professor e mestre" de forma que o trabalho tem "grande ressonância" e exerce "uma influência profunda nas gerações que estão se formando". 561 O livro, dividido em duas partes, uma teórica e outra de política econômica terá apenas a primeira examinada, pois "os problemas da política econômica apresentados em um elevado nível de generalidade não são mais do que uma projeção dos problemas da teoria econômica". ${ }^{562}$ Essa decisão, por parte de Celso Furtado, corrobora o que viemos

\footnotetext{
${ }^{560}$ Idem, p. 58.

561 FURTADO, Celso. Resenha de Princípios de economia monetária, vol II, de Eugênio Gudin. Econômica Brasileira, Rio de Janeiro: Clube dos Economistas, N. 1. Vol. 2, abril-junho, 1955, p. 120.

562 Idem, ibidem.
} 
argumentando sobre os elementos teóricos como um momento das disputas sobre política econômica.

O primeiro ponto discutido por Celso Furtado é a afirmação de que "Wicksell considera... a Teoria Quantitativa como a única teoria do valor da moeda com foros de científica". ${ }^{563}$ Esta citação, retirada do livro de Gudin, "não deixa de causar surpresa ao estudante de teoria monetária que se acostumou a ver em Wicksell o lúcido formulador da teoria da renda". De fato, Furtado argumenta que a Teoria Quantitativa é utilizada pelo economista sueco como um ponto de partida e de contraste para a formulação de sua explicação das "flutuações dos preços num regime de oferta elástica de moeda". Para corroborar sua afirmação, Celso Furtado apresenta alguns trechos do segundo volume de Lectures on political economy, de Wicksell — livro já citado no artigo A teoria do desenvolvimento na ciência econômica. Com isso, pretende mostrar equívocos na própria fundamentação que Gudin apresenta da Teoria Quantitativa da Moeda. Contrastando os textos de Wicksell, e também de Alvin Hansen, Celso Furtado esclarece que "a preocupação central de Wicksell foi formular uma teoria das flutuações do nível geral de preços e seu maior mérito consistiu em haver percebido que para formular essa teoria necessitava abandonar o raciocínio quantitativista”. 564

Entretanto, a despeito dessa filiação apresentada por Eugênio Gudin, Celso Furtado destaca que o economista carioca procura, ao longo do livro, observar unicamente o "núcleo de verdade" da Teoria Quantitativa da Moeda, muito embora, prossegue, "o que sempre faltou a essa teoria [...] foi exatamente esse 'núcleo de verdade",. 565

Essa crítica à Teoria Quantitativa, já discutida em sua primeira resenha publicada na Revista brasileira de economia em 1948 dá lugar a uma apreciação dos próprios conceitos utilizados por Eugênio Gudin, sobretudo sua distinção entre moeda de ação direta e moeda de ação indireta. ${ }^{566}$ Essa distinção está relacionada com

\footnotetext{
${ }^{563}$ Idem, ibidem.

564 Idem, p. 121.

565 Idem, p. 121.

566 “A moeda utilizada nas transações correntes da produção, do consumo e da realização de investimentos, isto é, nas transações de que resulta a formação da renda nacional, a moeda proveniente, de um excesso de exportações ou da expansão do crédito ou de um déficit orçamentário para pagamento de empreendimentos públicos ou de funcionalismo, é moeda que vai desde logo constituir rendimentos de alguém e, se a situação for próxima do pleno emprego, incentivar a alta de preços. É moeda de ação direta. / de outro lado, a moeda proveniente de economias à espera de aplicação, a moeda proveniente da venda e monetização de bens e que procura investimentos em outros bens, a moeda criada pela Autoridade Monetária ou pelos bancos por operações de 'open market', a moeda emitida para compra de ouro do exterior, a "hot money" que imigra á procura de melhor taxa, ou os capitais em fuga vindos do exterior, á procura de abrigo, essa moeda não está participando da formação da renda nacional e sim,
} 
preocupação do autor dos Princípios de economia monetária de permanecer dentro do "núcleo de verdade" da teoria quantitativa. De fato, a distinção feita por Gudin procura dar conta da forma como a moeda age sobre os preços. Assim, a moeda de ação direta é aquela utilizada "nas transações de que resulta a formação da renda nacional". Entretanto, para Furtado, a distinção não consegue abranger o fenômeno a ser explicado. Com efeito, pode ocorrer que o dinheiro criado com o uso de moeda de ação direta não seja reinvestido em consumo ou investimento, mas que permaneça sob a forma de poupança, ou seja, moeda de ação indireta. Dessa forma, "o fundamental, portanto, não é o dinheiro em si, mas os motivos que modificam a ação de 'indireta' em 'direta"'. Ou, dito de outra forma, é preciso observar as formas como o sistema financeiro atua no processo de transformação dos "fundos líquidos em procura efetiva". 567

Com isso, Celso Furtado, que criticara um excesso de keynesianismo no Relatório do Conselho Nacional de Economia, novamente contrapõe ao pensamento de Eugênio Gudin aspectos da teoria da procura efetiva e da taxa monetária de juros do autor da Teoria Geral. Efetivamente, aponta que Gudin atribui à Keynes uma definição muito simplista da taxa de juros, como unicamente uma "compensação pelo abandono da liquidez", muito embora demonstre que o texto de Gudin, e não o de Keynes é que possuiu uma visão da taxa de juros como um fenômeno "essencialmente monetário". 568

Dessa forma, os comentários de Celso Furtado têm um sentido muito semelhante ao que vimos no exame do Relatório do CNE. De fato, a partir da discussão de aspectos teóricos expõe a fragilidade da argumentação dos textos examinados. No caso específico deste livro-texto de Gudin, a crítica foi centrada num elemento central do pensamento econômico liberal no Brasil, a saber, o diagnóstico da economia brasileira elaborado em suas características monetárias. Ora, ao minar as próprias bases teóricas do monetarismo de Gudin, Celso Furtado automaticamente compromete seu diagnóstico e as propostas de política econômica, ou seja, o mesmo procedimento utilizado na resenha anterior. A própria estrutura argumentativa, na qual os argumentos de Gudin são contrapostos aos textos de Wicksell e Keynes, explicita como a disputa teórica passa pela correta interpretação dos textos econômicos, deslocando o foco do debate. Agora, não mais a política econômica, mas os fundamentos teóricos que lhe dão

unicamente, contribuindo por sua abundância ou escassez, para reduzir ou aumentar os juros. É moeda de ação indireta". Idem, p. 121-122.

${ }^{567}$ Idem, p. 122.

${ }^{568}$ Idem, p 123. 
suporte. Nesse esforço, Celso Furtado aparece como um leitor arguto, conhecedor dos textos econômicos originais, capaz de fazer reparos inclusive no livro-texto mais importante da escola liberal no Brasil.

Esse deslocamento na forma de debater os problemas e os diagnósticos sobre a economia brasileira pode ser percebida nas observações que Eugênio Gudin fez à resenha de Celso Furtado, publicada no mesmo número da Econômica Brasileira.

Eugênio Gudin admite os reparos feitos por Celso Furtado sobre a terminologia e a organização do texto. Quanto à filiação de Wicksell à Teoria Quantitativa da Moeda, Gudin remete ao primeiro volume de seus Princípios de Economia Monetária, onde estabelece uma distinção entre os partidários desta teoria, englobando o economista austríaco entre os que encaram os problemas monetários a partir da teoria dos rendimentos. Já sobre a questão da distinção entre moeda de ação direta e de ação indireta, explica que esta proposição foi uma forma de dar conta do conceito de moeda para motivos especulativo de Keynes, uma vez que "em um país como o Brasil, com um movimento muito reduzido de bolsa de títulos e sem mercado monetário o "motivo especulativo' tem muito pouca importância", 569 de forma que, também, "a moeda entesourada ou imobilizada não é suficiente para explicar uma série de fenômenos monetários". ${ }^{570}$ Finalmente, cita Alvin Hansen para destacar que é preciso uma distinção entre as formas de expansão monetária criadas pela monetização de bens privados ou por um "plano expansionista de consumo... ou de obras públicas". ${ }^{571}$ Assim, ao justificar os termos utilizados e sua interpretação da teoria quantitativa, Gudin o faz em um tom muito diverso daquele com o qual comentou a conferência da Cepal nos artigos para o Correio da Manhã. Gudin utiliza os mesmos critérios postos por Celso Furtado para se defender, ou seja, justifica a utilização da distinção entre moeda de ação direta e indireta como forma de adaptar uma teoria para que possa captar as especificidades da economia brasileira. Essa justificativa, ademais, presentes em outros aspectos de suas ideias econômicas ${ }^{572}$, pode explicitar como as resenhas de Celso Furtado estariam moldando ou condicionado os termos do debate. De fato, nesta

\footnotetext{
${ }^{569}$ GUDIN, Eugênio. Observações do prof. Eugênio Gudin. Econômica Brasileira, Rio de Janeiro: Clube dos Economistas, N. 1. Vol. 2, abril-junho, 1955, p. 124.

${ }^{570}$ Idem, p. 125.

${ }^{571}$ Idem, ibidem.

${ }^{572}$ Segundo Ricardo Bielschowisky, "Gudin foi um típico economista neoliberal, levado a reinterpretar os grandes enunciados das teorias liberais à luz da problemática econômica revelada pela depressão cíclica do período entre as duas guerras". BIELSCHOWSKY, Ricardo. Pensamento econômico Brasileiro. O ciclo ideológico do desenvolvimentismo. 1930-1964. Rio de Janeiro: Contraponto, 2003, pp. 40.
} 
resposta, Gudin cingiu-se não apenas aos pontos elencados pelo resenhista, como restringiu sua resposta ao nível teórico.

Celso Furtado, pro sua vez, procurou manter abertas linhas de diálogo sobre os diagnósticos da economia brasileira, discutindo os aspectos teóricos que sustentam as sugestões de política econômica, bem como mostrando as consequências que esses diagnósticos apresentam sobre os problemas da economia brasileira.

Entretanto, as resenhas e comentários que Celso Furtado publicou na Econômica Brasileira discutiam, também, temas relacionados mais diretamente com sua teoria do desenvolvimento econômico e a questão do planejamento. Esses temas, que também mobilizaram debates no Brasil, são abordados a partir de formulações contemporâneas de problemas sobre os quais Celso Furtado tem se debatido. Exemplo disso é a resenha do livro The Theory of Economic Growth, do economista jamaicano Arthur W. Lewis, publicado em 1955. Seu autor, mais conhecido pelo trabalho "O desenvolvimento econômico com oferta ilimitada de mão-de-obra", é apresentado como "um dos poucos professores universitários europeus que abordam os problemas do subdesenvolvimento com uma visão direta da realidade". ${ }^{573}$ Essa característica, se lembrarmos considerações no mesmo diapasão feitas sobre Ragnar Nurkse, reveste-se de importância para Furtado, pois essa visão da realidade subdesenvolvida é um primeiro passo para a consciência da especificidades dos problemas destas economias, bem como um freio para a generalização dos conhecimentos formulados pelas teorias econômicas a partir da realidade de países industrializados. Seu interesse nos problemas das economias atrasadas é ressaltada pela importância de seu trabalho sobre o excesso de mão-de-obra, dentro de um conjunto de preocupações "que apresentam notáveis afinidades com aquelas que, a partir de 1949, vem elaborando o grupo de economistas da Cepal". 574

No entanto, a despeito das credenciais de seu autor, o livro não agrada a Celso Furtado: "é uma discussão do que se poderia chamar 'os problemas mais gerais do desenvolvimento', entendido este como um processo social e não especificamente econômico". Criticando as considerações de "sociologia amadorística", a escrita de alguns capítulos "de forma demasiadamente prolixa e pouco sistemática", termina por

${ }^{573}$ FURTADO, Celso. Resenha de: The Theory of Economic Growth de W. Arthur Lewis, Londres, 1955. Econômica Brasileira. Rio de Janeiro: Clube dos Economistas, n. 1. Vol. 2, janeiro-março, 1956, p. 52. A publicação do artigo sobre oferta ilimitada de mão-de-obra, em 1954, pode ser considerada um avanço em comparação à teoria do desenvolvimento da Cepal. Para a reação de Prebisch ao artigo e de como ele impactava em sua própria dificuldade em desenvolver um trabalho mais formalizado em meio aos problemas burocráticos da Cepal, ver: DOSMAN, Edgar J. Raúl Prebisch (1901-1986). A construção da América Latina e do Terceiro Mundo. op. cit., p. 368.

${ }^{574}$ Idem, p. 52. 
caracterizá-lo como "desigual, carregado de digressões secundárias, pouco sistemático" de forma que "é de leitura difícil para o leigo e de utilidade limitada para o iniciante". 575

Ora, esta resenha, longe de ser um exercício de crítica despropositado, pois efetivamente não analisa o livro, revela como Celso Furtado preocupava-se com um conjunto de problemas específicos e a partir destes procurava avaliar o conhecimento disponível. Por sua vez, a importância de Arthur Lewis confessadamente gerou expectativas em Celso Furtado. No entanto, ao perceber que o livro oferecia pouca utilidade para a reflexão sobre os países subdesenvolvidos, a resenha serve como um alerta para que outros economistas não sejam seduzidos pelo autor ou pelo título, razão pela qual conclui avaliando seu aproveitamento para os leitores leigos e iniciantes em matéria econômica.

Perspectiva diversa oferece o Manual de Economia Política publicado pelo Instituto de Economia da Academia de Ciências da URSS, sob o selo da editora mexicana Grijalbo no mesmo ano de 1956. Celso Furtado reconhece a oportunidade de "criticar um tratado de economia política escrito na URSS", uma vez que "os soviéticos se têm preocupado muito mais com transformar as economias de seus países do que escrever sobre o que nelas está ocorrendo". ${ }^{576}$ Neste manual, prossegue Furtado, "se expõem pela primeira vez as transformações ocorridas na economia russa a partir das revoluções de 1917, mais precisamente a partir da introdução do sistema centralizado de economia planificada". ${ }^{577}$ Dividido em três partes, é a terceira, sobre o "sistema socialista de economia nacional", a mais importante. Entretanto, não há uma abordagem sobre os problemas técnicos da planificação, "nem se indicam as dificuldades com que certamente se deparam os planificadores soviéticos". ${ }^{578}$ Ora, Celso Furtado lamenta, sobretudo, a ausência de um problema específico da planificação, a saber, "o problema da distribuição da renda". Esta questão, segundo o autor, é a "medula central de uma economia planificada". Com efeito, prossegue, "sendo a economia soviética de caráter monetário (o poder de compra do consumidor está definido por uma renda monetária) é óbvio que o planificador terá de prever de alguma forma as reações do consumidor em face de modificações nos preços relativos". Ainda sobre a questão do nível de preços e de consumo, Celso Furtado também se indaga sobre a "técnica de previsão da procura

\footnotetext{
${ }^{575}$ Idem, p. 52.

${ }^{576}$ FURTADO, Celso. Resenha de Manual de Economia Política, Instituto de Economia da Academia de Ciências da URSS. Editora Grijalbo, 1956. Econômica Brasileira. Rio de Janeiro: Clube dos Economistas, n. 1. Vol. 2, janeiro-março, 1956, pp. 52-53.

${ }^{577}$ Idem, p. 53.

${ }^{578}$ Idem, ibidem.
} 
de produtos intermediários (interrelações do sistema produtivo), aos critérios em que se funda a distribuição de renda entre populações urbanas e o setor agrícola, etc".

A busca dessas questões centrais com respeito ao planejamento de uma economia monetária nos conduz diretamente à discussão com Otávio Gouveia de Bulhões sobre a técnica de planificação apresentada pela Cepal. De fato, não foram os problemas de aplicação da programação em uma economia de mercado o cerne da polêmica? Ao se indagar sobre a questão dos preços relativos e a impossibilidade de previsão do consumo, Bulhões estava colocando as mesmas interrogações que Celso Furtado agora lança ao Manual de Economia Política da URSS. Dito de outra forma, é novamente os temas do debate da economia brasileira que em última instância fundamentam as leituras que Celso Furtado faz. Neste caso específico, talvez a principal decepção com o Manual seja justamente por ele não oferecer a confirmação prática dos postulados da programação que a Cepal elaborara. Neste sentido, o interesse de Furtado é aplicação empírica do planejamento, critério último de verificação do conhecimento econômico.

A primeira parte do Manual, uma exposição da teoria de Marx, também é criticada por Celso Furtado pois, além de não substituir a leitura de $O$ Capital, a preocupação em “introduzir nesse esquema uma série de problemas ou realidades atuais da economia capitalista responde provavelmente por muitas das contradições em que se emaranharam os autores", ${ }^{579}$ a exemplo da análise do movimento dos salários reais nos Estados Unidos, para os quais utilizaram como ano-base 1938, escolha que invalida a análise, por se tratar, segundo Furtado, de um ano "de grande depressão" econômica. A avaliação final é que "de todo o livro transparece a convicção de que as condições atuais de uma economia como a da Suécia ou dos Estados Unidos são as mesmas que provocaram o colapso da velha economia da Rússia tczarista. Destarte, dificilmente se poderia admitir que esse 'Manual' constitua uma verdadeira contribuição dentro da economia marxista". ${ }^{580}$ Com isso, Celso Furtado expõe o livro ao mesmo tipo de critério de verificação para a teoria econômica: sua adequação à realidade. Ao constatar que o tratado desconhece as principais economias ocidentais, ao mesmo tempo em que trata a União Soviética com um grau de generalidade que não permite avaliar as transformações que estão ocorrendo nem, tampouco, visualizar os problemas e as soluções utilizadas no esforço de planificação, o Manual de Economia Política perde

\footnotetext{
${ }^{579}$ Idem, p. 53.

${ }^{580}$ Idem, p. 54.
} 
seu interesse e sua possibilidade de contribuir para esses debates. Por sua vez, é preciso considerar a recusa em utilizarem-se categorias criadas para a compreensão de uma realidade específica, "o colapso da velha economia da Rússia tczarista", no tratamento de economias modernas, como Estados Unidos e Suécia, sem estabelecer as principais diferenças entre cada uma delas. Dessa forma, critica no Manual, o procedimento de generalização de conceitos, identificando-o com o mesmo procedimento adotado pela economia clássica para explicar as economias subdesenvolvidas a partir da experiência inglesa. Aqui também, portanto, a preocupação com a formulação de categorias específicas para explicar realidades particulares permanece como uma problemática central de Celso Furtado.

No texto "Setor Privado e Poupança", Celso Furtado comenta as observações que João Paulo de Almeida Magalhães fez ao relatório do convênio Cepal-Bnde, intitulado "Esboço de um programa de desenvolvimento para a economia brasileira", publicado, também, pela Econômica Brasileira. Magalhães não discorda da conclusão do relatório, a respeito da necessidade de ampliar a propensão a poupar da economia, sobretudo num período de redistribuição da renda em favor dos setores empresariais e capitalista, como ocorrido entre 1947-1953, argumenta. No entanto, para Celso Furtado, há um ponto da análise que não pode ser derivado do relatório do Grupo Misto, a saber: "um sistemático pessimismo quanto à contribuição potencial do setor privado em uma política de desenvolvimento." ${ }^{581}$ Magalhães citara uma das conclusões do relatório: "a inoperância do referido mecanismo de acumulação espontânea torna indispensável a ação fiscal se se pretende aproveitar as etapas favoráveis para acelerar o processo acumulativo". ${ }^{582}$ Esta crítica, é preciso recordar, é semelhante à de Otávio Gouveia de Bulhões ao texto da Cepal, segundo a qual a Comissão da ONU pressupunha que o empresariado brasileiro era incapaz de liderar o desenvolvimento econômico. A resposta de Celso Furtado, portanto, enfatiza que a ação fiscal "não implica em pessimismo" frente ao setor privado, uma vez que "pode ter como objetivo central estimular a iniciativa privada, criar condições favoráveis ao seu fortalecimento, etc". Cita, neste sentido, o caso do BNDE, criado para "suprir o setor privado com os fundos de que carece em razão de sua baixa taxa de poupança". 583

${ }^{581}$ FURTADO, Celso. Setor Privado e Poupança. Econômica Brasileira. Rio de Janeiro: Clube dos Economistas, n. 2. Vol. 2, abril-junho, 1956, pp. 101.

582 Idem, ibidem.

583 Idem, ibidem. 
Outro ponto de discussão é o aumento da taxa de poupança para promover o desenvolvimento econômico estimulado pela política fiscal. $\mathrm{Na}$ perspectiva de Magalhães, a simples redistribuição de renda a favor dos capitalistas e empresários observada no período 1947-53 bastaria para estimular a ampliação dos investimentos. Ao contrário, para Furtado e o Grupo Misto, essa redistribuição não foi aproveitada para ampliar as inversões. No período considerado, a elevação da renda teve origem na melhora dos preços externos, de forma que não ocasionou uma elevação proporcional da taxa média de poupança. Daí, portanto, a necessidade da política fiscal para estimular as inversões neste período.

A discussão, portanto, tendo como referência um texto do Grupo Misto presidido por Celso Furtado e a crítica de um membro do próprio corpo editorial da Econômica Brasileira pode ser compreendida no âmbito da difusão das ideias desenvolvimentistas, levando-se em consideração que os estudos de conjuntura da economia brasileira têm também um elemento teórico e metodológico que ainda é objeto de disputa e interpretação. Por outro lado, cabe destacar, também, a presença da questão do planejamento e do papel que cabe ao Estado e à iniciativa privada no desenvolvimento econômico. Neste ponto específico, a intervenção de João Paulo de Almeida Magalhães demonstra a dificuldade de penetração do argumento cepalino da necessidade de intervenção do Estado na economia brasileira para promover o desenvolvimento econômico. Ao retomar a crítica de Octávio Gouveia de Bulhões, o autor explicita como o diagnóstico da economia brasileira elaborada pelos economistas ligados à Cepal têm dificuldade de generalização, frente à participação significativa do setor privado na economia brasileira. Por sua vez, importa destacar, também, que a discussão reflete uma conjuntura extramente problemática para o Estado brasileiro, com a crise cambial de 1953, o suicídio de Vargas em 1954 e as indecisões políticas que cercam a eleição de 1955. Esse momento delicado da política brasileira certamente enfraquece a crença no poder de comando das autoridades públicas na orientação da política econômica, explicando, em partes, o relevo atribuído ao setor privado. Nesse sentido, será preciso esperar a implantação do Plano de Metas para que esta questão seja reequacionada. Por hora, contudo, é preciso assinalar como a criação da Econômica Brasileira, e sua linha editorial foi capaz de dialogar com as críticas ao seu programa, explicitando uma abertura para o debate econômico.

A questão do desenvolvimento reaparece no relato do encontro anual da American Economic Review. Celso Furtado assinala a importância do evento, uma vez 
que "até há muito pouco tempo o desenvolvimento econômico não havia sido reconhecido como um problema autônomo pelo pensamento acadêmico nos Estados Unidos". ${ }^{584}$ Ressaltando os diversos temas tratados na reunião, não deixa de observar, entretanto, que "também foram incluídos alguns estudos relacionados com o desenvolvimento de áreas subdesenvolvidas, se bem que de qualidade lamentavelmente inferior. Tendo-se em conta que em matéria de teoria do crescimento os problemas do desenvolvimento estiveram sempre na vanguarda, não deixa de causar surpresa o nível baixo em que estes foram tratados numa reunião de especialistas de tão elevada categoria". 585

Dessa forma, podemos perceber a preocupação de Celso Furtado com os problemas do desenvolvimento econômico na medida em que estes possam contribuir para a compreensão dos países subdesenvolvidos. Por outro lado, constata como, fora das agências internacionais, especialmente dedicadas ao tema, a teoria do desenvolvimento econômico tem um alcance lento e desigual entre os economistas e as universidades. Certamente, nesta assertiva, sua perspectiva de membro da Cepal the permite apreciar sob uma ótica privilegiada a formulação e as versões da teoria do desenvolvimento econômico nos Estados Unidos.

Em seu texto, Celso Furtado destaca o trabalho de M. Abramovitz, "Resource and Output trends in the United States since 1870", que procurou, a partir de dados reunidos por Kuznets, examinar o aumento da taxa de crescimento dos Estados Unidos ao longo de quase um século, formulando, o seguinte problema: "que parte deste aumento se deve a uma maior utilização de recurso por habitante e que parte ao avanço da técnica?". Constatando que a produtividade do trabalho diminuiu enquanto a do capital aumentou, a conclusão do trabalho é que "a intensificação na utilização de recursos contribuiu com muito pouco para o aumento da produção por habitante, o qual se deveu fundamentalmente ao avanço da técnica". ${ }^{586}$ Essa predominância da tecnologia, fundamental para explicar o crescimento da economia norte-americana, por sua vez, deixa implícita a preocupação de Celso Furtado a respeito da dependência tecnológica que os países subdesenvolvidos têm neste aspecto.

\footnotetext{
${ }^{584}$ FURTADO, Celso. Resenha de American Economic Review, Pappers and Proceedings of the Sixtyeight Annual Meeting, maio, 1956. Econômica Brasileira. Rio de Janeiro: Clube dos Economistas, n. 2. Vol. 2, abril-junho, 1956, pp. 104.

585 Idem, ibidem.

586 Idem, p. 104.
} 
Finalmente, constata que "se estão realizando amplas pesquisas nas universidades norte-americanas orientadas para os problemas do desenvolvimento econômico", 587 com destaque para a questão do comportamento do consumidor, ainda que ligados à "velha preocupação relativa a um debilitamento crônico da procura de bens de consumo final". Celso Furtado conclui enfatizando "a relativa pobreza de pensamento original" nos estudos apresentados, o que seria "uma clara indicação de que nas universidades norte-americanas ainda não surgiu um verdadeiro pensamento criador no campo do desenvolvimento econômico. O melhor que se está fazendo ainda é o trabalho puramente empírico. O que se apresenta como teoria em boa parte não passa de velhas ideias com novos rótulos". 588

Com isso, ao notar a pobreza dos estudos desenvolvidos nos Estados Unidos, Celso Furtado não apenas legitima seu esforço e o de outros economistas latinoamericanos e de outras partes do mundo inseridos nas agências governamentais, como expõe as fraquezas teóricas de um dos maiores centros de difusão do pensamento econômico, relativizando sua importância nesta temática.

Entretanto, ao contrário do que aconteceu com os trabalhos apresentados na reunião da Associação Americana de Economistas, o livro de Gunnar Myrdal, diretor da Comissão Econômica para a Europa, da ONU, a equivalente europeia da Cepal, é saudado como um trabalho incomparável entre os escritos no "pós-guerra" por um economista. Para além da "agudeza do pensamento crítico" do autor, este livro "tem o atrativo da amplitude e oportunidade dos temas que aborda e a forma da excepcional experiência acumulada no campo das relações internacionais". 589

Temos, portanto, não apenas a experiência prática no trato com problemas do subdesenvolvimento, mas a inserção do livro num conjunto de preocupações da Cepal: as relações internacionais em seu aspecto econômico. Sobretudo porque o livro de Myrdal aborda "o processo de integração nacional do grupo de países que já alcançaram um elevado grau de desenvolvimento econômico; em seguida aborda o problema do conflito entre os objetivos das políticas de integração nacional e os ideais da integração internacional, e alguns aspectos concretos do mesmo, tais como, a questão dos

\footnotetext{
${ }^{587}$ Idem, p. 104.

588 Idem, p. 104-105

${ }^{589}$ FURTADO, Celso. Resenha de Solidariedad o Desintegración de Gunnar Myrdal. Fondo de Cultura Económica, México 1956. Econômica Brasileira. Rio de Janeiro: Clube dos Economistas, n. 4. Vol. 2, outubro-dezembro. 1956, pp. 220.
} 
pagamentos internacionais e a mobilidade internacional de mão-de-obra e de capital" 590 Ora, depreende-se facilmente o interesse de Celso Furtado nestas questões. O mesmo se pode dizer sobre a parte do livro "dedicada ao problema da divisão do mundo em economias avançadas e subdesenvolvidas, às perspectivas reais de progresso que se apresentam a estas últimas e aos aspectos particulares que apresentam as relações econômicas internacionais entre economias de diversos graus de desenvolvimento". 591

Celso Furtado destaca a compreensão de Myrdal de que esses problemas de integração econômica e de busca pela cooperação dependem de decisões de caráter político por parte das economias desenvolvidas. Por sua vez, o tema implica que "a integração nacional para ser alcançada pressupõe que se realizem amplos progressos no sentido da integração nacional dos atuais países subdesenvolvidos", ${ }^{592}$ daí a necessidade de cooperação internacional. Nesse sentido, ainda, Myrdal enfatiza "o amargo fracasso de todos os valentes planos traçados nos últimos anos da guerra e imediatamente depois para aliviar as dificuldades desses países no terreno do comércio exterior mediante uma ação internacional concertada, para estabilizar os preços das mercadorias, para fomentar movimentos compensatórios de capital, para controlar os monopólios industriais, etc". ${ }^{593}$ Assim, Celso Furtado destaca um conjunto de preocupações presentes desde os primeiros trabalhos da Cepal. Assinala, também, uma série de sugestões de política econômica para os países subdesenvolvidos que se relacionam diretamente com suas próprias propostas para a economia brasileira, discutidos há pouco. Com efeito, cita a recomendação de Myrdal de que "os países subdesenvolvidos terão de esforçar-se para elevar sua taxa de poupança"; "a necessidade de diversificar a estrutura produtiva e de exportação"; a busca de "cooperação com outros países subdesenvolvidos", bem como "a ampla intervenção no comércio exterior" e "a necessidade de rever os conceitos básicos da teoria do comércio internacional". ${ }^{594}$ Isso, ressalta Furtado, sob o perigo de que fora desse empenho "poucos países subdesenvolvidos lograrão atingir suas metas essenciais' ${ }^{595}$ Dessa forma, o destaque e a concordância completa que Celso Furtado demonstrou ao livro de Myrdal estabelece não apenas a semelhança de problemas que preocupa a ambos, como também demonstra a similaridade de propostas advindas da

\footnotetext{
${ }^{590}$ Idem, p. 220.

${ }^{591}$ Idem, ibidem.

592 Idem, p. 221.

593 Idem, p. 221.

${ }^{594}$ Idem, ibidem.

595 Idem, ibidem.
} 
"invejável experiência de dirigente de organismos internacionais" que marca a trajetória do economista sueco.

Outro evento do qual Celso Furtado participou foi o Encontro Este-Oeste de Economistas patrocinada pela Unesco com o objetivo de "pôr em contato professores e estudiosos no campo das ciências sociais dos dois blocos em que está dividido o mundo". 596

Celso Furtado inicia destacando uma série de problemas prévios que a reunião explicitou, tais como a "inexistência de uma terminologia comum" que estabeleça as matérias a serem discutidas, a "inexistência de um campo comum objeto (sic) de investigação científica", bem como "o grande desapego pelo que no Ocidente se chama de ciência econômica" que demonstram os russos.

O tema central da conferência foi os "Fatores Determinantes do Nível da Atividade em distintos sistemas econômicos". Celso Furtado considera que os estudos "deixavam muito a desejar" e sua resenha se restringirá a alguns trabalhos dos economistas orientais.

O primeiro deles permite recuperar as preocupações que Furtado explicitou em suas considerações sobre o Manual de Política Econômica da Academia de Ciências da URSS, a respeito da técnica de planificação. Os trabalhos examinados, de Dyatchencko e Friss, embora versassem sobre "o problema da técnica de planificação", não abordaram "diretamente o papel do consumidor no mecanismo de uma economia planificada". ${ }^{597}$ Celso Furtado destaca os dois aspectos mais importantes da questão, quais sejam "a necessidade de correspondência, em um momento dado, entre as estruturas da oferta e da procura de bens de consumo", sobretudo numa "economia em rápida transformação". O segundo aspecto é assim formulado: "se se limita o campo de escolha do consumidor por conveniência administrativa, não haverá risco de deslizar para um excesso de uniformidade com efeitos negativos sobre a personalidade do homem, em particular sobre o desenvolvimento de suas potencialidades estéticas?". Assim, retomam dois temas importantes dos debates sobre desenvolvimento econômico que compõem as preocupações de Celso Furtado. Com efeito, já vimos como a questão do papel do consumidor em uma economia planificada foi tema de debate com Bulhões, assim como a questão da programação cepalina sempre procurou se resguardar das

\footnotetext{
${ }^{596}$ FURTADO, Celso. Encontro Este-Oeste de economistas. Econômica Brasileira. Rio de Janeiro: Clube dos Economistas, n 3 e 4. Vol. 2, julho-dezembro, 1957, pp. 403.

${ }^{597}$ Idem, p. 404. Cumpre notar que a Econômica Brasileira publicará em 1958 o trabalho de Istvan Friss, "A estruturada oferta e da procura nas economias socialistas".
} 
críticas sobre a uniformização do consumo e de perda das liberdades individuais. ${ }^{598}$ A retomada dessas considerações, portanto, expressam como os problemas do desenvolvimento econômico e da planificação não deixavam de ocupar o pensamento de Celso Furtado, atento à respostas e proposições que pudessem incrementá-los.

Outro tema importante foi a consideração do "problema do comércio exterior entre economias planificadas", abordado pelo professor Kaigl, da então Tchecoslováquia. Celso Furtado observa que "a questão crucial dos preços relativos não foi abordada. E não o foi por uma razão muito simples: até hoje não foi resolvido, de um ponto de vista teórico, o problema da fixação dos preços relativos internos nas economias do bloco comunista". ${ }^{599}$ A questão deriva da utilização, pelos planificadores da teoria do valor, uma vez que a fixação dos preços dos produtos de exportação com base na teoria "provoca-se uma permanente transferência de renda em favor do país de mais baixa produtividade". 600

Celso Furtado destaca que as discussões foram mais interessantes que os textos apresentados e, a partir delas, estabelece algumas conclusões: "se está realizando um grande esforço no sentido de reformular os processos e técnicas de planificação", sendo que no país mais avançado em termos de programação, a Tchecoslováquia, estão introduzindo “incentivos monetários ao pessoal de direção das empresas”. No entanto, prossegue, "parece que ainda está longe o dia em que os economistas do bloco oriental possam apresentar algo que mereça chamar-se de 'teoria econômica da planificação", 601

Finalmente, tomando como referência a importância desses estudos para a solução dos problemas dos países subdesenvolvidos, Celso Furtado constata que “aparentemente do lado de lá ainda existe menos consciência do que no ocidente da necessidade de reconhecer na economia do subdesenvolvimento um campo autônomo a exigir um esforço criador de natureza teórica", 602

Esse conjunto de resenhas e intervenções de Celso Furtado reúne algumas evidências de suas preocupações entre a publicação de A Economia Brasileira e

\footnotetext{
${ }^{598}$ De fato, a questão da manutenção das liberdades individuais no regime socialista é um tema que já preocupava o jovem Celso Furtado, em um artigo sobre a situação da Iugoslávia, datado de outubro de 1947, podemos ler: "é justo que se indague, em face de um mundo que se transforma tão violentamente, qual a posição e qual o valor da pessoa humana - que espaço resta à liberdade pessoal para respirar". FURTADO, Celso. Na Iugoslávia. Panfleto, Ano 1, n 11, quarta semana de outubro de 1947, p. 23.

${ }^{599}$ Idem, p. 404.

${ }^{600}$ Idem, p. 404.

${ }^{601}$ Idem, p. 405.

${ }^{602}$ Idem, p. 406.
} 
Formação econômica do Brasil. Nesse sentido, é importante que ressaltemos que elas revelam desdobramentos de suas preocupações do início dos anos de 1950, bem como seu projeto de formulação de uma teoria do desenvolvimento econômico que seja permeada pela história e as ciências sociais.

Notamos nesses trabalhos como os diagnósticos sobre a economia brasileira apresentados pelos economistas liberais ou não, foram discutidos a partir de suas premissas teóricas, retomando as incursões que Celso Furtado fizera no texto "A teoria do desenvolvimento na ciência econômica". Esse movimento, no entanto, é paralelo a outro, de deslindar os problemas econômicos brasileiros valendo-se do instrumental fornecido por sua teoria do desenvolvimento econômico que, como vimos, fora elaborada conceitualmente explicando o processo histórico europeu e brasileiro. Foi precisamente a constituição desta teoria que lhe permitiu examinar os trabalhos dos outros teóricos do desenvolvimento econômico, inclusive avaliar suas proposições pela possibilidade de explicar e oferecer soluções aos problemas dos países subdesenvolvidos. Mas, notemos também, que esse conjunto de resenhas de Celso Furtado foi publicado a partir da abertura de um canal específico de divulgação das ideias desenvolvimentistas, a revista Econômica Brasileira. Por isso mesmo, esses trabalhos não podem ser examinados unicamente por seu aspecto teórico, pois são, também, um posicionamento no quadro de disputas com os economistas liberais. Mas, talvez o maior achado analítico que essas resenhas apresentam, é a consolidação dos temas de pesquisa de Celso Furtado, firmando suas pesquisas e abordagens de anos anteriores e servindo como crivo para o exame dos problemas de desenvolvimento econômico, tanto no nível teórico como no prático.

\section{A programação da economia brasileira: O Plano de Metas e os desequilíbrios econômicos}

Cumpre notar, ainda, que o posicionamento firmado nas resenhas e intervenções que acabamos de examinar sofrerá certo deslocamento em virtude de uma conjuntura nova, inaugurada pela presidência de Juscelino Kubitschek, em 1956. 
Os resultados teóricos alcançados por Celso Furtado maturam concomitantemente à implementação do Plano de Metas ${ }^{603}$, estabelecendo uma correlação entre a continuidade de suas elaborações conceituais e a viabilização política de um projeto de planejamento econômico. Dito de outra forma, a elaboração teórica e a proposta de diagnósticos deixam de se confrontar e passam a conformar, em certa medida, a política econômica.

Isso é possível, pois neste momento, "a ideologia desenvolvimentista incorporava-se à retórica oficial do governo". ${ }^{604}$ Mais ainda, Ricardo Bielschovisky considera que neste período, o pensamento desenvolvimentista "ganhava predomínio sobre o neoliberalismo"; resultado, é preciso reconhecer, de embates e de disputas das quais participou Celso Furtado. Trata-se, portanto, de período crucial para Celso Furtado e o pensamento econômico brasileiro, pois "o projeto de industrialização planejada tornava-se plenamente difundido na literatura econômica brasileira" e, sobretudo, a partir da segunda metade dos anos de 1950, "a reflexão econômica tornavase essencialmente subordinada à discussão sobre o problema do desenvolvimento econômico do país". 605

A expressão política dessa supremacia do desenvolvimentismo pode ser captada na implantação, por Juscelino Kubitschek, do Plano de Metas que, segundo Celso Lafer, "pela complexidade de suas formulações [...] e pela profundidade de seu impacto, pode ser considerado como a primeira experiência efetivamente posta em prática de planejamento governamental no Brasil". ${ }^{606}$ O Plano fora antecedido por um conjunto de missões técnicas, algumas delas tendo elaborado diagnósticos sobre os problemas brasileiros, “como é o caso da Missão Cooke (1942-1943), da Missão Abbink (1948), da Comissão Mista Brasil-EUA (1951-1953)”. ${ }^{607}$ Insere-se nesta lista, ainda, o relatório do Grupo Misto Cepal-BNDE, coordenado por Celso Furtado, Regino Boti e, do lado

\footnotetext{
603 “O Plano contemplava investimentos nas áreas de energia, transporte, indústrias de base, alimentação e educação, cujo montante orçado equivaleria a cerca de 5\% do PIB no período 1957-61. Os setores de energia e transporte receberiam a maior parcela dos investimentos previstos no Plano (71,3\%), a cargo quase que exclusivamente do setor público. Para as indústrias de base, foram previstos cerca de 22,3\% dos investimentos totais, sob a responsabilidade principalmente do setor privado (por vezes com ajuda de financiamentos públicos). As áreas de educação e alimentação receberiam os restantes 6,4\% dos recursos totais". VILLELA, André. Dos "Anos Dourado" de JK à crise não resolvida (1956-1963). In: GIANBIAGI, Fábio (et. alli). Economia brasileira contemporânea 1945-2004). Rio de Janeiro, Elsevier, 2005 , p. 55.

${ }^{604}$ BIELCHOWISKY, Ricardo. Pensamento econômico brasileiro. op. cit., p. 401.

${ }^{605}$ Idem, ibidem.

${ }^{606}$ LAFER, Celso. O planejamento no Brasil - observações sobre o Plano de Metas (1956-1961). In: LAFER, Betty Mindlin (org). O planejamento no Brasil. São Paulo, Perspectiva, 1987, p. 30.

${ }^{607}$ Idem, ibidem.
} 
banco brasileiro, Roberto Campos; documento que estabeleceu as linhas básicas da programação proposta pela Cepal, qual seja, o "planejamento integral" ${ }^{608}$ e que serviu de fonte de informações para o Plano de Metas, embora este, sob a coordenação de Lucas Lopes, tenha utilizado o conceito de planejamento seccional como conceito básico. ${ }^{609}$

Entretanto, interessa-nos captar como Celso Furtado percebe esta conjuntura, que apresenta uma série de novidades em relação ao período anterior, sobretudo se considerarmos, para além da implantação do planejamento econômico e da parceria entre a Cepal e o BNDE no levantamento da situação econômica brasileira, a fundação do Clube dos Economistas e da revista Econômica Brasileira. Ou seja, a conjuntura econômica e as condições de produção e divulgação das ideias desenvolvimentistas se alteraram e colocaram a Celso Furtado um novo leque de preocupações, que é preciso examinar.

Fundamental para isto é o conjunto de dez conferências que Celso Furtado pronuncia no segundo semestre de 1957, no âmbito do Curso de Treinamento em Problemas de Desenvolvimento Econômico promovido pela Cepal, com a colaboração do BNDE, CAPES, ISEB e TAA (Tecnical Assistance Agence - da Organização dos estados Americanos), onde apresenta um diagnóstico dos principais problemas da economia brasileira, e propõe uma série de medidas para equacioná-los a partir da programação.

Publicadas em 1958, sob o título de Perspectivas da economia brasileira, as palestras consolidam sua posição de que o diagnóstico e as soluções para a economia brasileira devem ser apresentados de forma conjunta, um pressupondo o outro, evitando a possível imputação de tomada de princípios teóricos a priori.

Como veremos na sequência, essas conferências, ao apresentarem um mapeamento das principais forças capazes de impulsionar ou retardar $\mathrm{o}$ desenvolvimento da economia brasileira, basearam-se, largamente, no resultado do trabalho do Grupo Misto Cepal-BNDE. O interesse que elas proporcionam deve-se também ao fato de terem sido publicadas, no ano seguinte, e, portanto, paralelamente à execução do Plano de Metas, porém sem mencioná-lo diretamente. Por sua vez, apresenta uma "particularidade", pois, ao mesmo tempo em que possuem um caráter

\footnotetext{
${ }^{608}$ BIELCHOWISKY, Ricardo. Pensamento econômico brasileiro. op. cit., p. 152.

${ }^{609}$ Lucas Lopes chefiara a equipe brasileira da Comissão Mista Brasil-Estados Unidos. Ver: LAFER, Celso. O planejamento no Brasil... op.cit., p. 34-35.
} 
oficial, pronunciamento para órgãos de cooperação internacional (Cepal, TAA) e instituições de caráter governamental (BNDE, Capes, ISEB), teria, segundo Carlos Mallorquin, exigido certa cautela de Celso Furtado, expressa ao "limitar as contradições econômicas do Brasil às suas mínimas consequências, quando expõe conferências oficiais". ${ }^{610}$ Assim, Mallorquin lê o livro Perspectivas da economia brasileira como uma proposta de política econômica a partir de um órgão oficial. Sem perder essa dimensão, nossa interpretação considera este texto como um diálogo paralelo ao Plano de Metas, o que não exime Celso Furtado de tecer críticas ao programa de desenvolvimento adotado. ${ }^{611}$

Como sabemos, o Plano também mobilizou os dados das missões anteriores, seja do CMBEU, seja da Cepal-BNDE. Vimos, também, que essas duas missões tinham concepções diversas do que é o planejamento econômico. De fato, enquanto a primeira se restringiu a elaborar projetos específicos, a segunda propunha uma planificação global da economia, como, ademais, já estava explícito nos trabalhos da Cepal sobre programação econômica. O Plano de Metas, por sua vez, adota uma concepção intermediária, de planejamento setorial. ${ }^{612}$ Dessa forma, ao apreciar o relatório precisamos, também, atentar para que tipo de diálogo estabelece com o Plano de Metas.

Celso Furtado dividiu as conferências em dois grandes blocos. No primeiro, preocupa-se em analisar as "tendências fundamentais" da economia brasileira, identificar as "principais caraterísticas do sistema econômico brasileiro" em seu conjunto, assinalando seus fatores dinâmicos, os setores com maior potencial de crescimento, recursos disponíveis e elementos que podem impulsionar ou frear o desenvolvimento. Em seguida, apresenta esses elementos em conjunto, procurando definir "o que se deve entender por crescimento ótimo da economia brasileira", de

\footnotetext{
${ }^{610}$ MALLORQUIN, Carlos. Celso Furtado: um retrato intelectual. [1993] São Paulo: Xamã; Rio de Janeiro: Contraponto, 2005, p. 152.

${ }^{611}$ Vera Cepêda também examina o livro sob o aspecto propositivo, não considerando o diálogo que o texto trava com o Plano de Metas. Em sua análise, Celso Furtado estaria propondo o planejamento econômico para solucionar os desequilíbrios econômicos dos anos de 1950. Todavia, não considera que Perspectivas da economia brasileira é uma discussão dentro da implantação do planejamento, o que também a faz estabelecer que "as linhas de sustentação da teoria de Celso Furtado condensam e expressam toda uma problemática que marca a produção intelectual mundial. Se sustenta (sic), do ponto de vista mundial na quebra do paradigma liberal e no aumento de socialização das decisões econômicas, surgidas como resultado de profundos desequilíbrios do capitalismo neste século". Entretanto, sem desconsiderar esse arcabouço mais amplo, nos parece que a chave interpretativa do planejamento cepalino e das propostas furtadianas têm uma inteligibilidade maior se referidas ao contexto imediato de disputa entre projetos econômicos no cenário de desenvolvimento latino-americano e, sobretudo, brasileiro. Ver: CEPÊDA, Vera Alves. Raízes do pensamento político de Celso Furtado: desenvolvimento, nacionalidade e Estado democrático. (Dissertação de Mestrado, Ciências Sociais, FFLCH-USP), 1998, p. 150.

612 "O planejamento da CMBEU, depois adotado também no Plano de Metas, era de natureza setorial". CAMPOS, Roberto. A Lanterna na popa: memórias. Rio e Janeiro: Topbooks, 1994, p. 164.
} 
forma a delimitar as "perspectivas que se apresentam" e, principalmente, "determinar os elementos de uma política sistemática de desenvolvimento". ${ }^{613}$ A junção, portanto, entre análise da economia brasileira e intervenção aparecem conjuntamente, reiterando uma das características de sua argumentação. Dessa forma, sua proposta

\begin{abstract}
toma corpo num programa e pressupõe um conhecimento pormenorizado do sistema econômico, a identificação clara das tendências que se fazem sentir no momento presente, a decisão de atuar oportuna e eficazmente sobre essas tendências, a definição de objetivos claros a alcançar nos setores estratégicos de produção, a mobilização de meios adequados de defesa contra desequilíbrios internos e externos demasiadamente acentuados, e capacidade política

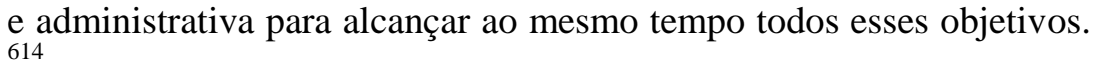

Ou seja, Celso Furtado novamente retoma a programação econômica ensejada pelo relatório da Cepal de 1953 de forma imbricada ao diagnóstico da economia brasileira. Nesse sentido, é importante notar que, muito embora no livro A economia brasileira o diagnóstico dos problemas estivesse implícito e o texto mantivesse um caráter exploratório dos problemas econômicos, aqui, como veremos, o próprio objetivo da programação conduz o exame da economia brasileira. Parte-se do pressuposto de que a programação é inevitável e indiscutível, cabendo unicamente esclarecer como deve ser executada.

É nesta perspectiva que inicia o exame da economia brasileira, constatando a existência de três sistemas econômicos distintos, um deles apresentando "um imenso vazio demográfico e econômico" e dois outros, o sul e o nordeste, com caraterísticas muito distintas. A região nordestina, "não apresenta o grau de integração necessário para constituir rigorosamente um sistema econômico". ${ }^{615}$ Possui baixo nível de renda per capta, tendente a declinar devido ao crescimento da população, pouca integração regional, "sem a ação estimulante de fatores externos". Por outro lado, possui recursos econômicos que não se transformam em investimentos devido a seu mercado restrito, mas que, no entanto, poderiam ser orientados neste sentido por uma política de desenvolvimento. ${ }^{616}$

Já o sul do país apresenta "um sistema econômico relativamente integrado", com renda per capta mais de duas vezes maior que a nordestina; conta, também, com alguns

\footnotetext{
${ }^{613}$ FURTADO, Celso. Perspectivas da economia brasileira. Rio de Janeiro: Ministério da Educação e Cultura: Instituto Superior de Estudos Brasileiros, 1958, (Textos Brasileiros de Economia), p. 9.

${ }^{614}$ Idem, p. 10.

${ }^{615}$ Idem, ibidem.

${ }^{616}$ Idem, p. 10-12.
} 
faixas ainda de economia de subsistência, muito embora "o nível médio de produtividade" seja elevado e "algumas zonas importantes já revelam certa homogeneidade". 617

O sistema econômico do sul do Brasil recebe seu dinamismo de dois setores, a agricultura de exportação (sobretudo o café) e o setor industrial, voltado para o mercado interno. O primeiro possui alta produtividade e tem sido favorecido pela alta dos preços internacionais na última década, gerando assim um importante fluxo de divisas para o país. Já o setor industrial tem papel dinâmico na economia, ao absorver e expandir internamente o impulso dado pela ampliação da renda da cafeicultura. Isso é possível, pois "a produtividade média e as dimensões absolutas do mercado do sul do Brasil já alcançaram nível suficientemente elevado para que esse sistema esteja em condições de gerar seu próprio impulso de crescimento". ${ }^{618}$ Embora Celso Furtado destaque que este sistema não possa prescindir das divisas do setor exportador, nota, entretanto, que a produção de bens de capital já alcançou importância relativa, podendo operar e "crescer por conta própria". Além disso, produz uma "importante massa de lucros" que, sendo reinvertida na produção, “cria automaticamente procura para as indústrias de bens de capital, as quais tendem a expandir-se e a ampliar o mercado das outras atividades". ${ }^{619}$ Esse exame das linhas de desenvolvimento da economia não deixa de indicar, também, que

os problemas de desequilíbrio com que se defronta a economia brasileira são, portanto, específicos da etapa atual de seu desenvolvimento. Se não os equacionarmos de forma precisa, corremos o risco de administrar receitas que, sem eliminar as verdadeiras causas do desequilíbrio, poderão ser de consequências danosas para o próprio crescimento ${ }^{620}$

Nesse ponto, portanto, a análise da conjuntura econômica revela os principais dados do problema e os entraves para o crescimento econômico. Ao constatar que os desequilíbrios são decorrentes da etapa atual da economia e do nível de desenvolvimento já alcançado, a intervenção da política econômica deve partir desse diagnóstico de conjunto, do contrário o combate aos efeitos dos desequilíbrios não consegue alterar seu mecanismo causador. Importa destacar, também, que este mapeamento dos sistemas econômicos da economia brasileira demonstra como as conferências seguem de perto uma proposta de planejamento, cuja primeira etapa é

\footnotetext{
${ }^{617}$ Idem, p. 12.

${ }^{618}$ Idem, p. 13.

${ }^{619}$ Idem, ibidem.

${ }^{620}$ Idem, p. 14.
} 
precisamente elaborar um quadro de conjunto, identificado suas inter-relações ou, no caso brasileiro, a ausência de conexão entre os sistemas econômicos existentes. Finalmente, é preciso observar que o surgimento de um núcleo industrial com relativa autonomia no sul do país, algo que fora indicado no livro A economia brasileira, aparece aqui como um dado já estabelecido, evidenciando a continuidade entre o diagnóstico elaborado e, agora, a proposição de soluções ancoradas na programação econômica. A relação entre os dois fica explícita no exame dos desequilíbrios gerados pelo desenvolvimento da economia brasileira. É sobre esse ponto que Celso Furtado se dedica na sequência.

De fato, "a tendência ao desequilíbrio, externo e interno, é inerente à etapa atual de desenvolvimento da economia brasileira", e "o sistema dificilmente poderia manter ótimo ritmo de crescimento, durante prolongado período, na ausência de uma ação orientadora de seus investimentos e corretora da estrutura de sua procura". ${ }^{621}$

Observando o comportamento da economia brasileira da última década, Celso Furtado constata que a taxa de crescimento efetivo não se igualou ao crescimento potencial. ${ }^{622} \mathrm{Ou}$ seja, espontaneamente, a economia não consegue manter um ritmo de crescimento tão intenso quanto poderia. Nesse sentido, torna-se necessária a programação, uma vez que "o próprio crescimento cria toda uma série de desequilíbrios. A defeituosa orientação dos investimentos, característica da etapa de desenvolvimento em que se encontra o Brasil, provoca permanente desgaste de recursos". ${ }^{623}$ Dessa forma, Celso Furtado identifica como as forças espontâneas da economia não conseguem maximizar a alocação dos recursos disponíveis. Desse conjunto de problemas, um dos fatores desestabilizadores do crescimento é examinado mais detidamente: a "inelasticidade da oferta de alimentos". ${ }^{624}$

No Brasil, “desenvolvimento significa basicamente a transferência de população de setores onde prevalecem atividades de subsistência para zonas urbanas onde predomina o trabalho nas indústrias e serviços". ${ }^{625}$ Com isso, a população que ingressa no mercado de trabalho urbano pressiona a oferta de alimentos, enquanto a agricultura se mantém no nível de subsistência e, assim, encarece os salários nas atividades

\footnotetext{
${ }^{621}$ Idem, p. 15.

${ }^{622}$ Considerando a taxa de poupança líquida e o coeficiente de produtividade média do capital no Brasil desde 1954, Celso Furtado observa que houve uma variação, de 8 a $13 \%$ na primeira e de 0,5 a 0,57 no segundo. Isso implica uma variação da taxa de crescimento entre 4 e 7,4\%. No entanto, no mesmo período a produção real cresceu 6,2 ao ano, ou seja, abaixo de seu nível ótimo.

${ }^{623}$ Idem, p. 17.

624 Idem, p. 18.

625 Idem, ibidem.
} 
industriais e de serviço. Para Celso Furtado, "a inexistência de uma agricultura moderna, de base capitalista, ligada ao mercado interno, é em grande parte responsável pela tendência permanente ao desequilíbrio interno que se observa no país". ${ }^{626}$ Esse problema acaba se traduzindo num conflito aberto entre trabalhadores e empresários pela preservação do poder de compra dos salários e das margens de lucro. No entanto, observa Furtado, novamente retomando suas discussões críticas sobre a política econômica monetarista, "lutar contra essa forma de desequilíbrio pela simples suspensão do crédito é eliminar a possibilidade de que a economia continue a crescer". 627 Dessa forma, "a existência de poderosos elementos dinâmicos não basta para assegurar à economia brasileira elevada taxa de crescimento".

Aqui podemos observar uma radical alteração na argumentação que desenvolveu na disputa com Otávio Gouveia de Bulhões sobre o dinamismo do empresariado brasileiro. Se naquele texto havia certa hesitação entre reconhecer a dinâmica relativa do setor privado e defender a programação, neste momento a análise aparece enraizada na constatação dos desequilíbrios observáveis na economia brasileira, indicando que a ausência de programação foi responsável por limitar e restringir o desenvolvimento econômico. Nesse sentido, o planejamento aparece não mais como opção, mas como necessidade: "quando pensamos em programação, temos em vista eliminar os fatores perturbadores do crescimento. Em outras palavras: pretendemos criar as condições para que o crescimento alcance e mantenha um ritmo ótimo". ${ }^{628}$ Dessa forma, não mais se discute se o método de programação é ou não totalitário, nem se considera ou não o nível de preços relativos. Aparece, agora, como medida corretora e solução para um conjunto de desequilíbrios econômicos já diagnosticados pela análise.

Para solucionar isso, Celso Furtado destaca que é preciso, além de aproveitar ao máximo a capacidade de exportação da economia, orientar os investimentos no setor industrial, já capacitado para um crescimento endógeno. Por sua vez, definidos os investimentos industriais, será possível prever a demanda de alimentos e serviços a ser atendida, orientando "recursos e assistência técnica para o campo a fim de estimular a oferta de alimentos e matérias-primas". 629

A preocupação com um exame conjunto da economia brasileira procurando uma interligação de seus problemas e soluções aparece, também, no exame das perspectivas

\footnotetext{
${ }^{626}$ Idem, p. $18-19$.

${ }^{627}$ Idem, p. 19.

${ }^{628}$ Idem, p. 20.

${ }^{629}$ Idem, p. 21.
} 
para a capacidade de importar brasileira. A primeira constatação de Celso Furtado é a perda de participação brasileira no comércio internacional, apenas compensada pela elevação no nível dos preços internacionais do café. O motivo dessa perda de espaço deve-se à política cambial seguida até 1953, que manteve uma taxa de câmbio fixa para as exportações enquanto os preços internos se elevaram consideravelmente, o que desestimulou os investimentos no setor cafeeiro, embora canalizasse sua renda e cambiais para o setor industrial. ${ }^{630}$ Essa política teve outro efeito, este sim negativo para o conjunto do país, pois as regiões que dependiam unicamente da exportação de alguns produtos primários, compravam alimentos e bens de consumo das regiões industriais, contribuindo para agravar a desigualdade regional. ${ }^{631}$

Dentro desse quadro, "o problema mais complexo que se apresenta no momento atual [...] é o de adaptar as importações à capacidade de importar". ${ }^{632}$ Nesse sentido, Celso Furtado observa as perspectivas para os dois principais produtos de exportação, o algodão e o café. No caso do primeiro, projeta um crescimento da demanda internacional de $2,1 \%$ ao ano e alerta que o Brasil tem perdido terreno nas exportações mundiais de algodão e os preços do produto não apresentam tendência de crescimento.

Por sua vez, as perspectivas para o mercado cafeeiro também não são mais auspiciosas. Esse produto tem uma grande estabilidade do lado da procura, de forma que o principal ponto dinâmico se dá pelo lado da oferta. As estimativas da Cepal e da FAO apontam um crescimento anual da oferta de 1,53\%. Já no que concerne aos preços de exportação, este tem variado de acordo com fatores climáticos e dos estoques mundiais, mas oscilando em um preço médio de 50-55 centavos de dólar por libra para os próximos dez anos. No entanto, para que esse preço se mantenha, argumenta Furtado, é preciso que se organize melhor interna e mundialmente o mercado de café. No mercado interno, Celso Furtado destaca o impacto que o setor tem para a inflação,

\footnotetext{
${ }^{630}$ A política cambial durante o governo Kubitschek procurou enfrentar a diminuição das receitas de cambiais, devido à queda dos preços do café a partir de 1953, bem como criar incentivos para a atração de capital estrangeiro para financiar o processo de substituição de importações do Plano de Metas. Nesse sentido, a Instrução 113 da Sumoc, e a Lei 3.244, de 1957 procurou definir os setores que contariam com cobertura cambial e proteção para os setores prioritários. Ver: ORENSTEIN, Luiz, SOCHACZEWSKI, Antonio Claudio. Democracia com desenvolvimento: 1956-1961. In: PAIVA, M. A.( org.). A ordem do Progresso. Cem anos de política econômica republicana, 1889-1989. Rio de Janeiro: Campus, 1992, pp. 171-175.

${ }^{631}$ Este diagnóstico, segundo o qual o Nordeste, ao fornecer cambiais para o sul - ao mesmo tempo em que dependia de sua produção de manufaturas e alimento - custeou a industrialização desta região está na base do diagnóstico da Operação Nordeste e da criação da SUDENE. Para uma crítica a esta interpretação, que trata as duas regiões como nações independentes, ver: CANO, Wilson. Desequilíbrios regionais e concentração industrial no Brasil, 1930-1970. Campinas: São Paulo: Editora do Instituto de Economia, Unicamp, 1998.

${ }^{632}$ FURTADO, Celso. Perspectivas da economia brasileira, op. cit., p. 24.
} 
sugerindo formas de financiamento de estoques que considerem o preço externo do produto e não as divisas, como forma de diluir seu impacto no nível de preços. ${ }^{633}$

Esse conjunto de restrições leva Celso Furtado a enfatizar que "o Brasil deverá tentar, por todos os meios, maior diversificação de suas exportações", o que implica não apenas a pesquisa sobre as possibilidades de produção de artigos com demanda no mercado internacional, quanto a melhor otimização dos fatores disponíveis no território nacional. ${ }^{634}$

O outro foco de dinamismo da economia brasileira é o setor industrial, voltado para o mercado interno. Este setor é responsável por $25 \%$ da renda nacional e como vimos, é o principal fator dinâmico capaz de transmitir ao resto da economia os impulsos externos, respondendo aos aumentos na demanda de produtos manufaturados internamente. ${ }^{635}$ No exame deste setor, é importante compreender a interdependência da demanda industrial para que os investimentos se distribuam de maneira a evitar desequilíbrios. O principal elemento dinâmico do setor é o de bens de capital, pois responde à procura das outras faixas de indústrias, ao mesmo tempo em que gera demanda para estas, através da ampliação dos salários. O estudo da Cepal-BNDE aponta que "a produção de equipamentos tem crescido consideravelmente no último decênio", tendo aumentado em 100\% no período 1949-1954. Em que pesem os simples serviços de reparo nesta expansão, “é provável que a produção interna não contribua com mais de um terço da acumulação líquida de equipamento". ${ }^{636}$

\footnotetext{
633 "É necessária uma política compensatória que poderia estar intimamente ligada ao método de financiamento dos estoques excedentes. A medula desse problema está em ligar a política de defesa do preço de exportação - sem que com isso se entenda a criação de preço artificial — com a de controle do impacto inflacionário da acumulação de estoques. É esse um problema de solução teórica possível, embora apresente grandes dificuldades práticas”. Idem, p. 28.

${ }^{634}$ Idem, p.28. Como indicamos, a diversificação da produção não esteve em consideração no Plano de Metas e a principal forma de captação de divisas foi feita através do incentivo ao ingresso do capital estrangeiro. O cenário para as exportação brasileira de café, ainda, apresentou-se pior do que a traçada por Celso Furtado, pois os preços caíram a 41,8 cents em 1958 e, durante a década, seu peso no PIB caiu de 2 para 4\%. VILLELA, André. Dos “Anos Dourado” de JK à crise não resolvida (1956-1963). op. cit., p. 54.

${ }^{635}$ Por sua vez, "a expansão industrial faz crescer simultaneamente a massa de lucros e a de salários. Essa maior massa de salários significa expansão da procura de alimentos e novo estímulo à produção agrícola". Idem, p. 30.

${ }^{636}$ Idem, p. 32 Esse visão era compartilhada pelos elaboradores do Plano de Metas: "O setor de indústrias de base, que absorvia 20,4\% dos investimentos inicialmente contemplados pelo Plano de Metas, era um dos setores cruciais para se atingir a vigorosa política de industrialização de que falava Kubitschek na sua campanha eleitoral de 1955. Os resultados do setor, no conjunto, mostram que esse objetivo foi atingido, pois o ritmo de crescimento da produção industrial aumentou mais de $96 \%$ sobre 1955 — índice do volume físico da produção industrial - crescimento que se compara muito favoravelmente com o índice de 1952-1955 que foi de 42\%. Por outro lado, a produção industrial diversificou-se, ganhando destaque maior ênfase no setor de produção". LAFER, Celso.. O planejamento no Brasil - observações sobre o Plano de Metas (1956-1961). op. cit., p. 45-46.
} 
Outro setor que possui importância dinâmica no conjunto da atividade industrial é o produtor de artigos semielaborados para atender o conjunto das outras indústrias, impactando positivamente no custo final. Nesse sentido, destaca a siderurgia brasileira, que atende à demanda de ferro e aço dos demais setores industriais e da construção civil. Para os próximos anos, o estudo da Cepal-BNDE prevê um aumento da demanda de mais de $70 \%$ na produção de lingotes de ferro e aço. $\mathrm{O}$ mesmo deve ocorrer com a produção de metais não ferrosos como cobre e alumínio, que deve ter sua procura aumentada nos próximos anos. Esses produtos, segundo Furtado, devem ser objeto de estudo e constar na programação do desenvolvimento econômico para evitar desequilíbrios e problemas de balanço de pagamentos.

Mapeadas as características gerais da economia brasileira e seus setores dinâmicos, Celso Furtado examina, nos próximos capítulos, "as tendências gerais do crescimento da economia brasileira". ${ }^{637}$ Essa análise considera que, "dado o crescimento da população, a abundância de recursos naturais não utilizados, o dinamismo da classe empresária e a consciência que se formou no setor público da necessidade de intensificar o desenvolvimento, pode-se admitir como altamente provável que se manterá no futuro o crescimento do sistema". ${ }^{638}$ Para lograr esse crescimento, Celso Furtado examina as possibilidades e o caminho que a economia brasileira tem de enfrentar:

qual a taxa 'natural' ou mais provável de crescimento a que tende o sistema nas condições atuais? Essa taxa, que traduziria um ritmo de crescimento espontâneo, determinado pela estrutura do sistema e pelo comportamento mais provável dos fatores exógenos, não passa de uma abstração, pois a realidade será em grande parte determinada pela política de desenvolvimento do Governo. Representa um limite, ao qual tenderá o crescimento, caso a ação corretiva e propulsora do Governo não se ajuste sensivelmente ao seu comportamento no último período observado. ${ }^{639}$

Com isso, Celso Furtado estabelece, de maneira unívoca, que a consideração do crescimento possível da economia brasileira deve abarcar, também, o exame da política de desenvolvimento do governo, entendida como passível de ser alterada, levando em conta a tendência potencial de crescimento.

Para examinar a possibilidade de crescimento da economia brasileira, Celso Furtado investiga as tendências e os dados que revelam o comportamento da

\footnotetext{
${ }^{637}$ Idem, p. 37.

${ }^{638}$ Idem, ibidem.

${ }^{639}$ Idem, p. 37.
} 
acumulação de capital. Detém-se em um conjunto de variáveis macroeconômicas, sobretudo a relação produto-capital, que mede o quanto o investimento age sobre a capacidade produtiva. Esta relação é estável ao longo do tempo e, segundo os cálculos da comissão Cepal-BNDE, ficou em 0,52 no período 1939-53. ${ }^{640} \mathrm{O}$ investimento, por sua vez, teve uma taxa média anual de 7,9\% entre 1945 e 1952. O estudo da CepalBNDE prevê um crescimento per capta de 1,7\% por habitante. Já a renda, condicionada mais diretamente por fatores externos, tem uma taxa prevista de 1,5\% ao ano, bem abaixo dos 3\% do período 1939-54. O consumo, refletindo o crescimento da renda inferior à produção devido ao escoamento de recursos para o exterior, mostra um crescimento de apenas $1,2 \%$.

Para Furtado, no entanto, "tais observações se referem a uma simples projeção das tendências manifestadas no período mais recente [...] A realidade seguramente será distinta, pois a ação dos poderes públicos tende a intensificar-se e a lograr maior coordenação e efetividade". ${ }^{641}$ Nesse ponto, Furtado passa a expor as medidas que devem ser tomadas para "neutralizar as forças tendentes a debilitar o crescimento". ${ }^{642}$

Celso Furtado sugere um conjunto de medidas para a elevação da produtividade média do capital. A própria manutenção do crescimento evitaria flutuações na procura industrial, o que induziria ao melhor aproveitamento da capacidade produtiva. Por outro lado, criar linhas de exportação para aproveitar recursos naturais com baixa demanda interna também aumentaria a produtividade do capital. Outra fonte, sobretudo para a agricultura, seria a "introdução de técnicas mais eficientes de produção mediante inversões de pequena monta", tais como "sementes híbridas, de inseticidas e pesticidas, de métodos de seminação artificial”, o que requer, por sua vez, investimentos em educação e formação de especialistas. ${ }^{643}$ No entanto, destaca que "a experiência brasileira indica, de modo claro, que as deficiências nos setores básicos de transporte e energia têm sido as principais causas do declínio na produtividade média do capital”. ${ }^{644}$

\footnotetext{
${ }^{640}$ Idem, p. 38.

641 Idem, p. 40.

${ }^{642}$ Idem, p. 41.

${ }^{643}$ Idem, p. 42. Os setores de agricultura e educação foram contemplados pelo Plano de Metas, porém em porcentagem muito pequena. Para o setor de alimentação foram destinados ,3,2\% dos recursos. Segundo Lafer, em que pesem os problemas sociais do campo, "a taxa de crescimento da produção agrícola brasileira no período 1955-60 foi de 7,2\% ao ano, o que contrasta favoravelmente com a taxa de 3,3\% do quinquênio anterior". Já sobre educação, que obteve 3,4\% dos recursos, Lafer destaca, sem citar números, que "o Governo aumentou, progressivamente, as verbas orçamentárias consignadas ao MEC e deixou subsídios importantes sobre o problema que resultaram dos trabalhos do ENATEC (Grupo Executivo de Ensino e Aperfeiçoamento Técnico)". LAFER, Celso. O planejamento no Brasil — observações sobre o Plano de Metas (1956-1961). op. cit., pp. 45 e 48.

${ }^{644}$ Idem, ibidem.
} 
Tanto mais que a diminuição da relação produto-capital observada a partir de 1948 "não foi causada por insuficiência da procura". Ao contrário, "sua causa está nos desequilíbrios crescentes entre setores: insuficiência relativa de transportes, de energia, de certas matérias-primas, de peças de máquinas importadas, etc.”. ${ }^{645}$ Para fazer frente a este desafio, Furtado observa que "um ascenso da relação produto-capital de 0,53 para 0,57 , durante um período de 8 anos, teria maior efeito sobre o ritmo de crescimento da economia do que um influxo de 500 milhões de dólares em recursos externos". ${ }^{646}$

Aqui, é preciso perceber o arcabouço mobilizado no exame de Celso Furtado. Com efeito, seu ponto de partida é a análise de conjunto da economia brasileira, considerando seus elementos dinâmicos e principiais problemas, traduzindo-os em tendências de crescimento econômico. É precisamente dessa visão integrada que surge a questão dos problemas de infraestrutura, transporte e energia, elementos já reconhecidos pelas comissões técnicas desde os anos de 1940 como inibidores do crescimento econômico. Por sua vez, não é difícil perceber o diálogo que o texto estabelece com a política econômica, pois reconhece problemas que, de fato, já estão sendo solucionados na prática. ${ }^{647}$ Essa relação entre o diagnóstico e os rumos da planificação adotada, por sua vez, pode ser vista como a resolução, no plano expositivo, de uma proposta de intervenção que já conta com adesão e implementação, de forma que o argumento aparece, ao final, como uma justificativa dos caminhos tomados, embora seja difícil aquilatar a real extensão e profundidade da adesão e apoio ao planejamento de Juscelino Kubitschek.

Outro ponto da análise refere-se à taxa de poupança necessária para acelerar o crescimento da economia, ou seja, o esforço que terá de ser feito pelo conjunto dos agentes econômicos. Celso Furtado destaca que "o primeiro passo para elevar a taxa de poupança consiste em criar condições que estimulem a poupança privada". ${ }^{648}$ Nesse aspecto, a principal dificuldade decorre dos efeitos da inflação, observando que, “é um erro raciocinar, em relação ao nosso país, com fórmulas gerais, baseadas na observação das economias tipicamente subdesenvolvidas", pois o sistema sulino apresenta um perfil de renda mais próximo a países desenvolvidos, de forma que "possivelmente a consequência mais grave da inflação no Brasil haja sido impossibilitar a formação de

\footnotetext{
${ }^{645}$ Idem p. 43.

${ }^{646}$ Idem, p. 44.

${ }^{647}$ Os dois principais alvos do Plano de Metas, respectivamente os setores de energia e transportes, responsáveis, juntos, por $71,4 \%$ do total de recursos previstos para o plano.

${ }^{648}$ Idem, p. 46.
} 
hábitos de poupança na classe média". ${ }^{649}$ Para solucionar esse problema, aponta uma série de medidas, tais como a criação títulos que garantam alguma proteção contra a inflação e a recusa da concentração de renda como meio de ampliar a poupança disponível do país. ${ }^{650}$ Outro mecanismo necessário para elevar o esforço da população para o desenvolvimento é a política fiscal, não no sentido de transferir recursos do setor privado para o público. Ao contrário, “o que se tem em vista é reduzir o consumo supérfluo de certos grupos de população que se acham desligados das atividades produtivas e tendem a crescer anormalmente nos setores em que a renda está por demais concentrada". ${ }^{651}$ Nessa questão, Celso Furtado propõe impostos à importação de bens de consumo suntuário, compensados por impostos internos indiretos, para evitar um estímulo à esta indústria no país. No entanto, "a medula do problema está em evitar que o desenvolvimento acarrete concentração da renda ou pelo menos que um alto nível de lucros implique elevado nível de distribuição de dividendos". ${ }^{652}$ Assim, o principal objetivo da política fiscal é a diminuição da desigualdade e da concentração da renda. Nesse sentido, aponta a necessidade de taxação das terras improdutivas como forma de estimular uma agricultura moderna capitalista e alterar a legislação para "induzir as empresas a reter parte muito maior de seus lucros para reinvestimento". ${ }^{653}$ Outra forma de ampliar os investimentos seria aumentar a participação do setor público em "empresas altamente lucrativas", como o petróleo, ou ampliar o dispêndio, fazendo com que os investimentos públicos cresçam mais que as despesas de custeio. Isso, ademais, foi responsável pelo aumento da taxa de poupança entre 1950-1952.

Aqui, é possível perceber uma das principais críticas ao Plano de Metas, pois este, efetivamente, não concebeu um mecanismo adequado de financiamento dos investimentos. Para além da política cambial protecionista ao setor industrial e dos instrumentos de estímulo ao ingresso do capital estrangeiro, o principal mecanismo que o governo utilizou foi a emissão inflacionária, agravando os conflitos distributivos e concentrando a renda e os lucros dos setores industriais e do capital estrangeiro. ${ }^{654}$ Esse aspecto crítico é evidente quando pensamos que sua publicação é concomitante ao descontrole da inflação, saltando de 7 para 24, 4\% entre 1957 e 1958. Em outubro desse

\footnotetext{
${ }^{649}$ Idem, p. 47.

650 "A concentração de renda não é meio eficaz de aumentar a taxa de poupança. É verdade que uma brusca concentração da renda repercute positivamente na taxa de poupança. Todavia esse efeito positivo terá duração limitada e o resultado final poderá ser negativo". Idem, ibidem.

${ }^{651}$ Idem, p. 48.

${ }^{652}$ Idem, p. 49.

${ }^{653}$ Idem, p. 50.

${ }^{654}$ VILLELA, André. Dos “Anos Dourado” de JK à crise não resolvida (1956-1963). op. cit., p. 57.
} 
ano, o governo anuncia um Programa de Estabilização Monetária que, aplicado no início de 1959 logo foi abandonado pela oposição que encontrou no congresso e em setores do próprio governo.

O último fator considerado por Furtado é a entrada de recursos externos, fundamental quando se considera "a dependência tecnológica de uma economia como a brasileira", pois "o ingresso mais intenso de recursos externos - na forma de patentes, equipamento e capacidade para manejá-los — pode ser o modo mais rápido de assimilar a técnica". ${ }^{655}$ Por sua vez, será preciso que o país também passe a desenvolver tecnologia à medida que o processo de desenvolvimento for avançando. ${ }^{656}$

Com isso, Celso Furtado examinou os principais fatores capazes de dinamizar o crescimento econômico, o papel dos setores externo e interno, bem como as medidas que o governo pode adotar para atingir o crescimento, atuando diretamente sobre as políticas fiscais e cambiais, sobretudo; e, também, indiretamente através de incentivos aos setores dinâmicos, bem como na formação de poupança. No entanto, como pudermos perceber, essas recomendações diferiam substancialmente das medidas efetivamente adotadas pelo Plano. Esse passo analítico, a proposição de políticas integradoras, será, na sequência, confrontada com as disparidades regionais, aquilatando os problemas adicionais que estas colocam para a formulação de uma política de desenvolvimento.

Para ele, "uma política bem concebida de programação do desenvolvimento deve partir da verificação de que a economia brasileira não é um sistema integrado". ${ }^{657}$ Essa preocupação se justifica, pois nos últimos quinze anos a disparidade regional aumentou. O crescimento demográfico tem se acentuado no nordeste, região com escassez de terras e baixa capacidade de absorver mão-de-obra, o que impacta negativamente sobre a renda per capta. O problema da disparidade regional brasileira deve ser encarado considerando-se que o país se constitui em "extenso território ocupado de modo irregular, apresentando combinações diversas de fatores e recursos, em sistemas econômicos com distintas potencialidades". ${ }^{658}$

Com isso, Celso Furtado não apenas retoma a constatação das disparidades, feita no início, mas agora oferece um diagnóstico indicando que o problema agravou-se em

\footnotetext{
${ }^{655}$ Idem, p. 51.

${ }^{656}$ Como já indicamos, o principal mecanismo de captação de recursos externos não foi com absorção de tecnologia, mas sim via captação de recursos através de incentivos cambiais e de remessas de lucros às matrizes estrangeiras.

657 Idem, p. 52.

658 Idem, p. 53.
} 
concomitância ao desenvolvimento econômico brasileiro a partir da Segunda Guerra Mundial. Detectada a existência dessas disparidades e as dificuldades que podem impor ao crescimento, afirma que "um plano de desenvolvimento de longo prazo para o Brasil exigiria, como elemento essencial, uma política nacional de colonização”. ${ }^{659}$ Esta política de colonização, buscando minimizar a dispersão da população, estaria subordinada à solução de um problema maior do desenvolvimento econômico nacional: o aumento da oferta de alimentos. Assim, "é de fundamental importância que se articulem os distintos aspectos do problema: deslocamento do excedente de população, organização da produção, transportes, garantia de preços e de mercados". ${ }^{660}$ Nesse sentido, a política de desenvolvimento regional deve estar articulada com os objetivos nacionais, considerando as transformações que o desenvolvimento trará para a região mais dinâmica do país. No caso brasileiro, isso aparece na criação de um mercado interno em rápida expansão, mercado este que pode ser um fator dinamizador da região nordestina. Ainda sobre a região, Celso Furtado observa que a forma de atingir uma alta produtividade por capital aplicado é a produção para a exportação, nomeadamente para o sul do Brasil. ${ }^{661}$ Por sua vez, a região pode receber, também, “indústrias leves com alta densidade de mão-de-obra por unidade de produto". ${ }^{662}$ No entanto, para que isto aconteça é preciso resolver, primeiramente, dois problemas da região nordestina: a ausência de infraestrutura de transportes e energia e uma agricultura de alimentos que não consegue suprir as necessidades da população, encarecendo o nível dos salários em relação ao sul do país. Para esse problema específico, é necessário um mapeamento das potencialidades da região, identificando as zonas onde é possível implantar culturas permanentes para fornecer alimentos às regiões urbanas. As zonas de produção intermitente deveriam fornecer os contingentes de população para migração, limitandose a uma agricultura que seja capaz de produzir excedentes para serem utilizados nos períodos de seca. No caso da Amazônia, o programa deve se empenhar em mapear "os setores suscetíveis de utilização econômica a curto e médio prazos", concentrando esforços para não dispersar os recursos investidos em uma região tão extensa territorialmente.

\footnotetext{
${ }^{659}$ Idem, p. 54.

660 Idem, p. 55.

661 Aqui reaparece o tratamento que Celso Furtado dá às regiões nordeste e sul como países independentes, caracterizando a venda de produtos do primeiro ao segundo como exportação. Para as consequências dessa análise, ver: CANO, Wilson. Raízes regionais do desequilíbrio industrial. op. cit, pp. Idem, p. 56.
} 
A retomada do problema das disparidades regionais ilustra a dificuldade que apresenta o exame do posicionamento de Celso Furtado em relação ao Plano de Metas. Como pudemos perceber, os principais problemas da região exigem a ação governamental para suprir a infraestrutura de energia e transportes, um mapeamento e a alteração da produção agrícola, bem como uma política de colonização. No entanto, os investimentos do Plano de Metas não levaram em consideração os desequilíbrios regionais, tendo como objetivo principal a solução dos pontos de estrangulamento da indústria brasileira, no sul do país. ${ }^{663}$

Podemos dizer, no entanto, que a questão regional passa a adquirir um peso maior nas preocupações de Celso Furtado, configurando-se um novo elemento no diagnóstico da economia brasileira, sobretudo se considerarmos seu papel subsidiário em A economia brasileira, sobretudo enquanto aspecto secundário do problema da oferta de alimentos nos centros urbano-industriais.

Detectada esta problemática, a sequência do texto tem como objetivo, "indicar como se poderia passar de formulação geral desses problemas à ação prática”. ${ }^{664}$

Esta consistiria, inicialmente, em "criar as condições requeridas pela verdadeira ação programadora, e que seria viabilizada por uma programação preliminar, ou seja, "uma tomada de consciência dos problemas nacionais", e que "requer a elaboração dos instrumentos necessários para atuar na programação efetiva". ${ }^{665}$ Nesse ponto, Celso Furtado sugere a criação de um "Conselho Nacional de Desenvolvimento", formado por especialistas recrutados nas "principais agências econômicas de governo e técnicos contratados no país e no estrangeiro", 666 responsável pelo levantamento e crítica de informações necessárias à elaboração do programa, organizando os dados "na forma que deverá ser utilizada pelo analista de economia". ${ }^{667}$ Feito esse levantamento, "o grupo de técnicos do Conselho Nacional de Desenvolvimento poderia utilizar os levantamentos

\footnotetext{
663 “A própria implementação do Plano levava ao aumento dos desequilíbrios regionais e das disparidades sociais, na medida em que implementava o desenvolvimento do polo dinâmico da economia nacional, através exatamente de um mecanismo de concentração de renda - não só por estratos sociais como também por regiões". COHN, Amélia. Crise regional e planejamento. São Paulo: Perspectiva, 1976, p. 127.

664 Idem, p. 60.

665 Idem, ibidem.

${ }^{666}$ Idem. Neste trecho podemos perceber o empenho de Celso Furtado em não explicitar suas referências ao Plano de Metas, mantendo-as subtendidas no texto. De fato, em 1956 o governo criou o Conselho de Desenvolvimento, do qual fazia parte "uma equipe de técnicos, chefiada por Lucas Lopes, que tinha participado das tentativas anteriores de planejamento e controle da economia brasileira - notadamente da Comissão Mista Brasil-Estados Unidos e da Assessoria Econômica de Getúlio Vargas no período 19501954". LAFER, Celso. O planejamento no Brasil — observações sobre o Plano de Metas (1956-1961). op. cit., p. 34-35.

${ }^{667}$ Idem, p. 62.
} 
feitos na primeira etapa do trabalho para elaborar um esboço de programa preliminar. Este último deveria ter como objetivo eliminar os principais focos de desequilíbrio e poderia circunscrever-se aos setores onde reconhecidamente existem pontos de estrangulamento." ${ }^{668}$ Dentro dessa identificação dos problemas, Celso Furtado destaca a importância que deve ser dada à "oferta de produtos agrícolas", "expansão da capacidade de importar", e "o da substituição das importações de crescimento mais rápido, o da produção nos setores básicos: energia, transportes, indústrias pesadas”. ${ }^{669}$ Ao identificar esses setores, podemos perceber que um dos pontos de estrangulamento, a produção de alimentos, teve atenção reduzida no Plano de Metas, bem como é preciso destacar a forma como Celso Furtado examina a resolução dada à questão de transporte e energia. Sobre esse tema, afirma que

$$
\begin{aligned}
& \text { nestes setores já existe um plano parcial em execução. O } \\
& \text { indispensável é ligar esse plano a uma política geral e permanente. O } \\
& \text { sistema de transporte deve ser estudado como um todo e o seu } \\
& \text { verdadeiro custo social deve ser tornado explícito. Ao comparar as } \\
& \text { vantagens relativas dos transportes ferroviários e rodoviários é } \\
& \text { necessário incluir neste último a depreciação e manutenção das } \\
& \text { estradas }{ }^{670}
\end{aligned}
$$

Algo semelhante é dito a respeito dos setores de base, com a definição de metas em consonância não apenas com a capacidade produtiva e recursos disponíveis, mas também em conjunto com as previsões de crescimento dos outros setores industriais. Assim, também nesse aspecto, Celso Furtado coloca o conceito de "custo social" como referência para determinar os setores e as soluções apresentadas ao programador do desenvolvimento. $\mathrm{O}$ conceito tem sua origem na resposta à Ragnar Nurkse e é semelhante àquele de produtividade social presente no relatório da Cepal sobre a técnica de planificação, e foi, também, retomado na polêmica com Bulhões, ao justificar os critérios de investimentos e incentivos que devem constar na programação. Esta concepção, no entanto, vai de encontro aos critérios estabelecidos pelo Plano de Metas, que utilizou o conceito de pontos de estrangulamento e de germinação. ${ }^{671}$

\footnotetext{
${ }^{668}$ Idem, p. 64.

${ }^{669}$ Idem, ibidem.

${ }^{670}$ Idem, p. 66.

671 “O conceito de ponto de estrangulamento, isto é, a percepção de que existiam certas áreas de demanda insatisfeitas que estrangulavam a economia justificou basicamente o planejamento dos setores de energia, transportes e alimentação [...] O conceito de pontos de germinação [...] partia do pressuposto de que a oferta de infraestrutura provocaria atividades produtivas — [...] justificou a meta de Brasília, que não fazia, inicialmente, parte do Plano de Metas. Justificou igualmente investimentos no setor de transportes (rodovias), pois as ligações do país com Brasília, assim se supunha, provocariam a integração e
} 
Outro ponto de exame é a política monetária, pois “para passar à ação prática, é indispensável que o governo interfira na formação de poupança, na canalização dos recursos financeiros e na orientação dos investimentos". ${ }^{672}$ Nesse campo, o principal objetivo da política monetária é "captar da melhor forma possível a poupança que o sistema produz e orientá-la, por meio do crédito, de acordo com a ordem de prioridade estabelecida no programa". ${ }^{673}$ A política fiscal deve ter como objetivo "elevar a taxa de poupança do sistema econômico, distribuir adequadamente o esforço financeiro requerido pelo desenvolvimento, orientar a utilização desses recursos financeiros e complementar diretamente a iniciativa dos empresários quando esta se revele insuficiente". 674

No entanto, no que se refere à política fiscal, não é necessariamente em sua formulação e operacionalização que reside o problema, mas sim em sua perda de efetividade "em situação de inflação aguda, como a que se observa atualmente no Brasil". Nesta situação, na qual a taxa de juros não consegue ser um instrumento canalizador de recursos, os agentes procuram, de todas as formas, "realizar seus ativos", dando ensejo a "inversões especulativas" que criam "uma deformação psicológica tanto nos homens de empresa como na população em geral". ${ }^{675}$ Dessa forma, "o objetivo central de um programa preliminar, no campo monetário, deveria ser o de contribuir para eliminar esse estado crônico de inflação". ${ }^{676}$ A percepção do problema inflacionário revela um posicionamento crítico à política econômica de Juscelino Kubitschek. Segundo André Villela, "o principal mecanismo de financiamento do Plano de Metas foi a inflação, resultante da expansão monetária que financiava o gasto público e do aumento do crédito, que viabilizaria os investimentos privados." ${ }^{677}$ Dessa forma, a observação de Celso Furtado revela-se, de fato, uma crítica ao Plano. Isso, pois apresenta não apenas um diagnóstico das causas da inflação, diagnóstico este que leva em consideração os desequilíbrios da economia brasileira, mas propõe também algumas orientações de política monetária. Por sua vez, é preciso destacar uma observação de Carlos Mallorquin, segundo a qual o diagnóstico da inflação a partir de desequilíbrios estruturais deixa de considerar outro elemento do processo inflacionário detectado no

desenvolvimento do hinterland [grifos do autor]". LAFER, Celso. O planejamento no Brasil observações sobre o Plano de Metas (1956-1961). op.cit., p. 35.

${ }^{672}$ Idem, p. 67.

673 Idem, ibidem.

674 Idem, ibidem.

675 Idem, p. 68.

676 Idem, ibidem.

${ }^{677}$ VILLELA, André. Dos “Anos Dourado” de JK à crise não resolvida (1956-1963). op. cit., p. 57 
livro A economia brasileira, a saber, de que esta é, também, expressão de um conflito distributivo entre diferentes setores sociais. Nesse ponto, a crítica atinge um limite, mas não nos parece que seja decorrente de sua posição de "técnico", como veremos em seguida. ${ }^{678}$

O primeiro ponto que destaca é que a inflação brasileira não pode ser explicada "pelos meios que geralmente se utilizam para diagnosticar um desequilíbrio inflacionário de país desenvolvido. Não basta reconhecer que existe excedente de procura sobre a oferta, desequilíbrio entre poupança e inversão ou entre entrada e saída de recursos, para identificar e classificar a inflação". ${ }^{679}$ Com isso, retoma a inadequação do diagnóstico monetarista, agora explicitando como suas hipóteses e pressupostos analíticos estão enraizados em um conjunto de características de países desenvolvidos. ${ }^{680}$ Ao contrário, sua explicação para o fenômeno inflacionário não decorre apenas da compreensão dos problemas estruturais, apreendidos a partir do mapeamento do conjunto da economia brasileira que a programação pressupõe. Ao contrário, e paradoxalmente, neste momento Celso Furtado explicita o caráter político da decisão de planejar. Para ele, "convém partir de uma tomada de posição: o preço da estabilidade não deve ser a estagnação". ${ }^{681}$ Nesse ponto, rompe com o discurso "objetivo" que vinha apresentando até então ${ }^{682}$, a respeito da programação da economia brasileira. No entanto, ao apontar esse posicionamento político, é preciso considerar que esta decisão já fora tomada pelo próprio governo: romper o equilíbrio orçamentário em favor do desenvolvimento econômico. Isso ficaria evidente, no âmbito da própria política econômica, quando, no início de 1959 (posterior às palestras e ao livro publicado, portanto,) Juscelino Kubitschek rompe negociações com o FMI e abandona o Programa de Estabilização Monetária. ${ }^{683}$

Retomando seu diagnóstico, Celso Furtado descarta um excesso de investimentos ou um esforço de poupança excessivo. Para ele, "a medula do problema"

\footnotetext{
${ }^{678}$ MALLORQUIN, Carlos. Celso Furtado: um retrato intelectual. op. cit., p. 153.

${ }^{679}$ Idem, p. 68.

680 “Os remédios ortodoxos são a contenção dos gastos públicos e a compressão do crédito. Assim se reduz o gasto global e se elimina a pressão inflacionária. Mas, todos sabemos que o preço dessa cura é a subutilização da capacidade produtiva, a redução no ritmo de crescimento ou mesmo a sua paralisação. A experiência, além disso, indica que, se o sistema retoma o crescimento, o desequilíbrio pode reaparecer imediatamente" idem, p. 68.

${ }^{681}$ Idem, p,. 69.

${ }^{682}$ De fato, essa afirmação pode servir como ponto para refutar a sugestão de Carlos Mallorquin, segundo a qual a Celso Furtado atenuaria as críticas no livro Perspectivas da economia brasileira, devido a seu caráter oficial. No entanto, a ausência da consideração do conflito distributivo da inflação permanece como um problema, sobretudo porque ele é retomado no livro Formação econômica do Brasil, de 1959. ${ }^{683}$ VILLELA, André. Dos “Anos Dourado” de JK à crise não resolvida (1956-1963). op. cit., p. 59.
} 
e "causa básica da tendência crônica ao desequilíbrio inflacionário da economia brasileira reside em que, nas etapas de crescimento, a procura global se diversifica muito mais rápida que a oferta global. Existe muito mais mobilidade do lado da procura que do lado da oferta". ${ }^{684}$ Trata-se, portanto, de uma característica de economias subdesenvolvidas, que possuem "relativa rigidez de seu aparelho produtivo". $685 \mathrm{O}$ crescimento acarreta rápidas modificações no aparelho produtivo, amplia a procura por bens de capital e intermediários e pressiona a capacidade para importar. Dessa forma, "o desequilíbrio inflacionário resulta menos do excesso de procura global sobre oferta global que da existência de faixas de procura sem contrapartida de oferta e de faixas de oferta sem contrapartida de procura". ${ }^{686}$ Daí surge o grande problema da política econômica ortodoxa pois, se se contrai o nível da procura, esta se equilibra, mas com grande capacidade ociosa e baixo nível de crescimento econômico. Dessa forma, "sempre que o sistema volta a crescer com intensidade, a tendência ao desequilíbrio novamente se apresentará". ${ }^{687}$ Assim,

o único meio de eliminar a tendência ao desequilíbrio é conseguir que a oferta adquira maior flexibilidade e se adapte mais rapidamente à procura. Esse objetivo dificilmente poderia ser alcançado, em uma economia subdesenvolvida, em condições de crescimento espontâneo. Por um lado, seria necessário identificar, com a devida antecipação, as linhas gerais de modificação da estrutura da procura; por outro, seria preciso criar as condições para que a oferta pudesse satisfazer a uma procura que cresce e se transforma rapidamente. É esse um dos objetivos fundamentais da programação do desenvolvimento.

A estabilidade é objetivo fundamental, embora se deva subordinar a outro mais amplo que é o desenvolvimento. Uma inflação de natureza estrutural, como a brasileira, para ser eliminada sem prejudicar o ritmo de desenvolvimento requer cuidadosa programação deste último.

Assim, Celso Furtado explicita que a única solução possível para a inflação não é seu combate por mecanismos monetários, mas sim a modificação da estrutura produtiva brasileira, visando maior integração e autonomia. Por sua vez, seu diagnóstico descarta o dinamismo do empresariado brasileiro traçado por Bulhões, argumentando que estes desequilíbrios resultam da ausência de coordenação dos investimentos

\footnotetext{
${ }^{684}$ Cumpre notar que, ao buscar a causas estruturais da inflação, Celso Furtado já conhecia o tratamento dado à questão por Osvaldo Sunkel. No entanto, não nos cabe neste trabalho buscar as influências ou a origem das ideias de Celso Furtado, muito embora não possamos deixar de dizer que este diagnóstico não é muito diferente dos proferidos na primeira metade dos anos de 1950, quando debatia com Gudin e Bulhões.

${ }^{685}$ Isso se deve, segundo Furtado, à "inexperiência dos empresários", pelo "problema do controle das patentes", acesso a "equipamentos técnicas", etc. Idem, p. 70.

${ }_{686}^{6}$ Idem, 71 .

${ }^{687}$ Idem, ibidem.
} 
produtivos. Nesse sentido, compreende-se a ênfase dada à questão da oferta de alimentos nos centros urbanos, pois também é um fator que interfere na produtividade da indústria e na formação de poupança, ao elevar os salários e, ao mesmo tempo, corroer seu valor real. O diagnóstico mais amplo, segundo o qual o crescimento espontâneo é o principal causador dos desequilíbrios econômicos, retoma as conclusões da argumentação que Celso Furtado apresentou contra Octávio Gouveia de Bulhões. A retomada, por sua vez, evidencia como os resultados gerais daqueles textos se mantiveram nestas análises posteriores. No entanto, seria errôneo afirmar que Celso Furtado não considera elementos importantes das proposições monetaristas, o que pode ser captado pela preocupação com a ausência de um Banco Central, temendo o caráter desordenado da expansão do sistema bancário nos últimos anos e sinalizando para a necessidade de saneamento das instituições como pré-requisito para "transformar o sistema bancário em instrumento efetivo de política econômica". ${ }^{688}$ No entanto, a preocupação monetarista termina aí, pois considera que o sistema bancário nacional deveria ser fortalecido. Embora a criação do BNDE e do Banco do Nordeste tenha sido "um passo importante nesse sentido", é preciso também um Banco Rural para intervir no setor agrícola e um Banco do Comércio Exterior para estimular exportações e estabelecer metas e resolver problemas de longo prazo. Nesse ponto, ainda, Celso Furtado propõe que todos esses bancos estejam subordinados ao Conselho Nacional de Desenvolvimento Econômico. ${ }^{689}$

Por fim, e de forma complementar à política monetária para o desenvolvimento, Celso Furtado destaca que "um dos principais itens de um programa preliminar deveria ser a adaptação do sistema fiscal-administrativo aos objetivos da programação". ${ }^{60}$

Nesse sentido, embora reconheça o caráter rígido do sistema tributário nacional, esclarece que "os impostos que devem obedecer a um comando central são os que incidem no comércio exterior, na renda, no consumo e na produção". ${ }^{691}$ Os impostos sobre importação e exportação são recolhidos, respectivamente, pelos governos federal e estadual, de forma que se torna indispensável que "sejam utilizados coordenadamente e que apresentem grande flexibilidade". No que concerne aos impostos de exportação,

\footnotetext{
${ }^{688}$ Idem, p. 72.

${ }^{689}$ Celso Lafer descreve a criação de uma administração paralela para coordenar o Plano de Metas, na qual novos organismos, conselhos e grupos de trabalho integraram-se a órgão já existentes, como o BNDE, Bando do Brasil e Sumoc. Ver: LAFER, Celso. O planejamento no Brasil — observações sobre o Plano de Metas (1956-1961). op. cit., p. 40.

${ }^{690}$ Idem, p. 74.

691 Idem, pp. 74-75.
} 
eles devem incidir sobre a renda do setor, para evitar que as elevações bruscas de preços se transfiram para o conjunto da economia, bem como controlar os investimentos na expansão do setor. Quanto aos impostos de importação, sua principal função é “adaptar as importações à capacidade para importar, reduzindo ao mínimo os ajustes por meio da taxa de câmbio". Isto, não para estabilizar a taxa de câmbio, mas sim, para "orientar a utilização da capacidade para importar em função dos objetivos da programação". 692

Já os impostos sobre renda, consumo e produção, devem ser coordenados para "orientar o modo pelo qual a população gasta a sua renda", sobretudo porque, nos países subdesenvolvidos como o Brasil, seja pelo baixo custo dos serviços, seja pela produção em escala relativamente grande dos bens de consumo, ocorre uma "forte elevação da tendência a consumir dos grupos de médias e altas rendas". ${ }^{693}$ Dessa forma, é preciso intervir nos preços relativos de alguns produtos, ao invés de atuar sobre o nível de renda, sob o risco de uma diminuição da poupança. Por último, Celso Furtado argumenta que os impostos indiretos, como vendas e consignações, devem ser "progressivamente eliminados", pois "o sistema fiscal é, antes de mais nada, um meio de influir conscientemente na utilização dos recursos produtivos, na distribuição da renda e na sua utilização pelos consumidores, e só secundariamente um instrumento de arrecadação de numerário para atender aos gastos públicos". 694

Esse conjunto de medidas implicaria em uma reforma tributária que a rápida execução do Plano não teria condições de executar. A política fiscal do governo teve como principais instrumentos "a adoção de uma tarifa aduaneira protecionista, complementada por um sistema cambial que subsidiava tanto a importação de bens de capital como de insumos básicos, e que atraía o investimento direto por parte do Capital estrangeiro". 695 Estes instrumentos não tocavam em pontos centrais elencados por Celso Furtado, as formas de taxação das exportações e as formas de financiamento dos estoques de café e, tampouco tiveram a preocupação em instaurar impostos progressivos e sobre a renda. Dessa forma, também neste aspecto, as considerações de Celso Furtado desvelam outro aspecto problemático do Plano, o qual, agravado pelo mecanismo inflacionário de poupança iria progressivamente distribuir para o conjunto da

\footnotetext{
${ }^{692}$ Idem, p. 76

${ }^{693}$ Idem p. 77.

${ }^{694}$ Idem, ibidem.

${ }^{695}$ VILLELA, André. Dos “Anos Dourado” de JK à crise não resolvida (1956-1963). In: GIAMBIAGI, Fábio (et. alli). Economia brasileira contemporânea (1945-2004). op. cit., p. 56.
} 
população, mas sobretudo para as classes médias e setores urbanos, o ônus do desenvolvimento, para além de agravar as disparidades regionais.

Se olharmos, no entanto, para o conjunto das palestras reunidas no livro Perspectivas da economia brasileira, constamos que apresenta a retomada e o fortalecimento das posições de Celso Furtado a partir do diagnóstico da economia brasileira feito desde o livro A economia brasileira, até o conjunto de resenhas e intervenções onde discutiu aspectos pontuais. Seus resultados permitiram que, mesmo num período de hegemonia do desenvolvimentismo, o olhar crítico apresentasse pontos problemáticos do Plano de Metas, muito embora reconhecendo como mérito do programa a opção pelo crescimento econômico sobre a estabilidade. Essa tomada de posição, que discutimos mais acima, não significa uma adesão irrestrita às políticas fiscais, monetárias e cambiais adotadas pelo governo, razão pela qual Celso Furtado dedicou bastante espaço para discuti-las a partir de proposições paralelas e não com um ataque frontal, o que ficou restrito para o tratamento monetarista da inflação.

Ponto de grande significação neste texto é a constatação da disparidade regional brasileira, que assume importância ao longo do livro, aparecendo como um problema não considerado pelo planejamento do Plano, mas, também, por constituir-se um fator de desequilíbrio na estrutura econômica e que está, também, comprometendo o crescimento da economia brasileira.

Contudo, é preciso reconhecer que mesmo as críticas tecidas por Celso Furtado pressupõem um campo comum de teoria e metodologia econômica, ou seja, menos do que justificar epistemologicamente suas afirmações, o tom geral de Perspectivas da economia brasileira já é um diálogo, não isento de críticas, dentro do vocabulário do desenvolvimentismo. É precisamente essa transformação que deve ser considerada na análise de Formação econômica do Brasil. 
Capítulo 5: Presente, passado e futuro: Formação econômica do Brasil 


\section{O sentido de Formação econômica do Brasil}

Como vimos, a segunda metade da década de 1950 marca o período de auge do pensamento desenvolvimentista e, consequentemente, de retração das ideias liberais frente à implantação do planejamento econômico pelo Estado brasileiro, com o Plano de Metas. Embora, como mostra Ricardo Bielschowsky, ainda houvesse espaço para disputas sobre a inflação e o equilíbrio das contas públicas, essas questões passaram a ser minimizadas ou subordinadas ao propósito do desenvolvimento. Se retomarmos a discussão da política monetária feita em Perspectivas da economia brasileira, a afirmação de que "a estabilidade é o objetivo fundamental, embora se deva subordinar a outro mais amplo que é o desenvolvimento"696 parece ter se tornado consenso no período. Nessas circunstâncias, poderíamos pensar que o projeto desenvolvimentista tenha sido vencedor, após um percurso de disputas políticas e maturação teórica. Isso nos leva à pergunta principal na sequência do trabalho: o que significa a supremacia do pensamento desenvolvimentista dentro do projeto teórico de Celso Furtado? Uma vez que os embates, as intervenções e as discussões com os economistas liberais estiveram subjacentes, em grande parte, ao esforço conceitual e à elaboração da teoria do desenvolvimento econômico, e que estes oponentes estão relativamente apaziguados na conjuntura de finais de 1950, quais seriam os influxos e os objetivos subjacentes à escrita de Formação Econômica do Brasil?

Dito de outro modo, se até o momento detectamos nos textos de Celso Furtado uma junção entre elaboração teórica e intervenção nos debates sobre os rumos da economia brasileira, haveria alguma outra especificidade em Formação econômica do Brasil? Se sim, deve-se a alguma alteração conceitual, à consolidação do instrumental analítico desenvolvido nos últimos anos, à conjuntura na qual Celso Furtado está inserido, à nova configuração dos debates econômicos da segunda metade da década de 1950 ou a esta constelação de fatores?

Responder estas perguntas envolve uma análise do livro que procure englobar, portanto, o conjunto de formulações sobre desenvolvimento econômico, a incorporação da história e das ciências sociais, a reescritura de alguns temas e manutenção de outros já escritos. Para responder essas indagações, o foco da análise recairá nas relações entre

\footnotetext{
${ }^{696}$ FURTADO, Celso. Perspectivas da economia brasileira. op. cit., p. 71.
} 
os circunstanciamentos biográficos e sociais de Celso Furtado, o contexto do pensamento econômico brasileiro e o projeto de intervenção na economia brasileira, bem como em suas formulações conceituais que olham simultaneamente para o passado brasileiro, buscando compreendê-lo para intervir no presente assentando um projeto de futuro.

Nossa leitura de Formação econômica do Brasil irá centrar-se, portanto, nas modificações e inovações que traz em relação aos escritos anteriores, nas referências que estabelece com o conjunto de problemas da economia brasileira e sua percepção através da elaboração conceitual de sua teoria do desenvolvimento econômico. Nesse ponto, cabe destacar algo indicado em nosso capítulo 3, a saber, a republicação de longos trechos do livro A Economia Brasileira, que aparecem nos capítulos, 9, 26, 27, 28, 30, 31, 32, 33, 34 e 35 de Formação Econômica do Brasil. Embora indicaremos, quando houver, alterações substanciais entre os textos, esse reaproveitamento nos parece um sinal de que o livro tem a principal preocupação de rever o passado econômico brasileiro, deixando que a discussão sobre a economia brasileira da primeira metade do século XX permaneça em suas linhas gerais, como apresentada em 1954. Essa retomada do passado brasileiro, evidentemente, insere-se sobretudo na resolução metodológica de sua intenção de conjugar os conceitos econômicos, as ciências sociais e a história na conformação de uma teoria do desenvolvimento econômico que consiga captar as peculiaridades brasileiras.

Assim, propomos, na sequência, ao analisar Formação econômica do Brasil, inserir o livro em dois contextos: no primeiro, identificar, no exame do passado brasileiro, o rastro das preocupações do presente, ou seja, em que medida os problemas e desequilíbrios que Celso Furtado identificou como característicos de uma economia subdesenvolvida foram originados no passado. Por outro lado, explicitar como estes podem ser compreendidos a partir de um exame que busque integrar a conceitualização da teoria do desenvolvimento econômico com o exame do passado brasileiro, ambos intentando responder aos problemas do presente.

As principais pistas sobre esse procedimento analítico já foram apresentadas por Celso Furtado e discutidas neste trabalho, quando examinamos o prefácio ao livro $A$ economia brasileira, de 1954. Como vimos, é com os conceitos e categorias vazadas de historicidade que se debruça sobre o passado brasileiro, recortando-o em unidades de sentido econômico e, a partir de cada uma delas, busca reconstituir o funcionamento de seus mecanismos econômicos. Procedimento semelhante é adotado neste livro, muito 
embora seja preciso reconhecer que não apenas sua formulação conceitual se depurou, como pudemos perceber no exame das resenhas e intervenções às quais se dedicou desde a publicação do livro anterior, como também suas condições de produção e divulgação se ampliaram nesses anos. Não menos importante, a economia brasileira avançou em seu processo de industrialização e desenvolvimento, porém amplificando o leque de problemas e de entraves do presente. Essas modificações, é escusado dizê-lo, alteram a percepção do momento vivido e as perguntas que Celso Furtado dirige ao passado. Serão esses pontos que iremos procurar destacar em nossa leitura de Formação econômica do Brasil.

É bastante discutida, na bibliografia, a influência de Caio Prado Júnior sobre Celso Furtado, sobretudo nos livros Economia colonial no Brasil nos séculos XVI e XVII e em Formação econômica do Brasil. ${ }^{697}$ Os intérpretes destacaram a dívida com o intelectual paulista na compreensão da estrutura social resultante da agricultura monocultora trabalhada por escravos, em sua persistência ao longo de quatro séculos e nos obstáculos que impôs à formação da Nação brasileira. ${ }^{698}$

O "Sentido da colonização" foi um conceito fundamental da obra de Caio Prado Júnior, não só pela forma como inseriu a história brasileira nos quadros mais amplos da Expansão comercial europeia, como pelo recorte epistemológico que inaugurou nos estudos sobre a história do Brasil. ${ }^{699}$ Com efeito, Caio Prado Júnior estabeleceu sua análise a partir da problemática da herança colonial e de como ela pode ser rompida.

\footnotetext{
${ }^{697}$ Para ficarmos apenas com alguns exemplos: CEPÊDA, Vera Alves. Raízes do pensamento político de Celso Furtado: desenvolvimento, nacionalidade e Estado democrático. (Dissertação de Mestrado, Ciências Sociais, FFLCH-USP), 1998; FURTADO, André Tosi. As contribuições de Caio Prado Júnior à Formação econômica do Brasil. In: COELHO; GRANZIERA, (orgs). Celso Furtado e a Formação econômica do Brasil (Edição comemorativa dos 50 anos de publicação (1959-2009). Prefácio Fernando Henrique Cardoso. São Paulo, Editora Atlas, 2009, pp. 72-88; OLIVEIRA, Francisco. "A navegação venturosa" [1983]. In: Idem. A navegação venturosa. Ensaios sobre Celso Furtado. São Paulo: Editora Boitempo, 2003; SZMRECSÁNYI, Tamás. Sobre a formação da Formação econômica do Brasil de C. Furtado. Estudos Avançados 13 (37), 1999, pp. 207-214. VIEIRA, Rosa Maria. Celso Furtado: reforma, política e ideologia (1950-1964). São Paulo: Educ, 2007.

${ }^{698}$ Vera Cepêda, embora destaque que Formação econômica do Brasil, de Celso Furtado, seja tributária "do viés analítico proposto por Caio Prado", argumenta que "se bem que Caio Prado se beneficie da sólida constituição da escola marxista, peca por outro lado, pela ausência de uma análise acurada sobre o quadro histórico específico do subdesenvolvimento". Mais adiante, elenca os pontos de influência de Caio Prado sobre Celso Furtado: "a percepção da economia colonial como orientada de fora para dentro, a herança do modelo mercantil-exportador baseada na existência de grandes propriedades latifundiárias, a especialização e a produção em moldes de monocultura, a restrição imposta pelos laços de dependência com o mercado mundial, a fragilidade dos setores capitalistas nacionais para dirigirem o processo de industrialização (debilidade da burguesia industrial nacional)". Ver: CEPÊDA, Vera Alves. Raízes do pensamento político de Celso Furtado... op. cit., fls. 63 e 74.

${ }^{699}$ NOVAIS, Fernando Antônio. Sobre Caio Prado Júnior. In: Aproximações. Estudos de história e historiografia. São Paulo: Cosac Naify, 2005. Idem, Entrevista. In: PRADO JÚNIOR, Caio. Formação do Brasil contemporâneo (Colônia). São Paulo, Cia das Letras, 2012.
} 
Delimitando-a na passagem do século XVIII ao XIX, é somente neste momento da história que é possível apreciar o resultado de três séculos de colonização e observar as forças contrárias que atuam para sua manutenção ou superação. Esta última daria início ao processo de formação da Nação, opondo-se, portanto, à antiga Colônia, dois polos dialéticos que o livro Formação do Brasil contemporâneo examinou. Fundamental para Caio Prado, portanto, é a formação da Nação ou, dito de outro modo, quais as possibilidades de surgimento de uma sociedade brasileira, na qual os escravos e os homens livres fossem os elementos constitutivos.

Assim como Caio Prado Júnior estabeleceu um recorte epistemológico que lhe permitiu rever a história brasileira a partir da ótica da formação da sociedade e da nação, Celso Furtado procurou rever o passado a partir da formação do mercado interno, esse sim o elemento que iria romper com o caráter colonial da economia brasileira. ${ }^{700}$

A primeira parte de Formação econômica do Brasil, "Fundamentos econômicos da ocupação territorial", retoma as considerações de Celso Furtado sobre o processo histórico de desenvolvimento econômico e, por isso, dialoga com suas abordagens anteriores. Vimos em "Desenvolvimento econômico (ensaio de interpretação históricoanalítico)", que a passagem da economia comercial para a industrial foi feita em resposta à pressão crescente pela diminuição dos custos, em decorrência do esgotamento das possibilidades de expansão do comércio europeu. ${ }^{701}$ Notamos, naquela ocasião, que esta interpretação, embora resulte na elaboração de conceitos e categorias que serão fundamentais para Celso Furtado compreender o desenvolvimento econômico

\footnotetext{
700 João Antônio de Paula considera que "a questão teórica central de Formação econômica do Brasil é a perquirição do processo de constituição do mercado interno para o capital no Brasil". Por sua vez, "é a partir desta exigência [o caráter dialético da exposição] que se deve entender a primeira parte do livro, seus sete primeiros capítulos, que são, rigorosamente, uma síntese a priori, isto é, uma síntese que pode aparecer, inicialmente, de modo abstrato universal, genérico, carente das determinações concretas, que a sequência da exposição se encarregará de trazer". Essa centralidade o leva a considerar a proposta de Celso Furtado como "materialização para o caso brasileiro da tese de Marx sobre a centralidade da constituição do mercado como processo fundante do capitalismo"[grifos do autor]. PAULA, João Antonio de. A formação do mercado interno e a superação do subdesenvolvimento em Celso Furtado. In: COELHO; GRANZIERA, (orgs). Celso Furtado e a Formação econômica do Brasil (Edição comemorativa dos 50 anos de publicação (1959-2009)). Prefácio Fernando Henrique Cardoso. São Paulo, Editora Atlas, 2009, pp. 108-110. Embora estejamos de acordo com a centralidade da questão do mercado interno, vincular seu método ao de Marx nos parece um pouco impreciso já que a formação do mercado não é algo exclusivo deste autor.

${ }^{701}$ Não iremos, nos limites deste trabalho, abordar a diferença entre esta abordagem e a tese de doutorado de Celso Furtado. No entanto, podemos dizer que o problema de uma formulação conceitual para o desenvolvimento econômico não estava em seu horizonte nos anos de 1940.. Ademais, a questão da expansão portuguesa e da colonização brasileira foi trabalhada a partir das considerações de António Sérgio sobre a Revolução de Avis como uma revolução burguesa e os descobrimentos como uma decorrência do caráter mercantil que precocemente tomou conta da monarquia portuguesa. Para isso, ver: SILVA, Roberto Pereira. O Jovem Celso Furtado. op. cit., pp. 110-136.
} 
brasileiro, deixou de lado o impacto dos descobrimentos para a economia europeia. No livro A economia brasileira, Celso Furtado contornou o problema apresentando a economia colonial (aquela que resultou da expansão comercial) como um tipo de colônia interligada às economias industriais. Essa abordagem, também, tem o problema de pressupor que os países colonizadores já funcionavam de acordo com a lógica da economia industrial nos séculos XIV e XV. A solução para essa dificuldade em conciliar a gênese da formulação conceitual do desenvolvimento econômico com a história econômica é resolvida em Formação econômica do Brasil, ao retomar essa problemática com ênfase, sobretudo, na delimitação do percurso histórico.

No que se refere à economia colonial e sua relação com a história europeia, a presença de Caio Prado Júnior é fundamental. O livro abre-se com a afirmação: "a ocupação econômica das terras americanas constitui um episódio da expansão econômica da Europa". ${ }^{702}$ Dessa forma, insere a colonização brasileira no quadro da economia comercial. Nesse ponto, implicitamente Celso Furtado revê sua explicação sobre a passagem da economia comercial para a industrial, pois considera a expansão mercantil, cujas origens remontam ao século XI, uma forma de contornar os obstáculos criados pelas invasões turcas que "começaram a criar dificuldades crescentes às linhas orientais de abastecimento de produtos de alta qualidade, inclusive manufaturas". ${ }^{703} \mathrm{Ou}$ seja, a expansão comercial do século XV aparece como uma renovada busca de mercados pelas economias comerciais, não sendo levantado, neste momento, o problema dos custos de produção. Além disso, neste momento, afasta-se de Caio Prado Júnior, pois considera as navegações portuguesas como decorrentes de condições internas. $^{704}$

A ocupação pelos portugueses dos territórios recém-descobertos resulta da preocupação, predominantemente política, de mantê-los sob sua posse, em vista da concorrência de outras nações europeias pelas terras americanas, atraídos pelos metais

\footnotetext{
${ }^{702}$ FURTADO, Celso. Formação econômica do Brasil. 36a edição. São Paulo, Cia das Letras, 2007, p. 25. A afirmação tem semelhança com Caio Prado Júnior, para quem "A expansão marítima dos países da Europa, depois do século XV, expansão de que o descobrimento e colonização da América constituem $o$ capítulo que particularmente nos interessa aqui... [grifo nosso]". PRADO JÚNIOR, Caio. Formação Econômica do Brasil (Colônia) [1942]. São Paulo: Publifolha, 2000, p. 9.

${ }^{703}$ Idem, ibidem.

704 "O desenvolvimento econômico de Portugal no século XV - a exploração da costa africana, a expansão agrícola nas ilhas do Atlântico e finalmente a abertura da rota marítima das Índias Orientais constitui um fenômeno autônomo na expansão comercial europeia, em grande parte independente das vicissitudes criadas ao comércio do Mediterrâneo pela penetração otomana". FURTADO, Celso. Formação econômica do Brasil. Op. cit, p. 25-26, nota 1. Essa ressalva à especificidade da história portuguesa, ao mesmo tempo em que diverge de Caio Prado Júnior, retoma as considerações de sua tese de doutorado.
} 
precisos encontrados pelos espanhóis na meseta mexicana e no altiplano andino. Enquanto estes se preocuparam em estabelecer uma defesa militar para proteger suas jazidas, Portugal, na ausência de reservas semelhantes, foi levado a ocupar as terras americanas como forma de protegê-las, procurando alguma atividade produtiva que reduzisse seus custos de defesa. Nesse ponto, os portugueses foram pioneiros na realização de que a América passasse "a constituir parte integrante da economia reprodutiva europeia, cuja técnica e capitais nela se aplicam para criar de forma permanente um fluxo de bens destinado ao mercado europeu". ${ }^{705}$ É precisamente a implantação de um centro produtor na América tropical que irá ocupar a atenção de Celso Furtado.

A compreensão da atividade produtiva portuguesa enquanto um elemento presente no quadro da expansão comercial e, portanto, obedecendo à sua lógica mercantil aparece na abordagem e na ênfase que Celso Furtado imprime à economia açucareira na América. A indústria do açúcar já era conhecida pelos portugueses nas ilhas do Atlântico, que dominavam não apenas a técnica produtiva mas, também produziam os equipamentos necessários para seu refino. No entanto, é a comercialização do açúcar que interessa a Celso Furtado, examinando os canais de distribuição e os preços do produto. Inicialmente, a produção portuguesa no Atlântico entrou na Europa pelos “canais controlados pelos comerciantes das cidades italianas". ${ }^{706}$ Ainda no século XV, no entanto, eleva-se a participação dos flamengos no comércio do açúcar português, que passavam também a refiná-lo e distribuí-lo pela Europa. A importância dessa associação decorre de que estes "eram nessa época o único povo que dispunha de suficiente organização comercial para criar um mercado de grandes dimensões para um produto praticamente novo, como era o açúcar". ${ }^{707}$ Para além desse aspecto organizacional, os holandeses também conseguiram que a produção portuguesa fosse absorvida "com preços firmes", além de terem sido, segundo Furtado, os principais financiadores do negócio na Europa e também da implantação da indústria açucareira na América portuguesa. Nesse sentido, percebe-se como a abordagem de Celso Furtado foi feita a partir de um questionamento típico dos países subdesenvolvidos, a saber: como expandir a exportação de um produto primário sem

\footnotetext{
${ }^{705}$ Idem, p. 29.

${ }^{706}$ Idem, p. 32.

${ }^{707}$ Idem p. 33.
} 
reduzir seu preço? Problemática esta largamente discutida por Furtado no exame da economia cafeeira.

Outro elemento examinado por Furtado é a questão da mão-de-obra. Nesse ponto, o raciocínio segue o de Caio Prado Júnior: a escassez populacional portuguesa e os custos de transporte de trabalhadores livres exigiriam salários "bem mais elevados que os da Europa", sendo a única saída possível a utilização de trabalho escravo, primeiro indígena e depois africano, o que contou também com a circunstância facilitadora de serem os portugueses "senhores de um completo conhecimento do mercado africano de escravos" ${ }^{\text {708 }}$, iniciado ainda sob o reinado de d. Henrique (11391185). Celso Furtado enfatiza, portanto, o "conjunto de circunstâncias favoráveis" que permitiu que os problemas de produção economicamente orientada para o comércio europeu na América, "técnica de produção, criação de mercado, financiamento, mão-deobra" fossem solucionados e garantissem, simultaneamente, a ocupação e posse das terras americanas, firmando economicamente a colonização e a produção açucareira no comércio europeu durante o século XVI.

Dessa forma, Celso Furtado concilia, sob sua perspectiva histórica, os elementos gerais da expansão comercial europeia e as circunstâncias específicas da histórica portuguesa. Por sua vez, seu exame da montagem da produção açucareira tem como eixo fundamental os elementos constitutivos de um sistema econômico mercantil, sobretudo os mecanismos de intermediação e comercialização do produto no mercado internacional em condições de monopólio.

A expansão da produção portuguesa, no entanto, é examinada em comparação com outra experiência econômica na América: a da extração de metais preciosos feita pelos espanhóis. Esse recurso de contraposição de experiências faz parte do método comparativo, utilizado por autores como Henri Pirenne e Marc Bloch e com o qual Celso Furtado teve contato, ainda que indireto, através de Maurice Byé, seu orientador de tese de doutorado na França. ${ }^{709}$ A mobilização da experiência espanhola servirá como um contraponto para esclarecer as peculiaridades da produção de açúcar portuguesa.

\footnotetext{
${ }^{708}$ FURTADO, Celso. Formação econômica do Brasil. op. cit., p. 35. Essa compreensão dos motivos econômicos para a adoção do trabalho escravo, difere da explicação antropológica que Celso Furtado apresentou em sua tese de doutorado. Esse ponto foi assinalado por: FURTADO, André Tosi. As contribuições de Caio Prado Júnior à Formação econômica do Brasil. In: COELHO; GRANZIERA, (orgs). Celso Furtado e a Formação econômica do Brasil (Edição comemorativa dos 50 anos de publicação (1959-2009). Prefácio Fernando Henrique Cardoso. São Paulo, Editora Atlas, 2009, p. 75.

${ }^{709}$ Sobre a relação de Celso Furtado com o método comparativo, ver: SILVA, Roberto P. O Jovem Celso Furtado, op. cit., pp. 174-201.
} 
Com o aumento da concorrência de outras nações pelas terras americanas, a solução espanhola foi o reforço da segurança de suas áreas mineradoras, que se singularizavam "por serem densamente povoadas". ${ }^{710}$ Segundo Furtado, "a empresa colonial espanhola tinha como base a exploração dessa mão-de-obra", mas sem estabelecer grandes trocas comerciais entre metrópole e colônias, buscando transformar estas últimas "em sistemas econômicos o quanto possível autossuficientes e produtores de um excedente líquido - na forma de metais preciosos - que se transferia periodicamente para a Metrópole". ${ }^{711}$ Com isso, Celso Furtado aborda a consequência desse afluxo de metais preciosos na economia espanhola com o mesmo recurso que utilizou em A Economia Brasileira: o fluxo de renda. De fato, o ouro e prata que chegavam à Espanha aumentaram o poder do Estado, ampliando a renda e "os gastos públicos", porém gerando inflação e déficit na balança comercial, o que ocasionou o declínio das atividades agrícolas e manufatureiras no reino espanhol. Contudo, ainda que a inflação espanhola tenha se alastrado por toda Europa, estimulou os demais países europeus a concorrerem entre si pelo mercado castelhano, expandindo suas exportações de alimentos e manufaturas para suprir essa demanda e, com isso, obtendo saldos comerciais em ouro e prata.

Esse conjunto de repercussões é examinado tendo em vista seus resultados para as colônias espanholas da América. As relações econômicas com a metrópole resumiam-se à exportação de metais preciosos, abastecendo-se internamente com artesanato local. Dessa forma, a metrópole não aproveitou este mercado consumidor para suas manufaturas, não estimulando essas atividades no reino. Assim, a ausência de "vínculos econômicos de natureza bem mais complexa" entre as duas regiões, impediu a "penetração de capitais e técnica europeus" que "provocaria necessariamente transformações nas estruturas arcaicas das economias indígenas". 712 Ao centrar a colonização das terras americanas na extração de metais precisos, a Espanha - que tinha uma produção de açúcar na Andaluzia e, portanto, seria capaz de implantar essa indústria na América - deixou livre para Portugal o monopólio do produto para o mercado europeu durante o século XVI e primeira metade do século XVII.

\footnotetext{
${ }^{710}$ A característica diferenciadora das colônias, densamente povoadas ou não, nos remete às conferências de Ragnar Nurkse e ao livro A Economia Brasileira e, como já indicamos, difere do tratamento etnográfico de René Maunier, utilizado em sua tese de doutorado.

${ }^{711}$ Idem, pp. 37-38.

${ }^{712}$ Idem, p. 39-40.
} 
Essa contraposição com a economia espanhola destaca o sucesso do estímulo dado pela coroa portuguesa, podendo ser atribuído, em alguma medida, à decadência das atividades comerciais e manufatureiras espanholas a partir do início da chegada dos metais preciosos. Com isso, Celso Furtado registra, também, a preocupação em compreender a produção açucareira dentro do conjunto de possibilidades das outras nações, destacando a importância da Coroa e das classes comerciais portuguesa e flamenga na organização da produção americana, ao mesmo tempo em que testa e comprova a validade de seus conceitos para o conjunto da colonização na América do Sul.

A preocupação com a economia açucareira nos quadros do comércio europeu prossegue ao examinar as causas de sua decadência no século XVII. Para tanto, recorre à história política europeia, afirmando que a decadência econômica do comércio português foi resultado das guerras com os holandeses, durante e depois da União Ibérica (1580-1640). Estes, que "controlavam praticamente todo o comércio dos países europeus realizado por mar", ${ }^{713}$ deixaram de distribuir o açúcar português e, agora, passaram a disputar as regiões produtoras, invadindo a América portuguesa. Nesse período, "adquiriram o conhecimento de todos os aspectos técnicos e organizacionais da indústria açucareira" e iniciaram a produção em suas próprias colônias no Caribe. Dessa forma, são as modificações no comércio internacional do produto, agora com a ruptura da cooperação que garantiu o monopólio português, que explicam a queda no preço do produto e no volume de exportação, na segunda metade do século XVII. Cumpre assinalar o destaque que Celso Furtado dá ao fato de que a redução das exportações foi acompanha pela depreciação da moeda portuguesa em relação ao ouro.

Esse mecanismo de "socialização das perdas" indica, segundo Furtado, o quanto Portugal dependia de suas exportações para manter o equilíbrio de sua balança comercial, bem como a importância dos "exportadores metropolitanos" na política econômica portuguesa. ${ }^{714} \mathrm{Com}$ isso, é possível perceber como os resultados conceituais dos diagnósticos que Celso Furtado fez da economia cafeeira nos séculos XIX e XX possuem um alcance interpretativo que ultrapassa aquele período, explicitando a

\footnotetext{
${ }_{713}$ FURTADO, Celso. Formação econômica do Brasil, op. cit., p. 43.

714 "A depreciação da moeda portuguesa com respeito ao ouro era uma consequência natural da redução substancial no valor real das exportações, decorrente da queda de preços e contração do volume do açúcar vendido. A depreciação minorava os prejuízos dos comerciantes que tinham capitais empatados nos negócios do açúcar, permitindo que esses negócios continuassem operando. Se outros fatores (a descoberta do ouro, meio século antes, por exemplo) houvessem impedido da depreciação, muito mais profunda teria sido a decadência das regiões açucareiras na segunda metade do século XVII”. Idem, p. 45.
} 
validade de suas categorias cuja generalização é possível pela abertura que têm para a história.

O conjunto da interpretação concentrou-se, até o momento, na estrutura comercial da produção açucareira, delimitando as questões de monopólio, comercialização, preços, compreendendo-os no quadro maior da história política europeia, com ênfase na relação entre as guerras e o comércio internacional.

A comparação com outras experiências para esclarecer as peculiaridades portuguesas prossegue com o exame das consequências, para as outras potências europeias, Holanda, França e Inglaterra, do "debilitamento da potência militar espanhola na primeira metade do século XVII". ${ }^{715}$ As duas últimas se preocuparam, desde o início do século XVII em conquistar ilhas do Caribe para "instalar colônias de povoamento com objetivos militares" ${ }^{, 716}$ para se apoderar das terras ou dos carregamentos de metais preciosos espanhóis. O povoamento dessas ilhas foi feito com homens livres, aos quais eram concedidas pequenas propriedades que deveriam ser pagas ao longo dos anos com a produção agrícola. As colônias inglesas se instalaram com mais rapidez, tenho influído nisso as transformações socioeconômicas geradas pelos cercamentos e as guerras religiosas da Inglaterra desde o início daquele século. Essas circunstâncias produziram um excedente populacional que "vivia em condições suficientemente precárias para submeter-se a um regime de servidão por tempo limitado, com o fim de acumular um pequeno patrimônio". ${ }^{717}$ Embora de início essas tentativas de colonização "acarretaram vultosos prejuízos para as companhias que as organizaram", é preciso considerar que esse processo marca "uma etapa nova na história da América", 718 seja pelos objetivos de povoamento, seja pela forma de recrutamento da mão-de-obra, que se distinguia do regime escravista das colônias portuguesa e espanhola no novo continente.

No entanto, as colônias inglesas no norte do continente americano, a Nova Inglaterra, possuíam condições geográficas que impunham um problema para as companhias de comércio. Com efeito, era preciso fixar a população nas novas terras e, ao mesmo tempo, desenvolver uma agricultura que tivesse rentabilidade no mercado internacional, para cobrir os custos de transporte e a manutenção dos colonos. As condições climáticas impediam a produção de bens que disputassem o mercado de

\footnotetext{
${ }^{715}$ Idem, p. 46.

${ }^{716}$ Idem, ibidem.

${ }^{717}$ Idem, p. 49.

${ }^{718}$ Idem, p. 49-50.
} 
produtos tropicais, fazendo com que as tentativas de colonização na região continental fossem, do ponto de vista financeiro, "um efetivo fracasso". ${ }^{719}$ Somente nas Antilhas foi possível a produção de alguns produtos tropicais de valor no mercado europeu, como "o algodão, o anil, o café e principalmente o fumo", os quais eram compatíveis com a produção em pequenas propriedades. Dessa forma, França e Inglaterra conseguiram resolver o problema do povoamento nas Antilhas o que lhes proporcionou bases militares próximas às colônias espanholas.

O êxito da ocupação, com o tempo, levantou novas dificuldades. A agricultura tropical encontrou uma demanda crescente no comércio europeu. Dessa forma, a contradição entre pequena propriedade trabalhada por mão-de-obra livre e a necessidade de produção em grande escala levou à adoção do trabalho escravo e à concentração da propriedade em grandes unidades agrícolas. A primeira região a desenvolver este sistema foi a Virgínia, desencadeando um processo de mudança na estrutura produtiva das outras regiões.

A principal consequência para o Brasil dessa transformação nos rumos da colonização antilhana foi a produção de açúcar nessas ilhas, rompendo definitivamente o monopólio brasileiro, que contou, ainda, com a ajuda técnica e financeira dos holandeses expulsos do Brasil e localização geográfica mais favorável à exportação do produto. Para as Antilhas, a consequência desse novo sistema econômico foi a diminuição da população europeia e o aumento do número de escravos africanos.

Contudo, consequência muito mais importante teve para as colônias inglesas da América setentrional, que não haviam conseguido instaurar uma produção de exportação. Estas desenvolveram uma "economia autossuficiente, suplementada por algumas atividades comerciais que lhes permitiam atender a um mínimo indispensável de importações". ${ }^{720}$ Essa economia praticamente autônoma que, nos termos da teoria do desenvolvimento econômico, tem baixa formação de capital e, portanto, "pareciam fadadas a um lento desenvolvimento", foram surpreendidas pelo "advento da economia açucareira antilhana", que lhes abriu "inesperadas perspectivas". Nas Antilhas inglesas, o processo de expansão das grandes propriedades produtoras de cana-de-açúcar, em detrimento da produção de subsistência, fez com que os pequenos proprietários vendessem suas terras e emigrassem para a América. Dessa forma,

\footnotetext{
${ }^{719}$ Idem, p. 50

${ }^{720}$ Idem, p. 56.
} 
as ilhas se transformaram, em pouco tempo, em grandes importadoras de alimentos, e as colônias setentrionais, que havia pouco não sabiam o que fazer com seu excedente de produção de trigo, se constituíram em principal fonte de abastecimento das prósperas colônias açucareiras

Com isso, Celso Furtado destaca uma transformação fundamental nas colônias do Atlântico Norte, pois ocorre entre a América setentrional e o Caribe uma divisão do trabalho e especialização produtiva, encadeadas pelo estabelecimento de laços comerciais entre as regiões. Esses laços se ampliam à medida que as Antilhas passam a demandar animais de tiro para os engenhos, madeira para encaixotar o açúcar, produtos estes que eram transportados em navios da Nova Inglaterra, fomentando, também, sua indústria naval, bem como a instalação das destilarias que se aproveitavam do melaço da cana. A relação entre as duas economias, segundo Furtado, foi fundamental.

as colônias do norte dos EUA se desenvolveram, assim, na segunda metade do século XVII e primeira do XVIII, como parte integrante de um sistema maior no qual o elemento dinâmico são as regiões antilhanas produtoras de artigos tropicais. $\mathrm{O}$ fato de que as duas partes principais do sistema - a região produtora do artigo básico de exportação e a região que abastecia a primeira - hajam estado separadas é de fundamental importância para explicar o desenvolvimento subsequente de ambas. A essa separação se deve que os capitais gerados no conjunto do sistema não tenham sido canalizados exclusivamente para a atividade açucareira, que na realidade era a mais lucrativa. Essa separação, ao tornar possível o desenvolvimento de uma economia agrícola não especializada na exportação de produtos tropicais, marca o início de uma nova etapa na ocupação econômica [...] Nesta terceira etapa [a primeira se refere à exploração de mão-de-obra preexistente, pela Espanha; a segunda a utilização de mão-de-obra importada] surgia uma economia similar à da Europa contemporânea, isto é, dirigida de dentro para fora, produzindo principalmente para o mercado interno, sem uma separação fundamental entre as atividades produtivas destinadas à exportação e aquelas ligadas ao mercado interno ${ }^{721}$

Esta longa citação explicita o cerne da exposição de Celso Furtado sobre as colônias norte-americanas e antilhanas. Primeiramente, notemos como o texto passa do exame da política europeia à análise da colonização a partir das categorias formuladas para a compreensão do processo histórico de desenvolvimento econômico.

São essas categorias que permitem unificar o tratamento dado às experiências portuguesa, espanhola, inglesa e francesa de colonização nos trópicos. É a partir das relações comerciais (metrópole/colônia), das formas de utilização da mão-de-obra, dos regimes de propriedade da terra, das atividades produtivas, dinamizados pelos fluxos de

${ }^{721}$ Idem, p. 58. 
renda, interno e externo, que surgem os elementos que compõem o quadro das colônias americanas, delineando, ao mesmo tempo, as características que as aproximam ou afastam-nas das possibilidades de desenvolvimento que rompa sua condição colonial, entendida aqui enquanto a determinação externa de um sistema econômico. ${ }^{722}$

A primeira distinção que efetivamente estabeleceu foi entre as colônias tropicais (pertencentes a Portugal e Espanha, no continente, e à França e Inglaterra, nas Antilhas caribenhas) e meridionais (pertencentes, sobretudo, à Inglaterra, na América do Norte).

Sobre as primeiras, distingue as formas de produção (agricultura e mineração), a mão-de-obra (escrava africana e escrava indígena), o regime de propriedade (grandes propriedades), as relações que estabelece com a metrópole (venda de produto de exportação e compra de alimentos e produtos manufaturados; exportação de metais preciosos e autossuficiência local de alimentos e manufaturas), o fluxo de renda e do capital (concentração da renda com os grandes proprietários, porém gasta com importações, sistema de extração de metais preciosos). Desse conjunto de interações Celso Furtado pôde estabelecer como a colônia portuguesa garantiu não apenas grandes lucros para os comerciantes portugueses e flamengos com a venda do açúcar, mas também demanda por manufaturas e produtos agrícolas do reino. Por sua vez, a metrópole espanhola, ao limitar sua relação com a colônia americana à extração de metais preciosos, conduziu, no longo prazo, ao declínio de suas atividades agrícolas e manufatureiras, tornando-se um reino deficitário no comércio europeu, para onde o ouro e a prata retirado das colônias foi redistribuído. Nos termos utilizados por Celso Furtado, o comércio exterior serviu para dinamizar as atividades produtivas tanto na colônia quanto na metrópole portuguesa, algo que não ocorreu na Espanha. Nesta última, sucedeu o que classificara como formas suntuárias de consumo, que paralisaram as atividades agrícolas e manufatureiras. Em ambas, ainda, os lucros e os capitais foram, em sua grande maioria, canalizados para as metrópoles ou para os intermediários comerciais, não ocorrendo acumulação de capital na colônia.

Quanto às colônias setentrionais, historicamente posteriores, sua análise é feita em relação com as regiões tropicais. As formas de produção (agricultura de produtos

\footnotetext{
${ }_{722}$ A definição de economia colonial que Celso Furtado está utilizando é a mesma de A economia brasileira. Relembremos: a qualificação de sistema colonial que aqui damos, aplica-se àquele que não pode crescer senão por indução do crescimento de um outro sistema, melhor ainda, àquele que não é capaz de criar o seu próprio impulso de crescimento. Esta peculiaridade é consequência do fato de que a produção em uma economia colonial só chega a completar-se economicamente quando a mercadoria produzida é exportada". FURTADO, Celso. A economia brasileira. op. cit., p. 15.
} 
semelhantes aos europeus, produtos tropicais em pequenas quantidades) a mão-de-obra (servidão temporária, mão-de-obra livre), o regime de propriedade (pequenas propriedades) e as relações que estabelece com a metrópole (autossuficiência) e com as outras colônias (fornecimento de produtos agrícolas e manufaturas) alteraram-se ao longo do tempo. Enquanto na América do Norte manteve-se a pequena propriedade, a servidão temporária e a produção autossuficiente, nas Antilhas, a demanda por produtos tropicais logo produziu alterações radicais: grandes propriedades, monocultura, trabalho escravo e dependência de importação de alimentos e produtos manufaturados, fornecidos pelas respectivas metrópoles. As guerras entre as potências europeias modificam as possibilidades de abastecimento das Antilhas, e estas se voltam para a colônia da América do Norte. Com isso, surge um novo tipo de fluxo comercial, entre as colônias, que beneficia esta última, tornando-se a principal fornecedora de alimentos, animais de tiro, manufaturas. Surge, assim, na região setentrional, o impulso externo dado pelas dificuldades das Antilhas, de forma que seu comércio amplia-se, desenvolve a construção naval e passa internalizar (trabalho livre) os impulsos e, dessa forma, desenvolve seu mercado interno forte que garante, também, a retenção dos lucros e do capital na região.

Vista no conjunto, portanto, a comparação com as experiências de colonização procurou identificar como cada uma delas se insere nas relações comerciais e quais suas consequências. O amplo leque de casos mobilizados, no entanto, teve o objetivo principal de destacar as peculiaridades da América do Norte. Nela surgiu uma sociedade com "muito menor concentração de renda", o que a tornou "menos sujeita a bruscas contrações econômicas", retendo os capitais gerados e, portanto, "os gastos de consumo se distribuíam pelo conjunto da população". ${ }^{723}$

Dessa forma, note-se que o principal elemento norteador da exposição de Furtado está na caracterização dos diversos tipos de funcionamento da economia na América. As experiências de ocupação territorial iluminam-se, ganhando destaque as possibilidades que cada uma comportava de criação de um mercado interno. Outro ponto de destaque, para explicar a viabilidade da ocupação territorial, foi o impulso externo como fator dinamizador que, no entanto, foi absorvido de formas diferentes por cada região/metrópole. Notemos, por sua vez, que a noção de excedente econômico não aparece, bem como o de classes expropriadoras, muito embora Celso Furtado considere

${ }^{723}$ Idem, p. 61. 
a dimensão política dentro do conjunto de forças dos Estados europeus e sua disputa pelos territórios americanos.

A reconstituição desses primeiros séculos de colonização, portanto, tem como eixo central organizador a possibilidade de formação do mercado interno.

Dessa forma, nesta análise podemos perceber que Celso Furtado está caracterizando uma economia que, embora ainda politicamente dominada pelo regime colonial, em termos econômicos já superou suas principais características: ausência de mercado interno, apropriação do excedente fora do sistema, instabilidade econômica devido às flutuações do mercado de produtos de exportação. Essa característica de uma economia nacional antes da nação introduz, também, a preocupação com os grupos dominantes. Nas Antilhas, "os grupos dominantes estavam intimamente ligados a poderosos grupos financeiros da Metrópole e tinham, inclusive uma enorme influência no Parlamento britânico", ${ }^{724}$ de forma que o negócio colonial inseria-se no conjunto de investimentos dessas classes estabelecidas na metrópole e que lá concentravam seus lucros. Por sua vez, as colônias setentrionais "eram dirigidas por grupos, uns ligados a interesses comerciais centralizados em Boston e Nova York - os quais frequentemente entravam em conflito com os interesses metropolitanos - , e outros representativos de populações agrícolas praticamente sem qualquer afinidade de interesses com a Metrópole”. ${ }^{725}$ Essa contraposição de interesses, manifestos como um conflito contra as normas metropolitanas teve como principal resultado para os colonos a criação de “órgãos políticos capazes de interpretar seus verdadeiros interesses, em vez de apenas refletir as ocorrências do centro econômico dominante". ${ }^{726}$ Com isso, fica explícita, outra vez, como esta reconstituição feita por Celso Furtado orienta-se por um conjunto de questões esboçadas na primeira metade dos anos de 1950, sobretudo no livro $A$ Economia brasileira e no artigo "Desenvolvimento econômico (ensaio de interpretação histórico-analítico)". É nestes textos que podemos perceber a emergência da preocupação com a relação entre os sistemas econômicos e os grupos dominantes, bem como a definição de uma economia colonial, na qual o substantivo assume predominância sobre o adjetivo. Por sua vez, foi nesses trabalhos que Celso Furtado pretendeu expor sua forma de conciliação entre a história e a teoria econômica, ou melhor, de elaborar uma teoria do desenvolvimento econômico vazada pela história.

\footnotetext{
${ }^{724}$ Idem, ibidem.

${ }^{725}$ Idem, ibidem.

${ }^{726}$ Idem, p. 62.
} 
Nesse sentido, é possível ver, nesta primeira parte de Formação econômica do Brasil, "o corte vertical no processo histórico", 727 muito embora, não mais centrado unicamente na economia brasileira, mas sim no conjunto da experiência colonizadora da América. Essa ampliação de horizonte, por sua vez, aparece como a solução para a junção da história europeia, reconstituída a partir da passagem dos sistemas econômicos antigo, comercial e industrial com o episódio da Expansão comercial e a colonização da América.

Outro ponto que precisamos esclarecer é a continuidade entre a tese de doutorado e Formação econômica do Brasil, utilizando como exemplo a comparação com as Antilhas francesas. No trabalho apresentado na França em 1948, Celso Furtado contrapôs a experiência francesa e portuguesa de colonização nos trópicos. Grande parte da bibliografia sobre as Antilhas foi reaproveitada no livro de 1959, porém, o propósito da comparação leva a respostas diversas, que só podem ser entendidas se admitirmos que o arcabouço conceitual e as preocupações de Celso Furtado foram substancialmente alterados.

Em A economia colonial no Brasil nos séculos XVI e XVII, respondendo a uma exigência de seu orientador, Maurice Byé, a comparação com as Antilhas francesas procura desenvolver um argumento colocado por Caio Prado Júnior, segundo o qual a colonização nos trópicos é incompatível com a pequena propriedade baseada no trabalho livre. ${ }^{728}$ Para isso, Celso Furtado examinou a passagem, nas Antilhas francesas, da produção em pequenas propriedades para as grandes plantações de tabaco e, depois, de açúcar. Essa transformação deveu-se a fatores econômicos, pois é impossível concorrer no comércio de produtos tropicais produzindo em pequena escala. Dessa maneira, rompe o determinismo geográfico, ao mesmo tempo em que comprova os elementos econômicos e sociais que determinam as formas de colonização. ${ }^{729}$

Essa problemática, tributária da discussão de autores como Paul Leroy-Beaulieu e René Maunier, desaparece no livro Formação econômica do Brasil, muito embora a

\footnotetext{
${ }^{727}$ FURTADO, Celso. A Economia Brasileira. op. cit., p. 14.

${ }^{728}$ Distinguindo as características das regiões americanas de clima temperado e tropical, para Caio Prado Júnior "para estes [trópicos], o europeu só se dirige, de livre e espontânea vontade, quando pode ser um dirigente, quando dispõe de cabedais e aptidões para isso; quando conta com outra gente que trabalhe para ele. Mais uma circunstância vem reforçar esta tendência e discriminação. É o caráter que tomará a exploração agrária nos trópicos. Esta se realizará em larga escala, isto é, em grandes unidades produtoras - fazendas, engenhos, plantações (as plantations das colônias inglesas) - que reúnem cada qual um número relativamente avultado de trabalhadores." PRADO JÚNIOR, Caio. Formação do Brasil contemporâneo (Colônia). op. cit., pp. 17-18.

${ }^{729}$ Um exame mais detalhado desse tema está em: SILVA, Roberto Pereira. O jovem Celso Furtado. op. cit., pp. 184-201.
} 
bibliografia sobre as Antilhas francesas reapareça neste livro, mas ampliada pelos trabalhos a respeito da colonização inglesa nas ilhas caribenhas. Entretanto, o problema e os resultados da comparação, como vimos, são fundamentalmente diversos, pois agora a preocupação é identificar o funcionamento dos conceitos e categorias do desenvolvimento econômico, sua dinamização através do fluxo de renda, e como sua interação diversificada em cada experiência de colonização deu origem a uma economia com dinâmica dada pelo mercado interno ainda no século XVIII, os Estados Unidos. A coincidência de tema, cronologia e bibliografia esconde (ou revela) preocupação diversa, inteligível pela preocupação de Celso Furtado em compreender o passado a partir dos conceitos que desenvolvera para interpretar o desenvolvimento econômico. Ademais, a aparente semelhança expressa a peculiaridade de Formação econômica do Brasil, que não pode ser buscada na bibliografia utilizada, mas sim na construção da problemática e em sua resolução em termos teórico-metodológicos, elementos que viemos rastreando na obra de Celso Furtado durante a década de 1950.

No entanto, as consequências mais claras da opção metodológica de Celso Furtado aparecem no último capítulo desta primeira parte, intitulado "Encerramento da etapa colonial". Retoma-se o exame da situação de Portugal no quadro da política europeia do século XVII, com a perda de grande parte de seus territórios orientais e principalmente, do monopólio da produção de açúcar. Nessa conjuntura, a ameaça de invasão territorial ligou-o à Inglaterra e, em consequência, os comerciantes ingleses passaram a gozar de uma série de privilégios no reino português e no comércio com suas colônias. Estas alterações políticas, contudo, não esgotam a análise, que se dedica, também, à situação da América portuguesa. Para Furtado, esta passava por um processo de "decadência", "decorrente da desorganização do mercado de açúcar". ${ }^{730}$ A política econômica portuguesa, tendo esgotada as possibilidades de desvalorização monetária, propõe o fomento de manufaturas para evitar as importações e, assim, equilibrar a balança comercial. Embora essa política tenha chegado a zerar as importações de tecidos de lã, foi abandonada após o anúncio da descoberta de ouro na América. Esse afluxo de metais preciosos deu novo fôlego a Portugal, sustentou financeiramente o Tratado de Methuen e garantiu uma posição de destaque na política europeia do século XVIII. Segundo Furtado, “a economia luso-brasileira do século XVIII se configurava com uma articulação — e articulação fundamental — do sistema econômico em mais

\footnotetext{
${ }^{730}$ Idem, Formação econômica do Brasil. op. cit., p. 65.
} 
rápida expansão na época, ou seja, a economia inglesa". ${ }^{731}$ De fato, o reino lusitano se transformou num entreposto comercial, canalizando o ouro que recebia das Minas para a Inglaterra que, dessa forma, ampliou suas exportações, desenvolveu suas manufaturas e consolidou um sistema monetário forte, lastreado em ouro. Já a América portuguesa presenciou uma grande expansão demográfica que pela primeira vez fez a população europeia suplantar a de escravos na região das Minas. Portugal, por sua vez, repetiu "a experiência da Espanha no século anterior". ${ }^{732}$ No entanto, a aliança com a Inglaterra foi fundamental para que o pequeno reino mantivesse seus domínios coloniais mais lucrativos. Ainda assim, "o último quartel do século XVIII veria a decadência da mineração do ouro no Brasil", enquanto a Inglaterra havia "entrado em plena Revolução Industrial". ${ }^{733}$ Isso alterou, novamente, as condições da política e da economia internacionais com a busca de ampliação dos mercados para as manufaturas inglesas, o que foi facilitado pela transferência da família e real e, depois a Independência do Brasil. Essas transformações foram consolidadas com a assinatura dos acordos de 1808 e 1810 que abriram o mercado brasileiro às manufaturas inglesas. A primeira metade do século XIX é, para o Brasil, "um período de transição durante o qual se consolidou a integridade territorial e se firmou a independência política". ${ }^{734}$ No entanto, em termos econômicos, as dificuldades enfrentadas pelo Brasil, desde a decadência da produção aurífera, só começaram a ser solucionadas à medida que o café tornou-se o principal produto de exportação que, não mais se dirige à Inglaterra, mas sim aos Estados Unidos ainda na primeira metade do século. Com isso, foi possível romper a dependência política e econômica da Inglaterra, enquanto o Governo Central passa a contar, a partir da década de 1850, com uma receita tributária que lhe garante maior autonomia. Esse longo processo, que para Celso Furtado arrastou-se por quase um século, assinala que “o passivo político da colônia portuguesa estava liquidado”. No entanto, prossegue:

do ponto de vista de sua estrutura econômica, o Brasil da metade do século XIX não diferia muito do que fora nos três séculos anteriores. A estrutura econômica, baseada principalmente no trabalho escravo, se mantivera imutável nas etapas de expansão e decadência. A ausência de tensões internas, resultante dessa imutabilidade, é responsável pelo atraso relativo da industrialização. A expansão cafeeira da segunda metade do século XIX, durante a qual se modificam as bases do sistema econômico, constituiu uma etapa de transição econômica, assim como a primeira metade desse século

\footnotetext{
${ }^{731}$ Idem, p. 66.

${ }^{732}$ Idem, p. 67.

${ }^{733}$ Idem, ibidem.

${ }^{734}$ Idem, p. 70.
} 
representou uma fase de transição política. É das tensões internas da economia cafeeira em sua etapa de crise que surgirão os elementos de um sistema econômico autônomo, capaz de gerar o seu próprio impulso de crescimento, concluindo-se então definitivamente a etapa colonial da economia brasileira ${ }^{735}$

Nesse trecho final do capítulo é possível deslindar melhor a estrutura de toda a primeira parte de Formação econômica do Brasil. Esta cobre quase os cinco séculos da história brasileira e sua argumentação é recheada de referências históricas que organizam cronologicamente os capítulos. Vimos, também, que as ênfases são diversas, variando as análises das nações europeias e de suas colônias, a política internacional do período, sobretudo séculos XV-XIX, as formas de integração entre metrópoles e colônias e, finalmente, os mecanismos que facilitaram ou impediram a formação do mercado interno nestas últimas. A chave metodológica da análise revela-se neste longo trecho citado, no qual Celso Furtado considera que as transformações trazidas pela economia cafeeira, não apenas resolveram os problemas políticos e econômicos que a nova nação enfrentou entre o declínio da extração aurífera na segunda metade do século XVIII e as dificuldades de consolidação política e financeira do Estado nacional que só foram efetivamente resolvidas a partir de, aproximadamente, 1850. No entanto, a característica de sistema econômico colonial manteve-se, embora o café tenha trazido alguns elementos novos, que forçariam, na segunda metade do século XIX, a superação dessa condição colonial. Esses elementos, no entanto, precisariam esperar pela crise da economia cafeeira para que o país pudesse romper finalmente sua característica colonial, proporcionando a formação de um mercado interno que garantiria um impulso autônomo da economia brasileira. Dessa forma, é a formação do mercado interno que organiza a exposição e a reconstituição da história econômica brasileira, bem como serve de parâmetro para as comparações com as outras experiências coloniais.

Visto agora, em suas linhas gerais, qual o significado desta primeira parte de Formação econômica do Brasil? Para Francisco de Oliveira:

Celso Furtado circunscreve a primeira parte mais rigorosamente à colônia; os elementos da herança ibérica são aproveitadas com grande economia. De fato, a primeira parte é um espécie de abertura, ouverture, ária, que será tematizada e desdobrada nas segunda e terceira partes.

A afirmação não pode ser corroborada se tomarmos colônia enquanto o estatuto político de subordinação à metrópole portuguesa. De fato, a condição de economia

${ }^{735}$ Idem, p. 71. 
colonial persiste após a ruptura política, sendo superada apenas quando suas características principais, centro dinâmico externo e ausência de um mercado interno, são eliminadas, ou seja, após a crise da economia cafeeira. No entanto, a avaliação de Francisco de Oliveira indica que o principal tema desta primeira parte, as condições do surgimento do mercado interno e da superação da dependência de outro centro econômico é elemento organizador das outras partes de Formação econômica do Brasil, retornando na análise de cada sistema econômico, açucareiro, minerador, cafeeiro e industrial, sintomaticamente denominados de "sistema de transição para o trabalho livre" e, "sistema de transição para uma economia industrial", pois estas são as duas condições de superação do subdesenvolvimento: o trabalho livre e a industrialização permitem que a economia funcione a partir de sua dinâmica interna. Se considerarmos, portanto, a estrutura de Formação econômica do Brasil, sua primeira parte, sua ouverture apresenta o andamento analítico do livro, esclarecendo, em seu movimento pelos quatro séculos da história brasileira, que a formação do mercado interno é o ponto de chegada da análise e ponto de partida para o desenvolvimento econômico.

\section{Impulso externo em uma economia subdesenvolvida: o Nordeste açucareiro e a pecuária}

A segunda parte de Formação econômica do Brasil, "Economia escravista de agricultura tropical - Séculos XVI e XVII”, permite diversas abordagens. Primeiramente, é possível estabelecer um diálogo com A Economia brasileira, já que parte do capítulo 9 fora publicado neste livro. Por sua vez, há elementos de complementariedade ou de avanço de perspectivas em relação à tese de doutorado, Economia colonial no Brasil nos séculos XVI e XVII. Além disso, é possível avaliá-la como uma formulação histórica do problema da disparidade regional que Celso Furtado identificou em Perspectivas da economia brasileira.

Para João Antônio de Paula, os trabalhos de 1948 e 1954 seriam uma preparação de Formação econômica do Brasil. A tese de doutorado corresponderia à primeira e segunda partes, enquanto Economia Brasileira às quarta e quinta, apenas a economia mineradora e sua crise constituem-se um campo de abordagem novo para Celso Furtado, ausente nos trabalhos anteriores. No entanto, como vimos, é possível 
problematizar essa visão da gênese do livro, sobretudo para esses três primeiros séculos, não sob o ponto de vista dos assuntos, da bibliografia ou período abordado. Mais interessante, nos parece, é mostrar como estes temas são abordados de forma diversa, respondendo a uma problemática que Celso Furtado começa a identificar ao longo dos anos de 1957 e 1958, a questão regional, sob o arcabouço teórico desenvolvido em $A$ economia brasileira, e que está ausente na tese de doutorado. Este enfoque, inclusive, permite corroborar nossa hipótese de que Formação econômica do Brasil é a maturação de problemas e soluções teóricas colocadas por Celso Furtado ao longo da década de 1950.

Primeiramente, é preciso constatar certa unidade entre as partes dois, três e quatro de Formação econômica do Brasil, unidade esta dada pelo recorte analítico escolhido por Celso Furtado - e que difere do utilizado na primeira parte do livro, o que garantiu a esta a especificidade que discutimos há pouco. Com efeito, neste momento, começamos a encontrar respostas às questões colocadas no trabalho de 1954 . Vale retomar o trecho já citado e discutido,

a técnica de análise aqui adotada consiste substancialmente em uma
tentativa de reconstituição da realidade através da caracterização de
uma série de pontos estratégicos. Não nos interessa reproduzir aquilo
que sucedeu em um dado momento histórico senão como elemento
subsidiário que esclarece a forma como funcionava o sistema. Como
se forma o fluxo de renda em cada um dos sistemas econômicos que
se sucederam no território do país; isto é, como se agregam os fatores
produtivos para criar essa massa de bens e serviços que é o lastro da
vida social. Como é distribuída e utilizada essa massa de bens e
serviços e que conexões existem entre o processo de utilização e
aquele de produção ${ }^{736}$

Aqui, percebe-se a diferença entre a primeira parte e as subsequentes, pois agora se trata de recortar uma série de "pontos estratégicos". Estes diferem substancialmente dos ciclos examinados na tese de doutorado, pois são definidos pelos fatores produtivos que os compõe e as formas sociais e de produção que ensejam. ${ }^{737}$ Daí que, não se trata de examinar a economia açucareira ou mineradora, mas sim a "economia escravista" de agricultura tropical e mineira, com a ênfase analítica recaindo não no produto, mas na utilização da mão-de-obra, sobretudo porque nesta se expressa o conjunto de elementos

\footnotetext{
${ }^{736}$ FURTADO, Celso. A Economia brasileira. (contribuição à análise de seu desenvolvimento). Rio de Janeiro: A noite, 1954, p. 14-15.

${ }^{737}$ Ao contrário da tese de doutorado, na qual a divisão não levava em conta a forma de utilização do fator trabalho, nem a capitalização e distribuição do fluxo de renda. No trabalho de 1948, a organização da análise fora feita pelos produtos, tendo, portanto, um ciclo do pau-brasil (ausente em Formação econômica do Brasil) e outro de cana-de-açúcar.
} 
que lhe são decorrentes, em interação com a produção: a agricultura escravista tropical irá produzir uma concentração de grandes propriedades de terra, com elevadíssima concentração de renda; a mineração formará unidades produtivas menores, mais permeáveis ao trabalho livre, diminuindo a desigualdade social em termos de rendimentos. Daí que seja fundamental, para compreender essas estruturas produtivas, que se observe o fluxo de renda, categoria que permite captar o "lastro da vida social" e, portanto, a ligação entre os fatores constitutivos dos sistemas econômicos e as formas de interação social que produz. Por sua vez, é preciso considerar, também que, ao contrário da primeira parte do livro - composta pela junção de acontecimentos econômicos, políticos e suas repercussões econômicas- estas prescindem da "reprodução do que sucedeu em um dado momento histórico", 738 muito embora haja o esforço de Celso Furtado em dotar sua apresentação com dados quantitativos. Vejamos como isso é feito.

Para Celso Furtado, "o rápido sucesso da indústria açucareira” deve-se ao "esforço do governo português" incentivando a produção neste setor. ${ }^{739}$ A principal dificuldade foi a mão-de-obra: na etapa de instalação dos engenhos, utilizaram-se os indígenas, depois substituídos pelos africanos, com a expansão da produção no Nordeste; outros núcleos, como o de São Vicente, subsistiram à base do apresamento dos povos autóctones, seja para uso próprio, ou para exportação aos engenhos açucareiros. A produção de açúcar cresceu rapidamente e, segundo Celso Furtado, ao final do século XVI, chegava a dois milhões de arrobas. ${ }^{740}$

No entanto, a preocupação principal de Celso Furtado é compreender a composição desta economia, primeiramente em termos de valores e montantes investidos (formação de capital) e, em seguida, na dinâmica do fluxo de renda. Sem adentrarmos na forma de utilização dos dados, ${ }^{741}$ nos concentraremos nos principais agregados que elaborou e em seus valores relativos.

\footnotetext{
${ }^{738}$ Idem, p. 14.

${ }^{739}$ FURTADO, Celso. Formação econômica do Brasil. op. cit., p. 75.

${ }^{740}$ Cabe destacar que a ênfase na experiência de São Vicente é uma inovação de Formação econômica do Brasil, pois não foi considerada em A economia brasileira. Para as peculiaridades da economia colonial vicentina, ver: ARRUDA, José Jobson de Andrade. São Paulo nos séculos XVI e XVII. São Paulo: Imprensa Oficial, 2011.

${ }^{741}$ Essa discussão deveria considerar: 1) a principal fonte foi a obra de Roberto Simonsen, que sintetizou um conjunto de dados fornecidos por viajantes estrangeiros e os comparou com o nível de preços da década de 1930; 2) a relação que Celso Furtado estabelece entre alguns dados localizados no tempo e no espaço e sua possibilidade de generalização para toda a economia açucareira no século XIX. Um exame da produção dos engenhos do Recôncavo baiano e sua comparação com as interpretações clássicas sobre a história econômica brasileira pode ser encontrada em: SCHWARTZ, Stuart. Segredos internos. Engenhos e escravos na sociedade colonial, 1550-1835. São Paulo: Cia das letras, 2005.
} 
Examinando as quantias gastas em engenhos, escravos, a produção exportada e renda estimada do conjunto dos produtores, Celso Furtado conclui que, do capital fixo utilizado na implantação da empresa açucareira, vinte por cento era gasto com mão-deobra escrava. Por sua vez, a produção açucareira gerava sessenta por cento da renda líquida, e $75 \%$ da renda total. Considerando-se uma população europeia (entenda-se: livre e detentora dos engenhos, ou vinculada a estes, como padres, engenheiros, técnicos, etc), "a pequena colônia açucareira era excepcionalmente rica", sendo que a renda disponível "estava fortemente concentrada em mãos da classe de proprietários de engenho". ${ }^{742}$ Desta renda, segundo Furtado, não mais que 5\% "correspondia a pagamentos por serviços prestados fora do engenho", outros $2 \%$ eram pagamentos a assalariados e $3 \%$, gastos monetários com gado e lenha, dispendidos fora do engenho. Dessa forma, "pelo menos noventa por cento da renda gerada pela economia açucareira dentro do país se concentrava nas mãos da classe de proprietários de engenhos e de plantações de cana". ${ }^{743}$ De seus gastos, metade era dispendida em importações e o restante ficava disponível para a ampliação da produção que, segundo Furtado, "era suficientemente rentável para autofinanciar uma duplicação de sua capacidade produtiva a cada dois anos". ${ }^{744}$ No entanto, essa capacidade de expansão foi realizada apenas em momentos excepcionais, de forma que o mais provável era que grande parte desses recursos não pertencia aos senhores de engenho, mas sim, aos comerciantes. Isso pode ser deduzido pela sincronia entre expansão da produção e manutenção dos preços do açúcar até meados do século XVII, comprovando-se a "excepcional habilidade na etapa da comercialização, e que era sobre esta última que se tomavam as decisões fundamentais com respeito ao negócio açucareiro". ${ }^{745}$

Com isso, Celso Furtado corrobora a importância dos holandeses no comércio do açúcar, ainda que sob uma ótica particular. De fato, não mobiliza evidências empíricas da presença dos holandeses nesta atividade. Ao contrário, sua explicação está informada pelos mesmos mecanismos econômicos que lhe serviram para examinar a economia cafeeira na passagem do XIX ao XX: o confronto com a expansão da produção de um lado, e a manutenção dos preços, de outro. Ou seja, examinando a economia escravista de agricultura tropical dos séculos XVI e XVII, sua inteligibilidade é dada a partir de categorias econômicas, no caso em questão, um de seus instrumentos

\footnotetext{
${ }^{742}$ FURTADO, Celso. Formação econômica do Brasil. op. cit., p. 79.

${ }^{743}$ Idem, p. 80.

${ }^{744}$ Idem, p 81.

${ }^{745}$ Idem, p. 82.
} 
mais antigos, a lei de oferta e demanda. Por sua vez, a própria ideia de potencial de crescimento remete à discussão sobre a programação econômica desenvolvida no livro Perspectivas da economia brasileira.

A caracterização de Celso Furtado, ao procurar, não uma reconstituição fiel da operação dos engenhos açucareiros e suas variações no tempo e no espaço colonial, mas sim estabelecer os agregados fundamentais da atividade, instrumentaliza aspectos já desenvolvidos sobre o que caracteriza uma economia colonial: dependência da demanda externa, baixa retenção de capital no sistema dependente - seja pela ausência de investimentos alternativos, seja pela baixa integração do setor exportador com o resto da economia de subsistência - e seu escoamento para o exterior, aqui viabilizada pelo comerciante, e, finalmente, uma extrema concentração de renda nas mãos dos senhores de engenho que, no entanto, consumiam seus recursos excedentes em importações. ${ }^{746}$

Dessa forma, a incursão que faz Celso Furtado, "o corte vertical no processo histórico", procurando seu sentido, é possibilitada pelo instrumental econômico que desenvolvera ao longo dos anos de 1950. Daí, também, que neste aspecto, a realidade histórica apareça explicada com os conceitos e categorias do desenvolvimento econômico. ${ }^{747}$ Esse procedimento, se nos impede de caracterizar o esforço de conciliação entre história e teoria econômica de Celso Furtado como apoiado nas premissas do conhecimento histórico, por outro lado evidencia como a operacionalização da transtemporalidade ocorre ressaltando a problemática do presente, que, embora não figure mais sob o aspecto de conflito e debate, como nos textos sobre planejamento econômico, ainda é o influxo principal que, não apenas resgata, mas organiza conceitualmente o passado.

Delineados esses aspectos gerais da produção açucareira, Celso Furtado se pergunta: "que possibilidade efetiva de expansão e evolução estrutural apresentava esse sistema econômico, base da ocupação do território brasileiro?". ${ }^{748}$ Para respondê-la,

\footnotetext{
746 Retomando as características de uma economia colonial no livro A economia brasileira: "a qualificação de sistema colonial que aqui damos, aplica-se àquele que não pode crescer senão por indução do crescimento de um outro sistema, melhor ainda, àquele que não é capaz de criar o seu próprio impulso de crescimento. Esta peculiaridade é consequência do fato de que a produção em uma economia colonial só chega a completar-se economicamente quando a mercadoria produzida é exportada". FURTADO, Celso. A economia brasileira. (Contribuição à análise de seu desenvolvimento). Rio de Janeiro: A noite, 1954, p. 15

${ }^{747}$ Idem, p. 14-15.

748 Idem, p. 83.
} 
volta-se à análise do fluxo de renda. Neste passo, ${ }^{749}$ entram em escrutínio alguns mecanismos referentes ao funcionamento do sistema econômico: a questão da formação de capital e a distribuição da renda. Para Furtado, "o que mais singulariza a economia escravista é, seguramente, o modo como nela opera o processo de formação de capital". 750 Produzindo em grande escala, o empresário açucareiro importa seu capital, inicialmente invertido em sua totalidade em equipamentos, "mão-de-obra especializada europeia" para a construção dos engenhos e escravos. A introdução do trabalhador africano não significou alteração fundamental nos custos do engenho e este, uma vez em funcionamento, teria uma rentabilidade duas vezes superior ao capital invertido em sua instalação. ${ }^{751}$ Uma vez cobertos os custos de importação de equipamentos e mão-deobra, os investimentos adicionais se realizavam "sem que houvesse lugar para a formação de um fluxo de renda monetária" ${ }^{952}$, já que a construção e a produção de alimentos eram supridas pela mão-de-obra escrava. Essa característica da economia escravista, a concentração dos investimentos na etapa de construção, via pagamentos ao exterior, e seu funcionamento com mão-de-obra escrava, marca sua peculiaridade em relação aos outros sistemas econômicos, comercial e industrial, examinados por Celso Furtado em A economia brasileira. Daí que surja a comparação com estes: "numa economia industrial a inversão faz crescer diretamente a renda da coletividade em quantidade idêntica a ela mesma". ${ }^{753}$ Por outro lado, "a inversão feita numa economia exportadora escravista é fenômeno inteiramente diverso. Parte dela transforma-se em pagamentos feitos no exterior: é a importação de mão-de-obra, de equipamentos e

\footnotetext{
${ }^{749}$ Trata-se, agora, de uma retomada com aprofundamento do segundo capítulo de A economia brasileira. Entretanto, assinalemos que, embora o arcabouço geral e as conclusões coincidam, o diferencial entre as duas escritas é os dados retirados de Roberto Simonsen, que, ao que parece, não foram consultados para o livro de 1954.

${ }^{750}$ Idem ibidem.

${ }^{751}$ A alteração da mão-de-obra indígena para a africana recebe explicações diferentes neste livro e na tese de doutorado. Enquanto neste trabalho a passagem se dá "pelo melhor aparelhamento dos africanos para o tipo de trabalho exigido pelo latifúndio monocultural", em Formação econômica do Brasil, como bem notou André Furtado: "essa tese cultural deixa praticamente de existir. Furtado enfatiza aí que a escravidão dos índios foi funcional quando o valor investido era limitado [...] no livro de 1959, a explicação se dá estritamente em bases econômicas, ao mesmo tempo em que aspectos complementares e acessórios, como a questão de por que os índios não foram funcionais para o escravismo da grande plantação, deixam de fazer parte do horizonte de considerações do autor. FURTADO, André Tosi. As contribuições de Caio Prado Júnior à Formação econômica do Brasil. In: COELHO; GRANZIERA, (orgs). Celso Furtado e a Formação econômica do Brasil (Edição comemorativa dos 50 anos de publicação (1959-2009). Prefácio Fernando Henrique Cardoso. São Paulo, Editora Atlas, 2009, p.75.

${ }_{752}^{7}$ Idem, p. 84.

${ }^{753}$ Idem, p. 85. Retomando, em uma economia industrial, "os lucros que afluem às mãos da classe empresária serão aplicados de maneira crescente no sistema produtivo para aumentar a produtividade, isto é, para expandir a renda global e, portanto, para incrementar o mercado interno". FURTADO, Celso. Desenvolvimento Econômico (Ensaio de Interpretação histórico-analítica). Revista Econômica Brasileira, v. 1. N. 1, jan-mar., 1955, p. 20.
} 
materiais de construção". Ou seja, nesta economia, baseada no trabalho escravo, na importação de máquinas, equipamentos e mão-de-obra, a concentração dos lucros nas mãos dos empresários e comerciantes não-residentes, impede, efetivamente, a formação de um fluxo de renda $n a$ colônia, ou melhor, este existe unicamente do senhor de engenho para o exterior, de forma que a atividade açucareira estabelece relações mínimas com outros setores produtivos dentro da colônia, a bem dizer, unicamente a compra de madeiras e animais de tiro.

Dessa forma, e retomando as considerações do livro de 1954 e do artigo "Desenvolvimento econômico (ensaio de interpretação histórico-analítica)", Celso Furtado novamente refuta a tese da existência do feudalismo no Brasil, indicando o aspecto capitalista da empresa açucareira e a existência de um fluxo monetário, ainda que meramente contábil, com o exterior.

As conclusões que extrai permanecem, em suas linhas gerais, as mesmas: a economia escravista açucareira, embora tenha capacidade para duplicar sua produção a cada dois anos, até ocupar todas as terras disponíveis, cresceu abaixo de suas potencialidades, pois este crescimento foi feito com vistas a "evitar um colapso nos preços", e ampliar as possibilidades de exportação.

Por sua vez, e aqui aparece o problema das repercussões dos influxos externos, a expansão produtiva "ocorria sem que houvesse modificações sensíveis na estrutura do sistema produtivo" ${ }^{, 754}$, seja nos momentos de crescimento (em extensão), seja nas fases de contração, caracterizadas pela diminuição da produção, (re)alocação dos fatores produtivos em atividades de subsistência e redução nos gastos de importação. Dessa forma, Celso Furtado define a principal característica da produção açucareira: "não havia, portanto, nenhuma possibilidade de que o crescimento com base no impulso externo originasse um processo de desenvolvimento de autopropulsão". Ou, dito de outro modo, "o mecanismo da economia, que não permitia uma articulação direta entre os sistemas de produção e consumo, anulava as vantagens desse crescimento demográfico como elemento dinâmico do desenvolvimento econômico". ${ }^{755}$

Aqui, portanto, podemos perceber como, no exame do funcionamento da economia escravista açucareira, considerando os investimentos, os custos e a forma de circulação do fluxo de renda, Celso Furtado utilizou os conceitos e categorias formulados em A economia brasileira para deslindar o caráter colonial, reflexo, do

\footnotetext{
${ }_{754}$ Idem, p. 89.

${ }^{755}$ Idem, p. 90.
} 
sistema e sua impossibilidade de gerar um processo de desenvolvimento. Nesse ponto, constata-se a explicação de que o impulso externo, capaz de melhorar a produtividade da economia e desencadear um processo de desenvolvimento, não operou neste sistema econômico devido: à utilização do trabalho escravo (que impede a propagação da renda para o conjunto da economia); à concentração de renda nas mãos dos senhores de engenhos, cujos gastos eram em sua grande maioria realizados no exterior; e, à autossuficiência que impedia que a região produtora estabelecesse ligação econômica significativa com os outros setores produtivos da colônia.

Encontramos, de forma cristalina, a resposta ao problema que apontamos na análise da polêmica com Nurkse, de que o impulso externo, por si só, não desencadeia o processo de desenvolvimento econômico. A confirmação disso é apresentada agora, ao examinar o fluxo de renda, a organização da produção, e a caracterização do tipo de relação que a economia estabelece com o exterior. Há que se considerar, também, que a ênfase nos gastos externos dos proprietários dos engenhos pode ser remetida à tese do consumo emulatório de Duesenberry, transposto para o caso colonial, não enfatizando tanto padrões de consumo diferentes, mas a ausência de produção no entorno das regiões açucareiras. A possibilidade de transposição de experiências qualitativamente tão diversas é justificada pelas consequências semelhantes, a ausência de retenção de capital e de criação de demanda que impulsione o mercado interno.

No entanto, essa ausência de dinamismo não esgota a problemática de Celso Furtado neste livro de 1959, pois, se assinalou diferenças e semelhanças com as repercussões do crescimento em uma economia colonial e industrial, o mesmo é feito na etapa de crise da economia açucareira.

Ora, uma vez em operação, o principal custo do empresário é a reposição de equipamento e mão-de-obra. Como esta última é contabilizada como um gasto fixo, qualquer redução na demanda ou nos preços ocasiona unicamente uma diminuição nos lucros do empresário. Enquanto estes forem suficientes para manter os gastos de manutenção, não há motivos para que ele abandone a atividade. Dessa forma, "a economia açucareira do Nordeste, com efeito, resistiu mais de três séculos às mais prolongadas depressões, logrando recuperar-se sempre que o permitiam as condições do mercado externo, sem sofrer nenhuma modificação estrutural significativa". ${ }^{756}$ Celso Furtado reafirma a desarticulação do mercado de açúcar na segunda metade do século XVII, bem como a tendência baixista do preço do açúcar no seguinte. Esse conjunto de 
circunstâncias levou o sistema a uma "letargia secular", embora, prossegue, "sua estrutura preservou-se, entretanto, intacta". ${ }^{757}$

Essa constatação, já apontada na obra de 1954, permite a Celso Furtado extrair uma série de consequências para a compreensão da economia brasileira que remetem às suas preocupações expressas nas palestras de 1957 publicadas em Perspectivas da economia brasileira. Da percepção dos entraves ao desenvolvimento econômico que a mão-de-obra escrava e a dependência externa impõem ao sistema, deriva um conjunto de consequências históricas profundas, cuja necessidade de explicação pode ser buscada nas transformações que a economia brasileira está passando em finais da década de 1950. Examinada brevemente em A economia brasileira, a questão da regressão da economia nordestina à subsistência e a expansão demográfica pelo sertão com a pecuária assume feições dramáticas com a seca de 1958 e, como fora adiantado nas palestras de 1957, colocou para Celso Furtado a questão das disparidades regionais. Esta pode ser a justificativa para a escrita dos três próximos capítulos de Formação econômica do Brasil, que irão, por sua vez, integrar as considerações de Celso Furtado a respeito da economia de subsistência.

A questão é introduzida para compreender que tipo de relação, efetivamente, se estabeleceu ao longo dos séculos, entre a unidade exportadora e o resto da economia nordestina. Como a crise do setor açucareiro foi absorvida na região e quais as consequências?

Esta pergunta relaciona-se ao dinamismo do setor externo. Ora, dada a alta produtividade e rentabilidade da economia açucareira, teria ela, efetivamente, concentrado apenas o máximo de $10 \%$ de sua renda líquida em pagamentos locais? Não se configuraria como uma empresa altamente especializada, demandando produtos locais? Segundo Celso Furtado, essa demanda foi desviada para o exterior devido aos interesses dos comerciantes e pela política econômica metropolitana de coibir o surgimento de atividades e indústrias concorrentes dos artigos importados.

Ao contrário do que ocorria com as Antilhas — escassez de terra - na região açucareira do Nordeste brasileiro, a possibilidade de expansão para terras livres gerou um segundo núcleo populacional e econômico para atender os engenhos com carne, lenha para as fornalhas, animais de tiro e madeiras para construção. A coroa, percebendo os problemas de conciliação no mesmo espaço das plantações de cana e criação de gado, determinou a separação das duas atividades, o que gerou "uma ${ }^{757}$ Idem, ibidem. 
economia dependente na própria região nordestina". ${ }^{758}$ Essa separação dá origem a um sistema econômico que terá repercussão importante nas etapas posteriores da economia brasileira: a pecuária. ${ }^{759}$

A compreensão dessa atividade recorre aos mesmos conceitos utilizados para caracterizar a economia açucareira, muito embora a pecuária fosse "uma atividade econômica de características radicalmente distintas das da unidade açucareira". ${ }^{760}$ A ocupação do território era extensiva e itinerante, as inversões eram mínimas para além do estoque inicial de gado, cujo crescimento do rebanho ocorria de forma vegetativa e independente da demanda. Em seu conjunto era uma atividade induzida e dependente da açucareira. Sua renda correspondia a algo em torno de 5\% daquela, congregando uma população "muito escassa". ${ }^{761}$ Até aqui, portanto, a caracterização é semelhante à de um sistema econômico dependente com baixa produtividade

As possibilidades de crescimento dessa economia eram distintas daquelas da economia açucareira. A pecuária dependia, pelo lado da oferta, basicamente, da disponibilidade de terras, cujo limite era a distância do litoral, logrando, até o início do século XVII, cruzar o rio São Francisco, alcançar Tocantins e, ao norte, o Maranhão. Do ponto de vista dos capitais requeridos, a atividade atraiu o colono com pouco ou nenhum recurso, reunindo capital ao longo do tempo na forma de cabeças de gado recebidas por tempo de trabalho no rebanho de outrem. Esses limites, sob a ótica da procura, revelam o tipo de articulação entre as duas economias. Segundo Furtado, "sendo a criação nordestina uma atividade dependente da economia açucareira, em princípio era a expansão desta que comandava o desenvolvimento daquela". ${ }^{762} \mathrm{Ou}$ seja, sistema dependente da economia açucareira, estava sujeito às oscilações da exportação de açúcar. Entretanto, essa dependência guardava algumas características peculiares. Sua expansão era feita pela ocupação de novas terras, afastando-se do litoral. A principal consequência do dinamismo da procura não é, portanto, um aumento de produtividade, mas precisamente o contrário, pois as distâncias e os custos dos transportes aumentam e a renda per capta da economia tende a cair, mesmo em períodos

\footnotetext{
${ }^{758}$ Idem, p. 96.

${ }^{759}$ Notemos que Celso Furtado assinala a separação da atividade pecuária (subsistência) da plantação de cana (exportação). A mesma separação fora constatada nas colônias inglesas da América do Norte e nas Antilhas. As consequências disso serão diversas, pois na pecuária nordestina a ausência de trabalho assalariado impediu um impulso de desenvolvimento.

${ }^{760}$ Idem, ibidem.

${ }^{761}$ Idem, p. 97.

762 Idem, p. 99.
} 
de demanda açucareira. A isso se soma a quase inexistência de comercialização e produção alternativa, salvo o couro, o principal artigo de comércio.

Dessa forma, Celso Furtado não apenas descortina um outro sistema econômico no Nordeste como, a partir de seu exame, articulado à produção açucareira, revela sua tendência para crescer extensivamente com diminuição da produtividade. Assim, estão estabelecidos os dois fatores que perpetuam a estagnação desse sistema. Porém, o exame do funcionamento e das articulações da pecuária com a empresa açucareira não apenas deriva do instrumental analítico que Celso Furtado desenvolveu, como permite captar, nos momentos de crise desta última, as consequências para o conjunto da economia brasileira, cuja ressonância é percebida nos séculos XIX e XX. De fato, a preocupação com o presente irrompe na análise, revelando seu papel na elaboração desta problemática:

as formas que assumem os dois sistemas da economia nordestina - $\mathrm{o}$ açucareiro e o criatório - no lento processo de decadência que se inicia na segunda metade do século XVII constituem elementos fundamentais na formação do que no século XX viria a ser a economia brasileira $^{763}$

Com isso, fica explícita a mudança de perspectiva de Celso Furtado, se pensarmos na pouca ênfase que deu ao sistema criatório em A Economia Brasileira. De fato, a preocupação com as disparidades regionais apareceu de forma insistente no livro Perspectivas da economia brasileira, sob a ótica do planejamento do conjunto da economia. Mas, observemos: no livro de 1958, resulta do processo de industrialização concentrada no sul do país, agravada pelos mecanismos cambiais, impondo-se no horizonte de futuro como algo a ser corrigido pelo planejamento; aqui, a região nordestina é apreendida em sua formação histórica, considerando as matrizes de longo prazo que configuraram a problemática da região. Com isso, a mesma questão desloca Celso Furtado para o passado e para o futuro, dando mostras da interdependência dos tempos, da transtemporalidade apreendida a partir do arcabouço conceitual forjado na decifração do presente.

Estabelecida a relação dos dois sistemas produtivos, resta analisá-los tanto em suas características comuns, quanto em suas respostas ao período de crise.

Ambas as economias cresciam de forma extensiva e sem modificações estruturais nos custos e na produtividade. Por sua vez, seu baixo nível de pagamentos e

\footnotetext{
${ }^{763}$ Idem, p. 101.
} 
salários tornava-as capazes de absorver a queda da procura de forma que "convinha continuar operando, não obstante os preços sofressem uma forte baixa, pois os fatores de produção não tinham uso alternativo". 764 Entretanto, em que pesem essas semelhanças, a contração da demanda tinha efeitos diferentes no longo prazo para os dois sistemas econômicos.

Enquanto a economia açucareira possuía gastos de manutenção e reposição de mão-de-obra e equipamentos importados, a pecuária recompunha-se vegetativamente, sem exigir gastos monetários. Dessa forma, em uma etapa de diminuição da dinâmica externa, a economia açucareira "entra numa etapa de relativa prostração", 765 porém sem deixar de operar. Com preços mais baixos a partir da segunda metade do século XVII e acentuando-se ao longo do XVIII, pelo aumento do valor dos escravos devido à mineração, "é provável que parte das antigas unidades produtivas se haja desorganizado em benefício daquelas que apresentavam condições mais favoráveis de terras e transporte". ${ }^{766}$ Ou seja, uma vez que cesse o impulso externo, por mais que este não tenha efeitos dinâmicos para o conjunto da atividade econômica, seu núcleo central, a produção açucareira, entra em crise.

Já o setor pecuário, cujo crescimento se constituía por "um processo endógeno, resultante do aumento vegetativo da população animal", absorveu a mão-de-obra que saía da economia açucareira e, embora não tenha mantido sua expansão enquanto atividade comercial, manteve seu crescimento "através do aumento relativo do setor de subsistência". ${ }^{767}$ Com isso, diminui a importância dos pagamentos e ela se torna praticamente autossuficiente, excetuando-se algum comércio de artigos de couro. Dessa forma, ocorre um "atrofiamento da economia monetária" que acentua-se "à medida que aumentam as distâncias do litoral”, refletindo os custos crescentes de transporte. Para Furtado

no longo período que se estende do último quartel do século XVII ao começo do século XIX a economia nordestina sofreu um lento processo de atrofiamento, no sentido de que a renda real per capta de sua população declinou secularmente. É interessante observar, entretanto, que esse atrofiamento constituiu o processo mesmo de formação do que no século XIX viria a ser o sistema econômico do Nordeste, cujas características persistem até hoje ${ }^{768}$

\footnotetext{
${ }^{764}$ Idem, p. 101.

765 Idem, p. 102.

${ }^{766}$ Idem, p. 103.

${ }^{767}$ Idem, ibidem.

${ }^{768}$ Idem, p. 104.
} 
Aqui, portanto, podemos perceber um diagnóstico de decadência do sistema econômico nordestino para o nível de subsistência, expresso pelo desaparecimento das transações monetárias. A caracterização desse processo como um "atrofiamento" não deixa de remeter à análise que Celso Furtado fez do feudalismo europeu como um momento de involução econômica até uma economia de subsistência. ${ }^{769}$ No entanto, o quadro apresenta dificuldades adicionais para a pecuária nordestina, pois não se trata de atrofiamento de um sistema que operava com alta produtividade, mas sim de uma economia com baixo grau de capitalização onde atividade produtiva e de subsistência se confundem. Por sua vez, se a economia feudal europeia pode responder rapidamente à retomada do comércio no mar mediterrâneo, o mesmo não acontecerá no Nordeste, pois não há um nível técnico a ser recuperado. Ao contrário, uma vez que a pecuária absorve a população que saía da atividade açucareira, esse seu processo de transformação em uma economia de subsistência teve, também, o efeito de promover "uma intensificação no crescimento demográfico”. ${ }^{770}$ Desta forma,

A expansão da economia nordestina durante esse longo período [séculos XVII a XIX] consistiu, em última instância, num processo de involução econômica: o setor de alta produtividade ia perdendo importância relativa, e a produtividade do setor pecuário declinava à medida que este crescia. Na verdade, a expansão refletia apenas o crescimento do setor de subsistência, no qual se ia acumulando uma fração crescente da população. Dessa forma, de sistema econômico de alta produtividade em meados do século XVII, o Nordeste se foi transformando progressivamente numa economia em que grande parte da população produzia apenas o necessário para subsistir ${ }^{77}$

Com isso, Celso Furtado deslinda o surgimento de uma imensa região que concentra uma população densa, cuja única atividade econômica é a subsistência. $\mathrm{O}$ atrofiamento desta economia, portanto, não guarda dentro de si elementos dinâmicos que possam ser ativados em uma nova fase de prosperidade. Dessa maneira, o exame da projeção da economia açucareira, a formação de um grande adensamento populacional com baixíssima produtividade, aparece como "elemento básico do problema econômico brasileiro em épocas posteriores", como fora analisado sob a ótica do planejamento, no livro Perspectivas da economia brasileira. Assim, a compreensão do passado ilumina

\footnotetext{
${ }^{769}$ Páginas atrás, em Formação econômica do Brasil, podemos ler: "o feudalismo é um fenômeno de regressão que traduz o atrofiamento de uma estrutura econômica. Esse atrofiamento resulta do isolamento imposto a uma economia, isolamento que engendra grande diminuição da produtividade pela impossibilidade em que se encontra o sistema de tirar partido da especialização e da divisão do trabalho que o nível técnico já alcançado the permite." FURTADO, Celso. Formação econômica do Brasil, op. cit., p. 87-88.

${ }_{770}$ Idem, p. 105.

${ }^{771}$ Idem p. 105-106.
} 
os problemas do presente, exigindo uma solução; mas, ao mesmo tempo, esse exame do passado não seria possível, nesses termos, sem a perspectiva das disparidades regionais da economia brasileira na década de 1950.

No entanto, não é apenas no nordeste que as atividades regridem para a subsistência. O fim da União Ibérica, a desorganização do mercado açucareiro pela concorrência holandesa e sua consequente queda no preço pago pelas exportações brasileiras, indicam que "o século XVII constitui a etapa de maiores dificuldades na vida política da colônia". ${ }^{772}$ De fato, uma vez que o dinamismo externo esmorece, é toda a colônia que entra em decadência. Esse processo inicia-se na segunda metade do setecentos, acarretando para Portugal a perda de entrepostos africanos, a invasão do nordeste pelos holandeses e o início de uma empresa concorrente, o aumento dos custos militares e de defesa, bem como a diminuição na arrecadação de tributos. Esse novo cenário irá exigir um esforço adicional para ocupar os territórios antes compartilhados com a Espanha, garantindo a posse das terras americanas. A ocupação da bacia amazônica permite a fixação dos portugueses na região, enquanto no Maranhão, deriva de um esforço especial da Coroa Portuguesa e enfrentou uma série de dificuldades pois se iniciou na fase de decadência da produção açucareira. Nesta região, o apresamento de indígenas e sua organização para a empresa extrativista no hinterland do Norte garantiu a ocupação do Estado do Brasil, ainda que, em grande parte, voltado para a economia de subsistência. No sul, a diminuição da demanda por escravos indígenas orientou as atividades dos paulistas para a pecuária na bacia do rio da Prata e a manufatura do couro, tornando-se um dos poucos produtos de exportação.

Esse conjunto de transformações regionais, iniciadas na segunda metade do século XVII, evidencia a importância da crise da economia açucareira, não apenas para Portugal, mas também para o conjunto da colônia.

Entretanto, é preciso, ainda, ponderar sobre a ênfase que Celso Furtado atribuiu a esse período de crise, na metade do século XVII. Ele delimita uma alteração importante, uma inflexão com consequências para a operacionalização do modelo de desenvolvimento econômico, centrado na importância do setor externo como fator dinamizador de uma economia subdesenvolvida. Vejamos.

O exame da economia açucareira demonstrou como a mão-de-obra escrava, a concentração de renda, a especialização produtiva e a dependência de importações neutralizou esse impulso para o conjunto da economia. O surgimento da pecuária, 
duplamente reflexa, seja da demanda externa, seja do setor açucareiro, deve-se à possibilidade de fornecer alguns poucos produtos que não eram importados, carne, lenhas, animais de tração e madeiras para construção. $\mathrm{O}$ sistema, entretanto, tinha a característica distintiva de absorver excedentes populacionais e transformar-se em economia de subsistência. Dessa forma, neste modelo elaborado por Celso Furtado, a ausência de dinamismo do setor externo promove um processo de crise econômica na qual cada sistema reage de acordo com seus recursos e características. No longo prazo, a crise ocasiona a desagregação da agricultura escravista de agricultura tropical e o crescimento extensivo da pecuária de subsistência, origem do complexo nordestino cujos problemas atravessaram séculos e colocam limites ao crescimento da economia brasileira do século XX.

No entanto, nossa abordagem, ao sublinhar a constituição do problema das disparidades regionais no final dos anos de 1950 e explicitar como a resposta de Celso Furtado operava tanto para seu entendimento formativo no passado quanto para sua resolução no futuro, pelo planejamento econômico, precisa ainda, revisar a hipótese central de sua argumentação, qual seja, a ocorrência de uma crise aguda na segunda metade do século XVII que desagregou a economia açucareira e fez involuir a pecuária nordestina à subsistência, mantendo-a estagnada até o presente do autor. Do ponto de vista teórico, a operacionalização de seus conceitos e categorias do desenvolvimento econômico não oferece problemas. A dinâmica é dada pelo setor externo, porém, diversas constrições características da economia escravista de agricultura tropical impedem sua propagação. Por sua vez, o declínio do impulso externo leva a economia a um estágio de involução econômica: como aquele que deu origem ao feudalismo europeu, como este que originou o complexo nordestino.

Mas, reflitamos: houve mesmo uma crise das proporções apontadas por Celso Furtado? Ela teve consequências desastrosas para a produção açucareira e a pecuária? Teria havido uma quase completa ausência de circulação monetária na economia nordestina que a impossibilitava de resistir à diminuição do influxo externo?

Uma maneira de responder essas questões seria observar se as principais fontes de informação sobre a economia açucareira na América portuguesa que Celso Furtado utilizou corrobora suas assertivas.

Para tanto, iremos comparar a formulação de Celso Furtado com outras interpretações disponíveis e que certamente consultou, quais sejam: Formação 
econômica do Brasil, [1937] de Roberto Simonsen, Formação do Brasil contemporâneo (Colônia) [1942] e História econômica do Brasil [1945], ambas de Caio Prado Júnior.

Roberto Simonsen examina a pecuária no âmbito dos fatores que garantiram a ocupação territorial da América Portuguesa: a criação de gado, a caça ao gentio, a mineração e a extração vegetal no Vale Amazônico.

O gado, nos primeiros séculos de colonização, além de importante meio de transporte, era a principal fonte de energia motora e de alimento. De acordo com Simonsen, o gado se expandiu desde os sertões da Bahia e Pernambuco, tendo como eixo o rio São Francisco. O desenvolvimento da pecuária foi considerado "a retaguarda econômica dos engenhos", e "exerceu ainda uma alta finalidade, quando se verificou a expansão mineradora do Brasil central". ${ }^{773}$ A criação nordestina foi importante fonte de abastecimento das minas e, embora cite a Carta Régia de 7 de fevereiro de 1701 proibindo a comunicação das zonas pecuaristas com os distritos extrativos, admite que "tal determinação foi logo depois atenuada, consentindo-se que pelo caminho dos currais passasse apenas o gado em demanda dos campos de mineração". ${ }^{774}$ Assim, apenas por volta da década de 1720 é que as zonas ao sul da colônia, São Paulo, Rio de Janeiro e, mais tarde, Rio Grande, passaram a fornecer o gado à região mineira. Finalmente, numa avaliação mais geral: "foi o gado o elemento de comércio por excelência em toda a hinterlândia brasileira, na maior parte da fase colonial" 775 , destacando as feiras de gado que surgiram no século XVIII: "de Santana, Curralinho e Candeúba, na Bahia; Itabaiana e Brejo d'Areia, na Paraíba; Campos de Santana e São Cristovam, no Rio de Janeiro; Itapemirim-mirim, no Maranhão; Três Corações do Rio Verde, Benfica e Sítio, em Minas; Sorocaba, em São Paulo”. 776

Para Roberto Simonsen, a origem da pecuária nordestina está relacionada com as necessidades de transporte e tração animal dos engenhos açucareiros. Essa origem da pecuária, entretanto, recebe um novo impulso com a descoberta das minas no século XVIII. A partir de então se estabelece uma relação entre as atividades mineradoras e a demanda por gado: “os mineradores de Mato Grosso, Goiás e Minas Gerais foram abastecidos pelos criadores do vale do São Francisco e sertões do Nordeste”. Por outro lado, essa demanda fez subirem os preços dos animais, prejudicando os engenhos do

773 SIMONSEN, Roberto. História econômica do Brasil, 1500-1820 [1938]. São Paulo: Companhia editora nacional, 1977, pp. 157 e 185.

${ }^{774}$ Idem, p. 158.

${ }^{775}$ Idem, p. 186.

${ }^{776}$ Idem, p. 178. 
litoral: "a alta que se verificou nos preços do gado nos campos de mineração, foi de tal monta, que repercutiu em toda a zona criadora, provocando os protestos dos senhores de engenho, já grandemente prejudicados com a elevação, da mesma origem, registrada nos preços dos escravos". 777

Dessa forma, segundo Simonsen, a crise do setor açucareiro não significou a involução econômica para a região pecuarista nordestina, mas criou uma nova demanda, reorientando seu comércio para as Minas, que garantia preços mais elevados e demanda em ascensão.

Se fizermos um exercício análogo com a obra de Caio Prado Júnior, podemos encontrar uma interpretação semelhante. Para o intelectual paulista, a relação da pecuária com a economia açucareira é vista através das consequências do "sistema geral da economia e da agricultura brasileira, voltadas para a produção de uns poucos gêneros destinados ao comércio exterior, e com a monocultura que daí resulta". ${ }^{778}$ Disso decorre "a separação completa e nítida entre a pecuária e a cultura da terra que aí se revela". ${ }^{779}$ Quanto às zonas de irradiação, os núcleos coincidem: "Norte (Bahia e Pernambuco), e São Vicente". 780

Quanto ao comércio propriamente dito, a pecuária nordestina é qualificada como um pujante centro mercantil: "em meados do século XVIII o sertão do Nordeste alcança o apogeu de seu desenvolvimento. O gado nele produzido abastece, sem concorrência, todos os centros populosos do litoral, desde o Maranhão até a Bahia". ${ }^{781}$ Mais a frente, assim se refere ao comércio interno da colônia:

o que realmente merece destaque neste terreno é o comércio de gado. Este sim tem um certo vulto no intercâmbio interno da colônia. E seu papel na formação do Brasil é considerável, pois estendendo-se sobre uma área muito extensa, como vimos, contribuiu grandemente para ligar entre si as diferentes partes do território brasileiro e seus núcleos de povoamento que de outra forma ter-se-iam conservado em segmentos estanques e sem possibilidades talvez de se unirem num bloco coeso, num único país, como se deu ${ }^{782}$

Assim, para Caio Prado Júnior, a importância da pecuária nordestina termina apenas em finais do XVIII, datada com certa precisão pelas secas de 1791 a 1793.

777 SIMONSEN, Roberto. História econômica do Brasil, 1500-1820. São Paulo: Companhia editora nacional, 1977, p. 157.

${ }^{778}$ PRADO JÚNIOR, Caio. Formação do Brasil contemporâneo (colônia) [1942]. São Paulo: Publifolha; Brasiliense, 2000, p. 190.

${ }^{779}$ Idem, ibidem.

${ }^{780}$ Idem, 191.

${ }^{781}$ PRADO JÚNIOR, Caio. História econômica do Brasil [1945]. São Paulo: Brasiliense, 1977, p. 68.

782 PRADO JÚNIOR, Caio. Formação do Brasil contemporâneo (colônia) [1942]. op. cit., p. 117. 
Declínio, cumpre notar, do abastecimento do mercado nordestino, sobretudo, litorâneo, e não do povoamento e do comércio de gado em todo o nordeste. ${ }^{783}$

Ressalta, portanto, nos dois autores, a continuidade da pecuária nordestina enquanto atividade comercial para além da metade do século XVII, sua ligação com as zonas de mineração logo em seus inícios e em condições de preço e demanda mais favoráveis de que com os engenhos nordestinos.

Por sua vez, como estamos argumentando, é a problemática específica de Celso Furtado, a origem e a constituição histórica do subdesenvolvimento nos cinco séculos de história brasileira, que explica a caracterização da pecuária nordestina. E aqui notamos, em consonância com os demais autores examinados, a relação intrínseca entre esta atividade e a produção açucareira. No entanto, Celso Furtado vê uma involução à economia de subsistência na segunda metade do XVII, pois

sendo a criação nordestina uma atividade dependente da economia açucareira, em princípio era a expansão desta que comandava o desenvolvimento daquela. A etapa de rápida expansão da produção de açúcar que vai até metade do século XVII, teve como contrapartida a grande penetração nos sertões. Da mesma forma, no século XVIII, a expansão da atividade mineira comandará o extraordinário desenvolvimento da criação do sul ${ }^{784}$

Temos, portanto, uma divergência entre os autores a respeito da perda de dinamismo da pecuária no século XVII em consequência do declínio da agricultura açucareira. Para Furtado, o surto minerador irá estimular apenas a pecuária do sul, uma vez que o nordeste entrou num processo de "involução" econômica. Aqui, portanto, nossa interrogação: quais considerações levaram Celso Furtado a acentuar a crise da economia açucareira na segunda metade do século XVII e o declínio da pecuária nordestina até uma involução para a subsistência? Discordava dos dados apresentados por Roberto Simonsen e Caio Prado Júnior? Possuía números alternativos que preferiu não utilizar?

Ora, a problemática nordestina, alongando-se no horizonte de preocupações de Celso Furtado, solicitava uma explicação em termos históricos e, ao mesmo tempo, que corroborasse os resultados de suas categorias e conceitos do desenvolvimento econômico. Assim, é a partir do presente, dos problemas econômicos e do aparato conceitual que interroga o passado. Se os autores examinados apresentavam uma

\footnotetext{
${ }^{783}$ Idem, Formação do Brasil contemporâneo (colônia). op. cit., p. 198.

${ }^{784}$ FURTADO, Celso. Formação Econômica do Brasil . op. cit, p. 99.
} 
explicação historicamente apoiada para a pecuária nordestina, não ofereciam uma interpretação da questão nordestina dentro do quadro das contradições da economia brasileira na década de 1950. ${ }^{785} \mathrm{O}$ surgimento do Nordeste como um assunto econômico é inaugurado pelo instrumental furtadiano, que conseguiu explicar a ausência de forças autônomas na região, permanecendo dependente, não só do litoral açucareiro, mas agora das políticas do governo federal e do mercado do sul do país. Nesse sentido, a leitura de Celso Furtado presta contas aos dilemas do presente.

Nisto, nada de contraditório com o objetivo de examinar o passado a partir de "uma série de cortes estratégicos", 786 mas, sim, algo esclarecedor do método de Celso Furtado.

\section{Impulso externo em uma economia subdesenvolvida: a economia mineira}

A terceira parte de Formação Econômica do Brasil, intitulada "Economia escravista mineira - século XVIII", mantém a estrutura da anterior: delimita o funcionamento deste sistema econômico, também baseado na escravidão, mas tendo como atividade econômica principal a mineração. É a parte mais curta do livro, com apenas quatro capítulos, o que nos revela que Celso Furtado escrutina um período da história econômica brasileira que ainda não recebera sua atenção, como as economias açucareira e cafeeira. ${ }^{787}$

Assim como na seção anterior, Celso Furtado conduz sua análise relacionando as atividades produtivas, a ocupação do território e a interação das regiões em seus distintos espaços econômicos. $\mathrm{O}$ estudo da mineração incorpora não apenas elementos da política portuguesa e europeia, mas, também, suas conexões econômicas e sociais com o conjunto do território lusitano na América.

De início, Celso Furtado retoma os problemas enfrentados com a comercialização do açúcar, a grande concorrência que as colônias francesas, inglesas e holandesas instauraram no ramo de produtos tropicais e assinala os custos crescentes

\footnotetext{
${ }^{785}$ Isso é verdade para Roberto Simonsen, mas não para Caio Prado Júnior que, a partir da década de 1960 começa a se preocupar com a questão agrária brasileira. O diagnóstico e as respostas que oferece, entretanto, são diversas.

${ }^{786}$ FURTADO, Celso. A economia brasileira. (Contribuição à análise de seu desenvolvimento). Rio de Janeiro: A noite, 1954, p. 14

${ }^{787}$ Maurício Coutinho considera que "das minas, Furtado conhecia muito pouco; e menos ainda do que sucedeu à região mineira no século XIX". COUTINHO, Maurício. Economia de Minas e economia da mineração em Celso Furtado. Nova Economia. Belo Horizonte: n. 18, v. 3, setembro-dezembro, 2008, p. 362.
} 
com a defesa do território. Uma vez diminuída a capacidade de exação fiscal da coroa pela queda do rendimento per capta na colônia, Portugal compreendeu "que a única saída estava na descoberta de metais preciosos". ${ }^{788}$ Contando com os "conhecimentos que do interior do país tinham os homens do planalto de Piratininga", a Metrópole forneceu a "ajuda técnica" decisiva para a descoberta do ouro nas primeiras décadas do século XVIII. Em decorrência, houve uma grande corrente emigratória para a região mineradora: paulistas, escravos do Nordeste e homens livres de Portugal. Com isso, "o facies da colônia iria modificar-se fundamentalmente". 789

Nesse ponto, percebemos uma primeira mudança significativa em comparação com o sistema açucareiro, pois o perfil da mão-de-obra é diverso e, melhor, diversificado, constituindo-se, pela primeira vez, de uma maioria de homens livres de origem portuguesa. Essa alteração deve-se à peculiaridade da atividade mineradora na colônia. De fato, na exploração açucareira só havia espaço para empresários com vultosos recursos em capital implantar e manter os engenhos. O resto dos trabalhadores eram, predominantemente, escravos. Nas outras regiões, a imigração havia ocorrido com objetivos militares de povoamento e segurança do território, financiada pela metrópole, como no Maranhão, ou resultado do fracasso da implantação da atividade açucareira, como em São Vicente, ou seja, em pequenos contingentes.

Essa característica tem implicações econômicas e sociais. Diferenciando-se daquelas experiências de ocupação, "a economia mineira abriu um ciclo migratório europeu totalmente novo para a colônia", ${ }^{790}$ pois era capaz de abrigar "pessoas com recursos limitados", uma vez que "não se exploravam grandes minas", como nas colônias espanholas. Criou-se um grande fluxo migratório de portugueses para a colônia, decuplicando a população branca livre. Também, ao contrário da economia açucareira, não houve uma predominância de população escrava, e mesmo estes contavam com maior possibilidade de ascensão na sociedade que se formava. A principal diferença, em termos sociais, entre as duas atividades econômicas coloniais estava em que

na economia mineira, as possibilidades que tinha um homem livre com iniciativa eram muito maiores. Se dispunha de recursos, podia organizar uma lavra em escala grande, com cem ou mais escravos [...] Se eram reduzidos os seus recursos iniciais, podia limitar sua empresa às mínimas proporções permitidas pela divisibilidade da mão-de-obra,

\footnotetext{
${ }^{788}$ FURTADO, Celso. Formação econômica do Brasil. op. cit., p. 117.

${ }^{789}$ Idem, p. 118.

${ }^{790}$ Idem, p. 118.
} 
isto é, a um escravo. Por último, se seus recursos não lhe permitam mais que financiar o próprio sustento durante um período limitado de tempo, podia trabalhar ele mesmo como faiscador. Se lhe favorecia a sorte, em pouco tempo ascenderia à posição de empresário ${ }^{791}$

Dessa forma, Celso Furtado assinala que a atividade mineradora origina uma sociedade mais aberta, com maiores possibilidades de ascensão social comparada à açucareira. Outras características distintivas são: a mobilidade decorrente da busca de novas lavras e a reversão da totalidade dos lucros na ampliação da empresa. É precisamente esse reaproveitamento dos lucros do negócio minerador que caracteriza essa atividade. Com efeito: "sendo a lucratividade maior na etapa inicial da mineração, em cada região, a excessiva concentração de recursos nos trabalhos mineratórios conduzia sempre a grandes dificuldades de abastecimento. [...] A elevação dos preços dos alimentos e dos animais de transporte nas regiões vizinhas constituiu o mecanismo de irradiação dos benefícios econômicos da mineração". 792

Dessa forma, a economia mineradora teve uma capacidade de integração e dinamização das demais atividades do entorno muito maior que a economia açucareira. A pecuária sulina, cujo único produto de valor econômico produzido era o couro será reativada e estabelecerá fluxos comerciais constantes com as Minas. O mesmo ocorre com o gado nordestino, que se desloca em busca dos maiores preços praticados na região - encarecendo o gado para os poucos engenhos nordestinos que ainda operavam, aprofundando a crise do setor. Outra característica de dinamismo e irradiação da economia mineradora foi a implantação de um sistema de transporte, baseado nas mulas, capaz de vencer as grandes distâncias do litoral, criando também, um "grande mercado para animais de carga”. ${ }^{793}$ Segundo Celso Furtado, apenas a demanda de animais para consumo e transporte indica que a economia mineira "constituiu, no século XVIII, um mercado de proporções superiores ao que havia propiciado a economia açucareira em sua etapa de máxima prosperidade”. ${ }^{794}$ Essa articulação foi "substancialmente" maior no sul da colônia, pela criação de gado bovino e muar no Rio Grande do Sul, reunindo-se nas grandes feiras de São Paulo, de onde eram redistribuídos para diversas regiões. Dessa forma, a economia mineradora

abriu um novo ciclo de desenvolvimento para todas elas. Por um lado, elevou substancialmente a rentabilidade da atividade pecuária,

\footnotetext{
${ }^{791}$ Idem, p. 120.

${ }^{792}$ Idem, p. 121.

${ }^{793}$ Idem, p. 122.

${ }^{794}$ Idem, ibidem.
} 
induzindo a uma utilização mais ampla das terras e do rebanho. Por outro, fez interdependentes as diferentes regiões, especializadas umas na criação, outras na engorda e distribuição e outras constituindo os principais mercados consumidores. É um equívoco supor que foi a criação que uniu essas regiões. Quem as uniu foi a procura de gado que se irradiava do centro dinâmico constituído pela economia mineira. ${ }^{795}$

As características dinâmicas da mineração, ao interligar essas diferentes regiões, instituiu uma melhora da produtividade do sistema econômico, a partir de um impulso externo, nos termos de Celso Furtado. A extração de ouro impulsionou as atividades internas, criando um mercado para a agricultura de alimentos e a pecuária, logrando alcançar maior grau de articulação entre as regiões produtoras que a atividade açucareira - superior, também, à atividade mineradora espanhola que, como vimos, era autossuficiente, dispensando vínculos comerciais, seja com outras regiões coloniais, seja com a metrópole. A atividade era mais aberta aos pequenos empresários e, mesmo, aos escravos libertos, garantindo uma maior circulação da renda monetária.

Com esses elementos, podemos perceber a orientação geral da argumentação de Celso Furtado. O instrumental analítico e o procedimento de interrogação do passado é semelhante àqueles mobilizados no exame da economia açucareira: fatores de produção, fluxo de renda e articulação territorial, mobilizados para interpretar um sistema econômico cuja característica distintiva é a forma de organização da produção: mineração escravista. O funcionamento desse sistema aparece em contraste com o nordestino e evidencia suas características definidoras: predominância de mão-de-obra livre com menor capital inicial; intensa especialização produtiva, que obrigava o sistema a importar alimentos, meios de transporte, bens de consumo, seja do exterior, sejam das regiões do entorno.

Surge, assim, novos fatores, capazes de romper os entraves da economia colonial. Vejamos. Os principais limites à melhora de produtividade e aumento da renda per capta na economia açucareira foram: o trabalho escravo (ausência de pagamentos a fatores de produção na economia colonial), a elevada concentração de renda e sua reversão em importações e, portanto, a ausência de impulsos ao mercado interno, seja pela autossuficiência dos engenhos, seja pelo elevado coeficiente de importações, o qual estava ligado aos comerciantes portugueses e holandeses que financiavam a produção e comercialização do açúcar. A mineração, como vimos, rompe essas restrições e

\footnotetext{
${ }^{795}$ Idem, p. 123.
} 
inaugura um mercado interno de gêneros de subsistência e transporte que se multiplica pelo território, mobilizando a produção do nordeste e do sul da colônia pela demanda derivada da especialização ou pela maior circulação monetária.

No entanto, se as condições econômicas para romper o caráter colonial da América portuguesa foram colocadas pela mineração, é preciso averiguar quais suas consequências. Assim, caberia indagar: a mineração deu início a um processo de desenvolvimento econômico? A pergunta, dentro da construção conceitual de Celso Furtado, é pertinente, pois estamos assistindo ao surgimento de duas condições para o desenvolvimento: de um lado, a integração entre regiões e o surgimento de um mercado interno que cria demanda para outros centros econômicos, melhorando a produtividade; uma menor concentração de renda, dentro um sistema de pagamentos monetários, ou seja, com maior circulação da renda, tanto para consumo como para reinversões na produção, permitindo a ação do mecanismo multiplicador. É com o exame do fluxo de renda que Celso Furtado deslinda a forma como esses elementos interagiram dentro das condições dadas para o desenvolvimento econômico.

O primeiro passo foi estabelecer as exportações de ouro. Elas cresceram durante a primeira metade do XVIII, atingindo seu auge em 1760 e, desde então, iniciam um movimento decrescente. Para Celso Furtado, a renda da economia mineradora corresponderia a $80 \%$ do valor das exportações. ${ }^{796}$ Por outro lado, considerando uma população mais numerosa, afirma que "a renda média era substancialmente inferior à que conhecera a economia açucareira na sua etapa de grande prosperidade", porém, "seu mercado apresentava potencialidades muito maiores". 797 Outras características distintivas são: a renda estava menos concentrada, devido ao grande contingente de homens livres; elevada parcela dos gastos se fazia em bens produzidos internamente, reduzindo a participação das importações nos gastos de consumo. Dessa forma, embora com uma renda per capta inferior, o mercado da economia mineradora tinha maiores dimensões que aquele do nordeste açucareiro. Porém, a despeito desse conjunto de fatores positivos, "o desenvolvimento endógeno - isto é, com base no seu próprio mercado — da região mineira foi praticamente nulo". ${ }^{798}$ Aqui, portanto, a constatação

\footnotetext{
${ }^{796} \mathrm{O}$ calculo de Celso Furtado é feito somando-se o total das exportações e retirando-se o quinto. Para um exame de todas as mudanças na forma de taxação da economia mineira no período, ver: PAULA, João Antônio de. Fundamentos da economia mineira. In: idem, Raízes da modernidade em Minas Gerais. Belo Horizonte: autêntica, pp. 71 e segs. Outro problema desse cálculo é examinado por COUTINHO, Maurício. Economia de Minas e economia da mineração em Celso Furtado. op. cit..

${ }^{797}$ FURTADO, Celso. Formação econômica do Brasil, op. cit., p. 125.

${ }^{798}$ Idem, p. 125-126.
} 
de que o conjunto de características positivas da mineração não foi capaz de promover o desenvolvimento econômico, rompendo a condição colonial.

A explicação deriva das categorias e conceitos desenvolvidos por Celso Furtado. O principal efeito da demanda do mercado interno é estimular o aumento da produtividade e o surgimento de atividades econômicas para atendê-la. Uma vez que a atividade mineradora dependia do fornecimento de bens de consumo, alimentos, transporte, produtos elaborados tais como têxteis, ferramentas e utensílios, seria natural, para Furtado, que se desenvolvessem atividades manufatureiras para atender essa demanda, sobretudo considerando os altos fretes dos produtos importados. Dadas essas circunstâncias,

é fácil compreender que a atividade mineradora haja absorvido todos os recursos disponíveis na etapa inicial. É menos fácil explicar, entretanto, que, uma vez estabelecidos os centros urbanos, não se tenham desenvolvido suficientemente atividades manufatureiras de grau inferior, as quais poderiam expandir-se na etapa subsequente de dificuldades de importação ${ }^{799}$

Com isso, Celso Furtado estabelece uma relação, em certa medida, unívoca - e que talvez não esteja presente em seu modelo - de que a demanda interna deveria, necessariamente, traduzir-se no consumo de manufaturas, exclusivamente. Ora, essa demanda não poderia estimular uma agricultura e pecuária mercantil? Grande parte da demanda, não era, precisamente, por alimentos e transporte, pois que outra demanda seria mais forte do que esta para unificar três regiões tão distantes da colônia? Por sua vez, as cidades mineradoras não originaram prestação de serviços e algum tipo de manufatura? Há uma relação direta entre mercado interno e produção manufatureira? Podemos supor, neste passo, que Celso Furtado tinha em mente o modelo de desenvolvimento da América do Norte, pois ali, sim, houve um desenvolvimento de manufaturas logo após a etapa de povoamento.

Para Celso Furtado, não havia restrições por parte do volume de capitais que, uma vez concentrados nas etapas de implantação, poderiam ser desviados para as atividades manufatureiras, dado os altos preços que vigoravam na região. Entretanto, a explicação para essa ausência de manufaturas decorre da "própria incapacidade técnica dos imigrantes para iniciar atividades manufatureiras em escala ponderável". ${ }^{800}$

\footnotetext{
${ }^{799}$ Idem, p. 126.

${ }^{800}$ Idem, ibidem.
} 
Nesse quadro, o Tratado de Methuen tem peso importante, pois neutralizou os esforços portugueses para a instauração de manufaturas na metrópole, sem criar uma base de conhecimentos técnicos que poderia ter sido transplantada à colônia pelos imigrantes e, assim, atender à procura local. A extração de ouro, ao ampliar substancialmente a capacidade de importação de Portugal entorpeceu "o desenvolvimento manufatureiro da Metrópole”. ${ }^{801}$ Dessa forma, colônia e metrópole não se aproveitaram do súbito aumento de produtividade proporcionado pelos metais preciosos, sendo estes canalizados para a Inglaterra, "país mais bem aparelhado para dele tirar o máximo proveito", pois já contava com uma avançada indústria manufatureira de exportação. Dessa forma, foi o desmonte da política protecionista de fomento às manufaturas portuguesas, viabilizado pelo afluxo de metais precisos que, a um só tempo, manteve a Metrópole dependente de importações e forneceu um mercado de grandes dimensões para a Inglaterra. A política econômica seguida por este país, que, segundo Furtado, centrou-se no desenvolvimento da indústria e no protecionismo, serve de contraponto para estabelecer que a ausência de uma política econômica consciente por parte de Portugal para fomentar suas atividades manufatureiras foi o principal responsável pela perda do impulso dinâmico criado pela exploração aurífera e, também, do dinamismo do mercado criado na colônia, o qual logo se transformou no destino final das manufaturas inglesas intermediadas pelo reino lusitano. Considerado sob a ótica da acumulação de capital, Portugal não reinverteu internamente as grandes somas de recursos produzidas em sua colônia americana, mas as dispendeu em consumo suntuário e improdutivo.

Mas, caberia perguntar, as manufaturas eram a única possibilidade de expansão do impulso interno da colônia? Não poderia o setor de produção de alimentos e pecuária organizar-se a partir da demanda das regiões auríferas e, aproveitando-se das vias de comunicação, criar fluxos contínuos de circulação de mercadorias. De resto, a implantação de manufaturas dependia tão estreitamente de imigrantes portugueses com aprendizado e conhecimento técnico.

Vejamos como, nesse ponto, o raciocínio de Celso Furtado parece ter seguido um caminho inesperado. De fato, a principal explicação para que o mercado interno não criasse um impulso endógeno de desenvolvimento foi a ausência de manufaturas na metrópole, resultado de erros de política econômica, que não protegeu sua indústria durante o século XVIII. A explicação, portanto, se desloca das condições da colônia 
para a conjuntura político-econômica da metrópole, sobretudo sua relação de dependência com a Inglaterra. Podemos aventar, apenas a título de hipótese, que a experiência da economia cafeeira, um século depois, que protegeu as atividades internas devido às constantes desvalorizações cambiais, estava no horizonte de Celso Furtado? Ora, se na economia cafeeira ocorreu uma conjugação de condições específicas, estimuladas pela política econômica, ainda que inconsciente, do governo brasileiro, faltou à metrópole portuguesa precisamente esse estímulo, ou melhor, ele foi bloqueado pelo Tratado de Methuen, a exploração aurífera e os conflitos europeus. ${ }^{802}$

Mas, se considerarmos os fatores internos à colônia, a explicação de Celso Furtado desafia algumas consequências que podem ser derivadas de seu modelo de desenvolvimento econômico. Ora, como aponta Maurício Coutinho, “as razões aventadas [para a ausência de um surto manufatureiro na colônia] chegam a ser prosaicas: teria faltado capacitação técnica, ou experiência manufatureira, aos imigrantes portugueses". ${ }^{803}$ Por sua vez, grande parte dos estudos sobre a economia do abastecimento em Minas Gerais, a começar pelo trabalho de Mafalda Zemella ${ }^{804}$, de 1950, já apontavam o desenvolvimento de uma agricultura mercantil na região, com fazendas mistas - roças e lavras —, bem como o surgimento de atividades manufatureiras. ${ }^{805}$ No entanto, contrapor evidências empíricas à argumentação de Celso Furtado, indica a direção de sua argumentação, mas não a explica. Para tanto, é preciso, ainda, verificar as consequências para o sistema minerador, do fracasso da atividade manufatureira.

Para Celso Furtado, ao diminuir a extração aurífera, a economia mineradora presencia um processo de declínio, manifesto em uma "lenta diminuição do capital aplicado no setor minerador": as grandes empresas descapitalizavam-se, a reposição da mão-de-obra estancou e, em alguns casos, os possuidores de lavras transformaram-se em faiscadores. Dessa forma, "todo o sistema se ia assim atrofiando, perdendo

\footnotetext{
${ }^{802}$ Neste ponto, mais uma vez, a possibilidade de confronto entre as explicações deslocadas no tempo mas unificadas pelo propósito de intervenção no presente é inspirada na dialógica da transtemporalidade. Ver ARRUDA, José Jobson de Andrade. Historiografia: consciência crítica da produção histórica. In: idem, Historiografia: teoria e prática. op. cit.

${ }^{803}$ COUTINHO, Maurício. Economia de Minas e economia da mineração em Celso Furtado. op. cit., p. 365-366.

${ }^{804}$ ZEMELLA, Mafalda. O abastecimento da Capitania de Minas Gerais no século XVIII. (Tese de Doutorado, História da Civilização Brasileira, FFCL-USP), 1950.

${ }^{805}$ Uma síntese da questão das atividades de abastecimento em Minas Gerais pode ser encontrada em: PAULA, João Antônio de. Fundamentos da economia mineira. In: idem, Raízes da modernidade em Minas Gerais. Belo Horizonte: autêntica, pp. 59-86.
} 
vitalidade, para finalmente desagregar-se numa economia de subsistência”. ${ }^{806}$ A questão da política econômica adotada por Portugal e seu insucesso em aproveitar-se do impulso dinâmico minerador retorna à análise, pela comparação com a experiência da Austrália, no século XIX. Segundo Celso Furtado, nesta colônia houve a conjugação de exploração aurífera e produção de alimentos; o governo estimulou os dois setores a desenvolverem-se conjuntamente, utilizando técnicas poupadoras de mão-de-obra. Por sua vez, estancada a extração de metais, a Austrália implantou uma "política protecionista que tornou possível a precoce industrialização deste país". ${ }^{807}$ No caso brasileiro, a predominância de trabalho escravo serviu para amenizar a grave crise resultante da ausência de atividades substitutivas à mineração, mas não havia técnica capaz de saltar da crise da atividade mineradora à implantação de manufaturas.

A perda do dinamismo ocasionou um processo de descapitalização que, no entanto, mantinha a estrutura social, muito embora, ao contrário da economia açucareira, "na mineração a rentabilidade tendia a zero e a desagregação das empresas produtivas era total". ${ }^{808}$ Dessa forma, o conjunto da população reverteu-se para atividades de subsistência, espalhando-se pela região, constituindo-se, ao longo do século XIX, em "um dos principais núcleos demográficos do país". Retomando a comparação,

neste caso, como no da economia açucareira do Nordeste, a expansão
demográfica se prolongará num processo de atrofiamento da economia
monetária. Dessa forma, uma região cujo povoamento se fizera em um
sistema de alta produtividade, e em que a mão-de-obra fora um fator
extremamente escasso, involuiu numa massa de população totalmente
desarticulada, trabalhando com baixíssima produtividade numa
agricultura de subsistência. Em nenhuma parte do continente
americano houve um caso de involução tão rápida e tão completa de
um sistema econômico constituído por população principalmente de
origem europeia $^{809}$

Assim, ambos sistemas econômicos involuíram para atividades de subsistência com a crise dos respectivos setores exportadores. No entanto, a explicação para essa involução é diversa. Se na economia açucareira os motivos resultam basicamente da desorganização do comércio de açúcar e da perda de monopólio português — que alterou consideravelmente a estrutura de custos das unidades produtivas brasileiras, funcionando enquanto foi possível manter os gastos de manutenção e reposição de

\footnotetext{
${ }^{806}$ Idem, p. 132.

${ }^{807}$ Idem, p. 133.

${ }^{808}$ Idem, p. 134.

${ }^{809}$ Idem, p. 134.
} 
equipamento e mão-de-obra —, na economia mineradora, a política econômica metropolitana teve um peso considerável para o resultado de rápida involução econômica mineradora. No entanto, se revertermos o raciocínio de Celso Furtado, teríamos que: o surgimento de manufaturas compensaria a queda da produção aurífera e o sistema poderia avançar para um processo de desenvolvimento econômico, pois dispunha de capitais, mão-de-obra predominantemente livre, e um mercado interno articulado com outras regiões do país. Na ausência dessas condições, o fracasso da atividade manufatureira acompanhou o declínio do setor externo.

Essa interpretação nos remete às categorias e conceitos do desenvolvimento econômico de Celso Furtado, cuja operacionalização já vimos para a economia açucareira. Em ambos sistemas, o elemento explicativo central está no impulso externo, o único fator capaz de dinamizar uma economia colonial. Cessando seu dinamismo, a economia colonial regride, embora por motivos diversos: na economia açucareira, a perda do monopólio comercial ocasionou a retração da atividade exportadora, absorvida pela pecuária de subsistência. No caso da mineração, o fim da extração teve proporções catastróficas, acentuadas pela ausência de uma política econômica protecionista para as manufaturas portuguesas.

Segundo Furtado, embora alguns entraves ao desenvolvimento econômico tivessem atuação reduzida — maior distribuição de renda, mobilidade social e existência de um mercado interno de dimensões significativas - o principal fator impeditivo do desenvolvimento não esteve nos fatores de produção e fluxo de renda, mas sim na política econômica metropolitana que, por uma série de contingências, não estimulou o surgimento de um núcleo manufatureiro, nem em Portugal (o que impediria o escoamento do ouro para a Inglaterra) nem na Colônia (que contribuiria para uma maior articulação do mercado interno, aumentando, assim, a base de arrecadação metropolitana). A inserção desse elemento político, portanto, dialoga com a crise da economia açucareira e, ao mesmo tempo, aborda as condições políticas necessárias à ativação do desenvolvimento econômico. A introdução desta variável na explicação de Celso Furtado pode ser um reflexo de suas preocupações com os grupos sociais em sua apropriação do excedente econômico, bem como na formação de interesses políticos, sociais, econômicos manufatureiros, o que não se configurou em Minas Gerais, entre outras coisas, porque as condições para o desenvolvimento econômico tinham um entrave, talvez maior, que é a condição colonial, ou seja, a impossibilidade de orientar os instrumentos fiscais, monetários e cambiais para atender seus interesses. Ao explicar 
a decadência da economia mineira, Furtado chama a atenção para o fato de que economia e política não são aspectos separados, sobretudo no período colonial. Dessa forma, a conjunção dessas duas esferas sob interesses comuns deverá esperar até o surgimento dos cafeicultores, como vermos em seguida. Nesse sentido, nos parece que a chave para a compreensão dessa interpretação, clarificada pela bibliografia que demonstra o surgimento de um mercado de abastecimento das minas, mesmo depois de sua decadência, é explicada pela introdução da política econômica como uma variável central na promoção do desenvolvimento econômico.

A economia escravista mineradora, reunindo aspectos característicos das economias açucareira e cafeeira, surge na análise de Celso Furtado para indicar a importância da política econômica para aproveitar os recursos e as potencialidades econômicas, pois estímulos e oportunidades podem desaparecer tão inesperadamente quanto aparecem. Assim, há a necessidade da política econômica adaptar-se rapidamente a estes estímulos, condição para canalizar os impulsos para o desenvolvimento.

Essa questão nos remete para a necessidade de utilizar os recursos disponíveis para lograr o crescimento, aproveitando o potencial econômico. Ora, vimos a importância desse tema em Perspectivas da economia brasileira, onde o empenho na programação deve abordar o conjunto das atividades do país. Dessa forma, por que não considerar a continuidade de uma política de industrialização como uma forma de aproveitar as oportunidades e os recursos disponíveis na economia?

\section{Uma longa decadência: final do século XVIII e meados do XIX}

A quarta parte de Formação econômica do Brasil, a mais extensa de todas, diferencia-se por não estar centrada em um sistema produtivo, mas sim na transição da forma de utilização de um fator de produção, a mão-de-obra: da escravidão para o trabalho assalariado; o principal fator, como vimos, para a dinamização da renda em economias comerciais e industriais. Se tomarmos, no entanto, os catorze capítulos que a compõe, veremos que há subdivisões nos temas abordados. Os capítulos 16 a 19 examinam a situação colonial da decadência da produção aurífera até as primeiras décadas do século XIX. É neste período, como anunciado na primeira parte de Formação, que têm lugar os principais acontecimentos que marcam a transição para a nação politicamente independente. Já a independência econômica, ou seja, o fim da 
economia colonial, dependerá, ainda, da formação e crise da economia cafeeira, que se organiza a partir da terceira década do século XIX, e ensejará a referida transição para a mão-de-obra assalariada, examinada nos capítulos 20 a 25. Em seguida, Celso Furtado, descreve o funcionamento do sistema econômico cafeeiro, e é nesse exame que o livro se encontra com A economia brasileira, cujo terceiro capítulo é reaproveitado em Formação econômica do Brasil, dividindo-se nos 26, 27 e 28. No entanto, cumpre destacar que o problema da mão de obra, foi tratado em pouco mais de três páginas em A economia brasileira, explicitando a importância que o exame histórico da constituição da mão-de-obra livre adquiriu em Formação econômica do Brasil. Mas, notemos que o longo trabalho de delineamento das linhas históricas não implica necessariamente que a interpretação geral tenha se alterado, pois nos dois trabalhos o principal fator distintivo da economia cafeeira é a utilização do trabalho livre.

Neste parte, também, há uma comparação com o desenvolvimento dos Estados Unidos, onde o tema da política econômica portuguesa é retomado, bem como as consequências do comércio triangular iniciado ainda no final do século XVII, pelas Treze Colônias inglesas.

Essa parte de Formação econômica do Brasil será abordada, para fins explicativos, em dois grandes blocos. O primeiro examina a situação colonial após o declínio da atividade mineradora que, segundo Furtado, estende-se até as primeiras décadas do século XIX. Em seguida, a economia cafeeira: suas origens, seu funcionamento e a questão da mão-de-obra.

O ponto de partida é, como dissemos, a situação da colônia após o declínio da mineração. As dificuldades econômicas manifestam-se na queda de aproximadamente dois terços do valor das exportações e no declínio do preço do açúcar. O crescimento da população, por sua vez, fez a renda per capta atingir "o nível mais baixo que haja conhecido o Brasil em todo o período colonial". ${ }^{810}$ Dessa forma, podemos perceber as consequências que o fim da mineração trouxe para a economia brasileira, atingindo o conjunto das atividades e incidindo negativamente sobre a renda.

Essas repercussões são examinadas por Celso Furtado em cada região da colônia. Esta, em seu conjunto, possuía dois núcleos econômicos principais, a região mineradora e a açucareira, e alguns sistemas isolados, como o Pará e o Maranhão. O núcleo açucareiro estava articulado com a pecuária nordestina, enquanto o centro minerador, com o sul, de São Paulo ao Rio Grande. Ambos "ligavam-se frouxamente

\footnotetext{
${ }^{810}$ Idem, p. 138.
} 
através do rio São Francisco", enquanto os dois centros autônomos, o Pará - orientado para a economia extrativa organizada pelos jesuítas - e o Maranhão, que "de maneira fluída e imprecisa", ligava-se à "região açucareira através da periferia pecuária". ${ }^{811}$

Para Furtado, nas últimas décadas do século XVIII, apenas o Maranhão "conheceu uma efetiva prosperidade no último quartel do século", embora a classifique de "falsa euforia". Ela se deve aos incentivos da política pombalina, em luta com os jesuítas; à criação de Companhias de Comércio; à "modificação no mercado mundial de produtos tropicais, provocada pela Guerra da Independência dos EUA e logo seguida pela Revolução Industrial inglesa”. ${ }^{812}$ Os esforços da Companhia do Grão Pará e Maranhão foram dirigidos para a produção de algodão e arroz, aproveitando-se da desorganização do mercado e consequente elevação dos preços.

O resto da colônia, entretanto, "atravessou uma etapa de séria prostração nos últimos decênios do século", ainda que a conjuntura política europeia - Guerra de Independência, Revolução Francesa, Independência do Haiti, Guerras Napoleônicas fizesse com que a demanda por produtos tropicais se alterasse favoravelmente à colônia portuguesa. As exportações de açúcar, por exemplo, ampliaram-se e o nordeste voltou a ocupar um lugar nesse comércio, iniciando a produção de algodão. Segundo Furtado, "praticamente todos os produtos da colônia se beneficiam de elevações temporárias de preço", muito embora decorrentes de convulsões políticas e, "superada essa etapa, o Brasil encontraria sérias dificuldades, nos primeiros decênios de vida como nação politicamente independente, para defender sua posição nos mercados de produtos que tradicionalmente exportava". ${ }^{813}$ Celso Furtado, embora destaque a retomada da procura de produtos tropicais, minimiza esse impulso, classificado como passageiro e submergindo-o na prostração generalizada que o declínio da mineração lançou a colônia. Para ele, a retomada da demanda internacional de produtos tropicais não foi capaz de dinamizar as atividades coloniais, pois não se sustentaram por muito tempo, sendo resultado de condições anormais do mercado, decorrente de problemas políticos na Europa. ${ }^{814}$ Nesta leitura, novamente, percebemos como Celso Furtado estabelece uma relação direta entre dinâmica externa e as atividades na colônia. No entanto, um período de elevação da procura internacional de produtos tropicais, que atingiria

\footnotetext{
${ }^{811}$ Idem, p. 139.

812 Idem, ibidem.

${ }^{813}$ Idem, p. 141.

${ }^{814}$ Pesquisas posteriores apontaram em outra direção, enfatizando a grande diversificação produtiva vivida pela colônia. ARRUDA, José Jobson de Andrade Arruda. O Brasil no comércio colonial. São Paulo, Ática, 1980.
} 
diversas regiões produtivas, foi minimizado em sua interpretação. ${ }^{815}$ Dessa forma, é possível inferir como os pressupostos de Celso Furtado operam na análise. Ora, a estagnação do período se deve não apenas à falta de dinâmica externa continuada, pois esta, embora curta, existiu e teve consequências, mas sim, à rigidez da economia de subsistência colonial, que não foi capaz de responder a esta solicitação externa, reativando suas interligações internas.

Outro ponto que caracteriza a interpretação, é que o período constitui um hiato, marcado pela ausência de um produto de exportação cuja significação econômica substituísse o açúcar ou o ouro. Daí, também, as dificuldades políticas de Portugal na passagem do século XVIII para o XIX. Dito de outra forma, a exemplo da análise desenvolvida sobre a mineração, a argumentação de Furtado concilia a crise econômica da colônia (o fim da mineração) com a crise política da metrópole (Bloqueio Continental, Invasão Francesa), explicando, Independência política da colônia como incapaz de resolver seus problemas econômicos.

Essa opção, portanto, evidencia a opção metodológica de Celso Furtado de minimizar o dinamismo produzido pela demanda internacional por esta não se traduzir na organização de um novo sistema monocultor, a exemplo do açucareiro e minerador, mas sim na ativação de diversas atividades produtivas dispersas, nenhuma delas com possibilidade de comandar a dinâmica de crescimento da economia como um todo. Estudos posteriores mostraram que a "falsa euforia" não decorria de uma conjuntura política anormal e passageira, mas, ao contrário, era o resultado de fatores estruturais, tais como o aumento do comércio internacional, o crescimento demográfico mundial, a ampliação da demanda europeia por manufaturas e alimentos e o surgimento do algodão como o principal produto tropical utilizado na indústria têxtil inglesa, nos inícios da Revolução Industrial. ${ }^{816}$

No entanto, Celso Furtado caracteriza esse período como de convulsão política na Europa, assinalando o descompasso entre os problemas políticos e os econômicos de

\footnotetext{
${ }^{815}$ Com efeito, neste ponto, também, Celso Furtado se desvia de Roberto Simonsen, para quem "as exportações agrícolas triplicaram no último quartel do século XVIII”, beneficiando, sobretudo Portugal, pois serviam como matérias-primas para suas manufaturas. Essa perspectiva é corroborada por Caio Prado Júnior, para quem, a segunda metade do século XVIII "ressurgirá novamente a agricultura, que volta a ocupar a posição dominante que desfrutara nos dois primeiros séculos de colonização". Ver, respectivamente: SIMONSEN, Roberto. História econômica do Brasil, 1500-1820 [1938]. São Paulo: Companhia editora nacional, 1977, pp. 364; PRADO JÚNIOR, Caio. História econômica do Brasil [1945]. São Paulo, editora Brasiliense, 1977, p. 79-80. A diversificação produtiva foi objeto de estudo detalhado, a partir das balanças de comércio de Portugal. Ver. ARRUDA, José Jobson de Andrade Arruda. O Brasil no comércio colonial. São Paulo, Ática, 1980.

${ }^{816}$ ARRUDA. José Jobson de Andrade. O Brasil no comércio colonial. Op. cit., pp. 637-648.
} 
Portugal e sua colônia americana. Em suas palavras "a repercussão no Brasil dos acontecimentos políticos da Europa em fins do século XVIII e começo do seguinte, se por um lado acelerou a evolução política do país, por outro contribuiu para prolongar a etapa de dificuldades econômicas que se iniciara com a decadência do ouro [grifo nosso]". 817 Aqui, portanto, a incorporação do diagnóstico de crise econômica metropolitana e colonial. De fato, assistimos a invasão do reino pelos exércitos franceses, a vinda da família real para a América, a abertura dos portos e o Tratado de 1810, a Independência do Brasil em 1822, a abdicação de D. Pedro I em 1831 e "a consequente ascensão definitiva ao poder da classe colonial dominante formada pelos senhores da grande agricultura de exportação". 818 Esse conjunto de acontecimentos, embora conduzam à ruptura com a metrópole, não foi capaz de solucionar os problemas econômicos da antiga colônia, pois esta condição subordinada foi transferida, de Portugal para a Inglaterra.

Para Furtado, esses eventos explicitam que os privilégios concedidos à Inglaterra derivam do longo histórico de relações com Portugal, cabendo ao Brasil o pagamento do passivo contraído pela ex-metrópole junto ao governo e comerciantes ingleses. Essa Independência, efetuada sem uma "luta prolongada", garantiu a unidade territorial do Brasil, evitando as lutas separatistas que ocorreram na América espanhola. No entanto, trata-se, unicamente, de aceleração da evolução política, mas não econômica. Assim, vale notar as consequências dessa leitura, que minimiza o impacto econômico de transformações tais como a vinda da Corte e a Abertura dos Portos. Como demonstrou Maria Teresa Ribeiro de Oliveira, as interpretações disponíveis para Furtado ressaltavam a ruptura econômica ocasionada pela chegada de Dom João VI ao Brasil. Nesse sentido, a periodização de Celso Furtado "subverte aquelas até então adotadas na literatura". ${ }^{819}$

Porém, é preciso compreender que não se trata, para ele, de uma questão de mudanças na periodização, mas sim de questionar o argumento a respeito da importância do protecionismo para a industrialização brasileira, ou, se os privilégios obtidos pela Inglaterra foram responsáveis "pelo fato de que o Brasil não se haja

\footnotetext{
${ }^{817}$ FURTADO, Celso. Formação econômica do Brasil. op. cit., p. 142.

${ }^{818}$ Idem, p. 143.

${ }^{819}$ OLIVEIRA, Maria Teresa Ribeiro de. O Século XIX, Segundo Furtado. EconomiA, Selecta, Brasília (DF), v.10, n.4, dezembro 2009, p. 891.
} 
transformado numa nação moderna já na primeira metade do século XIX, a exemplo do ocorrido nos EUA". ${ }^{820}$

Nesta explicação, antes de examinar as possibilidades de política econômica abertas ao Brasil, Celso Furtado aponta a ausência de uma classe comercial de importância, capaz de contrapor-se aos interesses agrários e frear os benefícios auferidos pelos ingleses. Dessa forma, para os grandes agricultores de exportação, sendo Portugal um entreposto comercial, o acesso direto aos mercados de produtos europeus representava um ganho substancial, o que impediu a união de brasileiros e portugueses para contraporem-se aos interesses dos comerciantes ingleses. Dessa forma, não existia bases sociais para uma política econômica industrialista naquele momento. ${ }^{821}$ Não se colocava, para a elite brasileira, a opção pela industrialização. Ao contrário, a principal fonte de conflitos no início do século XIX era entre os grandes proprietários brasileiros e a Inglaterra pela venda de produtos agrícolas, resultado, segundo Furtado, "da falta de coerência com que os ingleses seguiam a ideologia liberal", ${ }^{822}$ pois, ao mesmo tempo em que exigiam o livre comércio para suas mercadorias manufaturadas, mantinham o mercado de produtos tropicais reservado para suas colônias antilhanas, bloqueando o acesso dos produtos brasileiros ao mercado inglês. A isso se somava a campanha abolicionista, que insistia em impor o fim do tráfico de escravos para o Brasil. Nesse conjunto de disputas, o modelo agroexportador escravista se configurava como o modelo econômico que os grandes agricultores de exportação adotavam, não havendo espaço para uma discussão sobre protecionismo industrial após a independência, pois esta consolidou a posição dos grandes senhores de terra, ainda que estes passassem por um período de crise.

Mesmo esse quadro de tensões é minimizado por Celso Furtado, pois de parte dessas disputas, não havia, "nenhuma contradição séria de interesses", entre brasileiros e ingleses, e "não se pode afirmar que, se o governo brasileiro houvesse gozado de plena liberdade de ação, o desenvolvimento econômico do país teria sido

\footnotetext{
${ }^{820}$ Idem, p. 144.

${ }^{821}$ Pesquisas posteriores demonstram que Celso Furtado atribuiu um papel muito relevante aos interesses comerciais e manufatureiros nos Estados Unidos. Sobretudo sua contraposição de Hamilton industrialista e de um Cairu passadista vem sendo relativizada. De fato, as proposições industrialistas do primeiro foram letra-morta até a Guerra de Secessão enquanto a defesa das atividades agrícolas no Brasil era coerente com as possibilidades de política econômica do Império português, onde a produção primária no Brasil complementaria o comércio e as manufaturas portuguesas. Sobre isso, ver ARRUDA, José Jobson de Andrade. "José da Silva Lisboa: texto e contexto". In: idem, Historiografia: teoria e prática. op. cit., pp. 340 e segs.

822 Idem, p. 145.
} 
necessariamente muito intenso". ${ }^{823}$ Nesse aspecto, a argumentação afirma que os elementos impeditivos do desenvolvimento brasileiro no século XIX não decorrem da pressão inglesa, mas resultam da ausência de condições econômicas — trabalho escravo, ausência de mercado interno e de produtos de exportação — e sociais ausência de uma base classe de comerciantes e produtores manufatureiros — de forma que uma política econômica protecionista não surtiria efeito.

Entretanto, na sequência do texto, Celso Furtado reconhece que os privilégios ingleses impuseram, sim, uma série de dificuldades fiscais ao novo Estado brasileiro, cujo principal tributo incidia sobre as importações e fora reduzido para os ingleses. A dificuldade de arrecadação gerou descontentamento em praticamente todas as regiões do Brasil, por vezes transformando-se em conflitos armados. Esse quadro de instabilidade política e econômica persistirá até 1844 , quando expiraram as tarifas privilegiadas para Inglaterra.

É contra esse pano de fundo de dificuldades políticas e econômicas, decorrentes do surgimento do Estado do Brasil, a necessidade de financiamento da nova estrutura administrativa e a resolução dos conflitos regionais que Celso Furtado retoma a comparação com o desenvolvimento dos Estados Unidos, reiterando a concepção de que não foram os privilégios obtidos pela Inglaterra entre 1810 e 1827 que “impossibilitaram a industrialização do Brasil nessa etapa, retirando das mãos do governo o instrumento do protecionismo". ${ }^{824}$

Segundo Celso Furtado, a formação do Estado brasileiro compreendeu a eliminação do entreposto português, a ampliação das importações, a diminuição das exportações e necessidade de financiamento do déficit público, cuja solução adotada foi a desvalorização cambial, promovendo um forte encarecimento das importações. Para Furtado, como vimos, essa forma de financiamento correspondeu a algo semelhante a uma tarifa de importação da ordem de, no mínimo, 50\% ad valorem, o que, ainda assim, não iniciou um processo de desenvolvimento.

A insistência no tema pode ser compreendida pelo empenho em responder à pergunta: "por que se industrializaram os EUA no século XIX, emparelhando-se com as nações europeias, enquanto o Brasil evoluía no sentido de transformar-se no século XX

\footnotetext{
${ }^{823}$ Idem, p. 146. Celso Furtado argumenta, ainda, que as desvalorizações cambiais do Governo brasileiros tiveram um efeito muito mais protecionista para a produção brasileira de que uma tarifa alfandegária de $50 \%$ ad valorem. Idem, p. 151.

${ }^{824}$ Idem, p. 150.
} 
numa vasta região subdesenvolvida". ${ }^{825}$ O procedimento analítico da comparação surge para esclarecer a política econômica adotada pelos dois países, aspecto fundamental na explicação das razões da inexistência de produção manufatureira na colônia após o declínio da mineração.

Para Celso Furtado, o desenvolvimento dos Estados Unidos é explicado pelas relações integradas que estabeleceu com a Europa, "sendo em muito menor grau o resultado de medidas internas por essa nação americana", ${ }^{826}$ citando que a taxa máxima de importação de tecidos de algodão foi, em 1808, de 17,5\%, quase a mesma praticada pelo Brasil. Nesse sentido, ao mesmo tempo em que medidas protecionistas não surtiram efeitos no Brasil, elas não foram necessárias nos Estados Unidos.

O desenvolvimento estadunidense deve ser compreendido pelas relações peculiaridades com as Antilhas, nos séculos XVII e XVIII e, também, pela composição social da nova nação norte-americana. Comparando-as, "as diferenças sociais, entretanto, eram profundas, pois enquanto no Brasil a classe dominante era o grupo dos grandes agricultores escravistas, nos EUA uma classe de pequenos produtores e um grupo de grandes comerciantes urbanos dominava o país". ${ }^{827}$ Dessa forma, para Celso Furtado, o elemento social é o principal fator explicativo para os caminhos tomados pelos dois países. Desde que fracassara a implantação de colônias de exploração na região, a política mercantilista da metrópole agia de forma "muito especial", cujas linhas gerais eram: "fomentar nas colônias do norte aquelas indústrias que não competissem com as da Metrópole, permitindo a esta reduzir suas importações de outros países; não permitir que a produção manufatureira das mesmas nos demais setores concorresse com as indústrias da Metrópole em outros mercados coloniais". ${ }^{828}$ Apenas quando essas diretrizes foram rompidas o governo inglês iniciou a adoção de medidas coercitivas. Por sua vez, as próprias colônias incentivaram a autossuficiência na produção de manufaturas como forma de proteger-se das dificuldades de importação em períodos de guerra metropolitana, destacando-se a produção de tecidos, manufatura de couros e a construção naval.

A Guerra de Independência e, em seguida, a Revolução Francesa e as Guerras Napoleônicas criaram uma série de estímulos para a economia das colônias do norte, que agora supriam sozinhas seu mercado interno e, também, exportavam para o

\footnotetext{
825 Idem, p. 151.

${ }^{826}$ Idem, p. 152.

${ }^{827}$ Idem, ibidem.

${ }^{828}$ Idem, p. 153.
} 
conjunto das Antilhas e Caribe. Dessa forma, é possível perceber neste exercício comparativo, que as categorias do desenvolvimento econômico de Celso Furtado continuam operando. Com efeito, é o comércio exterior que impulsiona a economia dos Estados Unidos. A diferença com a brasileira reside no fato de que a primeira estava preparada para responder a este impulso, pois as principais restrições que operavam na América Portuguesa, mão-de-obra escrava e ausência de mercado interno, não tiveram peso significativo. As colônias do nordeste americano funcionavam com trabalho livre, pequena propriedade e autossuficiência desde o século XVII. As relações com as Antilhas, ainda na segunda metade do Setecentos impulsionaram as manufaturas, a produção de alimentos para exportação e a construção naval. Esses fatores já estavam disponíveis quando a conjuntura de final do XVIII, ocasionando a ruptura com a Inglaterra, ativou-os. Por sua vez, a diversidade social: agricultores, trabalhadores livres, comerciantes locais e grandes comerciantes de exportação, com interesses econômicos arraigados facilitou a união conseguiram unir-se contra a metrópole em um momento em que a atividade econômica estava dinamizada e, portanto, a independência política surge como consequência de um desenvolvimento econômico autônomo.

O contrário, como vimos, ocorreu no Brasil onde, segundo Celso Furtado, a conjuntura de crise e prostração econômica, tanto da metrópole quanto da colônia, impediram qualquer forma de desenvolvimento possível. Os interesses econômicos concentrados na grande propriedade de terra, sem a existência de um forte grupo comercial, orientou a Independência para a remoção de um intermediário econômico e não como uma possibilidade de formar uma economia autônoma.

Assim, Celso Furtado destaca que mesmo a conjuntura favorável ao desencadeamento da economia dos Estados Unidos não levou a um processo de industrialização. Em suas palavras, nem a "experiência técnica acumulada desde a época colonial", nem "a grande acumulação de capitais da fase das guerras napoleônicas" ocasionaram o surgimento de indústrias nos Estados Unidos. O processo técnico de mecanização da indústria têxtil coube, unicamente, à Inglaterra e os Estados Unidos participaram deste processo fornecendo "as quantidades imensas de algodão que permitiram, em alguns decênios, transformar a fisionomia da oferta de tecidos em todo o mundo". ${ }^{829}$ Essa expansão do consumo têxtil, assinala Furtado, não correspondeu a um aumento da demanda, mas foi obtido através da concorrência com manufaturas artesanais, vencida pela baixa dos preços, que se reduziram em duas terças partes até a

\footnotetext{
${ }^{829}$ Idem, p. 156.
} 
metade do XIX, possibilitada pela ampliação da produção algodoeira nos Estados Unidos.

Dessa forma, ao compreender o desenvolvimento dos Estados Unidos a partir da crescente demanda por algodão e os efeitos encadeadores produzidos em uma região onde algumas colônias baseavam-se em mão-de-obra livre e possuíam já um desenvolvimento manufatureiro e uma autossuficiência produtiva, Celso Furtado está exemplificando o desenvolvimento econômico a partir de um impulso externo. Este, produziu um aumento de produtividade que se propagou para outros sistemas econômicos e a redes comerciais internas, ocasionou o desenvolvimento geral da economia. Além disso, foi ajudado pelos déficits na balança comercial com a Inglaterra, que se transformaram em bônus e títulos de dívida de médio e longo prazo, atraindo capitais e financiando a política central e estadual baseada na "construção de uma infraestrutura econômica e no fomento direto de atividades básicas". ${ }^{830}$

Assim, do ponto de vista dos resultados da comparação entre os dois países, a política protecionista não foi um fator determinante em seus desenvolvimentos. No caso brasileiro, a ausência de demanda externa contínua e a formação de um grupo econômico baseado unicamente na agricultura de exportação retiraram as bases de sustentação de uma política de desenvolvimento autônomo. Exatamente o oposto ocorreu com os Estados Unidos, pois, além da demanda antilhana por alimentos e manufaturas, a mão-de-obra livre e o mercado interno já em estruturação formou um grupo de interesses distintos da metrópole Inglesa, garantindo que a Independência fosse, também, a ocupação do mercado interno por produtos norte-americanos, diminuindo a dependência comercial. Já no que se refere ao comércio exterior, os Estados Unidos se aproveitaram da demanda externa desde a segunda metade do século XVII, o que lhes permitiu a formação de seu mercado interno. O importante, no entanto, é notarmos que nos dois países a política econômica reflete as bases sociais e os grupos de pressão que as elabora e executa. Esses dois pontos, comércio exterior e bases sociais, precisam ser examinados.

A ênfase na importância do impulso externo, agora representado pela demanda de um único produto de exportação e não mais da diversificação produtiva do final do século XVIII, reaparece na sequência do texto: “condição básica para o desenvolvimento da economia brasileira, na primeira metade do século XIX, teria sido a

${ }^{830}$ Idem, p. 157-158. 
expansão de suas exportações". ${ }^{831}$ De fato, “é necessário reconhecer que a primeira condição para o êxito daquela política teria sido uma firme e ampla expansão do setor exportador. A causa principal do grande atraso relativo da economia brasileira na primeira metade do século XIX foi, portanto, o estancamento de suas exportações". ${ }^{832}$

Assim, o conjunto da explicação furtadiana para o final da crise econômica e política que marcou o final do século XVIII e a primeira metade do século XIX fica clarificada, pois trata-se do surgimento de um sistema de exportação que produza dinamismo ao conjunto da economia, mas uma dinâmica externa e caracterizada por um único produto de exportação.

Celso Furtado examina os dados de valor das exportações, demonstrando que os produtos que tiveram elevação foram unicamente o açúcar e o café, ambos concentrados em algumas regiões e, portanto, sem efeitos dinamizadores para o conjunto da economia. O mesmo vale para o cálculo do coeficiente de importações, que indica que "a queda do índice de intercâmbio foi de, aproximadamente, quarenta por cento, isto é, que a renda real gerada pelas exportações cresceu quarenta por cento menos que o volume físico desta" ${ }^{833}$ entre os decênios de 1820 e 1850. Com isso, depreende-se, também, que "a renda real per capita declinou sensivelmente na primeira metade do século XIX”, uma vez que o mercado interno não foi capaz de substituir o declínio no valor das exportações, ocorrendo, "provavelmente", "um aumento relativo do setor de subsistência". ${ }^{834}$ O quadro de estagnação se prolonga até meados do século XIX, quando se consolida a posição do café como principal produto de exportação brasileira. É o surgimento desse produto, como vimos na primeira parte de Formação econômica do Brasil, que irá modificar a estrutura produtiva, iniciando, com um século de atraso em relação aos Estados Unidos, o processo de superação da condição colonial da economia brasileira.

\section{A formação da economia cafeeira, a questão da mão-de-obra e a nacionalização da política econômica}

É sob a estagnação da segunda metade do XVIII e inícios do XIX que surge, a partir de 1830, aproximadamente, a agricultura cafeeira de exportação, ocupando o

\footnotetext{
${ }^{831}$ Idem, p. 159.

${ }^{832}$ Idem, p. 160.

${ }^{833}$ Idem p. 162.

${ }^{834}$ Idem, ibidem.
} 
vazio deixado pela mineração e atenuado pela "falsa euforia" maranhense. Segundo Furtado, "para superar a etapa de estagnação, o Brasil necessitava reintegrar-se nas linhas em expansão do comércio internacional", pois o "desenvolvimento com base em mercado interno só se torna possível quando o organismo econômico alcança um determinado grau de complexidade, que se caracteriza por uma relativa autonomia tecnológica". ${ }^{835}$

A economia brasileira dependia da retomada das exportações de um produto primário. O açúcar e o algodão enfrentaram a concorrência dos Estados Unidos e de Cuba, respectivamente. $\mathrm{O}$ arroz perdeu mercado devido à inovações técnicas implantadas pelos norte-americanos. O fumo deixou de contar com o mercado africano e só o cacau aparecia como "uma esperança". ${ }^{836}$ Dentro dessa conjuntura, surge, "um produto relativamente novo", o café, que, embora cultivado no Brasil desde inícios do XVIII, ocupa o espaço da produção haitiana, desorganizada pela luta da independência contra a França. Este produto, já entre 1840 e 1850 assume o primeiro lugar na pauta de exportações, com mais de $40 \%$ do valor total.

A fase de gestação desta cultura ocorre entre "o segundo e principalmente terceiro quartel do século XIX" ${ }^{, 37}$ e se expande pela área próxima à capital do país, contando com abundância de mão-de-obra originária da mineração, proximidade do porto do Rio de Janeiro e frotas de muares subutilizadas pela perda de importância das rotas para as Minas. Assim, "a primeira fase da expansão cafeeira se realiza com base num aproveitamento de recursos preexistentes e subutilizados", ${ }^{838}$ estimulando a expansão da produção mesmo com preços em declínio até 1850 .

Celso Furtado examina as principais características da economia cafeeira em comparação com a açucareira. Ambas possuem utilização intensiva da mão-de-obra e são culturas permanentes. Entretanto, a cultura do café possui "grau de capitalização mais baixo", "suas necessidades monetárias de reposição são muito menores" e os "custos monetários ainda menores que os da empresa açucareira". ${ }^{839}$ Dessa forma, havendo disponibilidade de terras e estoque de mão-de-obra, o crescimento da produção pode seguir sem encontrar restrições, sobretudo a partir da retomada dos preços do café no terceiro quartel do século.

\footnotetext{
${ }^{835}$ Idem, p. 165.

${ }^{836}$ Idem, pp. 166-168.

${ }^{837}$ Idem, p. 169.

${ }^{838}$ Idem, p. 169.

${ }^{839}$ Idem, p. 169-170.
} 
O funcionamento da economia é examinada, também, considerando-se a origem social dos empresários. Estes estavam ligados ao abastecimento da Corte, acumularam capitais no comércio de gêneros alimentícios e animais de transporte e passaram a dedicar-se à produção de café. ${ }^{840}$ Também nesse ponto, a comparação se estende aos empresários dos engenhos nordestinos. Na produção açucareira, as etapas de produção e comercialização estavam "rigorosamente isoladas", impedindo a formação de uma classe empresarial com "consciência clara de seus próprios interesses". ${ }^{841}$ Por sua vez,

a economia cafeeira formou-se em condições distintas. Desde o começo, sua vanguarda esteve formada por homens com experiência comercial. Em toda a etapa da gestação os interesses da produção $e$ do comércio estiveram entrelaçados. A nova classe dirigente formouse numa luta que se estende em uma frente ampla: aquisição de terras, recrutamento de mão-de-obra, organização e direção da produção, transporte interno, comercialização nos portos, contatos oficiais, interferência na política financeira e econômica. ${ }^{842}$

As características da classe empresarial cafeicultora ficam nítidas se as compararmos com a classe dirigente norte-americana. Como vimos, para Celso Furtado, a existência de uma forte classe comercial foi essencial para garantir a diferenciação de seus interesses em relação Inglaterra. A Independência do Brasil, ao contrário, foi feita sob o comando de uma classe agrária, incapaz de impor interesses outros que a participação no comércio exterior sem os intermediários lusitanos. Dito de outra forma, um requisito importante para a consciência nacional e direcionamento da política econômica para constituir uma economia autônoma é a formação de uma classe econômica com interesses enraizados no conjunto das atividades econômicas do país: não apenas na exportação de produtos primários, mas também na rede de transportes, no mercado interno, na produção de manufaturas, etc. $\mathrm{O}$ café, atividade ligada à exportação, mas dependente de uma série de serviços públicos e contando com um Estado Nacional capaz de orientar a política econômica, produz uma classe empresarial com interesses arraigados no conjunto da nação, ampliando a importância do setor interno.

Dito de outra forma, esse conjunto de características, que expressam nada mais que a integração dos produtores aos problemas econômicos e políticos do país estabelece, pela primeira vez, uma classe empresária efetivamente nacional, pois identificada às atividades que afetam o conjunto da produção. Dessa forma, é a classe

\footnotetext{
${ }^{840}$ Idem, p. 170.

${ }^{841}$ Idem, p. 171.

${ }^{842}$ Idem, p. 171-172.
} 
empresarial cafeeira que inaugura, pela primeira vez, a concomitância entre os interesses socioeconômicos e a condução da política econômica, exatamente a identidade que faltou para impulsionar o país para a industrialização após o declínio da mineração.

Este fato, por sua vez, permite perceber que um dos elementos a influir negativamente no período de declínio das atividades exportadoras foi, justamente, a impossibilidade de contornar esse problema com uma política econômica ativa. Ora, na explicação da crise econômica da segunda metade do século XVIII até as primeiras décadas do XIX, um elemento decisivo foi a ausência de uma classe comercial que pudesse se contrapor aos interesses agrícolas, estes centrados nos canais de exportação e importação mediados pelos comerciantes ingleses.

A economia cafeeira, ao contrário, opera em conjunto com o Estado, de forma que a política econômica nacional se torna a política econômica de um produto de exportação. Para Furtado, “desde cedo eles compreenderam a enorme importância que podia ter o governo como instrumento de ação econômica". ${ }^{843}$ Com isso, também, podemos perceber que Celso Furtado acrescenta um elemento importante em relação ao livro A economia brasileira, pois neste, embora haja um longo exame da economia cafeeira, pouca atenção é dada para a classe empresarial. É possível inferir que essa preocupação deriva, agora, da expansão da base comparativa, resultado do aprofundamento do exame dos grupos sociais que compuseram as principais atividades do país, tema que Formação econômica do Brasil abordou nos outros sistemas produtivos mas que, agora, adquire toda a sua relevância heurística, pois aparece justamente no momento em que a política passa a ser assunto nacional.

Dessa forma, o surgimento do café põe fim ao longo período de estagnação da economia. Em suas palavras

ao concluir-se o terceiro quartel do século XIX os termos do problema econômico brasileiro se haviam modificado basicamente. Surgira o produto que permitiria ao país reintegrar-se nas correntes de expansão do comércio mundial; concluída sua etapa de gestação, a economia cafeeira encontrava-se em condições de autofinanciar sua extraordinária expansão subsequente; estavam formados os quadros da nova classe dirigente que lideraria a grande expansão cafeeira. Restava por resolver, entretanto, o problema da mão-de-obra ${ }^{844}$

\footnotetext{
${ }^{843}$ Idem, p. 172.

${ }^{844}$ Idem, p. 172.
} 
Com isso, mais uma vez Celso Furtado reitera a importância da ligação com as linhas de comércio internacionais, única forma de uma economia colonial superar sua condição. Entretanto, neste momento passam a existir alguns fatores novos: o surgimento de um Estado nacional capaz de conduzir, ainda que equacionando uma série de constrições impostas pela política e a economia mundial, sua política econômica; os restos dos antigos sistemas econômicos que já havia se integrando em suas linhas gerais; o surgimento de uma nova classe empresarial cujos interesses, embora voltados para a exportação do café, assentava-se em estreita ligação com o conjunto de atividades econômicas internas, envolvendo as etapas de produção, comercialização, transporte e financiamento, forjando um início de interesses internos conscientes.

O exame da mão-de-obra teve papel central em todas as atividades econômicas anteriores, influindo diretamente nas possibilidades de ampliação e circulação da renda para o conjunto da economia. Agora ela também sofrerá alterações neste novo sistema econômico, o que exige de Celso Furtado um exame extenso desta questão, incorporando um conjunto de variáveis que não estavam presentes em $A$ economia brasileira.

O problema da mão-de-obra levará Celso Furtado a retomar o mapeamento das atividades e potencialidades das regiões brasileiras sob a ótica da possibilidade de oferta de braços para a lavoura de café. Compreender o alcance dessa questão e o longo esforço de elaboração que exigiu (afirmamos que o tema mereceu três páginas em $A$ economia brasileira) passa pela retomada das categorias do desenvolvimento econômico de Celso Furtado.

Como vimos, um dos principais fatores que caracterizam uma economia colonial, ou subdesenvolvida, é a grande massa de população produzindo em condições de subsistência, em desemprego disfarçado, ou desocupada, pressionando o consumo de alimentos e reduzindo os salários nos setores mais produtivos da economia, nomeadamente, o setor exportador. Ora, se o país se encontrava num longo período de decadência, quase secular, com diversas regiões reduzidas à subsistência, como a mãode-obra pode ser um problema para a lavoura cafeeira? Dito de outra forma, que fatores fizeram com que, no Brasil, a abundância de mão-de-obra não fosse, ao mesmo tempo, uma oferta de braços para a lavoura?

Ao examinar a força de trabalho no Brasil em meados do século XIX, Celso Furtado encontra uma população de aproximadamente dois milhões de escravos e 
considera que esse número coloca um problema de "inelasticidade da oferta de trabalho", pois, ao contrário dos Estados Unidos, na economia brasileira a taxa de mortalidade da população escrava era superior à natalidade, refletindo uma condição de vida "extremamente precária". ${ }^{845}$ Além disso, a demanda crescente na região cafeicultora, atraindo cativos de outras regiões, originaou um uso mais intenso da força de trabalho, no momento em que o tráfico cessava e os preços aumentavam. Dessa forma, "a questão da mão-de-obra se agrava e passa a exigir urgente solução". ${ }^{846}$

Comparando as formas de crescimento das economias europeias, no qual o avanço tecnológico, ao mesmo em tempo que desagrega os sistemas econômicos preexistentes libera mão-de-obra para novos setores, pressionado os salários para baixo, o crescimento da economia cafeeira se fazia, como nos outros sistemas econômicos, "puramente em extensão": ocupação de novas terras disponíveis e incorporação de "mais mão-de-obra". ${ }^{847}$ Neste modelo, "a chave de todo o problema econômico estava, portanto, na oferta de mão-de-obra". ${ }^{848}$

A centralidade da questão da força de trabalho na explicação das possibilidades de expansão da economia cafeeira marca um salto importante, em comparação com $A$ economia brasileira. Neste livro de 1954, o problema é abordado en passant, solucionando-se em decorrência do imenso reservatório do setor de subsistência, resultado da decadência da produção de outros produtos de exportação e a diminuição no custo do transporte marítimo, que permitiu a vinda de imigrantes europeus ao Brasil. Em suas palavras: "existindo mão-de-obra relativamente abundante e, ademais, a possibilidade de aumentar a oferta desta, quando, sob pressão da procura, os salários tendessem a subir em forma demasiadamente rápida, tornava-se economicamente praticável uma empresa colonizadora com base na mão-de-obra assalariada". ${ }^{849}$

Tendo examinado essa transição unicamente a partir da disponibilidade de fatores no conjunto da economia, a preocupação de Celso Furtado naquela obra de 1954 revela-se, sobretudo, na intenção de examinar o funcionamento desta nova economia, análise esta que será mantida em Formação econômica do Brasil. No entanto, neste livro, a transição para o trabalho livre se transformou no principal eixo explicativo desta quarta parte. Para compreendermos o sentido desta modificação, portanto, será preciso

\footnotetext{
${ }^{845}$ Idem, pp. 173-175.

${ }^{846}$ Idem, p. 176.

${ }^{847}$ Idem, pp. 176-177.

${ }^{848}$ Idem, p. 177.

${ }^{849}$ FURTADO, Celso. A Economia Brasileira (Contribuição à análise de seu desenvolvimento). op. cit., pp. $88-89$
} 
investigar, não apenas a forma de abordagem da "questão da mão-de-obra", quanto suas consequências para a explicação desta "economia de transição para o trabalho livre".

A primeira proposição de Celso Furtado é descartar a utilização da mão de obra do setor de subsistência na economia cafeeira. A população ocupada nessa atividade, dispersa por todo o território, não contava com a propriedade da terra, trabalhando em roças e prestando serviços para os grandes proprietários rurais, cujo pagamento cobria apenas a pequena parcela monetária de uma forma de vida baseada, predominantemente, no autoconsumo. Somando-se o vínculo pessoal ao grande proprietário de terras, para quem interessava dispor de grande número de agregados quando necessário, "a economia de subsistência de maneira geral estava de tal forma dispersa que o recrutamento de mão-de-obra dentro da mesma seria tarefa bastante difícil e exigiria grande mobilização de recursos". ${ }^{850}$

Por sua vez, também ao redor das zonas urbanas havia um sistema de subsistência com "baixíssima produtividade", cuja dificuldade de recrutamento está na "adaptação à disciplina do trabalho agrícola e às condições de vida nas grandes fazendas". ${ }^{851}$ Dessa forma, a dispersão territorial, o enraizamento em formas patriarcais de existência, bem como a resistência à imposição de um regime de trabalho agrícola regrado e constante, impediram a utilização da mão-de-obra disponível no sistema de subsistência de baixa produtividade. Neste quadro, Celso Furtado explicita a decadência econômica das regiões exportadoras e suas formas de involução têm consequências de longo prazo para o conjunto da economia brasileira. Assim, ao detectar a gênese de imenso reservatório de mão-de-obra, o autor reafirma as dificuldades de superação dos entraves que o processo de desenvolvimento econômico encontra numa economia subdesenvolvida.

A alternativa sugerida foi a imigração europeia. Neste caso, era preciso contornar uma "questão fundamental" e sem precedentes para as correntes imigratórias do Velho Mundo, qual seja, aumentar "a oferta de força de trabalho disponível para a grande lavoura [grifo do autor]", ${ }^{852}$ aspecto perceptível através da comparação com a experiência dos Estados Unidos. Enquanto os imigrantes europeus que se dirigiram à América do Norte encontram um mercado em expansão onde poderiam inserir suas atividades produtivas, no Brasil, as primeiras tentativas de colonização "careciam

\footnotetext{
${ }^{850}$ FURTADO, Celso. Formação econômica do Brasil. op. cit., p. 179.

${ }^{851}$ Idem, ibidem.

${ }^{852}$ Idem, p. 181.
} 
totalmente de fundamento econômico", ${ }^{853}$ subsidiadas pelo governo imperial e sem conexão com outros mercados.

A solução desse problema implicaria que o imigrante imediatamente trabalhasse em uma atividade rentável, de exportação ou para o mercado interno. Como a cultura do café estava organizada em grandes plantações, exigindo um considerável capital na etapa inicial, essa opção estava descartada, ademais que esses imigrantes teriam que competir com fazendas trabalhadas por escravos. A produção para o mercado interno, por sua vez, dependia de sua ampliação, a qual seria possível pela expansão do setor exportador, bloqueado pelo problema da mão-de-obra. A solução se deu somente na década de 1870, em ação conjunta do Governo com os fazendeiros de café paulistas. Enquanto o primeiro pagava os custos da passagem, ao segundo cabia a manutenção das famílias no primeiro ano de trabalho. Furtado assinala, ainda, que a solução foi possível, também, por alterações no lado da oferta, com a unificação italiana e a criação de um excedente de mão-de-obra agrícola oriunda do sul da Itália.

Dessa forma, foi a conjugação dos esforços da classe empresarial cafeeira e o Estado brasileiro que solucionou o problema da mão-de-obra. Nesse ponto, é preciso que recordemos a consciência de seus interesses, característica desse novo grupo econômico-social, e sua percepção de que o Estado é uma via de alcance de seus objetivos.

Sob o título de transumância amazônica, Celso Furtado examina o fluxo de população do nordeste para a região, que entrara em decadência em finais do XVIII e teria sua dinâmica novamente alterada, um século depois, pelo aumento da procura internacional de borracha. A principal dificuldade da região residia no recrutamento de mão-de-obra e organização da produção em atividade extrativa em extenso território. Durante as primeiras décadas do século XIX, embora houvesse exportação de cacau e borracha e outros produtos, seu volume de exportação permaneceu restrito.

Assim como o café, a expansão da produção dependia da disponibilidade de mão-de-obra. A triplicação do volume exportado entre 1870 e 1900 indica que foi possível ampliar a produção contando-se com um influxo de mão-de-obra. A população na bacia amazônica duplicou nesse período, sobretudo na última década do século XIX. Para Celso Furtado, “essa enorme transumância indica claramente que em fins do século XIX já existia um reservatório substancial de mão-de-obra e leva a crer que, se não tivesse sido possível solucionar o problema da lavoura cafeeira com imigrantes ${ }^{853}$ Idem, p. 183. 
europeus, uma solução alternativa teria surgido dentro do próprio país. Aparentemente, a imigração europeia para a região cafeeira deixou disponível o excedente de população nordestina para a expansão da produção da borracha". ${ }^{854}$

Para entender essa possibilidade de recrutamento, Celso Furtado examina os distintos sistemas de subsistência do país. No nordeste, o declínio da economia açucareira originou uma economia de subsistência baseada na pecuária como principal fonte de alimentos. A expansão desse sistema dependia da disponibilidade de terras. Foi justamente a abundância desse fator que permitiu o seu forte crescimento demográfico no sul do país, acompanhado da expansão na produção de alimentos.

No nordeste, onde a expansão da economia de subsistência iniciara-se na metade do XVII, havia pressão demográfica sobre a terra, agravada pela expansão da cultura algodoeira que atraiu e concentrou contingentes populacionais que pressionavam a agricultura de alimentos. É nesse quadro que a seca de 1877-1880, fará com que o socorro às vítimas fosse "orientado no sentido de promover sua emigração para outras regiões do país, particularmente a região amazônica" ${ }^{, 855}$, auxiliados pelos governos da região, que precisavam de um contingente de mão-de-obra para ampliar a oferta de borracha. Assim, foi a conjunção de pressão demográfica e desastre natural na região de subsistência nordestina, aliada à necessidade de força de trabalho para os seringais que permitiu o recrutamento dos trabalhadores da borracha. No entanto, este fluxo teve características distintas daquele enviado para a economia cafeeira. De fato, "enquanto o imigrante europeu, exigente e ajudado pelo seu governo, chegava à plantação de café com todos os gastos pagos, residência garantida, gastos de manutenção assegurados até a colheita", o que lhe permitia garantir-se contra eventuais abusos dos senhores de terra, "a situação do nordestino na Amazônia era bem diversa: começava a trabalhar endividado" para pagar os custos da viagem, instrumentos e custos de manutenção, dependia da obtenção de alimentos fornecidos pelo proprietário de terras, reduzindo-se “a um regime de servidão". ${ }^{856}$ Por sua vez, quando os preços da borracha começam a declinar, nas primeiras décadas do século XX, esses trabalhadores formarão mais um núcleo de subsistência no Norte do país, sem alterar as características estruturais da região.

\footnotetext{
${ }^{854}$ Idem, p. 192.

${ }^{855}$ Idem, p. 194.

${ }^{856}$ Idem, p. 195.
} 
Explicada, portanto, como foi possível o suprimento de mão-de-obra para as duas regiões em expansão, o planalto paulista e a bacia amazônica, Celso Furtado retoma à questão do trabalho escravo, agora sob o ponto de vista da abolição e suas consequências para a lavoura.

Furtado considera a abolição um problema econômico, pois se trata da "redistribuição da propriedade dentro de uma coletividade", de forma que o principal ponto em questão "radica no tipo de repercussões que a redistribuição da propriedade terá na organização da produção, no aproveitamento dos fatores disponíveis, na distribuição da renda e na utilização final dessa renda”. ${ }^{857}$ A abordagem privilegia o aspecto econômico, sobretudo, suas repercussões para os senhores de escravo e fazendeiros de café. Desse ponto de vista, examina as alterações que provoca "na forma de organização da produção e no grau de utilização dos fatores". ${ }^{858}$ Também aqui, o recurso comparativo delineia as características da abolição no Brasil. Os casos extremos ocorreram nas Antilhas inglesas, onde a completa ocupação de terras e a impossibilidade de imigração não deixou outra alternativa aos libertos senão permanecerem nas plantações recebendo um salário de subsistência que, na prática, fez do fim da escravidão algo meramente formal. Por sua vez, onde a disponibilidade de terras era ampla, a única maneira de manter a mão-de-obra nas propriedades seria elevando os salários, redistribuindo riqueza para os trabalhadores. Para Furtado, no Brasil, "a região açucareira aproximou-se mais do primeiro caso, e a cafeeira, mais do segundo". ${ }^{859}$ No nordeste, devido à longa extensão da economia de subsistência e à pressão demográfica e social dos centros urbanos, "os deslocamentos se faziam de engenho para engenho, e apenas uma fração reduzida infiltrou-se fora da região". Dessa forma, "não foi difícil, em tais condições, atrair e fixar uma parte substancial da antiga força de trabalho escravo, mediante um salário relativamente baixo". ${ }^{860}$ Por sua vez, o ingresso de capitais ingleses e a modernização das usinas de açúcar nordestinas, em finais do século XIX minimizou os efeitos da redução da oferta de mão-de-obra.

$\mathrm{Na}$ cafeicultura, a abolição trouxe consequências não apenas distintas da açucareira, mas diferenciou as duas regiões produtoras de café: a frente inicial, no vale do Paraíba fluminense e a do Oeste paulista, mais recente. A primeira, de terras menos férteis, terrenos mais acidentados estava em "situação desfavorável já na época

\footnotetext{
${ }^{857}$ Idem, p. 199.

${ }^{858}$ Idem, ibidem.

${ }^{859}$ Idem, p. 201.

${ }^{860}$ Idem, ibidem.
} 
imediatamente anterior à abolição”. A região paulista, com terras de alta produtividade, comandou a imigração europeia e não absorveu os escravos liberados pela decadência da agricultura fluminense, que passaram para a produção de subsistência, embora sem uma grande dispersão geográfica e em condições "muito mais favorável que a daqueles da região açucareira do Nordeste". ${ }^{861}$

Entretanto, segundo Furtado, "tudo indica que a região do café [paulista] provocou efetivamente uma redistribuição da renda em favor da mão-de-obra", muito embora tenha "tido efeitos antes negativos que positivos sobre a utilização dos fatores" ${ }^{\$ 662}$, pois a escravidão emprestou ao trabalho um aspecto negativo, de forma que a simples obtenção da subsistência era suficiente para o novo trabalhador. Dessa forma, na antiga região cafeeira a necessidade de reter o trabalhador na terra ocasionou uma elevação do salário ao mesmo tempo em que se reduziu "o grau de utilização da força de trabalho". 863

Sob uma perspectiva geral, entretanto, a abolição "constitui uma medida de caráter mais político que econômico", pois "praticamente em nenhuma parte houve modificações de real significação na forma de organização da produção e mesmo na distribuição da riqueza". Para Furtado, o problema de mão-de-obra foi efetivamente resolvido com a imigração europeia, que permitiu a expansão firme da cafeicultura em São Paulo. Quanto aos ex-escravos e aos homens livres do setor de subsistência, "por toda a primeira metade do século XX, a grande massa dos descendentes da antiga população escrava continuará vivendo dentro de seu limitado sistema de 'necessidades', cabendo-lhe um papel puramente passivo nas transformações econômicas do país". 864

Esse conjunto de considerações nos coloca a interpretação desde o longo exame que Celso Furtado empreendeu sobre a transição para o trabalho livre. Se compararmos com A economia brasileira, a interpretação se ampliou para a compreensão da imigração europeia, vista sob o estabelecimento de interesses comuns entre cafeicultores e o Governo. Porém, o exame também teve a finalidade de elaborar um mapa da situação da mão-de-obra no conjunto do território brasileiro, identificando as principais regiões e as formas de organização do trabalho. Esse exame se coaduna à sua hipótese inicial sobre as dificuldades de arregimentação de braços para a lavoura

\footnotetext{
${ }^{861}$ Idem, ibidem.

${ }^{862}$ Idem, p. 203.

${ }^{863}$ Idem, p. 204.

${ }^{864}$ Idem, p. 205.
} 
cafeeira, por viverem em condições de subsistência, baixa produtividade e pouca aptidão para o trabalho continuado e intenso das fazendas de café.

Celso Furtado, agora, delineia para o território nacional, o problema examinado em cada sistema econômico isolado: a existência de um núcleo produtor para exportação que não consegue estabelecer ligações dinâmicas com o conjunto da economia. Porém, antes o problema era devido, seja à separação entre atividades de exportação e de subsistência, à concentração da renda nas mãos de classes cujo perfil de consumo compunha-se de importações ou ao trabalho escravo que bloqueava o fluxo de renda e não criava mercado interno. A economia cafeeira, ao contrário, irá encontrar um país com mão-de-obra dispersa, arraigada a formas de produção e consumo herdados de sistemas econômicos anteriores, incapaz de responder aos seus impulsos. É precisamente a constituição de um novo sistema produtivo baseado no trabalho livre assalariado, contraposto ao amplo quadro secular de estagnação e produção de subsistência que dará a tônica da segunda metade do século XIX e colocará os principais problemas para o século vindouro. No entanto, as condições de resposta aos desafios econômicos, neste momento de surgimento da economia cafeeira, são dadas nacionalmente, em que pesem as constrições internacionais, pela nova classe dos empresários cafeicultores, com ramificações em outros setores produtivos, comerciais e financeiros, e acesso ao Estado para direcionar a política econômica de acordo com interesses definidos. Dessa forma, é preciso reter essa ênfase na política econômica, presente, não apenas na análise da cafeicultura, mas também compondo e jogando papel importante — sob o signo da ausência — na decadência secular que atingiu a economia brasileira do final do século XVIII à primeira metade do XIX.

Explicitado, portanto, o conjunto de elementos que distingue a economia cafeeira a complexidade do problema nacional de mão-de-obra, Celso Furtado irá examinar qual foi, no conjunto da atividade econômica do novo país, o crescimento econômico ao longo do século XIX.

Comparada ao longo declínio que ocorreu com o fim extração aurífera, e “considerada em conjunto, a economia brasileira parece haver alcançado uma taxa relativamente alta de crescimento na segunda metade do século XIX. Sendo o comércio exterior o setor dinâmico do sistema, é no seu comportamento que está a chave do processo de crescimento dessa etapa". ${ }^{865}$ Aqui, uma vez mais, é possível distinguir claramente qual a variável para o crescimento e a dinâmica econômica: o setor externo.

\footnotetext{
${ }^{865}$ Idem, p. 206.
} 
Entre os decênios de 1840 e 1890, o quantum de exportações subiu 214 \%, o valor exportado aumentou 46 pontos percentuais e o preço das importações declinaram em $8 \%$, resultando um incremento de $369 \%$ na renda gerada pelo setor exportador. ${ }^{866}$ No entanto, tendo em vista a composição regional dos produtos de exportação, "o desenvolvimento da segunda metade do século XIX não se estendeu a todo o território do país". ${ }^{867}$ Para examinar a renda per capta no Brasil, Celso Furtado distingue três grupos principais, o Nordeste, o Sul do país e a economia cafeeira.

O Nordeste vivenciou um crescimento populacional maior que a renda gerada pelo setor exportador, o que configura um declínio da renda per capta na região como um todo, embora seja difícil qualificar se esta foi mais acentuada no sistema exportador ou na economia de subsistência do hinterland nordestino.

Já o Sul do país foi beneficiado pelo aumento das exportações de erva-mate, que ativou um mercado capaz de absorver os excedentes da produção de subsistência. A pecuária no Rio Grande do Sul ampliou suas vendas ao mercado interno, sobretudo de charque, assim como a venda de vinho e banha de porco. Tendo a população sulina crescido a uma taxa semelhante às exportações e considerando as vendas para o mercado interno, "é muito provável que haja aumentado a produtividade econômica média e por conseguinte a renda per capta". ${ }^{868}$

O terceiro sistema econômico é constituído pela produção cafeeira nos estados de Espírito Santo, Rio de Janeiro, São Paulo e Minas Gerais, com duas regiões distintas. As zonas precursoras do Rio de Janeiro e Minas Gerais tiveram um crescimento populacional reduzido, enquanto São Paulo e Espírito Santo obtiveram as maiores taxas de crescimento do país. Dessa forma, "o desenvolvimento da região cafeeira se realizou, durante essa etapa, com transferência de mão-de-obra das regiões de baixa produtividade - e certamente do setor de subsistência dessa região — para outras de mais alta produtividade". ${ }^{869}$ Considerando as repercussões da exportação de café no aumento da demanda do setor de subsistência, Celso Furtado atribui para a região, uma elevação anual da renda per capta da ordem de 2,3 por cento, apenas inferior a do sul do país, que atingiu três pontos percentuais.

Dessa forma, Celso Furtado estima uma elevação anual da renda per capta no país de 1,5 por cento, “elevada, com respeito ao desenvolvimento da economia mundial

\footnotetext{
${ }^{866}$ Idem, ibidem

${ }^{867}$ Idem, p. 207.

${ }^{868}$ Idem, p. 211.

${ }^{869}$ Idem, p. 212.
} 
no século XIX" ${ }^{870}$, ainda mais por esse crescimento ter se iniciado na metade do século. Esses dados, no entanto, permitem-lhe tecer algumas considerações gerais sobre o conjunto da economia brasileira ao longo do século.

Para Furtado, considerando a renda per capta do final do XIX e aplicando-a na primeira metade do XIX, conclui que "a taxa de crescimento da economia brasileira tem sido relativamente estável no correr dos últimos cem anos". ${ }^{871}$ No entanto, se esta houvesse sido alcançada na primeira metade do XIX, a renda real da população brasileira, em 1950 seria "comparável à media dos países da Europa Ocidental, nesse ano". ${ }^{872}$ Dessa forma, o atraso relativo do Brasil "tem sua causa não no ritmo de desenvolvimento dos últimos cem anos, o qual parece haver sido razoavelmente intenso, mas no retrocesso ocorrido nos três quartos de século anteriores". Uma vez que o Brasil não conseguiu ligar-se às grandes linhas do comércio mundial num período de profundas transformações econômicas e tecnológicas, criaram-se "profundas dessemelhanças" entre "os sistemas econômicos", as quais são fundamentais para "analisar os problemas específicos de subdesenvolvimento com que se confronta a economia brasileira no presente". ${ }^{873}$

Com isso, Celso Furtado confronta a economia brasileira na década de 1950 com sua formação histórica. O desenvolvimento relativamente elevado a partir da segunda metade do século XIX, só não foi maior devido à decadência econômica a partir da mineração. Dessa forma, a comparação com os Estados Unidos serve, também, para ilustrar o que teria acontecido com o Brasil se houvesse reunido as condições econômicas, sociais e políticas para iniciar seu processo de desenvolvimento naquele momento.

Para concluirmos nosso exame das proposições de Celso Furtado na quarta parte de Formação econômica do Brasil, é preciso lembrar que a análise procurou detectar, em momentos decisivos, a inexistência ou inadequação da política econômica ou a ausência de outros grupos sociais que pudessem confrontar ou redirecionar os rumos da economia no Brasil. A importância dos grupos sociais foi novamente mobilizada por Celso Furtado quando destacou a origem social dos cafeicultores e de como eles inauguraram uma nova forma de integração de seus interesses com os do país.

\footnotetext{
${ }^{870}$ Idem, p. 215.

${ }^{871}$ Idem, p. 216.

${ }^{872}$ Idem, ibidem.

${ }^{873}$ Idem, p. 217.
} 
É precisamente a análise do surgimento de um grupo de interesses que consegue transformá-los em política nacional que vai ocupar o capítulo 29, "A descentralização republicana e a formação de novos grupos de pressão", capítulo inédito em relação a $A$ economia brasileira, evidenciando a importância que essa questão assumiu na interpretação furtadiana.

Se mantivéssemos a sequência de Formação Econômica do Brasil, teríamos a retomada do capítulo III do livro de $1954^{874}$, no qual é analisado o funcionamento da economia cafeeira, os fatores produtivos, os efeitos das oscilações cíclicas da demanda internacional sobre a renda e o mecanismo de ajuste cambial, conceitualizado como mecanismo de socialização das perdas. Do que fora exposto no livro de 1954, ficou evidenciado como a renda, não apenas do setor cafeeiro, mas dos setores urbanos, de serviços e a agricultura de alimentos dependia da cafeicultura, pois, uma vez operando com trabalho assalariado, o multiplicador da renda extrapola esta atividade, atingindo outros ramos produtivos e de serviços. Nesse quadro, os períodos de baixa cíclica eram absorvidos pela economia buscando evitar grandes perdas para os produtores de café, pois seu efeito se propagaria para a economia como um todo. Dessa forma, havia a percepção de que a defesa do setor era, ao mesmo tempo, a defesa da renda das atividades a ele ligadas. Entretanto, a política de desvalorização cambial, principal instrumento de proteção da renda daqueles grupos ligados à produção e exportação de café - o tema do capítulo 29 , intitulado “A descentralização republicana e a formação de novos grupos de pressão" —, acarretava, também, uma série de problemas para os outros grupos sociais, e também, no médio e longo prazo, para o próprio governo central, constituindo-se, portanto, os limites nacionais da política cafeeira.

A política de desvalorização cambial implicava em transferências de renda: do setor de subsistência para o exportador; do trabalhador rural para o proprietário de terras, muito embora o grupo mais afetado seja a população urbana, que dispendia grande parte de seu salário em importações, "inclusive alimentos". ${ }^{875} \mathrm{O}$ encarecimento destes artigos impactava fortemente nas finanças, pois a principal fonte de receita tributária do governo federal provinha das importações. Por sua vez, a desvalorização ampliava a parcela em moeda nacional mobilizada para o pagamento da dívida externa. Com isso, o governo se via na necessidade de financiar seus déficits com emissões

\footnotetext{
${ }^{874}$ Este capítulo foi analisado em nosso capítulo 3, no subitem "Fim da economia colonial, cafeicultura e crise de nascimento do mercado interno".

${ }^{875}$ FURTADO, Celso. Formação econômica do Brasil. op. cit., p. 242.
} 
monetárias, ampliando o impacto negativo para as classes urbanas. Esse conjunto de circunstâncias demonstra que o sistema fiscal, ao mesmo tempo em que lograva diminuir as flutuações externas, "agravava o processo de transferência regressiva da renda nas etapas de depressão". ${ }^{876}$ Assim, “a depressão externa (redução dos preços das exportações) transformava-se internamente em um processo inflacionário". 877

Aqui, portanto, a retomada da interpretação da inflação como conflito distributivo, ausente em Perspectivas da economia brasileira, mas formulada em $A$ economia brasileira. Vejamos: o setor cafeeiro, sujeito aos ciclos externos, é também o principal setor dinâmico da economia, responsável por parcela considerável do Produto Nacional Bruto. A oscilação em sua renda e lucros afeta amplos setores da economia. A solução do governo central para minimizar essas crises resultava em déficits orçamentários, emissão monetária e ampliação do endividamento externo. Esse conjunto de medidas, se por um lado beneficiava a economia, por outro transferia seus custos para o conjunto da sociedade, daí o surgimento dos conflitos, pois todos os setores tentam se proteger da inflação, aumentando seus preços.

O exame desse problema é aprofundado pela análise das políticas monetárias adotadas no último decênio do Império e na primeira década republicana. O final do Império assistiu não só um aumento da dívida pública, mas a escassez de numerário, no momento crítico de transição para o trabalho assalariado, quando "entraram no país cerca de 200 mil imigrantes". ${ }^{878}$ A lentidão com que as elites imperiais encaminharam financeiramente o problema do fim da escravidão, segundo Furtado, reflete "divergências crescentes de interesses entre distintas regiões do país”. ${ }^{879}$ Ao longo do século XIX, a luta pela manutenção da escravidão unificara as diversas regiões do país, no último decênio do Novecentos "a organização social do sul transformou-se rapidamente, sob a influência do trabalho assalariado nas plantações de café e nos centros urbanos, e da pequena propriedade agrícola na região de colonização das províncias meridionais". ${ }^{880}$ Ora, essas transformações exigiam do governo investimento s em serviço público, educação, saúde e sistemas bancário, mas foram barradas enquanto o Império esteve orientado por "homens ligados aos velhos interesses

\footnotetext{
${ }^{876}$ Idem, p. 244.

${ }^{877}$ Idem, p. 245.

${ }^{878}$ Idem, p. 245.

${ }^{879}$ Idem, p. 246.

${ }^{880}$ Idem, ibidem.
} 
escravistas", com "escassa sensibilidade com respeito a esses novos problemas". ${ }^{881}$ Celso Furtado assinala a dissociação entre os interesses do novo setor cafeeiro, principal produto de exportação operando com trabalho assalariado, e o Estado imperial, que não criava as condições monetárias e financeiras para consolidar a transição ao trabalho livre. É esta contradição de interesses, entre o funcionamento e manutenção da renda do setor cafeeiro concentrado nos estados do sul, e a estrutura política cuja orientação era dada pelos interesses dos proprietários de escravos, que explica a Proclamação da República, interpretada como "um movimento de reivindicação da autonomia regional". 882

Entre as primeiras medidas republicanas está a criação dos bancos regionais de emissão, sob controle dos governos estaduais, para reverter a carência de meios de pagamento onde o trabalho assalariado havia se expandido. Esse movimento, entretanto, produziu um excesso de emissão, pressionado a desvalorização da moeda nacional em mais $70 \%$.

Foi somente em 1898, no governo Campos Sales, que a situação se estabilizou, com o funding loan, que promoveu "a redução do serviço da dívida externa por meio de um empréstimo de consolidação (1898), a introdução da cláusula-ouro na arrecadação do imposto de importação (1900), uma série de medidas de caráter deflacionário e o substancial aumento no valor das exportações, de 26 milhões de libras em 1896-1899 para 37 milhões em 1900-03". ${ }^{883}$

Essas medidas, no entanto, não são interpretadas por Celso Furtado como resultado da hegemonia do setor cafeeiro. Ao contrário, a alteração do regime político e a ampliação da autonomia regional no campo fiscal e financeiro deu ensejo à expressão de outros grupos econômicos, que passarão a disputar os recursos públicos e impor resistências à política federal. Em suas palavras

os interesses diretamente ligados à depreciação externa da moeda grupos exportadores - terão a partir dessa época que enfrentar a resistência organizada de outros grupos. Entre estes se destacam a classe média urbana - empregados do governo, civis e militares, e do comércio - , os assalariados urbanos e rurais, os produtores agrícolas ligados ao mercado interno, as empresas estrangeiras que exploram serviços públicos, das quais nem todas têm garantia de juros. Os nascentes grupos industriais, mais interessados em aumentar a capacidade produtiva (portanto nos preços dos equipamentos

\footnotetext{
${ }^{881}$ Idem, ibidem.

${ }^{882}$ Idem, ibidem.

${ }^{883}$ Idem, p. 247.
} 
importados) que em proteção adicional, também se sentem prejudicados com a depreciação cambial ${ }^{884}$

Assim, Celso Furtado recoloca a importância dos grupos de interesse na orientação e - agora - disputa pelos mecanismos de política econômica. Um dos principais entraves da economia colonial - o trabalho escravo - estava superado e, uma vez que a estrutura política se adaptara a nova realidade do assalariamento, surge, também, uma diversificação de interesses: setores urbanos, profissões liberais, serviços públicos, empresas estrangeiras, industriais, trabalhadores assalariados ganham visibilidade política. Contrastado com a outra ruptura, a Independência, a situação social é diversificada, e contrapõe-se ao mecanismo de desvalorização cambial que beneficia o setor exportador. As restrições e os limites que, efetivamente, conseguem impor, foram analisados por Celso Furtado no capítulo IV de A economia brasileira, e se apresentam como um conjunto crescente de dificuldades econômicas e financeiras que irão levar à crise da economia cafeeira, engastada na crise mundial de 1929, a qual já examinamos e que é retomada com algumas alterações pontuais em Formação econômica do Brasil.

Assim, a leitura do século XIX, em suas duas partes nitidamente delineadas por Celso Furtado, explicam a origem do subdesenvolvimento brasileiro. De fato, a ausência de um setor com alta produtividade, a agricultura de subsistência, as dificuldades de constituição do mercado interno foram delineados na primeira metade do Novecentos.

O surgimento da economia cafeeira forneceu as bases para a modificação desse quadro, por marcar a "transição para o trabalho assalariado". Essa transição assumiu uma importância inédita na análise de Celso Furtado, pois guardava dois problemas colocados pela leitura da história brasileira, e que não estavam conceitualmente delimitadas nos escritos anteriores: o impulso externo não necessariamente promove uma elevação de produtividade para além de seu setor específico. Isso fora verificado na economia açucareira e, em parte, na mineradora. A economia cafeeira guarda sua peculiaridade, pois é uma economia colonial dentro de um Estado-Nação. A possibilidade de resolução interna do problema da mão-de-obra confrontou-se com limites e barreiras dadas pela herança colonial, mas foi superada com a orientação da política econômica pela classe cafeicultora, até o limite do desenvolvimento e contraposição de outros interesses econômicos.

${ }^{884} \mathrm{Idem}$, ibidem. 


\section{Perspectiva dos próximos decênios: dez anos de diagnósticos sobre o Brasil}

As dificuldades para superar o que Celso Furtado chamara de "atavismos coloniais do Brasil moderno" reiteraram e acentuaram o descolamento da trajetória de desenvolvimento dos Estados Unidos. Mas, também, o quadro econômico dos séculos XVIII e XIX permitiu explicar os problemas que, ainda nos anos de 1950, a economia brasileira enfrenta. Se retomarmos as considerações de Perspectivas da economia brasileira, veremos que o principal fator que dificulta o ritmo ótimo do desenvolvimento brasileiro reside na agricultura de subsistência, que não consegue fornecer alimentos para os centros urbanos, gerando uma espiral de preços e salários que, confrontados com uma estrutura produtiva ainda dependente de importações de bens de capital, equipamentos e matérias-primas, traduz-se em inflação aberta. Nessa perspectiva, as dificuldades enfrentadas pela economia cafeeira para recrutar mão-deobra remete ao problema enfrentado, cem anos depois, pelos programadores do Plano de Metas.

Essa diferença temporal, entretanto, é novamente rompida por Celso Furtado no último capítulo de Formação econômica do Brasil, intitulado "Perspectiva dos próximos decênios". A semelhança do título com o livro anterior, Perspectivas da economia brasileira, publicado em 1958, nos dá a chave interpretativa deste último capítulo: a retomada da formação econômica brasileira descortinou novos problemas? Confirmou impasses já delineados? Sua interpretação foi alterada no intervalo de um ano, imprimindo novos questionamentos ao diagnóstico apresentado nas palestras de $1957 ?$

O enredamento de presente e passado transparece logo no início do capítulo:

assim como a segunda metade do século XIX se caracteriza pela transformação de uma economia escravista de grandes plantações em um sistema econômico baseado no trabalho assalariado, a primeira metade do século XX está marcada pela progressiva emergência de um sistema cujo principal centro dinâmico é o mercado interno ${ }^{885}$

Aqui, podemos ver, novamente, a organização do livro. Com efeito, a quinta parte, intitulada "Economia de transição para um sistema industrial. Século XX" e que corresponde aos capítulos IV e V de A economia brasileira, aborda a ruptura da outra

${ }^{885}$ Idem, p. 322. 
barreira que uma economia colonial impõe ao desenvolvimento econômico: o surgimento do mercado interno. Retoma-se o argumento que finalizou a análise da segunda metade do XIX, houvesse a economia brasileira mantido a taxa de crescimento dos últimos cem anos - período no qual logrou superar a condição de economia colonial - também na primeira metade do Novecentos, teríamos o mesmo nível de renda das nações desenvolvidas. No entanto, isso não quer dizer que alcançaria esse padrão daqui a cinquenta anos, porque esse atraso ocasionou um conjunto de novos problemas, específicos de uma economia subdesenvolvida.

São os impasses, os problemas, as peculiaridades dessa economia, inteligíveis unicamente se considerarmos o quadro histórico de sua formação — pois esta é sua especificidade principal, que exige a formulação de novos conceitos e categorias- que Celso Furtado procurou desvendar ao longo da obra. Daí a importância do diagnóstico que formula para os próximos decênios, pois está imerso nessa transtemporalidade, na qual o passado informa e lastreia a percepção do presente e aponta os rumos do futuro. Vejamos como isso é operacionalizado.

Primeiramente, constata que "o desenvolvimento econômico não acarreta necessariamente redução da participação do comércio exterior no produto nacional", como ficou assentado pelo exame comparativo das economias brasileira e norteamericana no XIX mas, "o papel que nela desempenha o comércio exterior se vai modificando". ${ }^{886}$ Ora, foi exatamente esse processo que acompanhamos, nos capítulos IV e $\mathrm{V}$ de A economia brasileira, reaproveitados neste livro. De fato, em todos os sistemas econômicos — escravista de agricultura tropical, mineração, os surtos de exportações do Maranhão e Amazônia - o impulso externo não gerou um processo de desenvolvimento, e a baixa cíclica levou o sistema econômico à subsistência. Foi apenas com a economia cafeeira baseada no trabalho livre, e sua crise prolongada e aguda, que se modificaram as variáveis do modelo e surgiu um mercado interno e um setor industrial.

A partir desse momento, as oscilações cíclicas são atenuadas internamente pelo setor industrial, que responde por parcela importante da renda nacional. Com isso, o comércio exterior passa a ser responsável pela capitalização industrial, pois o sistema, com o "aumento relativo das inversões no setor industrial e serviços conexos", demanda mais equipamentos mecânicos. Assim, "o sistema entra, por conseguinte, numa etapa de intensa assimilação de processos tecnológicos mais complexos, aos quais tem acesso

\footnotetext{
${ }^{886}$ Idem, p. 323.
} 
através do intercâmbio externo". ${ }^{887}$ O comércio externo, portanto, altera sua funcionalidade, passando a viabilizar a ampliação da capacidade produtiva da economia, sobretudo do setor industrial que, agora, consegue garante o crescimento econômico mesmo com estancamento do comércio exterior, embora com fortes tendências inflacionárias. Essa crescente autonomia do setor industrial na geração da renda interna, embora dependente da capacidade de importar, passa a existir no Brasil a partir da Primeira Guerra Mundial. Até os anos de 1950, “o principal fator determinante do nível da procura [...] foram as inversões ligadas ao mercado interno". Concomitantemente, "é somente naqueles períodos em que ocorre uma elevação da capacidade para importar 1920-1929 e 1946-1954 — que se alcança um ritmo de crescimento realmente intenso". 888

Aqui, portanto, é preciso notar como Celso Furtado revê os argumentos apresentados sobre o deslocamento do centro dinâmico da economia nos dois livros, mas o faz organizando-o pelas categorias do desenvolvimento econômico. Com efeito, a evolução recente da economia brasileira é examinada pela da integração entre o setor interno, determinante da dinâmica do crescimento e sua relação com o setor externo, agora subordinado. Com isso, o diagnóstico do presente surge, em Formação econômica do Brasil, como inteligível a partir das transformações que sofreu ao longo do tempo. Podemos dizer que o livro consegue trazer o passado para a análise do presente. Não da mesma forma que em A economia brasileira, onde esta relação aparece nas categorias e conceitos formulados e vazados historicamente. Esse resultado é incorporado aqui, pois o aparato é o mesmo, mas o exame do passado efetivamente ilumina e dá veracidade ao argumento, emergindo como o critério verificador por excelência da análise.

No entanto, não só o diagnóstico do presente é impactado pelo passado; este também ilumina as perspectivas de futuro: "a transformação estrutural mais importante que possivelmente ocorrerá no terceiro quartel do século XX será a redução progressiva da importância relativa do setor externo no processo de capitalização". "889 Esse prognóstico, como podemos perceber, nada mais é que uma acentuação de uma tendência já identificada na economia brasileira. No entanto, Celso Furtado especifica,

\footnotetext{
${ }^{887}$ Idem, p. 324.

${ }^{888}$ Idem, p. 325.

${ }^{889}$ Sobre as complexas relações entre presente, passado e futuro, ver. ARRUDA, José Jobson de Andrade. Historiografia: consciência crítica da produção histórica. In: idem. Historiografia. Teoria e prática. São Paulo: Alameda, 2014, pp. 36-45.
} 
ressaltando a necessidade do setor de bens de capital "crescer acima do setor industrial em seu conjunto. Isso seria condição para que a política econômica se permita visar ao duplo objetivo de defesa do nível de emprego e do ritmo de crescimento". ${ }^{890}$ Assim, a compreensão do passado/presente brasileiro anunciam as tendências de futuro que, no entanto, não são inevitáveis, mas dependem de que política econômica siga o propósito do crescimento econômico com ampliação do nível de ocupação da economia.

No entanto, o diagnóstico de Celso Furtado não se esgota no dinamismo do setor industrial para o conjunto da economia. Um tema muito importante de Perspectivas da economia brasileira e que foi examinado em todos os sistemas econômicos analisados em Formação econômica do Brasil recebe um tratamento especial neste capítulo: as disparidades regionais.

Para ele, "o desenvolvimento da primeira metade do século XX apresenta-se basicamente como um processo de articulação das distintas regiões do país em um sistema com um mínimo de integração”. ${ }^{891}$ Somente com o surgimento do trabalho assalariado e de aumentos de produtividade baseados no uso mais intenso de capital, possibilitados pelo setor industrial, surge uma integração mais forte entre as regiões. Com efeito, a demanda dos centros urbanos atendidas pela agricultura, bem como a diversificação da produção agrícola de exportação, imposta após a crise de 1929, ativam as relações econômicas entre as distintas zonas geográficas. Essa articulação, é preciso ressaltar, foi feita pela economia cafeeira. Assim, o Sul do país passa a liderar as vendas ao novo núcleo agrícola de exportação, logo ampliando-as ao resto do mercado brasileiro, ocupando a fatia de mercado antes atendida pelos países da região do Prata. Por sua vez, o Nordeste ocupa o forte mercado para o açúcar na região cafeeiroindustrial, redirecionando sua produção, antes destinada à exportação. Também a Amazônia é beneficiada pela demanda desta região por borracha e juta. ${ }^{892}$

Entretanto, essa relativa integração nacional revela, também, que "a disparidade de níveis regionais de renda havia aumentado notoriamente", ${ }^{893}$ e as mais elevadas taxas se concentravam na região cafeeira, que capitaneava os investimentos industriais. Celso Furtado apresenta a causa desse desequilíbrio: "é da natureza do processo de industrialização que as inversões só alcancem sua máxima eficiência quando se completam mutuamente, isto é, quando se coordenam funcionalmente em um todo

\footnotetext{
${ }^{890}$ Idem, ibidem.

${ }^{891}$ Idem, p. 328.

${ }^{892}$ Idem, p. 328-329.

${ }^{893}$ Idem, p. 329.
} 
maior". ${ }^{894}$ Ora, aqui Celso Furtado retoma o problema que vem assinalando desde a polêmica com Bulhões: a ausência de coordenação dos investimentos e a necessidade do planejamento. Reiterando esse ponto, temos que "numa economia de livre-empresa essa coordenação se faz um pouco ao acaso, e a probabilidade que tem cada um de fruir o máximo de vantagens indiretas é tanto maior quanto maior é o número de indivíduos que estão atuando simultaneamente". ${ }^{895}$ Dessa forma, a ausência de programação dos investimentos foi responsável pelo processo de industrialização do Brasil não utilizar todo seu potencial de recursos, justamente devido a essa falta de coordenação.

Essa argumentação recorre, também, a uma perspectiva histórica, para evidenciar os momentos de diferenciação e consolidação da indústria no centro-sul do país. Segundo Furtado, "o processo de industrialização começou no Brasil concomitantemente em quase todas as regiões. Foi no Nordeste que se instalaram, após a reforma tarifária de 1844, as primeiras manufaturas têxteis modernas e ainda em 1910 o número de operários têxteis dessa região se assemelhava ao de São Paulo". ${ }^{896}$ Esse processo de concentração na região paulista se iniciou durante a Grande Guerra, prosseguiu nas décadas seguintes e se intensificou após o segundo conflito mundial.

As consequências, sobretudo em termos de uma acentuada diferenciação nos níveis de renda "poderá dar origem a sérias tensões regionais" pois,

assim como na primeira metade do século XX cresceu a consciência de interdependência econômica — à medida que se articulavam as distintas regiões em torno do centro cafeeiro-industrial em rápida expansão - na segunda poderá aguçar-se o temor de que o crescimento intenso de uma região é necessariamente a contrapartida da estagnação de outras ${ }^{897}$

Nesse ponto, percebemos como o diagnóstico das disparidades regionais apresentado em Perspectivas da economia brasileira é transformado em alerta aos perigos sociais que essa desigualdade regional pode trazer para o Brasil. Dessa forma, a compreensão dos problemas do presente se radicaliza, apontando tensões sociais no país. Por sua vez, a constatação dos desequilíbrios exigirá do governo, para sua atenuação, um esforço coordenado, pois "uma vez iniciado esse processo, sua reversão espontânea é praticamente impossível" além de que, "é de esperar que tal processo tenda a prolongar-se extremamente". ${ }^{898}$ Ou seja, há tendências no presente que foram

\footnotetext{
${ }^{894}$ Idem, p. 329.

${ }^{895}$ Idem, ibidem.

${ }^{896}$ Idem, ibidem.

${ }^{897}$ Idem, p. 331.

${ }^{898}$ Idem, p. 331.
} 
captadas no exame da formação histórica dessas disparidades, sem dúvidas um dos elementos construtores de Formação econômica do Brasil e que confirma o diagnóstico apresentado no livro de 1958. Além disso, a argumentação recoloca a imbricação entre diagnóstico do presente e proposição de política econômica, aqui reivindicando o planejamento econômico para reverter as desigualdades regionais.

A acentuação desse problema ocorre nas regiões mais pobres em recursos naturais, onde a rentabilidade por unidade de capital investido é menor. Assim, surge a tendência à migração para regiões de maior produtividade, criando uma oferta excedente de mão-de-obra que tem o efeito de baixar os salários e elevar, ainda mais, a rentabilidade do capital. Essa vantagem relativa, por seu turno, atrai, também, os capitais disponíveis em outras regiões. A principal dificuldade em corrigir esse desequilíbrio é a impossibilidade de criar estímulos monetários e cambiais para regiões dentro do mesmo sistema nacional. Sua solução, portanto, "exigirá uma nova forma de integração da economia nacional, distinta da simples articulação que se processou na primeira metade do século", ${ }^{899}$ ou seja, o redirecionamento de produtos exportados para o mercado consumidor da região cafeeiro-industrial. Para Celso Furtado, isso dependerá de um melhor aproveitamento dos recursos da região nordestina, dificultado, até agora, pela herança secular da monocultura e da produção de subsistência. Em suas palavras,

a decadência da região nordestina é um fenômeno secular, muito anterior ao processo de industrialização do sul do Brasil. A causa básica daquela decadência está na incapacidade do sistema para superar as formas de produção e utilização dos recursos estruturados na época colonial. A articulação com a região sul, através de cartelização da economia açucareira, prolongou a vida do velho sistema cuja decadência se iniciou no século XVII, pois contribuiu para preservar as velhas estruturas monoprodutoras.

O sistema de monocultura é, por natureza, antagônico a todo processo de industrialização [...], só é compatível com um alto grau de renda per capta quando a densidade demográfica é relativamente baixa $^{900}$

Ora, nesse momento podemos perceber, nitidamente, como o diagnostico está fundamentado no exame histórico empreendido ao longo de Formação econômica do Brasil. O problema nordestino, que se apresenta como incontornável, gerando e agravando tensões regionais, decorre de sua própria evolução histórica, das consequências do regime monocultor na produção da pressão demográfica e da forma de integração com a região cafeeiro-industrial. Este sistema, predominantemente

\footnotetext{
${ }^{899}$ Idem, p. 333.

${ }^{900}$ Idem, ibidem.
} 
urbanizado, depende da oferta de alimentos de regiões agrícolas. Ora, a monocultura nordestina, caracterizada pela baixa produtividade, elevada concentração da propriedade e pressão demográfica, não fornece alimentos suficientes sequer para seu mercado regional, e ao vender sua produção para o Sul do país, cria uma demanda adicional para a região de maior produtividade e renda, pois possibilita a diminuição dos salários urbano-industriais, o que tende a agravar ainda mais as disparidades ao ampliar os fatores de atração dos trabalhadores de outras regiões do país.

Esse conjunto de problemas,

se por um lado exigirá a ruptura de formas arcaicas de aproveitamento
de recursos em certas regiões, por outro requererá uma visão de
conjunto do aproveitamento de recursos e fatores no país. A oferta
crescente de alimentos nas zonas urbanas, exigida pela
industrialização, a incorporação de novas terras e os translados inter-
regionais de mão-de-obra são aspectos de um mesmo problema de
redistribuição geográfica de fatores ${ }^{901}$

Esse diagnóstico, que fecha o livro Formação econômica do Brasil, aponta para a necessidade de alterações significativas na forma de produção agrícola, na distribuição da terra, na ocupação do território, tudo isso sob um esforço consciente de coordenação, compreendo a questão regional como parte integrante do problema nacional. Entretanto, as projeções feitas por Celso Furtado para a segunda metade do século, indicam que a despeito desses esforços dirigidos para o melhor aproveitamento da constelação de recursos, ao final do século XX, "o Brasil ainda figurará como uma das grandes áreas da terra em que maior é a disparidade entre o grau de desenvolvimento e a constelação de recursos potenciais". ${ }^{902}$

Ora, o diagnóstico dramático da situação da economia brasileira demonstra exatamente os limites da política econômica, do planejamento, das possibilidades de alterar uma situação cuja força não decorre de uma constelação provisória de variáveis econômicas, mas de um longo processo de maturação, de constituição depurada de processos econômicos seculares, formados ainda quando a dimensão nacional não se apresentava no horizonte. Mas não só, pois tudo isso foi agravado no período em que a integração significou a articulação de diversas regiões do país sob o comande de uma só, a cafeeiro-industrial.

Formação econômica do Brasil, portanto, pode ser lido pela caracterização dos sistemas econômicos, "dos pontos estratégicos" que dão inteligibilidade articuladora aos

\footnotetext{
${ }^{901}$ Idem, p. 334-335.

902 Idem, p. 335.
} 
processos econômicos. Mas há, também, uma historia subterrânea que emerge brevemente em alguns momentos, volta a submergir no caudal das dinâmicas econômicas do setor externo, e explode numa erupção poderosa neste último capítulo. As atividades de subsistência, que acomodaram a crise dos diversos sistemas econômicos, com o tempo, assistiram ao crescimento da população, da expansão do território e passam, agora sim, a exigir a acolhida no sistema industrial em vias de consolidação. Nesse momento crucial revela-se sua natureza antagônica a este sistema e seu resultado são as tensões sociais que tendem a se prolongar no tempo, a agudizar-se, podendo comprometer a própria ideia de nação. E mesmo as armas teóricas que lhe permitiram seu reconhecimento e diagnóstico, não terão efeito para reverter a tendência à crise nacional.

No início desta parte, nos colocamos a interrogação sobre as condições imediatas de produção de Formação econômica do Brasil, e de como ela interagiu com a obra. Dissemos que os anos finais da década de 1950 foram de supremacia do desenvolvimentismo e que, portanto, mesmo as proposições liberais eram formuladas nos termos e sobre os problemas propostos por aquela corrente. $\mathrm{O}$ aspecto de crítica à esta corrente aparece no livro de 1959 mas, em grande parte, é a republicação dos capítulos III, IV e V, de A economia brasileira. Isso evidencia duas coisas. Primeiramente, que o diagnóstico sobre a economia cafeeira e, também sobre os problemas do presente, sobretudo as tensões que o setor industrial impõe ao conjunto do sistema econômico permaneceram e, portanto, foram corroboradas pelos acontecimentos. O arcabouço teórico construído por Celso Furtado conseguiu captar as tendências da economia. A republicação, no entanto, expressa também, que não era necessário adicionar novos elementos, pois, como procuramos mostrar, o diagnóstico do presente, ao estar alicerçado em uma interpretação econômica sustentada seja por conceitos elaborados historicamente, seja embasado em uma epistemologia da teoria econômica, teve sua validade corroborada pela própria evolução dos acontecimentos reais.

Assim, nos parece que a conjunção entre verificação do valor heurístico do método para a compreensão do presente e o arrefecimento da contraofensiva liberal abriu a Celso Furtado a possibilidade de uma nova abordagem sobre o passado 
brasileiro. Abordagem esta que, informada pelos problemas do presente, mas não apenas, viabilizou-se em uma leitura diferente daquela de A economia brasileira, pois, agora, o passado brasileiro adquire mais substância, uma materialidade acessada pelos conceitos formulados anteriormente, mas que agora se renovarão, não apenas pelos problemas específicos do presente, mas porque serão contrapostos com a experiência histórica brasileira, que lhe formulará novas questões, apresentará processos políticosociais que exigirão dos conceitos uma abertura para situações novas, diversas do quadro de diagnóstico que vinha orientado a preocupação de Celso Furtado.

Trata-se, uma vez mais, de responder ao presente recorrendo ao passado e também de integrar compreensivamente o passado no arcabouço teórico, demonstrar que este tem uma aplicabilidade que transcende a análise da economia brasileira dos últimos cinquenta anos. Foi o que procuramos reconstituir nesta análise. Que problemas enfrenta uma economia colonial com mão-de-obra escrava? O que acontece após a crise de um produto de exportação, sobretudo quando a atividade de subsistência que absorve população desocupada é móvel, como a pecuária, e encontra amplas terras livres? Quais possibilidades existem para um mercado interno de relativas proporções, com predominância de mão-de-obra livre quando não encontra um desenvolvimento manufatureiro para atender suas necessidades de consumo? Ou, diferentemente, é possível que uma economia com excesso de mão-de-obra tenha dificuldades para recrutá-la quando do surgimento de um novo surto exportador? Essas questões, e esboçamos apenas algumas das levantadas em Formação econômica do Brasil, não constavam em seus escritos anteriores, não eram problemas metodológicos. Foi a incursão sobre o passado brasileiro que exigiu respostas, demandou revisões, impôs maior concretude e menos generalização a um modelo já preocupado com as especificidades históricas. A leitura da formação econômica do Brasil pode parecer, e em alguns momentos parece, a aplicação de um método já acabado em uma massa maleável de evidências, dados e acontecimentos do passado. Entretanto acreditamos que é mais que isso. Celso Furtado empreende uma interpretação da formação histórica de nossa economia que revelou novas questões para os pesquisadores e, mais ainda, exigiu de seu autor a reconsideração de seus próprios conceitos e categorias, e é a partir dessa exigência que descortinou abordagens e problemas para a história econômica. 


\section{Conclusão}

Concluir o trabalho após o exame de Formação econômica do Brasil pode não ser a melhor escolha metodológica, não fosse nossa convicção de que o trabalho interpretativo que empreendemos não teve a pretensão de ser exaustivo no conjunto de questões suscitadas por esta obra.

A tese foi organizada em torno da questão da relação entre história e teoria econômica. Essa relação perpassa os trabalhos de Celso Furtado e forneceu nossa chave de leitura. Foi no movimento oscilante de construção de uma teoria econômica, permeada pela história, nos tensionamentos impostos a conceitos e categorias, no enrijecimento conceitual de circunstâncias históricas que apreendemos a dinâmica do pensamento de Celso Furtado. Operação analítica e compreensiva possibilitada pelo método historiográfico, em sua vinculação de trajetória biográfica e intelectual, condicionantes econômicos, políticos, culturais e sociais, cristalizados na produção escrita cujo propósito é a intervenção na realidade para consolidar um projeto de futuro, entendido e constituído a partir da compreensão particular do passado, inteligível na posição específica de seu autor, no presente.

A relação entre história e teoria econômica organizou os textos analisados de maneira peculiar. A preocupação do economista brasileiro foi formular uma teoria do desenvolvimento econômico que explicasse as peculiaridades dos países subdesenvolvidos, sobretudo, a economia brasileira. Para isso, precisou desenvolver três respostas complementares para o mesmo problema.

Em primeiro lugar, os fundamentos epistemológicos de sua teoria do desenvolvimento econômico exigiram e resultaram em uma revisão da história do pensamento econômico: deslindou as dificuldades de surgimento de uma teoria voltada para os países subdesenvolvidos ao indicar os autores que não se preocuparam com o problema do desenvolvimento, pois refletiam sobre uma realidade historicamente circunscrita, a Inglaterra dos séculos XVIII e XIX. Daí que a crítica de Celso Furtado denunciasse essa pretensão universalista, a ausência de considerações sobre os processos históricos específicos. Dito de outro modo, evidenciou como a história do pensamento econômico foi consolidada, justamente, excluindo as particularidades históricas, estabelecendo uma universalidade conceitual que se tornou desajustada frente aos problemas do desenvolvimento econômico da segunda metade do século XX. 
A fundamentação epistemológica de sua teoria necessitava, também, passar por outro crivo: a explicação de problemas concretos. Surge daí o empenho em formular diagnósticos conjunturais da economia brasileira. Os resultados aparecem logo em 1950, com "Características gerais da economia brasileira" e persistem, sendo alterados, retificados, reformulados em praticamente todos os textos que examinamos. Também nestes diagnósticos, a ênfase na realidade específica serviu para contrapor-se à teoria econômica universal, exigindo abertura para as peculiaridades históricas.

O terceiro elemento a considerar é precisamente este: a relação entre teoria econômica e história deve cobrir e fornecer conceitos e categorias ao exame desta última. Nesse ponto, por mais que sejam os conceitos da teoria do desenvolvimento econômico que dão inteligibilidade à história, estes já são formulados considerando as especificidades históricas; surgem ferramentas compreensivas com uma abertura e permeabilidade à história, ainda que procurem organizá-la. O resultado efetivo dessa operação, a maneira como esses dois polos foram equilibrados, foi explicitado em nosso exame de A economia brasileira e Formação econômica do Brasil. Nesse quadro, é preciso ressaltar a importância de A Economia Brasileira para a compreensão de Formação econômica do Brasil. Algo que só foi possível pela reconstituição, pelo crescendo da análise e que é decorrência deste método historiográfico que procura deslindar o desenvolvimento de formações conceituais remetidas ao entorno de problemas sociais, políticos e econômicos, nacionais e internacionais, no qual o autor se insere e é inserido pelos debates, exigindo respostas, formações conceituais, elaborações teóricas que, percebidas em sua sucessão, em seu momento de pronunciamento, empresta continuidade e revela rupturas na formação do pensamento de Celso Furtado;

Sem esquecermos nosso eixo argumentativo, é preciso considerar, reversivamente, que a relação entre teoria e história é também a chave de análise do método historiográfico que utilizamos no trabalho. Se nossa preocupação foi escrutinar a obra de Celso Furtado enquanto expressão de suas circunstâncias biográficas e sociais, captando a transtemporalidade operando em suas proposições, a tensão entre as duas disciplinas é uma entrada consistente.

Os circunstanciamentos biográficos e sociais de Celso Furtado foram examinados a partir de seu empenho em participar dos debates no âmbito do pensamento econômico brasileiro, erigindo sua obra com a preocupação de contrapor-se a proposições teóricas e propostas de política econômica específicas da conjuntura dos anos de 1950. Uma de suas principais formas de intervenção nestes debates foi 
demonstrando que sua teoria do desenvolvimento tinha uma abertura para a história, que lhe permitia compreender os problemas econômicos e lhe fornecer as soluções acertadas para cada momento.

Diagnóstico de presente, portanto, aliava-se às projeções da economia brasileira, às perspectivas de futuro que, através do planejamento econômico, permitia-lhe operacionalizar o poder do presente influir no futuro. Igualmente, a reconstituição do passado é uma forma de conciliação da relação entre história e teoria econômica, sob o signo da transtemporalidade, fazendo com que passado e futuro sejam articulados pelo presente, um presente que recebia as constrições da formação da economia brasileira que, também, indicava as tendências do futuro. Assim, a própria resposta para a interação entre as disciplinas adquiriu temporalidade e foi se transformando ao longo do tempo.

Se a relação entre história e teoria econômica nos forneceu o acesso aos textos de Celso Furtado e permitiu a operacionalização do método historiográfico, este último está presente, também, nos procedimentos formais que adotamos na tese. Com efeito, à medida que adentramos na análise dos textos de Celso Furtado, ao procurarmos deslindar como expressavam debates, conflitos; enquanto buscamos as conexões entre os escritos, investigando rupturas, continuidades, formulações conceituais, reelaborações, em suma, como respondiam a problemas específicos, ficava cada vez mais difícil o diálogo com a bibliografia disponível. O foco na filigrana, nos encadeamentos, se por um lado foi de fundamental importância para revelar os movimentos do autor, da obra e do meio - constituindo não uma preferência exegética, mas um procedimento cognitivo consequente com nossa formulação do problema dos desdobramentos da relação entre história e teoria econômica na obra e em seus cirscuntanciamentos - por outro nos fez perder elementos da paisagem interpretativa que cerca o autor. $\mathrm{O}$ trabalho deixa esse diálogo em aberto, reiterando a necessidade de um estudo de conjunto da bibliografia sobre Celso Furtado, uma reflexão que avalie as diversas propostas, os temas, as abordagens teóricas e sirva, também, para que tenhamos uma consciência mais clara de como a memória de Celso Furtado foi construída pelas diversas ciências humanas.

Fez parte de nossas preocupações, também, estabelecer relações entre os textos de Celso Furtado e a conjuntura imediata da economia brasileira, restituindo-lhes o que têm de imediato e historicamente circunscrito. Daí que nosso trabalho exija do intérprete, não apenas a familiaridade com a obra de Furtado, mas também dos objetos 
sobre os quais se debruçou: história econômica geral, a economia brasileira e da América Latina. No entanto, esses dois temas, tão imbricados em nossa concepção, aguardam esforço sistemático, sobretudo no mapeamento das políticas cambial, monetária e fiscal, mas que consiga explicá-las em conexão com os textos de Celso Furtado.

É preciso considerar, também, outros temas que aguardam estudos e pesquisas, e que nos auxiliariam na compreensão da obra de Celso Furtado. Embora tenhamos insistido que o estudo das fontes e obras citadas não seja o melhor caminho de acesso a seu pensamento, alguns aspectos demandam esclarecimentos. Quais foram os autores que mobilizou para elaborar a comparação com os Estados Unidos? Eram representativos dos debates sobre a história estadunidense nos anos de 1950? A retomada da história do pensamento econômico buscando encontrar elementos de uma teoria do desenvolvimento econômico tem precedentes nos teóricos do desenvolvimento econômico? Se respondermos afirmativamente, o que particulariza o esforço de Celso Furtado nesse campo? Essas questões iluminariam algumas de suas escolhas metodológicas, acrescentando elementos para compreender a elaboração e formulação de seu pensamento.

Questão semelhante seria a investigação dos desdobramentos posteriores que a obra de Celso Furtado inspirou. Se dissemos que as formas de conciliação entre história e teoria econômica não se restringiram à aplicação de um modelo teórico, nem se resolveram somente na empiria, é porque a fricção de ambas produz novos questionamentos, novos problemas, novas questões. Seria possível pensar os capitais holandeses no financiamento e comercialização do açúcar sem a atenção dada ao tema em Formação econômica do Brasil? A revisão que os historiadores fizeram da desagregação da economia mineira, das linhas de abastecimento, das manufaturas, da agricultura mercantil em Minas Gerais não resulta, também, das questões propostas neste livro? As origens da indústria e da industrialização brasileira, sobretudo a hipótese de sua relação com o setor cafeeiro, não são decorrências da importância que este tema adquiriu na problemática furtadiana e que procuramos indicar?

Questões que tornam uma abordagem exaustiva e conclusiva da análise de Formação econômica do Brasil tão difícil, pois revelam quão aberta permanece a obra de Celso Furtado. Sobretudo se pensarmos: o que resulta de seu esforço? Será que sua obra está circunscrita à conjuntura de sua formulação, em termos temporais e geográficos? Nada mais distante disso. Ao procurar compreender o presente, 
mobilizando o passado, ampliando a previsibilidade do futuro, ao diagnosticar os problemas de sua vivência imediata, Celso Furtado não fez apenas análise histórica ou diagnosticou o presente; nem, tampouco, unicamente formulou perspectivas para o futuro. Nem história, nem teoria ou política econômica. Ao sintetizar criativamente estes três elementos no desiderato de explicar os problemas das economias brasileira e latino-americanas, Celso Furtado formulou uma nova teoria. Nova, porque aberta para a história, para o passado enquanto elemento constitutivo essencial da realidade. Nova, pois comprometida com uma explicação estrutural, mas sensível às medidas urgentes do presente. Porque compreendeu o entrelaçamento entre os tempos históricos e formulou uma dialógica entre teoria e prática, ação e pensamento, sua teoria se torna tão original: nascida da prática, inspirada na história, comprometida com o futuro. Hoje, paira como um farol aos que pretendem compreender os países subdesenvolvidos, uma notável contribuição nascida na periferia que, voltada para a constituição histórica destas sociedades, soube aproveitar o que havia de disponível nas ciências humanas, avaliando-as, ruminando-as, sopesando-as com a balança da realidade presente, com o passado e com futuro. Da síntese de seus procedimentos, surge uma compreensão inovadora para a história econômica. 


\section{BIBLIOGRAFIA}

\section{Fontes Primárias}

\section{Obras de Celso Furtado}

FURTADO, Celso. A estrutura da Comissão do Serviço Civil dos Estados Unidos. Revista do Serviço Público, Brasil, ano VII, v. I, n. 2, fevereiro de 1944, pp. 66-69;

. Notas sobre a administração de pessoal no Governo Federal Americano. In: Revista do Serviço Público, Brasil, ano VII, v. III, n. 1, julho de 1944, pp. 49-53;

. Teoria da estrutura em organização. In: Revista do Serviço Público, Brasil, ano IX, v. I, n. 2. Brasil, fevereiro de 1946, pp.17-26;

—. Teoria do Departamento de Administração Geral. In: Revista do Serviço Público, Brasil, Ano, IX, v. II, n. 2. Brasil, maio de 1946, pp. 25-32.

. "Trajetória da democracia na América". Revista do Instituto Brasil-Estados Unidos. Rio de Janeiro, vol. V, No 11, 1947, pp. 5-27.

—. Na Iugoslávia. Panfleto, Ano 1, nº 11, quarta semana de outubro de 1947.

A crise econômica inglesa. In: Observador econômico e financeiro. Ano XII, n. ${ }^{\circ} 144$, janeiro de 1948;

Economia colonial no Brasil nos séculos XVI e XVII. São Paulo: Hucitec; ABPHE, 2001.

. França: evolução da política financeira. Observador econômico e financeiro. Ano XIII, n. ${ }^{\circ}$ 152, setembro de 1948.

Resenha de Jean Marchal, Les mecanismes de prix. Librarie de Médicis, 1948. Revista Brasileira de Economia, v. 2; n. 4, 1948, pp. 174-177.

Resenha de Richard Lewinsohn, Trustes y carteles, sus orígenes y influencia en la economia mundial. Editorial Claridad: Buenos Aires, 1948. Revista Brasileira de Economia, v. 3; n. 1, 1949, pp. 103-106.

- Características gerais da economia brasileira. Revista Brasileira de Economia. Rio de Janeiro, Fundação Getúlio Vargas, Ano 4, N. 1, março de 1950.

. Formação de capital e desenvolvimento econômico. In: Memórias do desenvolvimento. Ano 1; N. 1, junho de 2007. Rio de Janeiro: Centro Internacional Celso Furtado de Políticas para o Desenvolvimento.

A técnica do planejamento econômico. Palestra proferida na Escola Superior de Guerra, em 26 de outubro de 1953. Documento reservado A28-53.

A programação do desenvolvimento econômico. Revista do Conselho Nacional de Economia, Rio de Janeiro, Ano II, Números 19-20, Novembro-dezembro de 1953.

A economia brasileira. (Contribuição à análise de seu desenvolvimento). Rio de Janeiro: A noite, 1954.

Desenvolvimento Econômico (Ensaio de Interpretação histórico-analítica). Revista Econômica Brasileira, v. 1. N. 1, jan-mar., 1955. 
- Resenha de Migration and economic growth de Brinley Thomas. Econômica Brasileira. Rio de Janeiro: Clube dos Economistas, N.1, V. 1, janeiro-março, 1955.

. Comentário sobre a Exposição Geral da Situação econômica do Brasil (1954). Conselho Nacional de Economia. Econômica Brasileira. Rio de Janeiro: Clube dos Economistas, N.1, V. 1, janeiro-março, 1955.

Resenha de Princípios de economia monetária, vol II, de Eugênio Gudin. Econômica Brasileira, Rio de Janeiro: Clube dos Economistas, N. 1. Vol. 2, abril-junho, 1955.

- Resenha de The Theory of Economic Growth de W. Arthur Lewis, Londres, 1955. Econômica Brasileira. Rio de Janeiro: Clube dos Economistas, n. 1. Vol. 2, janeiro-março, 1956, p. 52.

Resenha de Manual de Economia Política, Instituto de Economia da Academia de Ciências da URSS. Editora Grijalbo, 1956. Econômica Brasileira. Rio de Janeiro: Clube dos Economistas, n. 1. Vol. 2, janeiro-março, 1956.

_. Resenha de American Economic Review, Pappers and Proceedings of the Sixty-eight Annual Meeting, maio, 1956. Econômica Brasileira. Rio de Janeiro: Clube dos Economistas, n. 2. Vol. 2, abril-junho, 1956.

- Setor Privado e Poupança. Econômica Brasileira. Rio de Janeiro: Clube dos Economistas, n. 2. Vol. 2, abril-junho, 1956.

Resenha de Solidariedad o Desintegración de Gunnar Myrdal. Fondo de Cultura Económica, México 1956. Econômica Brasileira. Rio de Janeiro: Clube dos Economistas, n. 4. Vol. 2, outubro-dezembro. 1956.

__ Encontro Este-Oeste de economistas. Econômica Brasileira. Rio de Janeiro: Clube dos Economistas, n 3 e 4. Vol. 2, julho-dezembro, 1957.

- Perspectivas da economia brasileira. Rio de Janeiro: Ministério da Educação e Cultura: Instituto Superior de Estudos Brasileiros, 1958, (Textos Brasileiros de Economia).

—. Formação e conômica do Brasil. 36 a edição. São Paulo, Cia das Letras, 2007.

_. Entre inconformismo e reformismo. [1987] In: FURTADO, Celso. Essencial Celso Furtado. Organização de Rosa Freire d'Aguiar. São Paulo: Cia das Letras, 2013.

___ Obra autobiográfica. Três Tomos. Organização de Rosa Freire d'Aguiar. São Paulo: Paz e Terra: 3. Volumes, 1997.

\section{Outras fontes primárias}

BULHÕES, Octavio Gouveia de. Estudos sobre a programação do desenvolvimento econômico. Revista do conselho Nacional de Economia. Rio de Janeiro, Ano II, Números 19-20, Novembro-dezembro de 1953.

- Considerações adicionais sobre a programação do desenvolvimento econômico. Revista do conselho Nacional de Economia. Rio de Janeiro, Ano II, Números 19-20, Novembro-dezembro de 1953.

CAMPOS, Roberto. A Lanterna na popa: memórias. Rio e Janeiro: Topbooks, 1994. 
COMISSÃO ECONÔMICA PARA AMÉRICA LATINA. Estudio Económico de América Latina, 1948. Nações Unidas, Departamento de Assuntos Econômicos, Nova York, 1949. (E/CN. 12/82: Número de venda: 1949. II. G. I).

GUDIN, Eugênio. Apresentação. Conjuntura Econômica. Ano 1. Número 1, Novembro de 1947.

A mística do planejamento. Correio da manhã. Rio de Janeiro, terça-feira, dia 29 de maio de $1953,1^{\circ}$ Caderno, fl. 2.

A mística do planejamento II. Correio da manhã. Rio de Janeiro, terça-feira, dia 2 de julho de 1953, $1^{\circ}$ Caderno, fl. 2.

- A mística do planejamento III - A filosofia. Correio da manhã. Rio de Janeiro, terça-feira, dia 2 de julho de 1953, $1^{\circ}$ Caderno, fl. 2.

Op.cit., fl.2.

A mística do planejamento IV - A órbita do Estado. Correio da manhã.

A mística do planejamento IV - A órbita do Estado. Correio da manhã. Rio de Janeiro, terça-feira, dia 9 de junho de 1953, $1^{\circ}$ Caderno, fl. 2.

A mística do planejamento V - As Forças de Equilíbrio. Correio da manhã. Rio de Janeiro, quinta-feira, 11 de junho de 1953, $1^{\circ}$ Caderno, fl. 2

A mística do planejamento V - As Forças de Equilíbrio. Correio da manhã. Rio de Janeiro, quinta-feira, 11 de junho de 1953, $1^{\circ}$ Caderno, fl. 2.

- Observações do prof. Eugênio Gudin. Econômica Brasileira, Rio de Janeiro: Clube dos Economistas, N. 1. Vol. 2, abril-junho, 1955.

NURKSE, Ragnar. "Notas sobre o trabalho do Sr. Furtado relativo a 'Formação de Capitais e Desenvolvimento Econômico. In: Memórias do desenvolvimento. Ano 1; N. 1, junho de 2007. Rio de Janeiro: Centro Internacional Celso Furtado de Políticas para o Desenvolvimento.

- Problemas da formação de capital em países subdesenvolvidos. In: Memórias do desenvolvimento. Ano 1; N. 1, junho de 2007. Rio de Janeiro: Centro Internacional Celso Furtado de Políticas para o Desenvolvimento.

PRADO JÚNIOR, Caio. Formação Econômica do Brasil (Colônia) [1942]. São Paulo: Publifolha, 2000.

História econômica do Brasil [1945]. São Paulo: Brasiliense, 1977.

PREBISCH, Raúl. O desenvolvimento econômico da América Latina e alguns de seus principais problemas. In: BIELSCHOWSKY, Ricardo. Cinqüenta anos de pensamento na Cepal. Rio de Janeiro, Record, 2000, volume 1.

. Os principais problemas da técnica preliminar de programação [1953]. In: PREBISCH, Raúl, O manifesto latino-americano e outros ensaios. Adolfo Gurrieri (org). Rio de Janeiro: Contraponto, Centro Celso Furtado, 2013.

A mística do equilíbrio espontâneo na economia. Diário de Notícias. São Paulo, domingo, 8 de novembro de 1953, terceira seção, oitava página.

A mística do equilíbrio espontâneo na economia [segundo artigo]. Diário de Notícias. São Paulo, domingo, 15 de novembro de 1953, terceira seção, oitava página. 
REVISTA DO CONSELHO NACIONAL DE ECONOMIA. "Problemas do desenvolvimento." [editorial]. Revista do conselho Nacional de Economia. Rio de Janeiro, Ano II, Números 19-20, Novembro-dezembro de 1953.

SIMONSEN, Roberto. História econômica do Brasil, 1500-1820 [1938]. São Paulo: Companhia editora nacional, 1977.

\section{Bibliografia citada}

ALCOUFFE, Alain. "Furtado, o Brasil e os economistas franceses: influências cruzadas". In: COELHO, Francisco Silva \& GRANZIERA, Rui Guilherme (orgs). Celso Furtado e a Formação econômica do Brasil (Edição comemorativa dos 50 anos de publicação (1959-2009)). Prefácio Fernando Henrique Cardoso. São Paulo, Editora Atlas, 2009.

ARRUDA, José Jobson de Andrade Arruda. O Brasil no comércio colonial. São Paulo, Ática, 1980.

Historiografia. Teoria e prática. São Paulo: Alameda, 2014.

- Historiografia: consciência crítica da produção histórica. In: idem. Historiografia. Teoria e prática. São Paulo: Alameda, 2014.

José da Silva Lisboa: texto e contexto. In: idem. Historiografia. Teoria e prática. São Paulo: Alameda, 2014.

ARRUDA, José Jobson de Andrade. São Paulo nos séculos XVI e XVII. São Paulo: Imprensa Oficial, 2011.

BASTOS, P. P. Z. "Ortodoxia e heterodoxia econômica antes e durante a era Vargas". In: BASTOS \& FONSECA (orgs). A era Vargas: desenvolvimentismo, economia e sociedade. São Paulo: Editora da Unesp, 2012 .

A construção do nacionalismo econômico de Vargas. In: BASTOS, P. P. Z. e FONSECA, P. C. D (orgs). A Era Vargas. Desenvolvimentismo, economia e sociedade. São Paulo, Editora Unesp, 2013.

BASTOS, P. P. Z. e FONSECA, P. C. D (orgs). A Era Vargas. Desenvolvimentismo, economia e sociedade. São Paulo, Editora Unesp, 2013.

BIANCONI, Renata. L'oeuvre de Celso Furtado à Paris: le parcours d'un intellectuel et homme d'État. (Tese de doutorado, História Moderna e Contemporânea, Université Paris-Sorbonne), 2014.

BIELSCHOWISKY, R. Pensamento econômico brasileiro. O ciclo ideológico do desenvolvimentismo 1930-1964. Rio de Janeiro: Contraponto, 2000.

BIELSCHOWISKY, Ricardo. Ideologia e desenvolvimento: Brasil, 19301964. In: LOUREIRO, Maria Rita. 50 anos de ciência econômica no Brasil. Pensamento, instituições, depoimentos. Rio de Janeiro: Editora Vozes, 1997.

Eugênio Gudin (1886-1986). In: SZMRECSÁNYI, T; COELHO, F. S. ATLAS, 2004. 
. Formação econômica do Brasil: uma obra prima do estruturalismo cepalino. In: ARAÚJO, Tarcisio Patricio de; WERNECK VIANNA, Salvador Teixeira; MACAMBIRA, Júnior. (orgs) 50 anos de Formação Econômica do Brasil: ensaios sobre a obra clássica de Celso Furtado. Rio de Janeiro: Ipea, 2009.

BORJA, Bruno. A formação da teoria do subdesenvolvimento de Celso Furtado. Rio de Janeiro, IE-UFRJ, 2013 (tese de doutorado).

BOURDIEU, Pierre. “A Ilusão Biográfica” [1986]. In: AMADO, Janaína; FERREIRA, Marieta de Moraes (coord). Usos e abusos da história oral. Rio de Janeiro, Editora FGV, 2006, p. 183-191.

CANO, Wilson. Desequilíbrios regionais e concentração industrial no Brasil, 19301970. Campinas: São Paulo: Editora do Instituto de Economia, Unicamp, 1998.

"Crise de 29, soberania na política econômica e industrialização". In:

BASTOS \& FONSECA (orgs). A era Vargas: desenvolvimentismo, economia e sociedade. São Paulo: Editora da Unesp, 2012.

CEPÊDA, Vera Alves. Raízes do pensamento político de Celso Furtado: desenvolvimento, nacionalidade e Estado democrático. (Dissertação de Mestrado, Ciências Sociais, FFLCH-USP), 1998.

COHN, Amélia. Crise regional e planejamento. São Paulo: Perspectiva, 1976.

COLISTETE, Renato Perin. A Cepal e os industriais paulistas na primeira metade da década de 1950. História Econômica \& História de Empresas, XI, 2, jul./dez., 2006.

CORREAA, Maria Letícia. Um estudo sobre o debate desenvolvimentista nas páginas de O Observador Econômico e Financeiro (1936 - 1954). Anais do XXVI Simpósio Nacional de História - ANPUH, São Paulo, julho 2011.

COUTINHO, Maurício C. "A teoria econômica de Celso Furtado: formação econômica do Brasil." In: LIMA, Marcos Costa. \& DAVID, Maurício Dias (orgs). A atualidade do Pensamento de Celso Furtado. Goiás: Verbena Editora, 2008.

Economia. Belo Horizonte: n. 18, v. 3, setembro-dezembro, 2008.

A política cambial: instrumento privilegiado na análise da Formação econômica do Brasil In: COELHO; GRANZIERA, (orgs). Celso Furtado e a Formação econômica do Brasil (Edição comemorativa dos 50 anos de publicação (1959-2009). Prefácio Fernando Henrique Cardoso. São Paulo, Editora Atlas, 2009, pp. 160-170.

DOSMAN, J. Raúl Prebisch (1901-1986): a construção da América Latina e do terceiro mundo. Rio de Janeiro: Contraponto, 2011.

DOSSE, François. O desafio biográfico: São Paulo: Edusp, 2010.

DRAIBE, Sonia. Rumos e metamorfoses. Um estudo sobre a constituição do Estado e as alternativas da industrialização no Brasil, 1930-1960. Rio de Janeiro: Paz e Terra, 2004.

EAGLETON, Terry. As ilusões do pós-modernismo. Rio de Janeiro: Jorge Zahar Editor, 1998.

FEBVRE, Lucien. Martin Luther: un destin [1928]. Paris: Presses Universitaires de France: 2009.

FOGEL, \& Elton. Qual de los caminhos al passado. México: Fondo de Cultura Económica 1983. 
FONSECA, Pedro Cezar Dutra Fonseca. Vargas: o capitalismo em construção, 19061954. São Paulo: Editora Brasiliense, 1999.

FONSECA, Pedro Cezar Dutra. Instituições e política econômica: crise e crescimento do Brasil na década de 1930. In: BASTOS, P. P. Z. e FONSECA, P. C. D (orgs). A Era Vargas. Desenvolvimentismo, economia e sociedade. São Paulo, Editora Unesp, 2013.

FURTADO, André Tosi. As contribuições de Caio Prado Júnior à Formação econômica do Brasil. In: COELHO; GRANZIERA, (orgs). Celso Furtado e a Formação econômica do Brasil (Edição comemorativa dos 50 anos de publicação (1959-2009). Prefácio Fernando Henrique Cardoso. São Paulo, Editora Atlas, 2009, pp. 72-88.

GARCIA, Afrânio. Entre fardas, fantasias e figurinos matemáticos para simbolizar condutas humanas: a "obra autobiográfica de Celso Furtado". Trabalho apresentado no Simpósio El recuerdo letrado: escritura memorialistica de artistas e intelectuales latinoamericanos del siglo XX. Buenos Aires, 23-35 de noviembre de 2011. [Texto provisório].

GIAMBIAGI, Fábio (et. alli). Economia brasileira contemporânea (1945-2004). Rio de Janeiro, Elsevier, 2005.

GONÇALVES, José Sergio R. C. Apresentação. In: FURTADO, Celso. Teoria e política do desenvolvimento econômico. São Paulo: Abril Cultura, 1983 (Os Economistas).

GRIMMER-SOLEN, Erik. The rise of historical economics and social reform in Germany, 1864-1894. Oxford, Clarendon Press, 2005.

GUIMARÃES NETO, Leonardo: "Itinerário de Celso Furtado até Formação econômica do Brasil". In: ARAÚJO, Tarcisio Patricio de; WERNECK VIANNA, Salvador Teixeira; MACAMBIRA, Júnior. (orgs) 50 anos de Formação Econômica do Brasil: ensaios sobre a obra clássica de Celso Furtado. Rio de Janeiro: Ipea, 2009, pp. 247-270.

GURRIERI, Adolfo. Las ideas del joven Prebisch. Revista de la Cepal, n. 75, diciembre 2001, pp. 69-82; GONZÁLEZ, Norberto \& POLLOCK, David. Del ortodoxo al conservador ilustrado. Raúl Prebisch en la Argentina, 1923-1943. Desarrollo económico. Vol. 30, n. 120, Jan-Mar, 1991, PP. 455-486.

HOBSBAWM, Eric. Da revolução industrial inglesa ao imperialismo. Rio de Janeiro, Forense Universitária, 2009.

IANNI, Octavio. Estado e planejamento econômico no Brasil. 2a ed. Rio de Janeiro, Civilização Brasileira, 1977.

IGLÉSIAS, Francisco. Celso Furtado: pensamento e ação. In: Idem. História e ideologia. São Paulo: Editora Perspectiva. 1971, pp. 159-234;

KUZNETS, Simon, "Os países subdesenvolvidos e a fase pré-industrial nos países avançados". In: AGARWALA, A. N \& SINGH, S. (orgs). A economia do subdesenvolvimento. Rio de Janeiro: Forense Universitária, 1969, pp. 141-158.

LAFER, Celso. O planejamento no Brasil - observações sobre o Plano de Metas (1956-1961). In: LAFER, Betty Mindlin (org). O planejamento no Brasil. São Paulo, Perspectiva, 1987.

LECAILLON, Jacques. Regards sur l'oeuvre de Jean Marchal. Revue économique. Volume 48, n²4, 1997. pp. 781-804. 
LOPES, Tiago Cararinha. Planejmaneto para a industrialização e o desenvolvimento: $o$ Brasil entre as lógicas de mercado e controle (1930-1956). Uberlândia: UFU (Dissertação de mestrado), 2011.

LOUREIRO, M. R. Economistas no Governo. Rio de Janeiro: FGV, 1997.

Circulation internationale des économistes brésilienes. Cahiers du Brésil contemporain, 2004-2005; nº 57/58 - 59/60.

LOVE, Joseph. A Construção do Terceiro Mundo. Teorias do subdesenvolvimento no Brasil e na Romênia. Rio de Janeiro: Paz e Terra, 1995.

MAKOWER, Helen. Review of Problems of capital formation in underdevelopment countries, by Ragnar Nurkse. The Economic Journal, V. 63, N. 252, (dec. 1953).

MALAN, P., Et ali. Política econômica externa e industrialização no Brasil (1939-52). Rio de Janeiro: IPEA, INPES, 1977.

MALlORQUIN, Carlos. Celso Furtado: um retrato intelectual. [1993] São Paulo: Xamã; Rio de Janeiro: Contraponto, 2005.

"Celso Furtado el hacedor del estruturalismo latino-americano". In: CORSI, Francisco Luiz; CAMARGO, José Marangoni (orgs). Celso Furtado e os desafios do desenvolvimento. Marília-SP: Oficina Universitária, 2010.

MENDONÇA, Marina Gusmão de. "A formação intelectual de Celso Furtado". In: CORSI, Francisco Luiz; CAMARGO, José Marangoni (orgs). Celso Furtado e os desafios do desenvolvimento. Marília-SP: Oficina Universitária, 2010, pp. 1-19.

MONTEIRO, Jorge Vianna; CUNHA, Luiz Roberto Azevedo. Alguns aspectos da evolução do planejamento econômico no Brasil. Pesquisa e Planejamento econômico. Rio de Janeiro, V. 4, N. 1, Fevereiro de 1974, pp. 1-24.

MORAIS, Reginaldo. Celso Furtado: o subdesenvolvimento e as ideais da Cepal. São Paulo: Editora Ática, 1995.

NOVAIS, Fernando Antonio. Portugal e Brasil na crise do Antigo Sistema Colonial (1777-1808). São Paulo: Hucitec., 2000.

- Sobre Caio Prado Júnior. In: Aproximações. Estudos de história e historiografia. São Paulo: Cosac Naify, 2005.

Entrevista. In: PRADO JÚNIOR, Caio. Formação do Brasil contemporâneo (Colônia). São Paulo, Cia das Letras, 2012.

NOVAIS, F. \& FORASTIERI. R. S. Introdução. In: idem (orgs), Nova história em perspectiva. São Paulo: Cosac e Naify, 2013, volume 1.

OLIVEIRA, Francisco. "A navegação venturosa" [1983]. In: Idem. A navegação venturosa. Ensaios sobre Celso Furtado. São Paulo: Editora Boitempo, 2003.

OLIVEIRA, Francisco. Viagem ao olho do furacão: Celso Furtado e o desafio do pensamento autoritário brasileiro. In, idem., A navegação venturosa. Ensaios sobre Celso Furtado. São Paulo: Editora Boitempo, 2003.

OLIVEIRA, Maria Teresa Ribeiro de. O Século XIX, Segundo Furtado. EconomiA, Selecta, Brasília (DF), v.10, n.4, dezembro 2009. 
ORENSTEIN, Luiz, SOCHACZEWSKI, Antonio Claudio. Democracia com desenvolvimento: 1956-1961. In: PAIVA, M. A.( org.). A ordem do Progresso. Cem anos de política econômica republicana, 1889-1989. Rio de Janeiro: Campus, 1992.

PAIVA, Marcelo de Abreu (orgs). A ordem do progresso. Cem anos de política econômica republicana (1889-1989). Rio de Janeiro, Campus, 1994.

PAULA, Christiane Jalles; LATTMAN-WELTMAN, Fernando (Coord). Dicionário Histórico - Biográfico Brasileiro Pós -30: Rio de Janeiro: CPDOC/FGV. Disponível em http://cpdoc.fgv.br/acervo/dhbb.

PAULA, João Antonio de. A formação do mercado interno e a superação do subdesenvolvimento em Celso Furtado. In: COELHO; GRANZIERA, (orgs). Celso Furtado e a Formação econômica do Brasil (Edição comemorativa dos 50 anos de publicação (1959-2009)). Prefácio Fernando Henrique Cardoso. São Paulo, Editora Atlas, 2009.

PAULA, João Antônio de. Fundamentos da economia mineira. In: idem, Raízes da modernidade em Minas Gerais. Belo Horizonte: autêntica, 2002.

RINGER, Fritz, $O$ declínio dos mandarins alemães. A comunidade acadêmica alemã: 1890-1933. São Paulo, EDUSP, 2000.

RODRIGUEZ, O. Teoria do subdesenvolvimento da Cepal. Rio de Janeiro: Forense Universitária, 1981.

SARETTA, Fausto. Octavio Gouvea de Bulhões. In: SZMRECSÁNYI, T; COELHO, F. S. Ensaios de história do pensamento econômico no Brasil contemporâneo. São Paulo: Atlas, 2005.

SCALETSKY, Eduardo Carnos. Dois projetos para o Brasil: 1945-1954. Uma análise dos Projetos da Missão Abbink, da Comissão Mista Brasil-Estados Unidos e do Grupo Misto BNDE-Cepal. Dissertação de Mestrado, UFRGS, 1988.

SCHWARTZ, Stuart. Segredos internos. Engenhos e escravos na sociedade colonial, 1550-1835. São Paulo: Cia das letras, 2005.

SILVA, Roberto Pereira. O jovem Celso Furtado. História, política e ideologia (19411948). Bauru/SP. Edusc, 2011.

SOLA, Lourdes. Ideias econômicas, decisões políticas. Desenvolvimento, estabilidade e populismo: São Paulo: Fapesp, Edusp, 1998.

SZMRECSÁNYI, Tamás. Sobre a formação da Formação econômica do Brasil de C. Furtado. In: Estudos Avançados. São Paulo: EDUSP, 13(37), 1999.

- Cinquentenário de A Economia brasileira de Celso Furtado. Boletim Informativo da ABPHE, dezembro de 2003.

"Celso Furtado (1920-2004) e a Economia do Desenvolvimento". In: SZMRECSÁNYI, T; COELHO, F. S. Ensaios de história do pensamento econômico no Brasil contemporâneo. São Paulo: ATLAS, 2004.

As raízes, a estrutura e o conteúdo da Formação econômica do Brasil. In: COELHO; GRANZIERA, (orgs). Celso Furtado e a Formação econômica do Brasil (Edição comemorativa dos 50 anos de publicação (1959-2009). Prefácio Fernando Henrique Cardoso. São Paulo, Editora Atlas, 2009. 
TEIXEIRA, Aloísio. Desenvolvimento econômico: a arqueologia do debate e a contribuição original de Celso Furtado. In: ARAÚJO, Tarcisio Patricio de; WERNECK VIANNA, Salvador Teixeira; MACAMBIRA, Júnior. (orgs) 50 anos de Formação Econômica do Brasil: ensaios sobre a obra clássica de Celso Furtado. Rio de Janeiro: IPEA, 2009.

VIANNA, Sergio Bresserman. Duas tentativas de estabilização: 1951-1954. PAIVA, Marcelo de Abreu (orgs). A ordem do progresso. Cem anos de política econômica republicana (1889-1989). Rio de Janeiro, Campus, 1994.

Política econômica externa e industrialização: 1946-1951. PAIVA, Marcelo de Abreu (orgs). A ordem do progresso. Cem anos de política econômica republicana (1889-1989. Rio de Janeiro, Campus, 1994.

\& VILLELA, André. O pós-Guerra (1945-1955). GIAMBIAGI, Fábio (et. alli). Economia brasileira contemporânea (1945-2004). Rio de Janeiro, Elsevier, 2005.

VIEIRA, Rosa Maria. "Celso Furtado: autorretrato e retórica". In: BRESSERPEREIRA, L. C. \& REGO, J. M. A grande esperança em Celso Furtado. Ensaios em homenagem aos seus 80 anos. São Paulo: Editora 34, 2001, pp. 157-165.

VIEIRA, Rosa Maria. Celso Furtado: reforma, política e ideologia (1950-1964). São Paulo: Educ, 2007.

VILLELA, André. Dos “Anos Dourado" de JK à crise não resolvida (1956-1963). In: GIAMBIAGI, Fábio (et. alli). Economia brasileira contemporânea 1945-2004). Rio de Janeiro, Elsevier, 2005.

WAHRLICH, Beatriz. Reforma administrativa na era Vargas. Rio de Janeiro: Ed. FGV, 1985.

ZEMELLA, Mafalda. O abastecimento da Capitania de Minas Gerais no século XVIII. (Tese de Doutorado, História da Civilização Brasileira, FFCL-USP), 1950. 